\title{
Echo Meadows Project Winter Artificial Recharge
}

\section{Baseline Data}

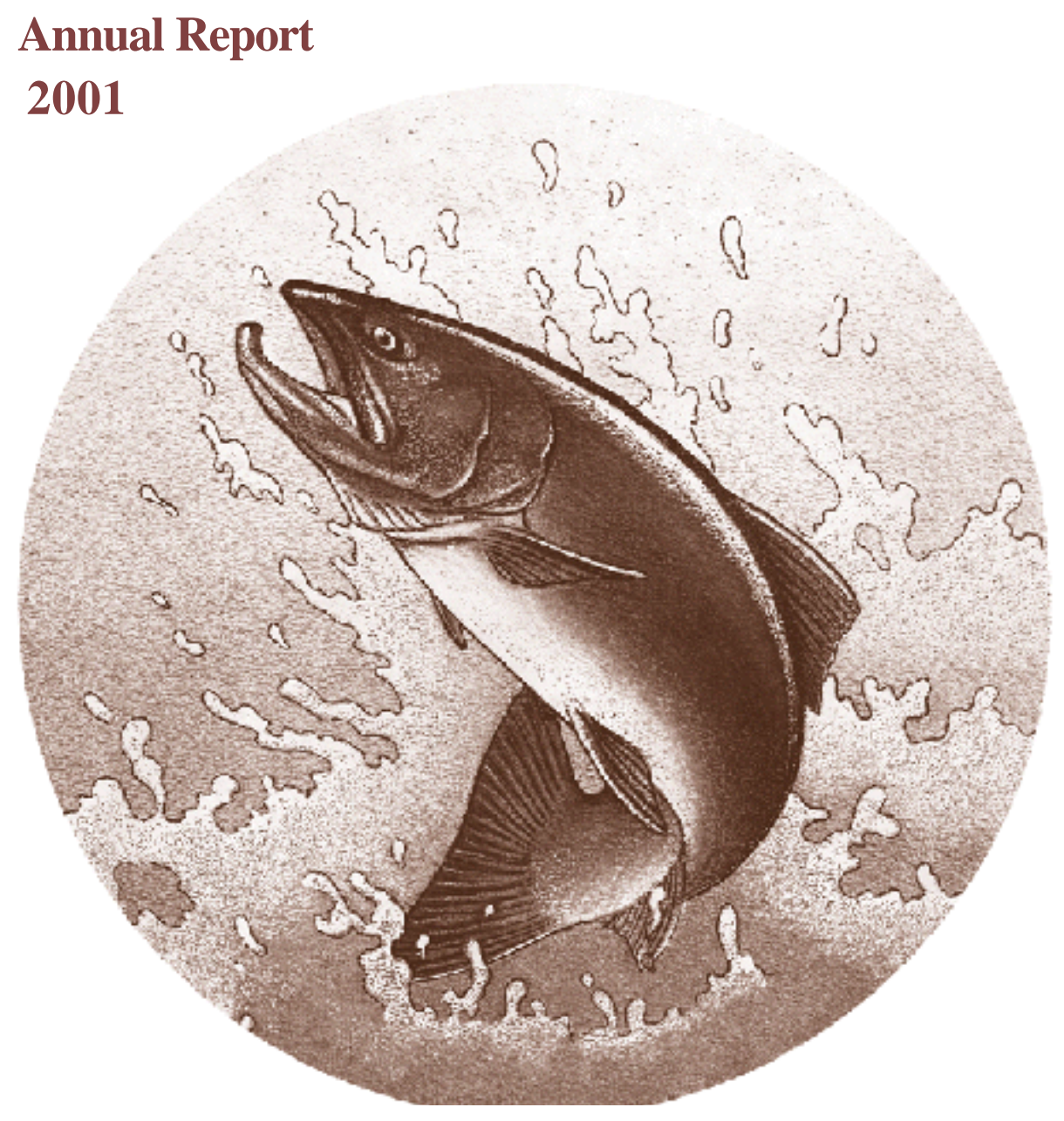

DOE/BP-00006925-1

December 2002 
This Document should be cited as follows:

Ziari, Fred, "Echo Meadows Project Winter Artificial Recharge", Project No. 2001-01500,

215 electronic pages, (BPA Report DOE/BP-00006925-1)

\author{
Bonneville Power Administration \\ P.O. Box 3621 \\ Portland, Oregon 97208
}

This report was funded by the Bonneville Power Administration (BPA), U.S. Department of Energy, as part of BPA's program to protect, mitigate, and enhance fish and wildlife affected by the development and operation of hydroelectric facilities on the Columbia River and its tributaries. The views in this report are the author's and do not necessarily represent the views of BPA. 


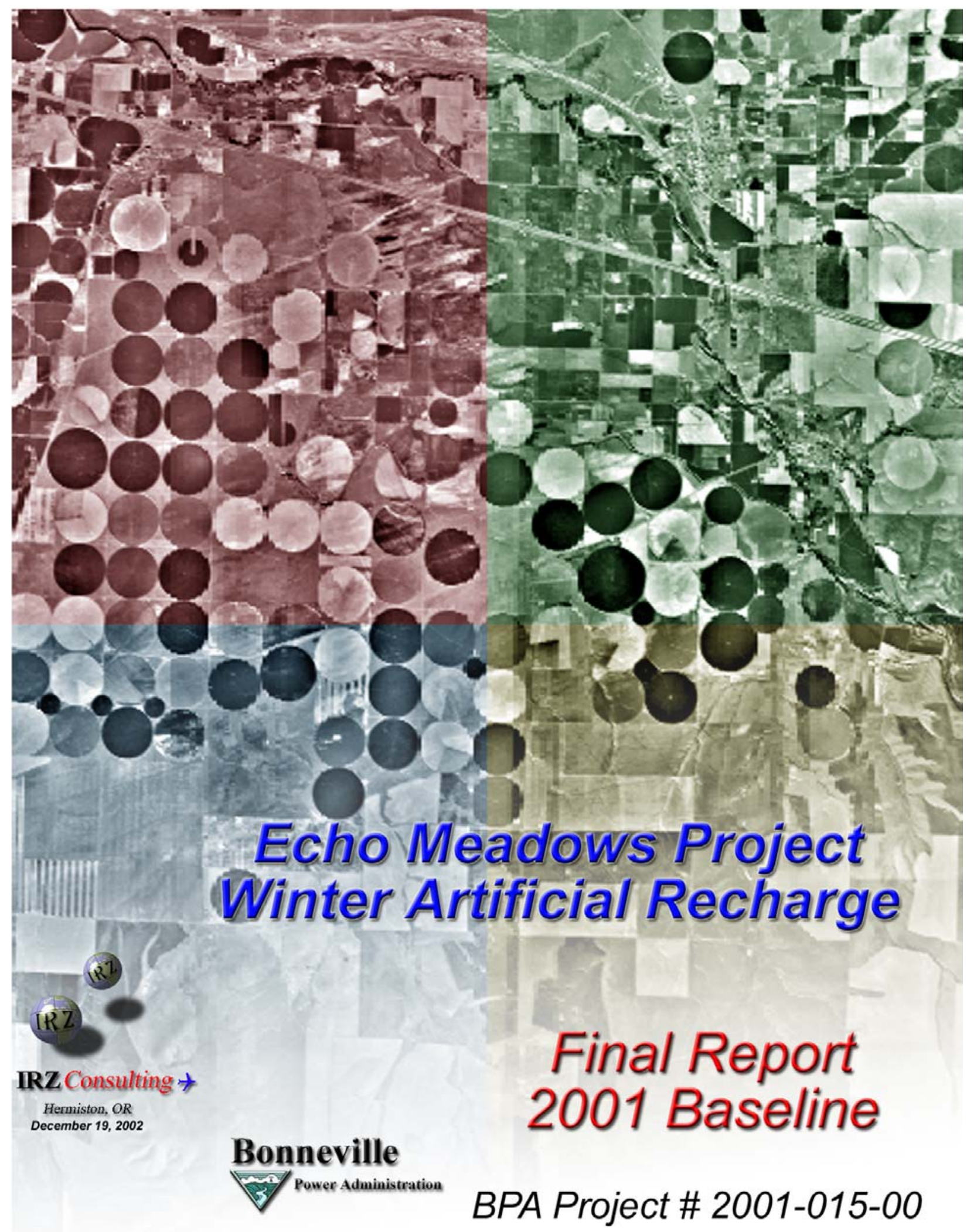




\section{Final Report 2001 Baseline "Echo Meadows Project Winter Artificial Recharge to Cool Rivers" BPA PROJECT\# 2001-015-00}

ENTITY:

TECHNICAL COORDINATOR: $\quad$ Fred Ziari

IRZ Consulting

505 East Main

Hermiston, OR 97838

(541) 567-0252, FAX (541) 567-4239

irz@irz.com

ADMINISTRATIVE CONTACT: $\quad$ Fred Ziari

IRZ Consulting, LLC

505 East Main

Hermiston, OR 97838

(541) 567-0252, FAX (541) 567-4239

irz@irz.com

Project leader (if different):

Project Type (if applicable):

Province:

Subbasin:

Project period:
Fred Ziari

IRZ Consulting, LLC

505 East Main

Hermiston, OR 97838

(541) 567-0252, FAX (541) 567-4239

irz@irz.com

Innovative

Columbia Plateau

Umatilla River

May 1, 2001 to March 31, 2002 


\section{(1RZ) IRZ CONSULTING, LLC}

505 East Main, Hermiston, Oregon 97838 Office (541) 567-0252 Fax (541) 567-4239

WwW.irz.com

\section{Mr. Peter Lofy - KEWL-4 COTR}

Bonneville Power Administration

Re: Final Report, Echo Meadow Project - "Winter Artificial Recharge to Cool Rivers" BPA Project \# 2001-015-00

Dear Peter:

$12-30-2002$

Presented is a Final Report of the 2001 Baseline data collection phase for the Echo Meadows Project. Although 2001 was to establish the baseline conditions only, our preliminary data collected and the analysis from our groundwater modeling is showing promising results consistent with the original goal of the project, which was to demonstrate that Winter Artificial Recharge can realistically cool the rivers of the Northwest by adding sufficient quantities of cold waters discharging into streams that will meet or nearly meeting the Temperature Standards of the Clean Water Act. We ask that you expeditiously consider this project for funding for the implementation phase during 2003. We are looking forward to hearing from you soon and should you have any questions, please feel free to call me at 541-567-0252 or by email at irz@irz.com.

Sincerely;

IRZ Consulting, LLC

Fred Ziari, CEO 


\section{Table of Contenet}

Final Report .................................................. II

Abstract ...................................................... 1

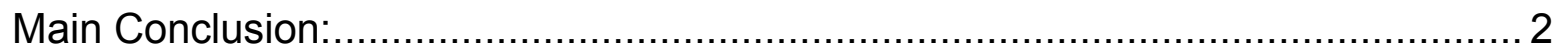

Introduction ........................................................ 3

Data Collection Efforts Completed in the Baseline

Phase ............................................................ 4

Figure-1. Echo Meadows area and locations of monitoring stations.................. 5

Objective 1. Determine if groundwater levels increase due to flooding.................... 8

Task 1.1 Review available wells and select well monitoring sites.................... 8

Task 1.2. Install piezometers ................................................................ 8

Task 1.3 and 1.4. Collect water level and temperature data......................... 9

Task 1.5 . Identify 10 wells. ..................................................................... 9

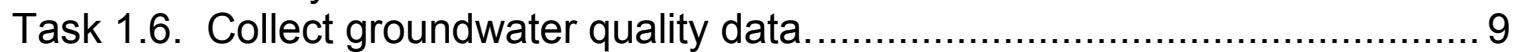

Objective 2. Collect and analyze weather data .......................................... 9

Task 2.1. On a monthly basis download the daily weather data from the Echo automated weather station.

Task 2.2. Input weather data into Irrigate 2000 \& software to calculate the daily evapotranspiration rates of crops growing in the study area. By subtracting evapotranspiration rates from the soil moisture readings, estimate the recharge rate into the groundwater.

Task 2.3. Use the weather data to statistically compare air temperature with the

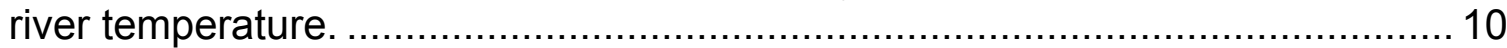

Objective 3. Determine amount, timing and frequency of water application ............ 10

Task 3.1. Identify fields and contact landowners to install 8 soil moisture monitoring site.

Task 3.2. Install moisture-monitoring sites (2 inch pvc tube) to same depth as of the groundwater level (normally 5-10 feet or to the limit of soil depth i.e. rock clay, etc.)

Task 3.3. On a weekly basis measure soil moisture on eight fields.

Measurements are to be for each foot increment down to the maximum depth allowed.

Task 3.4. Use this data to measure the amount and frequency of water application by each participating farm.

Task 3.5 Use this data in conjunction with weather data and evapotranspiration rate to do a groundwater water balance (inflow- outflow to groundwater).........11

Objective 4. Determine if Wetlands are influencing the recharge to groundwater. ... 11 Task 4.1. Contact and get permission from the landowner to monitor the existing wetlands.

Task 4.2. Get a permit for potential water application into the wetland from the Oregon Water Resource Department. 
Task 4.3. Install staff gauge in the deep portion of the wetland (portion of wetland dries out during the summer and recedes).

Task 4.4. On a weekly basis measure water level fluctuation within the wetlands.

Objective 5. To accurately determine the groundwater level in wells..................... 12

Task 5.1. Identify all point of measurements to be surveyed............................ 12

Task 5.2. Conduct survey of the Echo Meadows area using traditional surveying methods or by the use of accurate GPS.

Objective 6. Determine the hydraulic conductivity and rate of groundwater movement

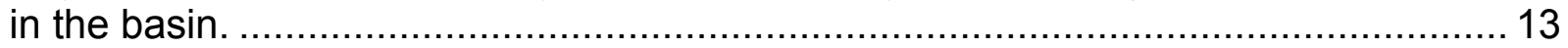

Task 6.1. Identify the locations for minimum of two wells............................. 13

Task 6.2. Get permission and coordinate with landowners to do pump test...... 13

Task 6.3. Do a pump test and measure well draw down between the two wells.

Task 6.4. Determine the hydraulic conductivity and specific yield of the aquifer 13 Objective 7. To determine timing and amount of groundwater recharging into the Umatilla River. ...................................................................................... 13

Task 7.1. Based on the measured data (i.e. pump tests and water levels) use GMS-MODFLOW software to develop a preliminary model of groundwater movements.

Task 7.2. Refine and calibrate groundwater model by acquiring new

groundwater data to match the actual field data. 14

Objective 8. To detect change in land-use activities in the Echo Meadows area and

measure the thermal variations within the Umatilla River. 14

Task 8.1. Conduct one aerial near infrared survey of lands within the Echo and Umatilla Meadows. ...................................................................... 15

Task 8.2. Conduct 3 aerial thermal infrared surveys of the Umatilla River. ....... 15

Task 8.3. Calibrate the aerial thermal infrared survey with field data (i.e.

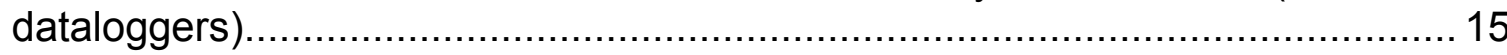

Task 8.4. Install temperature dataloggers in the Umatilla River...................... 15

Task 8.5. On a monthly basis download temperature from data loggers........... 16

Task 8.6 Obtain data from loggers owned by other entities (Oregon Water

Resources and Oregon Department of Environmental Quality)........................ 16

Objective 9. To determine if there will be adverse impact to water quality of the

groundwater and Umatilla River as a result of recharge..................................... 16

Task 9.1. Collect sampling bottles for a qualified laboratory .......................... 16

Task 9.2. On a quarterly basis collect water quality data (ph, conductivity,

temperature, nitrate, phosphorus, Fecal Coliform) at a maximum of 9 sites, using

procedure prescribed by Oregon Department of Environmental Quality. ........... 16

Task 9.3. Take samples to the laboratory for analysis................................... 16

Task 9.4. Input and analyze water quality data........................................... 16

Objective 10. To determine the quantity of water in the Umatilla River.................... 16

Task 10.1. On a monthly basis retrieve hydrograph data (river flows, diversion for

Irrigation Districts) from the US Bureau of Reclamation website. ...................... 17

Task 10.2. Input and analyze data............................................................ 17

Objective 11. To quantify the inflow into the Umatilla River ................................. 17 
Task 11.1. Identify all irrigation and natural drains into the Umatilla River. ...... 17

Task 11.2. Measure and record water heights at each drain........................ 17

Task 11.3. Calibrate flow rates by measuring water heights at various stages.. 18

Task 11.4. Input and analyze flows from the drains............................... 18

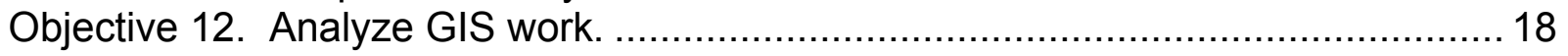

Task 12.1. Geo-reference each near and thermal infrared image to the real

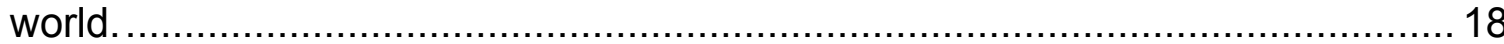

Task 12.2. Input all near infrared images into GIS ................................ 18

Task 12.3. Input all thermal infrared images into GIS.............................. 18

Task 12.4. Do GIS analysis showing "cold water refugia" or other points of

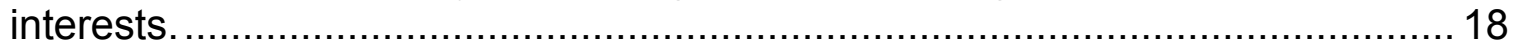

Objective 13. Report results. ................................................................. 18

Task 13.1. Provide to BPA a draft report within 60 days and a final report within 90 days after the end of contract. Report shall include all documents and data gathered as described in tasks listed above. Data will establish the baseline (pre-water application) condition of the Echo Meadows Winter Artificial Project. Data will be in hard copy and/or electroic format when possible. ..................... 18 Task 13.2. Provide a list of project cooperators, and places of use................ 18 Task 13.3. Provide maps, photos, and GIS data illustrating the above-mentioned

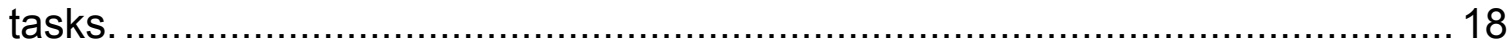

Task 13.4. Summarize and provide graphical and tabular data sets on water quality, groundwater levels, soil moisture, river/canal temperatures, weather station data, river stage records and the aerial infrared surveys.

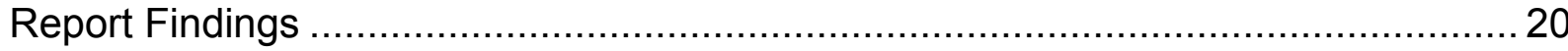

Description of the Project Area and Project Description ................................. 21

Echo Meadows Water Rights, Diverted and Applied Water, and Historic Return Flows

to the Umatilla River. 22

Figure 2. Echo Meadows surface water diversions. .................................. 24

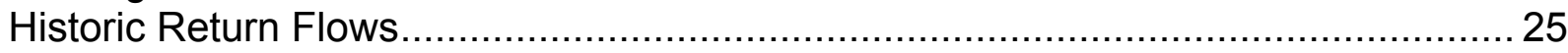

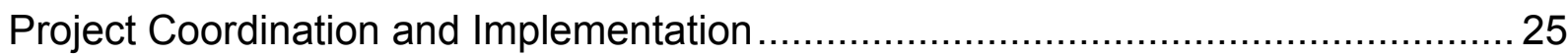

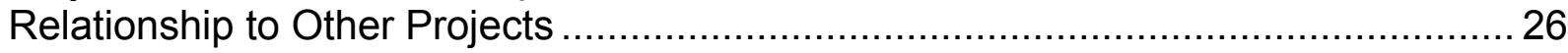

Groundwater and Surface Water Level Measurements ................................... 27

Figure 3. Piezometer water level measurements...................................... 28

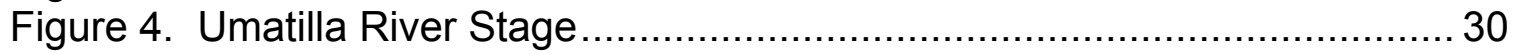

Figure 5. ERW-1 well continuous water level measurements..................... 31

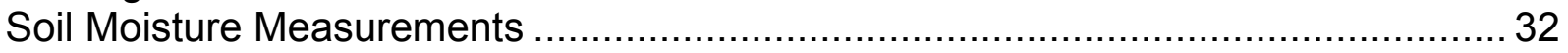

Figure 6. Soil Moisture Measurements, 1998-2002 for BAP-1...................... 33

Figure 7. Soil Moisture Measurements-2000-2002 for DMRP-1Groundwater and Surface Water Quality Data Collection ...................................................... 33

Groundwater and Surface Water Quality Data Collection ................................ 34

Figure 8. Groundwater, Umatilla River, and Air temperatures 2000-2001 ........ 35

Figure 9. Average groundwater temperature vs. Echo Meadows Area (Longitude

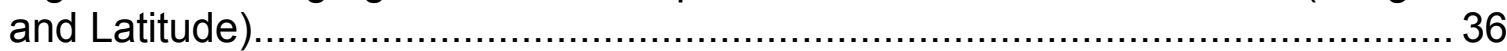

Thermal Infrared Imagery Along the Umatilla River .................................... 39

Figure 10A. Thermal Infrared Survey showing water temperatures along the 
Umatilla River flown on August 07, 2001. 40

Figure 10B. Thermal Infrared Survey showing water temperatures along the Umatilla River flown on August 07, 2001.

Figure 11. Thermal Infrared Survey showing water temperatures along Umatilla

River flown October 01, 2001 am flight. 43

Figure 12. Thermal Infrared Survey showing water temperatures, along Umatilla

River flown October 01, pm flight.......................................................... 44

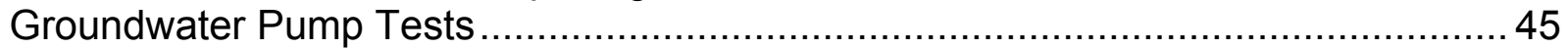

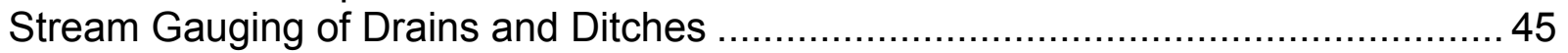

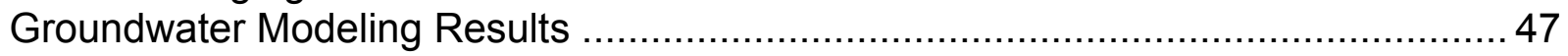

Figure 13. Groundwater Model Map of Echo Meadows................................. 49

Figure 15. Echo Meadows Response Functions based on a sample model run 52

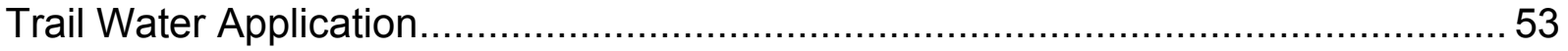

Cited References ............................................. 54

Appendix A ...................................................

Appendix B ...............................................

Appendix C ................................................ C-1

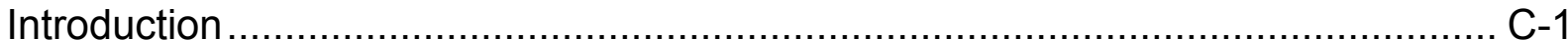

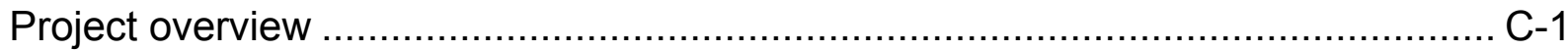

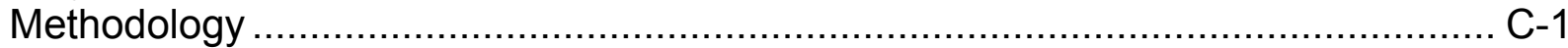

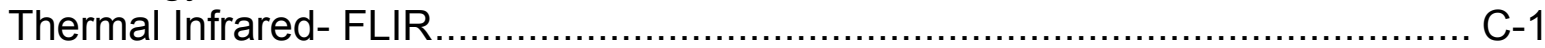

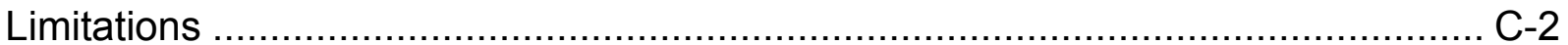

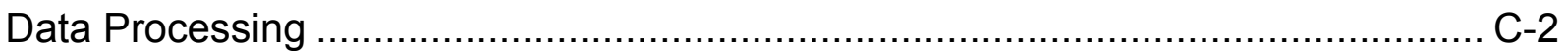

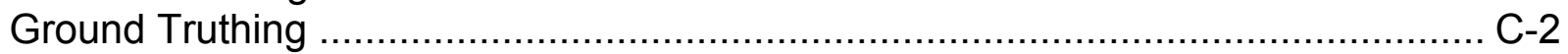

FLIR vs. In-river Datalogger In stream temperature monitors ............................. C-3

FLIR: Continuous measurement, short duration: ....................................... C-3

Datalogger In stream temperature monitors: Single point, long duration:......... C-3

Thermal Infrared Analysis ............................................................................. C-5

Geographic Information System (GIS) .................................................... C-5

Figure C-1- Side by side comparison of Thermal Infrared of the Umatilla River from three separate flights..................................................................... C-5

Fig-C2- Thermal Infrared (GIS Theme) of the Umatilla River flown on August 7,

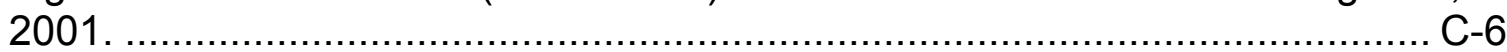

Fig-C3- Thermal Infrared (GIS Theme) of the Umatilla River flown on 08-07-

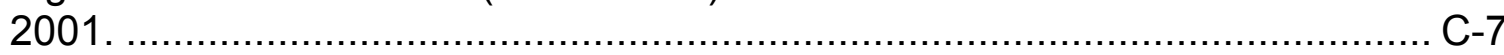

Fig-C4- Thermal Infrared (GIS Theme) of the Umatilla River flown on 10-01-2001

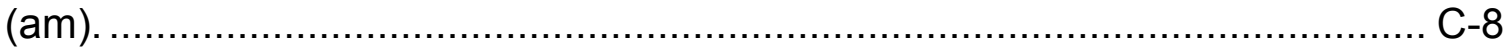

Fig-C5- Thermal Infrared (GIS Theme) of the Umatilla River flown on 10-01-2001

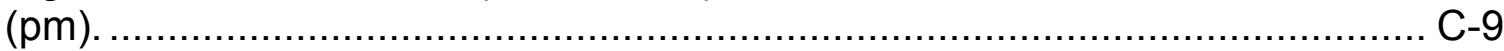

Paired Thermal and Color Infrared Images:................................................ C-10

Fig-C6- Thermal Infrared of the Umatilla River at RM-27.30 8-7-2001 ........... C-10

Color-Infrared Image Mosaic ..................................................................... C-20

Figure C-17- 2001 Color (Near) Infrared survey of Echo Meadows ............... C-21 


\section{Appendix D ................................................. D-1}

Trail Water Application.................................................................................... D-1

Figure D-1. Map showing the area of trail water application (blue area),

Diversion Headgates and the location of monitoring well sites...................... D-2

Figure D-2. Water level measurement during trail water application at well Site DMPW-1

Figure D-3. Water level measurement during trail water application at well Site DMW-1

Figure D-4. Water level measurement during trail water application at well Site DMPW-2.

Figure D-5. Dalalogger level measurement during trail application at well Site ERW-1....

Figure D-6. Datalogger level measurement during trail application at well Site ERW-2

Figure D-7. Water level measurement during trail water application at well Site JSPW-1

Figure D-8. Water level measurement during trail water application at well Site MMPW-1

Figure D-9. Water level measurement during trail water application at well Site BAPW-1 D-7

Appendix E ................................................. 


\section{Abstract}

This report discusses the findings of the Echo Meadows Project (BPA Project 2001-01500 ). The main purpose of this project is to artificially recharge an alluvial aquifer, WITH water from Umatilla River during the winter high flow period. In turn, this recharged aquifer will discharge an increased flow of cool groundwater back to the river, thereby improving Umatilla River water quality and temperature. A considerable side benefit is that the Umatilla River should improve as a habitat for migration, spanning, and rearing of anadromus and resident fish.

The scope of this project is to provide critical baseline information about the Echo Meadows and the associated reach of the Umatilla River. Key elements of information that has been gathered include:

Annual and seasonal groundwater levels in the aquifer with an emphasis on the irrigation season,

- Groundwater hydraulic properties, particularly hydraulic conductivity and specific yield, and

- Groundwater and Umatilla River water quality including temperature, nutrients and other indicator parameters.

One of the major purposes of this data gathering was to develop input to a groundwater model of the area. The purpose of the model is to estimate our ability to recharge this aquifer using water that is only available outside of the irrigation season (December through the end of February) and to estimate the timing of groundwater return flow back to the river.

We have found through the data collection and modeling efforts that this reach of the river had historically returned as much as 45 cubic feet per second (cfs) of water to the Umatilla River during the summer and early fall. However, this return flow was reduced to as low as $10 \mathrm{cfs}$ primarily due to reduced quantities of irrigation application, gain in irrigation efficiencies and increased groundwater pumping.

Our modeling indicated that it is possible to restore these critical return flows using applied water outside of the irrigation season. We further found that this water can be timed to return to the river during the desired time of the year (summer to early fall). This is because the river stage, which remains relatively high until this time, drops during the irrigation season-thereby releasing the stored groundwater and increasing river flows. A significant side benefit is that these enhanced groundwater return flows will be clean and cold, particularly as compared to the Umatilla River.

We also believe that this same type of application of water could be done and the resulting stream flows could be realized in other watersheds throughout the Pacific Northwest. This means that it is critical to compare the results from this baseline report to the full implementation of the project in the next phase. 
As previously stated, this report only discusses the results of data gathered during the baseline phase of this project. We have attempted to make the data that has been gathered accessible with the enclosed databases and spreadsheets. We provide computer links in this report to the databases so that interested parties can fully evaluate the data that has been gathered. However, we cannot emphasize too strongly that the real value of this project is to implement the phases to come, compare the results of these future phases to this baseline and develop the science and strategies to successfully implement this concept to other rivers in the Pacific Northwest.

\section{Main Conclusion:}

The results from our verified and calibrated groundwater model matches the observed groundwater data and trends collected during the baseline phase. The modeling results indicate that the return flows may increase to their historic values with the addition of 1 acre-ft/acre of recharge water to the groundwater system (about 9,600 acre-feet total). What this means is that through continued recharge project, you can double to quadruple the annual baseflow of the Umatilla River during the low summer and fall flow periods as compared to the present base-flow. The cool and high quality recharge water is a significant beneficial impact to the river system. 


\section{Introduction}

Presently, most of the rivers and streams of the Pacific Northwest do not meet the temperature standards of the Clean Water Act (CWA) during the summer to early fall. This is largely because the region has fairly high ambient temperatures during this time and the stream flows are low.

Traditionally, there are only a couple of methods to improve the flow/water quality during this time. They include:

- Selective withdrawal of low temperature water from reservoirs into streams, and

- Shading of the stream course to minimize stream heating

Both of these methods are useful. Reservoir regulation may augment the amount of water that is available during low flows. However, there are many disadvantages to reservoirs including their cost and that they may severely impeded the upstream migration of anadromous fish. Stream shading may minimize the heating of the stream. However, almost all water bodies will approach the ambient air temperature even if they are shaded (Kadlec and Knight, 1996).

In this project, we use a different approach. We use a groundwater aquifer for our storage project, thereby solving most of the drawbacks of a surface reservoir. We augment the aquifer storage during the winter and early spring when surface water is abundant (and cold). The groundwater will be timed to be available during the summerincreasing the amount of water in the stream and improving its quality because the groundwater is significantly colder and is of better quality than the receiving surface water. We will be able to accomplish these goals through the careful placement of water within the project boundaries. And we are able to provide proof of our concept and demonstrate the applicability to other watersheds through the completion of the Echo Meadows Project.

This final baseline report should be considered as a companion to our Progress Report (IRZ Consulting, Draft Progress Report, 2001 Baseline Analysis, dated January 7, 2002 in the Appendix E). We have augmented certain aspects of this report that were only initially discussed in the Progress Report. However, other aspects that were completed for the 2001 Progress Report are only included by reference here. Included with this final report is a CD that contains the databases that are referred to in this report and our previous Report. For easy access, all databases in this report are also hyperlinked.

Immediately following is a discussion of each task that we have proposed for this project and our accomplishments. In sections to follow, we will discuss the project results at the completion of the baseline data collection phase of the project. We provide historical data and projections with our groundwater models to bolster our proof that our project can enhance the river flow by restoring the groundwater recharge of the Echo Meadows area. 


\section{Data Collection Efforts Completed in the Baseline Phase}

The principal goal of the baseline phase of the project was to document the groundwater and surface water conditions in the Meadows area prior to the implementation phase (when recharge water is to be added in 2003). It is through the comparison of the pre and post project data that the merits of the project can be evaluated. In addition, the monitoring data collected during the baseline phase was used to develop, calibrate, and verify the groundwater model of the area. The groundwater model, in turn, will be used in development of the project implementation phase- contributing to such tasks as assisting in the planning of how much water will be added to what areas of the Meadows.

To date, much of the Meadows project has concentrated on establishing, maintaining, and monitoring a network of piezometers, pit wells, culverts and drains, and surface water stations which will be used to evaluate the effectiveness of the project during the implementation phase.

Figure 1 shows the locations of these monitoring locations on an aerial photo of the project area. Appendix A lists these stations and provides their coordinates in longitude and latitude, UTM, and UTM coordinates translated to feet. During 2001, 13 of the monitoring stations were surveyed (with over 8 miles of level lines) to establish their elevations. These stations that were surveyed were a mix of key piezometers and pit wells throughout the Meadows. These key stations provide a baseline of elevations for the groundwater model and for comparison of groundwater modeling results for calibration and verification. The Excel file LOCMON.xls includes the same information as well Elevation and other relevant information as shown in Appendix A.

Table-1 below shows the 50 tasks that were outlined in the BPA proposal \# 2001-01500 and completed during the baseline phase of the project. Following the table is a discussion of the results for each task. 
Figure-1. Echo Meadows area and locations of monitoring stations

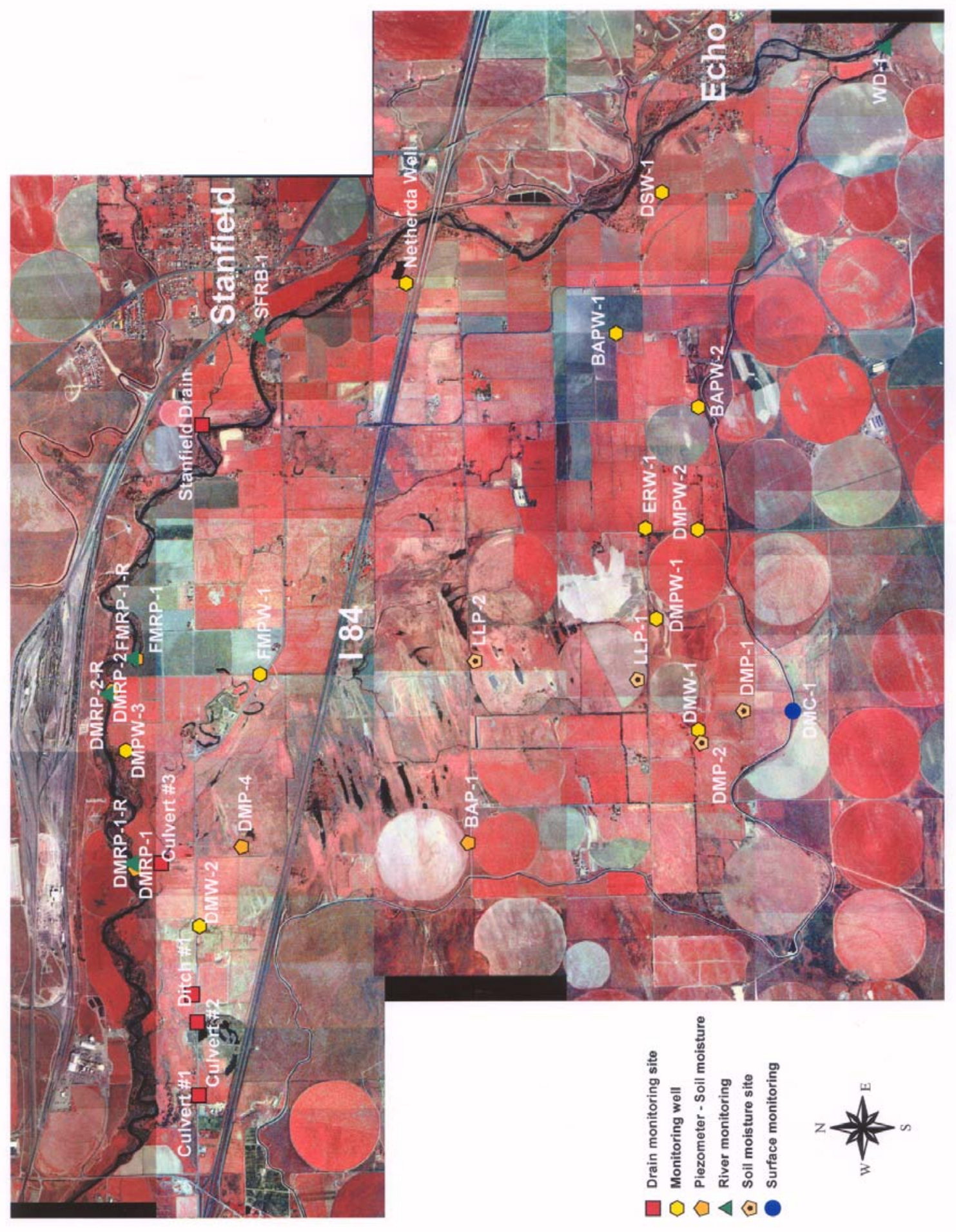


Table-1 Echo Meadows Task and Project Schedule

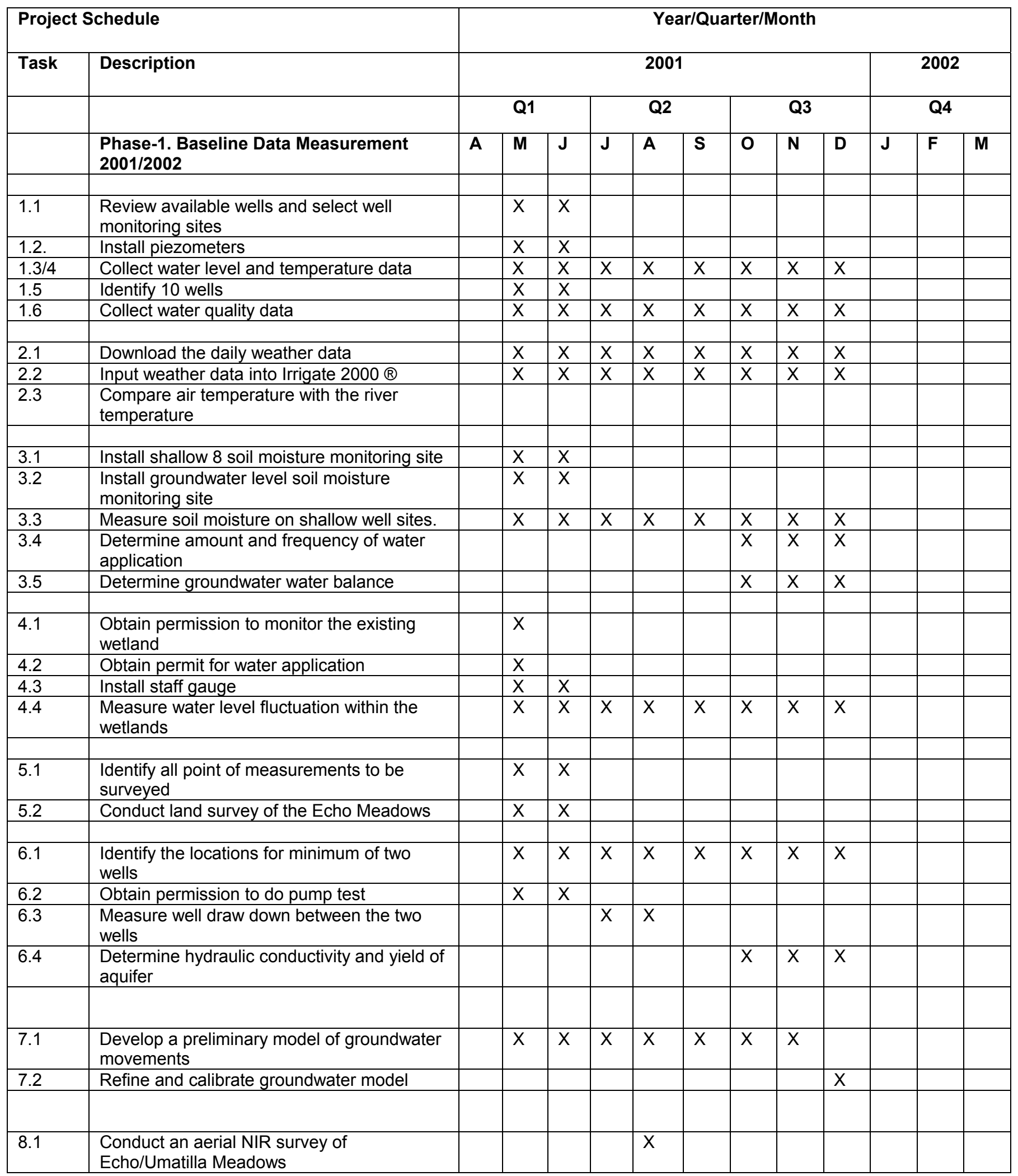




\begin{tabular}{|c|c|c|c|c|c|c|c|c|c|c|c|c|c|}
\hline \multicolumn{2}{|c|}{ Project Schedule } & \multicolumn{12}{|c|}{ Year/Quarter/Month } \\
\hline \multirow[t]{3}{*}{ Task } & \multirow{3}{*}{$\begin{array}{l}\text { Description } \\
\\
\text { Phase-1. Baseline Data Measurement } \\
2001 / 2002\end{array}$} & \multicolumn{9}{|c|}{2001} & \multirow{2}{*}{\multicolumn{3}{|c|}{$\frac{2002}{Q 4}$}} \\
\hline & & \multicolumn{3}{|c|}{ Q1 } & \multicolumn{3}{|c|}{ Q2 } & \multicolumn{3}{|c|}{ Q2 } & & & \\
\hline & & A & M & $\mathrm{J}$ & J & A & $S$ & 0 & $\mathbf{N}$ & D & $J$ & $\mathbf{F}$ & $\mathbf{M}$ \\
\hline 8.2 & $\begin{array}{l}\text { Conduct } 3 \text { aerial IR surveys of the Umatilla } \\
\text { River }\end{array}$ & & & & $\mathrm{X}$ & $\mathrm{X}$ & $\mathrm{X}$ & $\mathrm{X}$ & & & & & \\
\hline 8.3 & Calibrate aerial IR with field data & & & & $\mathrm{X}$ & $\mathrm{X}$ & $\mathrm{X}$ & $\mathrm{X}$ & & & & & \\
\hline 8.4 & $\begin{array}{l}\text { Install temperature dataloggers in the } \\
\text { Umatilla River. }\end{array}$ & & $\mathrm{X}$ & $\mathrm{x}$ & & & & & & & & & \\
\hline 8.5 & Download temperature from dataloggers & & $\mathrm{X}$ & $\mathrm{X}$ & $\mathrm{X}$ & $\mathrm{X}$ & $\mathrm{X}$ & $\mathrm{X}$ & $\mathrm{X}$ & $\mathrm{X}$ & & & \\
\hline 8.6 & $\begin{array}{l}\text { Obtain data from loggers owned by other } \\
\text { entities }\end{array}$ & & $\mathrm{X}$ & $\mathrm{x}$ & $\mathrm{x}$ & $\mathrm{X}$ & $\mathrm{x}$ & $\mathrm{X}$ & $\mathrm{X}$ & $\mathrm{x}$ & & & \\
\hline 9.1 & Collect samples & & $\mathrm{X}$ & $\mathrm{X}$ & $\mathrm{X}$ & $\mathrm{X}$ & $\mathrm{X}$ & $\mathrm{X}$ & $\mathrm{X}$ & $\mathrm{X}$ & & & \\
\hline 9.2 & $\begin{array}{l}\text { Collect water quality data at a maximum of } 9 \\
\text { sites }\end{array}$ & & $\mathrm{X}$ & $x$ & $\mathrm{X}$ & $x$ & $x$ & $X$ & $\mathrm{X}$ & $\mathrm{X}$ & & & \\
\hline 9.3 & $\begin{array}{l}\text { Deliver samples to the laboratory for } \\
\text { analysis }\end{array}$ & & $\mathrm{X}$ & $\mathrm{x}$ & $\mathrm{X}$ & $\mathrm{x}$ & $\mathrm{X}$ & $\mathrm{X}$ & $\mathrm{X}$ & $\mathrm{X}$ & & & \\
\hline 9.4 & Input and analyze water quality data & & $\mathrm{X}$ & $\mathrm{X}$ & $\mathrm{X}$ & $\mathrm{X}$ & $\mathrm{X}$ & $\mathrm{X}$ & $\mathrm{X}$ & $\mathrm{X}$ & & & \\
\hline 10.1 & Retrieve hydrograph data & & $\mathrm{X}$ & $\mathrm{X}$ & $\mathrm{X}$ & $\mathrm{X}$ & $\mathrm{X}$ & $\mathrm{X}$ & $\mathrm{X}$ & $\mathrm{X}$ & & & \\
\hline 10.2 & Input and analyze data & & $\mathrm{X}$ & $\mathrm{X}$ & $\mathrm{X}$ & $\mathrm{X}$ & $\mathrm{X}$ & $\mathrm{X}$ & $\mathrm{X}$ & $\mathrm{X}$ & & & \\
\hline 11.1 & $\begin{array}{l}\text { Identify irrigation and natural drains into } \\
\text { Umatilla River }\end{array}$ & & $\mathrm{X}$ & $\mathrm{X}$ & & & & & & & & & \\
\hline 11.2 & $\begin{array}{l}\text { Measure and record water heights at each } \\
\text { drain }\end{array}$ & & $\mathrm{X}$ & $\mathrm{X}$ & $\mathrm{X}$ & $\mathrm{X}$ & $x$ & $\mathrm{X}$ & $X$ & $\mathrm{X}$ & & & \\
\hline 11.3 & Calibrate flow rates & & $\mathrm{X}$ & $\mathrm{X}$ & $\mathrm{X}$ & $\mathrm{X}$ & & & & & & & \\
\hline 11.4 & Input and analyze flows from the drain & & & & $\mathrm{X}$ & $\mathrm{X}$ & $\mathrm{X}$ & $\mathrm{X}$ & $\mathrm{X}$ & $\mathrm{X}$ & & & \\
\hline 12.1 & $\begin{array}{l}\text { Georeference near and thermal IR image to } \\
\text { real world }\end{array}$ & & $\mathrm{X}$ & $\mathrm{x}$ & $\mathrm{X}$ & $\mathrm{X}$ & $\mathrm{X}$ & $\mathrm{X}$ & $\mathrm{X}$ & $X$ & $\mathrm{X}$ & $\mathrm{X}$ & $\mathrm{X}$ \\
\hline 12.2 & Input all near infrared images into GIS. & & $\mathrm{X}$ & $\mathrm{X}$ & $\mathrm{X}$ & $\mathrm{X}$ & $\mathrm{X}$ & $\mathrm{X}$ & $\mathrm{X}$ & $\mathrm{X}$ & $\mathrm{X}$ & $\mathrm{X}$ & $\mathrm{X}$ \\
\hline 12.3 & Input all thermal infrared images into GIS. & & $\mathrm{X}$ & $\mathrm{X}$ & $\mathrm{X}$ & $\mathrm{X}$ & $\mathrm{X}$ & $\mathrm{x}$ & $\mathrm{X}$ & $\mathrm{X}$ & $\mathrm{X}$ & $\mathrm{X}$ & $\mathrm{X}$ \\
\hline 12.4 & $\begin{array}{l}\text { Do GIS analysis showing "cold water } \\
\text { refugia" }\end{array}$ & & $x$ & $\mathrm{X}$ & $\mathrm{X}$ & $\mathrm{X}$ & $x$ & $X$ & $\mathrm{X}$ & $\mathrm{X}$ & $\mathrm{X}$ & $\mathrm{X}$ & $\mathrm{X}$ \\
\hline 13.1 & $\begin{array}{l}\text { Do data analysis and provide results BPA } \\
\text { with a draft report }\end{array}$ & & & & & & $\mathrm{x}$ & $\mathrm{x}$ & $\mathrm{x}$ & $\mathrm{x}$ & $\mathrm{x}$ & $\mathrm{X}$ & $\mathrm{x}$ \\
\hline 13.2 & $\begin{array}{l}\text { Provide a list of project cooperators, and } \\
\text { places of use }\end{array}$ & & & & & & & & & $\mathrm{X}$ & $\mathrm{X}$ & $\mathrm{X}$ & $\mathrm{X}$ \\
\hline 13.3 & $\begin{array}{l}\text { Provide maps, photos, and GIS data for } \\
\text { above tasks }\end{array}$ & & & & & & & & & $\mathrm{X}$ & $\mathrm{X}$ & $\mathrm{X}$ & $\mathrm{x}$ \\
\hline 13.4 & Provide graphical and tabular data sets & & & & & & & & & $\mathrm{X}$ & $\mathrm{X}$ & $\mathrm{X}$ & $\mathrm{X}$ \\
\hline & & & & & & & & & & & & & \\
\hline
\end{tabular}




\section{Objective 1. Determine if groundwater levels increase due to flooding.}

Approach: Collect groundwater levels measurement on minimum of 10 sites within the project area by installing piezometers and using exiting wells for water level measurements. Piezometers will be installed in a grid system stretching from south to north and to a depth below the groundwater level. This will establish pre-project conditions and trends to compare with any winter water application.

Existing wells or new piezometers will be monitored up-gradient of the project activities. These wells will be above the Westland Irrigation Canal (Hunt Ditch) near the Town of Echo. The purpose of monitoring these up-gradient wells is to document the time of positive groundwater fluctuations of the recharge project.

New Piezometers will also be installed along the southern bank of the Umatilla River in the Umatilla Meadows area. Water level and temperature data will be collected weekly. Water conductivity will also be used as an indicator in some of the piezometers. Data loggers may be periodically installed in these piezometers to record fluctuations in groundwater levels on an intensive basis (hourly basis), such as when river stages are expected to fluctuate quickly due to changing irrigation diversions (heavy diversion are normally during July-August).

A minimum of 10 shallow wells and piezometers within the project area will be identified for routine water quality testing (ph, Conductivity, nitrate) in accordance with the Water Quality Monitoring Plan.

\section{Task 1.1 Review available wells and select well monitoring sites.}

IRZ completed a review of all of the wells that are in the Echo Meadows region and selected 8 pit wells (large diameter, shallow wells installed with a backhoe) and 6 conventional wells for monitoring. These wells have been monitored for water levels and indicator water quality parameters (temperature, $\mathrm{pH}$, Nitrate, etc.) on a weekly basis, for several years (some since 1998). The well database is included in Excel files Pitwell00-01.xls, Piez00-01.xls, and Well01all.xls on the CD. Results from the well database (groundwater levels) have been included in the Bureau of Reclamation's MODFLOW regional model, which has in turn been used for this project. Results from this task, as well as all of the other tasks, follow this Task section. The locations of these wells, as well as other monitoring locations, are shown on Figure 1.

\section{Task 1.2. Install piezometers}

Following the development of the existing wells database (Task 1.1), IRZ installed 10 additional piezometers to monitor water levels in the Echo Meadows area. The piezometer database is included in Excel files Piez00-01.xls and Well01all.xls on the $\mathrm{CD}$. The location of these piezometers, as well as other monitoring locations, are 
shown on Figure 1. During 2001, taking advantage of the drought and lowered groundwater levels, 5 of the piezometers were deepened and improved to provide better groundwater levels and water quality measurements.

Task 1.3 and 1.4. Collect water level and temperature data.

Collected data on a weekly basis as discussed above. Temperature data at the monitoring wells are included in Excel spreadsheet files Piez00-01.xls and Well01all.xls.

Task 1.5. Identify 10 wells.

This Task was discussed on 1.1 above. IRZ actually monitors groundwater levels at 8 pit wells, 10 piezometers, and 6 conventional wells for a total of 24 wells. Due to the higher elevation and distance away from our recharge site, wells at site number BAPW1 and DSW-1 were selected as up gradient wells.

Task 1.6. Collect groundwater quality data.

As previously discussed, IRZ collected weekly groundwater quality indicator data (temperature, $\mathrm{pH}$, and conductivity) at 24 locations. In addition, a more complete suite of parameter (largely nutrients and biological) are taken at 4-5 sites on a quarterly basis. The water quality database is included as a table in the Results section of this report and included in Excel spreadsheet file $\underline{Q}$ Water Quality.xls.

\section{Objective 2. Collect and analyze weather data}

Approach: Collect daily weather data and calculate daily crop evapotranspiration rate. This data will be used in a water balance, measuring the amount of moisture taken from the soil. US Bureau of Reclamation Agrimet automated weather station (Echo station) located at the L\&L Farm will be used for weather monitoring. Further, the daily weather data fluctuation will be statistically compared with river temperature fluctuation.

Task 2.1. On a monthly basis download the daily weather data from the Echo automated weather station.

IRZ maintains weather data for a broad spectrum of agricultural clients. The weather data from the Echo site has been downloaded since 1980 and is available on their website at irz.com.

Task 2.2. Input weather data into Irrigate 2000 ( ) software to calculate the daily evapotranspiration rates of crops growing in the study area. By subtracting evapotranspiration rates from the soil moisture readings, estimate the recharge rate into the groundwater. 
As discussed above, IRZ maintains weather data for agricultural clients. We input the Echo site data and determine daily evapotranspiration rates for this site, as well as others on our Website www.irz.com/NIN/echows.pl using the program Irrigate $2000 \AA$. Soil moisture data collection is discussed in the tasks of Objective 3 and the resultant of these two tasks (estimated recharge) is discussed in the Results portion of this report.

Task 2.3. Use the weather data to statistically compare air temperature with the river temperature.

Weather data collection is discussed above. Statistical analysis are contained in the excel file temploggersnov2000-oct2001.xls (See Weather_Station_Data sheet)

Water temperature data collection is discussed in the tasks of Objective 8. The resultant of these two tasks (comparison of statistical air and river water temperature) is discussed in the Results portion of this report.

\section{Objective 3. Determine amount, timing and frequency of water application}

Approach: Collect soil moisture data on 8 fields located within the projects. Soil moisture will be monitored using Neutron Probe measurements. Soil moisture will be monitored on a weekly to monthly basis, depending on the variability of the soil moisture. Baseline soil moisture fluctuations will be monitored during the 2001 irrigation season. Soil moisture data will also indicate the amount, timing, and frequency of water application. This will establish pre-project conditions and trends to compare with any winter water application.

Task 3.1. Identify fields and contact landowners to install 8 soil moisture monitoring site.

Task 3.1 was completed by the first quarter of 2001. Soil moisture has been collected since July of 1998, on as many as 10 sites. The location of these sites can be seen in Figure 1 (Site 1 through 9).

Task 3.2. Install moisture-monitoring sites ( 2 inch pve tube) to same depth as of the groundwater level (normally 5-10 feet or to the limit of soil depth i.e. rock clay, etc.)

The soil moisture tubes were completed to depths of 5-10 feet as seen in the Excel spreadsheet $\underline{\text { Soil Moisture.xls. }}$

Task 3.3. On a weekly basis measure soil moisture on eight fields. Measurements are to be for each foot increment down to the maximum depth allowed.

As previously discussed, soil moisture data has been collected at these 10 sites for as many as four years. Soil Moisture was collected weekly using calibrated Neutron 
Probes soil moisture device to a maximum of 10 feet (limited to depth of hard pan or rocks). Data was collected and graphed for this task is available in the Excel spreadsheet $\underline{\text { Soil Moisture.xls. }}$

Task 3.4. Use this data to measure the amount and frequency of water application by each participating farm.

The soil moisture plots versus time are shown and discussed in the Results section and in the Excel spreadsheet Soil Moisture.xls, which clearly shows the frequency of each irrigation by observing the soil moisture fluctuation on the first foot.

Task 3.5 Use this data in conjunction with weather data and evapotranspiration rate to do a groundwater water balance (inflow- outflow to groundwater).

This task was completed through a comparison of the evapotranspiration data (Objective 2) and the soil moisture data (discussed above) and is discussed in the Results section.

\section{Objective 4. Determine if Wetlands are influencing the recharge to groundwater.}

Approach: Monitor Wetland area located in the northwest corner of Echo Meadows area by measuring water level in the wetland areas. Wetland areas may be an ideal location to apply additional water. This application will recharge the shallow aquifer enhancing the river. Upon written approval from the Oregon Water Resource Department or the Umatilla County Watermaster office, water may be applied to the wetland area during high spring flows.

The wetlands in Echo Meadows appear to be of diminishing size and importance according to long-time farmers in the area. This is probably due to diminished rates of water application and increased groundwater. However, we believe that they can be restored to their former prominence and importance by augmenting groundwater recharge and through direct application. As a result, IRZ has placed increased importance on the permitting and logistics of wetlands recharge.

Task 4.1. Contact and get permission from the landowner to monitor the existing wetlands.

IRZ has secured the permission to monitor several wetlands in the Echo Meadows area, thanks to cooperators such as Barbara Andrews and Mike Taylor. The wetland program is further discussed in the Results section. 
Task 4.2. Get a permit for potential water application into the wetland from the Oregon Water Resource Department.

The Water Resources Department, Limited License No. 00225, does not allows for application of water into the wetlands. For 2003 and 2004 water application/recharge phase IRZ Consulting LLC, have secured a new Limited License permit No. 661 that allows additional latitude to apply water at the wetlands. The new permit language allows us to apply water to the wetlands through the end of May, depending on river flows.

Task 4.3. Install staff gauge in the deep portion of the wetland (portion of wetland dries out during the summer and recedes).

The wetlands (former) that we have identified for monitoring do not have much standing water under present conditions. This task will be more fully developed when we apply water during the project implementation phase. At that time, we will install the staff gages and perform the necessary wetlands monitoring.

Task 4.4. On a weekly basis measure water level fluctuation within the wetlands.

See Task 4.3 above.

\section{Objective 5. To accurately determine the groundwater level in wells.}

Approach: Conduct an accurate survey of each piezometer, well, neutron probe and other monitoring sites using a geodetic quality GPS receivers for positioning and a laser level for elevation. This survey data will be used with our groundwater modeling and flow direction calculations.

Task 5.1. Identify all point of measurements to be surveyed.

See task 5.2 below.

Task 5.2. Conduct survey of the Echo Meadows area using traditional surveying methods or by the use of accurate GPS.

All of the Echo Meadows monitoring sites were located with a GPS during 2001. In addition, a level survey was made through Echo Meadows to tie the elevation of these locations to bench marks on bridges in the area. In this respect, virtually all of our groundwater depths are available as true elevations. The location and elevations of the monitoring network can be seen in Appendix A and in the Excel spreadsheet LOCMON.

The location, elevation, and changes in water levels over time were incorporated into the BOR's MODFLOW model. Examples of the elevation plots may be seen in the 
results section of this report.

\section{Objective 6. Determine the hydraulic conductivity and rate of groundwater movement in the basin.}

Approach: Perform pump tests of existing wells. These pump tests will monitor the groundwater levels of the pumping well and other nearby observation wells during an irrigation cycle (24-48 hours). The purpose of the pump test(s) is to determine the hydraulic conductivity and specific yield of the aquifer in the vicinity of the project so that groundwater return flow timing may be evaluated. These tasks are discussed together in the discussion of Task 6.4.

Task 6.1. Identify the locations for minimum of two wells.

Task 6.2. Get permission and coordinate with landowners to do pump test.

Task 6.3. Do a pump test and measure well draw down between the two wells.

Task 6.4. Determine the hydraulic conductivity and specific yield of the aquifer

There have been several pump tests conducted by the project staff in the Echo Meadows area, including pump tests at the Snow well(s), ERW-1 well, and Holeman well. The ERW-1pump test was previously discussed in IRZ 1998 (Appendix E). The results from the pumping of the Snow and Holeman wells have been discussed in previous submittals to the Water Resources Department (Graham, 1995) and are reviewed in the Results section of this report.

In 2001, a pump test of the Taylor well EMDMPW-3 was conducted. The location of this well is shown on Figure 1. In addition, a single well slug pump test was conducted on piezometer EMDMRP-2 (Figure 1). The results from all of the pump tests are discussed in the results section of this report. The Excel files for these pump tests are dmpw32.xls and Dmrp-2.xls.

\section{Objective 7. To determine timing and amount of groundwater recharging into the Umatilla River.}

Approach: Develop an operational groundwater model of the project area. An initial groundwater model will be developed, with existing data and many assumptions, to guide the location, timing, and quantity of recharge water. The model will help to identify potential recharge locations and will provide a means of estimating the timing and quantity of return flows from a given application point.

The operational model will be calibrated to this data and further used for the full application of water. A properly calibrated model can be used for quantifying project return flows and timing, particularly if the positive inflections of water cannot be demonstrated with the well network near the river. 
This task is one of the most important tasks that we have performed on the project and we have accomplished a great deal relating to the model. Progress on these tasks is discussed below. Results from the modeling are discussed in the Results portion of this report.

Task 7.1. Based on the measured data (i.e. pump tests and water levels) use GMSMODFLOW software to develop a preliminary model of groundwater movements.

Task 7.2. Refine and calibrate groundwater model by acquiring new groundwater data to match the actual field data.

The MODFLOW model of the Echo Meadows is an important task for several reasons:

- The calibrated/operational model provides the best "proof" that the aquifer recharge project will be successful (or is successful) for increasing groundwater return flows to the river. This is because, particularly during the initial phases of the project implementation, there will not be enough increase in groundwater return flows, that they can be measured by stream gaging.

- The calibrated/operational model provides the best means of optimizing the timing and emplacement of recharge water to improve the timing of the groundwater return flows.

A considerable amount of effort has been placed on development of the groundwater model. As previously discussed, data from this project was used to develop, in part, the BOR's Lower Umatilla River Basin MODFLOW model. This calibrated regional model, in turn, was used in this project, as our calibrated/operational model of Echo Meadows and the associated reaches of the Umatilla River.

A discussion of the modeling activities that were completed for the Echo Meadows project is found in the Results section of this report.

\section{Objective 8. To detect change in land-use activities in the Echo Meadows area and measure the thermal variations within the Umatilla River.}

Approach: Conduct aerial infrared survey of all of Echo/Umatilla Meadows lands to establish baseline maps and land-use activities. For best results, digital near-infrared system will be used. Data from this survey will help identify the extent of existing land use, wetlands, ponds, etc. and will determine the impact of artificial winter recharge on the landscape. GIS software was used to establish baseline map.

Conduct required aerial infrared surveys of the Umatilla River. Aerial surveys will consist of thermal infrared survey for temperature measurements along the entire river length and width in the project boundary area. These surveys will help in establishing the baseline, identification of cold water refugia sites, and identification of any potential 
anomalies in the river. All aerial surveys will be conducted at optimal times so that cold water seeps and hot spots can be best identified.

Data from temperature recorders will be used to field calibrate the aerial survey data. Based on the first year's aerial survey, additional river temperature measurements may be added.

The infrared surveys and synoptic measurements of river temperature will establish points of discharge (cold water refugia) along the southern shore of the Umatilla River. Temperature data logger units (DEQ qualified devices) will be installed in the selected locations to measure river temperature on a 30 minute intervals. Control loggers will be installed above the target reach, in both the river and in the Westland Irrigation Districts distribution system. Several loggers are installed throughout the river in the target reach. This data shall be used in conjunction with historical drain return flow data provided by the Pendleton Watermasters office.

Task 8.1. Conduct one aerial near infrared survey of lands within the Echo and Umatilla Meadows.

A copy of the infrared survey of the Meadows is seen on figure 1 of this report. The infrared survey was Georeference to remove distortion and so that it could be used as a registered basemap in our geographic information system (GIS). This file named cir_2001_4.img is found on the enclosed CD.

Task 8.2. Conduct 3 aerial thermal infrared surveys of the Umatilla River.

IRZ conducted 3 thermal surveys along the lower Umatilla River (upstream of the city of Echo to confluence with the Columbia River). They were conducted on August 8, 2001, October 10, 2001 (am), and October 10, 2001 (pm). Example graphics from this survey are found in the Results section of this report. The water temperature interpretations from the flights were further calibrated with our water temperature data logger. GIS shape files are found in files 10-01am line.shp, 10-01pm line.shp, and 8-07 line.shp found on the CD.

Task 8.3. Calibrate the aerial thermal infrared survey with field data (i.e. dataloggers).

This task is discussed above and Appendix C.

Task 8.4. Install temperature dataloggers in the Umatilla River.

Four water temperature dataloggers were installed in the Umatilla River during 20002001. The locations (DMRP-1R, DMRP-2R, DMRP-3R, WD-1) the loggers are shown on Figure 1. Computer files of the database are included as Excel spreadsheet files containing DMRP-1R and WD-1 is in temploggres oct 2001 - dec 2001.xls and temploggersnov2000-oct2001.xls on the accompanied CD. Two dataloggers were 
installed in the Umatilla River and were washed away and the data was lost.

Task 8.5. On a monthly basis download temperature from data loggers.

This task was accomplished as discussed in Task 8.4 above.

Task 8.6 Obtain data from loggers owned by other entities (Oregon Water Resources and Oregon Department of Environmental Quality).

At this time, we have identified that Idaho DEQ and the Confederated Tribe of Umatilla Indian Reservations has additional temperature data loggers along the river. At this time, we have not exchange logger information. However, we have offered our temperature data to CTUIR to assist their water quality modeling efforts (Kate Ely, CTUIR, personal communications- October, 2002).

\section{Objective 9. To determine if there will be adverse impact to water quality of the groundwater and Umatilla River as a result of recharge.}

Approach: Collect water quality samples on a quarterly basis at 5 groundwater and 3 surface water sites. Water quality samples includes: ph, conductivity, temperature, nitrate, phosphorus, and fecal coliform. These tasks are discussed jointly in Task 9.4.

Task 9.1. Collect sampling bottles for a qualified laboratory.

Task 9.2. On a quarterly basis collect water quality data ( $\mathrm{ph}$, conductivity, temperature, nitrate, phosphorus, Fecal Coliform) at a maximum of 9 sites, using procedure prescribed by Oregon Department of Environmental Quality.

Task 9.3. Take samples to the laboratory for analysis.

Task 9.4. Input and analyze water quality data.

Quarterly water quality samples from five groundwater stations and three surface water stations were analyzed for bacteria (coliforms), nitrate, and phosphorous. The results from the sampling program are included in Excel file $\underline{Q}$ Water Quality.xls on the $C D$ and are completely discussed in the Results section of this report. A summary of the results indicates that the groundwater is of good quality and is low in nutrients and bacteria, thereby suggesting that fertilizer migration to the aquifer is not an issue. In addition, the analysis shows that augmenting the groundwater flow would be helpful to the water quality in the Umatilla River.

\section{Objective 10. To determine the quantity of water in the Umatilla River}

Approach: River hydrograph data will be collected from the existing river gages. 
Task 10.1. On a monthly basis retrieve hydrograph data (river flows, diversion for Irrigation Districts) from the US Bureau of Reclamation website.

Task 10.2. Input and analyze data.

There are two stream gages that are in the project area and are extremely useful in the evaluation of this project. They are:

- UMDO-Umatilla River below Dillon Dam and

- UMBO-Umatilla River below Butter Creek

UMDO, during the irrigation season, often shows essentially zero flow as all of the Umatilla River is diverted for irrigation. UMBO (and the Maxwell diversion and Stanfield Drain) record the return flows from the Echo Meadows area. The BOR has recorders in these gages that indicate the daily flows at those stations and are available on their web site. These recorders are for operations purposes and are not entirely reliable, but make available near real time data.

The Water Resources Department (WRD) maintains these stations for the BOR and improves the record quality. The WRD's information is available on their web site, but only after several months have past.

Because the information is so readily available in the web sites, we have not made our own measurements at these sites. We will download the data, as necessary, for our future work on the project, particularly during the project implementation phase.

\section{Objective 11. To quantify the inflow into the Umatilla River}

Approach: Monitor return flows in the drains within the Echo and Umatilla meadows.

Task 11.1. Identify all irrigation and natural drains into the Umatilla River.

We have identified all of the major irrigation and natural drains into the Umatilla River in this reach and identified in Figure-1 as Culvert\#1, Culvert\#2, Culvert\#3, Ditch\#1 and Stanfield Drain. We have also identified the locations where the WRD made their synoptic measurements during 1985-86 and 1991-1997 and identified as DrainA and StanDitch which were located in the vicinity of monitoring site Stanfield Drain.

Task 11.2. Measure and record water heights at each drain.

On a weekly basis, we measured the water heights at these drains at locations that have a correlation between gage height and discharge. The drain height measurements are included in the Excel spreadsheet Drains2001.xls which is found on the CD. 
Task 11.3. Calibrate flow rates by measuring water heights at various stages.

We have made the necessary calculations so that we can convert the gage height to discharge. We have not yet made those conversions in our database.

Task 11.4. Input and analyze flows from the drains.

With the exception of a few direct flow measurements of the Stanfield Drain, we have not yet made the conversions between gage height and drain flows. See task 11.3 above.

\section{Objective 12. Analyze GIS work.}

Approach: All images will be inputted in ArcView GIS software for further analysis. Images will be referenced to visual data. We will search for cold water areas.

Task 12.1. Geo-reference each near and thermal infrared image to the real world.

Task 12.2. Input all near infrared images into GIS.

Task 12.3. Input all thermal infrared images into GIS.

Task 12.4. Do GIS analysis showing "cold water refugia" or other points of interests.

All GIS work has been completed. Infrared images have been geo-referenced and are found as shape files 10-01am line.shp, 10-01pm line.shp, and 8-07 line.shp on the CD. Results from this task are discussed in the Results section of this report.

\section{Objective 13. Report results.}

Approach: A progress report will be prepared before December 1, 2001. The Final report will be prepared and delivered by Before March 31, 2002. These tasks are discussed jointly in Task 13.4.

Task 13.1. Provide to BPA a draft report within 60 days and a final report within 90 days after the end of contract. Report shall include all documents and data gathered as described in tasks listed above. Data will establish the baseline (pre-water application) condition of the Echo Meadows Winter Artificial Project. Data will be in hard copy and/or electroic format when possible.

Task 13.2. Provide a list of project cooperators, and places of use.

Task 13.3. Provide maps, photos, and GIS data illustrating the above-mentioned tasks. 
Task 13.4. Summarize and provide graphical and tabular data sets on water quality, groundwater levels, soil moisture, river/canal temperatures, weather station data, river stage records and the aerial infrared surveys.

A progress report was submitted to BPA on January, 2002. This 119-page report was also made available electronically on IRZ's web site so that interested parties could download the report. It proved to be too large to email.

Although the progress report was fairly well received, the appendices did not prove to be useful because they were only available in a text format. In this final report, we have rectified that problem by referring readers to specific database files that are available on the CD (the main text of this report will be available in both printed form and on IRZ's web site.

The final report is later than our task approach said because our project staff was working on the groundwater model for BOR, as previously discussed. The scrutiny that this model received and the scope of the model was much greater than that we had anticipated for this project. The result, however, is a model that can be used for project operations as we begin the next phase (project implementation).

In the sections that follow are discussions of the results from this initial phase of data collection. 


\section{Results}

\section{Report Findings}

The initial phase of the Echo Meadows project was primarily related to data collection. Most of our findings are related to the data, such as groundwater levels over time and comparisons of groundwater and surface water quality and temperature. As a result, much of the value of the project is found in the Excel databases referred to in this report and included in the CD that accompanies this report.

In the sections that follow we discuss the data and provide example figures that help in our explanation. However, there are many more graphics contained in the spreadsheets and additional elements of the data that can be gleaned from these spreadsheets.

Much of the data that was collected was done so to support the input and the conclusions of our groundwater model. The model provides much of the support needed to support our conclusions that the project implementation phase is needed and will be successful. The conclusion from the modeling (and in general from the data collection phase) follows at the end of the next section.

Our major project conclusions include:

- The Echo Meadows area presently discharges approximately 10-20 cfs to the Umatilla River during the irrigation season. This discharge compares to 20-25 cfs during the 1980's and as much as $45 \mathrm{cfs}$ during the 1950's. Recharging the Alluvial Aquifer to 1950 conditions is the long term goal of this project.

- Echo Meadows area discharge diminished during this time due to lower application rates of water and the development of groundwater water rights in the area.

- Echo Meadows recharge during the pre-irrigation portion of the year will be practical and will result in an increase in Umatilla River flows during the times that are desirable (June-October).

- The water quality associated with the recharge project will be significantly colder and of (generally) better water quality than the water in the Umatilla River.

- Groundwater modeling of the Echo Meadows area indicates that water applied during the pre-irrigation season will augment stream flows in the summer and early fall. A calibrated and verified model, using both base conditions and trial applications, provides the best short-term method to verify that the Echo Meadows Recharge Project is a viable and cost effective method of enhancing summertime and early fall stream flows. However, when the project has been fully implemented and groundwater levels increase to their historic levels, it will be possible to show the effect of the project through streamflow measurements along the Umatilla River. 


\section{Description of the Project Area and Project Description}

The Echo Meadows Project is a groundwater recharge project that has the ultimate purpose of augmenting summer-time stream flows on the Umatilla River by increasing groundwater discharge. A considerable secondary benefit is that the groundwater that is discharged to the river will have a substantially lower water temperature than the receiving waters. These dual benefits of increased and colder river flows will be beneficial for fish habitat and migration and for improvements of water quality.

Echo Meadows (meadows) is located between river miles 16 and 26.3 on the Umatilla River near the towns of Hermiston, Stanfield and Echo, Oregon (Figure 1). It is bounded to the south by the Hunt (Westland) Canal, to the east and north by the Umatilla River, and to the west by Service Butte. The Butte is basaltic bedrock that separates the meadows from Butter Creek to the west. The meadows are approximately 9,600 acres in size.

The meadows area has been geologically interpreted as river alluvium by the Water Resources Department (Department of Environmental Quality, 1995). In the geologic past, the Umatilla River has cut through the area, leaving river channel cut and fill deposits, where lenses of clean sands and gravels of limited size (less than 100 feet in width) may be surrounded by poorer sorted and/or finer sediments. Based on well logs, sediments may extend to 70 feet or more in depth. In many portions of the meadows, the upper portion of the aquifer consists of a wind blown silty-sand (loess) deposit that may extend to depths greater than 15 feet.

This 9600 acre, 70 feet deep river deposit constitutes the aquifer that will be recharged. At present, the Echo Meadows area is saturated to within about 5-15 feet of the ground surface during most of the year. The unsaturated zone is further reduced by irrigation recharge-leaving in some areas, only a few feet of unsaturated soils during the irrigation season. However, the aquifer is not as fully saturated as it could be or has been. Longtime farmers in the area have shown us several areas of considerable acreage that use to be wetlands. They are now dry.

The hydrology of the meadows is also influenced by portions of the Teel Irrigation District, which is directly south of the meadows. The Teel Irrigation District is composed of nearly 7,700 acres of center pivot irrigation. Groundwater losses from these circles enter the meadows from the south.

Our groundwater modeling of the area demonstrates that a loss of only about 5 feet of saturated thickness could have reduced groundwater discharge in the area from about $45 \mathrm{cfs}$ to less than $20 \mathrm{cfs}$ during the last few decades.

Our main project objective is simple: We will use the existing irrigation delivery system (Westland Main Canal and supplemental canals) to deliver water to our cooperator's flood irrigation fields outside of the irrigation season (December-February). A list of our cooperators and their potential acres are shown in Appendix B. 
This newly-introduced water will be in addition to the irrigation rights in the area. In addition, we will flood some wetlands in the area until late April, at which time water from the Umatilla River flows are not available under our limited license.

This surplus of water will fill the aquifer more completely than at present. Higher groundwater levels will, in turn, result in higher groundwater return flows to the Umatilla River.

The timing of these augmented groundwater return flows should be fortuitous for resident and migrating species- early June through late October. This is because the high river stage associated with the high flows (November through May) acts as a "groundwater dam" thereby limiting most groundwater recharge outside of this period. When the river stage drops during the irrigation season, the groundwater dam is lowered and groundwater recharge increases.

The groundwater temperature is much cooler than the receiving water in the Umatilla River. Our data shows that the groundwater temperature is below $60 \mathrm{~F}$ during the summer. The Umatilla River temperature may exceed 80F. By increasing the groundwater recharge, we will decrease stream temperatures- particularly at the location of the numerous seeps in the area.

\section{Echo Meadows Water Rights, Diverted and Applied Water, and Historic Return Flows to the Umatilla River.}

It is not strictly necessary to know the number of irrigated acres and their duty to achieve a successful recharge project. However, by knowing the history of the diverted water and recharge to the Umatilla River, we can better estimate the importance of the recharge project after it is fully implemented.

Although the size of Echo Meadows (9,600 acres \pm ) can be measured, the number of acres that are irrigated and how much irrigated water that they receive is less well known. This is because the meadows have a mix of federal and state water rights. An irrigated parcel may receive federal live flow water, federal storage water (from McKay Reservoir), and/or state groundwater.

Computer spectral imagery of satellite data completed for the Bureau of Reclamation (BOR) showed that essentially all of the acres in the Meadows are irrigated. However, many of the acres in these photos when field checked are sub-irrigated (water table near the surface) and do not receive irrigated water. Federally recognized surface water rights (BOR, 1989) in the Meadows total 3,601 acres including:

- Allen -958 acres

- Courtney- 1,113 acres

- Pioneer- 860 acres

- Dillon- 670 acres 
We believe that the federally recognized estimate is a good approximate of the surface water rights in the Meadows.

The Water Resources Department (WRD) database (see Draft Progress Report, 2001 Baseline Analysis Appendix E), indicates that approximately 2,000 acres have groundwater rights only and an additional 740 acres have supplementary groundwater rights (they have primary surface water rights). Therefore, the number of total irrigated acres in Echo Meadows would be approximately 5,600 acres.

The amount of water diverted and used in Echo Meadows is also difficult to estimate. Very few of the acres have reservoir rights. CH2MHill (1999) estimated that the Meadows received about 5,000 and 6,000 acre-feet per year of surface water and groundwater respectively or about 11,000 acre-feet per year. However, their diversion records were for Allen and Dillon gages only (they did not locate, or know about, the Pioneer-Courtney diversions.

Water use may be estimated based on water rights. The federally recognized acres in Allen, Courtney, and Pioneers are senior enough that they typically should receive their full duty (4.5 acre-feet/ acre). Many of the acres in the Dillon District (north of I-84 in Figure 1) have supplementary groundwater rights and may only receive 2 acrefeet/acre of surface water. Therefore, based on a water rights assessment, it may be expected that 14,530 acre-feet per year of surface water would be diverted to Echo Meadows.

Groundwater irrigation is more effective than surface water (flood irrigation) and their duty is generally restricted to 3 acre-feet/acre. If we estimate that the 2,000 acres of groundwater rights (no surface primary rights) receive 6,000 acre-feet of water and the 740 acres of supplementary groundwater rights receive 1 acre-feet/acre/year. This means that groundwater use in Echo Meadows is approximately 6,740 acre-feet/acre. The total amount of water diverted and applied or pumped and applied is about 21,270 acre-feet per year, based solely on water rights.

Historic diversion records of the Allen, Pioneer-Courtney, and Dillon Canals show that the average Echo Meadows surface diversions is approximately 14,200 acre-feet/year, closely matching estimates based on water rights. However, the trend of the diversions has dropped from 14,000-16,000 acre-feet/acre/year before the late 1970's to less than 12,000 acre-feet/acre in the 1990's as seen in Figure 2. This is a decrease of nearly 1 acre-feet/acre/year.

This reduction in surface water diversions shown in Figure 2, has been largely offset with groundwater pumping and use since the 1970's. Therefore, the rate of applied water has probably remained fairly stable. However, the pumping of groundwater depletes the aquifer. If we assume that groundwater irrigation is $90 \%$ efficient $(10 \%$ returns to the aquifer), then the 6,740 acre-feet of annual groundwater pumping could deplete the aquifer discharge by about 6,060 acre-feet/ac/year. If all of the losses to 
groundwater occur during the 150 day irrigation season, then the groundwater discharge to the Umatilla River could decline by 20 cfs.

\section{Echo Meadows Historic Diversions}

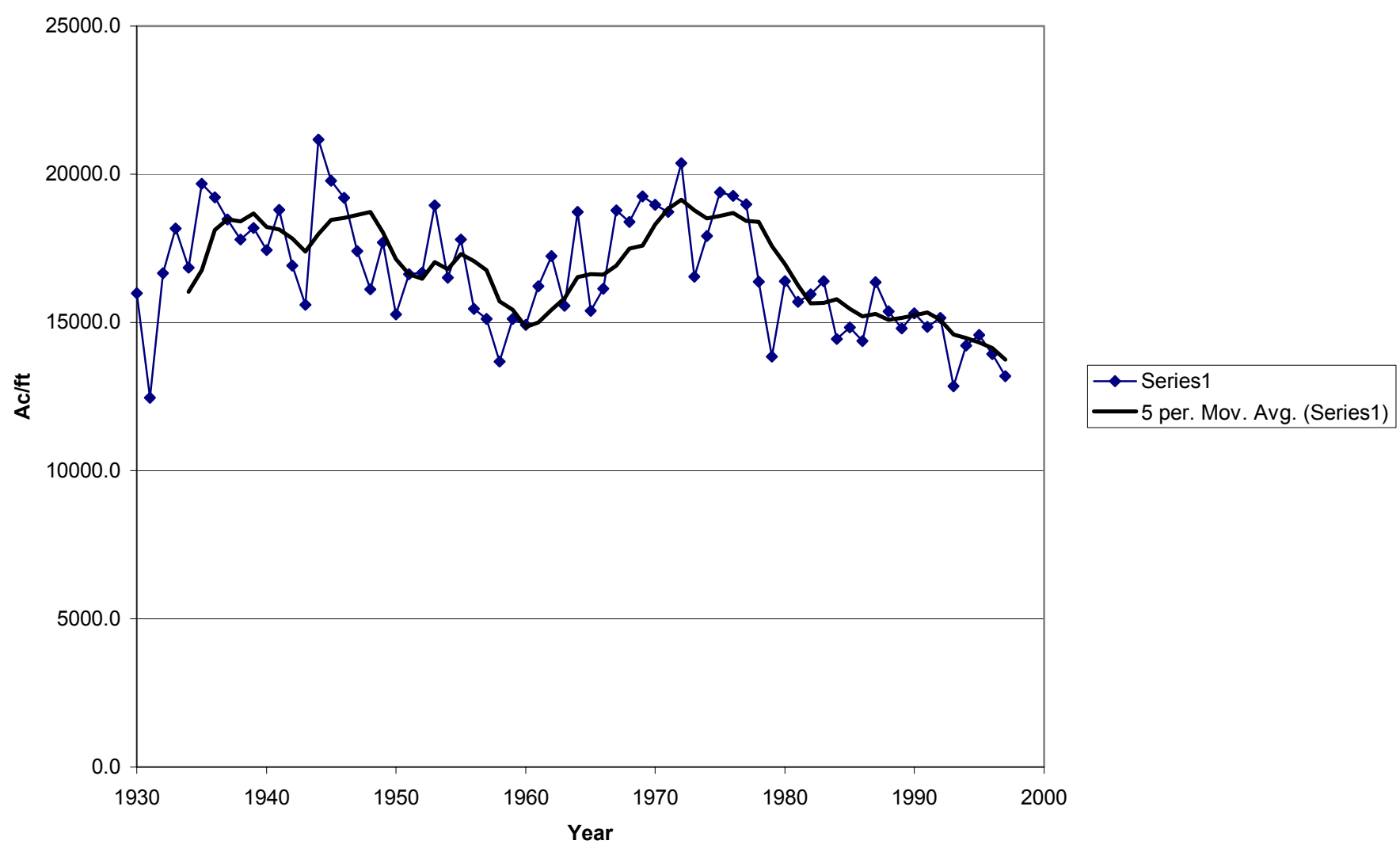

Figure 2. Echo Meadows surface water diversions. 


\section{Historic Return Flows}

It is generally impossible to determine how much return flow can be attributed to a given reach of a river- much less the changes in return flows over time. Echo Meadows is different because during most of the irrigation season, the entire river flow is diverted into irrigation canals. As a result, the river flow is essentially zero after the Dillon Canal Diversion (RM 23). The flow then increases to a few tens of a cfs along the Echo Meadows reach, and is finally re-diverted at the Maxwell Diversion at RM15.4.

Return flows over time can be determined because the WRD took synoptic measurements at the canals and ditches and at several locations along the main stem in 1985-86 and 1991-97. These measurements became much of the basis for our understanding of the location and magnitude of return flows along the Umatilla River.

The WRD, in their 1991 publication of the 1985-86 data showed that return flow from Echo Meadows was about $20 \mathrm{cfs}$. When they re-measured these same locations in the 1990 's the return flow appears to have dropped to around $10 \mathrm{cfs}$. These reductions in return flow measurements can be seen on IRZ (2002, Figure 2). Ely (2000) indicated that return flows from the Meadows was probably about 35 cfs during 1980, from Corp of Engineers measurements that were essentially similar to the WRD's.

Using these historic measurements and combining this information with recently rediscovered measurements of the Stanfield and South Hermiston drain, Graham (2002) determined that return flows from Echo Meadows probably peaked in the 1940-1970's at about $45 \mathrm{cfs}$.

The results of the historic study of water diversions and return flow measurements provides proof that the historic decrease and the potential increases of return flows from Echo Meadows may be as great as $35 \mathrm{cfs}$.

In the short term (next 2 years), outside of the groundwater modeling it will be impossible to measure the increase in groundwater discharge to the river from an initial trial application of recharge water because the amount of water to be applied is slight compared to that required to restore the return flow from the Meadows. However, when the project is fully implemented and groundwater levels have fully recovered we may be able to measure the impacts of the project in the river through conventional stream gaging measurements as well as increased groundwater levels.

\section{Project Coordination and Implementation}

To combat these reductions in return flows, IRZ Consulting proposed to augment the recharge of the Alluvial Aquifer by flood irrigating agricultural fields before the beginning of the irrigation season when Umatilla River flows exceed minimum stream flows for fish rearing and migration (December through February). Water applied during this time and at distances of 0-4 miles from the river is expected to discharge to the Umatilla River during the summer and fall, thereby improving streamflows during this critical season. 
Because the water will be filtered though the Alluvial Aquifer, it is expected to be of better quality and lower temperature than the Umatilla River at that time.

The project sponsor (Oregon Water Coalition) secured a WRD Limited License \# 00225, which provides for as much as 10,000 acre-feet of water to be diverted from the Umatilla River and applied to agricultural fields in Echo Meadows.

The recharge of the aquifer through flooding of these fields is a cooperative effort of several groups including:

- Land owners-provide the land for flood irrigation and much of the manpower to flood irrigate the fields,

- Westland Irrigation District- who will provide for the diversion and transmission of the water to be applied,

- Oregon Water Coalition who sponsored this project,

- Columbia Water Trust who funded the 1999 pre-baseline evaluation,

- Water Resources Department- who approved Limited License and provided invaluable information regarding the aquifer recharge program and the geology of the Echo Meadows area,

- Department of Environmental Quality- the approving organization for the Water Pollution Control Facility Permit, and a funding agency for 2000 water quality measurement,

- US Bureau of Reclamation, who funded our 2000 pre-baseline evaluation as well as additional funding for groundwater modeling,

- Bonneville Power Administration- who provided funding for the base line data collection portion of the project, and

- Northwest Public Power Council - who approved the funding and conducted the initial evaluation, also provided the fisheries expertise (ISRP) in approving the intended scope of this project.

In the sections that follow, we discuss the activities that were performed during this initial stage and the findings that resulted from our tasks.

\section{Relationship to Other Projects}

Although this project is desirable for its merits, it also benefits and benefits from, other projects. For example:

- USGS (1991 and 2000). These regional groundwater projects that were undertaken by the USGS show the benefits of a history of irrigated agriculture in recharging alluvial aquifers and augmenting stream flows in eastern Oregon and Washington. This augmentation of flows is somewhat contrary to the prevailing theories about irrigated agriculture. Our project utilizes some of the same techniques (groundwater modeling) and data inputs as these regional studies. In turn, our project will provide more refined and conclusive data than is what possible using a broad-brushed regional approach. 
- BOR- Umatilla Project (1988-present). The BOR was authorized by Congress in 1988 to develop the water resources of the Umatilla River for irrigation and fisheries enhancement. Current activities of the BOR has been to use Columbia River flows in lieu of Umatilla River flows for irrigated agriculture and enhancement of targeted stream flows during fish migration. The BOR has developed an extensive Geographic Information System (GIS) database of the lower Umatilla River that has been invaluable for the development of this project. In return, this project may serve as a low cost, efficient mitigation project for the irrigation districts as they seek to expand their authorized federal boundaries. Data developed during the implementation of this Echo Meadows project was used to calibrate and verify the BOR's groundwater model of the lower Umatilla Basin (Graham 2002b). In turn, the BOR's model was used to generate model results discussed in this report.

- Department of Environmental Quality (1995). This Groundwater Management Area study concentrated on the groundwater quality of the lower Umatilla River Basin (including Echo Meadows) with a special emphasis on nitrate contamination. This 1995 study provided vital geological and hydrological analysis that was used in the Echo Meadows study. In turn, groundwater recharge provides one of the most efficient ways of diminishing nitrate levels in groundwater (through the introduction of dilute surface water to the aquifer).

- Northwest River Studies and TMDL's. Most northwest streams suffer from low summertime flows and from water temperature that is too warm for effective salmon rearing and good water quality. Many watershed studies have recommended stream shading as a means of minimizing water temperature. However, stream shading cannot "produce" water that is lower temperature than the ambient air temperature and cannot "manufacture" more water. A groundwater recharge project is a means of doing both. And, the Echo Meadows project is perhaps the best way to demonstrate that low summer flows and high summer river temperature is not an insolvable problem.

In the sections that follow, we discuss the baseline data collection effort and the analysis of that data, as well as other complimentary data that augmented our study.

\section{Groundwater and Surface Water Level Measurements}

The groundwater and surface water levels were measured largely for input in the groundwater model (MODFLOW) but, they also reveal important clues to the groundwater system in the Meadows.

For example, Figure 3 shows the water level measurements during 2000-2001 at a piezometer that is along the north edge of the Meadows and within a hundred feet of the Umatilla River. As can be seen in Figure 3, the groundwater level was approximately $10 \mathrm{ft}$. below ground surface on January 2000 . The water levels rose with irrigation and river stage to 6 feet until mid-April. The water level then declined until mid-August when 
it again began to rise. The drought of 2000-2001 really started to show and water levels then decreased to below 10 feet during the winter of 2001.

Perhaps reflecting the drought of 2001 and low irrigation applications, water levels in the aquifer were approximately 1 foot lower than at the same time in 2001. Water levels have remained low in this well since July 2001.

Depth to groundwater at EMFMRP-1

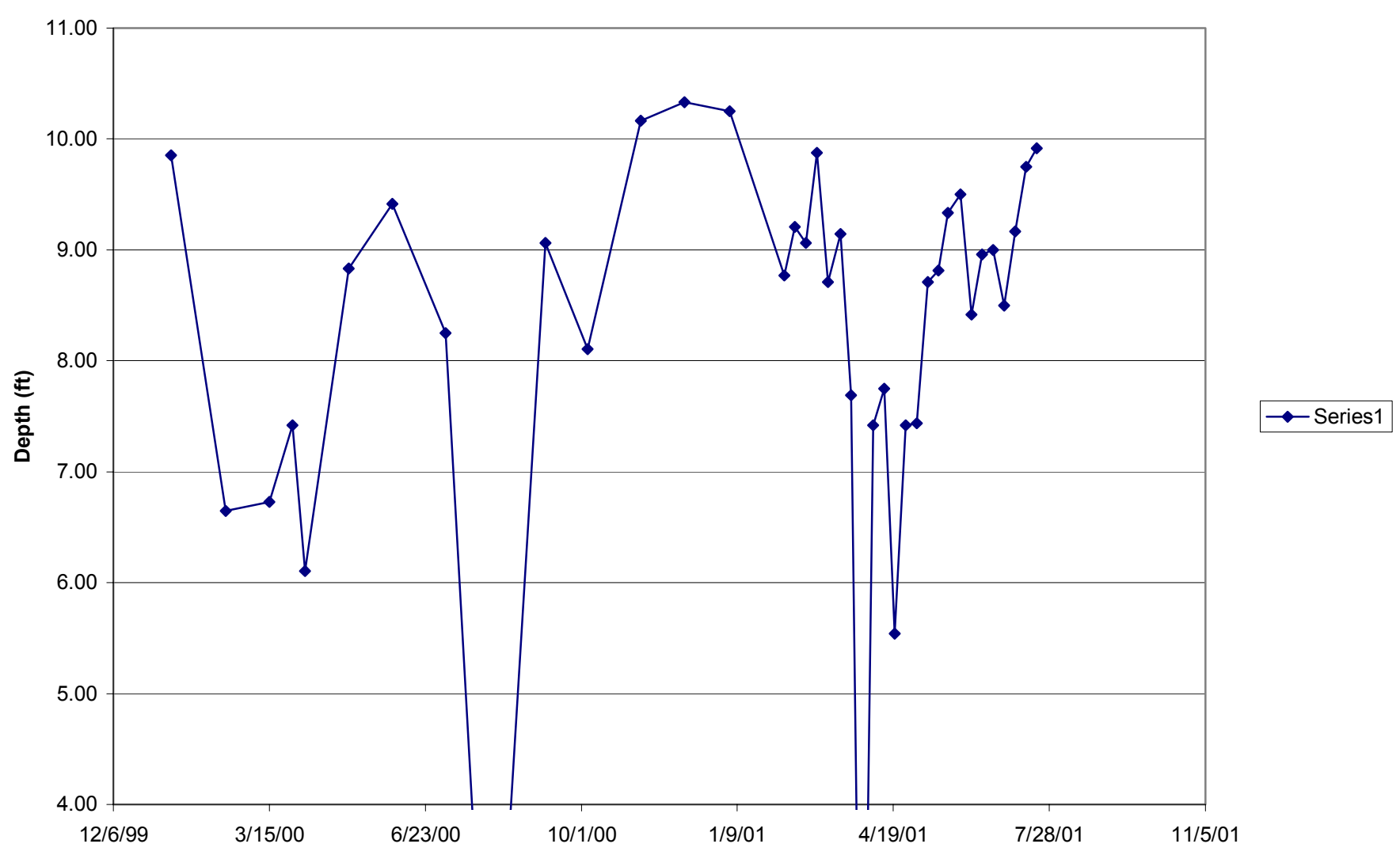

Figure 3. Piezometer water level measurements 
Figure 3 shows a nearly identical pattern to the stage of the Umatilla River (Figure 4). This pattern is reasonable given that the piezometer is so close to the river, but it also demonstrates that water builds up in the aquifer until April or May, when the stage drops. This is important for the recharge project because our water is added early in the year. The relationship shown in Figures 3 and 4 indicate that the water will remain in the aquifer until the spring and summer when the recharge to the river is truly desirable. Some other wells that were monitored that are further south in the Meadows (away from the river) show this same seasonal pattern. However, the seasonal pattern is not as pronounced as wells that are closer to the river.

During, 2001, a data logger/pressure transducer was added to the monitoring network at the ERW-1 well near the northern portion of the Meadows. Weekly measurements were also taken at this well to check on the data logger accuracy and provide a means of correcting the data logger data if necessary. Figure 5 shows a representative plot of the water level form this well. As can be seen in Figure 5, the continuous monitoring of water levels provides some detail of water levels between the weekly measurements. For example, in the period of May 22- June 2, 2001, the continuous recorder shows the effect of a flood irrigation cycle on that field during that time. The logger also show the effect of a nearby pumping well cycles, where water levels were declining during early June (due to pumping) but would temporarily recover when the well was shut off. The comparisons of the two methods of water level measurements were not always good, such as that shown during late April and early June. Some of these differences may be due to operator error of differences in water level instruments which can be seen at the two measurements taken with two different instruments on May 24, 2001.

The continuous water level measurements also provide an indication of the recharge from irrigation to groundwater. For example, during the period from approximately July 1 to July 31 , water levels rose in the ETW-1 well from about 11 feet to 6.5 feet. This time period was also punctuated by 2 pumping cycles. Separating these pumping cycles from the long term trend (much as a flood hydrograph is separated) it appears that as much as 10.5 feet of groundwater elevation gains can be attributed to irrigation. If the specific yield of the soils in the area is 0.20 , this means that 2.1 feet of water reaches the water table. If this area received 4.5 feet of water during the irrigation season, then the recharge to the aquifer would be about $47 \%$ of the applied water. Of course, this area also receives groundwater from up-gradient sources and the effects of pumping cannot be easily separated, but this is a reasonable percentage for aquifer recharge from flood irrigated fields (OSU, 1992).

Excel Files Prior Well 0417-0620, Prior Well 0620-0727.xls and Prior Well 07270905.xls includes the water level database from 2000-2001 for the Prior well continuous recorder. Excel Files Piez00-01.xls, Pitwell00-01.xls, and Well01all.xls show the monitoring measurements from the wells that were monitored on a weekly basis. 
Umatilla River Stage and Temperature

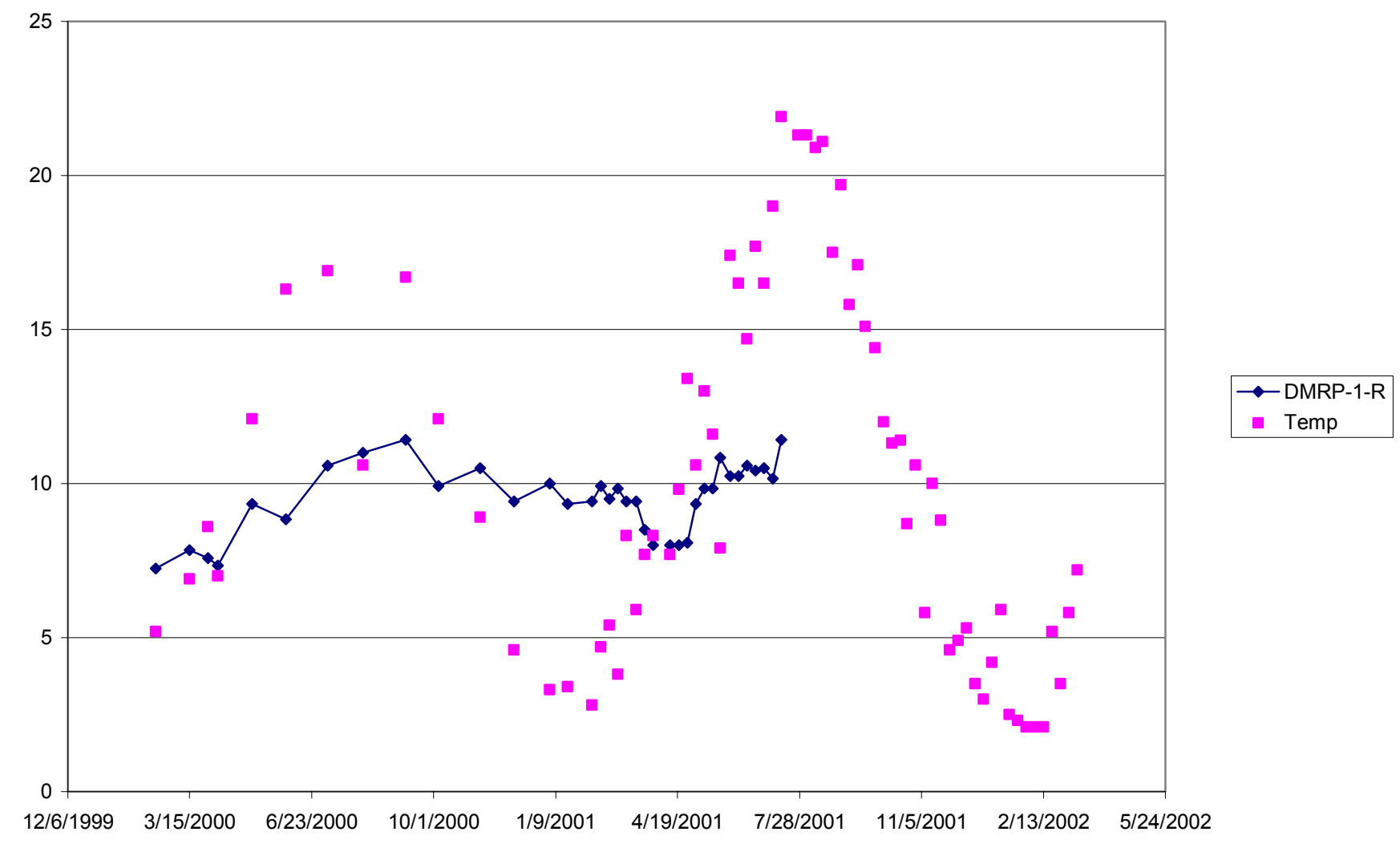

Figure 4. Umatilla River Stage 
Prior Well Water Levels

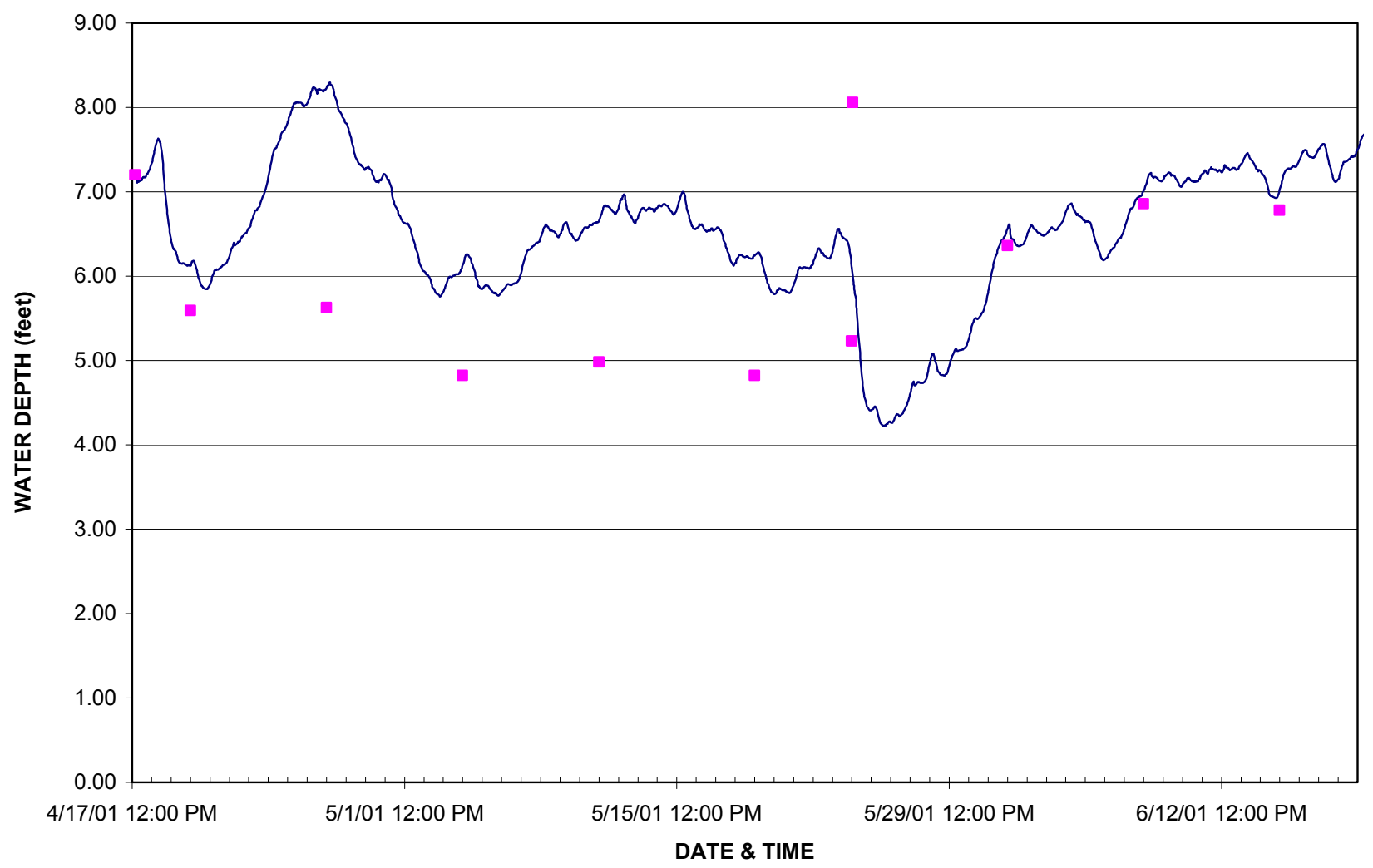

Figure 5. ERW-1 well continuous water level measurements. 


\section{Soil Moisture Measurements}

IRZ collected soil moisture data on a weekly basis at nine sites from August 1998 to March 2002 (not all sites had this extensive of a period of data collection). We collected the data using a neutron activation device that allowed us to measure the soil moisture at 1 foot intervals throughout the season. The database for the soil moisture and graphs for all nine sites can be found in Excel File Soil moisture.xls. Figures 6 and 7 show examples of the database graphed on an annual and a period of data collection basis, respectively. As can be seen on Figure 6, the top four feet of the soil column losses much of its soil moisture during the irrigation season. The top two feet probably approach the wilting point by late August. The three and four foot levels (below the root zone) show only three periods of irrigation from early June to late July that appear to recharge the water table. However, the third irrigation cycle (near the middle of July) caused only a subtle change in soil moisture below the root zone.

These graphs (and the Prior Well graph- Figure 5) are significant because they show that virtually all of the recharge to the water table from irrigation occurs before the end of July and most of the recharge occurs before the end of June.

Figure 7 also shows that the maximum soil moisture in the upper three feet of the soil horizon for Stite-6 has diminished from the winter of 2000 to the winter of 2002. What this indicates that by the time farmers start irrigation in March and April they will only irrigate to fill the first 3 feet of profile and as a results, no water are discharged below the root zone (3') and into groundwater. This is very evident in this graph since soil moisture from 4 to 8 feet do not fluctuate much during these years. With a groundwater recharge we start irrigation early in the winter (when there is no evapotranspiration) and saturate the entire soil profile and into the groundwater. 


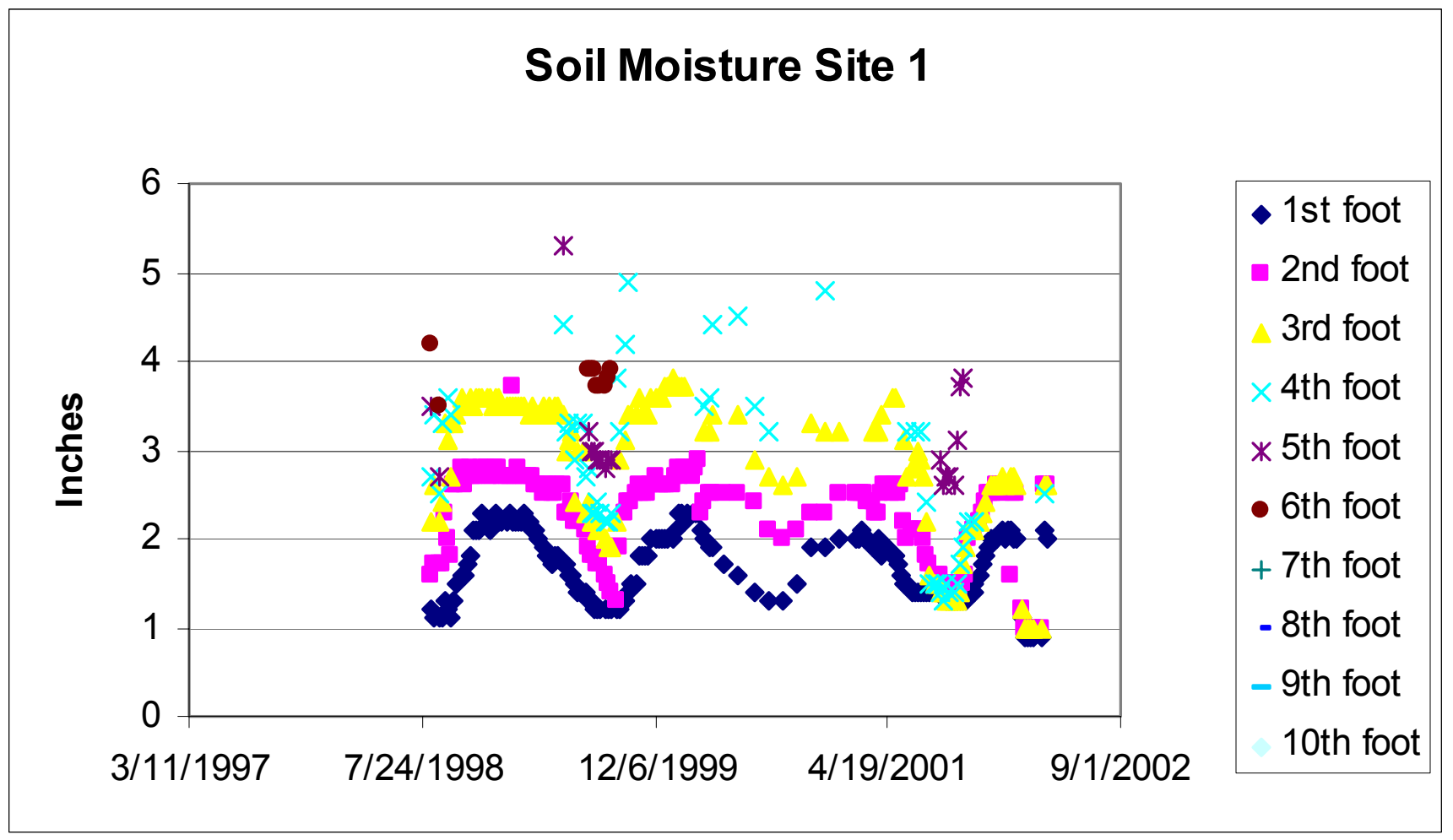

Figure 6. Soil Moisture Measurements, 1998-2002 for BAP-1

Soil Moisture Reading - DMRP-1

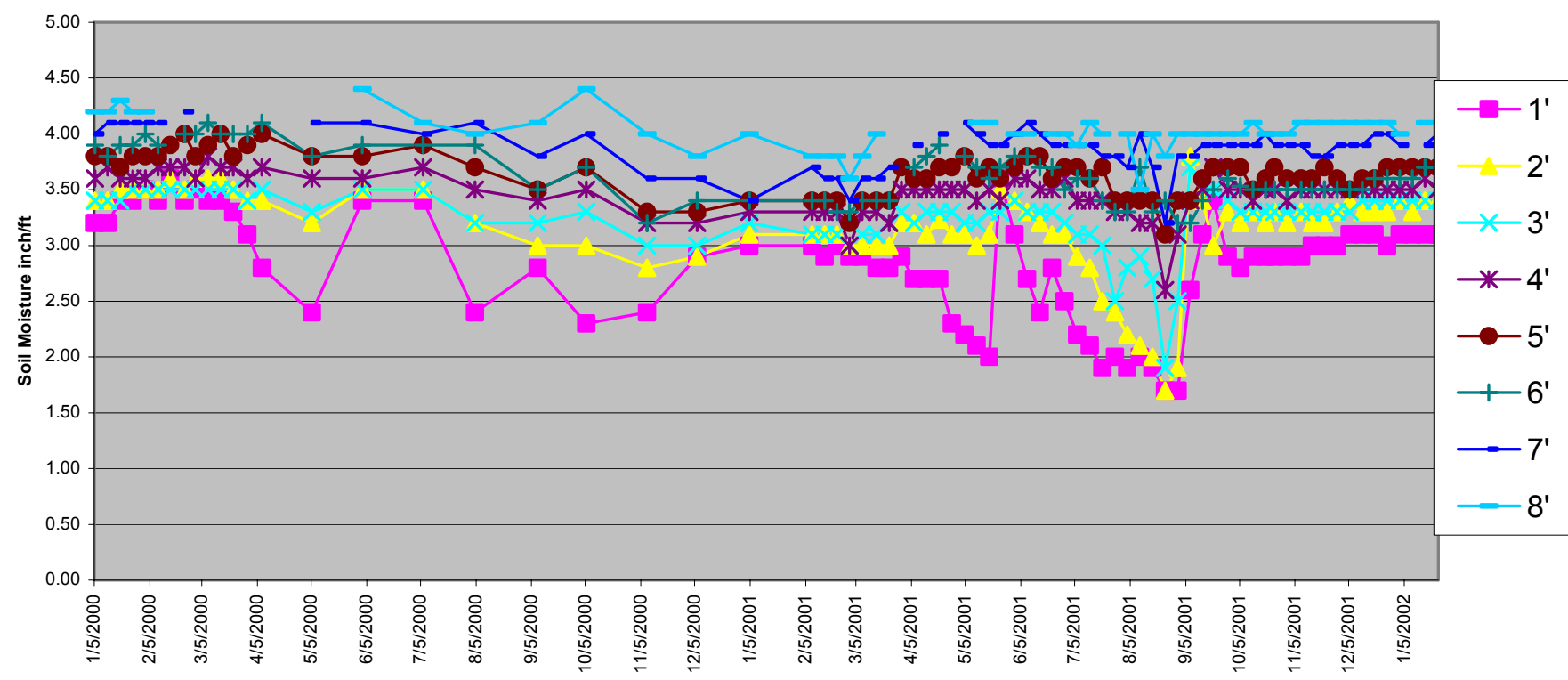

Figure 7. Soil Moisture Measurements-2000-2002 for DMRP-1 


\section{Groundwater and Surface Water Quality Data Collection}

Weekly indicator water quality parameters $(\mathrm{pH}$, temperature, and conductivity) were measured at the 16 groundwater stations and at several locations along the Umatilla River. A copy of the water quality database is included in Excel Files Well01all.xls, Pitwell00-01.xls, and Piez00-01.xls for groundwater and Surface00-01.xls, Surface Station WQ.xls, and $\mathrm{Q}$ Water Quality.xls for surface water. Additionally, half and hour interval surface and groundwater temperature data were collected using HOBO temperature dataloggers that are found in Excel files Temploggers Oct2001dec2001.xls and Templogger nov2000-oct-2001.xls

Certainly, the most important conclusion from the water quality database is how much more uniform is groundwater temperature as opposed to surface water temperature and how much colder the groundwater temperature is during the summer.

Figure 8 shows an example of groundwater temperature from the piezometers at monitoring sites BAP1 and DMPRP-2 as well as surface river water temperatures at EMDMRP1-R graphed from 2000 to 2002 (see data and graphs in spreadsheet Templogger nov2000-oct-2001.xls). In addition, mean daily air temperatures are also graphed. As can be seen in Figure 8 , the groundwater temperature stays fairly constant and ranges from about 54-58 $\mathrm{F}$ at site DMPRP-2 and is a typical of most of the groundwater monitoring stations. The minor fluctuation in temperature is consistent with most of the temperature monitoring station in Echo Meadows. At piezometer BAP-1, the fluctuation is greater, ranging from about $45-65 \mathrm{~F}$. We believe that this greater fluctuation may be due to the effects of surface water irrigation near BAP-1 and a shallow depth to groundwater. 


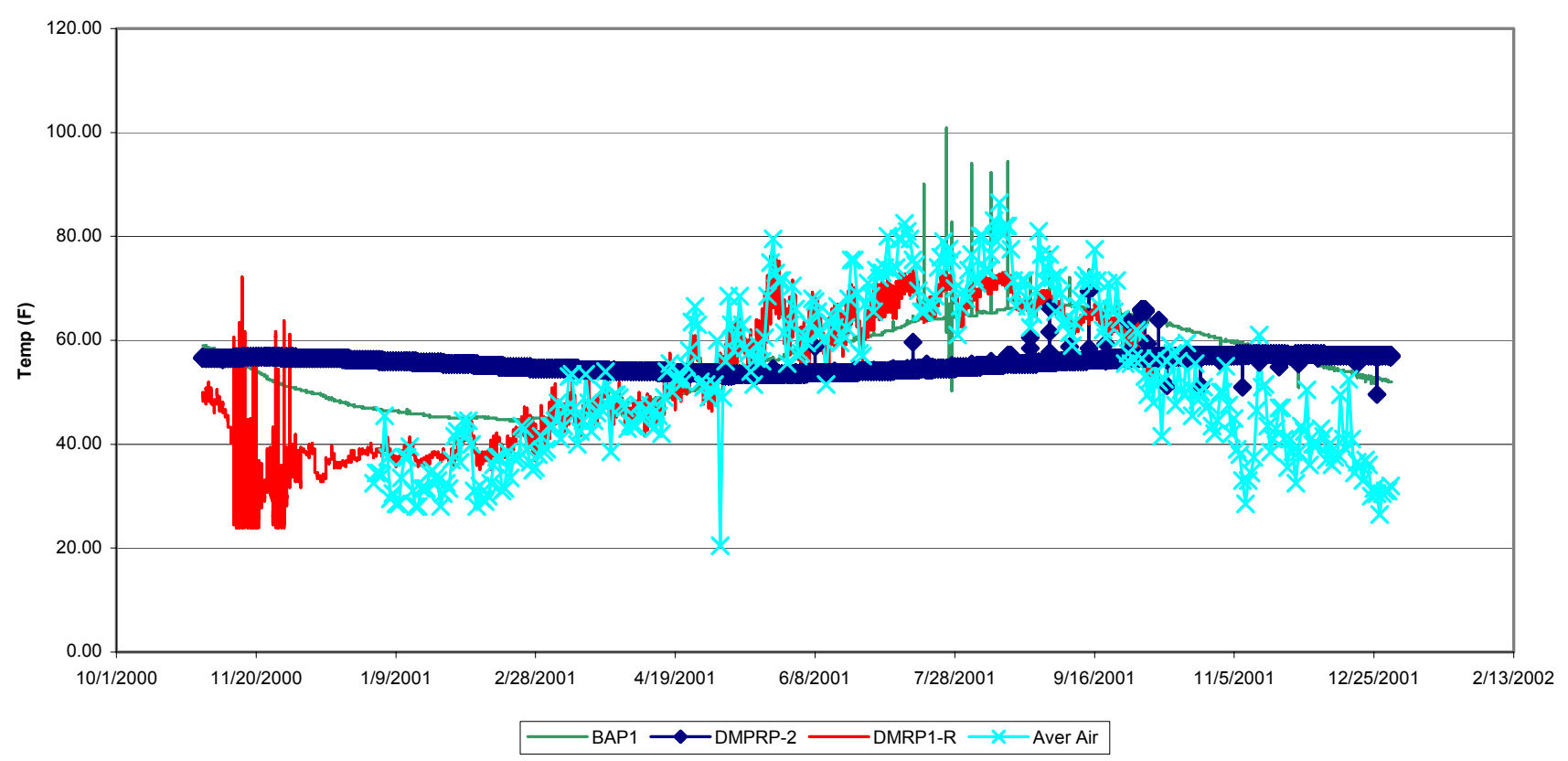

Figure 8. Groundwater, Umatilla River, and Air temperatures 2000-2001

Surface river water temperatures were as high as $75 \mathrm{~F}$ as measured at monitoring site DMRP1-R and as low as 38F. Daily fluctuations were as much as 10F. The surface river water temperature closely followed the average air temperature as seen in Figure 8. This can be best seen during early April in 2001 , when mean daily air temperatures spiked to nearly $80 \mathrm{~F}$ and river water temperature rose to $75 \mathrm{~F}$.

Clearly, this data shows that the surface water temperature will follow and closely mimic air temperatures, thereby suggesting that the Umatilla River may never reach appropriate water temperatures during the summer for fish survival. However, this data also shows the potential ability of the groundwater return flows to cool the Umatilla River, particularly if this project is fully implemented.

It is possible, using the data in (Draft Progress Report, 2001 Baseline Analysis see Appendix E ) to provide a snapshot of a particular parameter throughout the Meadows by contouring the parameter on a given date (or the average of a parameter at a location). An example of this contouring can be seen on Figure 9. Figure 9 shows the average groundwater temperature in the Meadows. The black crosses are the data points (wells) that were contoured. As can be seen in Figure 9, the average groundwater temperature in the Meadows is between about 12 and $13 \mathrm{C}$ (53.6 and 55.5 Deg F). A lower temperature trough may be seen running from southeast to northwest in this figure, perhaps indicating the direction of flow and colder surface water that was used for irrigation or some other factor. 
These contour maps of water quality may provide some hints regarding the groundwater in the Meadows and certainly provide a good indication that the groundwater is of good quality and that enhancing the Umatilla River through recharge of the aquifer would be beneficial for the river.

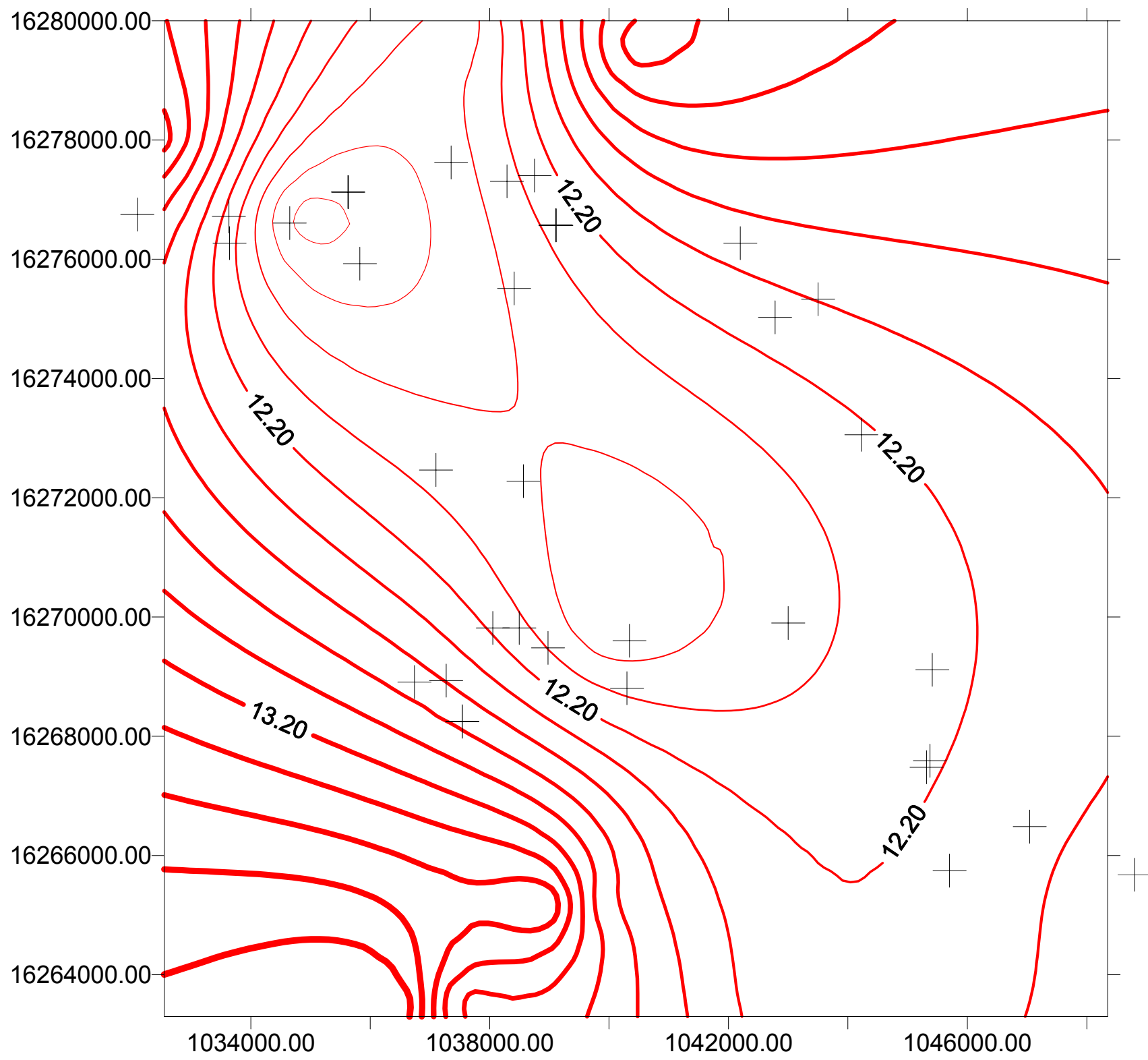

Figure 9. Average groundwater temperature vs. Echo Meadows Area (Longitude and Latitude). 
In addition to the indicator parameters discussed above, a more complete of parameters were sampled and analyzed on a quarterly basis. Samples from five groundwater stations and three surface water stations were analyzed for bacteria (coliforms), nitrate, and phosphorous. Results from the sampling program shown in the following table.

Quarterly Water Quality Sampling Results- Echo Meadows 2001.

\begin{tabular}{|r|r|r|l|r|r|r|l|l|}
\hline $\begin{array}{l}\text { Rec } \\
\text { No }\end{array}$ & $\begin{array}{l}\text { sample } \\
\text { date }\end{array}$ & $\begin{array}{l}\text { site } \\
\text { ID }\end{array}$ & Location & $\begin{array}{l}\text { Fecal } \\
\text { count }\end{array}$ & TKN & $\begin{array}{l}\text { NO3- } \\
\text { N [1] }\end{array}$ & TOTAL P & ORTHO P \\
\hline & & & & & & & & \\
\hline $\mathbf{1}$ & $\mathbf{7 / 1 0 / 2 0 0 1}$ & $\mathbf{2 4}$ & WD-1 [2] & $\mathbf{1 0 3}$ & $\mathbf{6 . 6 2}$ & $\mathbf{0 . 4 1}$ & $\mathbf{0 . 2}$ & $\mathbf{0 . 0 9}$ \\
\hline 2 & $7 / 10 / 2001$ & 36 & PRIORPU & 6 & 5.24 & 3.76 & 0.4 & 0.15 \\
\hline 3 & $7 / 27 / 2001$ & 38 & SNOW & 6 & 0.5 & 0.2 & 0.07 & \\
\hline 4 & $7 / 27 / 2001$ & 8 & FMRP-1 & & 3.6 & 3.1 & 0.6 & \\
\hline 5 & $7 / 27 / 2001$ & 6 & DMRP-1 & 2 & 1.3 & 3.1 & 0.18 & \\
\hline 6 & $7 / 27 / 2001$ & 1 & BAP-1 & 2 & 1.6 & 0 & 0.4 & \\
\hline $\mathbf{7}$ & $\mathbf{7 / 2 7 / 2 0 0 1}$ & $\mathbf{2 4}$ & WD-1 & & $\mathbf{0 . 7}$ & $\mathbf{3}$ & $\mathbf{0}$ & \\
\hline $\mathbf{8}$ & $\mathbf{7 / 2 7 / 2 0 0 1}$ & $\mathbf{1 8}$ & DMRP-1-R & $\mathbf{4 2}$ & $\mathbf{0 . 7}$ & $\mathbf{0}$ & $\mathbf{0}$ & \\
\hline 9 & $10 / 24 / 2001$ & 10 & BAPW-1 & 5070 & 3.53 & 0.12 & & \\
\hline $\mathbf{1 0}$ & $\mathbf{1 0 / 2 4 / 2 0 0 1}$ & $\mathbf{2 4}$ & WD-1 & $\mathbf{5 2}$ & $\mathbf{2 . 8 5}$ & $\mathbf{0 . 1 2}$ & & \\
\hline $\mathbf{1 1}$ & $\mathbf{1 0 / 2 4 / 2 0 0 1}$ & $\mathbf{8}$ & FMRP-1 & $\mathbf{6 0}$ & $\mathbf{3 0 . 5 6}$ & $\mathbf{0 . 8}$ & & \\
\hline 12 & $10 / 24 / 2001$ & 38 & SNOW & 10 & 0.41 & 1.75 & & \\
\hline 13 & $10 / 24 / 2001$ & 1 & BAP-1 & 1 & 1.9 & 1.92 & & \\
\hline $\mathbf{1 4}$ & $\mathbf{1 0 / 2 4 / 2 0 0 1}$ & $\mathbf{1 8}$ & DMRP-1-R & $\mathbf{9 2}$ & $\mathbf{2 . 1 7}$ & $\mathbf{0 . 1 2}$ & & \\
\hline 15 & $10 / 24 / 2001$ & 5 & DMP-4 & 14 & 5.3 & 1.68 & & \\
\hline 16 & $10 / 24 / 2001$ & 6 & DMRP-1 & 1 & 3.26 & 0.12 & & \\
\hline $\mathbf{1 7}$ & $\mathbf{1 2 / 1 9 / 2 0 0 1}$ & $\mathbf{1 8}$ & DMRP-1-R & $\mathbf{2 8}$ & $\mathbf{0 . 5 4}$ & $\mathbf{0 . 6 9}$ & & \\
\hline 18 & $12 / 19 / 2001$ & 1 & BAP-1 & 1 & 1.49 & 1.15 & & \\
\hline 19 & $12 / 19 / 2001$ & 6 & DMRP-1 & 16 & 1.09 & 0.19 & & \\
\hline 20 & $12 / 19 / 2001$ & 5 & DMP-4 & 116 & 1.63 & 0.98 & & \\
\hline 21 & $12 / 19 / 2001$ & 8 & FMRP-1 & 20 & 7.6 & 3.62 & & \\
\hline 22 & $12 / 19 / 2001$ & 38 & SNOW & 5 & 0.14 & 1.31 & & \\
\hline 23 & $12 / 19 / 2001$ & 10 & BAPW-1 & 1 & 1.63 & 0.35 & & \\
\hline $\mathbf{2 4}$ & $\mathbf{1 2 / 1 9 / 2 0 0 1}$ & $\mathbf{2 4}$ & WD-1 & $\mathbf{3 6}$ & $\mathbf{0 . 6 1}$ & $\mathbf{0 . 4 9}$ & & \\
\hline 25 & $3 / 6 / 2002$ & 38 & SNOW & 1 & 2.05 & 0.9 & & \\
\hline $\mathbf{2 6}$ & $\mathbf{3 / 6 / 2 0 0 2}$ & $\mathbf{2 4}$ & WD-1 & $\mathbf{3 8}$ & $\mathbf{2 . 0 5}$ & $\mathbf{0 . 5 2}$ & & \\
\hline 27 & $3 / 6 / 2002$ & 8 & FMRP-1 & 1 & 6.55 & 3.41 & & \\
\hline 28 & $3 / 6 / 2002$ & 10 & BAPW-1 & 1 & 3.55 & 0.12 & & \\
\hline 29 & $3 / 6 / 2002$ & 5 & DMP-4 & 1 & 3.69 & 0.68 & & \\
\hline 30 & $3 / 6 / 2002$ & 1 & BAP-1 & 1 & 2.87 & 0.33 & & \\
\hline $\mathbf{3 1}$ & $\mathbf{3 / 6 / 2 0 0 2}$ & $\mathbf{1 8}$ & DMRP-1-R & $\mathbf{5 0}$ & $\mathbf{1 . 9 1}$ & $\mathbf{0 . 6}$ & & \\
\hline 32 & $3 / 6 / 2002$ & 6 & DMRP-1 & 1 & 3 & 0.12 & & \\
\hline & & & & & & & & \\
\hline & & & & & & \\
\hline
\end{tabular}

[1] units are in ppm with drinking water quality standard of $7 \mathrm{ppm}$

[2] Samples shown in bold are surface water samples others are from piezometers and pit wells. 
The summary of the results from the above table indicate that the groundwater is good quality and is low in nutrients ( $<7 \mathrm{ppm}$ drinking water standard) and bacteria, thereby suggesting that fertilizer migration to the aquifer is not an issue. We believe that the elevated bacteria in record 9 were a function of well installation and/or contamination during sampling since the subsequent samples from that location did not indicate a bacteria problem. Fecal count were found to be mostly high on the surface water (i.e. Umatilla River) samples. For more information please see data in attached spreadsheet Q Water Quality.xls.

In addition, this analysis shows that augmenting the groundwater flow would be helpful to the water quality in the Umatilla River. For example, the water that would be used for the recharge project can be best characterized by site WD-1, records 24 and 26 . This sample location is along the Hunt Canal (near the sites for recharge). The water quality at this site in the winter-time is low in nitrates and relatively low in bacteria (particularly as compared to other sample dates from the same site). This water will be filtered by the soil column and will be almost devoid of bacteria as seen at sites BAPW-1, FMRP-1, Snow, and Priorpu. This groundwater that re-enters the Umatilla River will be colder as discussed previously, lower in bacteria (compare these groundwater sites to location DMRP-1-R) and lower in nutrients (see samples in July, 10,\& 27, 2001 analysis in Table above).

We expect that the cold, clean groundwater from Echo Meadows has, and will continue to have, a beneficial effect on the Umatilla River. See the following section for a discussion of water temperature along the Umatilla River and the effects of cold groundwater from the Echo Meadows reach, based on our near infrared remote sensing study. 


\section{Thermal Infrared Imagery Along the Umatilla River}

There has been a considerable amount of thermal imagery work completed for this project. A complete analysis is included in Appendix C. A synopsis follows.

In 2001, IRZ Consulting conducted aerial Thermal Infrared survey of the Umatilla River (downstream of Westland Diversion in Echo) and using GIS software developed a continuous thermal imagery of the River three times as shown below:

\begin{tabular}{|l|l|}
\hline Date & Time \\
\hline Aug 7, 2001- PM Flight & $14: 30-15: 00$ \\
\hline October 01, 2001 AM Flight & $11: 00-11: 30$ \\
\hline October 01, 2001 PM Flight & $15: 15-15: 45$ \\
\hline
\end{tabular}

The purpose of these flights was to develop a continuous thermal profile of the river and to look at river thermal properties such as:

- Thermal heating or cooling in the downstream direction,

- Thermal cooling due to ground water recharge, seeps, springs, and drains, and

- Overall temperatures in relationship to fisheries requirements and TMDL's.

Figure-10A and Figure-10B (with smaller temperature scale to show more details) shows the temperature profile along the Echo Meadows reach of the Umatilla River flown on August 7,2001. As can be seen in the figures and the accompanied legend, water enters near Echo at a temperature that is approximately 70F (21C). Downstream of the Dillon Diversion (just before the river turns from a northward to a western direction) and the Town of Echo, the water temperature has increased to about $77 \mathrm{~F}$ (24.5 C). In the downstream of this reach (below River Mile 21.7) and within the Echo Meadows areas, the stream temperature decreases to $70 \mathrm{~F}(21 \mathrm{C})$. This 7 degrees decrease in temperature is due to the influence of the Stanfield Drain and seeps/ groundwater recharge from the Echo Meadows area.

Downstream of the Echo Meadows reach, the river temperature increases to about 86 degrees in the Cottonwood Bend area. This extremely warm reach is downstream of the Maxwell Diversion, which diverts most of the Umatilla River flow. The Cottonwood Bend, in addition, is a wide, long, and shallow reach of the river, which has essentially no flow during the summer irrigation season.

Downstream of the Cottonwood Bend reach, the river is again cooled to low 70's by groundwater return flows and flows from the Hermiston Drains. Downstream of these area much of the flow is re-diverted and the river temperature rises to around $80 \mathrm{~F}$. 


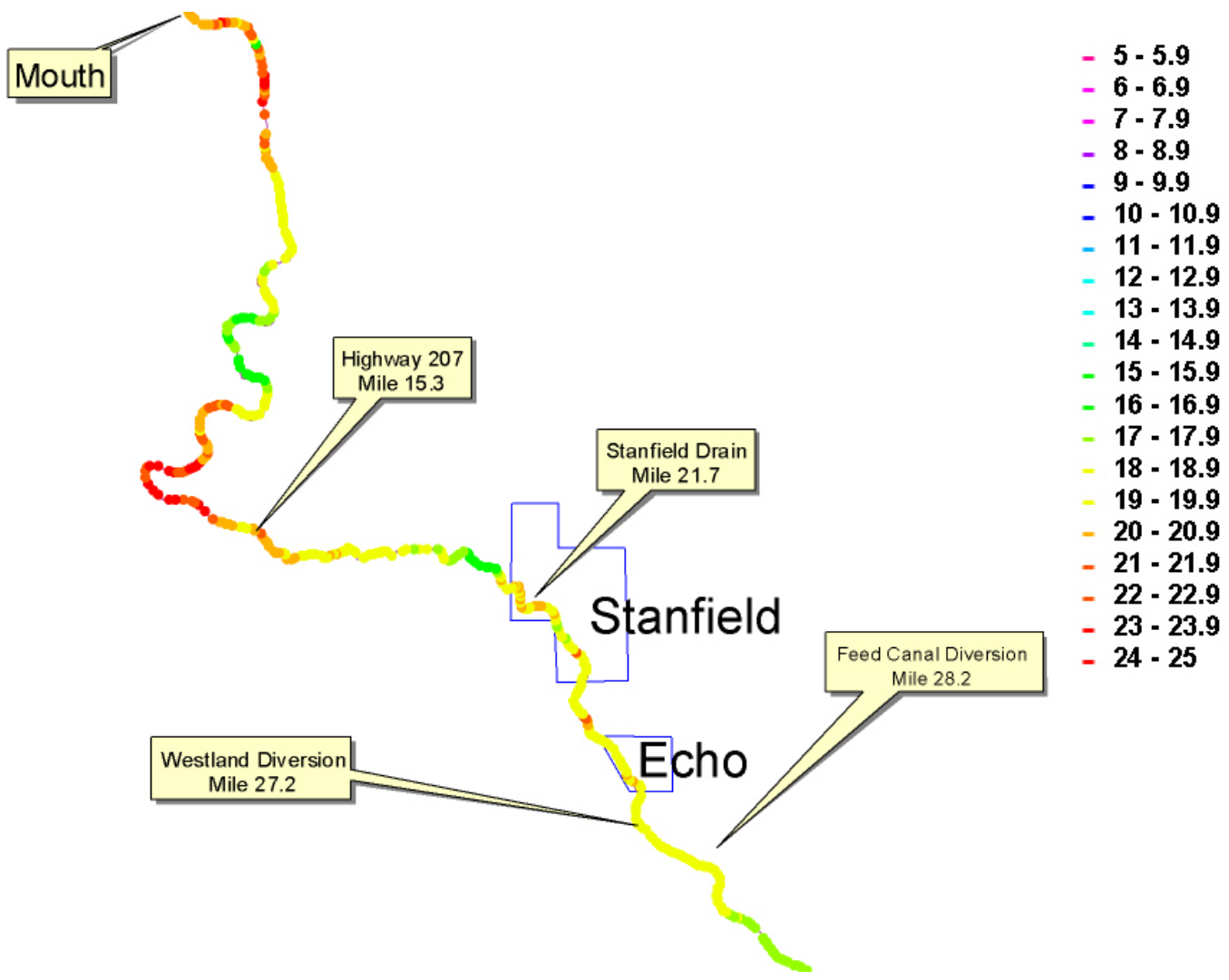

Figure 10A. Thermal Infrared Survey showing water temperatures along the Umatilla River flown on August 07, 2001. 


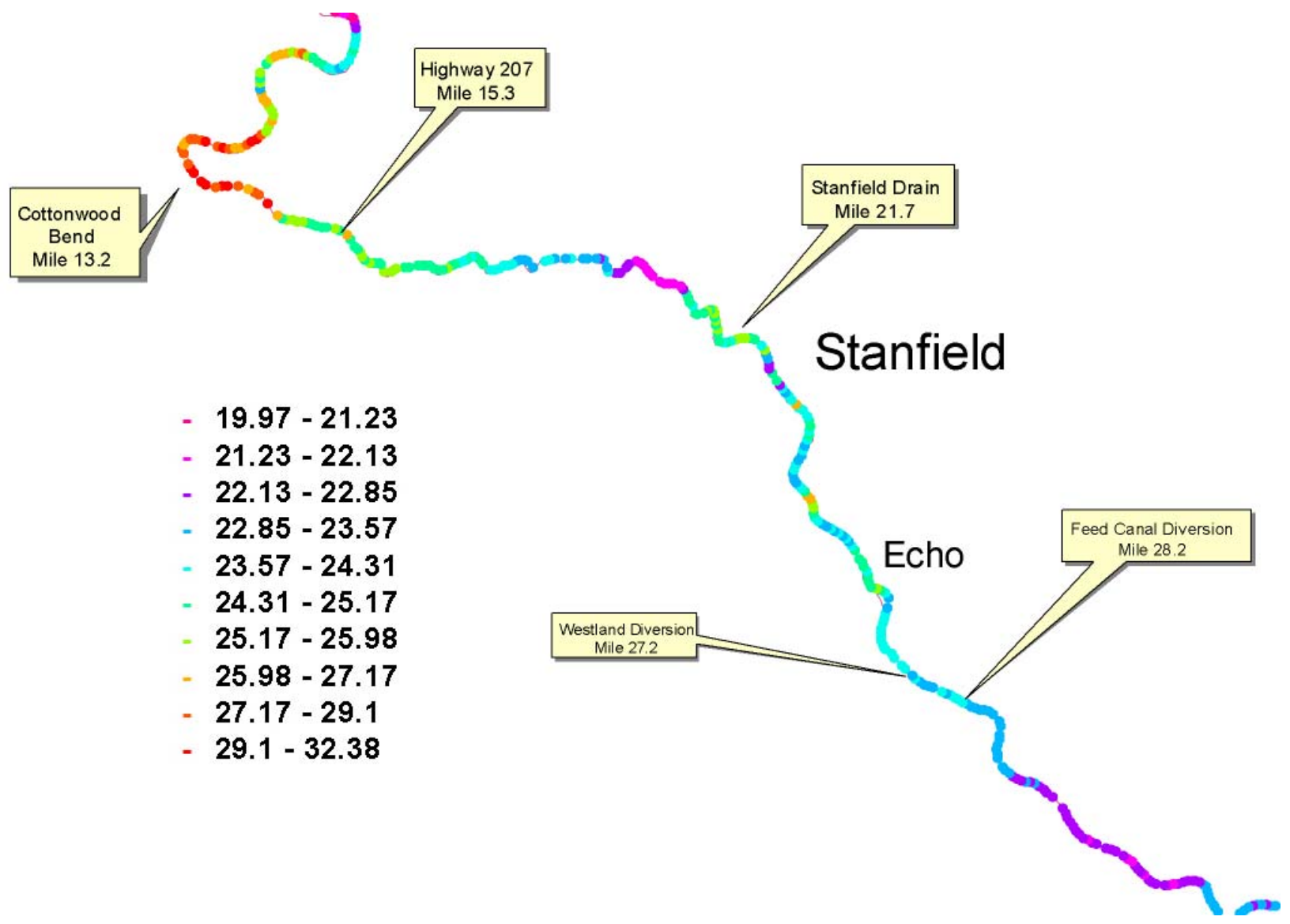

Figure 10B. Thermal Infrared Survey showing water temperatures along the Umatilla River flown on August 07, 2001. 
The river temperature as flown twice (am and pm flight) on October 10, 2001 has some similarities and differences to the river temperature during August 7, 2001. The water temperature, during the morning of October 10, 2001 (Figure 11), enters the lower Umatilla River basin at a temperature of about $57 \mathrm{~F}$. It warms to about $59 \mathrm{~F}$ by the time that it enters the Echo Meadows reach (before it turns west). At that time it cools slightly to about $57.5 \mathrm{~F}$ reflecting the seeps in the Echo Meadows reach and the Stanfield Drain. The river temperature warms in the Cottonwood Bend reach, before it is cooled again by the Hermiston Drains and Minehaha Springs.

During the afternoon flight of October 10, 2001 (Figure 12), the water temperature coming into the lower Umatilla River basin had warmed up to about $65 \mathrm{~F}$. It cooled nearly continuously in the downstream direction until it reached the confluence with the Columbia River.

From the analysis above, it appears that the influence of the Echo Meadows groundwater in cooling river temperatures is important during August, but not during October. This may be because return flows from the reach during October are not large compared to the flow of the river (this is the time that fish releases from McKay would be at their highest. Additionally, our soil moisture data indicated that not much water reached the aquifer after July in a typical year. Therefore, return flows would also be expected to diminish after that time.

In the above analysis, the thermal imagery was "ground truthed" using the temperature data loggers previously discussed. The comparison showed that the temperatures form the thermal imagery was exceedingly close to that using the data temperature loggers. As a result, there was no reason to recalibrate the imagery for any additional purpose. A complete discussion of the comparison and additional imagery is found in Appendix C. 


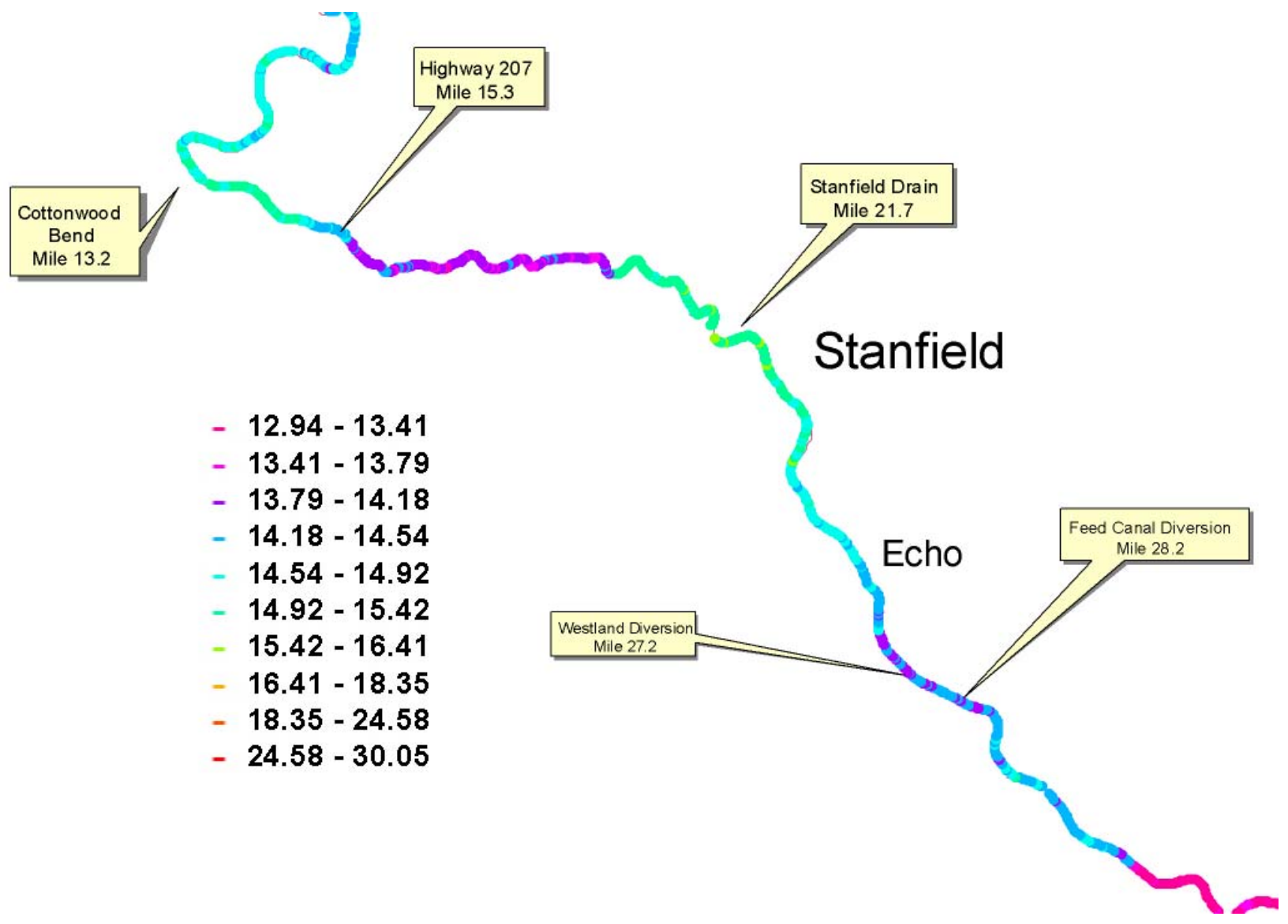

Figure 11. Thermal Infrared Survey showing water temperatures along Umatilla River flown October 01, 2001 am flight. 


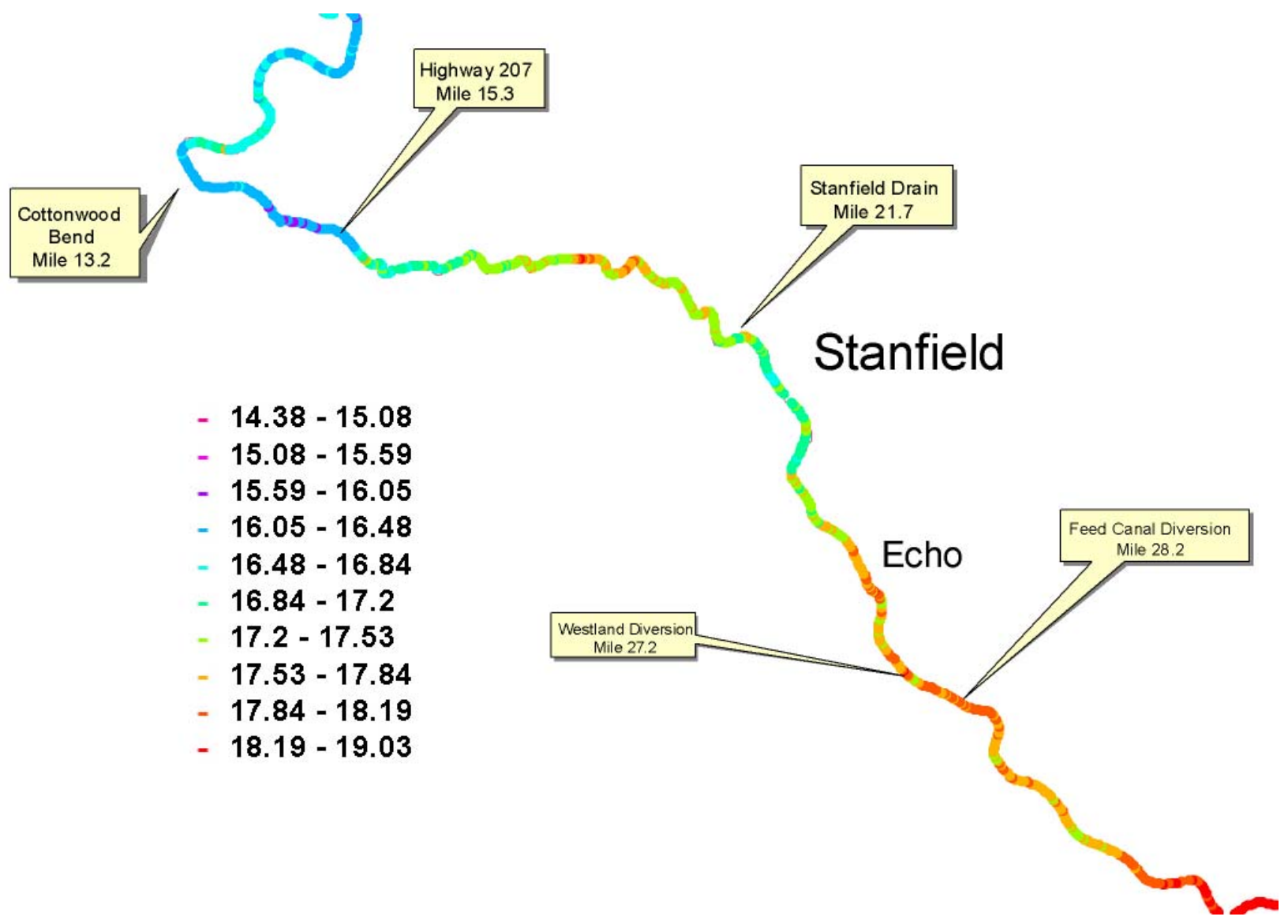

Figure 12. Thermal Infrared Survey showing water temperatures, along Umatilla River flown October 01, pm flight. 


\section{Groundwater Pump Tests}

Two groundwater pump tests were performed on October 3 and 4, 2001 in Echo Meadows. They were at EMDMPW-3 and EMDMRP-2, in the northern portion of the Meadows. The test at EMDMPW-3 was a twenty four hour pump test and the test at EMDMRP-2 was a piezometer slug test.

A complete analysis of these pump tests were included in Appendix G (Draft Progress Report, 2001 Baseline Analysis see Appendix E. The pump tests showed that the hydraulic conductivity in this area (northern portion of the Meadows) was about 37-88 feet/per day at EMDMPW-3 and was $0.44 \mathrm{ft} /$ day at EMDMRP-2. The lower value at EMDMRP-2 was associated with the silty sands material that composed the top 15 feet of the aquifer. The silty sands are believed to be loess deposits on top of the river alluvium found below. Likely, the higher values associated with EMDMPW-3 was from coarser material that was found below the silty sand. This same type of stratigraphy (silty sand above, coarser material below) was also found at EMDMRP-1. The specific yield (amount of water that can drain from aquifer while it is being pump a unit-less index) that was measured at EMDMPW-3 was 0.1 (the lower number indicates less water can be drained).

These pump tests showed a lower value of hydraulic conductivity than the pump test of the Prior well in September of 1998 and the Snow and Holeman wells in July 1995 (approximately 200-1000 ft/day). These pump tests were completed in the southern portion of the Meadow. The specific yield of these pump tests ranged from 0.1 to 0.15 . The variability of all of the pump tests in the Meadows probably reflects that this area has cut and fills features.

The hydraulic conductivity found in the pump tests in the Meadows was used in the MODFLOW model of the area. The groundwater model had the best calibration (best match of heads and return flows in the Meadows) with values of 400-800 ft/day for hydraulic conductivity and 0.15 for specific yield. Once again, the benefits of these two projects completed together were instrumental in developing the calibrated model of the lower Umatilla River basin.

\section{Stream Gauging of Drains and Ditches}

The drains and ditches in the Meadow are very important to monitor. For example, if the discharge from the Stanfield Drain were not considered in the mass balance of the reach, then the calculated recharge from the Meadows would be considered to be much higher than it actually is. Or if the drains in the Meadows discharged most of the return flow, then applications of recharge water would not be effective because the water would quickly be diverted to the drains and to the Umatilla River and would not be available for summer and fall recharge. 
The WRD (1991), found that the Stanfield Drain has a steady discharge of about 10-20 cfs. Their discharge measurements of the drain in the 1990's showed that the discharge was approximately the same as that during 1985-86. They also determined that the drains in the Meadows did not (appreciably) discharge much water to the Umatilla, except when there was high precipitation or some other external factor. This could mean that the drains do not appreciably intersect groundwater and that they probably act more like an irrigation ditch (a means of conveyance).

IRZ measured the stage of the Stanfield Drain throughout 2001 and found that it varied from a high of 11 feet in April (below a fixed datum) to a low of about 13 feet in AugustSeptember. During virtually all of the irrigation season, the stage was 12.0 and 13.0 feet.

Several discharge measurements were made at the Stanfield Drain during this time. The discharge was measured from $10.3 \mathrm{cfs}$ on October 4 to $15.7 \mathrm{cfs}$ on August 17, 2001. These measurements suggest that the flow of the Stanfield Drain is fairly consistent with that measured in the 1990's. Substantial amount of Umatilla River flow below Westland Diversion is compromised of Stanfield Drain and the groundwater discharge from Echo Meadows region.

IRZ measured the discharge of several drains and ditches in Echo Meadows in 2001. The discharge was often near zero, but was occasionally as high as 2-3 cfs. This later condition occurred when the ditches were transmitting water to a place of irrigation. There were few times that surface water was seen that was directly transmitted to the Umatilla River, consistent with WRD observations (WRD, 1991). The drains could start to intercept groundwater, and act as true drains, if groundwater levels are raised sufficiently. 


\section{Groundwater Modeling Results}

We believe that our groundwater model is a critical element of the project and, since the January 2002 Progress Report, we have put a considerable amount of time and effort into development of the model.

The groundwater model has two main functions:

- Provide assurance that the recharge project will be successful prior to having measurable improvements of water levels and return flows and

- Provide an operational means to determine the best locations and timing of aquifer recharge.

We also know from the review of the progress report that others could have more questions and/or doubts about the validity of the previous model results than those of us on the project staff.

As a result, we decided to pool our resources to the development of the lower Umatilla River Basin groundwater model. This regional model (from the town of Echo to the confluence with the Columbia River) was developed under contract from the Bureau of Reclamation and had a considerable amount of calibration, verification, and sensitivity work and the work was reviewed by the BOR, a contractor for the Bureau of Indian Affairs, and CTUIR.

We provided valuable input to this regional model including groundwater elevations at key wells for the calibration run and estimates of hydraulic parameters. In return, because the model is in the public domain, we were able to use the model to evaluate the impacts of changes in recharge in the Meadows and groundwater return flows. Below, we discuss the calibration, verification, and model predictions that are germane to Echo Meadows.

Figure 13 shows the groundwater levels in the lower Umatilla River basin as predicted by the groundwater model during the calibration period. Echo Meadows is in the southeast corner of the model and the location of the Snow, Prior, Muller, and Netherda wells are shown in the model. The error bars indicate the closeness of the predicted model results versus that which was measured. As can be seen in Figure 13, three of the four wells are within 5 feet of the measured results (seen as green error bars) and the fourth well (Snow) is slightly greater than 5 feet. Based on the analysis discussed above, The BOR considered the model calibration acceptable.

After model calibration was completed, a verification model run was completed. This was completed by using the state variables from the calibration run (those variables that do not change) to determine if the model would predict acceptable values in another simulation. Generally, a model's predictive value is considerably more reliable if it has been demonstrated to be verified as well as calibrated (Anderson and Woessner, 1992).

Figure 14 shows the results from a verification run that modeled the period from 1947 to 
1992. As can be seen in Figure 14-A, the models estimated head at the end of the modeling simulation match the observed heads fairly well. Figure 14-B shows the computed versus observed values at the Muller well. As can be seen in this simulation, the predicted values (red-horizontal line) are slightly lower than observed value (bluevertical error bar) but are entirely acceptable at the end of a 45 plus year simulation. The model shows that the water level would decline by less than 5 feet as the application rate declined during this same period (Figure 2).

Figure 14 (bottom graph; measured as cubic feet of flow per day vs. time [1947 to 1992]) shows that the groundwater return flow from Echo Meadows declined from about $45 \mathrm{cfs}$ in the 1940's to about $22 \mathrm{cfs}$ in the early 1990's as application volume diminished from 17-20,000 acre-ft/year to less than 15,000 acre-feet/year in the Meadows.

The verification model result is almost exactly the same as the groundwater return flow values and trends that we indicated in our 2001 progress report. And Figure 14-B , shows that this trend occurred with only a few feet (about 5 feet) decline in water levels in the area. If the specific yield in the Meadows is 0.2 (a reasonable value and the one that is used in the model), this means that the return flows may increase to their historic values with the addition of 1 acre-ft/acre to the groundwater system (about 9,600 acrefeet total). What this means is that you can double to quadruple the flow of the Umatilla River during the low summer flow as compared to the present base-flow through continued recharge project. A significant beneficial impact to the river system. 


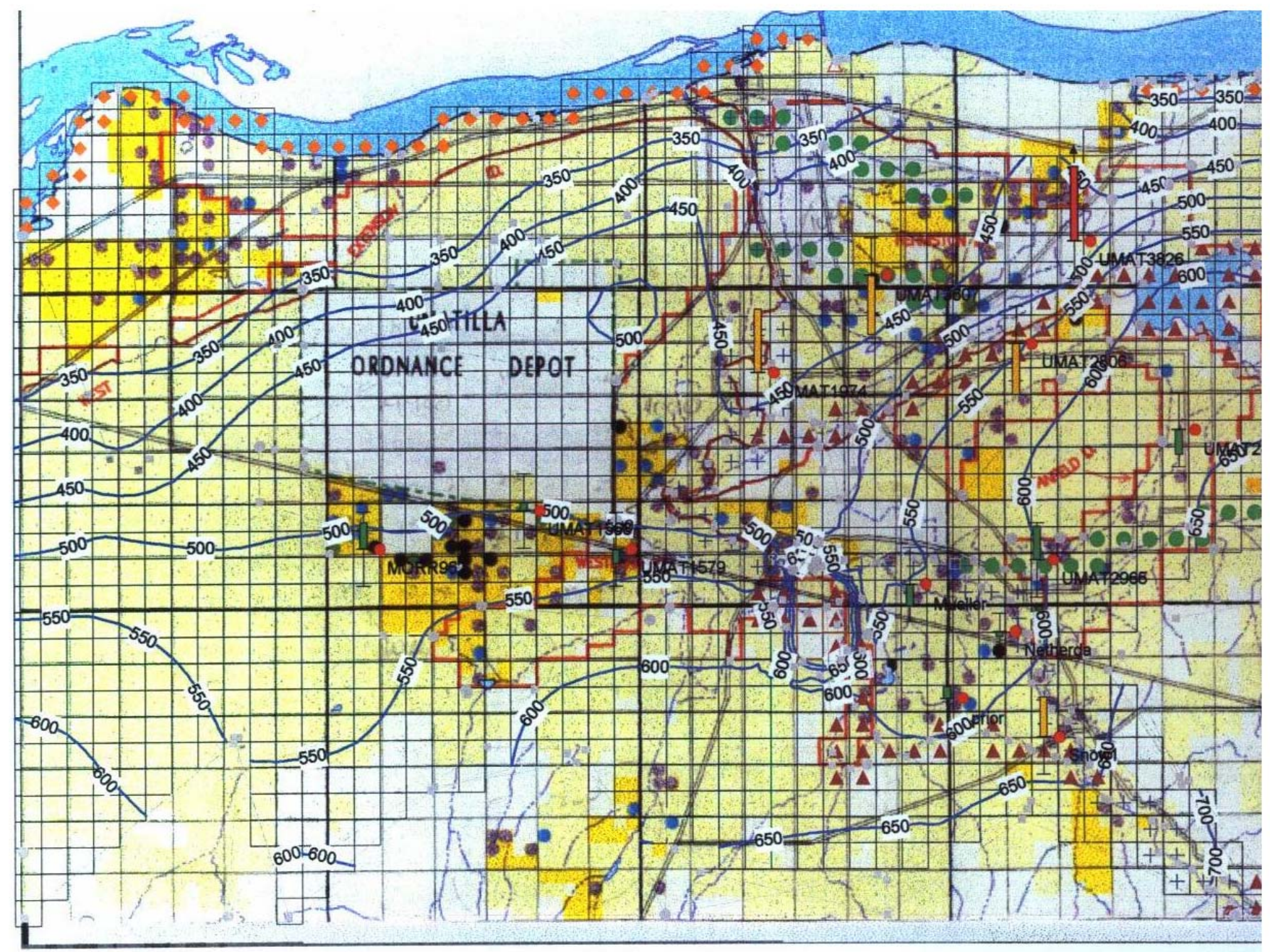

Figure 13. Groundwater Model Map of Echo Meadows 
$14-\mathrm{A}$

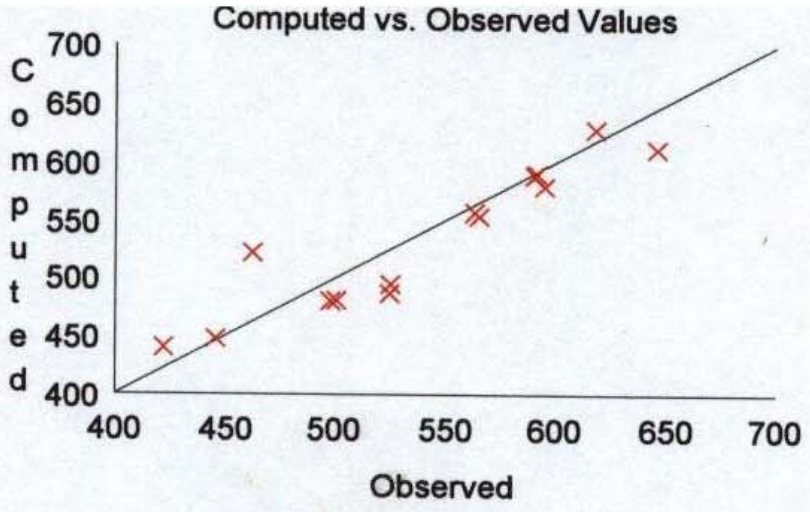

$14-B$

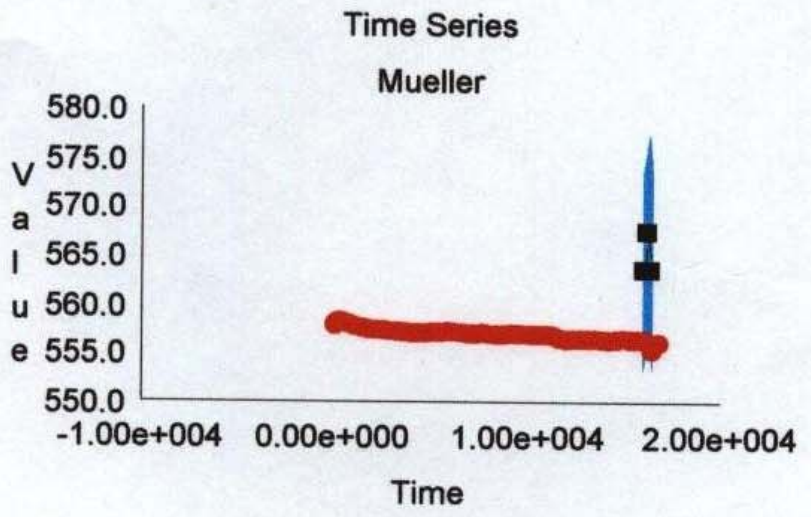

$14-\mathrm{C}$

Time Series

Return Flows

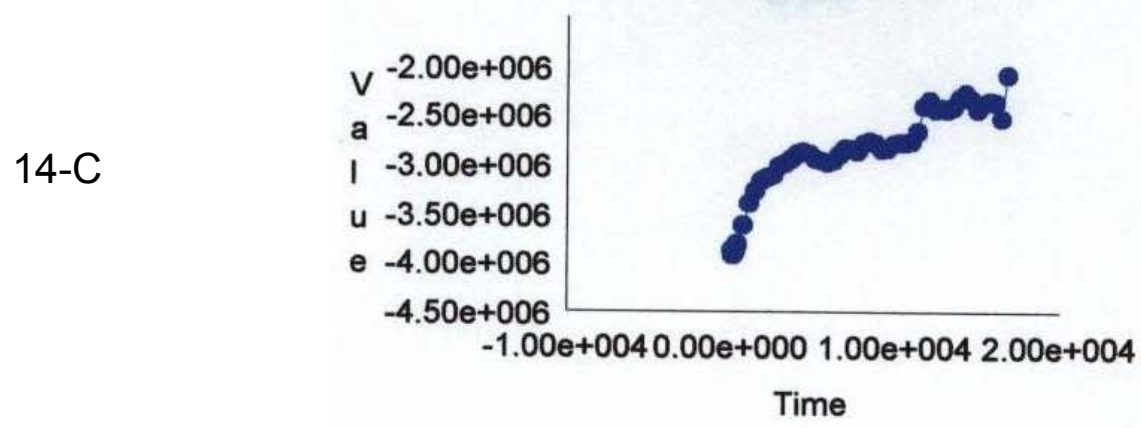

Figure-14. 50 year simulation Verification run showing Echo Meadows return flows (19471992). 
Finally, an additional series of MODFLOW runs were done to help determine how effective the Echo Meadows recharge project could be in promoting Umatilla River stream flows during the summer/early fall if the majority of the recharge takes place in the late winter. In addition, we wanted to determine the locations in the Meadows that would be most effective to place the recharged water.

To do so we compared the loading (adding additional water) to two cells in the model (1/4 square mile each) with water during February of a given year. The two cell locations were:

- 3 miles from the Umatilla River (south end of the Meadows) and

- $1 / 2$ mile from the river (far north end of the Meadows).

This modeling exercise is known as determining the "response function" for those cells. Response functions are "the analytical expressions, graphs, or coefficients that describe the relative response of the aquifer system at a given location to a unit stress at a second location" (Johnson, et al, 1998). In our case the cells that are loaded is the "second location' and the Umatilla River is the "first location". The response functions are essentially linear so they can be scaled up or down depending on the magnitude of the loading or added or subtracted over time.

Figure 15 shows the response functions for the two loaded cells. The unit stress was applied between the 365-393 days of the simulation (February). As can be seen in Figure 15, the response function of the $1 / 2$ mile cell is rapid. The response is the greatest during the first month (March-April) and declines fairly rapidly towards zero by day 600 (late August).

The response function of the cell that is 3 miles away is much more attenuated. The maximum response is about three months (May-June) after the application, but it continued to discharge to the River through October. There would be a noticeable improvement in groundwater return flows at the end of the simulation (until February of the following year). This means that applications of water away from the river will benefit return flows for more than one year and will allow a steady buildup of groundwater levels. Also this indicates that we can time our return flow into the River by selecting various places of applications (function of distance from the river).

Figure 15 shows that the locations nearest the river would not be as effective in promoting summer-time return flows as locations that are farther from the river, particularly if the application occurs in the early portions of the irrigation season. It appears from this modeling, however, that any application of water, at any time or place in the Meadows, will result in some improvement in summer-time return flows

These results discussed in this section strongly demonstrate that the groundwater discharge from the Meadows area can be greatly restored (to historical base-flow of 40 cfs as compared to present condition of 10 to $15 \mathrm{cfs}$ ) with only a few feet increase in groundwater levels. It also appears that this increase in groundwater levels can be 
achieved within about 10 years if we add about 3,000 acre-feet of water/year to the Meadows and about $1 / 3$ of that is added to long-term storage. Of course, the aquifer will need annual recharge to maintain those levels.

Echo Meadows Response Functions

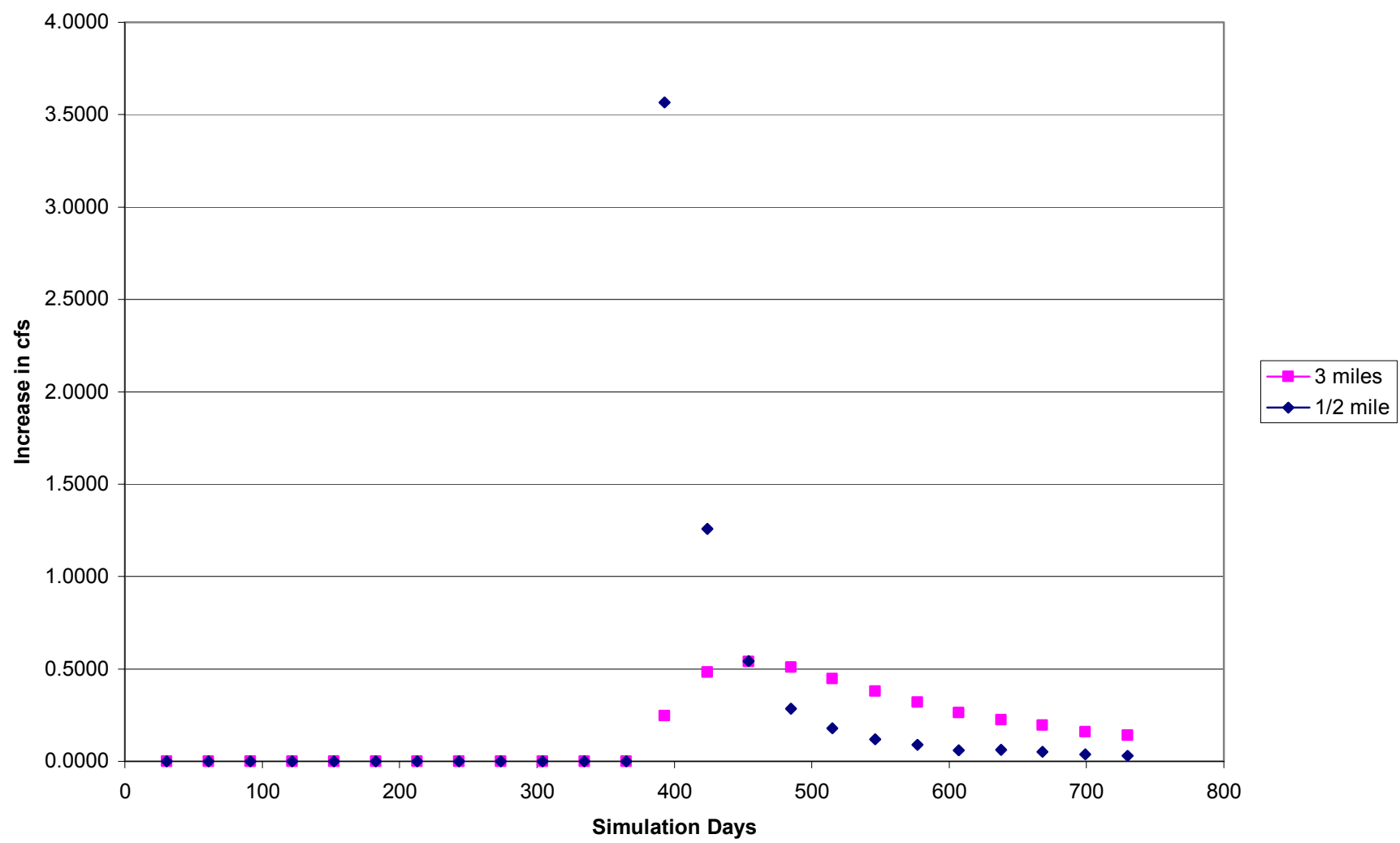

Figure 15. Echo Meadows Response Functions based on a sample model run 


\section{Trail Water Application}

IRZ Consulting, LLC conducted a trial application of recharge water from 11:00 am on February 25, 2002 to March 1, 2002 at 06:00 am. Approximately 20 acre-feet of water were applied to three fields along the southern portions of the Echo Meadows the area of which are shown in Figure D-1. The purpose of the application was to familiarize ourselves with all aspects of the application program including recording of diversions, water applications and groundwater monitoring. Additionally, we wanted to use the data to improve the MODFLOW groundwater model of the Meadows for operational purposes.

In our opinion, the trial application was a complete success. We observed that wells that were nearby the flooded areas showed positive inflection and that we were able to track the application of even this small amount of water (as compared to the project under full operations). We also found that the MODFLOW model did an excellent job of simulating the application, offering further proof of its value for predictions and operations. A complete account of the trial application is included in Appendix D. 


\section{Cited References}

Anderson, M.P. and Woessner, W.W. 1992. Applied Groundwater Modeling. Academic Press, San Diego, CA.

Bureau of Reclamation, 1989. Review of Umatilla Project Operations.

Department of Environmental Quality, 1995. Hydrogeology, Groundwater Chemistry, and Land Uses in the Lower Umatilla Basin Groundwater Management Area.

Graham, J., 1995. Pump test analysis of the Holeman and Snow wells near Echo, OR. Report sent to Water Resources Department in 1995.

Graham, J. 2002. Changes in Irrigation District Diversions and Conservation Practices and their Effects on Low and Return Flows. March, 2002 report to Irrigation Districts, CTUIR, and BOR.

IRZ, 1998. Echo/Umatilla Meadows Project. Winter Artificial Groundwater Recharge Project Enhancing Return Flows and Water Quality in the Umatilla River. Prepared for: Oregon Water Coalition.

IRZ, January 2002, Draft Progress Report, 2001 Baseline Analysis. For: the Bonneville Power Administration. Available at irz.com.

Kadlec, R.H. and Knight, R.L., 1996. Treatment Wetlands. CRC Press, Boca Raton, FL.

United States Geological Survey, 2000. Hydrology of the Columbia Plateau Regional Aquifer System, Washington, Oregon, and Idaho. Water Resources Investigations Report 96-4106

Water Resources Department, 1991. Umatilla River Return Flow Analysis During 1985 and 1986. 


\section{Appendix A}

Location of Echo Meadows Monitoring Network:

Location and elevation of Echo Meadows monitoring network as of December 12-2001

\begin{tabular}{|c|c|c|c|c|c|c|c|}
\hline Location & Latitude & Longitude & Easting & Northing & East-ft & North-ft & $\begin{array}{c}\text { Elevation } \\
\mathrm{ft}\end{array}$ \\
\hline Allen\#1 & 45.7322527 & -119.1968083 & 329,078 & $5,066,646$ & $1,079,704.92$ & $16,623,665.53$ & \\
\hline Culvert\#1 & 45.7844749 & -119.3122805 & 320,262 & $5,072,701$ & $1,050,779.62$ & $16,643,531.98$ & \\
\hline Culvert3 & 45.7870074 & -119.2855395 & 322,348 & $5,072,923$ & $1,057,623.79$ & $16,644,260.36$ & \\
\hline Ditch\#1 & 45.7821714 & -119.3004574 & 321,173 & $5,072,419$ & $1,053,768.61$ & $16,642,606.74$ & \\
\hline DrainA & 45.7769472 & -119.2309194 & 326,563 & $5,071,685$ & $1,071,453.20$ & $16,640,198.49$ & \\
\hline DrainB & 45.7769472 & -119.3158083 & 324,395 & $5,072,595$ & $1,064,340.00$ & $16,643,184.20$ & \\
\hline DrainlrDi & 45.7845583 & -119.3006416 & 321,167 & $5,072,684$ & $1,053,748.93$ & $16,643,476.20$ & \\
\hline DrainLgCu & 45.7870305 & -119.2856138 & 322,343 & $5,072,925$ & $1,057,607.38$ & $16,644,266.93$ & \\
\hline DrainMu\#1 & 45.7845861 & -119.2590305 & 324,401 & $5,072,595$ & $1,064,359.68$ & $16,643,184.20$ & \\
\hline DrainMu\#2 & 45.7845861 & -119.2591138 & 324,395 & $5,072,595$ & $1,064,340.00$ & $16,643,184.20$ & \\
\hline EMBAP-1 & 45.7625057 & -119.2734274 & 323,212 & $5,070,174$ & $1,060,458.57$ & $16,635,240.89$ & \\
\hline EMBAPW-2 & 45.7497794 & -119.2281683 & 326,692 & $5,068,661$ & $1,071,876.45$ & $16,630,276.74$ & \\
\hline EMDM-C-1 & 45.7401689 & -119.2691780 & 323,472 & $5,067,683$ & $1,061,311.63$ & $16,627,067.92$ & \\
\hline EMDMP-1 & 45.7402139 & -119.2691798 & 323,472 & $5,067,688$ & $1,061,311.63$ & $16,627,084.33$ & \\
\hline EMDMP-2 & 45.7436340 & -119.2728151 & 323,000 & $5,068,076$ & $1,059,763.00$ & $16,628,357.36$ & \\
\hline EMDMP-4 & 45.7806778 & -119.2838399 & 322,460 & $5,072,216$ & $1,057,991.26$ & $16,641,940.70$ & 562.74 \\
\hline EMDMPW-1 & 45.7469590 & -119.2585640 & 324,319 & $5,068,414$ & $1,064,090.64$ & $16,629,466.33$ & \\
\hline EMDMPW-2 & 45.7435772 & -119.2484002 & 325,100 & $5,068,016$ & $1,066,653.10$ & $16,628,160.50$ & \\
\hline EMDMPW-3 & 45.7899116 & -119.2726120 & 323,362 & $5,073,217$ & $1,060,950.72$ & $16,645,224.98$ & 563.98 \\
\hline EMDMRP-1 & & & & & & & 556.18 \\
\hline EMDMRP-2 & 45.7883706 & -119.2654602 & 323,913 & $5,073,030$ & $1,062,758.55$ & $16,644,611.43$ & 566.97 \\
\hline EMDMW-1 & 45.7437888 & -119.2713687 & 323,313 & $5,068,090$ & $1,060,789.95$ & $16,628,403.29$ & 606.02 \\
\hline EMDMW-2 & 45.7841056 & -119.2928953 & 321,767 & $5,072,617$ & $1,055,717.53$ & $16,643,256.38$ & 558.57 \\
\hline EMFMRP-1 & 45.7889620 & -119.2619589 & 324,187 & $5,073,088$ & $1,063,657.55$ & $16,644,801.73$ & 567.32 \\
\hline EMLLP-1 & 45.7485924 & -119.2656239 & 323,775 & $5,068,611$ & $1,062,305.78$ & $16,630,112.69$ & \\
\hline EMLLP-2 & 45.7486588 & -119.2622710 & 324,036 & $5,068,611$ & $1,063,162.12$ & $16,630,112.69$ & \\
\hline EMLLPW-1 & 45.7617461 & -119.2622729 & 324,077 & $5,070,065$ & $1,063,296.64$ & $16,634,883.27$ & \\
\hline EMSFRB-1 & 45.7786605 & -119.2255370 & 326,987 & $5,071,864$ & $1,072,844.35$ & $16,640,785.78$ & \\
\hline EMWD-1 & 45.7281416 & -119.2068214 & 328,286 & $5,066,211$ & $1,077,106.37$ & $16,622,238.29$ & \\
\hline HW207 & & & & & & & 554.66 \\
\hline Mueller & 45.7788638 & -119.2641694 & 323,984 & $5,071,970$ & $1,062,991.50$ & $16,641,133.57$ & 568.47 \\
\hline Nethedra & 45.7684933 & -119.2207040 & 327,414 & $5,070,523$ & $1,074,245.33$ & $16,636,385.96$ & 599.3 \\
\hline Pioneer\#2 & 45.7372805 & -119.2101138 & 328,058 & $5,067,233$ & $1,076,358.30$ & $16,625,591.47$ & \\
\hline ERW-2 & 45.7478083 & -119.2482527 & 325,124 & $5,068,485$ & $1,066,731.84$ & $16,629,699.29$ & 601.06 \\
\hline DSW-1;Snow1 & 45.7378613 & -119.2096853 & 328,093 & $5,067,297$ & $1,076,473.13$ & $16,625,801.46$ & 628.78 \\
\hline Snow3 & 45.7459749 & -119.2097805 & 328,116 & $5,068,198$ & $1,076,548.60$ & $16,628,757.64$ & 624.03 \\
\hline StanDitch & 45.7834596 & -119.2355953 & 326,219 & $5,072,419$ & $1,070,324.54$ & $16,642,606.74$ & \\
\hline WID Head & 45.7282249 & -119.1937561 & 329,298 & $5,065,974$ & $1,080,426.74$ & $16,621,460.69$ & \\
\hline Model 1 & & & 295,849 & $5,063,430$ & $970,680.57$ & $16,613,113.83$ & \\
\hline Model 2 & & & 334,852 & $5,061,654$ & $1,098,649.41$ & $16,607,286.77$ & \\
\hline Model 3 & & & 335,364 & $5,081,129$ & $1,100,329.28$ & $16,671,184.25$ & \\
\hline
\end{tabular}




\section{Appendix B}

Echo Meadows Cooperators and Acreage available for Aquifer Recharge Project

\begin{tabular}{|l|c|}
\hline Name of Cooperators & Acres \\
\hline & \\
\hline Barbara Andrews & 400 \\
\hline Mike Taylor & 400 \\
\hline Robert Levy & 100 \\
\hline Jack Correa & 200 \\
\hline Dan Mills & 250 \\
\hline Wendell Lampkin & 100 \\
\hline Jeff Spike & 600 \\
\hline Dick Snow & 110 \\
\hline & \\
\hline Total acres & $\mathbf{2 , 1 6 0}$ \\
\hline
\end{tabular}




\section{Appendix C}

\section{GIS Thermal Imagery of the Lower Umatilla River with an Emphasis on the Echo}

Meadows Reach.

\section{Introduction}

During the summer of 2001, IRZ Consulting was contracted to provide aerial images of the Echo Meadows Project. This work included three thermal infrared flights on the Umatilla River and a collection of color-infrared images of the entire Echo Meadows project area. The purpose of the project was as follows:

- Provide baseline temperature data for the Echo Meadows Project.

- Document diurnal fluctuations from a temporally constant perspective.

- Color infrared image mosaic for GIS basemap

\section{Project overview}

This project consists of study areas on the lower Umatilla River from a point just upstream of Echo, OR to the mouth. Table C-1 shows the dates and times of the data collect.

\begin{tabular}{|l|l|}
\hline Date & Time \\
\hline Aug 7, 2001- PM Flight & $14: 30-15: 00$ \\
\hline October 01, 2001 AM Flight & $11: 00-11: 30$ \\
\hline October 01, 2001 PM Flight & $15: 15-15: 45$ \\
\hline
\end{tabular}

Table C-1: FLIR flight dates and times.

\section{Methodology}

\section{Thermal Infrared- FLIR}

To measure and record imagery in the long wave region of the electromagnetic spectrum. The detector consists of a staring focal plane array with a $256 \times 256$ pixel density. The camera can differentiate temperatures as small as 0.07 degrees centigrade within an image or a collection of images to measure and record river temperatures, a high-resolution thermal infrared camera was used images and the accuracy of any measured temperatures are within 2 degrees centigrade of the absolute temperature without a calibration. 
The thermal infrared camera was mounted vertically in a custom designed gyrostabilized, steer-able mount in an Enstrom Helicopter. Images were saved on PCMCIA type II card at a rate of 1 second per image. The geographic coordinates of each image were recorded into a separate file using real time GPS with sub-meter accuracy.

Ground resolution (pixel size) of the images is determined by flight altitude. For the Umatilla River the average pixel resolution is 1-1.5 meters.

\section{Limitations}

When measuring river temperature with FLIR imagery it is necessary to recognize that the camera is seeing and recording temperature exclusively at the surface of the water. Rivers with a turbulent flow will show very little thermal variability between surface and sub-surface temperature measurements. Some factors that might influence thermal mixing:

- Tributaries / Springs

- Irrigation return flows

- Industrial / Municipal influences

By studying the results of this type of a temperature survey informed decisions can be made regarding the placement of in-stream temperature monitors to supplement and enhance the FLIR data.

\section{Data Processing}

Using image processing software, over 4,000 thermal infrared images were analyzed in the offices of IRZ Consulting and temperature information (max, min, avg.) was extracted and input into a database. The temperature value from each image is the average of several points within that image.

\section{Ground Truthing}

In-stream datalogger were placed in the river to continuously measure in stream temperature at various locations throughout the study area provides ground truthing data. These devices are anchored in the stream in a fixed location and record temperatures at pre-determined intervals varying from between 15-60 minutes. They were set at a 30 minute interval. Table C-2 shows the comparison between Flir and dataloggers. 
Table C-2 Ground truthing comparison

\begin{tabular}{|c|c|c|c|c|c|c|c|}
\hline \multirow{2}{*}{$\begin{array}{l}\text { Monitoring-Site } \\
\text { name }\end{array}$} & \multirow[b]{2}{*}{$\begin{array}{l}\text { River } \\
\text { mile }\end{array}$} & \multicolumn{3}{|c|}{ Morning (F) } & \multicolumn{3}{|c|}{ Afternoon (F) } \\
\hline & & $\begin{array}{l}\text { In-stream } \\
\text { temperature } \\
\text { logger temp }\end{array}$ & $\begin{array}{c}\text { FLIR } \\
\text { Temp } \\
\text { F }\end{array}$ & $\begin{array}{c}\text { Diff } \\
\text { Tem } \\
p \\
F \\
\end{array}$ & $\begin{array}{l}\text { In-stream } \\
\text { temperature } \\
\text { logger temp }\end{array}$ & $\begin{array}{l}\text { FLIR } \\
\text { Temp } \\
\text { F }\end{array}$ & $\begin{array}{c}\text { Diff } \\
\text { F }\end{array}$ \\
\hline \multicolumn{8}{|l|}{ August 7, 2001} \\
\hline EMDMRP1-R & 18.0 & & & & 70.4 & 75.4 & 5.0 \\
\hline EMWD-1 & 26.8 & & & & 75.2 & 73.8 & 1.4 \\
\hline \multicolumn{8}{|l|}{ October 1, 2001} \\
\hline EMDMRP1-R & 18.0 & 57.5 & 56.7 & 0.8 & 62.0 & 63.4 & 1.4 \\
\hline EMWD-1 & 26.8 & 56.2 & 57.3 & 1.1 & 62.4 & 64.0 & 1.6 \\
\hline $\begin{array}{l}\text { Average } \\
\text { difference }\end{array}$ & & & & 0.95 & & & 1.9 \\
\hline
\end{tabular}

\section{FLIR vs. In-river Datalogger In stream temperature monitors}

\section{FLIR: Continuous measurement, short duration:}

Using an aerial survey the temperature of hundreds of river miles can be recorded in a matter of just a few hours. In effect, the flow of the river is halted in time and the temperature of the river is measured along its entire length.

\section{Datalogger In stream temperature monitors: Single point, long duration:}

An in-stream datalogger in-stream temperature monitor records the temperature of a river or a stream from a fixed location for a long period of time. Diurnal and seasonal fluctuations can be monitored and the variability viewed and studied.

The correlation between the FLIR imagery and the datalogger in stream temperature monitor data provides an important view of two very important aspects of river dynamics. Because the FLIR imagery measures temperature at the surface of the river, the datalogger in-stream temperature monitors provide another view of the river. Datalogger in stream temperature monitor data is enhanced by FLIR imagery because the FLIR fills in the blanks between datalogger $n$ stream temperature monitor sites. As shown in the above table, FLIR and datalogger in stream temperature monitor temperature values correlate very well, generally less than $2 \mathrm{~F}$. The FLIR system shows a slightly higher temperature, perhaps due it is measuring surface water temperature. 
The high deviation value (August 7, 2001 at EMDMRP1-R) may be due to the effects of cold water springs at that location. It should be noted that FLIR data is an average temperature measured at the center of the streams, normally about a 2-meter wide strip of varying length from 50 meters to 200 meters long. Datalogger In-stream temperature monitors measure a single point at each site normally around the edge of the bank.

Of note in the table above is the variability of the temperature at each station when comparing morning and evening FLIR images. Some possible explanations:

- Thermal stratification

- Location/placement of the datalogger in stream temperature monitor

- Surface effects on the water affecting the accuracy of the FLIR imagery ${ }^{*}$

* High wind causing localized ripples and clouds being mirrored can change the reflectivity of the water causing a false temperature reading of up to 1.5 degrees. On the days these images were collected winds were generally less than 5 knots and the skies were clear. 


\section{Thermal Infrared Analysis}

\section{Geographic Information System (GIS)}

To view, analyze, and organize the temperature information for this project, ArcView 3.2 Geographic Information System (GIS) was employed. GIS is an excellent tool for gaining a basin-wide overview of temperature dynamics. Figure $\mathrm{C}-1$ shows an example of the type of broad scale comparisons that are possible for comparing temperatures at different times.

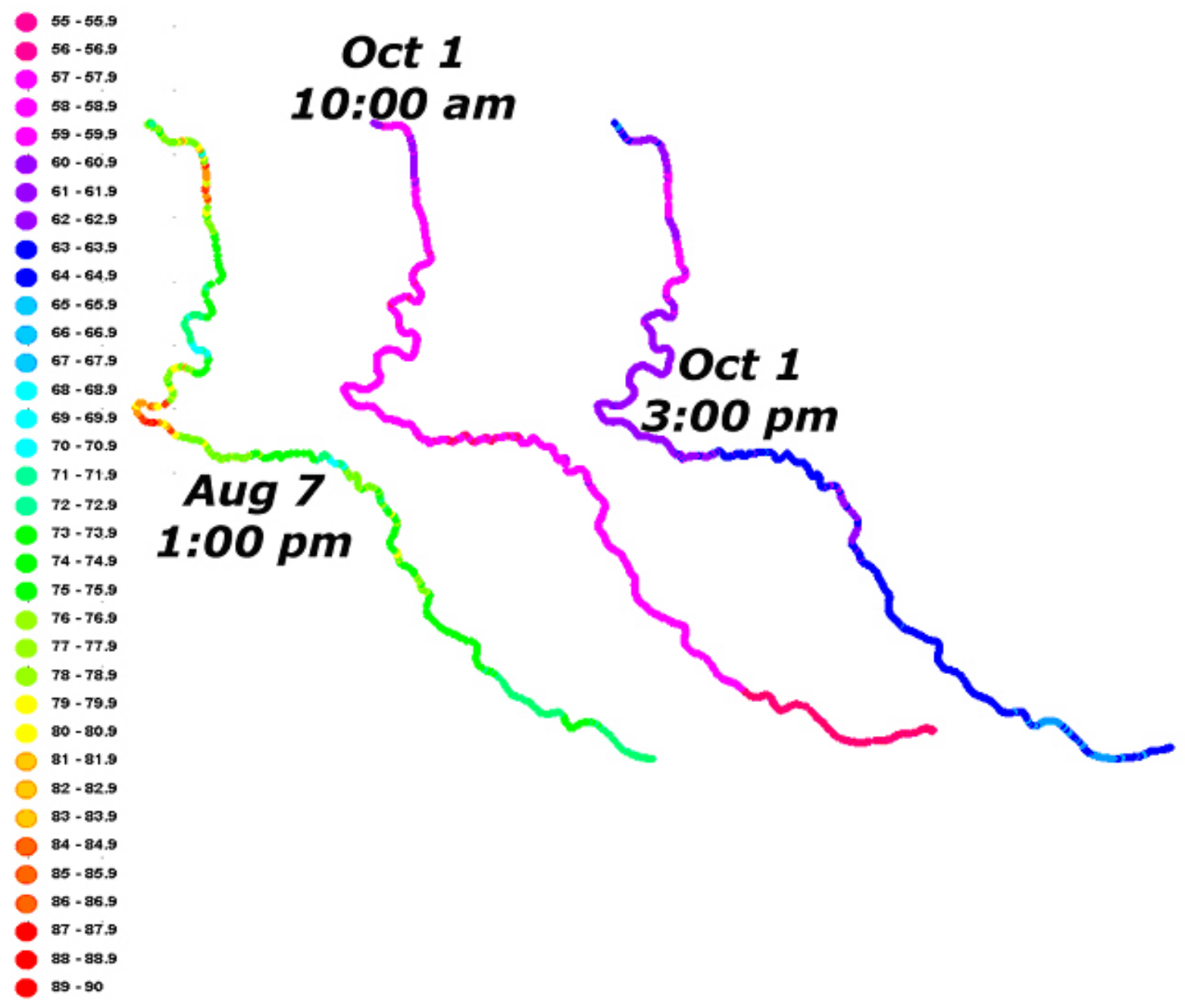

Figure C-1- Side by side comparison of Thermal Infrared of the Umatilla River from three separate flights.

During the flights, real-time differentially corrected GPS location information was being continually recorded to an onboard laptop computer. The data was extracted in the 
office and matched up with the corresponding images by synchronizing the image file with GPS time. Once the image times and the GPS times were linked, a GIS theme could be created.

In the office the images were analyzed for temperature information. The mean temperature from center of each image (river) was transferred to ArcView and classified by color. The image above shows that there variation in temperatures due to groundwater recharge as well as heating and cooling within different reaches of the river.

Figure C-2 shows a thermal infrared survey (GIS Theme) of the Umatilla River from River Mile (RM) 33 to the Mouth (confluence with the Columbia River) flown on August 7, 2001. Echo Meadows project area is shown between River Mile 27.2 (Westland Diversion) to River Mile 15.3(Hwy 207). The color legend shows a temperature scale in Degree Centigrade ranging from 5 to 25 Degrees (41-77 Deg F). As can be seen different reaches of the river shows heating and then cooling stretch mainly due groundwater recharge

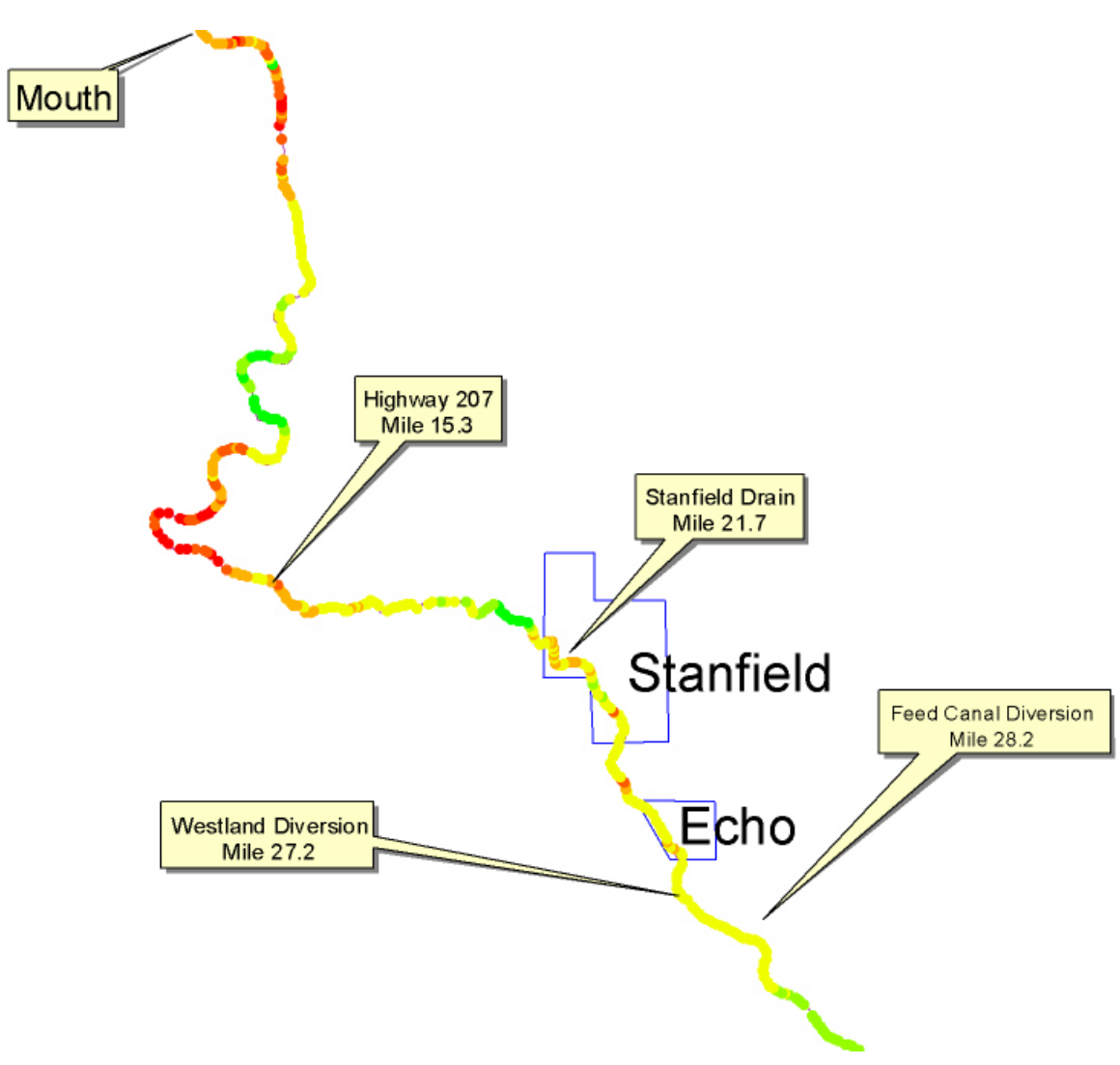

Dearee

$-5-5.9$

$-6 \cdot 6.9$

$-7 \cdot 7.9$

$-8-8.9$

$-9-9.9$

- $10 \cdot 10.9$

- 11 - 11.9

- $12-12.9$

- $13-13.9$

- 14 - 14.9

$-15-15.9$

- $16-16.9$

- $17-17.9$

18 - 18.9

$19-19.9$

$20-20.9$

- $21-21.9$

- 22 - 22.9

- $23-23.9$

- $24-25$

Fig-C2- Thermal Infrared (GIS Theme) of the Umatilla River flown on August 7, 2001. 
Figure C-3 shows a thermal infrared survey of the Umatilla River from River Mile (RM) 33 to the RM-13.2(Cottonwood Bend) flown on August 7, 2001. Echo Meadows project area is shown between RM-27.2 to RM-15.3. The temperature scale was stretched from 19.97 to 32.38 Degree C (68-90 Deg F) to show more detail. As can be seen a number reaches show significant cooling mainly due to groundwater recharge in the middle of Echo Meadows area (RM 20 to 15) warming by RM-13.2.

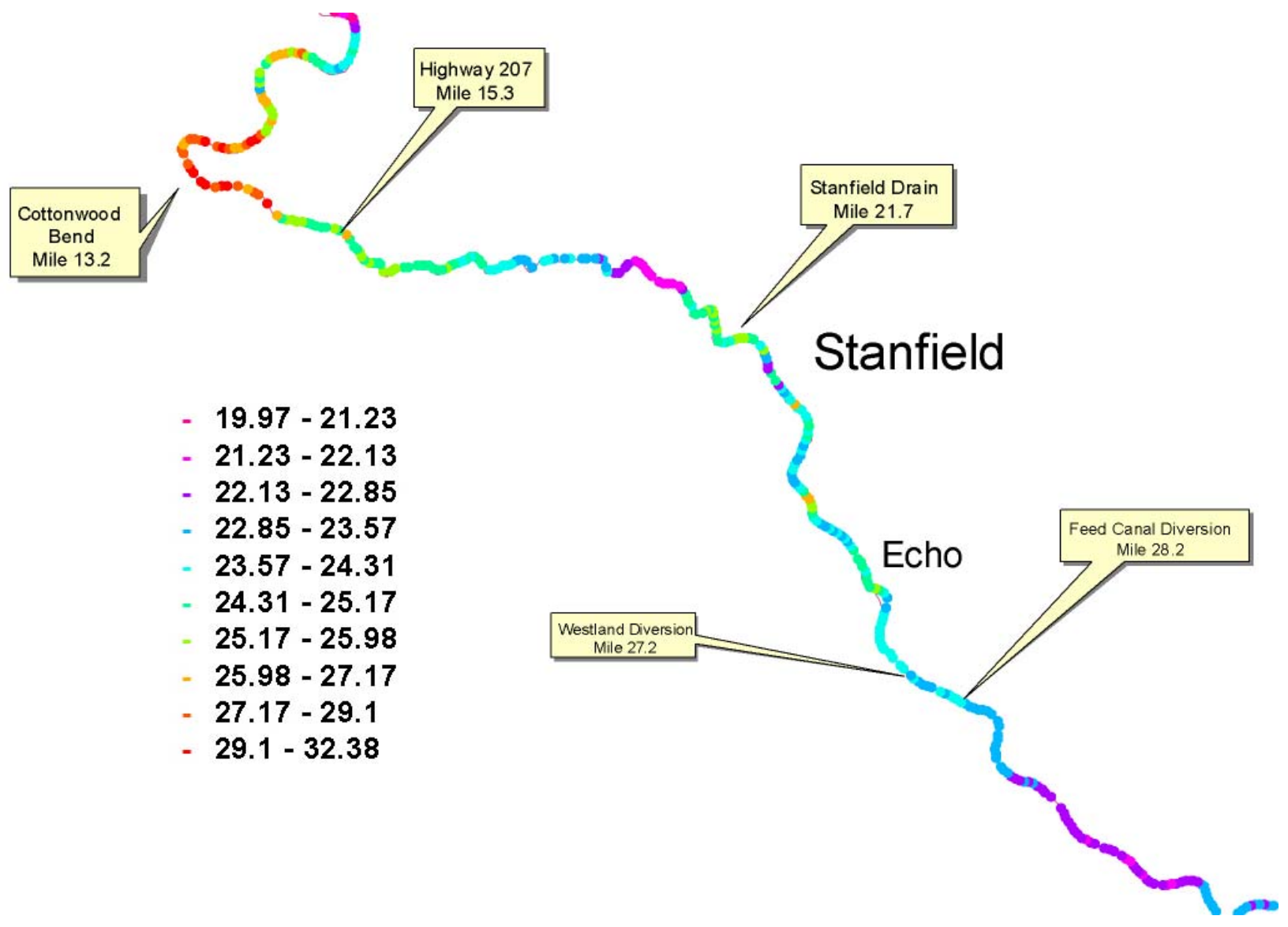

Fig-C3- Thermal Infrared (GIS Theme) of the Umatilla River flown on 08-07-2001. 
Figure C-4 shows a thermal infrared survey of the Umatilla River from River Mile (RM) 33 to the RM-13.2 (Cottonwood Bend) flown in the morning of October 1, 2001. The temperature scale was stretched from 12.97 to 30 Degree C (55-86 Deg F) to show more detail. As can be seen a number reaches show significant cooling mainly due to groundwater recharge in the middle of Echo Meadows area (RM 20 to 15) warming only a little (degree or so) by RM-13.2.

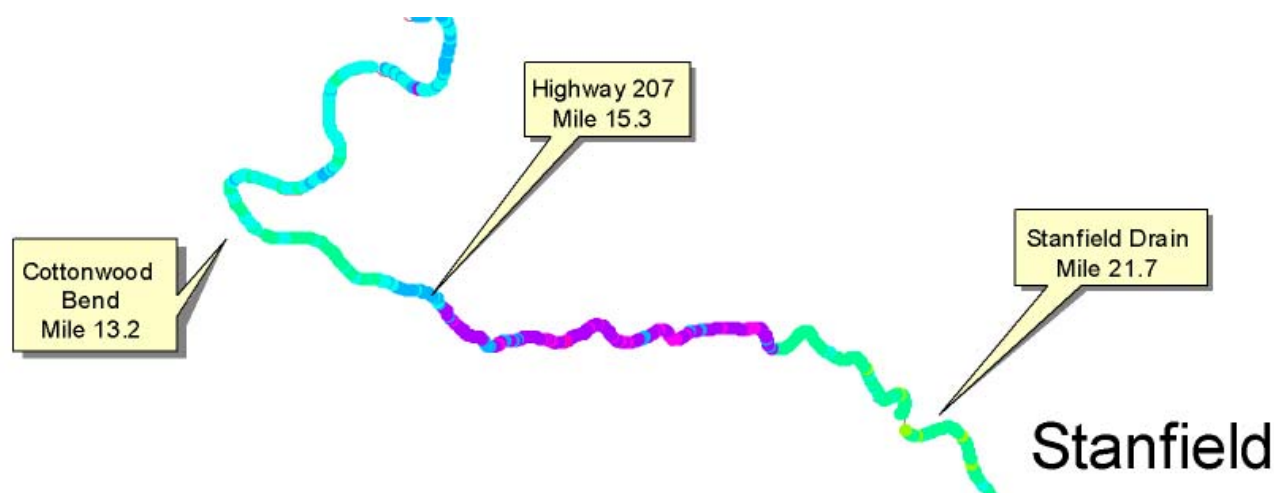

$-12.94-13.41$

- $13.41-13.79$

- $13.79-14.18$

$-14.18-14.54$

$-14.54-14.92$

- $14.92-15.42$

- $15.42-16.41$

$-16.41-18.35$

$-18.35-24.58$

- $24.58-30.05$

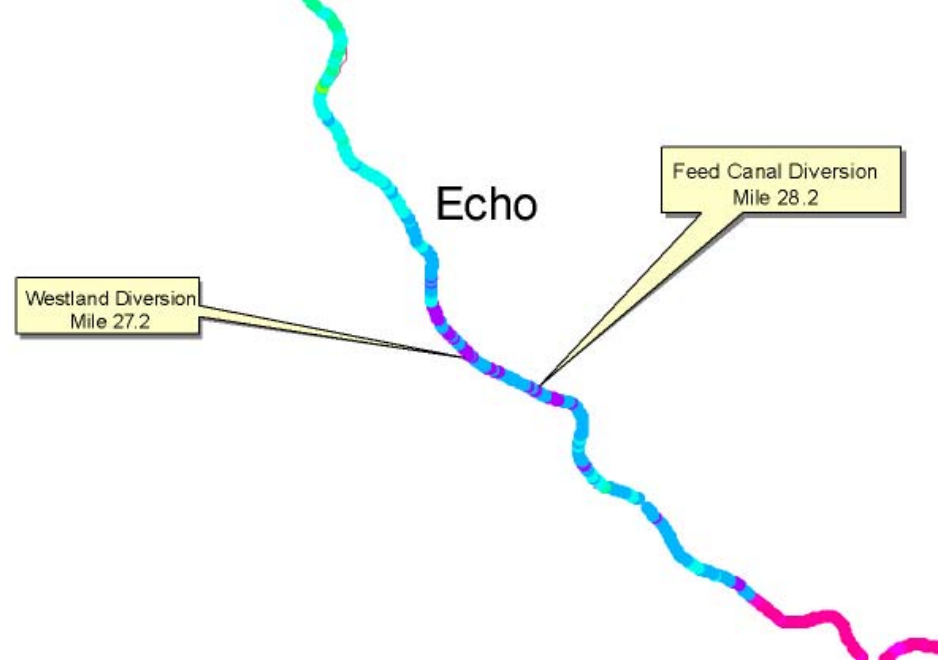

Fig-C4- Thermal Infrared (GIS Theme) of the Umatilla River flown on 10-01-2001 (am). 
Figure C-5 shows a thermal infrared survey of the Umatilla River from River Mile (RM) 33 to the RM-13.2 (Cottonwood Bend) flown in the afternoon of October 1, 2001. The temperature scale was stretched from 14.38 to 19 Degree C (55-66 Deg F) to show more detail. As can be seen a number reaches show cooling mainly due to groundwater recharge as it exit Echo Meadows area RM15 to RM-13.2. (Note: at this date there is very little flow in the river and weather was much cooler).

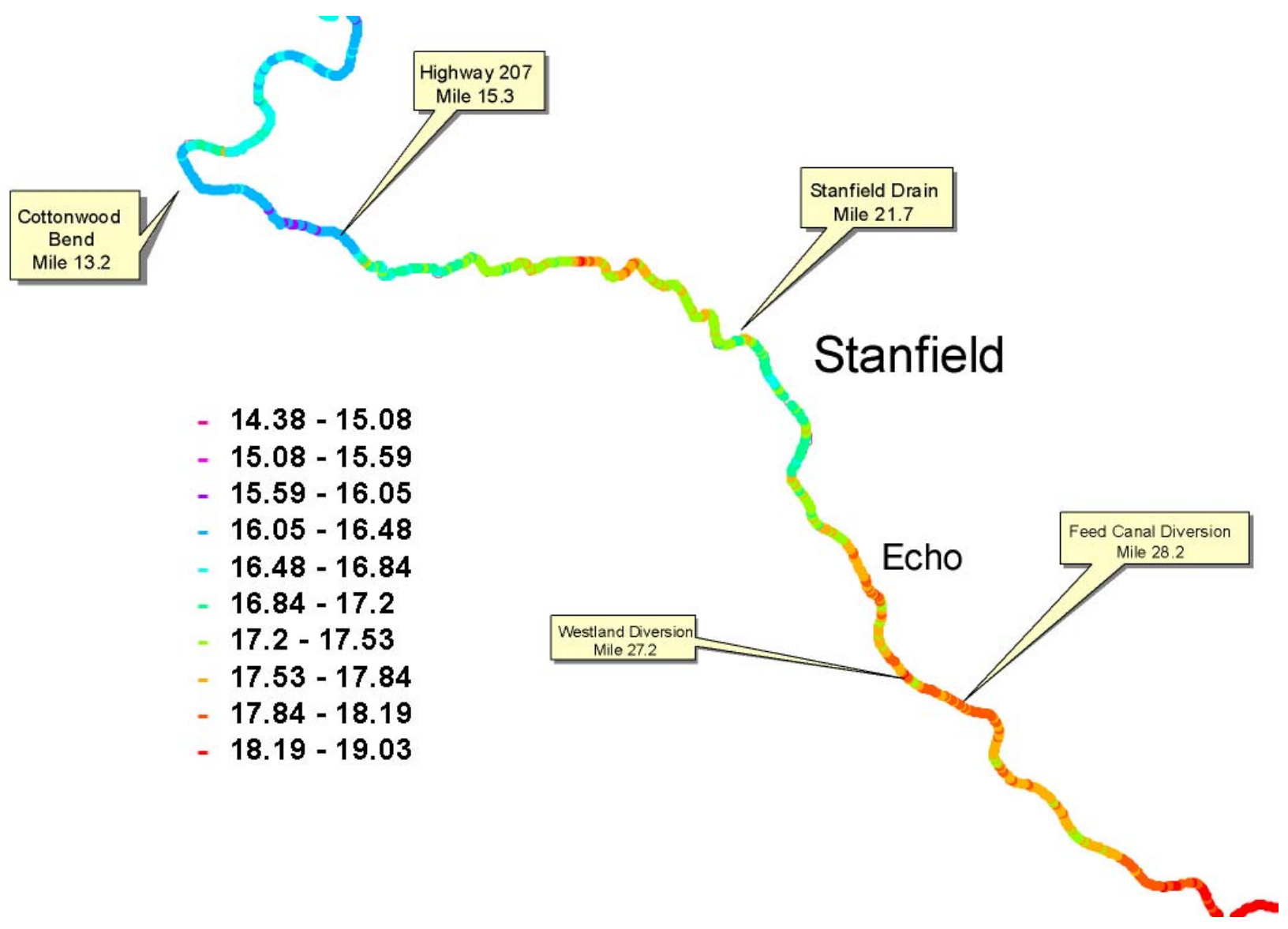

Fig-C5- Thermal Infrared (GIS Theme) of the Umatilla River flown on 10-01-2001 (pm). 


\section{Paired Thermal and Color Infrared Images:}

The Thermal and Color images were flown during summer and fall of 2001. Thermal Infrared Images are paired with Color Infrared to show both thermal and riparian zone and the landmass around the river. Figures C-6-through C-16 shows the paired images. The thermal infrared images show extremely interesting thermal cooling patterns (cold water refugias) mostly along the south bank of the river. The south bank of the river is the area within the Echo Meadow's irrigated area contributing to the groundwater recharge. Figure C-6 below shows a sample Thermal Infrared image at River Mile 27.3 with potential cold groundwater discharging into river (at the arrow) cooling some distance downstream. A movie of the thermal infrared images for the entire project reach of the Umatilla River can be found in files Fig-AVI-1Thermal infrared 08-07-01PM.AVI, Fig-AVI-2-Thermal infrared 10-01-01AM.AVI, and Fig-AVI-3-Thermal infrared 10-01-01PM.AVI.
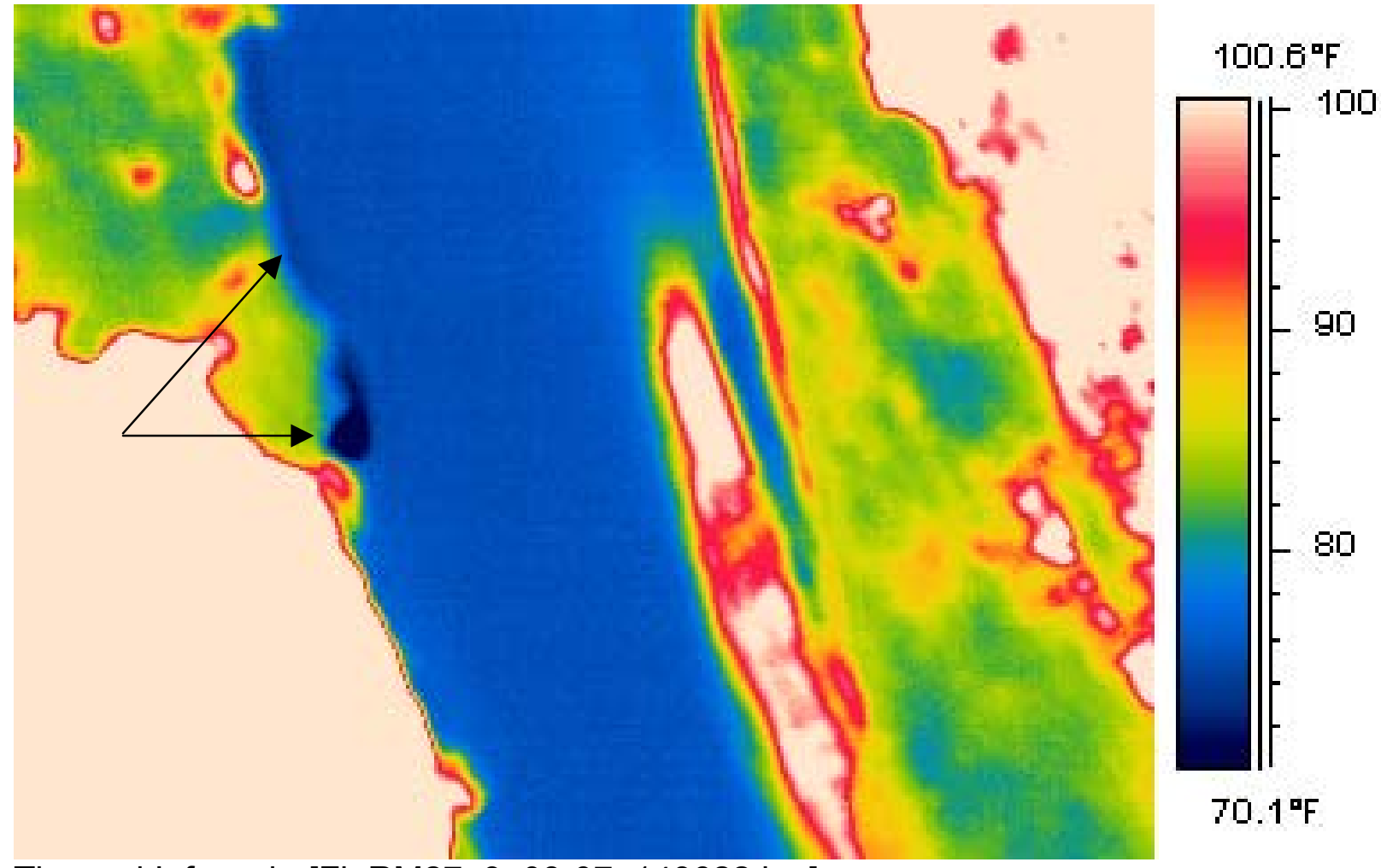

$70.1^{\mathrm{D}} \mathrm{F}$

Thermal Infrared- [FigRM27p3_08-07_143622.jpg]

Fig-C6- Thermal Infrared of the Umatilla River at RM-27.30 8-7-2001 


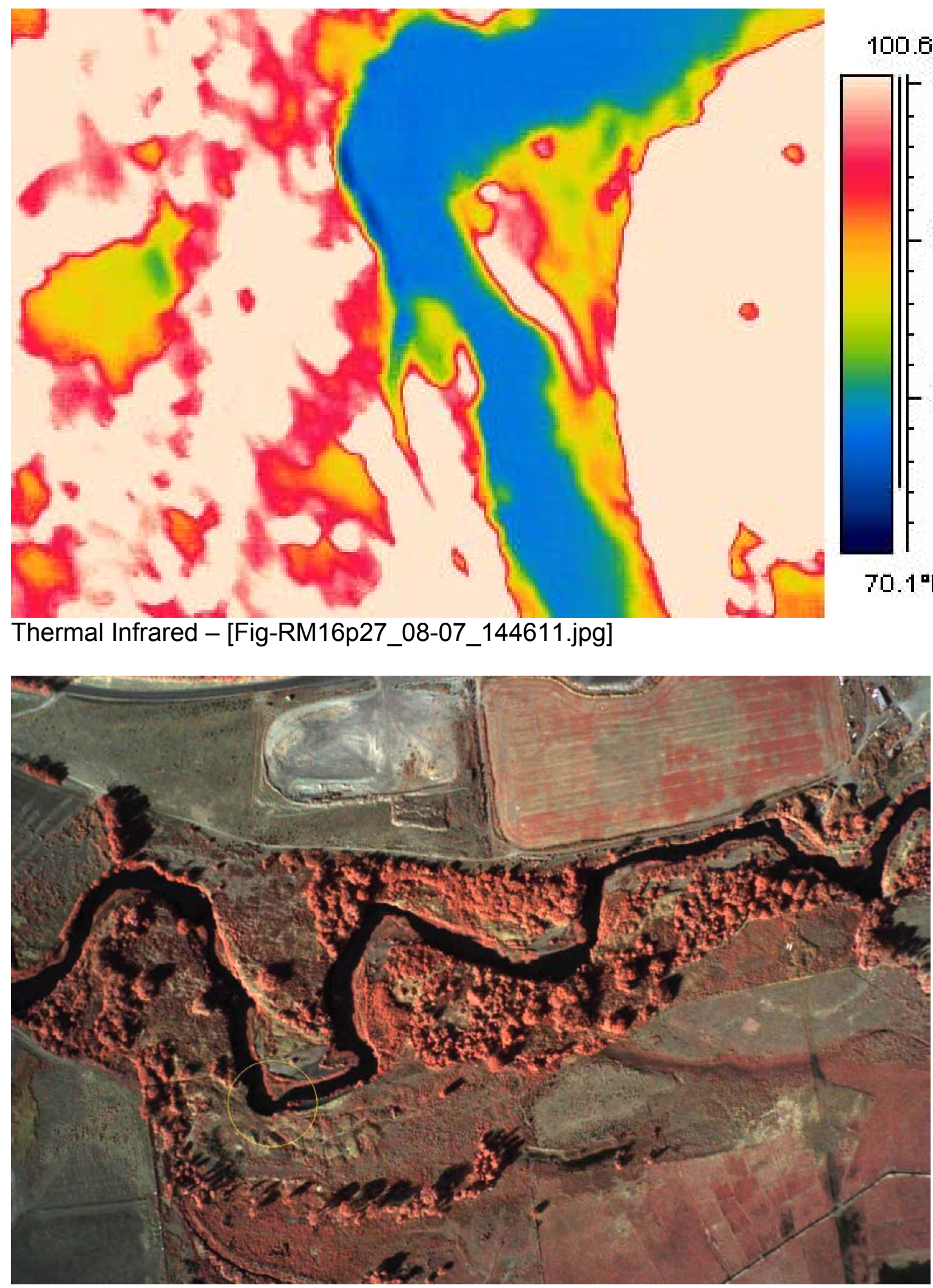

Color Infrared - [Fig-rm16p27cir.jpg]

Fig-C7-Thermal Infrared\&Color Infrared of the Umatilla River at RM-16.27 8-7-2001 


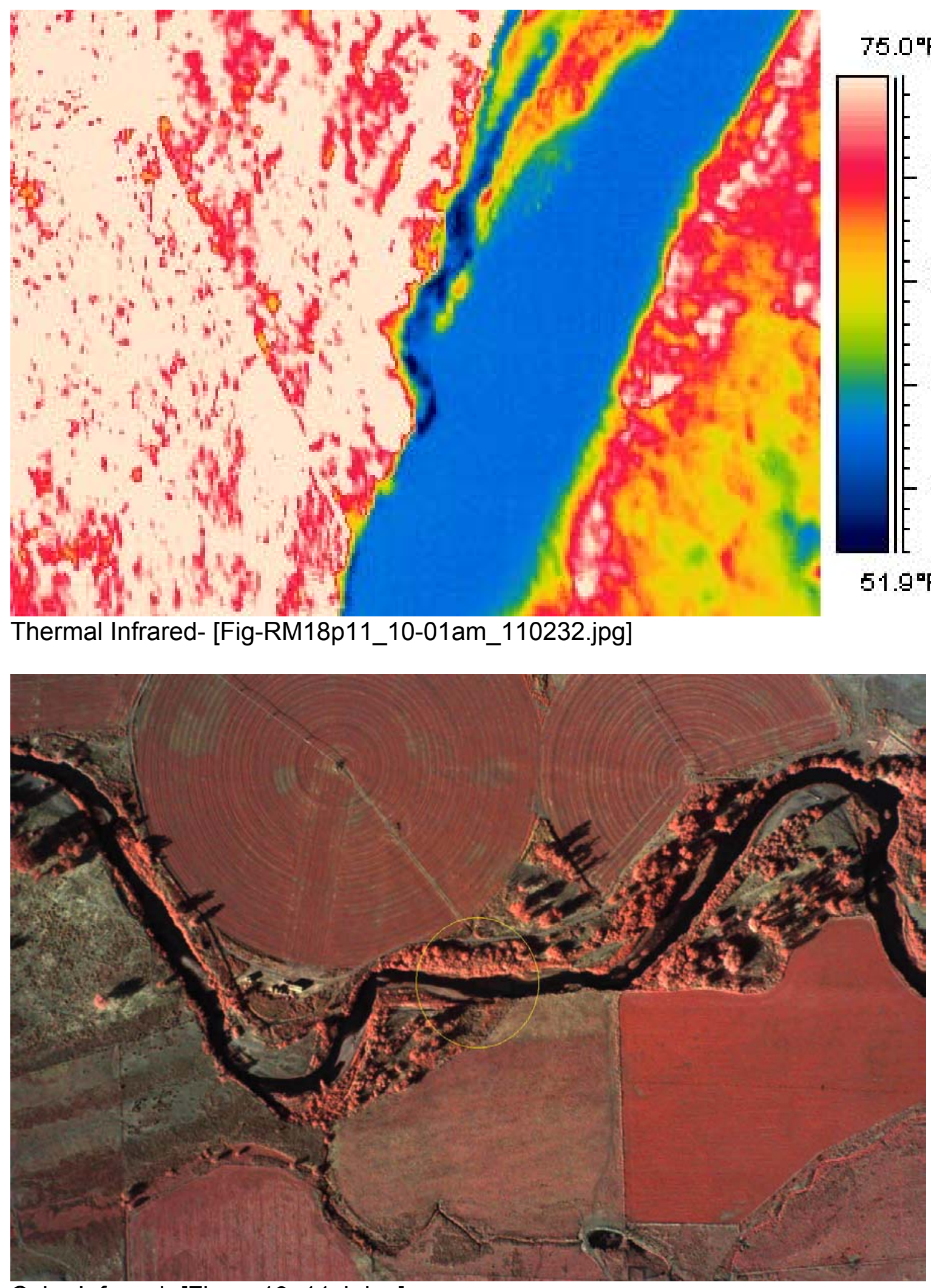

Color Infrared- [Fig-rm18p11cir.jpg]

Fig-C8- Thermal Infrared \& Color Infrared of the Umatilla River at RM-18.11 10-1-2001 


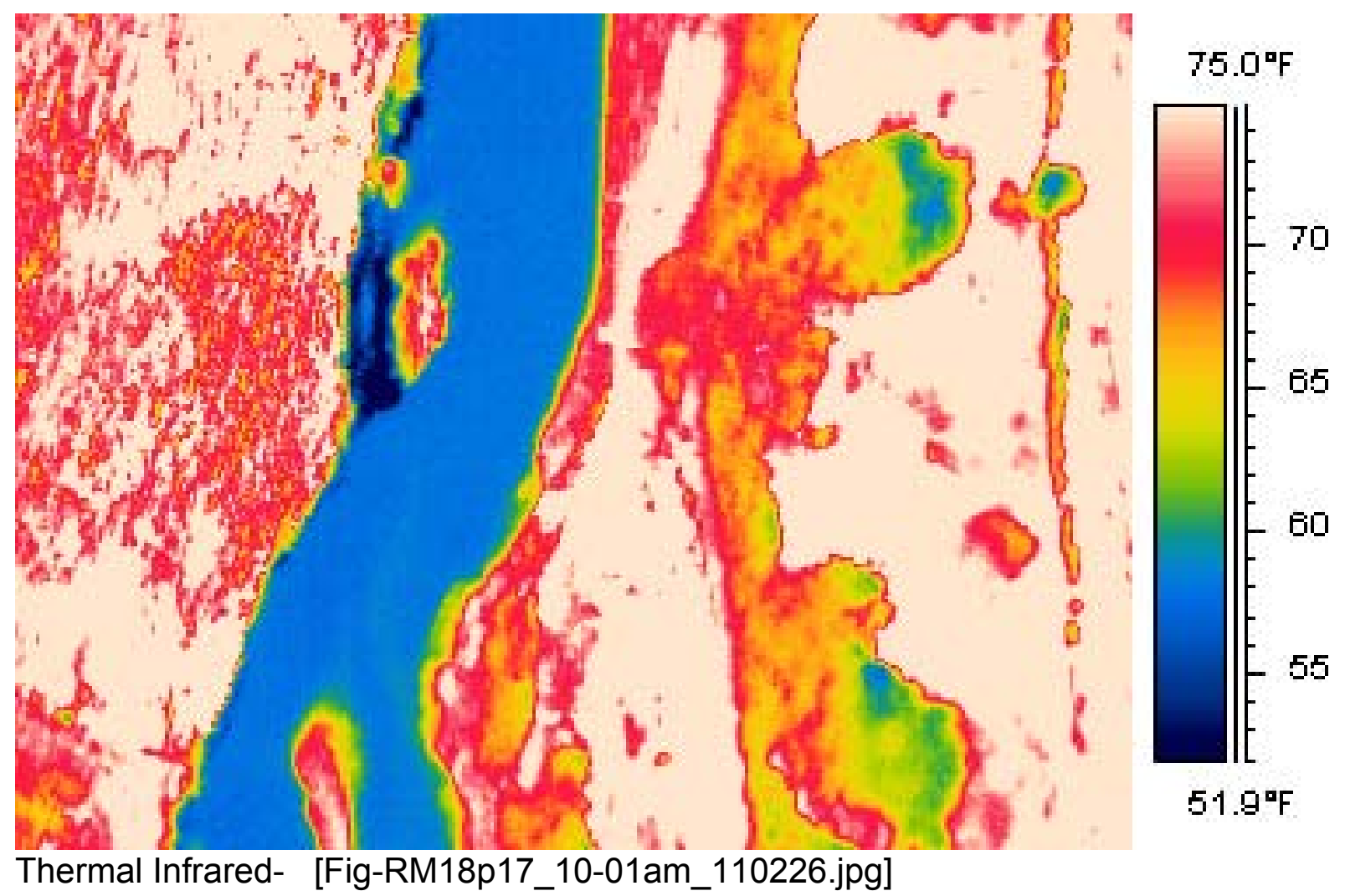

Fig-C9- Thermal Infrared of the Umatilla River at RM-18.17 10-1-2001 


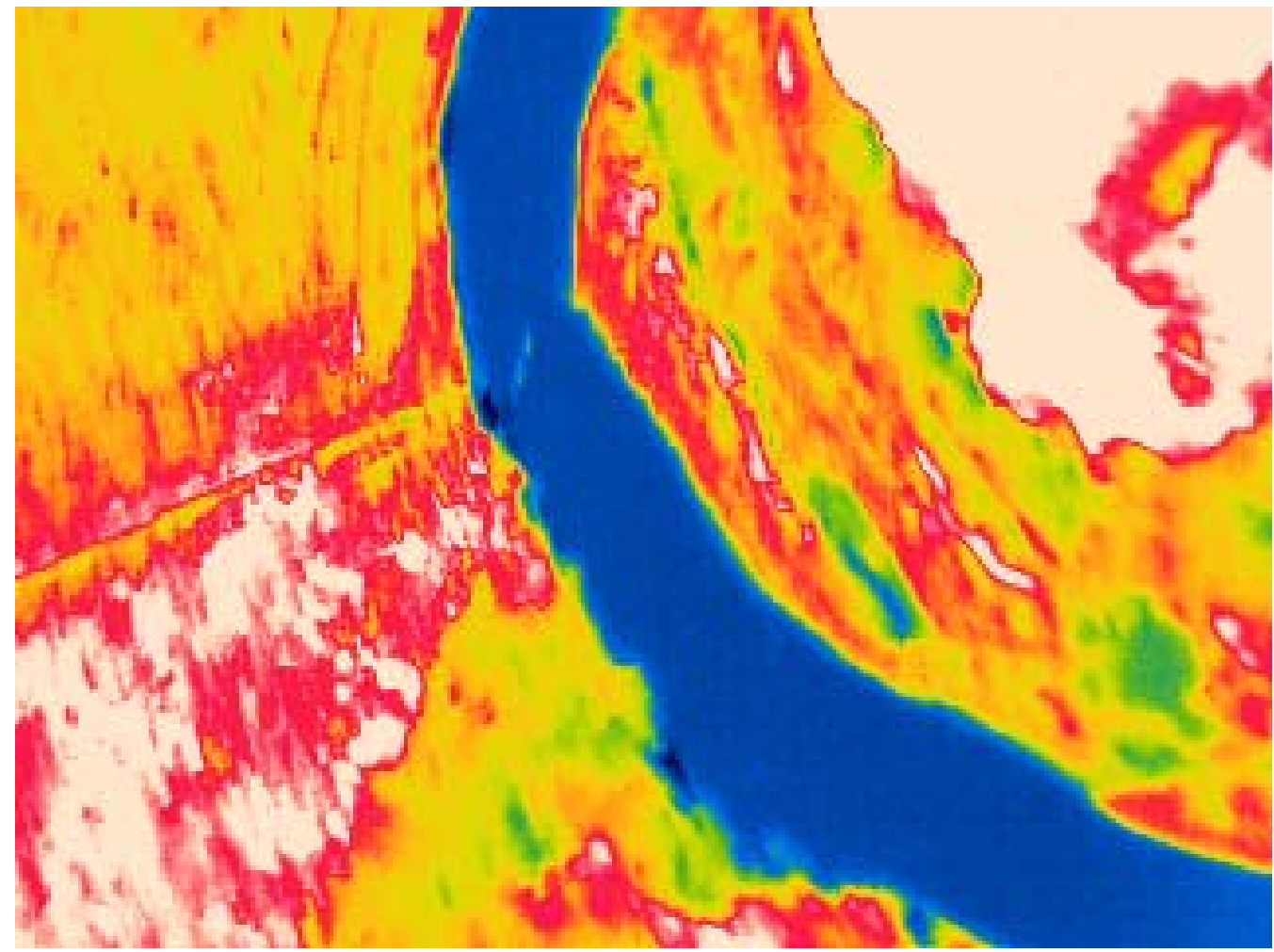

90.7 听

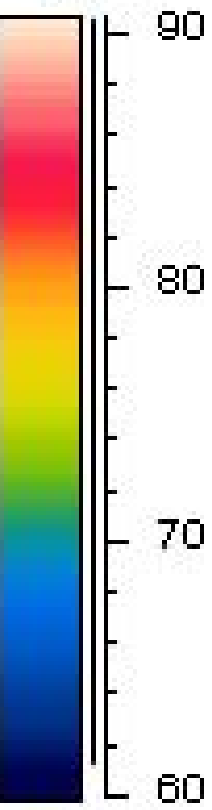

59.7 郋

Thermal Infrared- [FigRM18p71_10-01pm_153131.jpg]

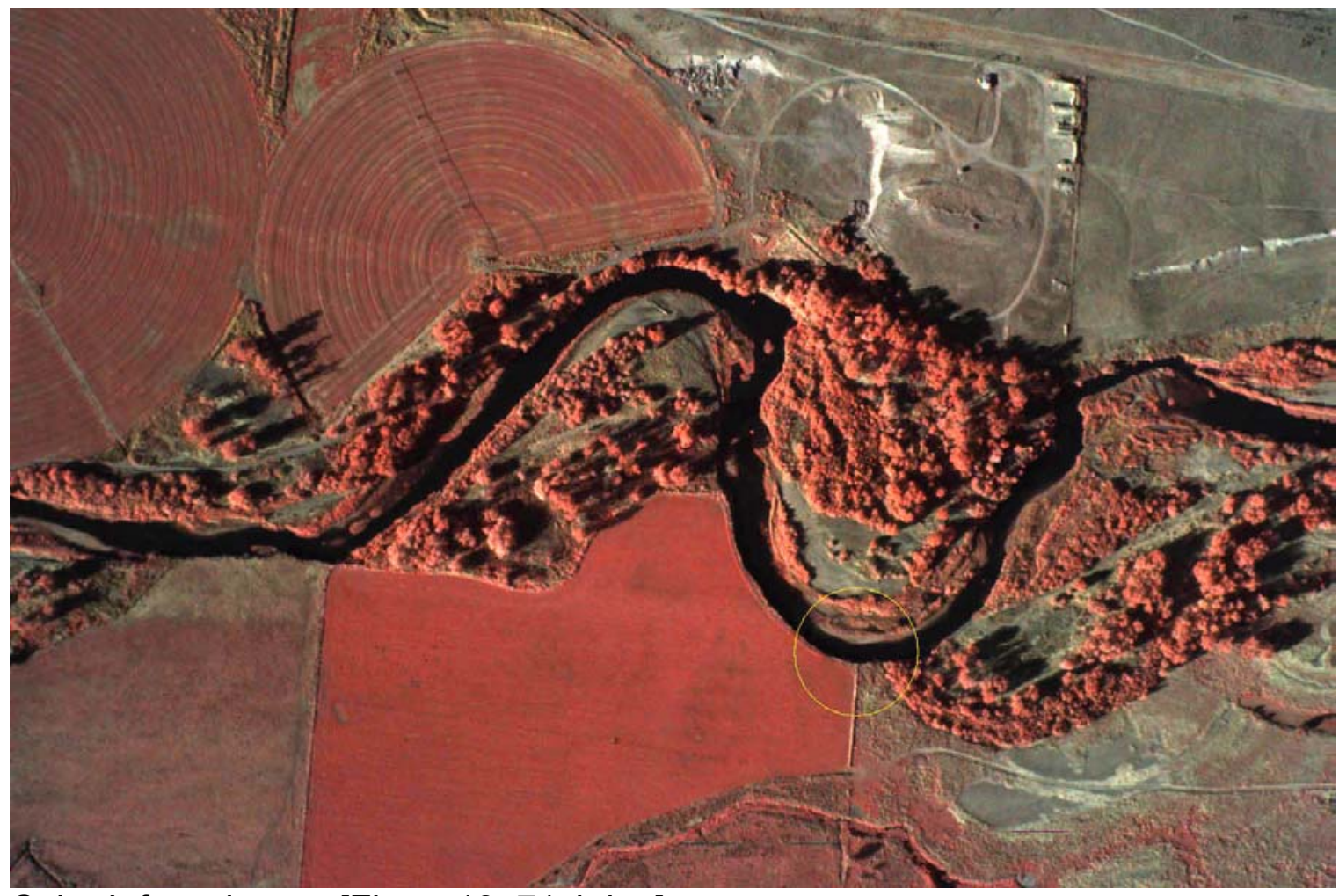

Color Infrared- [Fig-rm18p71cir.jpg]

Fig-C10- Thermal Infrared \&Color Infrared of the Umatilla River at RM-18.71, 10-1-2001 

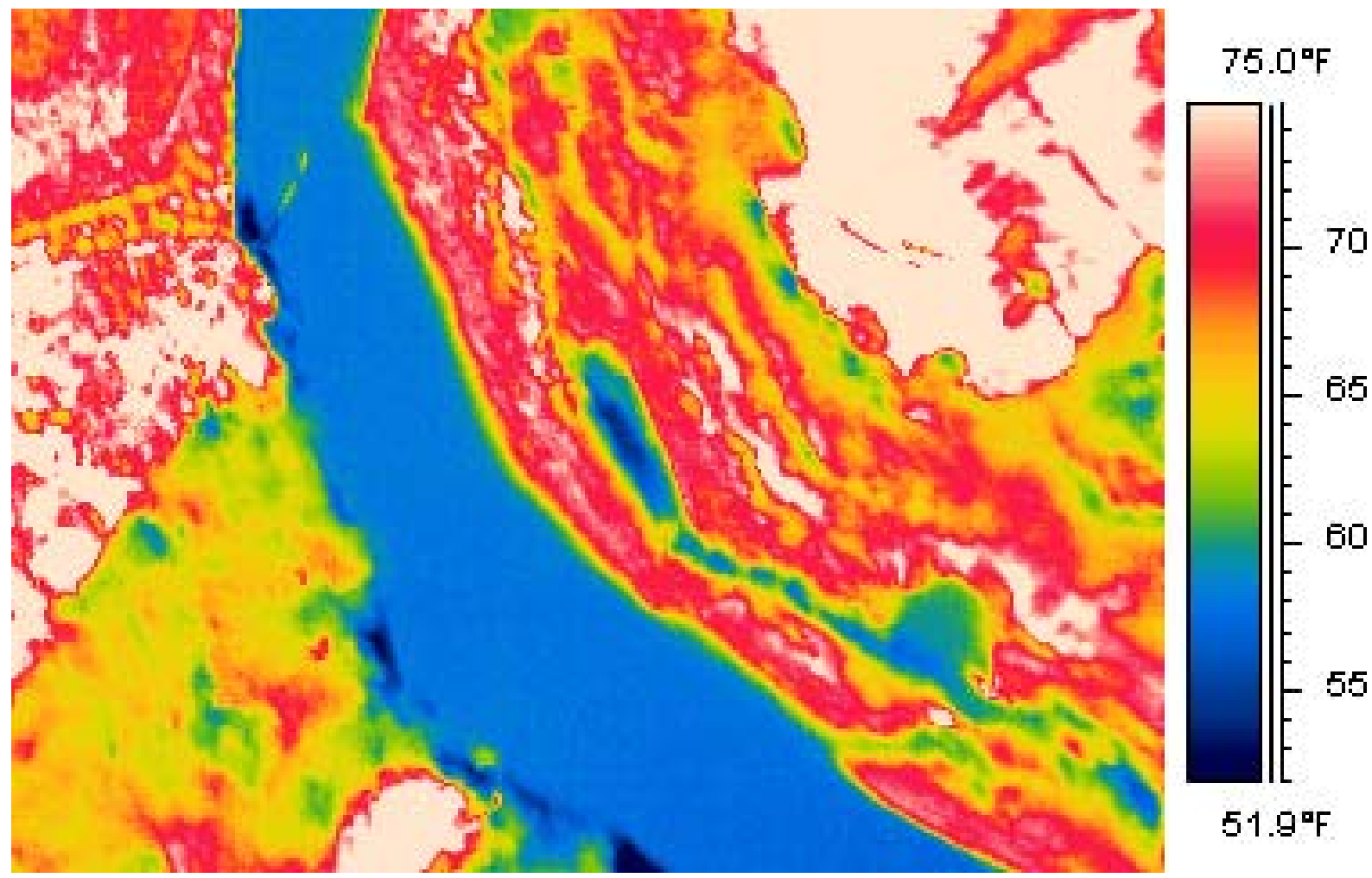

$51.9^{\circ} \mathrm{F}$

Thermal Infrared- [FigRM18p68_10-01am_110150.jpg]

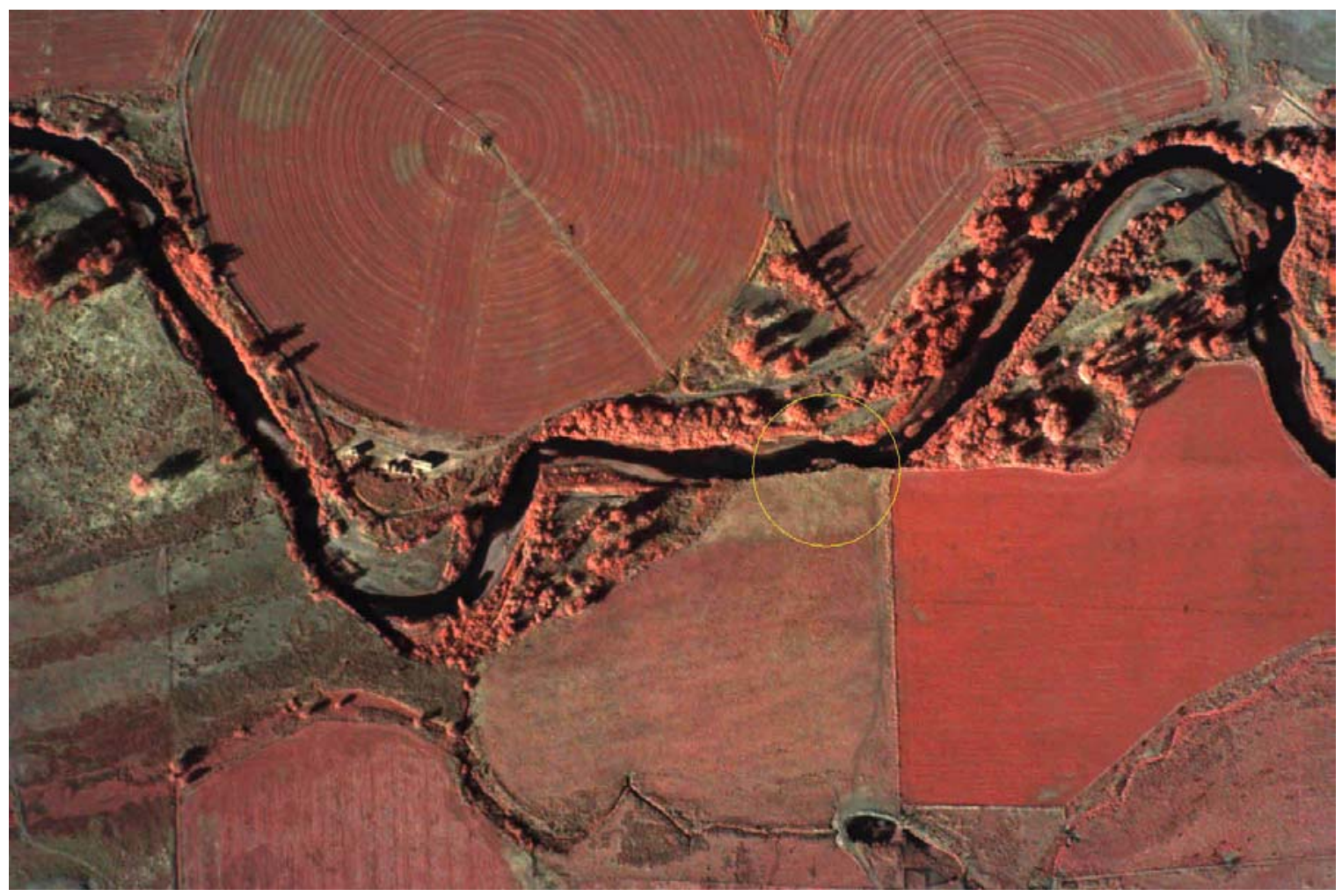

Color Infrared- [Fig-rm18p70cir.jpg]

Fig-C11-Thermal Infrared \& Color Infrared of the Umatilla River at RM-18.70, 10-1-2001 


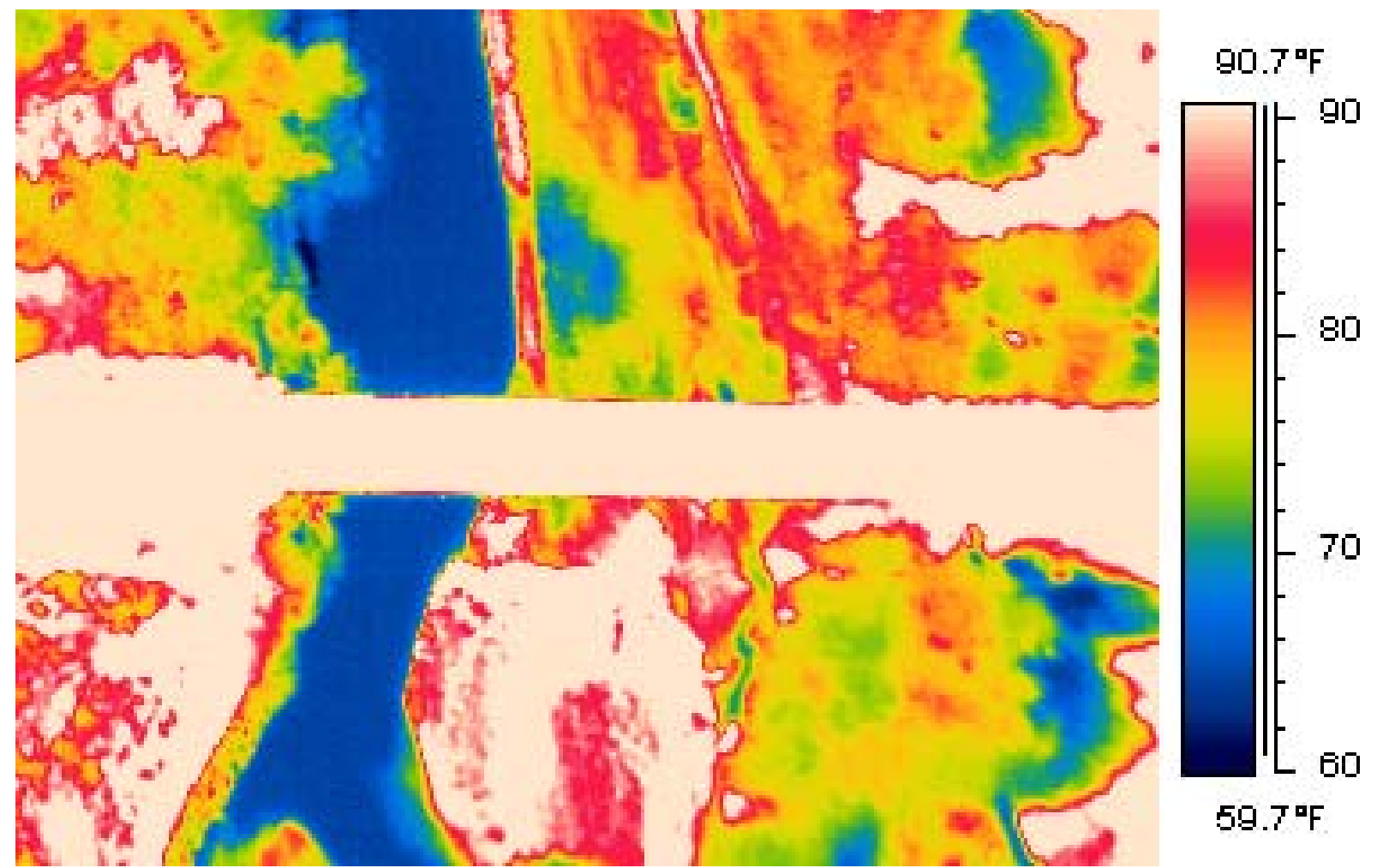

Thermal Infrared- [FigRM22p59_10-01pm_152717.jpg]

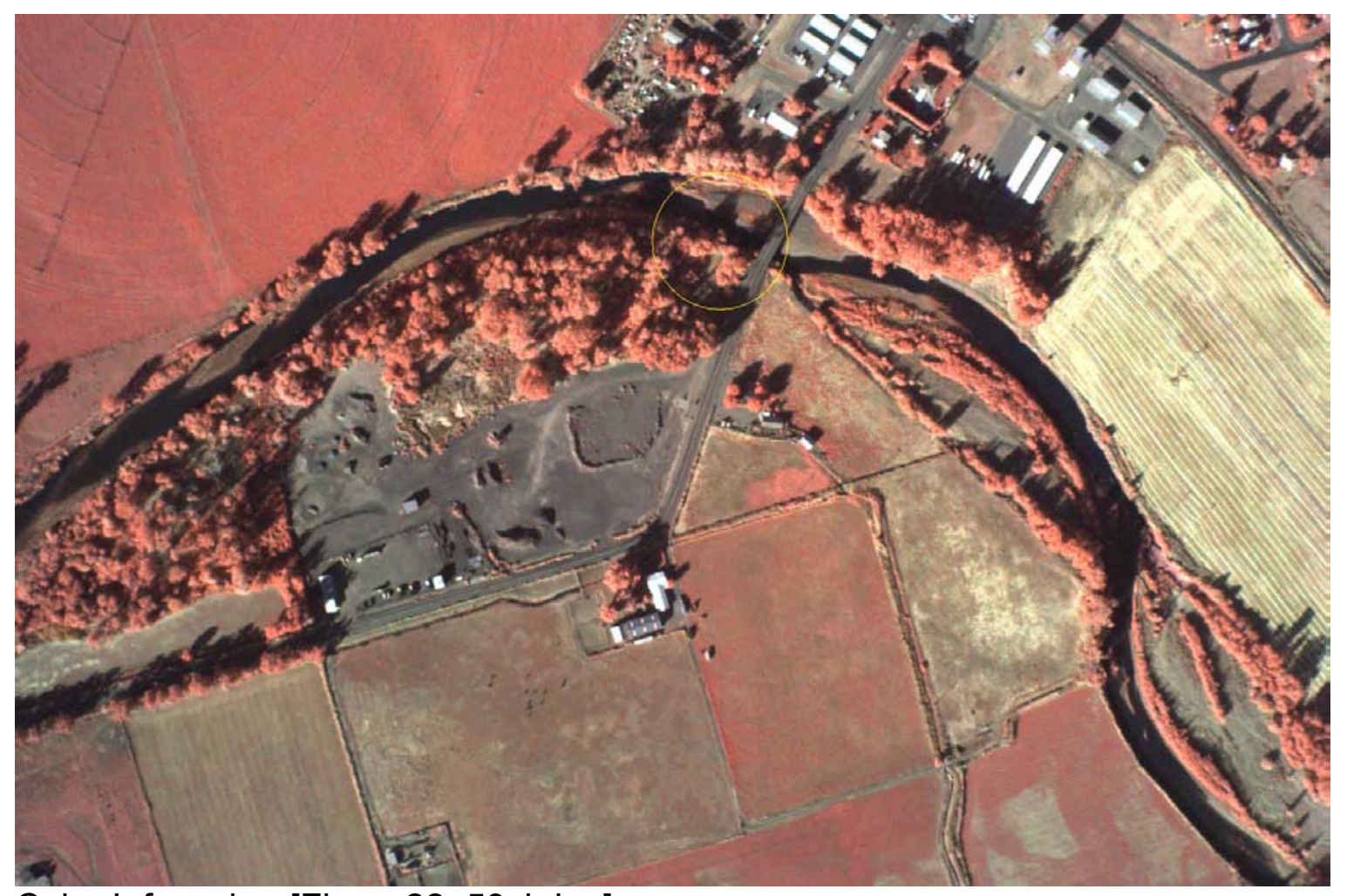

Color Infrared- [Fig-rm22p59cir.jpg]

Fig-C12- Thermal Infrared \&Color Infrared of the Umatilla River at RM-22.59, 10-1-2001 


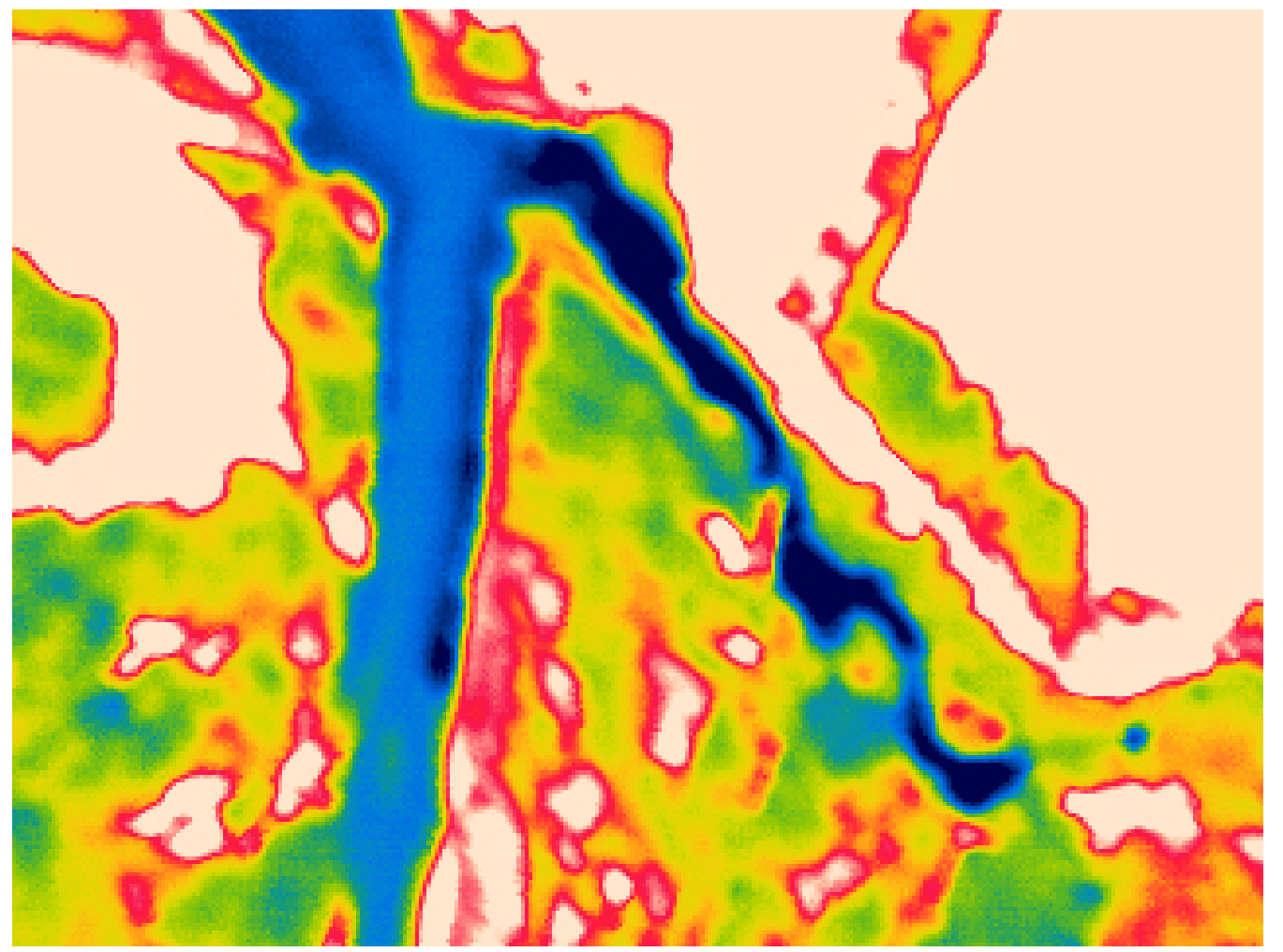

100.6 听

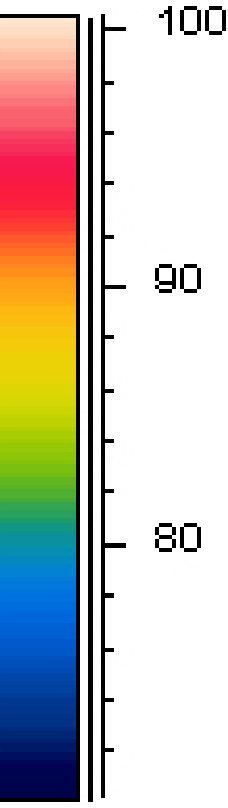

70. $1^{\circ \mathrm{F}}$

Thermal Infrared- [FigRM21p7_08-07-144143.jpg]

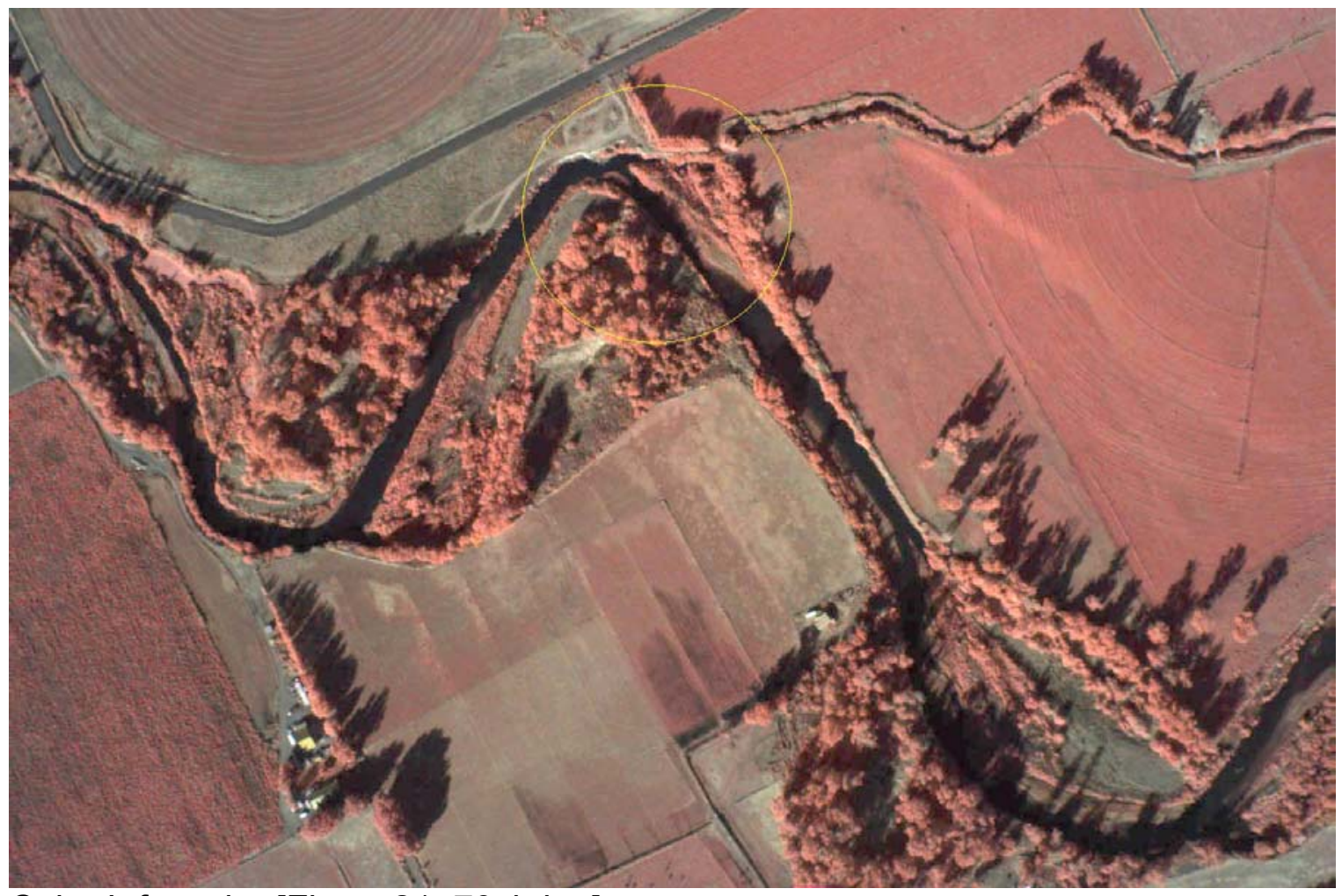

Color Infrared- [Fig-rm21p70cir.jpg]

Fig-C13-Thermal Infrared \& Color Infrared of the Umatilla River at RM-21.70, 10-1-2001 


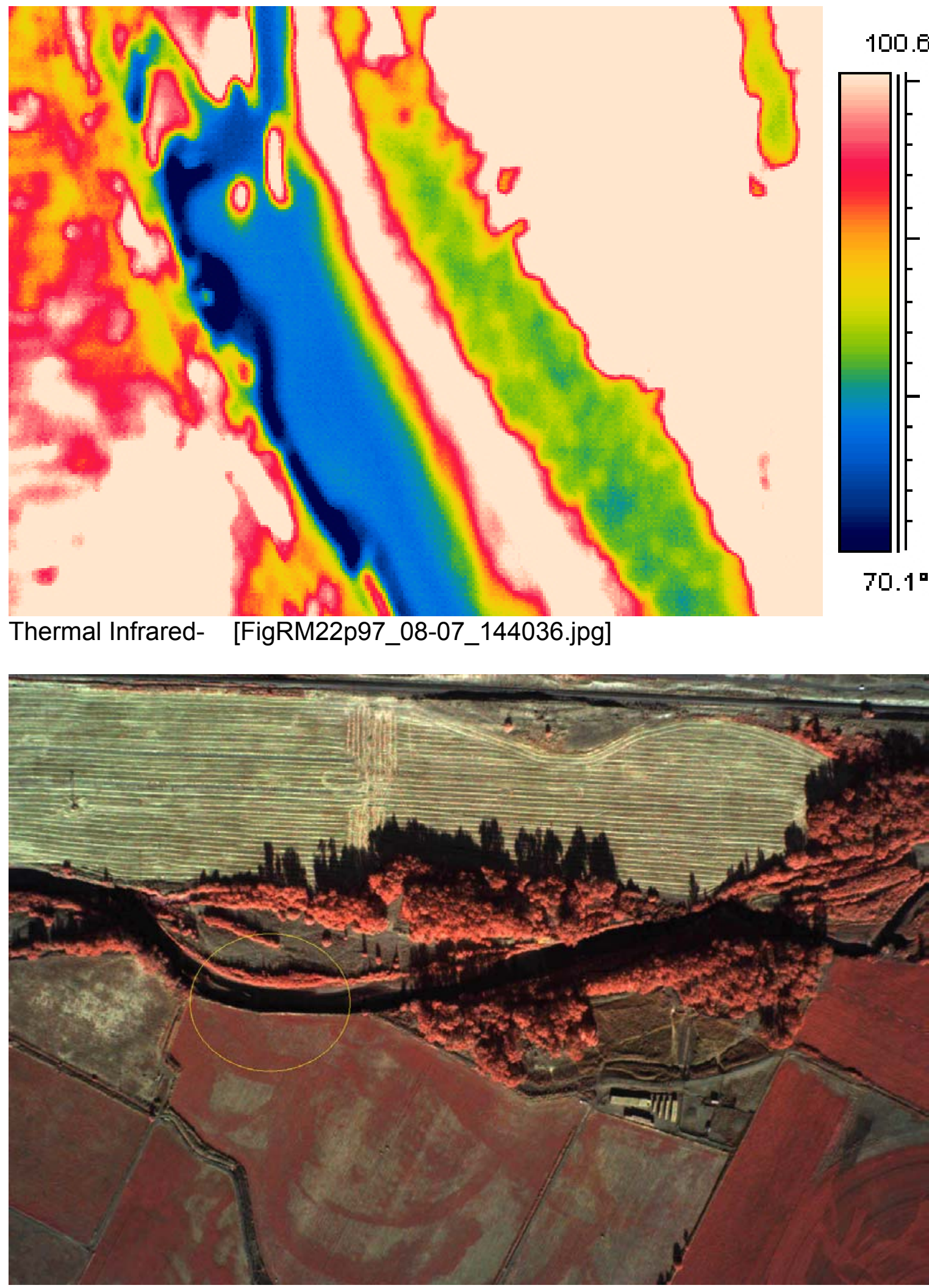

Color Infrared- $\quad$ [Fig-rm22p97cir.jpg]

Fig-C14-Thermal Infrared \& Color Infrared of the Umatilla River at RM-22.97, 8-7-2001 


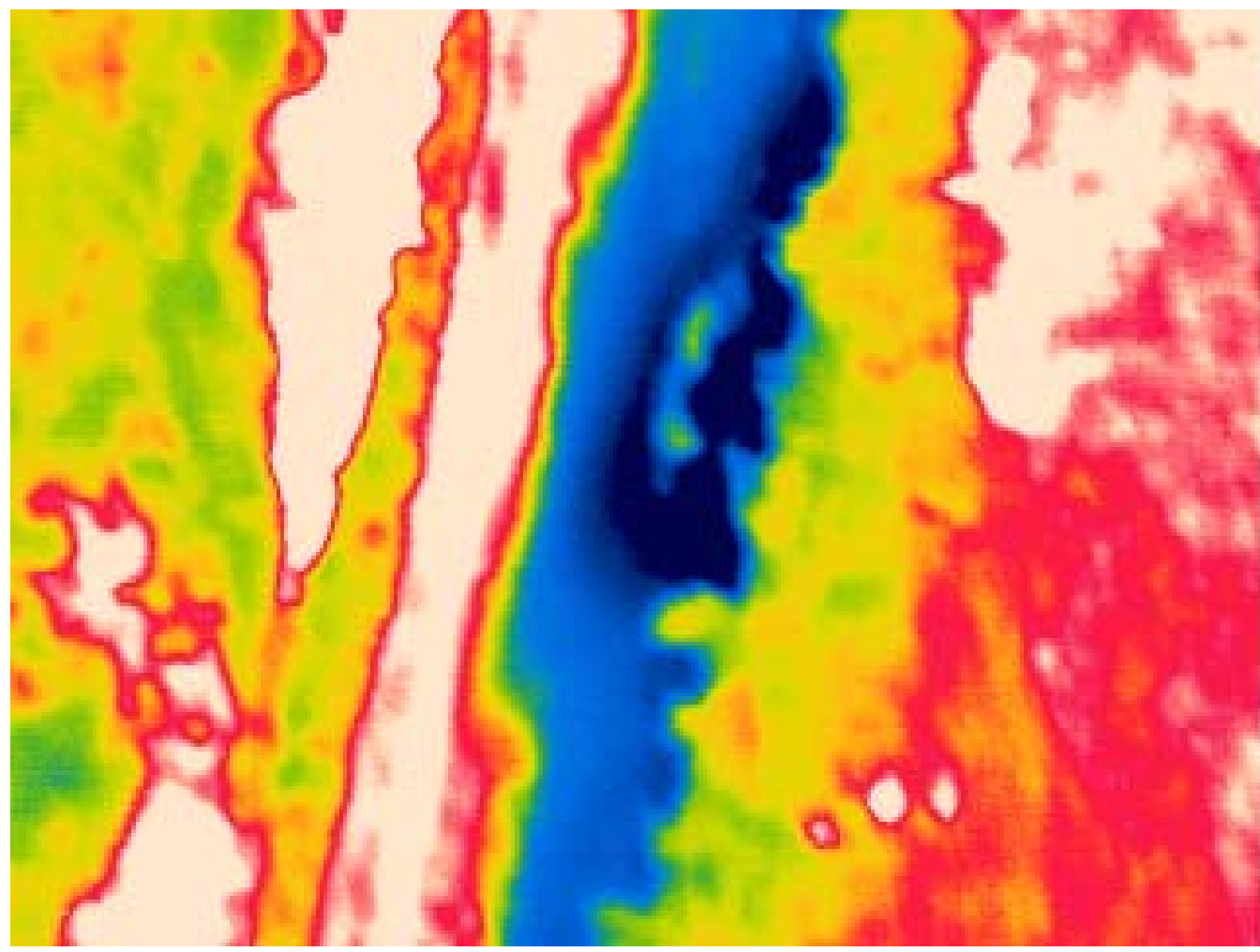

$100.6 \mathrm{~F}$

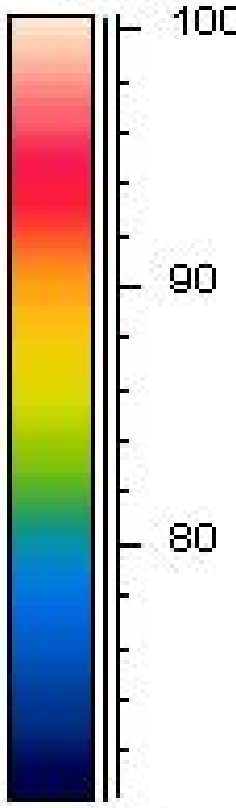

70. $1^{\circ} \mathrm{F}$

Thermal Infrared- [FigRM24p26_08-07_143930.jpg]

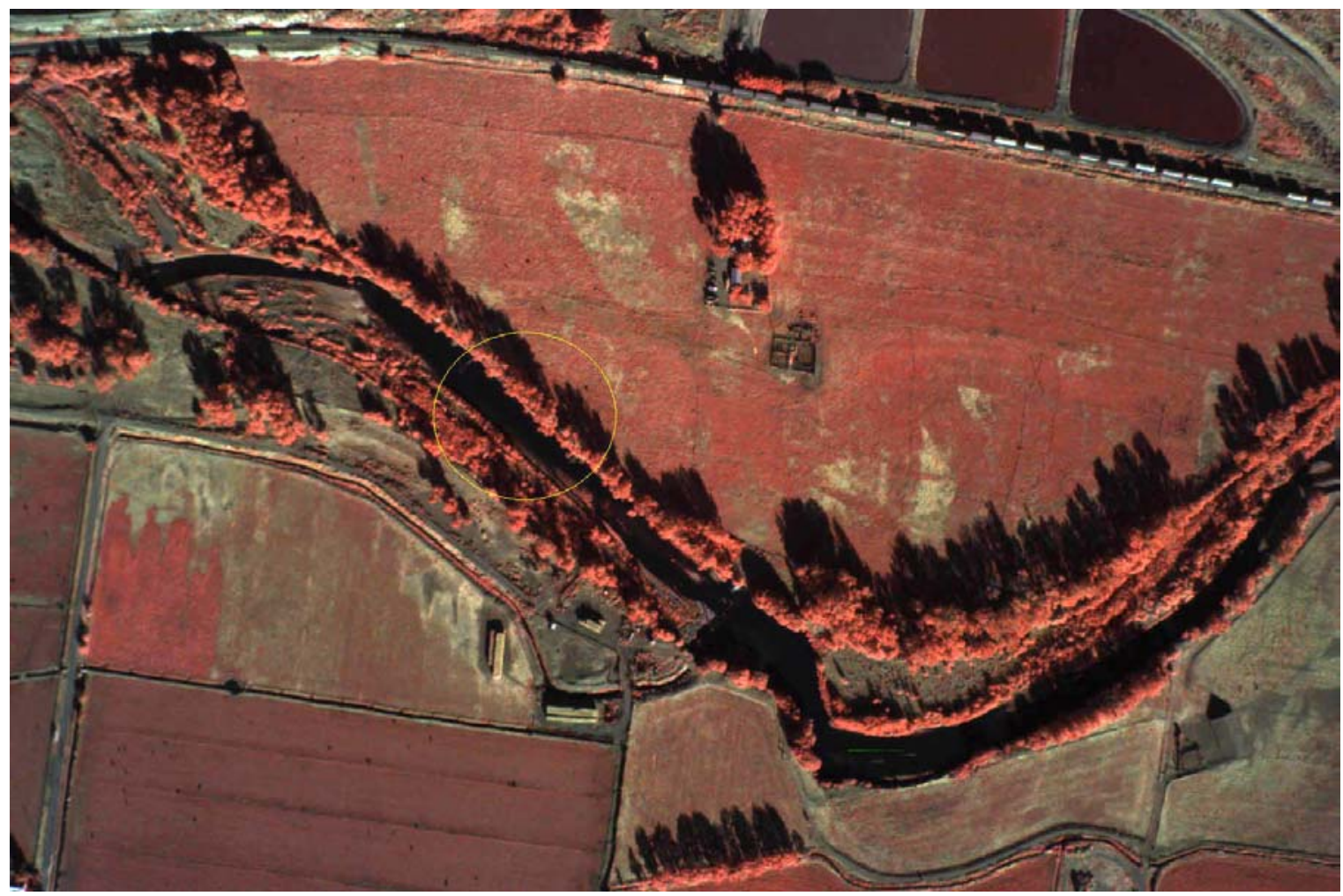

Color Infrared- [Fig-rm24p26cir.jpg]

Fig-C15- Thermal Infrared \& Color Infrared of the Umatilla River at RM-24.26, 8-7-2001 


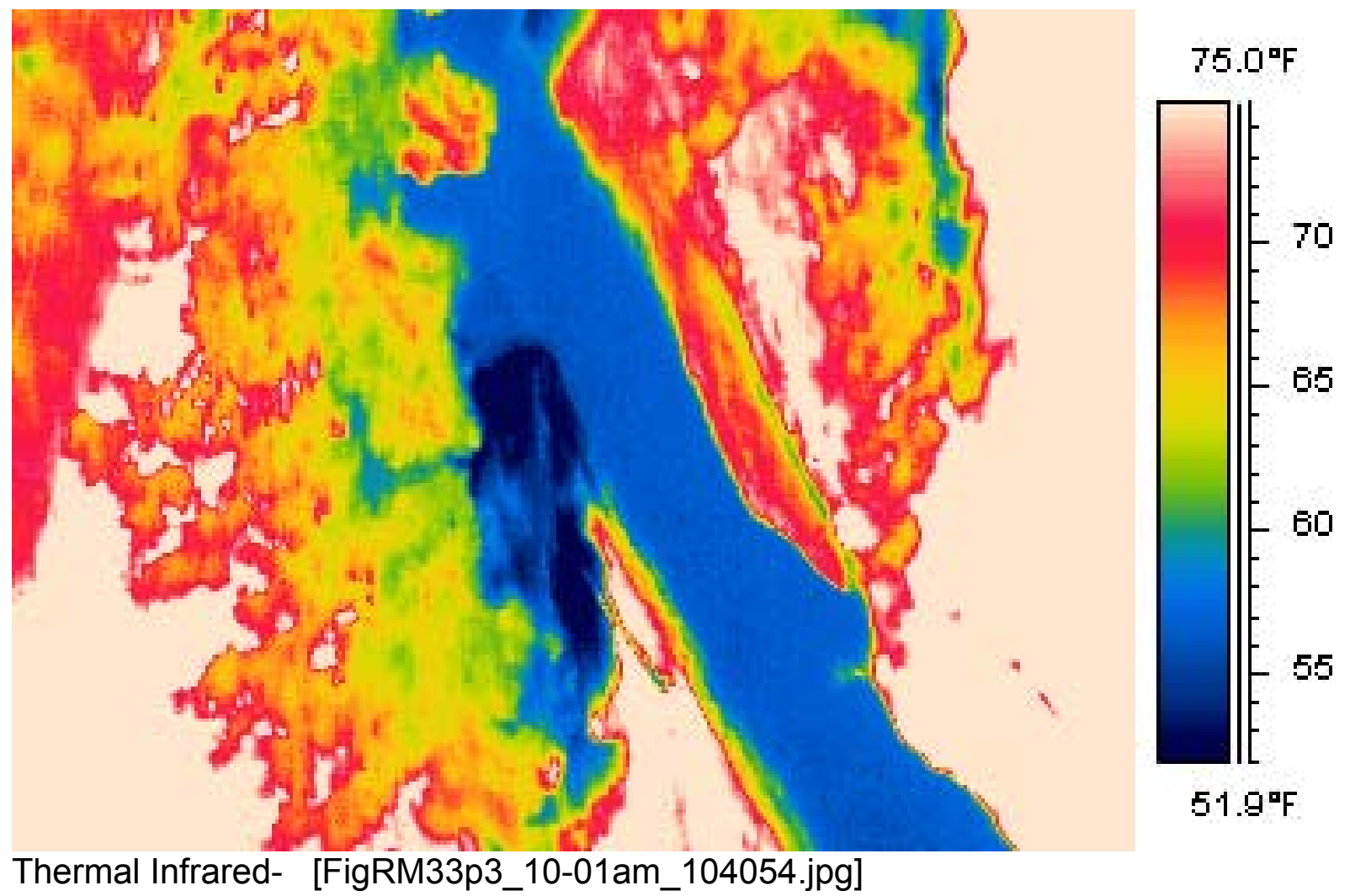

Fig-C16- Thermal Infrared of the Umatilla River at RM-33.30 10-01-2001

\section{Color-Infrared Image Mosaic}

Color infrared images (CIR) of the entire Echo Meadows Project area were collected on October 26, 2001. The CIR images shows vegetations in red color with more red colors equating to more vegetation vigor and health. Bare soil or areas devoid of vegetation are shown in dark/block colors and water/wetlands showing in black. The CIR images are used primarily as a base map for other GIS themes and for change detection. Any change in this image will be compared to a subsequent image of the landmass to be flown in 2003 (implementation phase). Changes such as conversion to center pivot irrigation, wetland expansion or contraction, riparian zone vegetation, etc. will be documented and used in the final implementation phase report.

The images are obtained by flying a grid pattern over the project area with sufficient end lap and side lap between adjacent images. In the office, IRZ used specialized image processing software to color balance each image, orthorectified and stitched together to form a seamless mosaic. A 1998 CIR images is shown in Figure-1. A number of changes in the landmass are detectable. High-resolution river riparian zone $\mathrm{CIR}$ images are shown in Figures C6 Through C14. 
This imagery is available as ArcView files on the CD entitled cir 2001 4.img. A bit map version of this image is shown on Figure C-17.

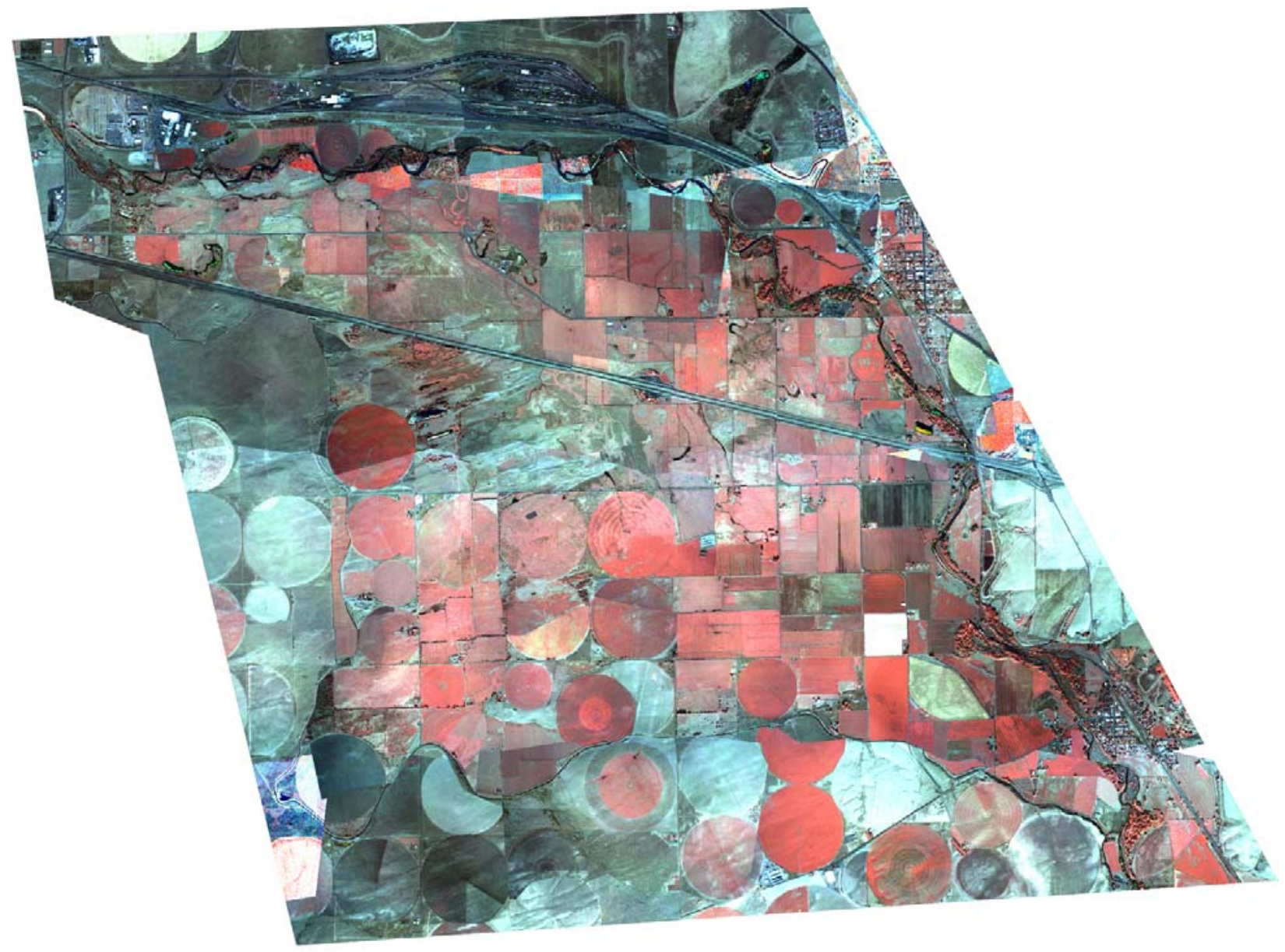

Figure C-17- 2001 Color (Near) Infrared survey of Echo Meadows 


\section{Appendix D}

\section{Trail Water Application}

IRZ conducted a trial application of recharge water from 11:00 am on February 25, 2002 to March 1, 2002 at 06:00 am. The purpose of the trial was to develop techniques for recharge applications in the future (such as measuring the amount and location of the recharged water) and the measurement of the positive inflection of the water table during recharge. In addition, this trial application of water was simulated with our MODFLOW model for further validation of the model and to improve its operational capabilities.

Water was diverted through three diversion gates \#; G06A, G09, and G11. The locations of these gates (and other gates along the Hunt Ditch) are shown in Figure D-1. This application of water was a significant amount of water for testing purposes (as compared to a pump test), but could not be expected to result in a significant change to the groundwater regime in the Meadows.

Nearly 20 acre-feet of water was diverted and applied to fields in the southern portion of the Meadows. Approximately 9.6, 4.4, and 5.8 acre-feet of water were diverted from headgates G06A, G09, and G11, respectively. Calculations of the amount of water that was diverted through these headgates are found in Excel file Water application.xls.

Figure D-1 shows the resulting fields that were flooded during the trial. As can be seen on Figure D-1, a 10 acres wetland was flooded near Headgate G06A and about 2 acres was flooded near Headgate G11. The water diverted from Headgate G09 was confined to a diversion ditch that runs through the field. Nearby wells that were monitored during this application period and are discussed in the following paragraphs are also shown on Figure D-1.

As can be seen on Figure D-2, the 4.4 acre-feet diversion through Head gate G09 caused the nearby down-gradient well DMPW-1 to rise about 1.5 inches from February 27, 2002 to March 5, 2002. This same trend can be seen in Figure D-3, where the 5.8 acre-feet of water that was diverted from Headgate G-11 caused the down-gradient water levels in well DMW-1 to increase 1-2 inches during this same time. Water levels that were measured at the nearby observation wells are found in the Excel file Water application.xls.

A much more extensive trial application and monitoring program was completed in the vicinity down-gradient of the water diverted from Headgate G06A (9.6 acre-feet). This trial application had several wells that were monitored in the vicinity as can be seen in Figure D-1. The table D-1 shows the wells that were monitored during this trial water application as well as several other important variables for simulating this application. This table and model results are discussed in more detail in following sections. 
Table D-1- Monitoring well sites and measurements during trail water application as compared to Model.

\begin{tabular}{|c|c|c|c|c|}
\hline Well ID & Distance (ft) & $\begin{array}{c}\text { Measured } \\
\text { Fluctuation (ft) }\end{array}$ & Date & $\begin{array}{c}\text { Modeled } \\
\text { Fluctuation }(\mathrm{ft})^{1}\end{array}$ \\
\hline DMPW-2 & $<100$ & 1.67 & $3 / 2 / 02$ & 1.90 \\
\hline ERW-1 & 1,300 & 0.10 & $3 / 1 / 02$ & 0.30 \\
\hline ERW-2 & 1,530 & 0.44 & $3 / 1 / 02$ & 0.30 \\
\hline JSPW-1 & 2,775 & 0.15 & $3 / 4 / 02$ & 0.048 \\
\hline BAPW-1 & 3,670 & 0.29 & $3 / 4 / 02$ & 0.048 \\
\hline MMPW-1 & 4,140 & 0.02 & $3 / 4 / 02$ & 0.008 \\
\hline
\end{tabular}

${ }^{1}$ Comparable cell in the model

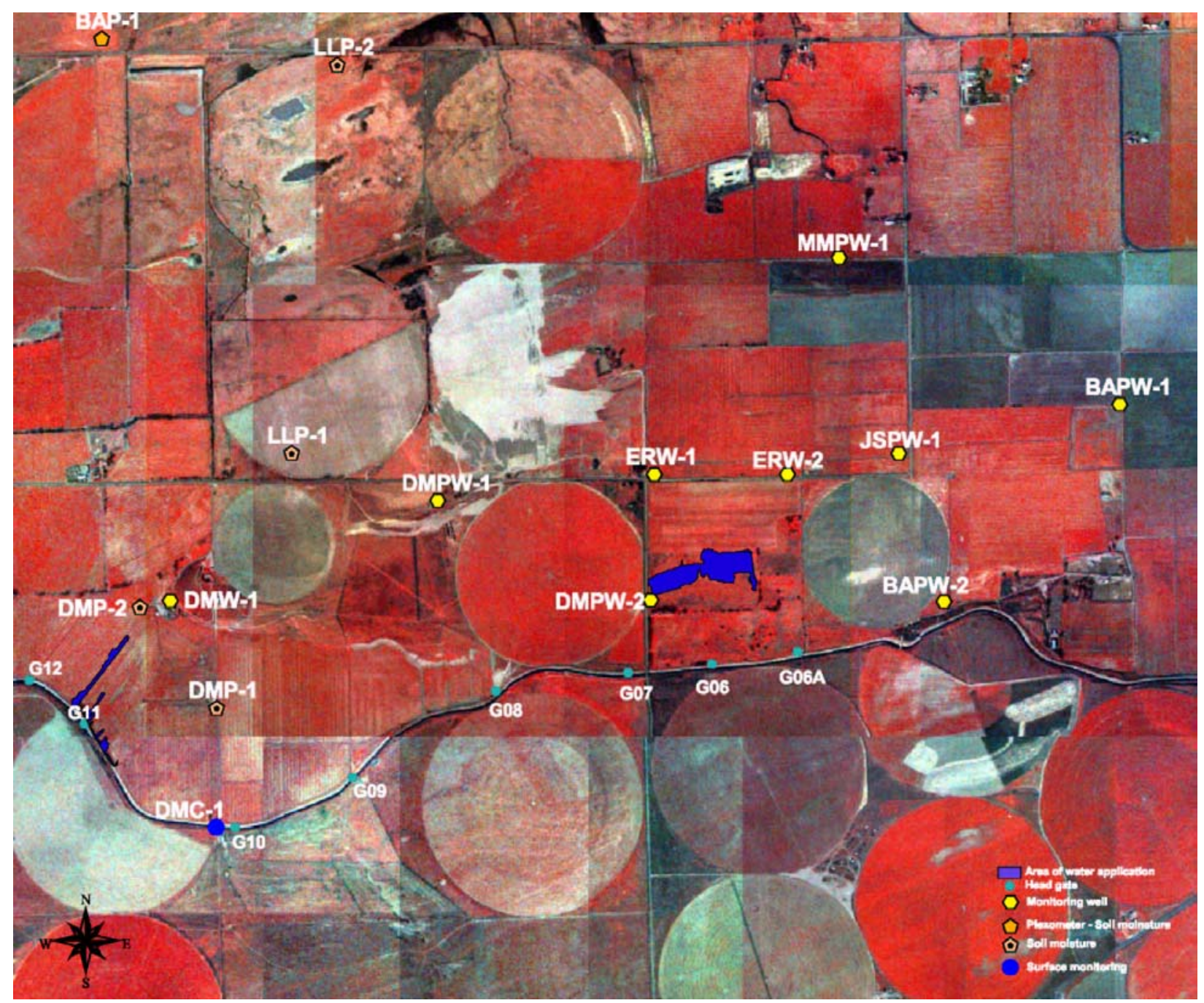

Figure D-1. Map showing the area of trail water application (blue area), Diversion Headgates and the location of monitoring well sites. 
The measured water levels over time from the wells in the above table are shown in Figures D-4 to D-9, respectively. As can be seen in these figures, the maximum fluctuation for the most distant wells may not have been observed due to the lack of time that the wells were monitored.

Wells ERW-1 and ERW-2 (Figures 5 and 6) contained data loggers that were recording water levels both before and after the trial application. The data bases that contains the datalogger data is found in Excel spreadsheet levellogger 3-19.xls. As can be seen in Figures 5 and 6 , groundwater levels appeared to be declining slightly before the application and slightly rising after the application. This means that during the water application, the groundwater levels would not have changed very much unless they were influenced by the trial application. This also means that there is no need to take regional adjustments in groundwater levels into account during the trial application period.

It is fairly easy to estimate that the trial application of 9.6 acre-feet could cause the changes in water level as shown in Table D-1. Assuming a 0.10 specific yield (used in the model), 9.6 acre feet of water would cause water levels to increase by 0.15 feet in a square mile area. This is roughly equivalent to the wells that were measured in the trial application. In addition, it is comparable to the positive inflections in the water table as observed in the wells shown in the above table.

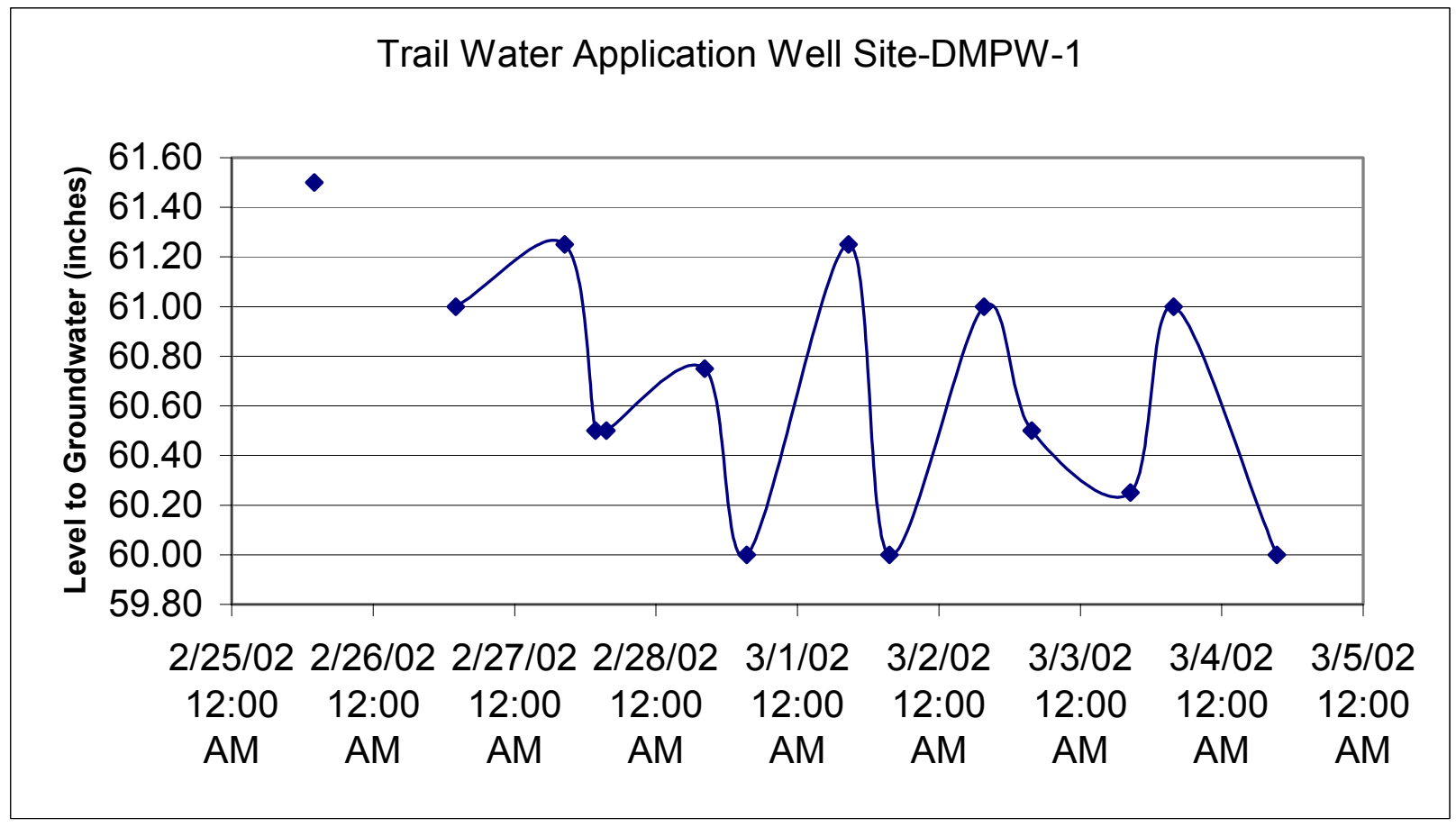

Figure D-2. Water level measurement during trail water application at well Site DMPW-1 


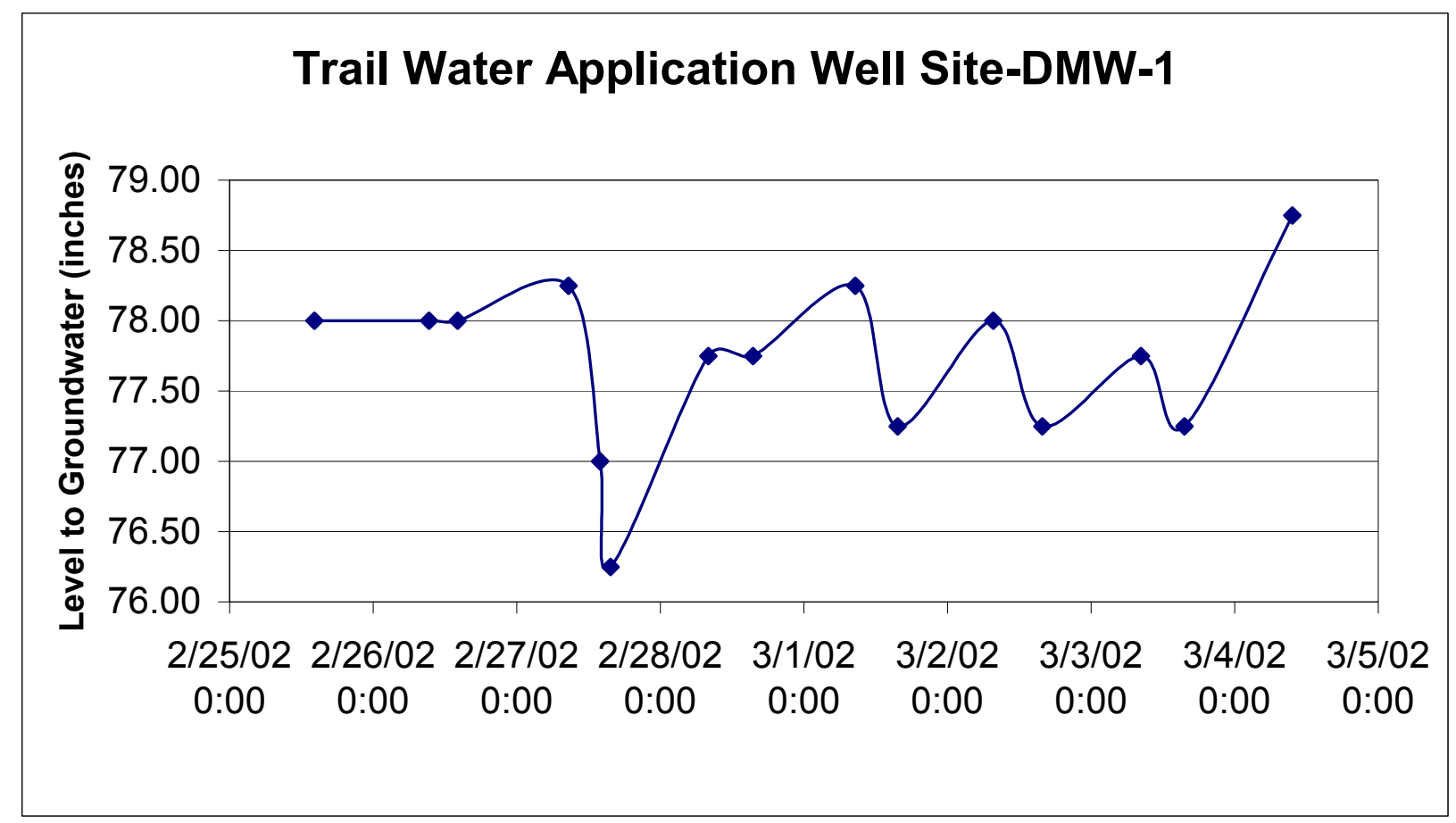

Figure D-3. Water level measurement during trail water application at well Site DMW-1

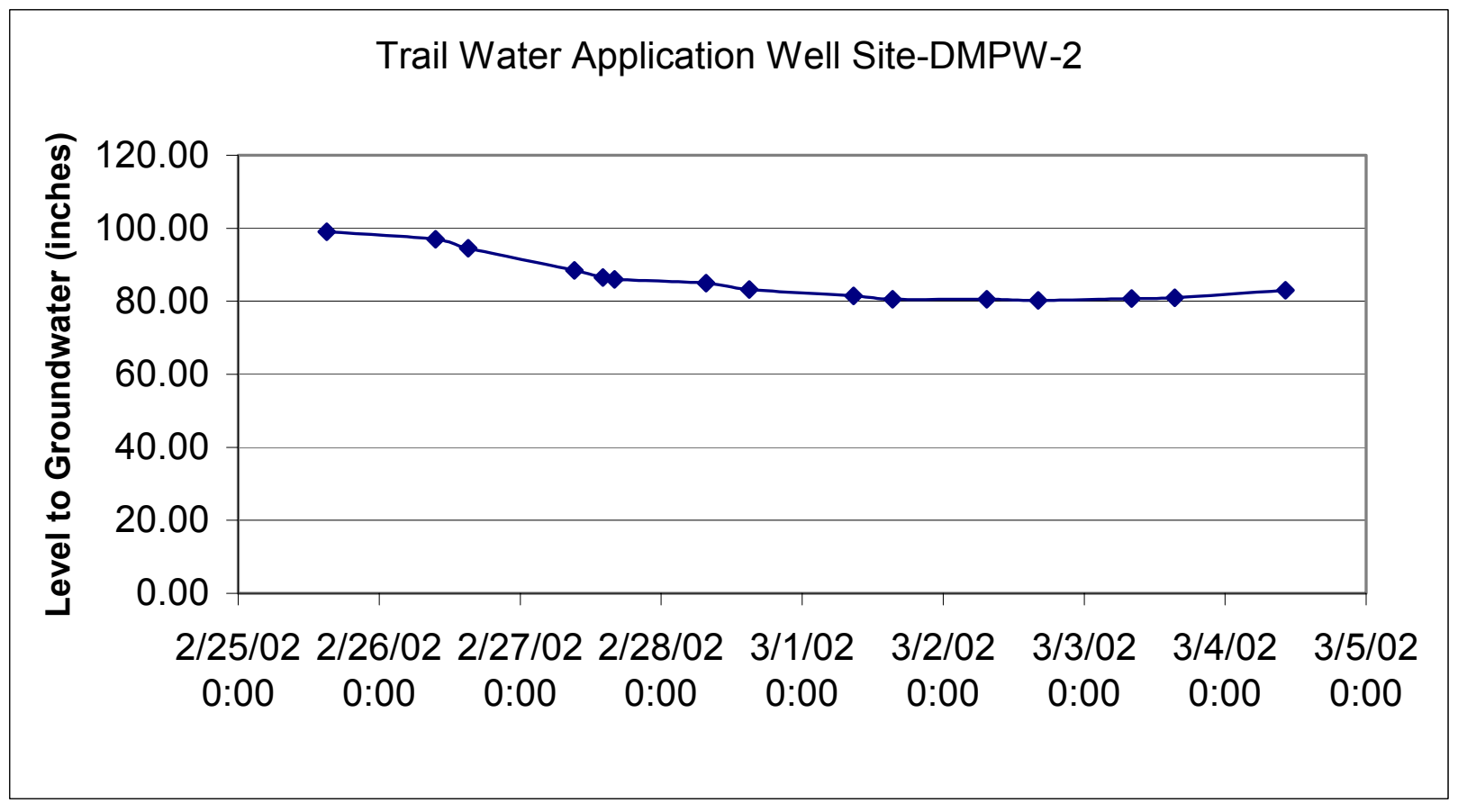

Figure D-4. Water level measurement during trail water application at well Site DMPW-2 


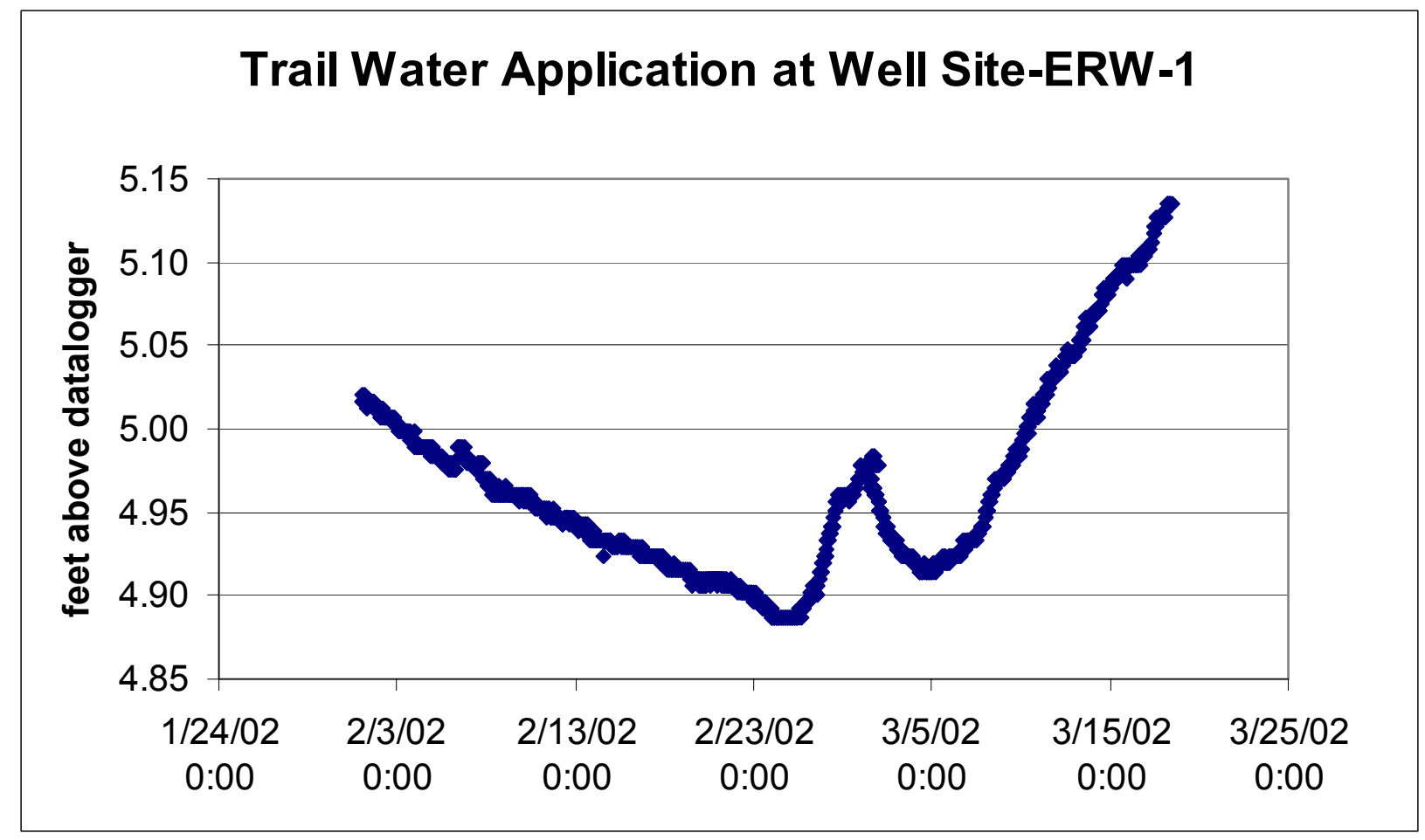

Figure D-5. Dalalogger level measurement during trail application at well Site ERW-1

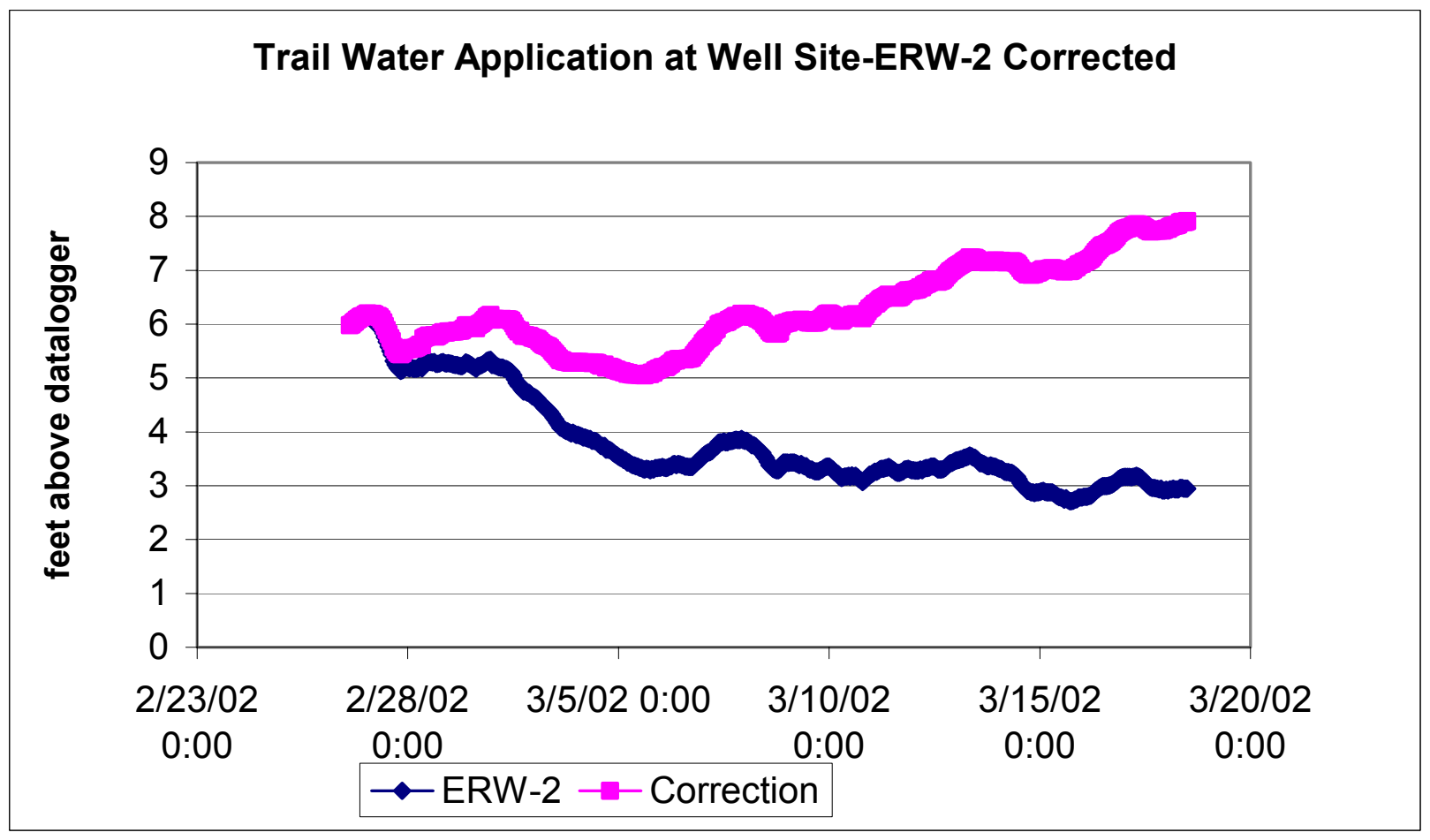

Figure D-6. Datalogger level measurement during trail application at well Site ERW-2 


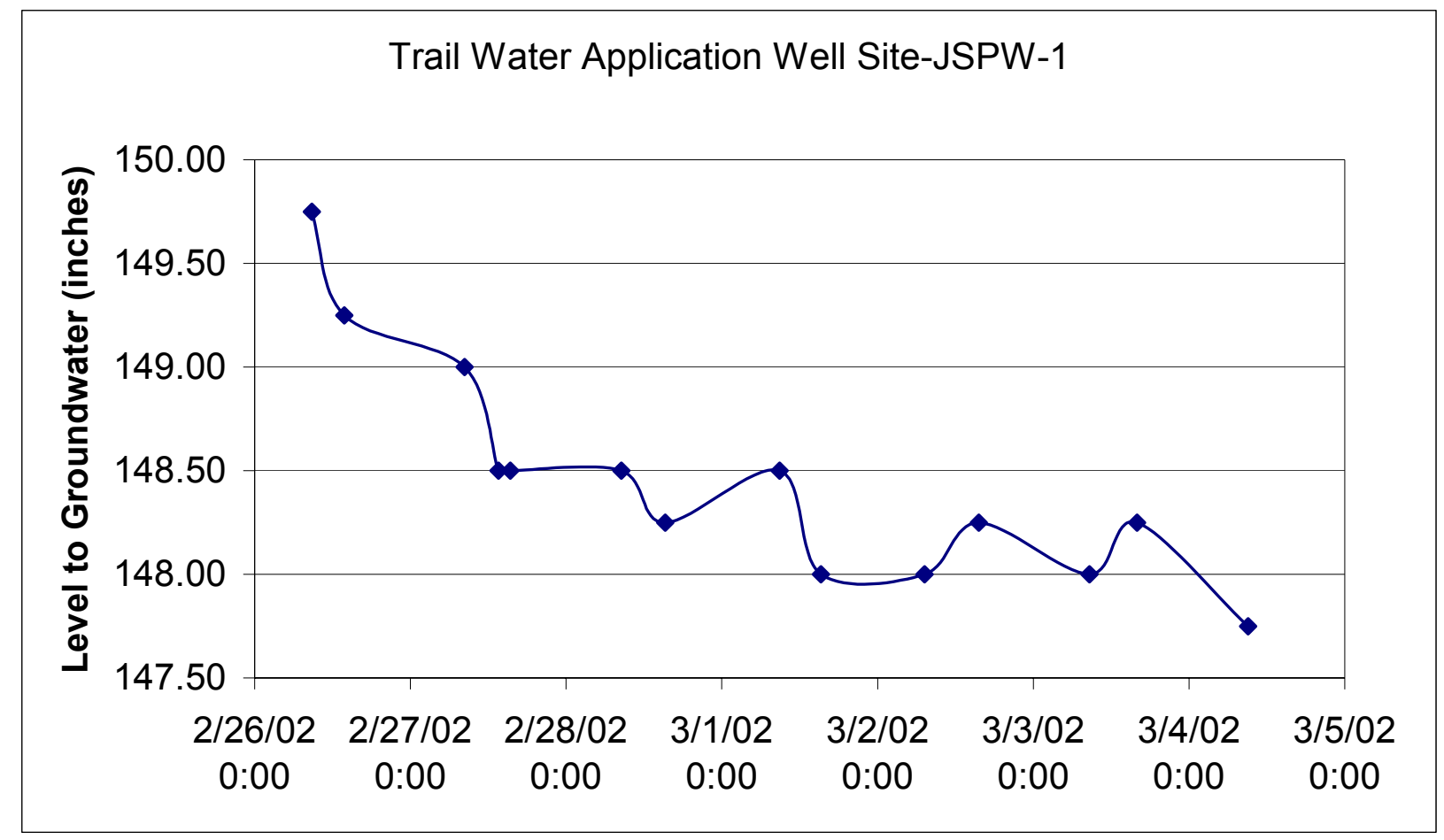

Figure D-7. Water level measurement during trail water application at well Site JSPW-1

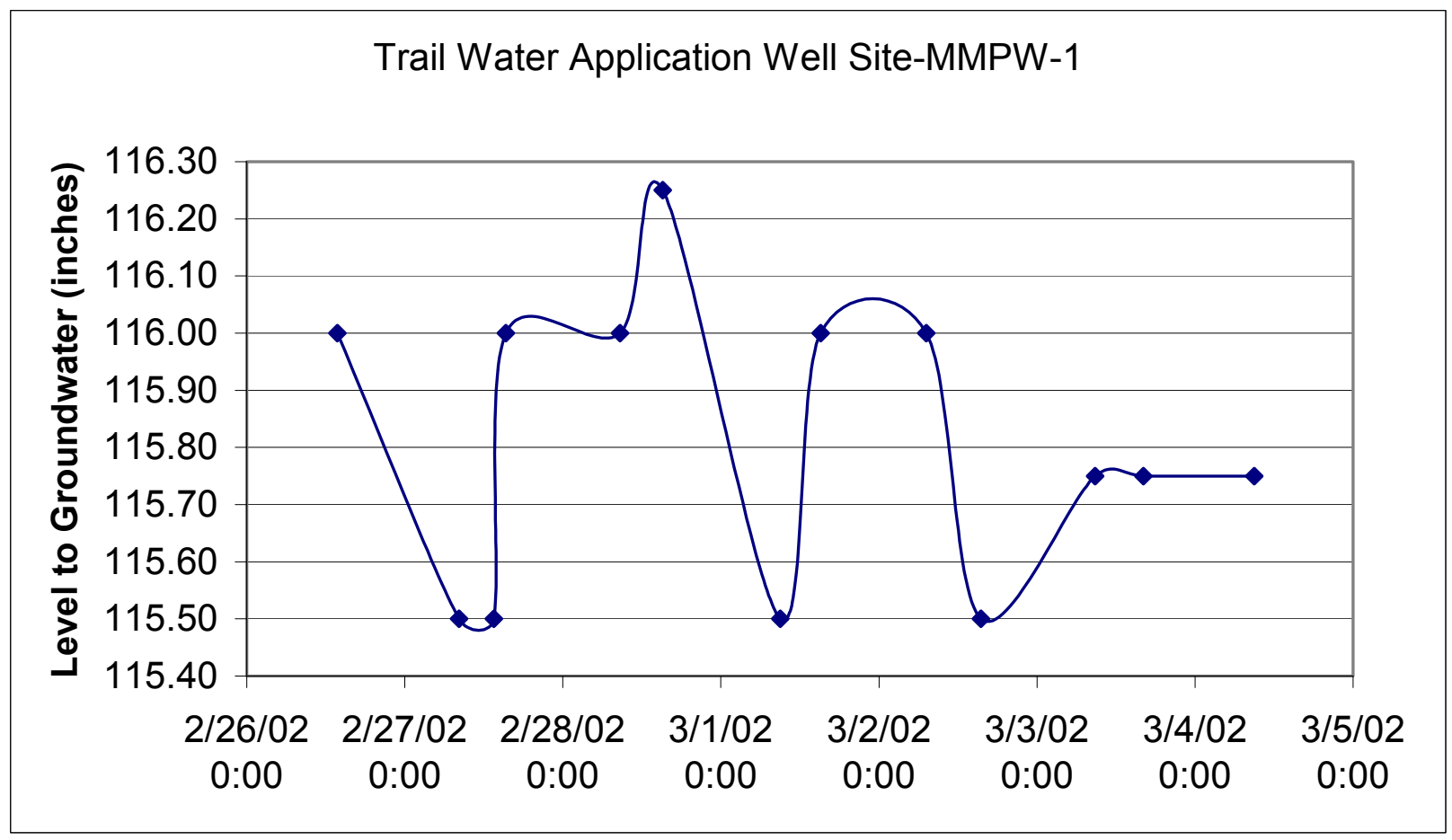

Figure D-8. Water level measurement during trail water application at well Site MMPW-1 
As discussed above, this trial application of water was partially done to continue to refine and test the MODFLOW model. Using the model state variables (hydraulic conductivity and specific yield), we modeled the trial application of water using an injection well (which simulated the precise amount of water over time to the water table at the location of application). The injection well, however, does not account for the lag time between the surface application of water and the introduction of the water at the water table. However, based on our monitoring of nearby well DMPW-2 (Figure D-4), this lag time is not long.

As a comparison, an up gradient well at site BAPW-1 was monitored during the Trail water application period and as can be seen in Figure D-9, it shows no raise in water level during this period.

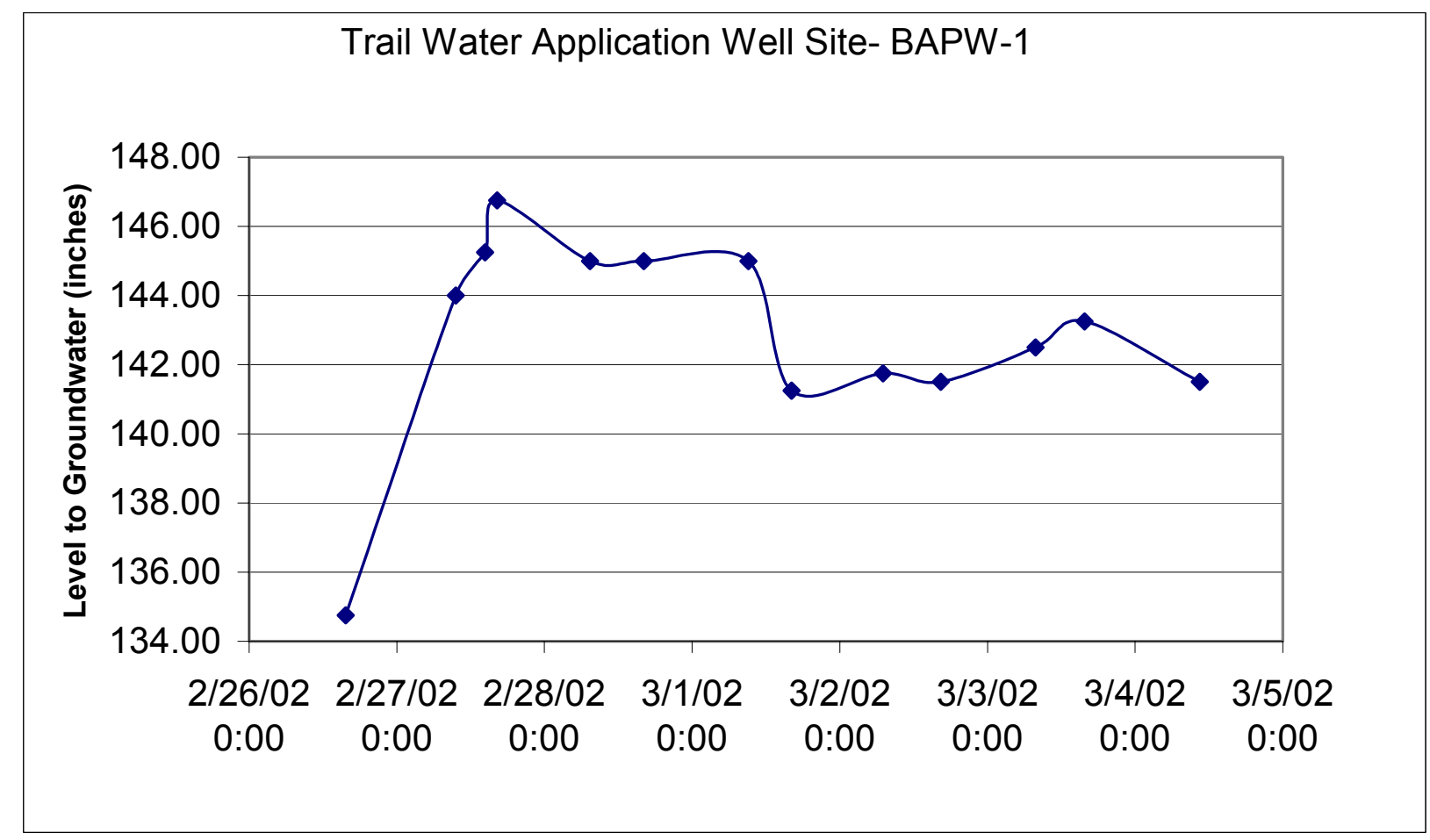

Figure D-9. Water level measurement during trail water application at well Site BAPW-1

Figures D-10 and D-11 show a modeling comparison of the trial application of water as compared to no application of water, respectively, as seen in the monitoring well site ERW1.

Based on the results shown in Figures D-10 and D-11 and the above table, we believe that the model does an excellent job of simulating the trial application. The model shows (as does the wells that we monitored) that large areas could be influenced by the recharge water application (that the water spreads as the local hydraulic gradient is increased). 
The applicability of the model will allow us to optimize the times and locations for water applications and to track the beneficial effects of the project on the groundwater regime. 


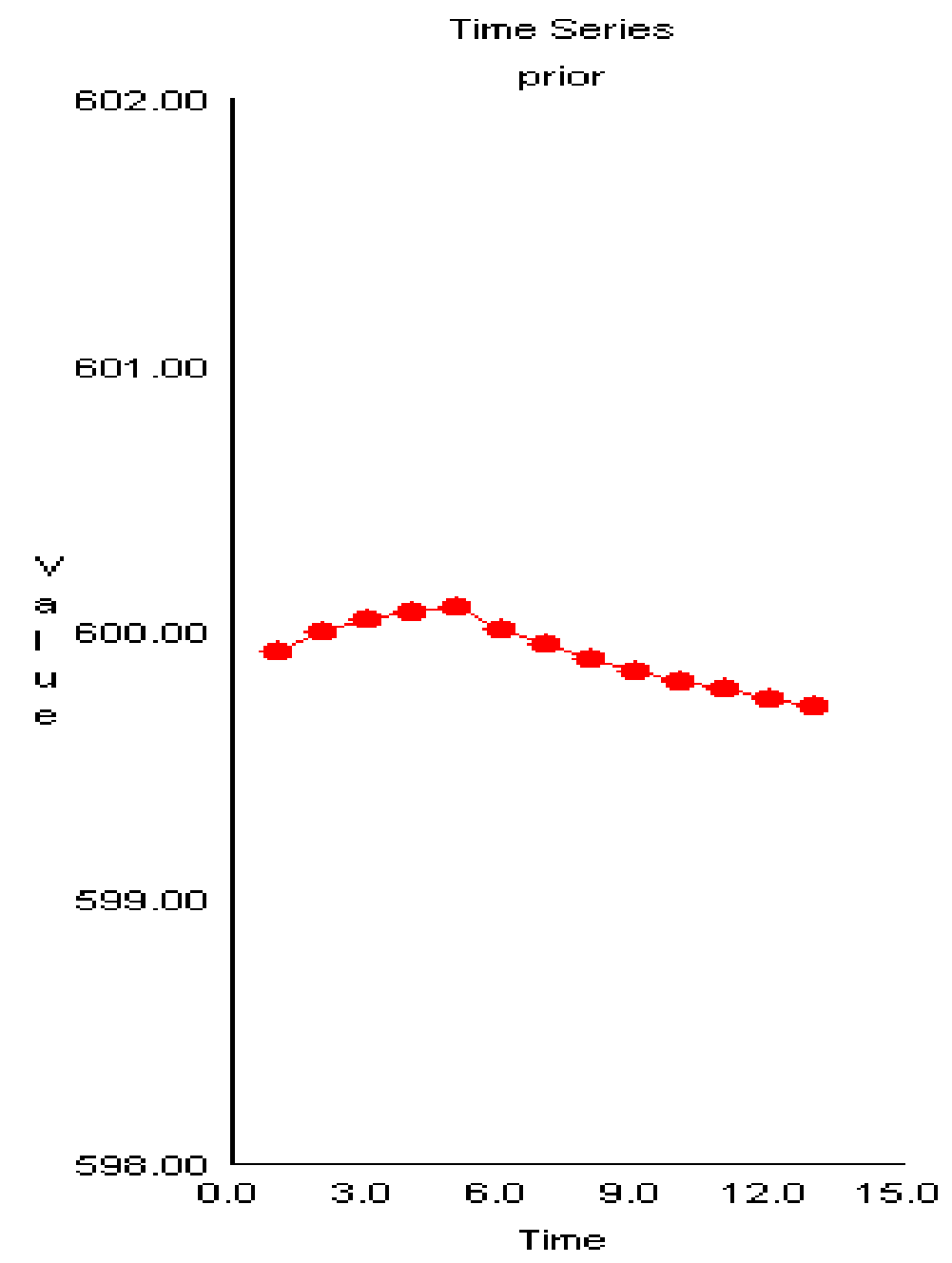

Figure D-10. Simulation of trial application of water from Headgate 06A. Note the inflection of the water table and the subsequent decline as water is spread across the water table. Note comparison with Figure D-11 which shows no positive inflection. 


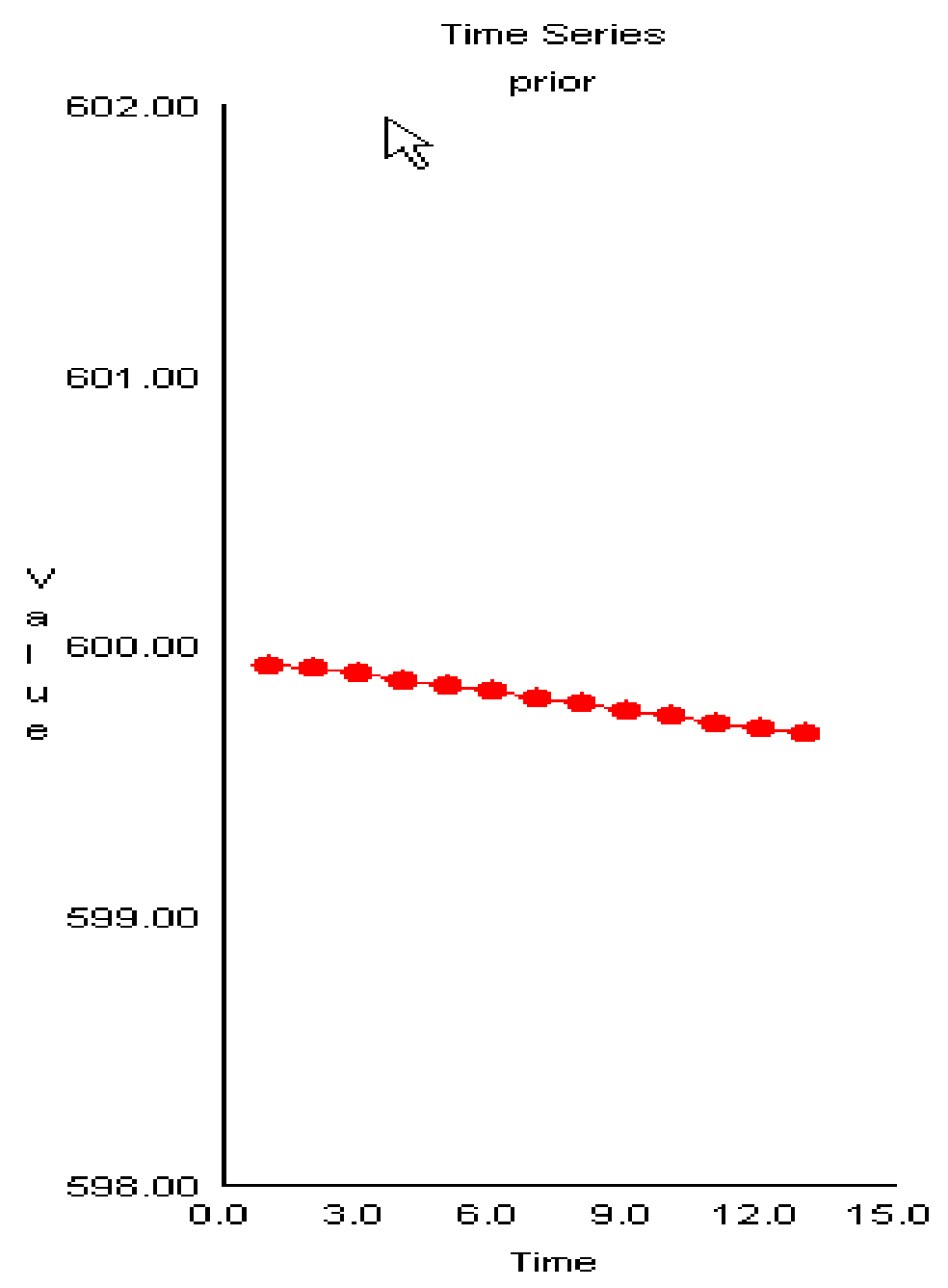

Figure D-11. Simulation of nearby well without application of water. To be compared with Figure D-10. 


\section{Appendix E}

\section{Draft Progress Report, 2001 Baseline Analysis, January 7, 2002}

This Progress Report was presented to BPA in January 2002 and can be found on our web site at www.irz.com/echo password: bpa (all lower case). A copy is enclosed in this appendix and are to be used as supplement to this final report. 


\title{
DRAFT Progress Report 2001 Baseline Analysis
}

Echo Meadow Project - Winter Artificial Recharge to Cool Rivers

\author{
BPA PROJECT\# 2001-015-00
}

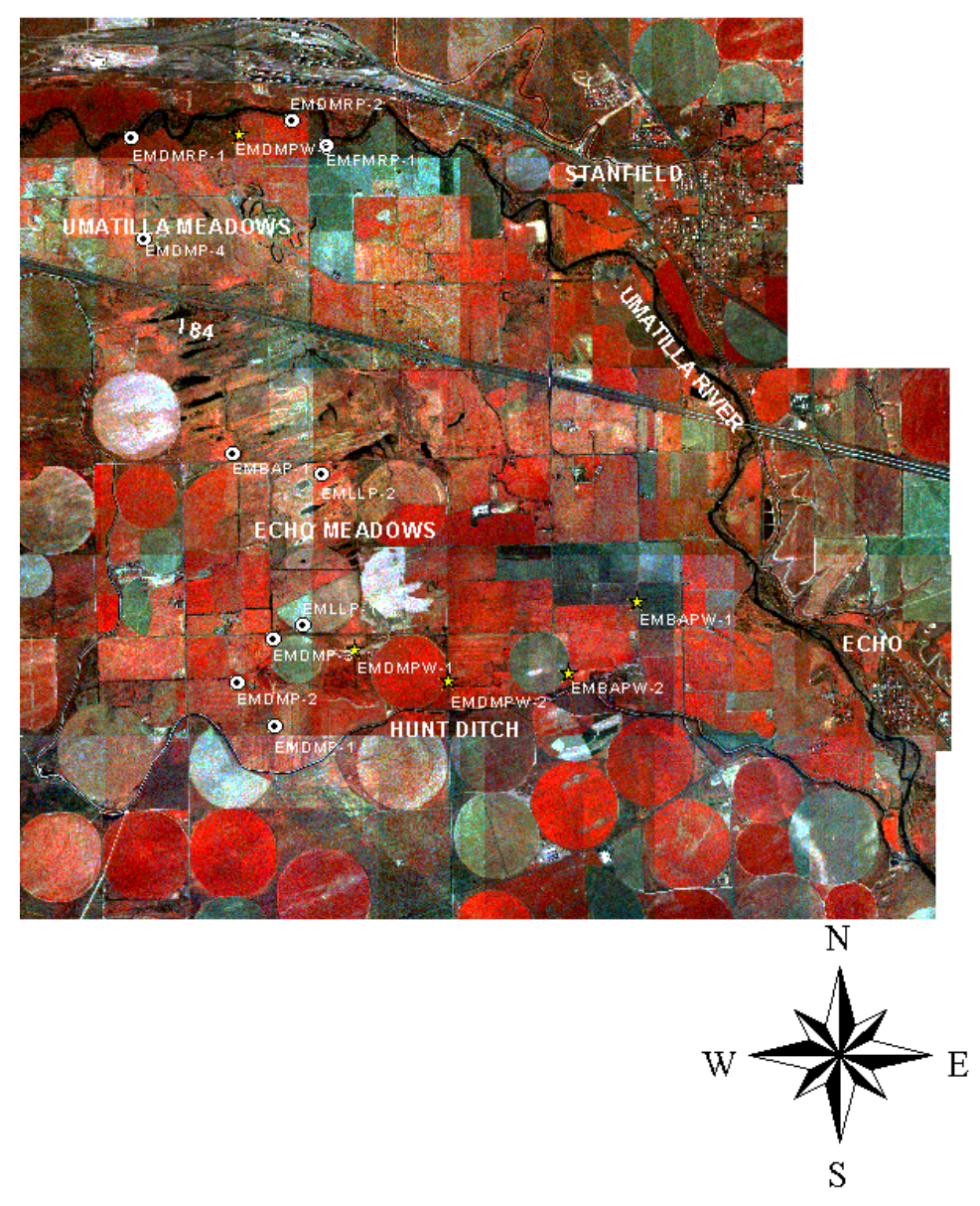

\section{IRZ Consulting, LLC \\ 541-567-0252 \\ January 7, 2002}




\section{(1RZ) IRZ CONSULTING, LLC}

505 East Main, Hermiston, Oregon 97838 Office (541) 567-0252 Fax (541) 567-4239

Www.irz.com

Mr. Peter Lofy - KEWL-4 COTR

Bonneville Power Administration

Re: Draft Report, Echo Meadow Project - Winter Artificial Recharge to Cool Rivers BPA PROJECT\# 2001-015-00

Dear Peter:

$12-20-2001$

Presented is a draft report of the Echo Meadow Project. 2001 was the baseline data collection phase; data in this report is updated until the end of October 2001. Although 2001 was to establish the baseline conditions only, our preliminary data collected to-date and the results from our groundwater modeling is showing promising results consistent with the original goal of the project, which was to demonstrate that Winter Artificial Recharge can realistically cool the rivers of the Northwest by adding sufficient quantities of cold waters to meet the Temperature Standards of the Clean Water Act. We ask that you expeditiously consider this project for funding for the next phase, which is the implementation phase during 2002 and also 2003 . We are still compiling and analyzing 2001 data and if it will be helpful to you we will be more than happy to make a presentation of the results to-date. We are looking forward to hearing from you soon and should you have any questions, please feel free to call me at 541-567-0252 or by email at irz@irz.com.

Sincerely;

IRZ Consulting, LLC

Fred Ziari, CEO

Ce: Tom Iverson- CBFWA 


\section{Table of Contents}

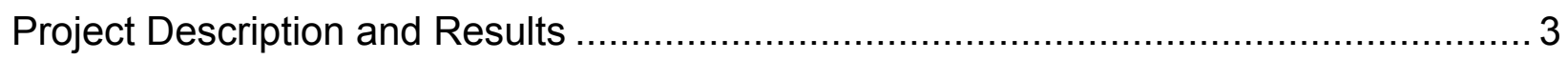

Figure 1. Echo Meadows Monitoring Network Sites ............................................. 5

Figure 2. Water Rights map of the Echo Meadows …............................................ 6

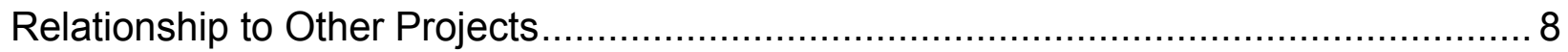

Echo Meadows Water Rights, Diverted and Applied Water, and Historic Recharge

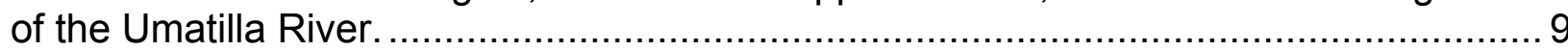

Figure 3. Color infrared photos of Echo Meadows in 1995 and 1981 ....................... 10

Figure 4. Echo Meadows Historic Diversions ....................................................... 13

Figure 5. Historical return Flows in the Meadows ................................................. 14

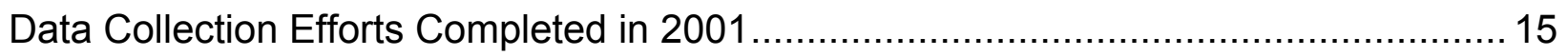

Groundwater and Surface Water Level Measurements.......................................... 18

Figure 6. Depth to groundwater at Mueller EMFMRP-1 ........................................ 19

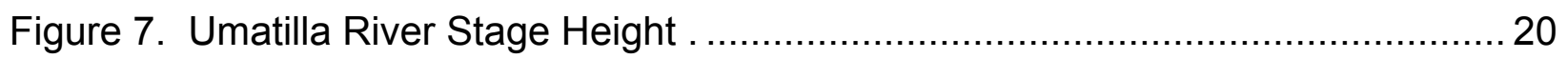

Figure 8. Depth to Groundwater at Andrews EMBAP-1 ........................................ 21

Groundwater and Surface Water Quality Data Collection ......................................... 22

Figure 9. Water Levels at Site\# Prior Well............................................................ 23

Figure 10. Water Temperature at site \# EMDMPW-2 …........................................ 24

Figure 11. Average groundwater temperature contour map ..................................... 25

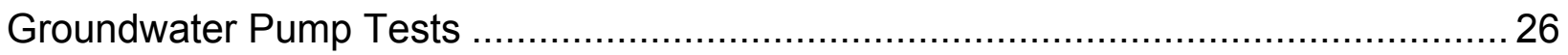

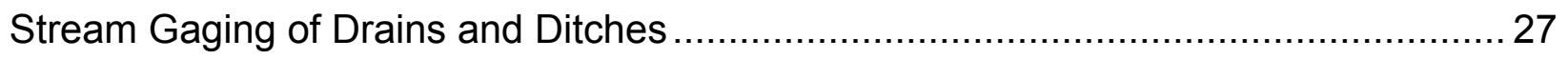

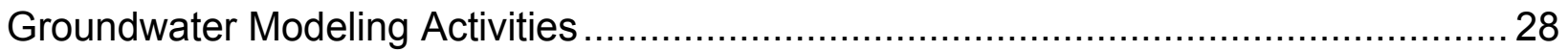




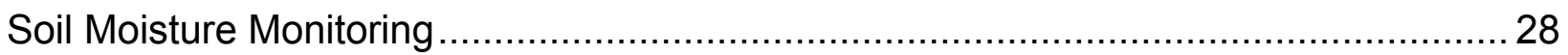

Thermal Infrared Imagery Along the Umatilla River.................................................. 29

Figure 12. Thermal Infrared Image of the Umatilla river ......................................... 30

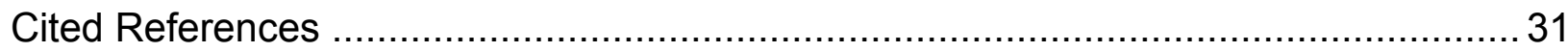

\section{Appendix:}
A. Water Rights in Echo Meadows
B. Echo Meadow Historic Diversions
C. Echo Meadows Monitoring Network Locations and Elevations
D. Groundwater Data Base, Including Water Quality
E. Contour Plots from Appendix D.
F. Groundwater and Surface Water Quality Laboratory Analysis
G. Pump Test Analysis Report
H. Groundwater Model Report 


\section{Project Description and Results}

Presently most of the rivers and streams in the Pacific Northwest do not meet the temperature standards of the Clean Water Act (CWA). Planting trees to shade streams is the most common method of addressing high river temperature. Based on our over a decade of experience conducting aerial thermal infrared surveys of thousands of miles of rivers, we have come to believe that tree shading alone is not an effective way to reduce river temperatures sufficiently to meet the temperature standards of the CWA. Millions of dollars are being spent on planting trees (it has other benefits beside temperature) without demonstrating significant temperature reduction benefits. To date few realistic river temperature cooling projects have been proposed.

The Echo Meadows Winter Artificial Recharge Project is a groundwater recharge project, which will augment summer-time stream flows on the Umatilla River by increasing groundwater discharge. A considerable secondary benefit is that the groundwater that is discharged to the river will have a substantially lower water temperature. The dual benefits of increased flows and colder water will be beneficial for fish habitat and migration, for improvement of water quality, and establishments of natural riparian zone vegetation.

Echo Meadows (Meadows) is located between River Miles 16 and 26.3 on the Umatilla River near the towns of Stanfield and Echo, Oregon. It is bounded to the south by Hunt (Westland) Canal, to the east and north by the Umatilla River, and to the west by Service Butte, which is basaltic bedrock that separates the Meadows from Butter Creek to the west (Figure 1). The Echo Meadows is approximately 7,000 acres in size (CH2MHill, 1999).

The upper stratum of the Meadows has been geologically mapped as river alluvium and is called the Alluvial Aquifer by the Oregon Water Resources Department (WRD). The geologic course of the Umatilla River has created cut and fill features, where lenses of clean gravels of limited size may be surrounded by poorer sorted and/or finer sediments. Based on well logs, these sediments may extend to 70 feet or more in depth. In many places in the Meadows, the upper portion of the aquifer consists of a wind blown silt deposit that may extend to depths greater than 15 feet.

Portions of the Meadows have been irrigated since 1870 and virtually all of the surface water rights dates before 1900. Large portions of the Meadows are flood irrigated with a duty of 4.5 acre-feet/acre (Bureau of Reclamation (BOR), 1989). These acres are served from the Allan, Pioneer, Courtney, and Dillon Canals, as well as numerous unnamed drains and ditches (Figures 1 and 2). Since the early 1970's, groundwater irrigation has served an increasing number of acres (Figure 2, black vertical lines).

Additionally, the hydrology of the Meadows is influenced by portions of the Teel 
Irrigation District, which is directly south of the Westland Canal. The Teel Irrigation District is composed of nearly 7,700 acres of center pivot irrigation. Groundwater losses from these center pivots enters the Meadows from the south.

Echo Meadows has been known as an area of recharge to the Umatilla River since the Oregon Water Resources Department began taking synoptic discharge measurements along the river's course in 1985. These measurements indicate that this groundwater recharge has diminished since the 1980's and perhaps since the 1950's (Graham, 2001). A more complete description of the Meadows hydrology is discussed in following sections. 


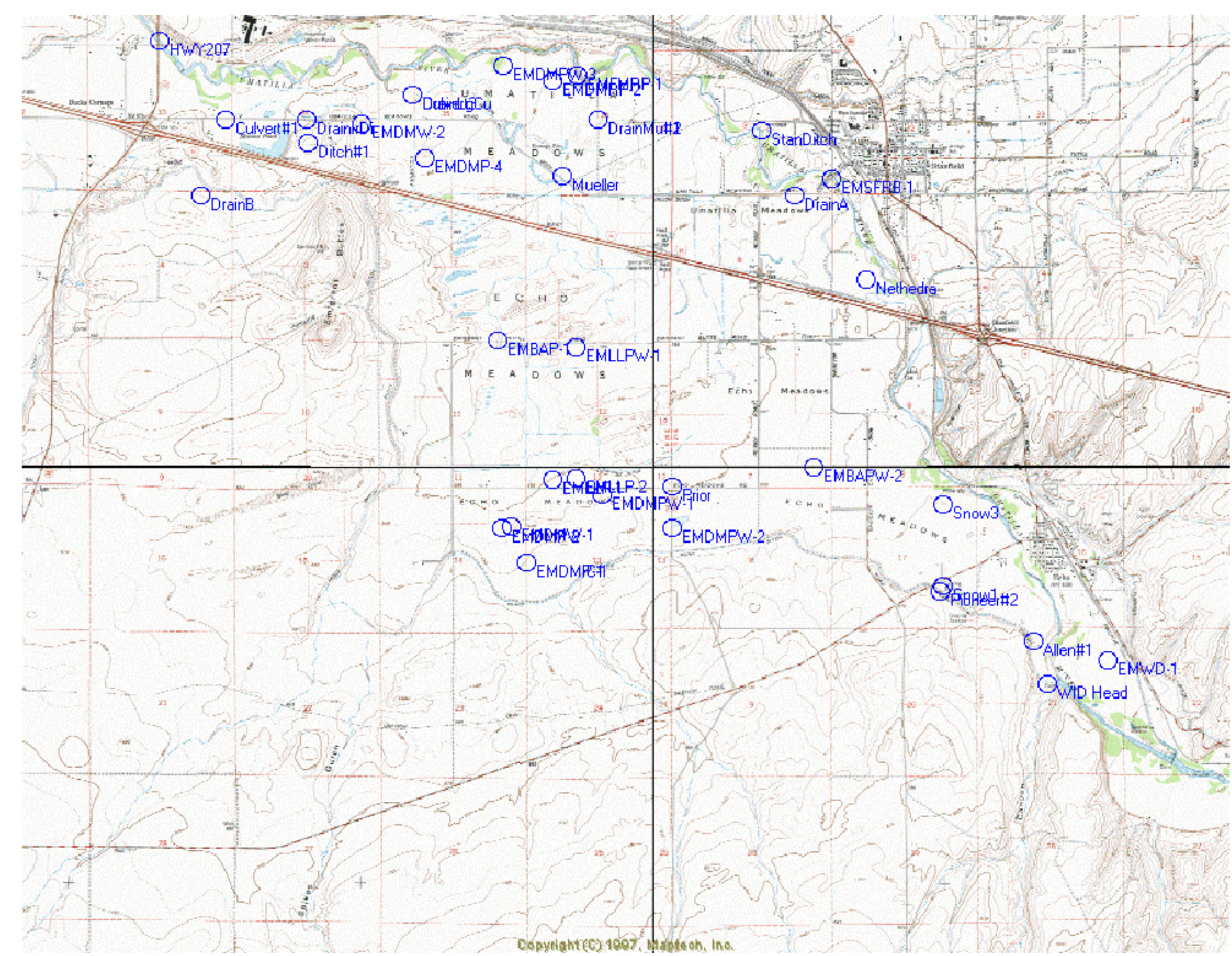

Figure 1. Echo Meadows Monitoring Network. Source: USGS Echo Quadrangle. Approximate Scale 1 in $=1$ mile. 


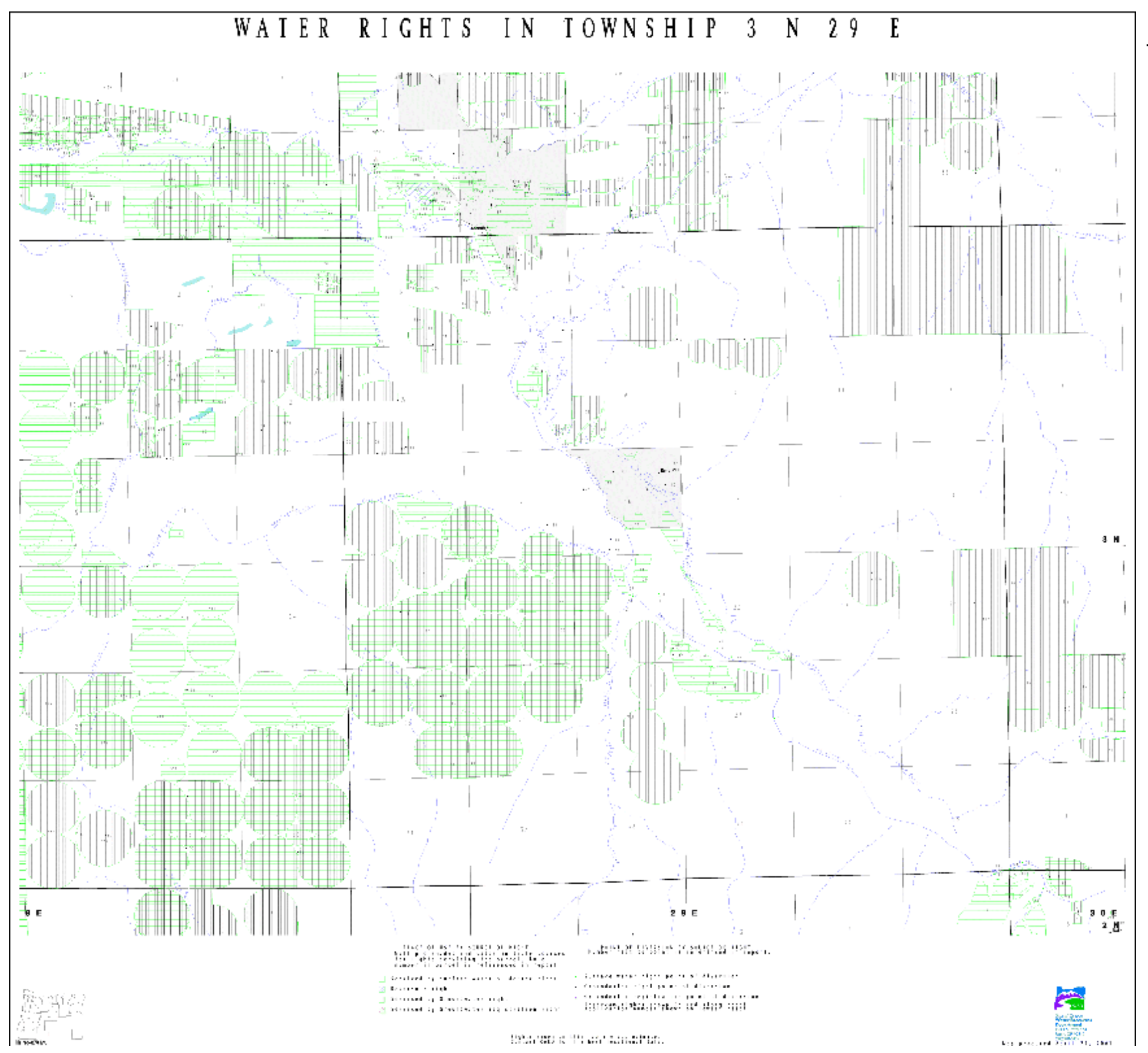

Figure 2. Water rights map of Echo Meadows.

Source: Water Resources Department. Scale= in $=1$ mile. 
To combat these reductions in return flows, IRZ Consulting proposed to augment the recharge of the Alluvial Aquifer by flood irrigating agricultural fields before the beginning of the irrigation season when the Umatilla River flows exceed minimum stream flows for fish rearing and migration (December through February). Water applied during this time and at distances of 0-4 miles from the river is expected to discharge to the Umatilla River during the summer and fall, thereby improving streamflow during the low flow periods of the year. Because the water will be filtered though the Alluvial Aquifer, it is expected to be of better quality and lower temperature than the Umatilla River.

A limited License (\#00225) Water Permit from Oregon Water Resource Department was secured, which provides for a maximum of $125 \mathrm{cfs}$ of water to be diverted from the Umatilla River and applied to agricultural fields in Echo Meadows.

The recharge of the aquifer through flooding of these fields is a cooperative effort of several groups including:

- Land owners-who provide the land for flood irrigation and much of the manpower to flood irrigate the fields,

- Westland Irrigation District- who will provide for the diversion and transmission of the water to be applied,

- Oregon Water Coalition- who does outreach to farmers,

- Water Resources Department- who approved Limited License Permit and provided invaluable information regarding the aquifer recharge program and the geology of the Echo Meadows area,

- Department of Environmental Quality- who provided funding to this project during the pre-assessment period and for approving means for the Water Pollution Control Facility Permit,

- US Bureau of Reclamation- who provided funding to this project during the preassessment period, and made available the stream flow data,

- The Northwest Power Planning Council and Bonneville Power Administrationwho provided funding for the 2001 baseline data collection portion of the project.

In the sections that follow, we discuss the activities that were performed during 2001 and the preliminary findings that resulted from our tasks. Our project results to date include:

- With the present (baseline) farming activities, the Echo Meadows area discharges approximately $10-20$ cfs to the Umatilla River during the irrigation season. This discharge compares to $20-25$ cfs during the 1980's and as much as 45 cfs during the 1950's. Recharging the Alluvial Aquifer to 1950 conditions is the long-term goal of this project.

- The Echo Meadows area discharge since the 1950's continued to diminish due to increased irrigation efficiencies, lower application rates of irrigation water and 
increased development of groundwater water rights in the area.

- The Proposed Echo Meadows recharge during the winter (pre-irrigation) portion of the year will be practical and will result in an increase in Umatilla River flows (estimated as much as $\mathbf{1 0 0 \% + )}$ ) during the low flow periods (June-October) that are desirable.

- The water quality associated with the recharge project will be significantly colder and of (generally) better water quality than the water in the Umatilla River.

- Groundwater modeling of the Echo Meadows area indicates that water applied during the pre-irrigation season (groundwater recharge) will augment stream flows in the summer and early fall. A calibrated and verified model, using both base conditions (pre-2002) and trial water applications (2002), provides the best short-term method to verify if the Echo Meadows Recharge Project is a viable and cost effective method of enhancing summertime and early fall stream flows. However, when the project has been fully implemented and groundwater levels increase to their historic levels, it will be possible to show the effect of the project through streamflow measurements along the Umatilla River.

\section{Relationship to Other Projects}

Although this project is desirable for its own merits, it also benefits and benefits from, other projects. For example:

- USGS (1991 and 2000). These regional groundwater projects that were undertaken by the USGS show the benefits of a history of irrigated agriculture in recharging alluvial aquifers and augmenting stream flows in eastern Oregon and Washington. This augmentation of flows is somewhat contrary to the prevailing theories about irrigated agriculture. Our project utilizes some of the same techniques (groundwater modeling) and data inputs as these regional studies. In turn, our project will provide more refined and conclusive data that is possible using a broad-brush regional approach.

- BOR- Umatilla Project (1988-present). The BOR was authorized by Congress in 1988 to develop the water resources of the Umatilla River for irrigation and fisheries enhancement. Current activities of the BOR have used Columbia River flows in lieu of Umatilla River flows for irrigated agriculture and enhancement of targeted stream flows during fish migration. The BOR has developed an extensive GIS database of the lower Umatilla River that has been invaluable for the development of this project. In return, this project may serve as a low cost, efficient mitigation project for the irrigation districts.

- Department of Environmental Quality (1995). This Groundwater Management Area study concentrated on the groundwater quality of the lower Umatilla River Basin (including Echo Meadows) with a special emphasis on nitrate 
contamination. This study provided vital geological and hydrological analysis that was used in the Echo Meadows study. In turn, groundwater recharge provides one of the most efficient ways of diminishing nitrate levels in groundwater.

- $\quad$ Clean Water Act /TMDL. Most northwest streams suffer from low summertime flows and from water temperature that is too warm for effective salmon rearing and good water quality. Many watershed studies have recommended stream shading as a means of minimizing water temperature. However, stream shading cannot "produce" water that is lower temperature than the ambient air temperature and cannot "manufacture" more water. The groundwater recharge project as proposed addresses both. The Echo Meadows project is perhaps the best way to demonstrate that low summer flows and high summer river temperature is not an insolvable problem.

In the sections that follow, we discuss the 2001 data collection effort and the analysis of that data, as well as other complimentary data that will augment our study.

\section{Echo Meadows Water Rights, Diverted and Applied Water, and Historic Recharge of the Umatilla River.}

It is not strictly necessary to know the number of irrigated acres and their duty to achieve a successful recharge project. However, by knowing the history of the diverted water and recharge to the Umatilla River, we can better estimate the importance of the recharge project after it is fully implemented. In 2001, we spent a considerable effort to quantify the irrigation rights and the amount of water applied in the Meadows.

Although the size of Echo Meadows (6,956 acres \pm ) can be measured, the number of acres that are irrigated and how much irrigation water that they receive is less well known. This is because on the Meadows there is a variety of sources of federal and state water rights. An irrigated parcel may receive federal live flow water, federal storage water (from McKay Reservoir), and/or state groundwater. Figure 2 shows the state water rights map for the Meadows area (including federal water). Appendix A provides the data base of the water rights shown on Figure 2. However, the water rights map is not complete. For example, this map does not show hundreds of irrigated acres served by the Allen Ditch (west of Echo) and immediately north of the Westland Canal in Ranges 29 and 28.

Database work completed by $\mathrm{CH} 2 \mathrm{MHill}$ in 1999, shown in Appendix A, indicated that there were 6,100 irrigated acres in 1981. However, as many as 3,000 of these 6,100 acres have domestic use or stock watering permits and the water use of those acres would be trivial. Therefore, according to the state database about 3,100 acres have irrigated water rights. Spectral imagery of satellite data completed for the BOR showed that essentially all of the acres in the Meadows were irrigated (Figure 3.) 

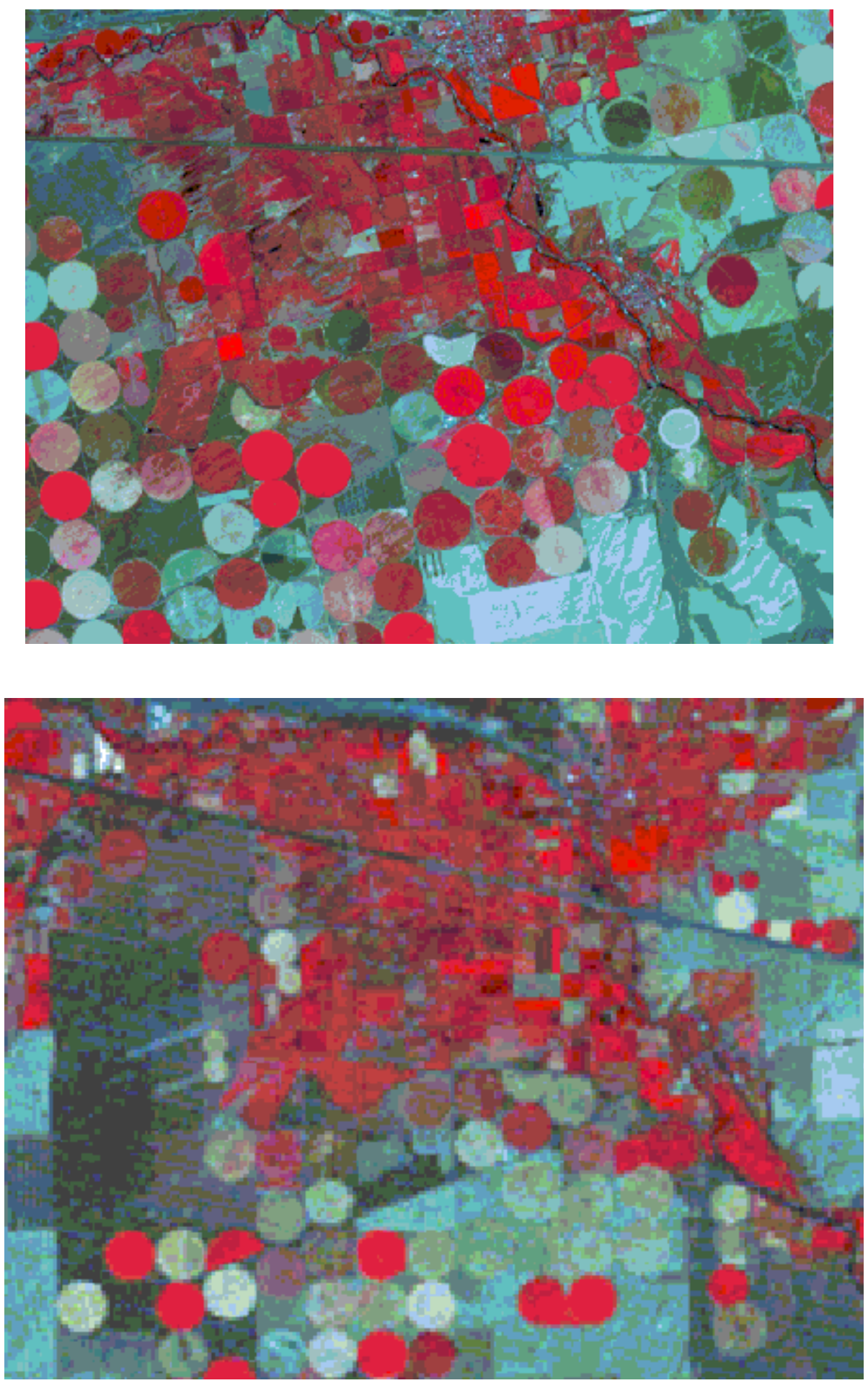

Figure 3. Color infrared photos of Echo Meadows in 1995 (above) and 1981 (below). Approximate scale 1 inch=2 miles. Source: USBOR. 
However, many of the acres in these photos when field checked are sub-irrigated (water table near the surface) and do not receive irrigation water.

Federally recognized surface water rights (BOR, 1989) in the Meadows total 3,600 acres including:

- Allen -958 acres

- Courtney- 1,113 acres

- Pioneer- 860 acres

- Dillon- 670 acres

We believe that the federally recognized estimate is a better estimate because of omissions in the state data base discussed above. As a result, 3,600 acres would be a low approximate of the surface water rights in the Meadows.

Figure 2 shows that approximately 2,000 acres have groundwater rights only and an additional 740 acres have supplementary groundwater rights (they have primary surface water rights). Therefore, the number of total irrigated acres in Echo Meadows would be approximately 5,600 acres. The amount of water diverted and used in Echo Meadows is also difficult to estimate. Very few of the acres have reservoir rights. CH2MHill (1999) estimated that the Meadows received about 5,000 and 6,000 acre-feet per year of surface water and groundwater respectively or about 11,000 acre-feet per year. However, their diversion records were for Allen and Dillon gages only (they did not locate, or know about, the Pioneer-Courtney diversions.

Water use may be estimated based on water rights. The federally recognized acres in Allen, Courtney, and Pioneers are senior enough that they typically should receive their full duty (4.5 acre feet/foot/year). Many of the acres in the Dillon District (north of I-84 in Figure 3 ) have supplementary groundwater rights and may only receive 2 acre feet/acre/year. Therefore, based on water rights, it may be expected that 14,530 acre feet per year of surface water would be diverted to Echo Meadows.

Groundwater irrigation utilizes more efficient irrigation methods (mainly sprinklers) than surface water (flood irrigation) . Groundwater duty is generally restricted to 3 acrefeet/year. If we estimate that the 2,000 acres of primary groundwater rights receive 6,000 acre-feet of water and the 740 acres of supplementary groundwater rights receive 1 acre-feet/year, this means that groundwater use in Echo Meadows is approximately 6,740 acre-feet/year and water diverted and used, as a whole, is 21,270 acre-feet per year, based on water rights.

Historic diversion records of the Allen, Pioneer-Courtney, and Dillon Canals, and a summary table (Echo Meadows Historic Diversions) is found in Appendix B. A plot of the annual diversions from 1930 to 1997 is shown on Figure 4. As can be seen in Appendix B, the average Echo Meadows diversions is approximately 14,200 acre 
feet/year, closely matching estimates based on water rights. However, the trend of the diversions have dropped from 14,000-16,000 acre-feet per year before the late 1970's to less than 12,000 acre-feet/acre in the 1990's or a decrease of nearly 1 acre feet/acre/year.

This reduction in surface water diversions as shown in Figure 4, has been largely offset with groundwater use since the 1970's. Therefore, the rate of applied water has probably remained fairly stable. However, the pumping of groundwater depletes the aquifer. If we assume that groundwater irrigation that uses mainly sprinklers is $90 \%$ efficient (10\% returns to the aquifer), then the 6,740 acre feet of annual groundwater pumping could deplete the aquifer discharge by about 6,060 acre feet/year. If all of the losses to groundwater discharge occurred during the 150 day irrigation season, then the recharge to the Umatilla River could have declined by $20 \mathrm{cfs}$. A further discussion of the trend of Echo Meadows groundwater recharge is discussed in the following paragraphs.

It is generally impossible to define how much return flow can be attributed to a given reach of a river much less the changes in return flows over time. Echo Meadows is different because most of the time during the irrigation season the entire river is diverted into the canals and the flow is essentially zero after the Dillon Canal (RM 23), then increases to a few tenth of a cfs along the Echo Meadows reach, and is finally rediverted at the Maxwell Diversion at RM 15.4. The return flow can be determined during recent history because the WRD took synoptic measurements at the canals and ditches and at several locations along the main stem in 1985-86 and 1991-97. These measurements became much of the basis for our understanding of the location and magnitude of return flows along the Umatilla River.

The WRD, in their 1991 publication of the 1985-86 data showed that return flow from Echo Meadows was about $20 \mathrm{cfs}$. When they re-measured these same locations in the 1990 's the return flow appears to have dropped to around $10 \mathrm{cfs}$. These reductions in return flow measurements can be seen on Figure 5. Ely (2000) indicated that return flows from the Meadows was probably about 35 cfs from Corp of Engineers measurements that were similar to the WRD's.

Using these historic measurements that showed where return flows occurred and their magnitude and combining this information with recently re-discovered measurements of the Stanfield and South Hermiston drain, Graham (2001) determined that return flows from Echo Meadows probably peaked in the 1940-1970's at 45 cfs. 
Figure 4. Echo Meadows Historic Diversions

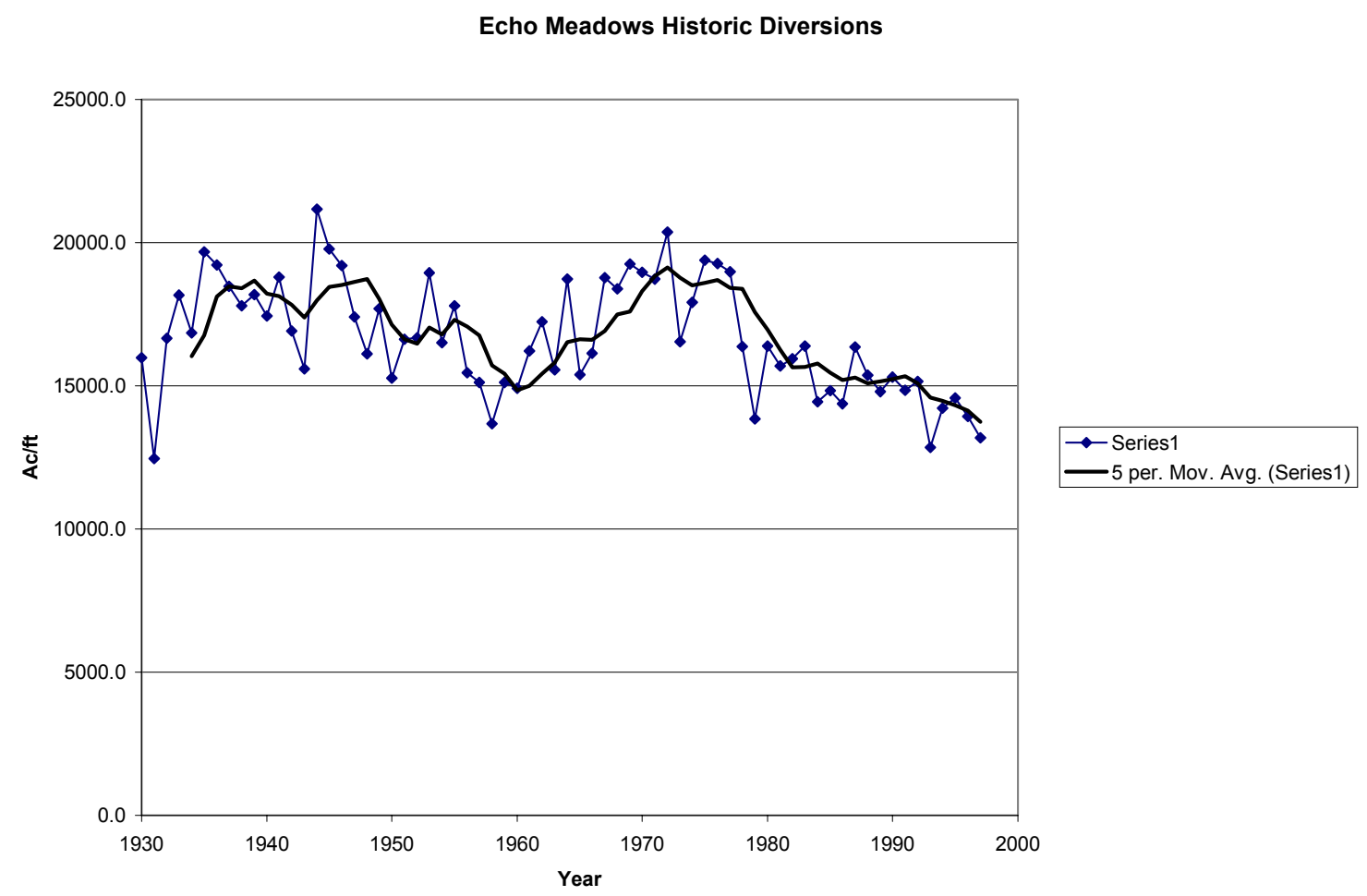


Figure 5. Historical Return Flows in the Meadows

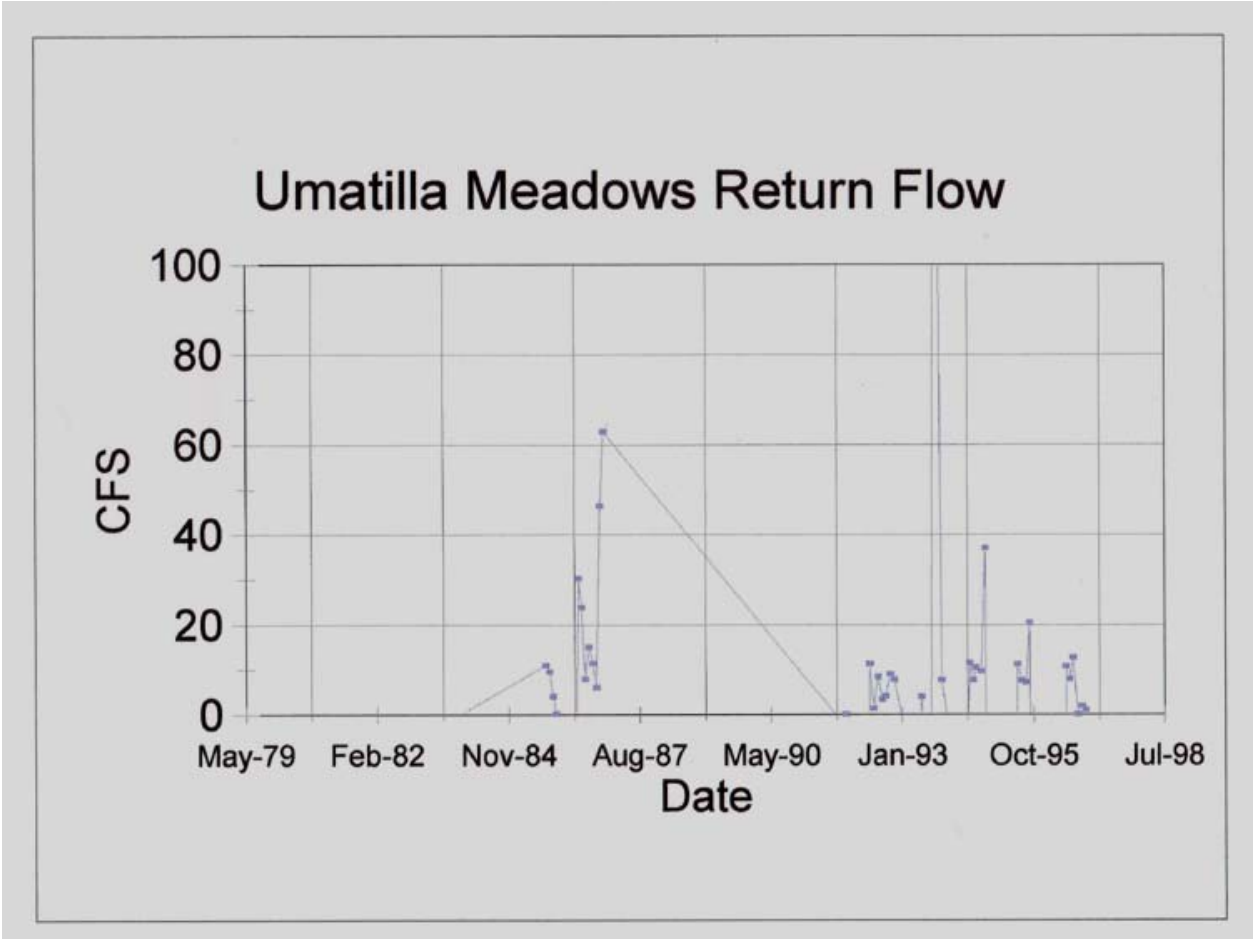


The results of the historic study of water diversions and return flow measurements provide conclusive proof that the potential increase of return flows from Echo Meadows may be as great as $35 \mathrm{cfs}$.

It will be difficult to measure the increases in the river flows from our initial trial applications proposed for January and February 2002 because the amount of water to be applied is smaller as compared to that required to restore the return flow from the Meadows. That is why our modeling tasks are so critical at this juncture. However, when the project is fully implemented and groundwater levels have recovered to 1950's like levels, we will be able to see and measure the impacts of the project in the river through conventional stream gauging measurements. In the sections that follow, we discuss data collection activities completed in 2001,

\section{Data Collection Efforts Completed in 2001}

The goal of 2001 data collection was to establish the baseline condition prior to recharge water application period of 2002 and 2003 . The following table shows the tasks accomplished during 2001 baseline as of end of October.

\begin{tabular}{|c|c|c|c|c|c|c|c|c|c|c|c|c|c|}
\hline \multicolumn{2}{|c|}{ Project Schedule } & \multicolumn{12}{|c|}{ Year/Quarter/Month } \\
\hline \multirow[t]{3}{*}{ Task } & \multirow{3}{*}{$\begin{array}{l}\text { Description } \\
\text { Phase-1. Baseline Data } \\
\text { Measurement } 2001\end{array}$} & \multicolumn{9}{|c|}{2001} & \multirow{2}{*}{\multicolumn{3}{|c|}{$\begin{array}{r}2002 \\
\text { Q4 }\end{array}$}} \\
\hline & & \multicolumn{3}{|c|}{ Q1 } & \multicolumn{3}{|c|}{ Q2 } & \multicolumn{3}{|c|}{ Q3 } & & & \\
\hline & & $\mathbf{A}$ & \begin{tabular}{l|l}
$\mathbf{M}$ \\
\end{tabular} & $\mathbf{J}$ & $\mathbf{J}$ & $\mathbf{A}$ & $\mathbf{S}$ & $\mathbf{O}$ & $\mathbf{N}$ & D & $\mathbf{J}$ & $\mathbf{F}$ & $\mathbf{M}$ \\
\hline & & & & & & & & & & & & & \\
\hline 1.1 & Review available wells and select well monitoring sites & & $\mathrm{X}$ & $\mathrm{X}$ & & & & & & & & & \\
\hline 1.2. & Install piezometers & $\mathrm{X}$ & & $\mathrm{X}$ & $\mathrm{X}$ & & & & & & & & \\
\hline $1.3 / 4$ & Collect water level and temperature data & & $\mathrm{X}$ & $\mathrm{X}$ & $\mathrm{X}$ & $\mathrm{X}$ & $\mathrm{X}$ & $\mathrm{X}$ & & & & & \\
\hline 1.5 & Identify 10 wells & & $\mathrm{X}$ & $\mathrm{X}$ & & & & & & & & & \\
\hline 1.6 & Collect water quality data & & $\mathrm{X}$ & $\mathrm{X}$ & $\mathrm{X}$ & $\mathrm{X}$ & $\mathrm{X}$ & $\mathrm{X}$ & & & & & \\
\hline 2.1 & Download the daily weather data & & $\mathrm{X}$ & $\mathrm{X}$ & $\mathrm{X}$ & $\mathrm{X}$ & $\mathrm{X}$ & $\mathrm{X}$ & & & & & \\
\hline 2.2 & Input weather data into Irrigate $2000 \AA$ & & $\mathrm{X}$ & $\mathrm{X}$ & $\mathrm{X}$ & $\mathrm{X}$ & $\mathrm{X}$ & $\mathrm{X}$ & & & & & \\
\hline 2.3 & Compare air temperature with the river temperature & & & & & & & & & & & & \\
\hline & & & & & & & & & & & & & \\
\hline 3.1 & Install 8 shallow soil moisture monitoring site & $\mathrm{X}$ & & & & & & & & & & & \\
\hline 3.2 & Install groundwater level soil moisture monitoring site & $\mathrm{X}$ & & & & & & & & & & & \\
\hline 3.3 & Measure soil moisture on shallow well sites. & & & $\mathrm{X}$ & $\mathrm{X}$ & $\mathrm{X}$ & $\mathrm{X}$ & $\mathrm{X}$ & & & & & \\
\hline 3.4 & Determine amount and frequency of water application & & & & & & & $\mathrm{X}$ & & & & & \\
\hline 3.5 & Determine groundwater water balance & & & & & & & $\mathrm{X}$ & & & & & \\
\hline & & & & & & & & & & & & & \\
\hline 4.1 & Obtain permission to monitor the existing wetland & & $\mathrm{X}$ & & & & & & & & & & \\
\hline
\end{tabular}




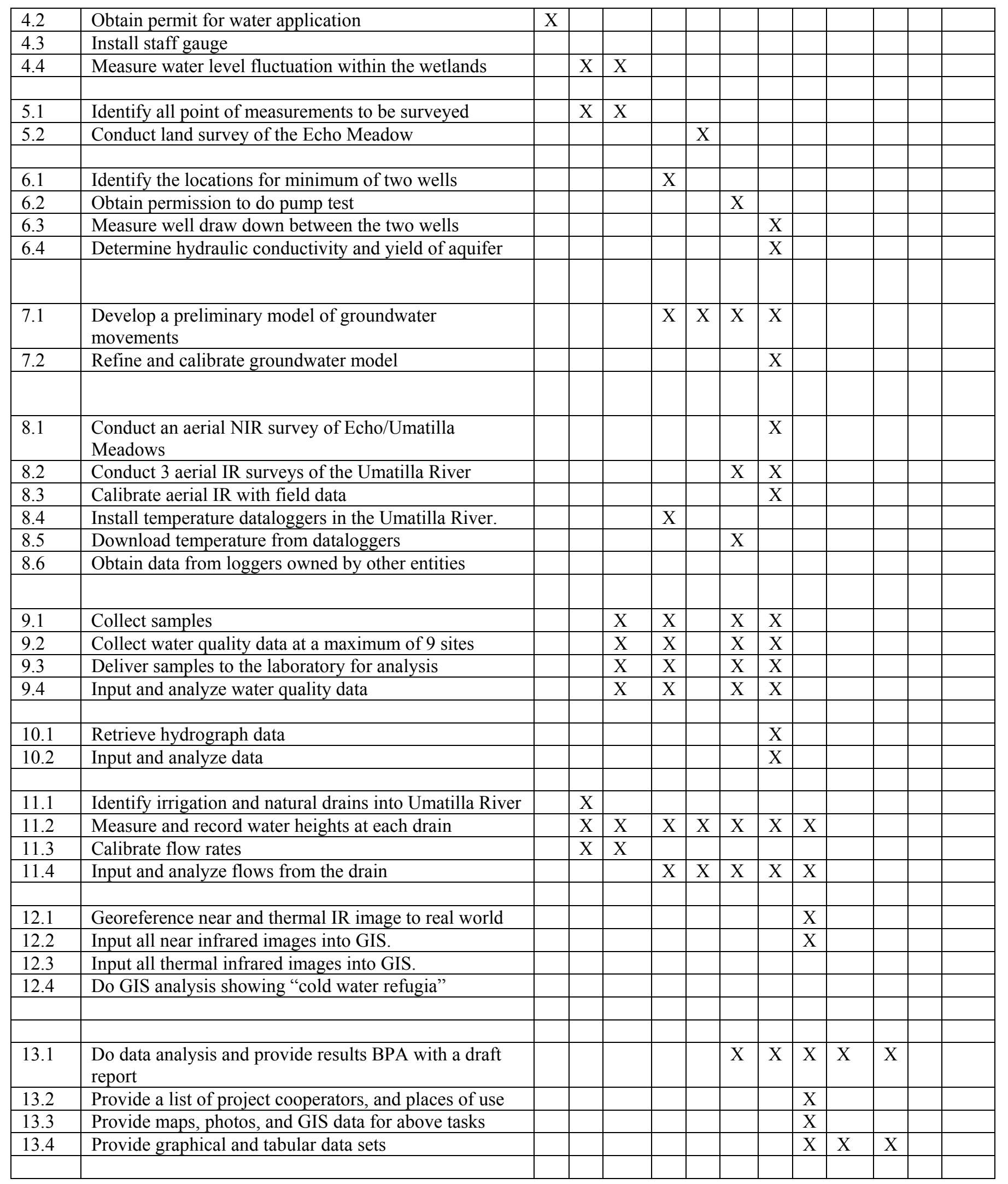


The 2001 baseline data collection for the Meadows project has concentrated on establishing, maintaining, and monitoring a network of piezometers, pit wells, culverts and drains, and surface water stations.

Figure 2 shows the locations of these monitoring locations on a contour map of the area. Appendix $\mathrm{C}$ lists these stations and provides their coordinates in longitude/latitude, UTM, and UTM coordinates translated to feet.

During 2001, 13 of the monitoring stations were surveyed (with over 8 miles of level lines) to establish their elevations. These stations that were surveyed were a mix of key piezometers and pit wells throughout the Meadows. These key stations provide a baseline of elevations for the groundwater model and for comparison of groundwater modeling results for calibration and verification. The elevation of these wells are seen in Appendix C.

During 2001, taking advantage of the drought and lowered groundwater levels, 5 of the piezometers were deepened and improved to provide better groundwater levels and water quality measurements.

The weekly monitoring during 2001 includes groundwater level and water quality measurements at 8 piezometers, 8 pit wells, 5 surface water stations, and 9 drains and culverts, and 10 soil moisture tubes. Several other locations shown on Figure 2 and Appendix C are locations where others, such as the Westland Irrigation District, and the WRD provide data collection services that are used in this project. At most of these locations, water temperature, $\mathrm{pH}$, and conductivity measurements were taken.

The weekly monitoring data was inputted into a Microsoft Access database. All 2000 data collection (pre-assessment data) measurements were also inputted. We are current with our data. During November of 2001, all data input is done through the use of a GPS/Personal Productivity Device that allows for direct entry from data collected in the field to the computer, thereby bypassing transcription errors.

Two groundwater pump tests were completed. These pump tests were done in the far northern portion of the Meadows and provided needed information regarding hydraulic properties of the groundwater aquifer. Subsequently, a groundwater model of the area was developed.

IRZ also flew the river using thermal infrared imagery. Three helicopter flights of the river were made in 2001 . These flights provide valuable information about the water temperature of the river throughout the Meadows. The imagery shows where cold water locations, such as the Stanfield Drain, and groundwater springs enter the river. They will provide a baseline for comparisons with future years when the project is fully implemented. 
In the following sections, we provide details from our 2001 monitoring program.

\section{Groundwater and Surface Water Level Measurements}

The groundwater and surface water levels were measured largely for input in the groundwater model (MODFLOW) but, they also reveal important clues to the groundwater system in the Meadows.

For example, Figure 6 shows the water level measurements during 2000-2001 at a piezometer that is along the north edge of the Meadows and within a hundred feet of the Umatilla River. As can be seen in Figure 6, the groundwater level was approximately $10 \mathrm{ft}$. below ground surface on January 2000 . The water levels rose with irrigation and river stage to 6 feet until mid-April. The water level then declined until mid-August when it again began to rise. The drought of 2000-2001 really started to show and water levels then decreased to below 10 feet during the winter of 2001.

Perhaps reflecting the drought of 2001 and low irrigation applications and Umatilla River stage (Figure 7), water levels in the aquifer were approximately 1 foot lower than at the same time in 2001. Water levels have remained low in this well since July 2001.

Figure 6 shows a nearly identical pattern to the stage of the Umatilla River (Figure 7). This pattern is reasonable given that the piezometer is so close to the river, but it also demonstrates that water builds up in the aquifer until April or May, when the stage drops. This is important for the recharge project because our water is added early in the year. The relationship shown in Figures 6 and 7 indicate that the water will remain in the aquifer until the spring and summer when the recharge to the river is truly desirable. Some other wells that were monitored that are further south in the Meadows (away from the river) show this same seasonal pattern. However, as shown in Figure 8, the seasonal pattern is not as pronounced as wells that are closer to the river. 
Figure 6. Depth to groundwater at Mueller EMFMRP-1.

Depth to groundwater at EMFMRP-1

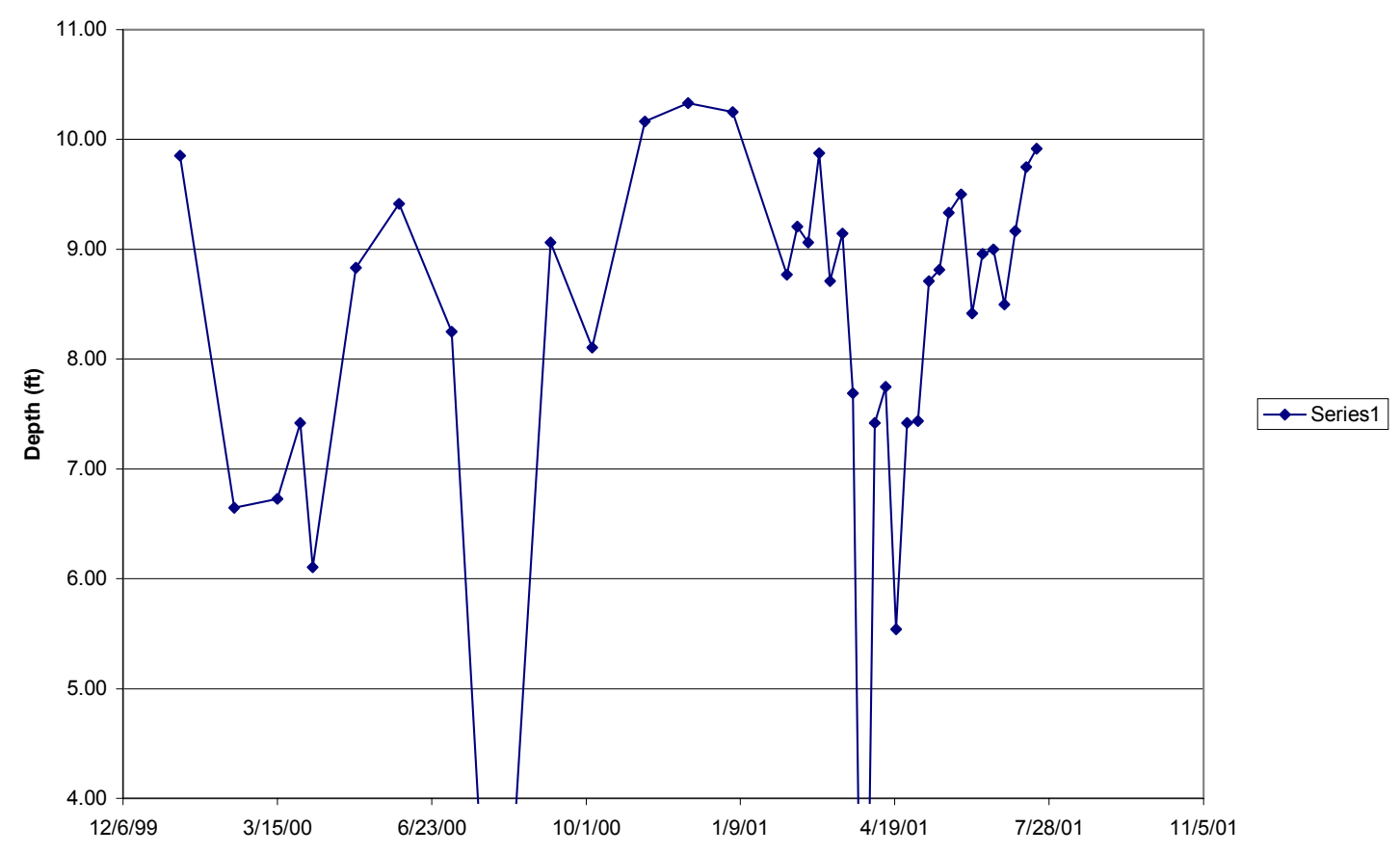


Figure 7. Umatilla River Stage height in 2000 and 2001.

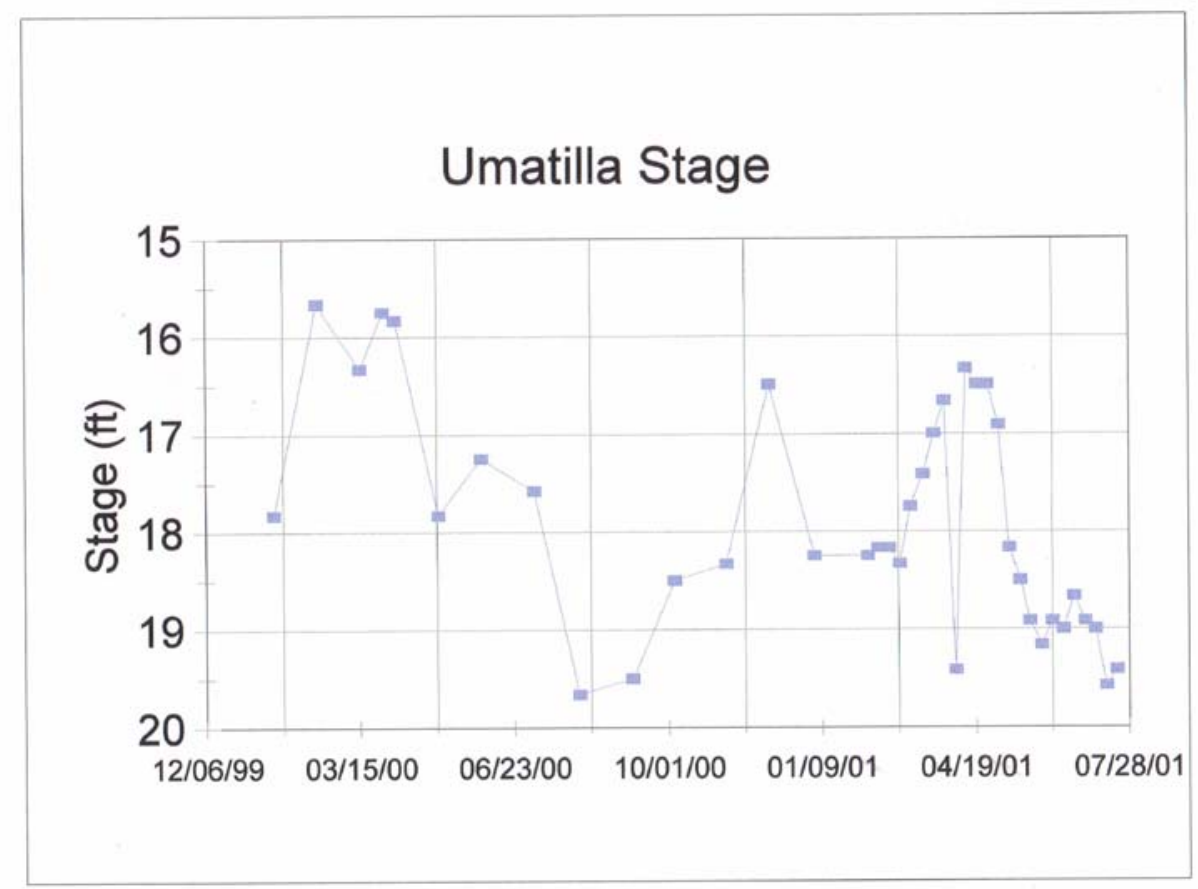


Figure 8. Depth to Groundwater at Andrews EMBAP-1.

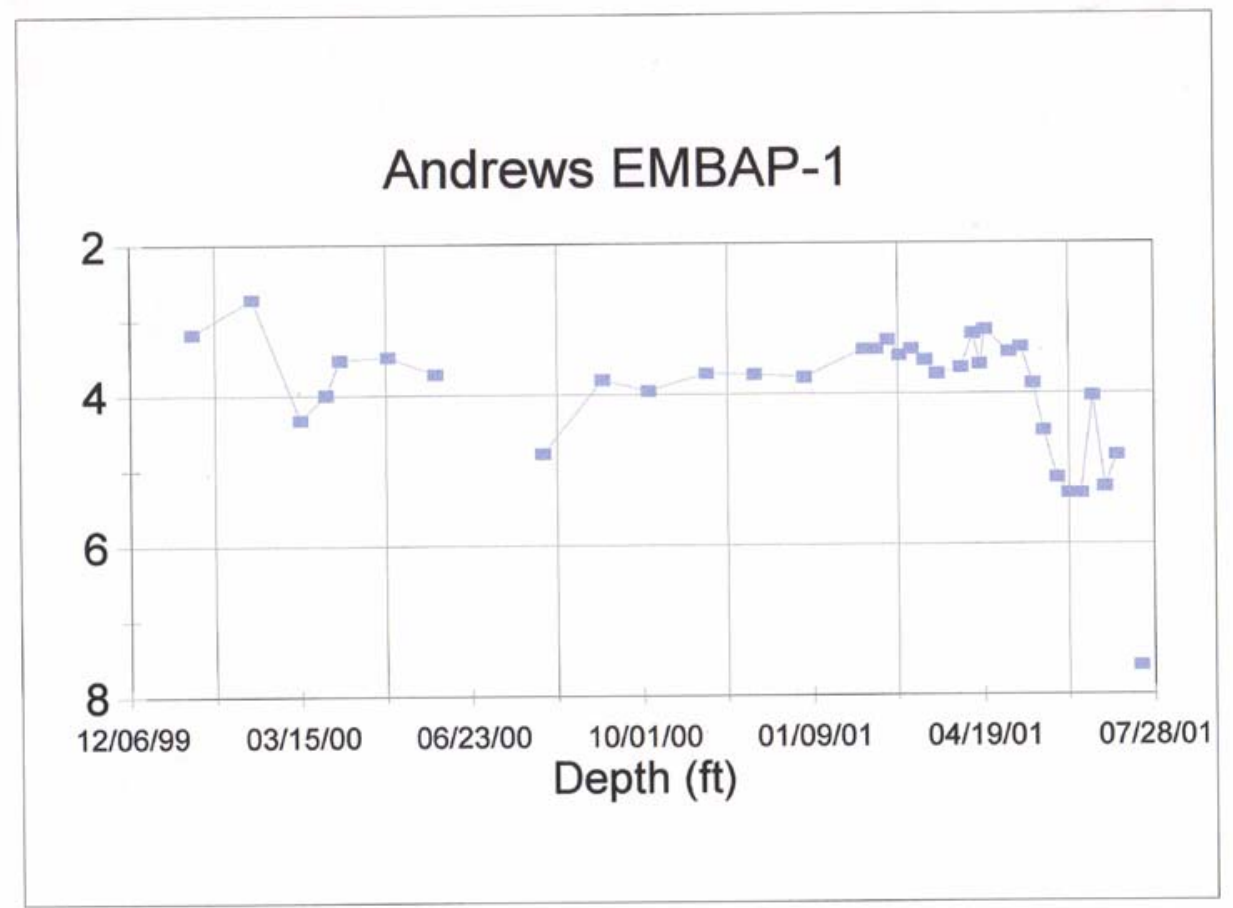


During, 2001, an hourly data logger/pressure transducer was added to the monitoring network at the Prior well near the northern portion of the Meadows. Weekly measurements were also taken at this well to check on the data logger accuracy and to provide a means of correcting the data logger data if necessary. Figure 9 shows a representative plot of the water level form this well. As can be seen in Figure 9, the continuous monitoring of water levels provides some detail of water levels between the weekly measurements. For example, in the period of May 22-June 2, 2001, the continuous recorder shows the effect of a flood irrigation cycle on that field during that time. The loggers also show the effect of a nearby pumping well cycles, where water levels were declining during early June (due to pumping) but would temporarily recover when the well was shut off.

The comparisons of the two methods of water level measurements were not always good, such as that shown during late April and early June. Some of these differences may be due to operator error or using different water level instruments. This difference may be seen on Figure 7 at the two measurements taken with two different instruments on May 24, 2001.

Appendix D includes the water level database from 2000-2001. Appendix D also shows plots of the water levels form this database for several other wells.

\section{Groundwater and Surface Water Quality Data Collection}

Weekly indicator water quality parameters $(\mathrm{pH}$, temperature, and conductivity) were measured at the 16 groundwater stations and at several locations along the Umatilla River. A copy of the water quality database is included in Appendix D.

Certainly, the most important conclusion from the water quality database is how much more uniform groundwater temperature as opposed to surface water temperature and how much colder the groundwater temperature is during the summer.

Figure 10 shows an example of the water temperature from one of the pit wells. As can be seen in Figure 10, the water temperature ranges form about 13-16C, during this nearly 2 year monitoring period. Surface water during the summer was as high as $22 \mathrm{C}$ (several individual water temperature measurements taken in the summer on the Umatilla River show that the temperature may be greater than 25C). Clearly, this groundwater temperature data shows the potential ability of the return flow to substantially cool the Umatilla River, particularly if the project is fully implemented during the water application recharge phase (2002-2003). 
Figure 9. Water Levels at site \#Prior Well.

Prior Well Water Levels

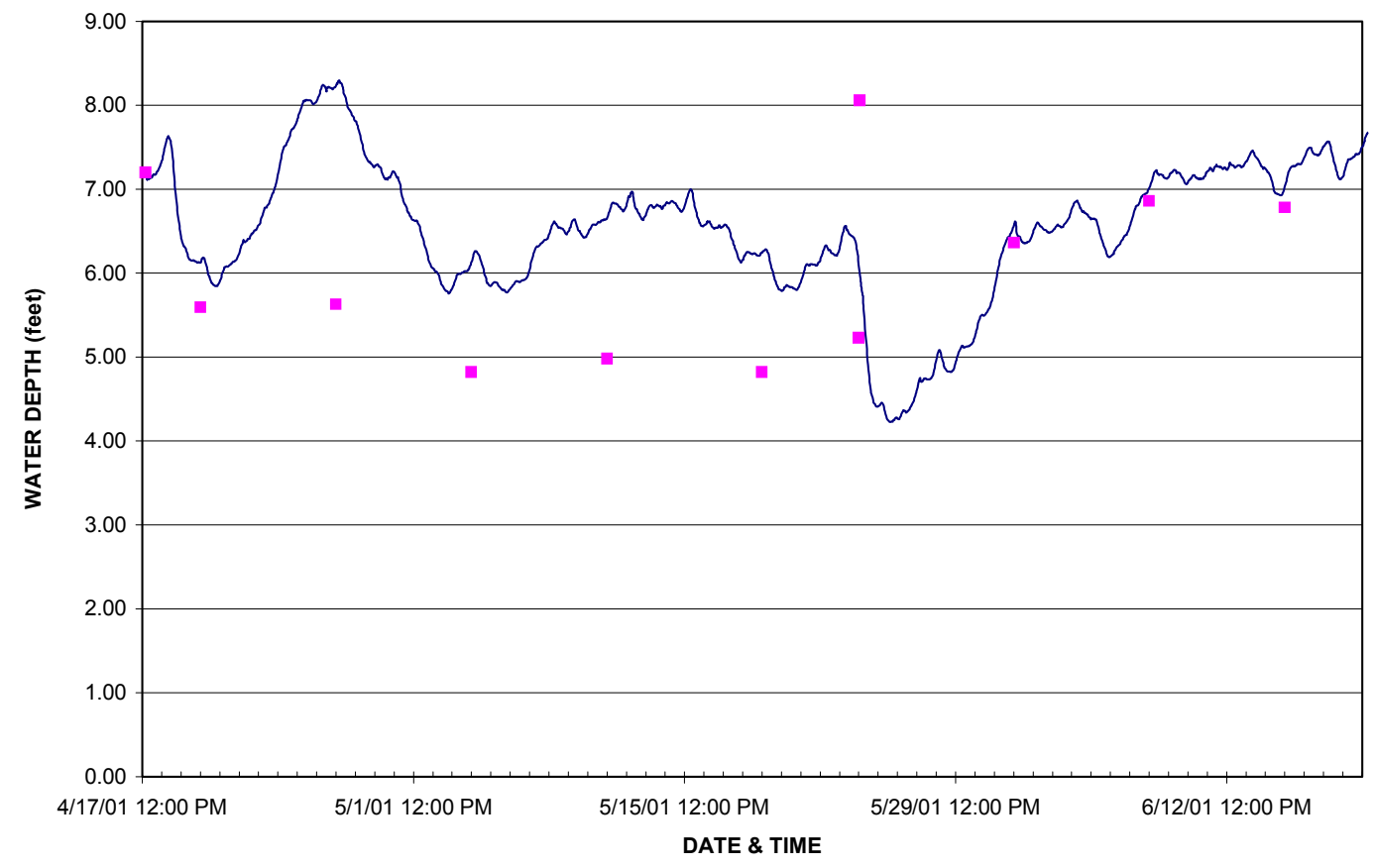


Figure 10. Average Groundwater Temperature at site \# EMDMPW-2.

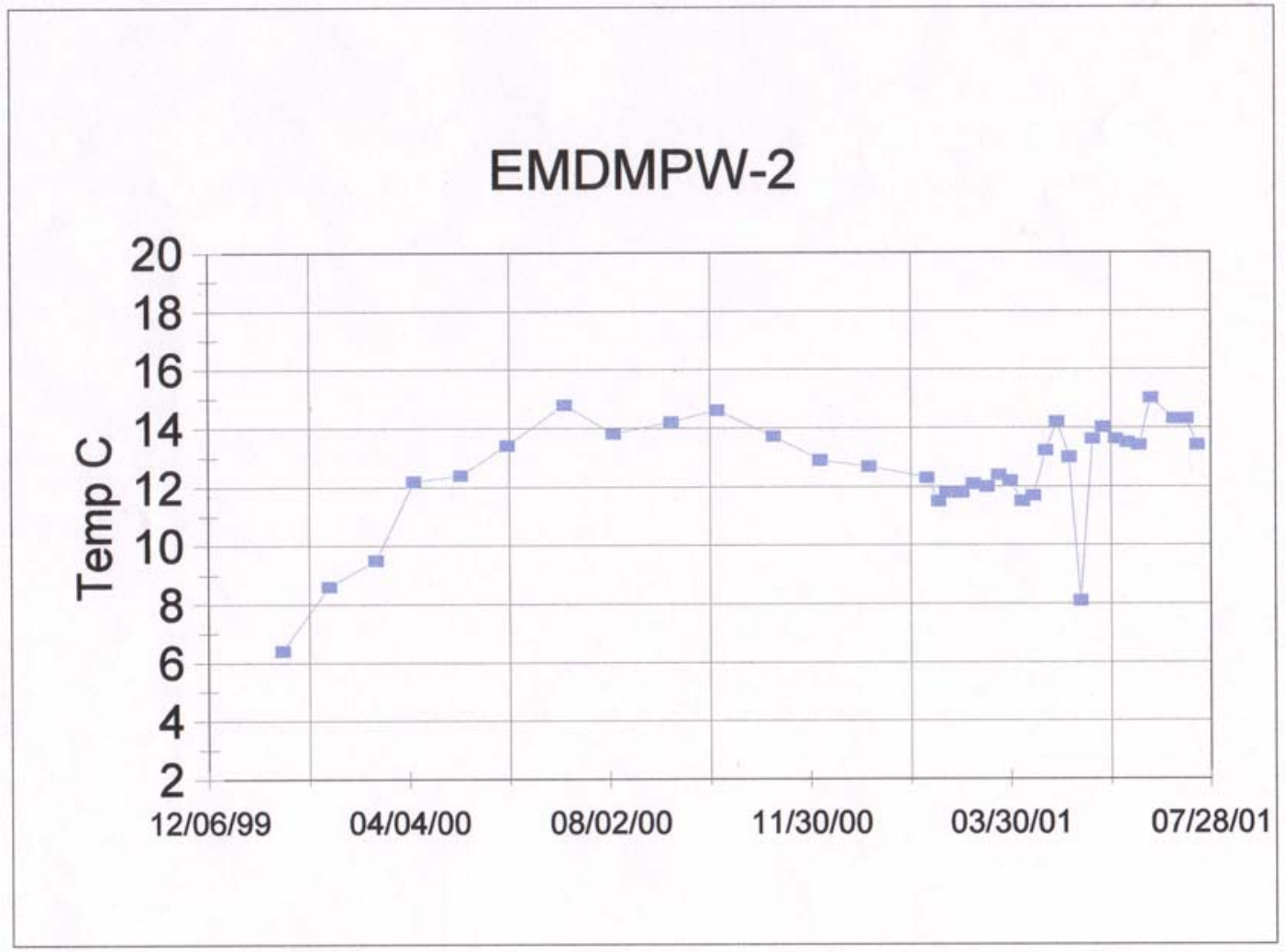


It is possible, using the data in Appendix $D$ to provide a snapshot of a particular parameter throughout the Meadows by contouring the parameter on a given date (or the average of a parameter at a location). An example of this contouring can be seen on Figure 11. Figure 11 shows the average groundwater temperature in the Meadows.

Figure 11. Average groundwater temperature contour map. Black crosses are well locations. Approximate scale 1 in. $=3,000 \mathrm{ft}$.

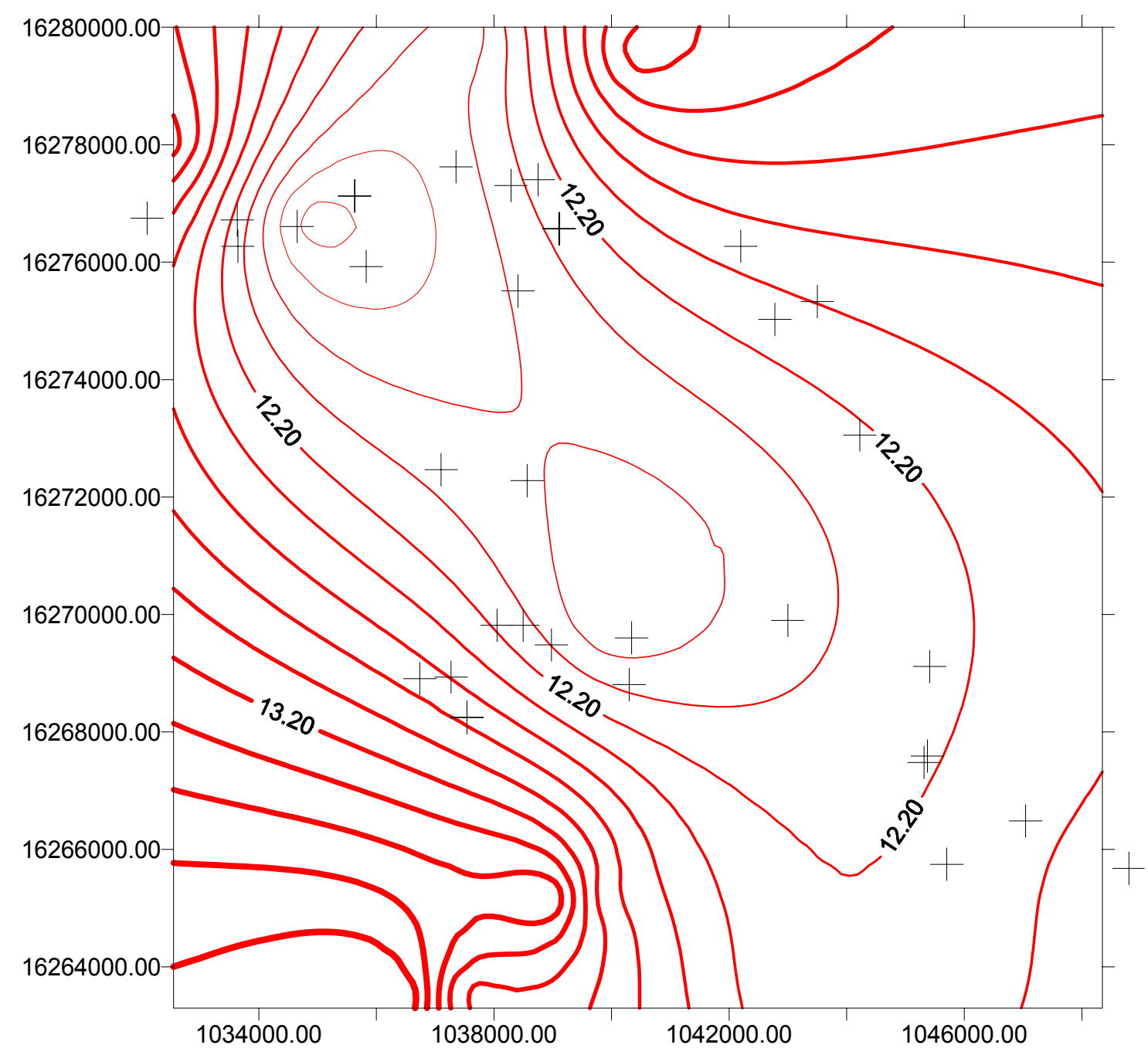


The black crosses are the data points (wells) that were contoured. As can be seen in Figure 10, the average water temperature in the Meadows is between about 12 and 13 degrees. A lower temperature trough may be seen running from southeast to northwest in this figure, perhaps indicating colder water from irrigation or some other factor.

Other plots in Appendix E show contour plots of Conductivity, $\mathrm{pH}$, and other water quality parameters that can be contoured from Appendix D. Some of these plots show mathematical oddities that occur form computer contouring outside of the areas where there is real data (outside of the black crosses). These contoured maps of water quality may provide some hints regarding the groundwater in the Meadows and certainly provide a good indication that the groundwater is of good quality and that enhancing the Umatilla River through recharge of the aquifer would be beneficial for the river.

In addition to the indicator parameters discussed above, a more complete number of parameters were sampled and analyzed on a quarterly basis. Five groundwater stations and three surface water stations. The samples were analyzed for bacteria (coliforms), nitrate, and phosphorous. Results from the sampling program are included in Appendix F. The summary of the results indicate that the groundwater is good quality and is low in nutrients and bacteria, thereby suggesting that fertilizer migration to the aquifer is not an issue. In addition, the analysis shows that augmenting by recharge of the groundwater flow improve the water quality in the Umatilla River.

\section{Groundwater Pump Tests}

Two groundwater pump tests were performed on October 3 and 4, 2001 in Echo Meadows. They were at EMDMPW-3 and EMDMRP-2, in the northern portion of the Meadows. The test at EMDMPW-3 was a twenty four hour pump test and the test at EMDMRP-2 was a piezometer slug test.

A complete analysis of these pump tests are included in Appendix G. The pump tests showed that the hydraulic conductivity in this area was about 37-88 feet/per day at EMDMPW-3 and was $0.44 \mathrm{ft} /$ day at EMDMRP-2. The lower value at EMDMRP-2 was associated with the silty sands material that composed the top 15 feet of the aquifer. Likely, the higher values associated with EMDMPW-3 was from coarser material that was found below the silty sand. This same type of stratigraphy (silty sand above, coarser material below) was also found at EMDMRP-1.

The specific yield that was measured at EMDMPW-3 was 0.1 . This value may have increased if the well was pumped longer.

These pump tests showed a much lower value of hydraulic conductivity than the pump test of the Prior well in September of 1998 and the Snow wells in July 1995 (approximately $200 \mathrm{ft} /$ day). These older pump tests were in the southern portion of the 
Meadow. The variability of all of the pump tests in the Meadows probably reflects that the area has numerous cut and fill features and discontinuous buried river channels.

The lower hydraulic conductivity found in this years pump tests will be used to refine the data input in the groundwater model.

\section{Stream Gauging of Drains and Ditches}

The drains and ditches in the Meadow are very important to monitor. For example, if the discharge from the Stanfield Drain was not considered in the mass balance of the reach, then the recharge from the Meadows would be considered to be much higher than it actually is. Or if the drains in the Meadows discharged most of the return flow, then applications of recharge water would not be effective because the water would quickly be diverted to the drains and to the Umatilla River and would not be available for summer and fall recharge.

The WRD, 1991 found that the Stanfield Drain was a steady discharge of about 10-20 cfs. There discharge measurements of the drain in the 1990's showed that the discharge was approximately the same as that during 1985-86. They also determined that the drains in the Meadows did not (appreciably) discharge much water to the Umatilla, except when there was high precipitation or some other external factor. This could mean that the drains do not appreciably intersect groundwater and that they probably act more like an irrigation ditch (a means of conveyance).

IRZ measured the stage of the Stanfield Drain throughout 2001 and found that it varied from a high of 11 feet in April (below a fixed datum) to a low of about 13 feet in AugustSeptember. During virtually all of the irrigation season, the stage was 12.0 and 13.0 feet.

Several discharge measurements were made at the Stanfield Drain during this time. The discharge was measured from $10.3 \mathrm{cfs}$ on October 4 to $15.7 \mathrm{cfs}$ on August 17, 2001. These measurements suggest that the flow of the Stanfield Drain is consistent with previous years.

IRZ measured the discharge of several drains and ditches in Echo Meadows in 2001. The discharge was often near zero, but was occasionally as high as 2-3 cfs. This later condition occurred when the ditches were transmitting water to a place of irrigation. There were few times that surface water was seen that was directly transmitted to the Umatilla River, consistent with WRD observations (WRD, 1991). The drains could start to intercept groundwater, and act as true drains, if groundwater levels are raised sufficiently. 


\section{Groundwater Modeling Activities}

A preliminary MODFLOW groundwater model was developed during 2001. The model used Umatilla River stages, hydraulic conductivity, and many other parameters developed through the 2001 monitoring period.

The model was deemed sufficiently calibrated when head and return flow matches were similar to that seen in the Echo Meadows reach. After calibration, the model was ran to see if water applied to the Meadows in the winter/early spring would be seen as return flow in the summer and fall.

The model showed that the peak difference in return flow would be seen in August, but that over $1 / 2$ of the applied water would remain in the aquifer past the first year and contribute to building up the groundwater levels. This model analysis showed that that the full effect of the project would not be seen in one year, but that the recharge would be at the desired time of year and of sufficient magnitude that the difference could actually be measured by stream gauging activities.

A more complete description of model results is found in Appendix $\mathrm{H}$.

\section{Soil Moisture Monitoring}

Using calibrated Neutron Probe, IRZ monitored moisture levels at 10 locations throughout the Meadow on a weekly basis throughout 2001. Soil moisture was measured at 1 foot intervals from the ground surface to as much as 10 feet, or until groundwater is encountered.

Tracking soil moisture over time shows the effect of flood irrigation as the wetted front moves through the soil column and is ultimately seen as an increase in groundwater level. We are still compiling the soil moisture measurements completed during 2001.

Another aspect of the soil moisture monitoring is that by following the application of recharge water through the soil column and into the groundwater, we can clearly differentiate between recharge water and irrigation water, thereby ensuring that the permitted water is used for its intended purpose. 


\section{Thermal Infrared Imagery Along the Umatilla River}

IRZ has flown thermal imagery of the Umatilla River three times during 2001. The dates of the imagery are on August 8,2001 and October 1, 2001. The thermal imagery is particularly well suited to showing differences in water temperature on a spatial basis. Comparing images from different times of the year can show important areas of groundwater seeps and other coldwater refuges.

Figure 12 shows an example of the thermals imagery from October 1, 2001. The two images are the morning (coolest) and the afternoon (warmest) images of the Umatilla River with its intersection with the Stanfield Drain. The Stanfield Drain is the colder water and smaller stream shown on the bottom right side of each image (the river is flowing north-top of the page).

As can be seen on Figure 12, the Stanfield Drain has a substantially lower water temperature than the Umatilla River. This is because the drain originates from groundwater return flow in the Stanfield Irrigation District. Both images also show important groundwater seep areas (upper, left) in the Echo Meadows area.

These thermal flight images are particularly valuable when they are correlated by river mile, river flow, and other parameters, and are used in comparison with other dates. We believe that these images will show noticeable differences in thermals conditions when the project has been fully implemented. We expect to see noticeable improvements in water temperature after the project is implemented. 
Figure 12. Thermal Imagery taken October 1,2001along the Umatilla River at the confluence of the Stanfield Drain. The upper image is the morning and the lower image is the afternoon flight.
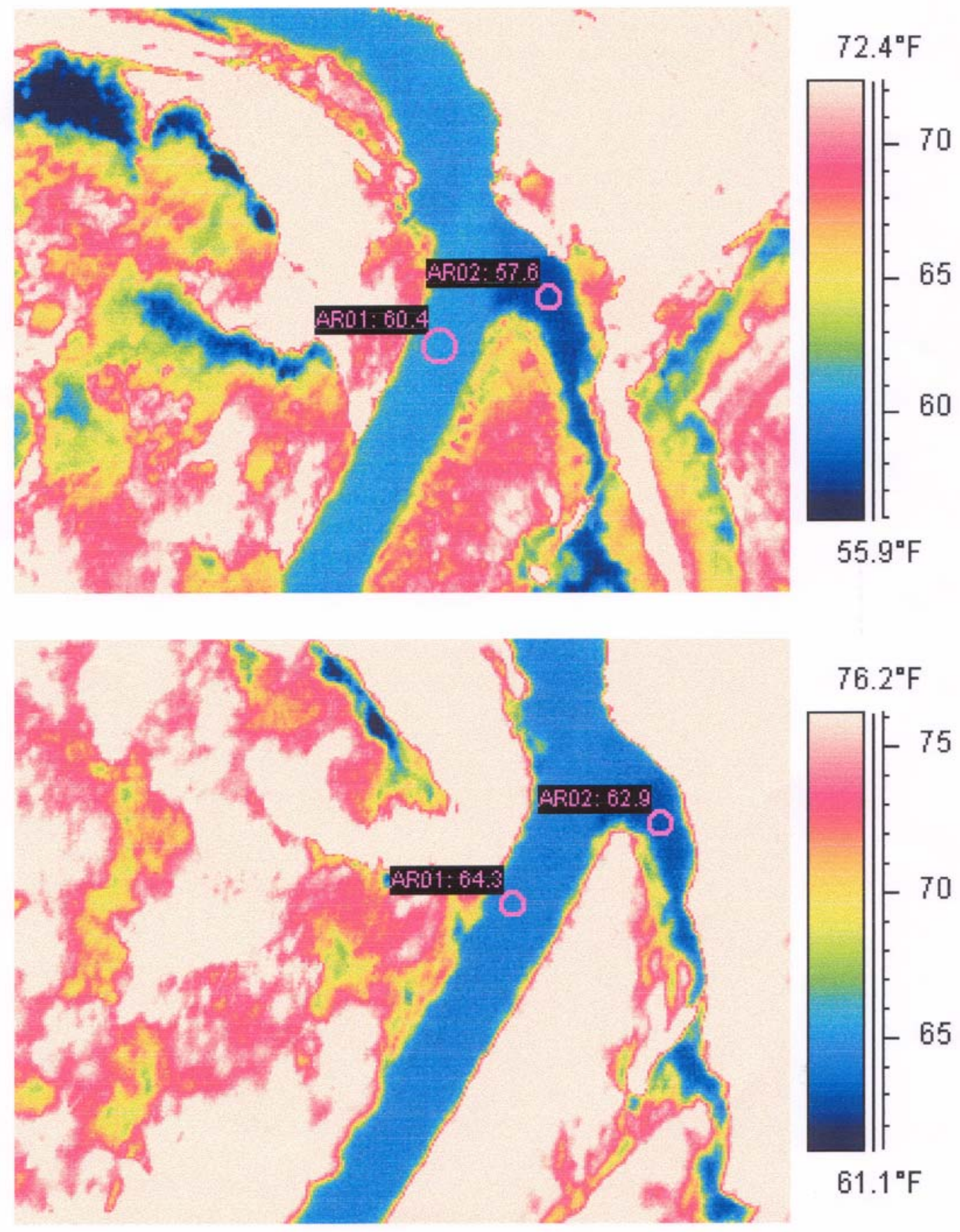

$76.2^{\circ} \mathrm{F}$

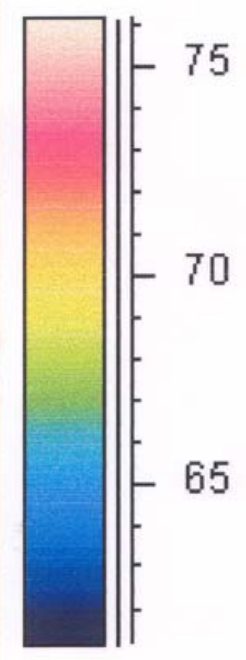

$61.1^{\circ} \mathrm{F}$ 


\section{Cited References}

Bureau of Reclamation, 1989. Review of Umatilla Project Operations.

Department of Environmental Quality, 1995. Hydrogeology, Groundwater Chemistry, and Land Uses in the Lower Umatilla Basin Groundwater Management Area.

Ely, Kate. CTUIR, 2000. Data Base of WRD and Corps Of Engineers Synoptic Flow Measurements along the Umatilla River from 1981-1997.

Graham, James, 2001. Umatilla River Return Flow Analysis and relationship to Irrigation District and Other Management Activities. IN DRAFT: Client, Umatilla Irrigation Districts.

United States Geological Survey, 2000. Hydrology of the Columbia Plateau Regional Aquifer System, Washington, Oregon, and Idaho. Water Resources Investigations Report 96-4106

Water Resources Department, 1991. Umatilla River Return Flow Analysis During 1985 and 1986. 
Appendix: A

Water Rights in Echo Meadows 
PLACE OF USE REPORT $3 \mathrm{~N} \quad 29 \mathrm{E}$

TWP/RNG POU-ID PO D-ID APP LICATION P ERMIT CERT \# USE

\begin{tabular}{|c|c|c|c|c|c|c|c|}
\hline 2.00N28.00E & 1 & 2 & G & 6645 & G & 6069 & 61532 IR \\
\hline $2.00 \mathrm{~N} 28.00 \mathrm{E}$ & 1 & 3 & G & 6645 & G & 6069 & 61532 IR \\
\hline 2.00N28.00E & 1 & 1 & G & 6645 & G & 6069 & 61532 IR \\
\hline 2.00N28.00E & 2 & 3 & G & 6645 & G & 6069 & 61532 IR \\
\hline $2.00 \mathrm{~N} 28.00 \mathrm{E}$ & 2 & 1 & G & 6645 & G & 6069 & 61532 IR \\
\hline $2.00 \mathrm{~N} 28.00 \mathrm{E}$ & 2 & 2 & G & 6645 & G & 6069 & 61532 IR \\
\hline 2.00N28.00E & 3 & 2 & G & 6645 & G & 6069 & 61532 IR \\
\hline $2.00 \mathrm{~N} 28.00 \mathrm{E}$ & 3 & 1 & G & 6645 & G & 6069 & 61532 IR \\
\hline 2.00N28.00E & 3 & 3 & G & 6645 & G & 6069 & 61532 IR \\
\hline 2.00N28.00E & 7 & 5 & $S$ & 62173 & $S$ & 48968 & 0 IR \\
\hline $2.00 \mathrm{~N} 30.00 \mathrm{E}$ & 21 & 18 & $\mathrm{~S}$ & 39688 & $\mathrm{~S}$ & 29537 & 36922 IR \\
\hline $2.00 \mathrm{~N} 30.00 \mathrm{E}$ & 40 & 18 & $S$ & 39688 & $S$ & 29537 & 36922 IS \\
\hline 2.00N30.00E & 40 & 18 & $\mathrm{~T}$ & 5847 & G & 10 & 67233 IR \\
\hline 2.00N30.00E & 42 & 19 & G & 1047 & G & 910 & 30132 IR \\
\hline 2.00N30.00E & 42 & 19 & G & 1047 & G & 910 & 30132 IR \\
\hline 2.00N30.00E & 46 & 23 & $S$ & 25129 & $\mathrm{~S}$ & 19771 & 23757 IR \\
\hline 2.00N30.00E & 47 & 24 & $\mathrm{~S}$ & 29197 & $S$ & 25222 & 31809 IR \\
\hline 2.00N30.00E & 48 & 18 & $S$ & 39688 & $S$ & 29537 & 36922 IR \\
\hline 2.00N30.00E & 49 & 18 & $S$ & 39688 & $S$ & 29537 & 36922 IR \\
\hline $2.00 \mathrm{~N} 30.00 \mathrm{E}$ & 50 & 18 & $S$ & 39688 & $S$ & 29537 & 36922 IR \\
\hline 2.00N30.00E & 51 & 25 & $S$ & 51561 & $S$ & 38899 & 52410 IR \\
\hline 2.00N30.00E & 52 & 26 & $S$ & 53629 & $S$ & 40118 & 61801 IR \\
\hline 2.00N30.00E & 53 & 26 & $S$ & 53629 & $S$ & 40118 & 61801 IR \\
\hline 2.00N30.00E & 54 & 27 & $S$ & 53629 & $S$ & 40118 & 61801 IR \\
\hline $2.00 \mathrm{~N} 30.00 \mathrm{E}$ & 55 & 27 & $S$ & 53629 & $S$ & 40118 & 61801 IR \\
\hline 2.00N30.00E & 56 & 27 & $S$ & 53629 & $\mathrm{~S}$ & 40118 & 61801 IR \\
\hline $2.00 \mathrm{~N} 30.00 \mathrm{E}$ & 101 & 20 & G & 396 & $\mathrm{G}$ & 1142 & 28606 IR \\
\hline 2.00N30.00E & 112 & 23 & $S$ & 25129 & $S$ & 19771 & 23757 IR \\
\hline $3.00 \mathrm{~N} 28.00 \mathrm{E}$ & 1 & 2 & $G$ & 3334 & G & 3131 & $37616 \mathrm{DO}$ \\
\hline $3.00 \mathrm{~N} 28.00 \mathrm{E}$ & 1 & 1 & G & 3334 & $G$ & 3131 & $37616 \mathrm{DO}$ \\
\hline 3.00N28.00E & 2 & 2 & G & 3334 & G & 3131 & $37616 \mathrm{DO}$ \\
\hline $3.00 \mathrm{~N} 28.00 \mathrm{E}$ & 2 & 1 & G & 3334 & G & 3131 & $37616 \mathrm{DO}$ \\
\hline $3.00 \mathrm{~N} 28.00 \mathrm{E}$ & 3 & 1 & G & 3334 & G & 3131 & 37616 DO \\
\hline 3.00N28.00E & 3 & 2 & G & 3334 & G & 3131 & 37616 DO \\
\hline $3.00 \mathrm{~N} 28.00 \mathrm{E}$ & 4 & 1 & $G$ & 3334 & $G$ & 3131 & 37616 DO \\
\hline 3.00N28.00E & 4 & 2 & G & 3334 & G & 3131 & $37616 \mathrm{DO}$ \\
\hline $3.00 \mathrm{~N} 28.00 \mathrm{E}$ & 5 & 4 & $S$ & 17118 & $S$ & 12847 & 14165 IS \\
\hline $3.00 \mathrm{~N} 28.00 \mathrm{E}$ & 5 & 3 & $\mathrm{~S}$ & 17118 & $\mathrm{~S}$ & 12847 & 14165 IS \\
\hline $3.00 \mathrm{~N} 28.00 \mathrm{E}$ & 6 & 3 & $S$ & 17118 & $S$ & 12847 & 14165 IS \\
\hline $3.00 \mathrm{~N} 28.00 \mathrm{E}$ & 6 & 4 & $\mathrm{~S}$ & 17118 & $S$ & 12847 & 14165 IS \\
\hline $3.00 \mathrm{~N} 28.00 \mathrm{E}$ & 7 & 3 & $S$ & 17118 & $\mathrm{~S}$ & 12847 & 14165 IS \\
\hline 3.00N28.00E & 7 & 4 & $S$ & 17118 & $\mathrm{~S}$ & 12847 & 14165 IS \\
\hline $3.00 \mathrm{~N} 28.00 \mathrm{E}$ & 8 & 5 & $G$ & 6368 & G & 5964 & 51694 IR \\
\hline 3.00N28.00E & 8 & 6 & G & 7493 & G & 6969 & 51696 IS \\
\hline $3.00 \mathrm{~N} 28.00 \mathrm{E}$ & 15 & 5 & $G$ & 6368 & G & 5964 & 51694 IR \\
\hline $3.00 \mathrm{~N} 28.00 \mathrm{E}$ & 15 & 6 & G & 7493 & G & 6969 & 51696 IS \\
\hline $3.00 \mathrm{~N} 28.00 \mathrm{E}$ & 84 & 46 & $S$ & 54215 & $\mathrm{~S}$ & 40576 & 54556 IS \\
\hline $3.00 \mathrm{~N} 28.00 \mathrm{E}$ & 84 & 45 & $\mathrm{G}$ & 7353 & G & 6781 & 54558 IS \\
\hline
\end{tabular}


PLACE OF USE REPORT $3 \mathrm{~N} \quad 29 \mathrm{E}$

TWP/RNG POU-ID PO D-ID APP LICATION P ERMIT CERT \# USE

\begin{tabular}{|c|c|c|c|c|c|c|c|}
\hline $3.00 \mathrm{~N} 28.00 \mathrm{E}$ & 84 & 44 & $S$ & 51601 & $S$ & 39173 & 54555 IR \\
\hline 3.00N28.00E & 84 & 0 & $S$ & 74318 & $S$ & 51665 & 0 IS \\
\hline 3.00N28.00E & 85 & 0 & $S$ & 74318 & $S$ & 51665 & 0 IS \\
\hline $3.00 \mathrm{~N} 28.00 \mathrm{E}$ & 85 & 44 & $S$ & 51601 & $\mathrm{~S}$ & 39173 & 54555 IR \\
\hline $3.00 \mathrm{~N} 28.00 \mathrm{E}$ & 85 & 45 & G & 7353 & G & 6781 & 54558 IS \\
\hline $3.00 \mathrm{~N} 28.00 \mathrm{E}$ & 85 & 46 & $S$ & 54215 & $S$ & 40576 & 54556 IS \\
\hline $3.00 \mathrm{~N} 28.00 \mathrm{E}$ & 86 & 47 & G & 11182 & G & 10292 & 64441 IS \\
\hline $3.00 \mathrm{~N} 28.00 \mathrm{E}$ & 86 & 46 & $G$ & 11182 & G & 10292 & 64441 IS \\
\hline $3.00 \mathrm{~N} 28.00 \mathrm{E}$ & 86 & 44 & $S$ & 51601 & $\mathrm{~S}$ & 39173 & 54555 IR \\
\hline 3.00N28.00E & 86 & 0 & $S$ & 74318 & $S$ & 51665 & 0 IS \\
\hline $3.00 \mathrm{~N} 28.00 \mathrm{E}$ & 87 & 46 & S & 68587 & $S$ & 51126 & 0 IS \\
\hline 3.00N28.00E & 87 & 0 & $S$ & 74318 & $\mathrm{~S}$ & 51665 & 0 IS \\
\hline $3.00 \mathrm{~N} 28.00 \mathrm{E}$ & 87 & 46 & $G$ & 11182 & G & 10292 & 64441 IR \\
\hline $3.00 \mathrm{~N} 28.00 \mathrm{E}$ & 87 & 44 & $S$ & 51601 & $S$ & 39173 & 54555 IR \\
\hline $3.00 \mathrm{~N} 28.00 \mathrm{E}$ & 88 & 46 & G & 11182 & G & 10292 & 64441 IR \\
\hline $3.00 \mathrm{~N} 28.00 \mathrm{E}$ & 88 & 44 & $\mathrm{~S}$ & 51601 & $S$ & 39173 & 54555 IR \\
\hline 3.00N28.00E & 88 & 0 & $S$ & 74318 & $S$ & 51665 & 0 IS \\
\hline $3.00 \mathrm{~N} 28.00 \mathrm{E}$ & 88 & 46 & $S$ & 68587 & $S$ & 51126 & 0 IS \\
\hline $3.00 \mathrm{~N} 28.00 \mathrm{E}$ & 89 & 0 & $S$ & 74318 & $S$ & 51665 & 0 IS \\
\hline $3.00 \mathrm{~N} 28.00 \mathrm{E}$ & 89 & 46 & $S$ & 68587 & $S$ & 51126 & 0 IS \\
\hline $3.00 \mathrm{~N} 28.00 \mathrm{E}$ & 89 & 46 & $\mathrm{G}$ & 11182 & G & 10292 & 64441 IR \\
\hline $3.00 \mathrm{~N} 28.00 \mathrm{E}$ & 89 & 44 & $S$ & 51601 & $\mathrm{~S}$ & 39173 & 54555 IR \\
\hline $3.00 \mathrm{~N} 28.00 \mathrm{E}$ & 90 & 44 & $S$ & 51601 & $\mathrm{~S}$ & 39173 & 54555 IR \\
\hline $3.00 \mathrm{~N} 28.00 \mathrm{E}$ & 90 & 46 & $G$ & 11182 & G & 10292 & 64441 IR \\
\hline $3.00 \mathrm{~N} 28.00 \mathrm{E}$ & 90 & 0 & $S$ & 74318 & $S$ & 51665 & 0 IS \\
\hline $3.00 \mathrm{~N} 28.00 \mathrm{E}$ & 90 & 46 & $S$ & 68587 & $S$ & 51126 & 0 IS \\
\hline $3.00 \mathrm{~N} 28.00 \mathrm{E}$ & 91 & 0 & $S$ & 74318 & $S$ & 51665 & 0 IS \\
\hline $3.00 \mathrm{~N} 28.00 \mathrm{E}$ & 91 & 46 & $\mathrm{G}$ & 11182 & G & 10292 & 64441 IS \\
\hline $3.00 \mathrm{~N} 28.00 \mathrm{E}$ & 91 & 44 & $S$ & 51601 & $\mathrm{~S}$ & 39173 & 54555 IR \\
\hline $3.00 \mathrm{~N} 28.00 \mathrm{E}$ & 91 & 47 & $G$ & 11182 & G & 10292 & 64441 IS \\
\hline 3.00N28.00E & 92 & 44 & $S$ & 51601 & $S$ & 39173 & 54555 IR \\
\hline $3.00 \mathrm{~N} 28.00 \mathrm{E}$ & 92 & 46 & $G$ & 11182 & G & 10292 & 64441 IS \\
\hline $3.00 \mathrm{~N} 28.00 \mathrm{E}$ & 92 & 47 & G & 11182 & G & 10292 & 64441 IS \\
\hline $3.00 \mathrm{~N} 28.00 \mathrm{E}$ & 92 & 0 & $\mathrm{~S}$ & 74318 & $\mathrm{~S}$ & 51665 & 0 IS \\
\hline $3.00 \mathrm{~N} 28.00 \mathrm{E}$ & 93 & 0 & $\mathrm{~S}$ & 74318 & $S$ & 51665 & 0 IS \\
\hline $3.00 \mathrm{~N} 28.00 \mathrm{E}$ & 93 & 44 & $S$ & 51601 & $\mathrm{~S}$ & 39173 & 54555 IR \\
\hline $3.00 \mathrm{~N} 28.00 \mathrm{E}$ & 93 & 51 & G & 6677 & G & 6229 & 54557 IS \\
\hline $3.00 \mathrm{~N} 28.00 \mathrm{E}$ & 94 & 51 & $G$ & 11444 & G & 11148 & 0 IR \\
\hline $3.00 \mathrm{~N} 28.00 \mathrm{E}$ & 94 & 46 & G & 11444 & G & 11148 & 0 IR \\
\hline $3.00 \mathrm{~N} 28.00 \mathrm{E}$ & 94 & 46 & $\mathrm{~S}$ & 68587 & $\mathrm{~S}$ & 51126 & 0 IS \\
\hline 3.00N28.00E & 95 & 51 & G & 11444 & G & 11148 & $0 \mathrm{IR}$ \\
\hline $3.00 \mathrm{~N} 28.00 \mathrm{E}$ & 95 & 46 & $S$ & 68587 & $\mathrm{~S}$ & 51126 & 0 IS \\
\hline $3.00 \mathrm{~N} 28.00 \mathrm{E}$ & 95 & 46 & $G$ & 11444 & G & 11148 & 0 IR \\
\hline $3.00 \mathrm{~N} 28.00 \mathrm{E}$ & 96 & 49 & $G$ & 6429 & G & 6038 & 53736 IR \\
\hline $3.00 \mathrm{~N} 28.00 \mathrm{E}$ & 96 & 48 & $G$ & 6429 & G & 6038 & 53736 IR \\
\hline $3.00 \mathrm{~N} 28.00 \mathrm{E}$ & 97 & 48 & G & 6429 & G & 6038 & 53736 IR \\
\hline $3.00 \mathrm{~N} 28.00 \mathrm{E}$ & 97 & 49 & G & 6429 & $\mathrm{G}$ & 6038 & 53736 IR \\
\hline $3.00 \mathrm{~N} 28.00 \mathrm{E}$ & 98 & 48 & G & 6429 & G & 6038 & 53736 IR \\
\hline $3.00 \mathrm{~N} 28.00 \mathrm{E}$ & 98 & 49 & $G$ & 6429 & G & 6038 & 53736 IR \\
\hline $3.00 \mathrm{~N} 28.00 \mathrm{E}$ & 99 & 49 & G & 6429 & $\mathrm{G}$ & 6038 & 53736 IR \\
\hline
\end{tabular}


PLACE OF USE REPORT $3 \mathrm{~N} \quad 29 \mathrm{E}$

TWP/RNG POU-ID PO D-ID APP LICATION P ERMIT CERT \# USE

\begin{tabular}{|c|c|c|c|c|c|c|c|}
\hline $3.00 \mathrm{~N} 28.00 \mathrm{E}$ & 99 & 48 & G & 6429 & G & 6038 & 53736 IR \\
\hline $3.00 \mathrm{~N} 28.00 \mathrm{E}$ & 100 & 48 & G & 6429 & G & 6038 & 53736 IR \\
\hline $3.00 \mathrm{~N} 28.00 \mathrm{E}$ & 100 & 49 & G & 6429 & G & 6038 & 53736 IR \\
\hline 3.00N28.00E & 101 & 48 & G & 6429 & G & 6038 & 53736 IS \\
\hline 3.00N28.00E & 101 & 49 & G & 6429 & G & 6038 & 53736 IS \\
\hline $3.00 \mathrm{~N} 28.00 \mathrm{E}$ & 102 & 48 & G & 6429 & G & 6038 & 53736 IS \\
\hline 3.00N28.00E & 102 & 49 & G & 6429 & G & 6038 & 53736 IS \\
\hline $3.00 \mathrm{~N} 28.00 \mathrm{E}$ & 103 & 49 & $G$ & 6429 & $G$ & 6038 & 53736 IS \\
\hline 3.00N28.00E & 103 & 48 & G & 6429 & G & 6038 & 53736 IS \\
\hline 3.00N28.00E & 104 & 49 & G & 6429 & G & 6038 & 53736 IS \\
\hline 3.00N28.00E & 104 & 48 & G & 6429 & G & 6038 & 53736 IS \\
\hline 3.00N28.00E & 105 & 49 & G & 6429 & G & 6038 & 53736 IS \\
\hline 3.00N28.00E & 105 & 48 & G & 6429 & G & 6038 & 53736 IS \\
\hline $3.00 \mathrm{~N} 28.00 \mathrm{E}$ & 106 & 49 & $\mathrm{G}$ & 6429 & G & 6038 & 53736 IS \\
\hline 3.00N28.00E & 106 & 48 & G & 6429 & G & 6038 & 53736 IS \\
\hline $3.00 \mathrm{~N} 28.00 \mathrm{E}$ & 106 & 44 & $\mathrm{~T}$ & 5494 & D & 1443732 & 0 IS \\
\hline 3.00N28.00E & 107 & 50 & G & 8015 & G & 8470 & 53746 IR \\
\hline $3.00 \mathrm{~N} 28.00 \mathrm{E}$ & 108 & 50 & G & 8015 & G & 8470 & 53746 IR \\
\hline $3.00 \mathrm{~N} 28.00 \mathrm{E}$ & 109 & 50 & G & 8015 & G & 8470 & 53746 IR \\
\hline $3.00 \mathrm{~N} 28.00 \mathrm{E}$ & 110 & 50 & G & 8015 & G & 8470 & 53746 IR \\
\hline 3.00N28.00E & 111 & 50 & G & 8015 & G & 8470 & 53746 IR \\
\hline $3.00 \mathrm{~N} 28.00 \mathrm{E}$ & 111 & 44 & $\mathrm{~T}$ & 3621 & $D$ & 1443732 & 0 IS \\
\hline 3.00N28.00E & 112 & 50 & G & 8015 & G & 8470 & 53746 IR \\
\hline 3.00N28.00E & 112 & 44 & S & 65131 & $S$ & 47820 & 53734 IR \\
\hline $3.00 \mathrm{~N} 28.00 \mathrm{E}$ & 113 & 50 & G & 8015 & G & 8470 & 53746 IR \\
\hline 3.00N28.00E & 114 & 53 & S & 38765 & $S$ & 28936 & 36920 IS \\
\hline $3.00 \mathrm{~N} 28.00 \mathrm{E}$ & 114 & 53 & S & 38765 & $S$ & 28936 & 36920 IS \\
\hline 3.00N28.00E & 115 & 53 & $S$ & 38765 & $S$ & 28936 & 36920 IS \\
\hline 3.00N28.00E & 117 & 53 & S & 38765 & $S$ & 28936 & 36920 IS \\
\hline 3.00N28.00E & 118 & 52 & S & 37613 & S & 28053 & 36919 IR \\
\hline $3.00 \mathrm{~N} 28.00 \mathrm{E}$ & 119 & 54 & $\mathrm{~T}$ & 6532 & $C \mathrm{G}$ & 6574 & 0 IR \\
\hline 3.00N28.00E & 119 & 55 & $\mathrm{~T}$ & 6532 & C G & 6574 & 0 IR \\
\hline $3.00 \mathrm{~N} 28.00 \mathrm{E}$ & 120 & 54 & $\mathrm{~T}$ & 6532 & C G & 6574 & 0 IR \\
\hline 3.00N28.00E & 120 & 55 & $\mathrm{~T}$ & 6532 & C G & 6574 & 0 IR \\
\hline 3.00N28.00E & 121 & 55 & $\mathrm{~T}$ & 6532 & C G & 6574 & 0 IR \\
\hline 3.00N28.00E & 121 & 54 & $\mathrm{~T}$ & 6532 & C G & 6574 & 0 IR \\
\hline $3.00 \mathrm{~N} 28.00 \mathrm{E}$ & 122 & 54 & $\mathrm{~T}$ & 6532 & $C G$ & 6574 & 0 IS \\
\hline $3.00 \mathrm{~N} 28.00 \mathrm{E}$ & 122 & 55 & $\mathrm{~T}$ & 6532 & C G & 6574 & 0 IS \\
\hline $3.00 \mathrm{~N} 28.00 \mathrm{E}$ & 123 & 55 & $\mathrm{~T}$ & 6532 & C G & 6574 & 0 IS \\
\hline $3.00 \mathrm{~N} 28.00 \mathrm{E}$ & 123 & 54 & $\mathrm{~T}$ & 6532 & C G & 6574 & 0 IS \\
\hline $3.00 \mathrm{~N} 28.00 \mathrm{E}$ & 124 & 55 & G & 12481 & G & 12438 & 0 IS \\
\hline 3.00N28.00E & 125 & 56 & G & 11077 & G & 10234 & 61114 IR \\
\hline 3.00N28.00E & 126 & 56 & G & 11077 & G & 10234 & 61114 IR \\
\hline $3.00 \mathrm{~N} 28.00 \mathrm{E}$ & 127 & 56 & G & 11077 & G & 10234 & 61114 IS \\
\hline 3.00N28.00E & 128 & 44 & S & 51645 & $\mathrm{~S}$ & 38943 & 53732 IR \\
\hline $3.00 \mathrm{~N} 28.00 \mathrm{E}$ & 129 & 44 & $S$ & 51645 & $S$ & 38943 & 53732 IR \\
\hline 3.00N28.00E & 130 & 44 & $S$ & 51645 & $S$ & 38943 & 53732 IR \\
\hline 3.00N28.00E & 136 & 44 & $\mathrm{~T}$ & 6091 & $S$ & 46568 & 0 IR \\
\hline 3.00N28.00E & 136 & 0 & S & 74318 & $S$ & 51665 & 0 IS \\
\hline $3.00 \mathrm{~N} 28.00 \mathrm{E}$ & 137 & 44 & $\mathrm{~T}$ & 6091 & $\mathrm{~S}$ & 46568 & 0 IR \\
\hline
\end{tabular}


PLACE OF USE REPORT $3 \mathrm{~N} \quad 29 \mathrm{E}$

TWP/RNG POU-ID PO D-ID APP LICATION P ERMIT CERT \# USE

\begin{tabular}{|c|c|c|c|c|c|c|c|}
\hline 3.00N28.00E & 137 & 0 & $S$ & 74318 & $S$ & 51665 & 0 IS \\
\hline 3.00N28.00E & 138 & 0 & $S$ & 74318 & $S$ & 51665 & 0 IS \\
\hline 3.00N28.00E & 138 & 44 & $\mathrm{~T}$ & 6091 & $S$ & 46568 & $0 \mathrm{IR}$ \\
\hline $3.00 \mathrm{~N} 28.00 \mathrm{E}$ & 172 & 68 & G & 4165 & G & 4048 & 36676 IR \\
\hline 3.00N28.00E & 172 & 0 & $\mathrm{~S}$ & 74318 & $S$ & 51665 & 0 IS \\
\hline $3.00 \mathrm{~N} 28.00 \mathrm{E}$ & 173 & 0 & $S$ & 74318 & $S$ & 51665 & 0 IS \\
\hline $3.00 \mathrm{~N} 28.00 \mathrm{E}$ & 173 & 70 & $\mathrm{G}$ & 6476 & G & 5275 & 61530 IR \\
\hline 3.00N28.00E & 173 & 71 & G & 6476 & G & 5275 & 61530 IR \\
\hline 3.00N28.00E & 173 & 72 & G & 6476 & G & 5275 & 61530 IR \\
\hline $3.00 \mathrm{~N} 28.00 \mathrm{E}$ & 173 & 69 & $G$ & 6476 & G & 5275 & 61530 IR \\
\hline $3.00 \mathrm{~N} 28.00 \mathrm{E}$ & 174 & 75 & G & 9205 & $G$ & 8570 & 51783 IS \\
\hline 3.00N28.00E & 174 & 74 & G & 9205 & G & 8570 & 51783 IS \\
\hline $3.00 \mathrm{~N} 28.00 \mathrm{E}$ & 174 & 73 & $G$ & 9205 & G & 8570 & 51783 IS \\
\hline $3.00 \mathrm{~N} 28.00 \mathrm{E}$ & 174 & 68 & G & 4165 & G & 4048 & 36676 IR \\
\hline 3.00N28.00E & 174 & 0 & $S$ & 74318 & $S$ & 51665 & 0 IS \\
\hline $3.00 \mathrm{~N} 28.00 \mathrm{E}$ & 175 & 0 & $\mathrm{~S}$ & 74318 & $S$ & 51665 & 0 IS \\
\hline 3.00N28.00E & 175 & 75 & $\mathrm{G}$ & 9205 & G & 8570 & 51783 IR \\
\hline 3.00N28.00E & 175 & 74 & G & 9205 & G & 8570 & 51783 IR \\
\hline $3.00 \mathrm{~N} 28.00 \mathrm{E}$ & 175 & 73 & G & 9205 & G & 8570 & 51783 IR \\
\hline $3.00 \mathrm{~N} 28.00 \mathrm{E}$ & 176 & 75 & G & 9205 & G & 8570 & 51783 IR \\
\hline $3.00 \mathrm{~N} 28.00 \mathrm{E}$ & 176 & 73 & $G$ & 9205 & G & 8570 & 51783 IR \\
\hline $3.00 \mathrm{~N} 28.00 \mathrm{E}$ & 176 & 74 & $G$ & 9205 & $G$ & 8570 & 51783 IR \\
\hline $3.00 \mathrm{~N} 28.00 \mathrm{E}$ & 176 & 0 & $S$ & 74318 & $S$ & 51665 & 0 IS \\
\hline $3.00 \mathrm{~N} 28.00 \mathrm{E}$ & 177 & 0 & $S$ & 74318 & $S$ & 51665 & 0 IS \\
\hline $3.00 \mathrm{~N} 28.00 \mathrm{E}$ & 177 & 75 & G & 9205 & G & 8570 & 51783 IR \\
\hline $3.00 \mathrm{~N} 28.00 \mathrm{E}$ & 177 & 73 & G & 9205 & G & 8570 & 51783 IR \\
\hline $3.00 \mathrm{~N} 28.00 \mathrm{E}$ & 177 & 74 & G & 9205 & G & 8570 & 51783 IR \\
\hline $3.00 \mathrm{~N} 28.00 \mathrm{E}$ & 178 & 74 & G & 9205 & G & 8570 & 51783 IS \\
\hline $3.00 \mathrm{~N} 28.00 \mathrm{E}$ & 178 & 73 & $G$ & 9205 & G & 8570 & 51783 IS \\
\hline $3.00 \mathrm{~N} 28.00 \mathrm{E}$ & 178 & 75 & G & 9205 & $G$ & 8570 & 51783 IS \\
\hline $3.00 \mathrm{~N} 28.00 \mathrm{E}$ & 178 & 0 & $S$ & 74318 & $S$ & 51665 & 0 IS \\
\hline 3.00N28.00E & 179 & 75 & G & 9205 & G & 8570 & 51783 IS \\
\hline $3.00 \mathrm{~N} 28.00 \mathrm{E}$ & 179 & 73 & G & 9205 & G & 8570 & 51783 IS \\
\hline $3.00 \mathrm{~N} 28.00 \mathrm{E}$ & 179 & 74 & $\mathrm{G}$ & 9205 & G & 8570 & 51783 IS \\
\hline $3.00 \mathrm{~N} 28.00 \mathrm{E}$ & 194 & 74 & $\mathrm{~T}$ & 6380 & $\mathrm{~S}$ & 6936 & 0 IR \\
\hline 3.00N28.00E & 228 & 80 & G & 5820 & G & 5812 & 51295 IR \\
\hline 3.00N28.00E & 229 & 80 & G & 5820 & G & 5812 & 51295 IR \\
\hline $3.00 \mathrm{~N} 28.00 \mathrm{E}$ & 316 & 0 & $S$ & 74318 & $S$ & 51665 & 0 IS \\
\hline 3.00N28.00E & 336 & 0 & $S$ & 74318 & $S$ & 51665 & 0 IS \\
\hline $3.00 \mathrm{~N} 28.00 \mathrm{E}$ & 344 & 0 & $\mathrm{~S}$ & 74318 & $S$ & 51665 & 0 IS \\
\hline $3.00 \mathrm{~N} 28.00 \mathrm{E}$ & 345 & 0 & $S$ & 74318 & $S$ & 51665 & 0 IS \\
\hline 3.00N28.00E & 350 & 0 & $S$ & 74318 & S & 51665 & 0 IS \\
\hline $3.00 \mathrm{~N} 28.00 \mathrm{E}$ & 351 & 0 & $S$ & 74318 & $S$ & 51665 & 0 IS \\
\hline $3.00 \mathrm{~N} 28.00 \mathrm{E}$ & 352 & 0 & $S$ & 74318 & $S$ & 51665 & 0 IS \\
\hline 3.00N28.00E & 353 & 0 & $S$ & 74318 & S & 51665 & 0 IS \\
\hline 3.00N28.00E & 355 & 0 & $S$ & 74318 & $S$ & 51665 & 0 IS \\
\hline 3.00N28.00E & 356 & 0 & $\mathrm{~S}$ & 74318 & S & 51665 & 0 IS \\
\hline $3.00 \mathrm{~N} 28.00 \mathrm{E}$ & 359 & 0 & $S$ & 74318 & $S$ & 51665 & 0 IS \\
\hline 3.00N29.00E & 1 & 1 & G & 9815 & G & 8907 & $0 \mathrm{IR}$ \\
\hline
\end{tabular}


PLACE OF USE REPORT $3 \mathrm{~N} \quad 29 \mathrm{E}$

TWP/RNG POU-ID PO D-ID APP LICATION P ERMIT CERT \# USE

\begin{tabular}{|c|c|c|c|c|c|c|c|}
\hline 3.00N29.00E & 2 & 3 & G & 9815 & G & 8907 & $0 \mathrm{IR}$ \\
\hline 3.00N29.00E & 2 & 4 & G & 9815 & G & 8907 & $0 \mathrm{IR}$ \\
\hline 3.00N29.00E & 2 & 2 & G & 9815 & G & 8907 & 0 IS \\
\hline $3.00 \mathrm{~N} 29.00 \mathrm{E}$ & 2 & 1 & G & 9815 & G & 8907 & 0 IS \\
\hline $3.00 \mathrm{~N} 29.00 \mathrm{E}$ & 2 & 2 & $G$ & 9815 & G & 8907 & $0 \mathrm{IR}$ \\
\hline $3.00 \mathrm{~N} 29.00 \mathrm{E}$ & 2 & 4 & $G$ & 9815 & G & 8907 & 0 IS \\
\hline 3.00N29.00E & 3 & 5 & G & 8772 & G & 8126 & 56282 IR \\
\hline 3.00N29.00E & 4 & 6 & $\mathrm{G}$ & 8772 & G & 8126 & 54118 IR \\
\hline 3.00N29.00E & 5 & 7 & $\mathrm{~T}$ & 5699 & D & 2583 & 55604 IR \\
\hline 3.00N29.00E & 6 & 12 & G & 2696 & G & 2501 & 35680 IS \\
\hline $3.00 \mathrm{~N} 29.00 \mathrm{E}$ & 7 & 13 & G & 5043 & $G$ & 4753 & 40931 IS \\
\hline $3.00 \mathrm{~N} 29.00 \mathrm{E}$ & 8 & 13 & G & 5043 & G & 4753 & 40931 IS \\
\hline 3.00N29.00E & 9 & 14 & G & 5712 & G & 5517 & 60417 IR \\
\hline $3.00 \mathrm{~N} 29.00 \mathrm{E}$ & 10 & 15 & G & 7142 & G & 6592 & 46100 IS \\
\hline 3.00N29.00E & 11 & 20 & G & 11032 & G & 10196 & 63718 IR \\
\hline 3.00N29.00E & 12 & 13 & G & 5043 & G & 4753 & 40931 IS \\
\hline $3.00 \mathrm{~N} 29.00 \mathrm{E}$ & 13 & 15 & G & 7142 & G & 6592 & 46100 IS \\
\hline 3.00N29.00E & 14 & 7 & $\mathrm{~T}$ & 5699 & $\mathrm{D}$ & 2583 & 55604 IR \\
\hline $3.00 \mathrm{~N} 29.00 \mathrm{E}$ & 14 & 65 & $\mathrm{~T}$ & 5699 & $\mathrm{D}$ & 2583 & 55603 IR \\
\hline 3.00N29.00E & 15 & 7 & $\mathrm{~T}$ & 5761 & $S$ & 36410 & 55605 IR \\
\hline $3.00 \mathrm{~N} 29.00 \mathrm{E}$ & 16 & 21 & $U$ & 471 & $U$ & 427 & 20814 IR \\
\hline $3.00 \mathrm{~N} 29.00 \mathrm{E}$ & 18 & 7 & $\mathrm{~T}$ & 5699 & $\mathrm{D}$ & 2583 & 55604 IR \\
\hline $3.00 \mathrm{~N} 29.00 \mathrm{E}$ & 18 & 7 & $\mathrm{~T}$ & 5761 & $\mathrm{~S}$ & 36410 & 55605 IR \\
\hline $3.00 \mathrm{~N} 29.00 \mathrm{E}$ & 19 & 23 & $\mathrm{~T}$ & 6139 & G & 1854 & 68764 IS \\
\hline $3.00 \mathrm{~N} 29.00 \mathrm{E}$ & 20 & 23 & $\mathrm{~T}$ & 6139 & $G$ & 4748 & 68765 IS \\
\hline $3.00 \mathrm{~N} 29.00 \mathrm{E}$ & 21 & 22 & $G$ & 42 & G & 44 & 26080 IS \\
\hline $3.00 \mathrm{~N} 29.00 \mathrm{E}$ & 22 & 25 & $G$ & 1890 & G & 1729 & 33486 IS \\
\hline 3.00N29.00E & 22 & 25 & $S$ & 34207 & $S$ & 26863 & 33487 IS \\
\hline 3.00N29.00E & 23 & 25 & $S$ & 34207 & $\mathrm{~S}$ & 26863 & 33487 IS \\
\hline $3.00 \mathrm{~N} 29.00 \mathrm{E}$ & 23 & 25 & $G$ & 1890 & G & 1729 & 33486 IS \\
\hline 3.00N29.00E & 24 & 25 & G & 1890 & G & 1729 & 33486 IS \\
\hline 3.00N29.00E & 24 & 25 & $S$ & 34207 & $\mathrm{~S}$ & 26863 & 33487 IS \\
\hline $3.00 \mathrm{~N} 29.00 \mathrm{E}$ & 25 & 26 & $\mathrm{~S}$ & 17617 & $S$ & 13306 & 14346 IR \\
\hline $3.00 \mathrm{~N} 29.00 \mathrm{E}$ & 26 & 28 & $\mathrm{~S}$ & 17617 & $S$ & 13306 & 14346 IS \\
\hline 3.00N29.00E & 26 & 27 & $\mathrm{~S}$ & 17617 & $S$ & 13306 & 14346 IS \\
\hline $3.00 \mathrm{~N} 29.00 \mathrm{E}$ & 27 & 27 & $S$ & 17617 & $\mathrm{~S}$ & 13306 & 14346 IS \\
\hline 3.00N29.00E & 27 & 28 & $\mathrm{~S}$ & 17617 & $\mathrm{~S}$ & 13306 & 14346 IS \\
\hline $3.00 \mathrm{~N} 29.00 \mathrm{E}$ & 29 & 29 & $G$ & 2141 & G & 1977 & 36801 IR \\
\hline 3.00N29.00E & 30 & 30 & G & 6153 & G & 6097 & 49556 IR \\
\hline 3.00N29.00E & 31 & 30 & $G$ & 6153 & G & 6097 & 49556 IS \\
\hline $3.00 \mathrm{~N} 29.00 \mathrm{E}$ & 32 & 31 & G & 12416 & G & 12132 & 0 IR \\
\hline $3.00 \mathrm{~N} 29.00 \mathrm{E}$ & 33 & 32 & $\mathrm{D}$ & 0 & $\mathrm{D}$ & 2491 & $53515 \mathrm{I}^{*}$ \\
\hline $3.00 \mathrm{~N} 29.00 \mathrm{E}$ & 34 & 32 & $\mathrm{D}$ & 0 & $\mathrm{D}$ & 2491 & $53515 I^{*}$ \\
\hline 3.00N29.00E & 35 & 32 & $\mathrm{D}$ & 0 & $\mathrm{D}$ & 2491 & $53515 I^{*}$ \\
\hline 3.00N29.00E & 36 & 33 & $G$ & 6681 & G & 6233 & 0 IR \\
\hline 3.00N29.00E & 37 & 33 & G & 6681 & G & 6233 & $0 \mathrm{IR}$ \\
\hline $3.00 \mathrm{~N} 29.00 \mathrm{E}$ & 38 & 33 & G & 6681 & $\mathrm{G}$ & 6233 & $0 \mathrm{IS}$ \\
\hline 3.00N29.00E & 39 & 33 & G & 6681 & G & 6233 & 0 IS \\
\hline $3.00 \mathrm{~N} 29.00 \mathrm{E}$ & 40 & 33 & $G$ & 6681 & G & 6233 & 0 IS \\
\hline 3.00N29.00E & 41 & 34 & $\mathrm{G}$ & 11350 & $\mathrm{G}$ & 10538 & $0 \mathrm{IM}$ \\
\hline
\end{tabular}


PLACE OF USE REPORT $3 \mathrm{~N} \quad 29 \mathrm{E}$

TWP/RNG POU-ID PO D-ID APP LICATION P ERMIT CERT \# USE

\begin{tabular}{|c|c|c|c|c|c|c|c|}
\hline $3.00 \mathrm{~N} 29.00 \mathrm{E}$ & 42 & 32 & D & 0 & D & 2535 & $2535 I^{*}$ \\
\hline 3.00N29.00E & 43 & 32 & $\mathrm{D}$ & 0 & $\mathrm{D}$ & 2577 & $2577 I^{*}$ \\
\hline 3.00N29.00E & 44 & 40 & $S$ & 74318 & $\mathrm{~S}$ & 51665 & 0 IS \\
\hline 3.00N29.00E & 44 & 41 & G & 7311 & G & 7078 & 61534 IR \\
\hline $3.00 \mathrm{~N} 29.00 \mathrm{E}$ & 44 & 37 & G & 7125 & G & 6339 & 60019 IR \\
\hline $3.00 \mathrm{~N} 29.00 \mathrm{E}$ & 44 & 42 & G & 7311 & G & 7078 & 61534 IR \\
\hline 3.00N29.00E & 44 & 36 & G & 7125 & G & 6339 & 60019 IR \\
\hline $3.00 \mathrm{~N} 29.00 \mathrm{E}$ & 45 & 37 & $G$ & 7125 & G & 6339 & 60019 IR \\
\hline $3.00 \mathrm{~N} 29.00 \mathrm{E}$ & 45 & 36 & G & 7125 & G & 6339 & 60019 IR \\
\hline 3.00N29.00E & 45 & 40 & $S$ & 74318 & $S$ & 51665 & 0 IS \\
\hline $3.00 \mathrm{~N} 29.00 \mathrm{E}$ & 46 & 38 & $S$ & 31110 & $S$ & 24516 & 26178 IS \\
\hline 3.00N29.00E & 47 & 39 & $S$ & 51943 & $S$ & 37406 & 45000 IR \\
\hline $3.00 \mathrm{~N} 29.00 \mathrm{E}$ & 60 & 48 & $S$ & 47928 & S & 35811 & 54758 IR \\
\hline $3.00 \mathrm{~N} 29.00 \mathrm{E}$ & 61 & 47 & G & 11457 & G & 10664 & 61115 IS \\
\hline $3.00 \mathrm{~N} 29.00 \mathrm{E}$ & 61 & 48 & $S$ & 61736 & $\mathrm{~S}$ & 47673 & 61116 IR \\
\hline 3.00N29.00E & 61 & 40 & $S$ & 74318 & $S$ & 51665 & 0 IS \\
\hline 3.00N29.00E & 62 & 40 & $S$ & 74318 & $S$ & 51665 & 0 IS \\
\hline $3.00 \mathrm{~N} 29.00 \mathrm{E}$ & 62 & 42 & G & 7311 & $G$ & 7078 & 61534 IR \\
\hline $3.00 \mathrm{~N} 29.00 \mathrm{E}$ & 62 & 41 & $G$ & 7311 & G & 7078 & 61534 IR \\
\hline $3.00 \mathrm{~N} 29.00 \mathrm{E}$ & 68 & 41 & G & 7311 & G & 7078 & 61534 IR \\
\hline $3.00 \mathrm{~N} 29.00 \mathrm{E}$ & 68 & 42 & $G$ & 7311 & G & 7078 & 61534 IR \\
\hline $3.00 \mathrm{~N} 29.00 \mathrm{E}$ & 68 & 40 & $S$ & 74318 & $\mathrm{~S}$ & 51665 & 0 IS \\
\hline 3.00N29.00E & 73 & 40 & $S$ & 74318 & $S$ & 51665 & 0 IS \\
\hline $3.00 \mathrm{~N} 29.00 \mathrm{E}$ & 73 & 42 & $G$ & 7311 & G & 7078 & 61534 IR \\
\hline $3.00 \mathrm{~N} 29.00 \mathrm{E}$ & 73 & 41 & G & 7311 & $G$ & 7078 & 61534 IR \\
\hline $3.00 \mathrm{~N} 29.00 \mathrm{E}$ & 79 & 57 & $S$ & 38804 & $\mathrm{~S}$ & 30114 & 36679 IR \\
\hline $3.00 \mathrm{~N} 29.00 \mathrm{E}$ & 80 & 42 & $G$ & 7311 & G & 7078 & 61534 IR \\
\hline $3.00 \mathrm{~N} 29.00 \mathrm{E}$ & 80 & 41 & G & 7311 & G & 7078 & 61534 IR \\
\hline $3.00 \mathrm{~N} 29.00 \mathrm{E}$ & 80 & 40 & $S$ & 74318 & $\mathrm{~S}$ & 51665 & 0 IS \\
\hline $3.00 \mathrm{~N} 29.00 \mathrm{E}$ & 81 & 53 & $\mathrm{D}$ & 0 & D & 2507 & $2507 \mathrm{I}^{*}$ \\
\hline 3.00N29.00E & 82 & 40 & $S$ & 74318 & $\mathrm{~S}$ & 51665 & 0 IS \\
\hline $3.00 \mathrm{~N} 29.00 \mathrm{E}$ & 82 & 42 & $G$ & 7311 & G & 7078 & 61534 IR \\
\hline 3.00N29.00E & 82 & 41 & G & 7311 & G & 7078 & 61534 IR \\
\hline $3.00 \mathrm{~N} 29.00 \mathrm{E}$ & 82 & 47 & G & 11457 & G & 10664 & 61115 IS \\
\hline $3.00 \mathrm{~N} 29.00 \mathrm{E}$ & 83 & 43 & $G$ & 6673 & G & 6010 & 61531 IR \\
\hline 3.00N29.00E & 83 & 40 & $S$ & 74318 & $\mathrm{~S}$ & 51665 & 0 IS \\
\hline 3.00N29.00E & 84 & 40 & $\mathrm{~S}$ & 74318 & $\mathrm{~S}$ & 51665 & 0 IS \\
\hline $3.00 \mathrm{~N} 29.00 \mathrm{E}$ & 84 & 44 & $G$ & 7923 & G & 7314 & 61535 IR \\
\hline $3.00 \mathrm{~N} 29.00 \mathrm{E}$ & 86 & 40 & $S$ & 74318 & $S$ & 51665 & 0 IS \\
\hline $3.00 \mathrm{~N} 29.00 \mathrm{E}$ & 87 & 40 & $\mathrm{~S}$ & 74318 & $\mathrm{~S}$ & 51665 & 0 IS \\
\hline 3.00N29.00E & 87 & 47 & G & 11457 & G & 10664 & 61115 IS \\
\hline 3.00N29.00E & 88 & 47 & G & 11457 & G & 10664 & 61115 IS \\
\hline $3.00 \mathrm{~N} 29.00 \mathrm{E}$ & 88 & 40 & $S$ & 74318 & $\mathrm{~S}$ & 51665 & 0 IS \\
\hline $3.00 \mathrm{~N} 29.00 \mathrm{E}$ & 89 & 40 & $S$ & 74318 & $S$ & 51665 & 0 IS \\
\hline $3.00 \mathrm{~N} 29.00 \mathrm{E}$ & 90 & 49 & $G$ & 7031 & G & 6095 & 61533 IR \\
\hline 3.00N29.00E & 90 & 50 & G & 7031 & G & 6095 & 61533 IR \\
\hline 3.00N29.00E & 91 & 49 & G & 7031 & G & 6095 & 61533 IR \\
\hline $3.00 \mathrm{~N} 29.00 \mathrm{E}$ & 91 & 50 & $G$ & 7031 & G & 6095 & 61533 IR \\
\hline $3.00 \mathrm{~N} 29.00 \mathrm{E}$ & 92 & 64 & $G$ & 7728 & G & 7367 & 50380 IR \\
\hline 3.00N29.00E & 96 & 51 & $\mathrm{G}$ & 6475 & $\mathrm{G}$ & 6099 & 51826 IR \\
\hline
\end{tabular}


PLACE OF USE REPORT $3 \mathrm{~N} \quad 29 \mathrm{E}$

TWP/RNG POU-ID PO D-ID APP LICATION P ERMIT CERT \# USE

\begin{tabular}{|c|c|c|c|c|c|c|c|}
\hline $3.00 \mathrm{~N} 29.00 \mathrm{E}$ & 96 & 52 & G & 6475 & G & 6099 & 51826 IR \\
\hline $3.00 \mathrm{~N} 29.00 \mathrm{E}$ & 96 & 40 & $S$ & 74318 & $S$ & 51665 & 0 IS \\
\hline $3.00 \mathrm{~N} 29.00 \mathrm{E}$ & 97 & 53 & D & 0 & $\mathrm{D}$ & 2507 & $2507 I^{*}$ \\
\hline $3.00 \mathrm{~N} 29.00 \mathrm{E}$ & 98 & 53 & D & 0 & D & 2507 & $2507 I^{*}$ \\
\hline $3.00 \mathrm{~N} 29.00 \mathrm{E}$ & 100 & 54 & G & 8976 & G & 8369 & 53082 IR \\
\hline $3.00 \mathrm{~N} 29.00 \mathrm{E}$ & 100 & 55 & G & 8976 & G & 8369 & 53082 IR \\
\hline $3.00 \mathrm{~N} 29.00 \mathrm{E}$ & 102 & 32 & $\mathrm{~S}$ & 9349 & $\mathrm{~S}$ & 6179 & 7536 IR \\
\hline $3.00 \mathrm{~N} 29.00 \mathrm{E}$ & 103 & 32 & $S$ & 9349 & $S$ & 6179 & 7536 IR \\
\hline $3.00 \mathrm{~N} 29.00 \mathrm{E}$ & 106 & 56 & $S$ & 9365 & $S$ & 6183 & 7537 IR \\
\hline $3.00 \mathrm{~N} 29.00 \mathrm{E}$ & 107 & 56 & S & 9365 & $\mathrm{~S}$ & 6183 & 7537 IR \\
\hline $3.00 \mathrm{~N} 29.00 \mathrm{E}$ & 108 & 58 & S & 53887 & $S$ & 40208 & 53072 IS \\
\hline $3.00 \mathrm{~N} 29.00 \mathrm{E}$ & 109 & 58 & $S$ & 53887 & $S$ & 40208 & 53072 IS \\
\hline $3.00 \mathrm{~N} 29.00 \mathrm{E}$ & 109 & 53 & D & 0 & D & 2507 & $2507 I^{*}$ \\
\hline $3.00 \mathrm{~N} 29.00 \mathrm{E}$ & 110 & 58 & $S$ & 53887 & $\mathrm{~S}$ & 40208 & 53072 IS \\
\hline 3.00N29.00E & 111 & 59 & $S$ & 8883 & $S$ & 5819 & 5157 IR \\
\hline $3.00 \mathrm{~N} 29.00 \mathrm{E}$ & 112 & 59 & S & 8883 & $\mathrm{~S}$ & 5819 & 5157 IR \\
\hline 3.00N29.00E & 113 & 39 & S & 9350 & $S$ & 6180 & 5169 IR \\
\hline 3.00N29.00E & 114 & 39 & $S$ & 9350 & $S$ & 6180 & 5169 IR \\
\hline $3.00 \mathrm{~N} 29.00 \mathrm{E}$ & 115 & 39 & $S$ & 45823 & $S$ & 34194 & 40949 IR \\
\hline $3.00 \mathrm{~N} 29.00 \mathrm{E}$ & 116 & 61 & G & 7606 & G & 7041 & 53078 IR \\
\hline 3.00N29.00E & 117 & 62 & G & 7195 & G & 6626 & 49733 IR \\
\hline $3.00 \mathrm{~N} 29.00 \mathrm{E}$ & 117 & 63 & G & 7195 & G & 6626 & 49733 IR \\
\hline $3.00 \mathrm{~N} 29.00 \mathrm{E}$ & 118 & 7 & $\mathrm{~T}$ & 5699 & D & 2583 & 55604 IR \\
\hline 3.00N29.00E & 118 & 7 & $\mathrm{~T}$ & 5761 & $\mathrm{~S}$ & 36410 & 55605 IR \\
\hline $3.00 \mathrm{~N} 29.00 \mathrm{E}$ & 119 & 22 & $\mathrm{~T}$ & 6139 & $G$ & 4748 & 63675 IS \\
\hline 3.00N29.00E & 120 & 22 & $\mathrm{~T}$ & 6139 & G & 4748 & 63675 IS \\
\hline 3.00N29.00E & 121 & 40 & $S$ & 74318 & $S$ & 51665 & 0 IS \\
\hline $3.00 \mathrm{~N} 29.00 \mathrm{E}$ & 1012 & 13 & G & 5043 & G & 4753 & 40931 IR \\
\hline 3.00N29.00E & 1072 & 13 & G & 5043 & G & 4753 & 40931 IR \\
\hline 3.00N29.00E & 1073 & 24 & $S$ & 38681 & $\mathrm{~S}$ & 29198 & 35174 IR \\
\hline $3.00 \mathrm{~N} 29.00 \mathrm{E}$ & 1074 & 24 & $S$ & 38681 & $\mathrm{~S}$ & 29198 & 35174 IR \\
\hline 3.00N29.00E & 1076 & 13 & G & 5043 & G & 4753 & 40931 IR \\
\hline $3.00 \mathrm{~N} 29.00 \mathrm{E}$ & 1077 & 13 & G & 5043 & G & 4753 & 40931 IS \\
\hline 3.00N29.00E & 1078 & 13 & G & 5043 & G & 4753 & 40931 IS \\
\hline 3.00N29.00E & 1079 & 13 & G & 5043 & G & 4753 & 40931 IR \\
\hline $3.00 \mathrm{~N} 30.00 \mathrm{E}$ & 28 & 7 & G & 8910 & G & 8367 & 53188 IR \\
\hline $3.00 \mathrm{~N} 30.00 \mathrm{E}$ & 28 & 8 & G & 8910 & G & 8367 & 53188 IR \\
\hline $3.00 \mathrm{~N} 30.00 \mathrm{E}$ & 29 & 7 & G & 8910 & G & 8367 & 53188 IR \\
\hline $3.00 \mathrm{~N} 30.00 \mathrm{E}$ & 29 & 8 & G & 8910 & G & 8367 & 53188 IR \\
\hline $3.00 \mathrm{~N} 30.00 \mathrm{E}$ & 38 & 7 & G & 7153 & G & 6600 & 53178 IR \\
\hline 3.00N30.00E & 38 & 8 & G & 7153 & G & 6600 & 53178 IR \\
\hline $3.00 \mathrm{~N} 30.00 \mathrm{E}$ & 42 & 7 & G & 8910 & G & 8367 & 53188 IR \\
\hline $3.00 \mathrm{~N} 30.00 \mathrm{E}$ & 42 & 8 & G & 8910 & G & 8367 & 53188 IR \\
\hline $3.00 \mathrm{~N} 30.00 \mathrm{E}$ & 43 & 8 & G & 8910 & G & 8367 & 53188 IR \\
\hline 3.00N30.00E & 43 & 7 & G & 8910 & G & 8367 & 53188 IR \\
\hline 3.00N30.00E & 44 & 8 & G & 8910 & G & 8367 & 53188 IR \\
\hline 3.00N30.00E & 44 & 7 & G & 8910 & G & 8367 & 53188 IR \\
\hline 3.00N30.00E & 45 & 8 & G & 7153 & G & 6600 & 53178 IR \\
\hline 3.00N30.00E & 45 & 7 & G & 7153 & G & 6600 & 53178 IR \\
\hline
\end{tabular}




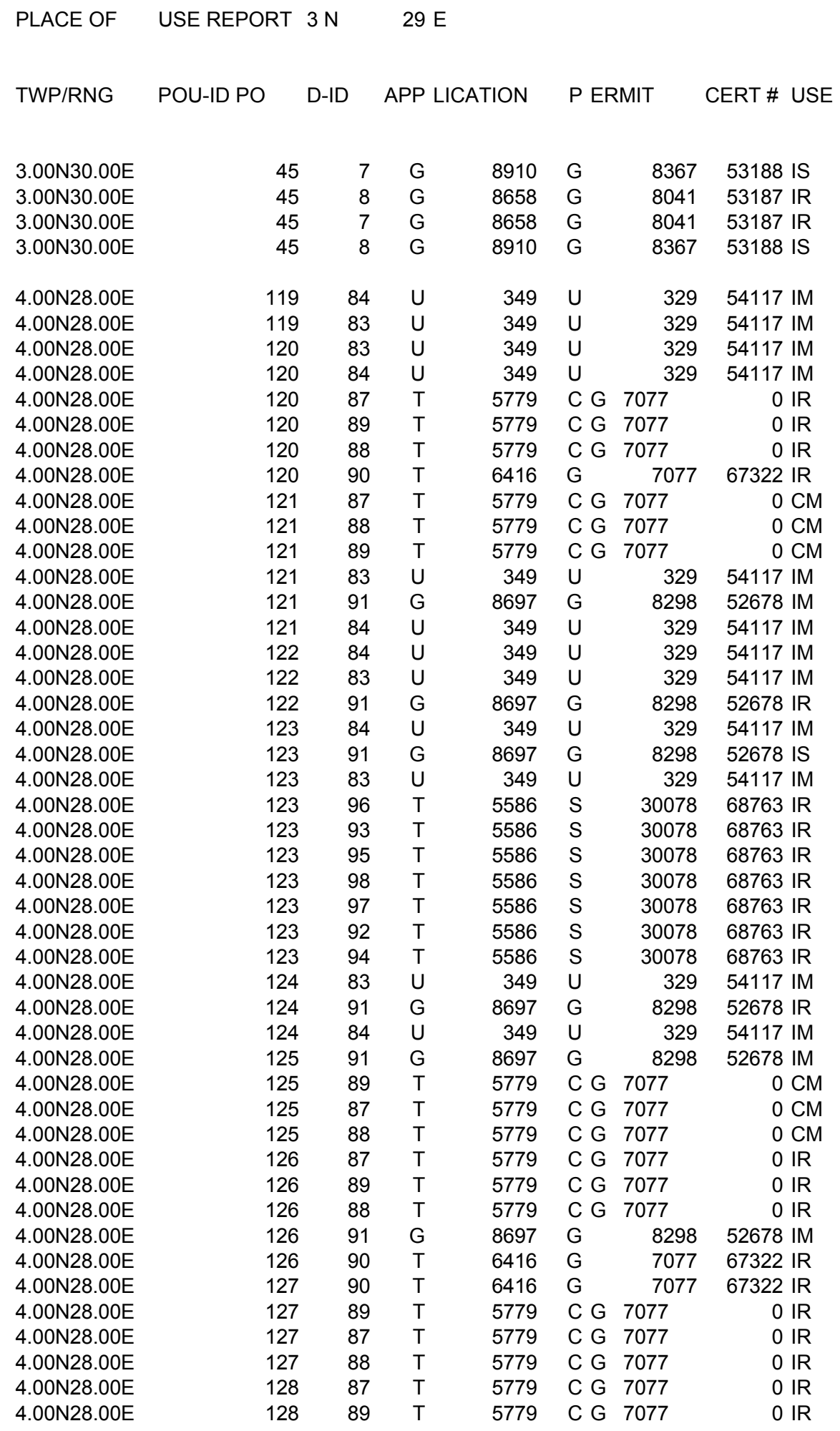


PLACE OF USE REPORT $3 \mathrm{~N} \quad 29 \mathrm{E}$

TWP/RNG POU-ID PO D-ID APP LICATION P ERMIT CERT \# USE

\begin{tabular}{|c|c|c|c|c|c|c|c|}
\hline $4.00 \mathrm{~N} 28.00 \mathrm{E}$ & 128 & 88 & $\mathrm{~T}$ & 5779 & C G & 7077 & 0 IR \\
\hline 4.00N28.00E & 128 & 90 & $\mathrm{~T}$ & 6416 & $\mathrm{G}$ & 7077 & 67322 IR \\
\hline 4.00N28.00E & 128 & 91 & G & 8697 & G & 8298 & 52678 IS \\
\hline $4.00 \mathrm{~N} 28.00 \mathrm{E}$ & 129 & 91 & G & 8697 & G & 8298 & 52678 IS \\
\hline $4.00 \mathrm{~N} 28.00 \mathrm{E}$ & 129 & 90 & $\mathrm{~T}$ & 6416 & G & 7077 & 67322 IR \\
\hline $4.00 \mathrm{~N} 28.00 \mathrm{E}$ & 129 & 89 & $\mathrm{~T}$ & 5779 & C G & 7077 & 0 IR \\
\hline $4.00 \mathrm{~N} 28.00 \mathrm{E}$ & 129 & 87 & $\mathrm{~T}$ & 5779 & C G & 7077 & 0 IR \\
\hline $4.00 \mathrm{~N} 28.00 \mathrm{E}$ & 129 & 88 & $\mathrm{~T}$ & 5779 & $C G$ & 7077 & 0 IR \\
\hline $4.00 \mathrm{~N} 28.00 \mathrm{E}$ & 130 & 87 & $\mathrm{~T}$ & 5779 & C G & 7077 & 0 IR \\
\hline $4.00 \mathrm{~N} 28.00 \mathrm{E}$ & 130 & 89 & $\mathrm{~T}$ & 5779 & C G & 7077 & $0 \mathrm{IR}$ \\
\hline $4.00 \mathrm{~N} 28.00 \mathrm{E}$ & 130 & 88 & $\mathrm{~T}$ & 5779 & C G & 7077 & $0 \mathrm{IR}$ \\
\hline $4.00 \mathrm{~N} 28.00 \mathrm{E}$ & 130 & 90 & $\mathrm{~T}$ & 6416 & $\mathrm{G}$ & 7077 & 67322 IR \\
\hline $4.00 \mathrm{~N} 28.00 \mathrm{E}$ & 131 & 90 & $\mathrm{~T}$ & 6416 & G & 7077 & 67322 IR \\
\hline $4.00 \mathrm{~N} 28.00 \mathrm{E}$ & 131 & 87 & $\mathrm{~T}$ & 5779 & C G & 7077 & 0 IR \\
\hline $4.00 \mathrm{~N} 28.00 \mathrm{E}$ & 131 & 89 & $\mathrm{~T}$ & 5779 & C G & 7077 & $0 \mathrm{IR}$ \\
\hline $4.00 \mathrm{~N} 28.00 \mathrm{E}$ & 131 & 88 & $\mathrm{~T}$ & 5779 & $C G$ & 7077 & $0 \mathrm{IR}$ \\
\hline $4.00 \mathrm{~N} 28.00 \mathrm{E}$ & 132 & 87 & $\mathrm{~T}$ & 5779 & C G & 7077 & $0 \mathrm{IR}$ \\
\hline $4.00 \mathrm{~N} 28.00 \mathrm{E}$ & 132 & 88 & $\mathrm{~T}$ & 5779 & $C G$ & 7077 & $0 \mathrm{IR}$ \\
\hline $4.00 \mathrm{~N} 28.00 \mathrm{E}$ & 132 & 89 & $\mathrm{~T}$ & 5779 & C G & 7077 & 0 IR \\
\hline $4.00 \mathrm{~N} 28.00 \mathrm{E}$ & 132 & 90 & $\mathrm{~T}$ & 6416 & G & 7077 & 67322 IR \\
\hline $4.00 \mathrm{~N} 28.00 \mathrm{E}$ & 132 & 91 & G & 8697 & $\mathrm{G}$ & 8298 & 52678 IS \\
\hline $4.00 \mathrm{~N} 28.00 \mathrm{E}$ & 133 & 91 & G & 8697 & G & 8298 & 52678 IS \\
\hline $4.00 \mathrm{~N} 28.00 \mathrm{E}$ & 133 & 90 & $\mathrm{~T}$ & 6416 & G & 7077 & 67322 IR \\
\hline $4.00 \mathrm{~N} 28.00 \mathrm{E}$ & 133 & 88 & $\mathrm{~T}$ & 5779 & C G & 7077 & 0 IR \\
\hline $4.00 \mathrm{~N} 28.00 \mathrm{E}$ & 133 & 87 & $\mathrm{~T}$ & 5779 & C G & 7077 & 0 IR \\
\hline $4.00 \mathrm{~N} 28.00 \mathrm{E}$ & 133 & 89 & $\mathrm{~T}$ & 5779 & C G & 7077 & 0 IR \\
\hline $4.00 \mathrm{~N} 28.00 \mathrm{E}$ & 134 & 87 & $\mathrm{~T}$ & 5779 & C G & 7077 & 0 IR \\
\hline $4.00 \mathrm{~N} 28.00 \mathrm{E}$ & 134 & 89 & $\mathrm{~T}$ & 5779 & C G & 7077 & 0 IR \\
\hline $4.00 \mathrm{~N} 28.00 \mathrm{E}$ & 134 & 88 & $\mathrm{~T}$ & 5779 & C G & 7077 & 0 IR \\
\hline $4.00 \mathrm{~N} 28.00 \mathrm{E}$ & 134 & 90 & $\mathrm{~T}$ & 6416 & $\mathrm{G}$ & 7077 & 67322 IR \\
\hline 4.00N28.00E & 134 & 91 & G & 8697 & G & 8298 & 52678 IS \\
\hline $4.00 \mathrm{~N} 28.00 \mathrm{E}$ & 135 & 90 & $\mathrm{~T}$ & 6416 & $\mathrm{G}$ & 7077 & 67322 IR \\
\hline $4.00 \mathrm{~N} 28.00 \mathrm{E}$ & 135 & 89 & $\mathrm{~T}$ & 5779 & C G & 7077 & 0 IR \\
\hline $4.00 \mathrm{~N} 28.00 \mathrm{E}$ & 135 & 88 & $\mathrm{~T}$ & 5779 & $C G$ & 7077 & $0 \mathrm{IR}$ \\
\hline $4.00 \mathrm{~N} 28.00 \mathrm{E}$ & 135 & 87 & $\mathrm{~T}$ & 5779 & C G & 7077 & $0 \mathrm{IR}$ \\
\hline $4.00 \mathrm{~N} 28.00 \mathrm{E}$ & 136 & 87 & $\mathrm{~T}$ & 5779 & C G & 7077 & $0 \mathrm{IR}$ \\
\hline $4.00 \mathrm{~N} 28.00 \mathrm{E}$ & 136 & 89 & $\mathrm{~T}$ & 5779 & $C G$ & 7077 & 0 IR \\
\hline $4.00 \mathrm{~N} 28.00 \mathrm{E}$ & 136 & 88 & $\mathrm{~T}$ & 5779 & C G & 7077 & 0 IR \\
\hline $4.00 \mathrm{~N} 28.00 \mathrm{E}$ & 136 & 90 & $\mathrm{~T}$ & 6416 & $\mathrm{G}$ & 7077 & 67322 IR \\
\hline $4.00 \mathrm{~N} 28.00 \mathrm{E}$ & 136 & 91 & G & 8697 & G & 8298 & 52678 IS \\
\hline $4.00 \mathrm{~N} 28.00 \mathrm{E}$ & 137 & 90 & $\mathrm{~T}$ & 6416 & $\mathrm{G}$ & 7077 & 67322 IR \\
\hline $4.00 \mathrm{~N} 28.00 \mathrm{E}$ & 137 & 87 & $\mathrm{~T}$ & 5779 & C G & 7077 & 0 IR \\
\hline $4.00 \mathrm{~N} 28.00 \mathrm{E}$ & 137 & 88 & $\mathrm{~T}$ & 5779 & C G & 7077 & 0 IR \\
\hline $4.00 \mathrm{~N} 28.00 \mathrm{E}$ & 137 & 89 & $\mathrm{~T}$ & 5779 & C G & 7077 & 0 IR \\
\hline $4.00 \mathrm{~N} 28.00 \mathrm{E}$ & 138 & 89 & $\mathrm{~T}$ & 5779 & C G & 7077 & 0 IS \\
\hline $4.00 \mathrm{~N} 28.00 \mathrm{E}$ & 138 & 87 & $\mathrm{~T}$ & 5779 & C G & 7077 & 0 IS \\
\hline 4.00N28.00E & 138 & 88 & $\mathrm{~T}$ & 5779 & $C G$ & 7077 & 0 IS \\
\hline $4.00 \mathrm{~N} 28.00 \mathrm{E}$ & 138 & 90 & $\mathrm{~T}$ & 6416 & $\mathrm{G}$ & 7077 & 67322 IS \\
\hline $4.00 \mathrm{~N} 28.00 \mathrm{E}$ & 138 & 96 & $\mathrm{~T}$ & 5583 & $\mathrm{~S}$ & 37853 & 68760 IR \\
\hline 4.00N28.00E & 138 & 102 & $\mathrm{~T}$ & 5583 & $\mathrm{~S}$ & 37853 & 68760 IR \\
\hline
\end{tabular}




\begin{tabular}{|c|c|c|c|c|c|c|c|}
\hline $4.00 \mathrm{~N} 28.00 \mathrm{E}$ & 138 & 91 & $G$ & 8697 & G & 8298 & 52678 IS \\
\hline 4.00N28.00E & 141 & 96 & $\mathrm{~T}$ & 5583 & $S$ & 37853 & 68760 IR \\
\hline $4.00 \mathrm{~N} 28.00 \mathrm{E}$ & 141 & 90 & $\mathrm{~T}$ & 6416 & G & 7077 & 67322 IS \\
\hline $4.00 \mathrm{~N} 28.00 \mathrm{E}$ & 141 & 102 & $\mathrm{~T}$ & 5583 & $\mathrm{~S}$ & 37853 & 68760 IR \\
\hline $4.00 \mathrm{~N} 28.00 \mathrm{E}$ & 141 & 87 & $\mathrm{~T}$ & 5779 & $C G$ & 7077 & 0 IS \\
\hline $4.00 \mathrm{~N} 28.00 \mathrm{E}$ & 141 & 89 & $\mathrm{~T}$ & 5779 & $C G$ & 7077 & 0 IS \\
\hline $4.00 \mathrm{~N} 28.00 \mathrm{E}$ & 141 & 88 & $T$ & 5779 & $C G$ & 7077 & 0 IS \\
\hline $4.00 \mathrm{~N} 28.00 \mathrm{E}$ & 142 & 88 & $T$ & 5779 & C G & 7077 & 0 IS \\
\hline $4.00 \mathrm{~N} 28.00 \mathrm{E}$ & 142 & 89 & $\mathrm{~T}$ & 5779 & C G & 7077 & 0 IS \\
\hline $4.00 \mathrm{~N} 28.00 \mathrm{E}$ & 142 & 87 & $T$ & 5779 & $C G$ & 7077 & 0 IS \\
\hline $4.00 \mathrm{~N} 28.00 \mathrm{E}$ & 142 & 90 & $\mathrm{~T}$ & 6416 & $\mathrm{G}$ & 7077 & 67322 IS \\
\hline 4.00N28.00E & 142 & 96 & $\mathrm{~T}$ & 5583 & $S$ & 37853 & 68760 IR \\
\hline $4.00 \mathrm{~N} 28.00 \mathrm{E}$ & 142 & 102 & $\mathrm{~T}$ & 5583 & $\mathrm{~S}$ & 37853 & 68760 IR \\
\hline $4.00 \mathrm{~N} 28.00 \mathrm{E}$ & 142 & 91 & G & 8697 & G & 8298 & 52678 IS \\
\hline 4.00N28.00E & 143 & 90 & $\mathrm{~T}$ & 6416 & G & 7077 & 67322 IS \\
\hline $4.00 \mathrm{~N} 28.00 \mathrm{E}$ & 143 & 96 & $\mathrm{~T}$ & 5584 & $\mathrm{~S}$ & 32631 & 68761 IR \\
\hline $4.00 \mathrm{~N} 28.00 \mathrm{E}$ & 143 & 102 & $\mathrm{~T}$ & 5583 & $\mathrm{~S}$ & 37853 & 68760 IR \\
\hline $4.00 \mathrm{~N} 28.00 \mathrm{E}$ & 143 & 96 & $\mathrm{~T}$ & 5583 & $\mathrm{~S}$ & 37853 & 68760 IR \\
\hline 4.00N28.00E & 143 & 102 & $\mathrm{~T}$ & 5584 & $\mathrm{~S}$ & 32631 & 68761 IR \\
\hline $4.00 \mathrm{~N} 28.00 \mathrm{E}$ & 143 & 89 & $\mathrm{~T}$ & 5779 & $C G$ & 7077 & 0 IS \\
\hline $4.00 \mathrm{~N} 28.00 \mathrm{E}$ & 143 & 88 & $T$ & 5779 & $C G$ & 7077 & 0 IS \\
\hline $4.00 \mathrm{~N} 28.00 \mathrm{E}$ & 143 & 87 & $\mathrm{~T}$ & 5779 & C G & 7077 & 0 IS \\
\hline $4.00 \mathrm{~N} 28.00 \mathrm{E}$ & 144 & 89 & $\mathrm{~T}$ & 5779 & $C G$ & 7077 & 0 IS \\
\hline 4.00N28.00E & 144 & 87 & $T$ & 5779 & $C G$ & 7077 & 0 IS \\
\hline $4.00 \mathrm{~N} 28.00 \mathrm{E}$ & 144 & 88 & $\mathrm{~T}$ & 5779 & $C G$ & 7077 & 0 IS \\
\hline $4.00 \mathrm{~N} 28.00 \mathrm{E}$ & 144 & 90 & $\mathrm{~T}$ & 6416 & $\mathrm{G}$ & 7077 & 67322 IS \\
\hline 4.00N28.00E & 144 & 96 & $T$ & 5584 & $S$ & 32631 & 68761 IR \\
\hline $4.00 \mathrm{~N} 28.00 \mathrm{E}$ & 144 & 102 & $\mathrm{~T}$ & 5584 & $\mathrm{~S}$ & 32631 & 68761 IR \\
\hline $4.00 \mathrm{~N} 28.00 \mathrm{E}$ & 145 & 90 & $\mathrm{~T}$ & 6416 & G & 7077 & 67322 IS \\
\hline 4.00N28.00E & 145 & 102 & $\mathrm{~T}$ & 5584 & $S$ & 32631 & 68761 IR \\
\hline $4.00 \mathrm{~N} 28.00 \mathrm{E}$ & 145 & 96 & $\mathrm{~T}$ & 5584 & $\mathrm{~S}$ & 32631 & 68761 IR \\
\hline $4.00 \mathrm{~N} 28.00 \mathrm{E}$ & 145 & 87 & $\mathrm{~T}$ & 5779 & $C G$ & 7077 & 0 IS \\
\hline $4.00 \mathrm{~N} 28.00 \mathrm{E}$ & 145 & 89 & $\mathrm{~T}$ & 5779 & C G & 7077 & 0 IS \\
\hline $4.00 \mathrm{~N} 28.00 \mathrm{E}$ & 145 & 88 & $\mathrm{~T}$ & 5779 & C G & 7077 & 0 IS \\
\hline $4.00 \mathrm{~N} 28.00 \mathrm{E}$ & 145 & 91 & $G$ & 8697 & $\mathrm{G}$ & 8298 & 52678 IS \\
\hline $4.00 \mathrm{~N} 28.00 \mathrm{E}$ & 146 & 87 & $\mathrm{~T}$ & 5779 & $C G$ & 7077 & 0 IS \\
\hline $4.00 \mathrm{~N} 28.00 \mathrm{E}$ & 146 & 88 & $\mathrm{~T}$ & 5779 & $C G$ & 7077 & 0 IS \\
\hline 4.00N28.00E & 146 & 89 & $\mathrm{~T}$ & 5779 & $C G$ & 7077 & 0 IS \\
\hline 4.00N28.00E & 146 & 90 & $\mathrm{~T}$ & 6416 & $\mathrm{G}$ & 7077 & 67322 IS \\
\hline $4.00 \mathrm{~N} 28.00 \mathrm{E}$ & 146 & 102 & $\mathrm{~T}$ & 5584 & $\mathrm{~S}$ & 32631 & 68761 IR \\
\hline $4.00 \mathrm{~N} 28.00 \mathrm{E}$ & 146 & 96 & $\mathrm{~T}$ & 5584 & $S$ & 32631 & 68761 IR \\
\hline $4.00 \mathrm{~N} 28.00 \mathrm{E}$ & 147 & 90 & $\mathrm{~T}$ & 6416 & G & 7077 & 67322 IS \\
\hline $4.00 \mathrm{~N} 28.00 \mathrm{E}$ & 147 & 102 & $\mathrm{~T}$ & 5583 & $\mathrm{~S}$ & 37853 & 68760 IR \\
\hline $4.00 \mathrm{~N} 28.00 \mathrm{E}$ & 147 & 96 & $\mathrm{~T}$ & 5583 & $S$ & 37853 & 68760 IR \\
\hline $4.00 \mathrm{~N} 28.00 \mathrm{E}$ & 147 & 87 & $\mathrm{~T}$ & 5779 & $C G$ & 7077 & 0 IS \\
\hline 4.00N28.00E & 147 & 88 & $\mathrm{~T}$ & 5779 & $C G$ & 7077 & 0 IS \\
\hline $4.00 \mathrm{~N} 28.00 \mathrm{E}$ & 147 & 89 & $\mathrm{~T}$ & 5779 & $C G$ & 7077 & 0 IS \\
\hline $4.00 \mathrm{~N} 28.00 \mathrm{E}$ & 148 & 87 & $\mathrm{~T}$ & 5779 & C G & 7077 & 0 IS \\
\hline 4.00N28.00E & 148 & 89 & $\mathrm{~T}$ & 5779 & $C G$ & 7077 & 0 IS \\
\hline $4.00 \mathrm{~N} 28.00 \mathrm{E}$ & 148 & 88 & $\mathrm{~T}$ & 5779 & $C G$ & 7077 & 0 IS \\
\hline
\end{tabular}


PLACE OF USE REPORT $3 \mathrm{~N} \quad 29 \mathrm{E}$

TWP/RNG POU-ID PO D-ID APP LICATION P ERMIT CERT \# USE

\begin{tabular}{|c|c|c|c|c|c|c|c|}
\hline $4.00 \mathrm{~N} 28.00 \mathrm{E}$ & 148 & 93 & $\mathrm{~T}$ & 5586 & $S$ & 30078 & 68763 IR \\
\hline $4.00 \mathrm{~N} 28.00 \mathrm{E}$ & 148 & 94 & $\mathrm{~T}$ & 5586 & $\mathrm{~S}$ & 30078 & 68763 IR \\
\hline $4.00 \mathrm{~N} 28.00 \mathrm{E}$ & 148 & 92 & $\mathrm{~T}$ & 5586 & $S$ & 30078 & 68763 IR \\
\hline $4.00 \mathrm{~N} 28.00 \mathrm{E}$ & 148 & 90 & $\mathrm{~T}$ & 6416 & G & 7077 & 67322 IS \\
\hline $4.00 \mathrm{~N} 28.00 \mathrm{E}$ & 148 & 96 & $\mathrm{~T}$ & 5586 & $S$ & 30078 & 68763 IR \\
\hline $4.00 \mathrm{~N} 28.00 \mathrm{E}$ & 148 & 97 & $\mathrm{~T}$ & 5586 & $S$ & 30078 & 68763 IR \\
\hline $4.00 \mathrm{~N} 28.00 \mathrm{E}$ & 148 & 98 & $\mathrm{~T}$ & 5586 & $\mathrm{~S}$ & 30078 & 68763 IR \\
\hline $4.00 \mathrm{~N} 28.00 \mathrm{E}$ & 148 & 95 & $\mathrm{~T}$ & 5586 & $\mathrm{~S}$ & 30078 & 68763 IR \\
\hline $4.00 \mathrm{~N} 28.00 \mathrm{E}$ & 148 & 91 & G & 8697 & G & 8298 & 52678 IS \\
\hline $4.00 \mathrm{~N} 28.00 \mathrm{E}$ & 149 & 90 & $\mathrm{~T}$ & 6416 & $G$ & 7077 & 67322 IS \\
\hline $4.00 \mathrm{~N} 28.00 \mathrm{E}$ & 149 & 92 & $\mathrm{~T}$ & 5586 & $S$ & 30078 & 68763 IR \\
\hline $4.00 \mathrm{~N} 28.00 \mathrm{E}$ & 149 & 94 & $\mathrm{~T}$ & 5586 & $S$ & 30078 & 68763 IR \\
\hline $4.00 \mathrm{~N} 28.00 \mathrm{E}$ & 149 & 98 & $\mathrm{~T}$ & 5586 & $S$ & 30078 & 68763 IR \\
\hline $4.00 \mathrm{~N} 28.00 \mathrm{E}$ & 149 & 95 & $\mathrm{~T}$ & 5586 & $S$ & 30078 & 68763 IR \\
\hline 4.00N28.00E & 149 & 96 & $\mathrm{~T}$ & 5586 & $\mathrm{~S}$ & 30078 & 68763 IR \\
\hline $4.00 \mathrm{~N} 28.00 \mathrm{E}$ & 149 & 93 & $\mathrm{~T}$ & 5586 & $\mathrm{~S}$ & 30078 & 68763 IR \\
\hline $4.00 \mathrm{~N} 28.00 \mathrm{E}$ & 149 & 97 & $\mathrm{~T}$ & 5586 & $\mathrm{~S}$ & 30078 & 68763 IR \\
\hline $4.00 \mathrm{~N} 28.00 \mathrm{E}$ & 149 & 87 & $\mathrm{~T}$ & 5779 & $C G$ & 7077 & 0 IS \\
\hline $4.00 \mathrm{~N} 28.00 \mathrm{E}$ & 149 & 89 & $\mathrm{~T}$ & 5779 & $C G$ & 7077 & 0 IS \\
\hline $4.00 \mathrm{~N} 28.00 \mathrm{E}$ & 149 & 88 & $\mathrm{~T}$ & 5779 & $C G$ & 7077 & 0 IS \\
\hline $4.00 \mathrm{~N} 28.00 \mathrm{E}$ & 150 & 88 & $\mathrm{~T}$ & 5779 & $C G$ & 7077 & 0 IS \\
\hline $4.00 \mathrm{~N} 28.00 \mathrm{E}$ & 150 & 87 & $\mathrm{~T}$ & 5779 & C G & 7077 & 0 IS \\
\hline $4.00 \mathrm{~N} 28.00 \mathrm{E}$ & 150 & 89 & $\mathrm{~T}$ & 5779 & $C G$ & 7077 & 0 IS \\
\hline $4.00 \mathrm{~N} 28.00 \mathrm{E}$ & 150 & 98 & $\mathrm{~T}$ & 5586 & $S$ & 30078 & 68763 IR \\
\hline $4.00 \mathrm{~N} 28.00 \mathrm{E}$ & 150 & 97 & $\mathrm{~T}$ & 5586 & $S$ & 30078 & 68763 IR \\
\hline $4.00 \mathrm{~N} 28.00 \mathrm{E}$ & 150 & 90 & $\mathrm{~T}$ & 6416 & G & 7077 & 67322 IS \\
\hline 4.00N28.00E & 150 & 95 & $\mathrm{~T}$ & 5586 & $S$ & 30078 & 68763 IR \\
\hline $4.00 \mathrm{~N} 28.00 \mathrm{E}$ & 150 & 92 & $\mathrm{~T}$ & 5586 & $\mathrm{~S}$ & 30078 & 68763 IR \\
\hline $4.00 \mathrm{~N} 28.00 \mathrm{E}$ & 150 & 93 & $\mathrm{~T}$ & 5586 & $\mathrm{~S}$ & 30078 & 68763 IR \\
\hline 4.00N28.00E & 150 & 96 & $\mathrm{~T}$ & 5586 & $S$ & 30078 & 68763 IR \\
\hline $4.00 \mathrm{~N} 28.00 \mathrm{E}$ & 150 & 94 & $\mathrm{~T}$ & 5586 & $\mathrm{~S}$ & 30078 & 68763 IR \\
\hline $4.00 \mathrm{~N} 28.00 \mathrm{E}$ & 150 & 91 & G & 8697 & G & 8298 & 52678 IS \\
\hline 4.00N28.00E & 151 & 94 & $\mathrm{~T}$ & 5586 & $S$ & 30078 & 68763 IR \\
\hline $4.00 \mathrm{~N} 28.00 \mathrm{E}$ & 151 & 97 & $\mathrm{~T}$ & 5586 & $\mathrm{~S}$ & 30078 & 68763 IR \\
\hline $4.00 \mathrm{~N} 28.00 \mathrm{E}$ & 151 & 93 & $\mathrm{~T}$ & 5586 & $S$ & 30078 & 68763 IR \\
\hline $4.00 \mathrm{~N} 28.00 \mathrm{E}$ & 151 & 96 & $\mathrm{~T}$ & 5586 & $\mathrm{~S}$ & 30078 & 68763 IR \\
\hline $4.00 \mathrm{~N} 28.00 \mathrm{E}$ & 151 & 98 & $\mathrm{~T}$ & 5586 & $\mathrm{~S}$ & 30078 & 68763 IR \\
\hline $4.00 \mathrm{~N} 28.00 \mathrm{E}$ & 151 & 90 & $\mathrm{~T}$ & 6416 & G & 7077 & 67322 IS \\
\hline $4.00 \mathrm{~N} 28.00 \mathrm{E}$ & 151 & 92 & $\mathrm{~T}$ & 5586 & $\mathrm{~S}$ & 30078 & 68763 IR \\
\hline $4.00 \mathrm{~N} 28.00 \mathrm{E}$ & 151 & 95 & $\mathrm{~T}$ & 5586 & $S$ & 30078 & 68763 IR \\
\hline $4.00 \mathrm{~N} 28.00 \mathrm{E}$ & 151 & 88 & $\mathrm{~T}$ & 5779 & C G & 7077 & 0 IS \\
\hline $4.00 \mathrm{~N} 28.00 \mathrm{E}$ & 151 & 87 & $\mathrm{~T}$ & 5779 & $C G$ & 7077 & 0 IS \\
\hline 4.00N28.00E & 151 & 89 & $\mathrm{~T}$ & 5779 & $C G$ & 7077 & 0 IS \\
\hline $4.00 \mathrm{~N} 28.00 \mathrm{E}$ & 152 & 88 & $\mathrm{~T}$ & 5779 & $C G$ & 7077 & 0 IS \\
\hline $4.00 \mathrm{~N} 28.00 \mathrm{E}$ & 152 & 87 & $\mathrm{~T}$ & 5779 & $C G$ & 7077 & 0 IS \\
\hline $4.00 \mathrm{~N} 28.00 \mathrm{E}$ & 152 & 89 & $\mathrm{~T}$ & 5779 & $C G$ & 7077 & 0 IS \\
\hline $4.00 \mathrm{~N} 28.00 \mathrm{E}$ & 152 & 93 & $\mathrm{~T}$ & 5586 & $\mathrm{~S}$ & 30078 & 68763 IR \\
\hline $4.00 \mathrm{~N} 28.00 \mathrm{E}$ & 152 & 95 & $\mathrm{~T}$ & 5586 & $\mathrm{~S}$ & 30078 & 68763 IR \\
\hline $4.00 \mathrm{~N} 28.00 \mathrm{E}$ & 152 & 92 & $\mathrm{~T}$ & 5586 & $\mathrm{~S}$ & 30078 & 68763 IR \\
\hline $4.00 \mathrm{~N} 28.00 \mathrm{E}$ & 152 & 98 & $\mathrm{~T}$ & 5586 & $\mathrm{~S}$ & 30078 & 68763 IR \\
\hline
\end{tabular}


PLACE OF USE REPORT $3 \mathrm{~N} \quad 29 \mathrm{E}$

TWP/RNG POU-ID PO D-ID APP LICATION P ERMIT CERT \# USE

\begin{tabular}{|c|c|c|c|c|c|c|c|}
\hline $4.00 \mathrm{~N} 28.00 \mathrm{E}$ & 152 & 90 & $\mathrm{~T}$ & 6416 & G & 7077 & 67322 IS \\
\hline 4.00N28.00E & 152 & 97 & $\mathrm{~T}$ & 5586 & $S$ & 30078 & 68763 IR \\
\hline 4.00N28.00E & 152 & 94 & $\mathrm{~T}$ & 5586 & $S$ & 30078 & 68763 IR \\
\hline 4.00N28.00E & 152 & 96 & $T$ & 5586 & $\mathrm{~S}$ & 30078 & 68763 IR \\
\hline 4.00N28.00E & 152 & 91 & G & 8697 & G & 8298 & 52678 IS \\
\hline 4.00N28.00E & 153 & 93 & $\mathrm{~T}$ & 5586 & $\mathrm{~S}$ & 30078 & 68763 IR \\
\hline 4.00N28.00E & 153 & 95 & $T$ & 5586 & $S$ & 30078 & 68763 IR \\
\hline 4.00N28.00E & 153 & 90 & $\mathrm{~T}$ & 6416 & $\mathrm{G}$ & 7077 & 67322 IS \\
\hline 4.00N28.00E & 153 & 97 & $\mathrm{~T}$ & 5586 & $\mathrm{~S}$ & 30078 & 68763 IR \\
\hline 4.00N28.00E & 153 & 98 & $\mathrm{~T}$ & 5586 & $S$ & 30078 & 68763 IR \\
\hline 4.00N28.00E & 153 & 96 & $\mathrm{~T}$ & 5586 & $S$ & 30078 & 68763 IR \\
\hline 4.00N28.00E & 153 & 94 & $\mathrm{~T}$ & 5586 & $\mathrm{~S}$ & 30078 & 68763 IR \\
\hline $4.00 \mathrm{~N} 28.00 \mathrm{E}$ & 153 & 92 & $\mathrm{~T}$ & 5586 & S & 30078 & 68763 IR \\
\hline 4.00N28.00E & 153 & 89 & $\mathrm{~T}$ & 5779 & $C G$ & 7077 & 0 IS \\
\hline $4.00 \mathrm{~N} 28.00 \mathrm{E}$ & 153 & 88 & $\mathrm{~T}$ & 5779 & $C G$ & 7077 & 0 IS \\
\hline $4.00 \mathrm{~N} 28.00 \mathrm{E}$ & 153 & 87 & $\mathrm{~T}$ & 5779 & $C G$ & 7077 & 0 IS \\
\hline 4.00N28.00E & 154 & 87 & $\mathrm{~T}$ & 5779 & $C G$ & 7077 & 0 IR \\
\hline 4.00N28.00E & 154 & 89 & $\mathrm{~T}$ & 5779 & $C G$ & 7077 & 0 IR \\
\hline 4.00N28.00E & 154 & 88 & $\mathrm{~T}$ & 5779 & $C G$ & 7077 & 0 IR \\
\hline 4.00N28.00E & 154 & 90 & $T$ & 6416 & G & 7077 & 67322 IR \\
\hline $4.00 \mathrm{~N} 28.00 \mathrm{E}$ & 155 & 91 & $\mathrm{G}$ & 8697 & $\mathrm{G}$ & 8298 & 52678 IM \\
\hline 4.00N28.00E & 156 & 91 & $G$ & 8697 & G & 8298 & 52678 IM \\
\hline 4.00N28.00E & 157 & 91 & G & 8697 & G & 8298 & 52678 IS \\
\hline 4.00N28.00E & 157 & 102 & $\mathrm{~T}$ & 5584 & $S$ & 32631 & 68761 IR \\
\hline 4.00N28.00E & 157 & 96 & $\mathrm{~T}$ & 5584 & $S$ & 32631 & 68761 IR \\
\hline $4.00 \mathrm{~N} 28.00 \mathrm{E}$ & 158 & 102 & $\mathrm{~T}$ & 5583 & $S$ & 37853 & 68760 IR \\
\hline 4.00N28.00E & 158 & 90 & $T$ & 6416 & $\mathrm{G}$ & 7077 & 67322 IS \\
\hline $4.00 \mathrm{~N} 28.00 \mathrm{E}$ & 158 & 96 & $\mathrm{~T}$ & 5583 & S & 37853 & 68760 IR \\
\hline 4.00N28.00E & 158 & 102 & $\mathrm{~T}$ & 5584 & $S$ & 32631 & 68761 IR \\
\hline 4.00N28.00E & 158 & 96 & $\mathrm{~T}$ & 5584 & $S$ & 32631 & 68761 IR \\
\hline $4.00 \mathrm{~N} 28.00 \mathrm{E}$ & 158 & 91 & G & 8697 & $\mathrm{G}$ & 8298 & 52678 IS \\
\hline 4.00N28.00E & 158 & 87 & $\mathrm{~T}$ & 5779 & $C \mathrm{G}$ & 7077 & 0 IS \\
\hline 4.00N28.00E & 158 & 88 & $\mathrm{~T}$ & 5779 & $C G$ & 7077 & 0 IS \\
\hline $4.00 \mathrm{~N} 28.00 \mathrm{E}$ & 158 & 89 & $\mathrm{~T}$ & 5779 & $C G$ & 7077 & 0 IS \\
\hline 4.00N28.00E & 159 & 91 & $\mathrm{G}$ & 8697 & G & 8298 & 52678 IS \\
\hline 4.00N28.00E & 159 & 102 & $\mathrm{~T}$ & 5584 & $S$ & 32631 & 68761 IR \\
\hline 4.00N28.00E & 159 & 96 & $\mathrm{~T}$ & 5584 & $S$ & 32631 & 68761 IR \\
\hline 4.00N28.00E & 160 & 92 & $\mathrm{~T}$ & 5586 & $\mathrm{~S}$ & 30078 & 68763 IR \\
\hline 4.00N28.00E & 160 & 93 & $\mathrm{~T}$ & 5586 & $\mathrm{~S}$ & 30078 & 68763 IR \\
\hline 4.00N28.00E & 160 & 94 & $\mathrm{~T}$ & 5586 & $S$ & 30078 & 68763 IR \\
\hline $4.00 \mathrm{~N} 28.00 \mathrm{E}$ & 160 & 96 & $\mathrm{~T}$ & 5586 & S & 30078 & 68763 IR \\
\hline 4.00N28.00E & 160 & 95 & $T$ & 5586 & $S$ & 30078 & 68763 IR \\
\hline 4.00N28.00E & 160 & 98 & $\mathrm{~T}$ & 5586 & $S$ & 30078 & 68763 IR \\
\hline 4.00N28.00E & 160 & 97 & $\mathrm{~T}$ & 5586 & $S$ & 30078 & 68763 IR \\
\hline $4.00 \mathrm{~N} 28.00 \mathrm{E}$ & 160 & 91 & G & 8697 & $\mathrm{G}$ & 8298 & 52678 IS \\
\hline $4.00 \mathrm{~N} 28.00 \mathrm{E}$ & 161 & 91 & $\mathrm{G}$ & 8697 & $\mathrm{G}$ & 8298 & 52678 IS \\
\hline $4.00 \mathrm{~N} 28.00 \mathrm{E}$ & 161 & 97 & $\mathrm{~T}$ & 5586 & S & 30078 & 68763 IR \\
\hline $4.00 \mathrm{~N} 28.00 \mathrm{E}$ & 161 & 94 & $\mathrm{~T}$ & 5586 & $S$ & 30078 & 68763 IR \\
\hline 4.00N28.00E & 161 & 93 & $\mathrm{~T}$ & 5586 & S & 30078 & 68763 IR \\
\hline 4.00N28.00E & 161 & 96 & $\mathrm{~T}$ & 5586 & $\mathrm{~S}$ & 30078 & 68763 IR \\
\hline
\end{tabular}


PLACE OF USE REPORT $3 \mathrm{~N} \quad 29 \mathrm{E}$

TWP/RNG POU-ID PO D-ID APP LICATION P ERMIT CERT \# USE

\begin{tabular}{|c|c|c|c|c|c|c|c|}
\hline $4.00 \mathrm{~N} 28.00 \mathrm{E}$ & 161 & 98 & $T$ & 5586 & $S$ & 30078 & 68763 IR \\
\hline 4.00N28.00E & 161 & 95 & $\mathrm{~T}$ & 5586 & $S$ & 30078 & 68763 IR \\
\hline 4.00N28.00E & 161 & 92 & $\mathrm{~T}$ & 5586 & $S$ & 30078 & 68763 IR \\
\hline 4.00N28.00E & 162 & 91 & G & 8697 & $G$ & 8298 & 52678 IS \\
\hline 4.00N28.00E & 164 & 100 & G & 5599 & G & 5045 & 55009 IR \\
\hline 4.00N28.00E & 166 & 101 & G & 10408 & G & 9456 & 55023 IR \\
\hline $4.00 \mathrm{~N} 28.00 \mathrm{E}$ & 167 & 91 & G & 8697 & G & 8298 & 52678 IR \\
\hline 4.00N28.00E & 168 & 91 & $G$ & 8697 & G & 8298 & 52678 IS \\
\hline 4.00N28.00E & 169 & 91 & G & 8697 & $G$ & 8298 & 52678 IR \\
\hline 4.00N28.00E & 170 & 91 & G & 8697 & G & 8298 & 52678 IR \\
\hline 4.00N28.00E & 171 & 91 & $\mathrm{G}$ & 8697 & G & 8298 & 52678 IR \\
\hline 4.00N28.00E & 201 & 122 & $\mathrm{G}$ & 6409 & G & 6730 & 49883 IR \\
\hline 4.00N28.00E & 203 & 125 & $\mathrm{~S}$ & 53080 & $S$ & 42204 & 58969 IS \\
\hline 4.00N28.00E & 203 & 124 & G & 8236 & G & 7614 & 58968 IR \\
\hline $4.00 \mathrm{~N} 28.00 \mathrm{E}$ & 204 & 124 & G & 8236 & G & 7614 & 58968 IR \\
\hline $4.00 \mathrm{~N} 28.00 \mathrm{E}$ & 204 & 125 & $\mathrm{~S}$ & 53080 & $S$ & 42204 & 58969 IS \\
\hline 4.00N28.00E & 205 & 129 & S & 13204 & $S$ & 9451 & 10556 IR \\
\hline 4.00N28.00E & 205 & 128 & $S$ & 13204 & $S$ & 9451 & 10556 IR \\
\hline 4.00N28.00E & 205 & 127 & G & 11458 & G & 10709 & 0 IS \\
\hline $4.00 \mathrm{~N} 28.00 \mathrm{E}$ & 205 & 125 & $S$ & 7975 & $S$ & 5261 & 8407 IR \\
\hline $4.00 \mathrm{~N} 28.00 \mathrm{E}$ & 206 & 127 & $\mathrm{G}$ & 11458 & G & 10709 & 0 IS \\
\hline 4.00N28.00E & 207 & 127 & $G$ & 11458 & G & 10709 & 0 IS \\
\hline 4.00N28.00E & 208 & 127 & G & 11458 & G & 10709 & 0 IS \\
\hline 4.00N28.00E & 209 & 127 & $\mathrm{G}$ & 11458 & G & 10709 & 0 IR \\
\hline 4.00N28.00E & 210 & 126 & $\mathrm{G}$ & 11458 & G & 10709 & 0 IR \\
\hline $4.00 \mathrm{~N} 28.00 \mathrm{E}$ & 211 & 126 & $\mathrm{G}$ & 11458 & G & 10709 & 0 IS \\
\hline 4.00N28.00E & 212 & 127 & $\mathrm{G}$ & 11458 & G & 10709 & 0 IS \\
\hline $4.00 \mathrm{~N} 28.00 \mathrm{E}$ & 212 & 128 & S & 13204 & S & 9451 & 10556 IR \\
\hline $4.00 \mathrm{~N} 28.00 \mathrm{E}$ & 212 & 129 & $S$ & 13204 & $\mathrm{~S}$ & 9451 & 10556 IR \\
\hline 4.00N28.00E & 213 & 130 & G & 6277 & G & 5909 & 54733 IS \\
\hline 4.00N28.00E & 214 & 130 & $\mathrm{G}$ & 6277 & $\mathrm{G}$ & 5909 & 54733 IR \\
\hline 4.00N28.00E & 215 & 131 & $\mathrm{G}$ & 8574 & G & 7913 & 0 IS \\
\hline $4.00 \mathrm{~N} 28.00 \mathrm{E}$ & 216 & 132 & $S$ & 33930 & $S$ & 26753 & 33877 IS \\
\hline $4.00 \mathrm{~N} 28.00 \mathrm{E}$ & 217 & 91 & $\mathrm{G}$ & 8697 & $\mathrm{G}$ & 8298 & 52678 IR \\
\hline 4.00N28.00E & 227 & 91 & $\mathrm{G}$ & 8697 & G & 8298 & 52678 IS \\
\hline 4.00N28.00E & 227 & 93 & $\mathrm{~T}$ & 5586 & $S$ & 30078 & 68763 IR \\
\hline 4.00N28.00E & 227 & 98 & $\mathrm{~T}$ & 5586 & $S$ & 30078 & 68763 IR \\
\hline 4.00N28.00E & 227 & 92 & $\mathrm{~T}$ & 5586 & $S$ & 30078 & 68763 IR \\
\hline 4.00N28.00E & 227 & 94 & $\mathrm{~T}$ & 5586 & $S$ & 30078 & 68763 IR \\
\hline 4.00N28.00E & 227 & 96 & $\mathrm{~T}$ & 5586 & $S$ & 30078 & 68763 IR \\
\hline $4.00 \mathrm{~N} 28.00 \mathrm{E}$ & 227 & 97 & $\mathrm{~T}$ & 5586 & S & 30078 & 68763 IR \\
\hline $4.00 \mathrm{~N} 28.00 \mathrm{E}$ & 227 & 95 & $\mathrm{~T}$ & 5586 & $S$ & 30078 & 68763 IR \\
\hline 4.00N28.00E & 228 & 96 & $\mathrm{~T}$ & 5584 & $S$ & 32631 & 68761 IR \\
\hline $4.00 \mathrm{~N} 28.00 \mathrm{E}$ & 228 & 102 & $\mathrm{~T}$ & 5584 & S & 32631 & 68761 IR \\
\hline $4.00 \mathrm{~N} 28.00 \mathrm{E}$ & 228 & 91 & G & 8697 & G & 8298 & 52678 IR \\
\hline $4.00 \mathrm{~N} 28.00 \mathrm{E}$ & 229 & 93 & $\mathrm{~T}$ & 5586 & $S$ & 30078 & 68763 IR \\
\hline $4.00 \mathrm{~N} 28.00 \mathrm{E}$ & 229 & 94 & $\mathrm{~T}$ & 5586 & S & 30078 & 68763 IR \\
\hline $4.00 \mathrm{~N} 28.00 \mathrm{E}$ & 229 & 92 & $\mathrm{~T}$ & 5586 & $S$ & 30078 & 68763 IR \\
\hline 4.00N28.00E & 229 & 96 & $\mathrm{~T}$ & 5586 & S & 30078 & 68763 IR \\
\hline 4.00N28.00E & 229 & 98 & $\mathrm{~T}$ & 5586 & $\mathrm{~s}$ & 30078 & 68763 IR \\
\hline
\end{tabular}


PLACE OF USE REPORT $3 \mathrm{~N} \quad 29 \mathrm{E}$

TWP/RNG POU-ID PO D-ID APP LICATION P ERMIT CERT \# USE

\begin{tabular}{|c|c|c|c|c|c|c|c|}
\hline $4.00 \mathrm{~N} 28.00 \mathrm{E}$ & 229 & 97 & $\mathrm{~T}$ & 5586 & $S$ & 30078 & 68763 IR \\
\hline 4.00N28.00E & 229 & 95 & $\mathrm{~T}$ & 5586 & $S$ & 30078 & 68763 IR \\
\hline $4.00 \mathrm{~N} 28.00 \mathrm{E}$ & 230 & 97 & $\mathrm{~T}$ & 5586 & $S$ & 30078 & 68763 IR \\
\hline $4.00 \mathrm{~N} 28.00 \mathrm{E}$ & 230 & 92 & $\mathrm{~T}$ & 5586 & S & 30078 & 68763 IR \\
\hline $4.00 \mathrm{~N} 28.00 \mathrm{E}$ & 230 & 95 & $\mathrm{~T}$ & 5586 & $S$ & 30078 & 68763 IR \\
\hline $4.00 \mathrm{~N} 28.00 \mathrm{E}$ & 230 & 93 & $\mathrm{~T}$ & 5586 & $S$ & 30078 & 68763 IR \\
\hline $4.00 \mathrm{~N} 28.00 \mathrm{E}$ & 230 & 96 & $\mathrm{~T}$ & 5586 & S & 30078 & 68763 IR \\
\hline $4.00 \mathrm{~N} 28.00 \mathrm{E}$ & 230 & 94 & $T$ & 5586 & $S$ & 30078 & 68763 IR \\
\hline $4.00 \mathrm{~N} 28.00 \mathrm{E}$ & 230 & 98 & $\mathrm{~T}$ & 5586 & $S$ & 30078 & 68763 IR \\
\hline $4.00 \mathrm{~N} 28.00 \mathrm{E}$ & 231 & 91 & $G$ & 8697 & G & 8298 & 52678 IR \\
\hline $4.00 \mathrm{~N} 28.00 \mathrm{E}$ & 232 & 91 & G & 8697 & $G$ & 8298 & 52678 IS \\
\hline $4.00 \mathrm{~N} 28.00 \mathrm{E}$ & 232 & 96 & $\mathrm{~T}$ & 5584 & $\mathrm{~S}$ & 32631 & 68761 IR \\
\hline $4.00 \mathrm{~N} 28.00 \mathrm{E}$ & 232 & 102 & $\mathrm{~T}$ & 5584 & $S$ & 32631 & 68761 IR \\
\hline $4.00 \mathrm{~N} 28.00 \mathrm{E}$ & 233 & 96 & $\mathrm{~T}$ & 5584 & $S$ & 32631 & 68761 IR \\
\hline $4.00 \mathrm{~N} 28.00 \mathrm{E}$ & 233 & 102 & $\mathrm{~T}$ & 5584 & $\mathrm{~S}$ & 32631 & 68761 IR \\
\hline $4.00 \mathrm{~N} 28.00 \mathrm{E}$ & 234 & 90 & $\mathrm{~T}$ & 6416 & G & 7077 & 67322 IS \\
\hline $4.00 \mathrm{~N} 28.00 \mathrm{E}$ & 234 & 96 & $\mathrm{~T}$ & 5584 & $\mathrm{~S}$ & 32631 & 68761 IR \\
\hline $4.00 \mathrm{~N} 28.00 \mathrm{E}$ & 234 & 102 & $\mathrm{~T}$ & 5584 & $S$ & 32631 & 68761 IR \\
\hline 4.00N28.00E & 234 & 88 & $\mathrm{~T}$ & 5779 & C G & 7077 & 0 IS \\
\hline $4.00 \mathrm{~N} 28.00 \mathrm{E}$ & 234 & 89 & $\mathrm{~T}$ & 5779 & $C G$ & 7077 & 0 IS \\
\hline 4.00N28.00E & 234 & 87 & $\mathrm{~T}$ & 5779 & C G & 7077 & 0 IS \\
\hline $4.00 \mathrm{~N} 29.00 \mathrm{E}$ & 44 & 86 & G & 7086 & $G$ & 6555 & 54084 IS \\
\hline $4.00 \mathrm{~N} 29.00 \mathrm{E}$ & 44 & 85 & $\mathrm{G}$ & 7086 & G & 6555 & 54084 IS \\
\hline 4.00N29.00E & 45 & 88 & $S$ & 41443 & $S$ & 31223 & 38868 IR \\
\hline 4.00N29.00E & 45 & 88 & $S$ & 41443 & $S$ & 31223 & 38868 IS \\
\hline 4.00N29.00E & 46 & 88 & $\mathrm{~S}$ & 41443 & $S$ & 31223 & 38868 IR \\
\hline $4.00 \mathrm{~N} 29.00 \mathrm{E}$ & 46 & 88 & $S$ & 41443 & $\mathrm{~S}$ & 31223 & 38868 IS \\
\hline $4.00 \mathrm{~N} 29.00 \mathrm{E}$ & 48 & 53 & $G$ & 5233 & G & 5091 & 53478 IS \\
\hline 4.00N29.00E & 49 & 53 & G & 5233 & G & 5091 & 53478 IS \\
\hline $4.00 \mathrm{~N} 29.00 \mathrm{E}$ & 50 & 110 & G & 6216 & G & 5221 & 44778 IS \\
\hline 4.00N29.00E & 51 & 111 & G & 9353 & G & 8629 & 53486 IR \\
\hline $4.00 \mathrm{~N} 29.00 \mathrm{E}$ & 52 & 112 & $\mathrm{G}$ & 10773 & $\mathrm{G}$ & 9955 & 63697 IR \\
\hline $4.00 \mathrm{~N} 29.00 \mathrm{E}$ & 54 & 113 & $G$ & 11681 & G & 10778 & 68724 IR \\
\hline $4.00 \mathrm{~N} 29.00 \mathrm{E}$ & 55 & 114 & $\mathrm{~S}$ & 7150 & $\mathrm{~S}$ & 4543 & 3266 IR \\
\hline $4.00 \mathrm{~N} 29.00 \mathrm{E}$ & 56 & 105 & G & 6439 & G & 6042 & 53483 IR \\
\hline $4.00 \mathrm{~N} 29.00 \mathrm{E}$ & 57 & 105 & G & 6439 & G & 6042 & 53483 IR \\
\hline $4.00 \mathrm{~N} 29.00 \mathrm{E}$ & 58 & 108 & $\mathrm{~S}$ & 61506 & $\mathrm{~S}$ & 45800 & 62277 IS \\
\hline 4.00N29.00E & 59 & 107 & $S$ & 48070 & $S$ & 36058 & 48483 IR \\
\hline 4.00N29.00E & 60 & 107 & S & 48070 & S & 36058 & 48483 IR \\
\hline $4.00 \mathrm{~N} 29.00 \mathrm{E}$ & 61 & 107 & $S$ & 48070 & $\mathrm{~S}$ & 36058 & 48483 IR \\
\hline $4.00 \mathrm{~N} 29.00 \mathrm{E}$ & 61 & 97 & $S$ & 16662 & $\mathrm{~S}$ & 12433 & 12164 IR \\
\hline $4.00 \mathrm{~N} 29.00 \mathrm{E}$ & 62 & 107 & $\mathrm{~S}$ & 48070 & $\mathrm{~S}$ & 36058 & 48483 IR \\
\hline $4.00 \mathrm{~N} 29.00 \mathrm{E}$ & 62 & 97 & $\mathrm{~S}$ & 16662 & $\mathrm{~S}$ & 12433 & 12164 IR \\
\hline 4.00N29.00E & 66 & 107 & $S$ & 48070 & $S$ & 36058 & 48483 IR \\
\hline 4.00N29.00E & 66 & 97 & $S$ & 16662 & $S$ & 12433 & 12164 IR \\
\hline $4.00 \mathrm{~N} 29.00 \mathrm{E}$ & 67 & 107 & $\mathrm{~S}$ & 48070 & $\mathrm{~S}$ & 36058 & 48483 IR \\
\hline $4.00 \mathrm{~N} 29.00 \mathrm{E}$ & 67 & 97 & $\mathrm{~S}$ & 16662 & $\mathrm{~S}$ & 12433 & 12164 IR \\
\hline $4.00 \mathrm{~N} 29.00 \mathrm{E}$ & 82 & 104 & G & 5076 & G & 4794 & 41026 IR \\
\hline 4.00N29.00E & 83 & 103 & $\mathrm{G}$ & 4478 & $\mathrm{G}$ & 4220 & 41150 IR \\
\hline
\end{tabular}


PLACE OF USE REPORT $3 \mathrm{~N} \quad 29 \mathrm{E}$

TWP/RNG POU-ID PO D-ID APP LICATION P ERMIT CERT \# USE

\begin{tabular}{|c|c|c|c|c|c|c|c|}
\hline $4.00 \mathrm{~N} 29.00 \mathrm{E}$ & 84 & 103 & G & 4478 & $\mathrm{G}$ & 4220 & 41150 IR \\
\hline 4.00N29.00E & 84 & 0 & $\mathrm{D}$ & 0 & $\mathrm{D}$ & 2583 & $55602 \mathrm{I}^{*}$ \\
\hline 4.00N29.00E & 85 & 103 & G & 4478 & $\mathrm{G}$ & 4220 & 41150 IR \\
\hline 4.00N29.00E & 86 & 0 & $\mathrm{D}$ & 0 & $\mathrm{D}$ & 2644 & $\left.2644\right|^{*}$ \\
\hline 4.00N29.00E & 87 & 0 & $\mathrm{D}$ & 0 & $\mathrm{D}$ & 2583 & 55602 I $^{*}$ \\
\hline $4.00 \mathrm{~N} 29.00 \mathrm{E}$ & 88 & 0 & $\mathrm{D}$ & 0 & $\mathrm{D}$ & 2583 & 55602 I* $^{*}$ \\
\hline 4.00N29.00E & 88 & 97 & $\mathrm{~S}$ & 16662 & $\mathrm{~S}$ & 12433 & 12164 IR \\
\hline $4.00 \mathrm{~N} 29.00 \mathrm{E}$ & 89 & 97 & $\mathrm{~S}$ & 16662 & $\mathrm{~S}$ & 12433 & 12164 IR \\
\hline $4.00 \mathrm{~N} 29.00 \mathrm{E}$ & 89 & 0 & $\mathrm{D}$ & 0 & $\mathrm{D}$ & 2583 & 55602 I $^{*}$ \\
\hline 4.00N29.00E & 90 & 90 & $\mathrm{~T}$ & 5369 & $\mathrm{~S}$ & 18122 & 0 IS \\
\hline $4.00 \mathrm{~N} 29.00 \mathrm{E}$ & 90 & 89 & $\mathrm{~T}$ & 5369 & $S$ & 18122 & 0 IS \\
\hline 4.00N29.00E & 94 & 0 & $\mathrm{D}$ & 0 & $\mathrm{D}$ & 2583 & $55602 I^{*}$ \\
\hline 4.00N29.00E & 95 & 0 & $\mathrm{D}$ & 0 & $D$ & 2583 & 55602 I* $^{*}$ \\
\hline 4.00N29.00E & 105 & 102 & $S$ & 59543 & $S$ & 45370 & 66247 IR \\
\hline $4.00 \mathrm{~N} 29.00 \mathrm{E}$ & 106 & 102 & $S$ & 59543 & $\mathrm{~S}$ & 45370 & 66247 IR \\
\hline 4.00N29.00E & 111 & 102 & $S$ & 59543 & $\mathrm{~S}$ & 45370 & 66247 IS \\
\hline $4.00 \mathrm{~N} 29.00 \mathrm{E}$ & 112 & 102 & $S$ & 59543 & $\mathrm{~S}$ & 45370 & 66247 IS \\
\hline $4.00 \mathrm{~N} 29.00 \mathrm{E}$ & 112 & 96 & $\mathrm{~S}$ & 8198 & $\mathrm{R}$ & 5303 & 3962 IR \\
\hline 4.00N29.00E & 113 & 96 & $S$ & 8198 & $\mathrm{R}$ & 5303 & 3962 IR \\
\hline $4.00 \mathrm{~N} 29.00 \mathrm{E}$ & 114 & 101 & S & 50029 & $\mathrm{~S}$ & 37612 & 53491 IR \\
\hline $4.00 \mathrm{~N} 29.00 \mathrm{E}$ & 115 & 100 & $\mathrm{~S}$ & 33580 & $\mathrm{~S}$ & 26564 & 31294 IS \\
\hline $4.00 \mathrm{~N} 29.00 \mathrm{E}$ & 116 & 99 & $S$ & 68408 & $S$ & 49487 & 0 IR \\
\hline $4.00 \mathrm{~N} 29.00 \mathrm{E}$ & 116 & 99 & $S$ & 68408 & $S$ & 49487 & $0 \mathrm{IR}$ \\
\hline 4.00N29.00E & 117 & 99 & $\mathrm{~S}$ & 68408 & $S$ & 49487 & $0 \mathrm{IR}$ \\
\hline $4.00 \mathrm{~N} 29.00 \mathrm{E}$ & 117 & 99 & $S$ & 68408 & $S$ & 49487 & 0 IR \\
\hline $4.00 \mathrm{~N} 29.00 \mathrm{E}$ & 118 & 98 & $\mathrm{~S}$ & 57347 & $\mathrm{~S}$ & 43323 & 53073 IR \\
\hline 4.00N29.00E & 164 & 72 & $\mathrm{G}$ & 8665 & $\mathrm{G}$ & 8209 & 54740 IR \\
\hline $4.00 \mathrm{~N} 29.00 \mathrm{E}$ & 164 & 73 & G & 8665 & G & 8209 & 54740 IR \\
\hline $4.00 \mathrm{~N} 29.00 \mathrm{E}$ & 164 & 71 & $G$ & 8665 & $G$ & 8209 & 54740 IR \\
\hline $4.00 \mathrm{~N} 29.00 \mathrm{E}$ & 164 & 74 & G & 9062 & $\mathrm{G}$ & 8446 & 54741 IS \\
\hline $4.00 \mathrm{~N} 29.00 \mathrm{E}$ & 165 & 71 & G & 8665 & G & 8209 & 54740 IR \\
\hline $4.00 \mathrm{~N} 29.00 \mathrm{E}$ & 165 & 74 & G & 9062 & G & 8446 & 54741 IS \\
\hline $4.00 \mathrm{~N} 29.00 \mathrm{E}$ & 165 & 72 & G & 8665 & $\mathrm{G}$ & 8209 & 54740 IR \\
\hline $4.00 \mathrm{~N} 29.00 \mathrm{E}$ & 165 & 73 & $G$ & 8665 & $\mathrm{G}$ & 8209 & 54740 IR \\
\hline $4.00 \mathrm{~N} 29.00 \mathrm{E}$ & 166 & 73 & $G$ & 8665 & $\mathrm{G}$ & 8209 & 54740 IR \\
\hline $4.00 \mathrm{~N} 29.00 \mathrm{E}$ & 166 & 71 & G & 8665 & G & 8209 & 54740 IR \\
\hline $4.00 \mathrm{~N} 29.00 \mathrm{E}$ & 166 & 74 & G & 9062 & G & 8446 & 54741 IS \\
\hline $4.00 \mathrm{~N} 29.00 \mathrm{E}$ & 166 & 72 & $\mathrm{G}$ & 8665 & $\mathrm{G}$ & 8209 & 54740 IR \\
\hline $4.00 \mathrm{~N} 29.00 \mathrm{E}$ & 167 & 74 & G & 9062 & G & 8446 & 54741 IS \\
\hline $4.00 \mathrm{~N} 29.00 \mathrm{E}$ & 167 & 72 & $\mathrm{G}$ & 8665 & $\mathrm{G}$ & 8209 & 54740 IR \\
\hline $4.00 \mathrm{~N} 29.00 \mathrm{E}$ & 167 & 73 & $\mathrm{G}$ & 8665 & $\mathrm{G}$ & 8209 & 54740 IR \\
\hline $4.00 \mathrm{~N} 29.00 \mathrm{E}$ & 167 & 71 & G & 8665 & G & 8209 & 54740 IR \\
\hline 4.00N29.00E & 168 & 72 & $\mathrm{G}$ & 8665 & $\mathrm{G}$ & 8209 & 54740 IR \\
\hline $4.00 \mathrm{~N} 29.00 \mathrm{E}$ & 168 & 71 & G & 8665 & $\mathrm{G}$ & 8209 & 54740 IR \\
\hline $4.00 \mathrm{~N} 29.00 \mathrm{E}$ & 168 & 74 & G & 9062 & $\mathrm{G}$ & 8446 & 54741 IS \\
\hline $4.00 \mathrm{~N} 29.00 \mathrm{E}$ & 168 & 73 & $\mathrm{G}$ & 8665 & $\mathrm{G}$ & 8209 & 54740 IR \\
\hline $4.00 \mathrm{~N} 29.00 \mathrm{E}$ & 172 & 73 & $\mathrm{G}$ & 8665 & $\mathrm{G}$ & 8209 & 54740 IS \\
\hline $4.00 \mathrm{~N} 29.00 \mathrm{E}$ & 172 & 71 & $G$ & 8665 & $\mathrm{G}$ & 8209 & 54740 IS \\
\hline $4.00 \mathrm{~N} 29.00 \mathrm{E}$ & 172 & 74 & $\mathrm{G}$ & 9062 & $\mathrm{G}$ & 8446 & 54741 IS \\
\hline $4.00 \mathrm{~N} 29.00 \mathrm{E}$ & 172 & 72 & $\mathrm{G}$ & 8665 & $\mathrm{G}$ & 8209 & 54740 IS \\
\hline
\end{tabular}


PLACE OF USE REPORT $3 \mathrm{~N} \quad 29 \mathrm{E}$

TWP/RNG POU-ID PO D-ID APP LICATION P ERMIT CERT \# USE

\begin{tabular}{|c|c|c|c|c|c|c|c|}
\hline $4.00 \mathrm{~N} 29.00 \mathrm{E}$ & 176 & 73 & $G$ & 10991 & G & 10452 & 66824 IR \\
\hline 4.00N29.00E & 176 & 74 & G & 10991 & G & 10452 & 66824 IR \\
\hline $4.00 \mathrm{~N} 29.00 \mathrm{E}$ & 178 & 73 & G & 10991 & G & 10452 & 66824 IS \\
\hline $4.00 \mathrm{~N} 29.00 \mathrm{E}$ & 178 & 72 & G & 10991 & G & 10452 & 66824 IS \\
\hline $4.00 \mathrm{~N} 29.00 \mathrm{E}$ & 181 & 81 & $G$ & 7638 & $G$ & 7094 & 53481 IS \\
\hline 4.00N29.00E & 181 & 81 & G & 7638 & G & 7094 & 53481 IS \\
\hline $4.00 \mathrm{~N} 29.00 \mathrm{E}$ & 181 & 78 & G & 3781 & G & 3566 & 38733 IS \\
\hline $4.00 \mathrm{~N} 29.00 \mathrm{E}$ & 182 & 79 & $G$ & 4946 & G & 4668 & 38734 IS \\
\hline $4.00 \mathrm{~N} 29.00 \mathrm{E}$ & 183 & 78 & G & 3781 & G & 3566 & 38733 IS \\
\hline $4.00 \mathrm{~N} 29.00 \mathrm{E}$ & 183 & 81 & $G$ & 7638 & G & 7094 & 53481 IS \\
\hline $4.00 \mathrm{~N} 29.00 \mathrm{E}$ & 183 & 80 & $G$ & 6055 & $G$ & 5753 & 53479 IS \\
\hline $4.00 \mathrm{~N} 29.00 \mathrm{E}$ & 183 & 81 & G & 7638 & G & 7094 & 53481 IS \\
\hline $4.00 \mathrm{~N} 29.00 \mathrm{E}$ & 184 & 78 & $G$ & 3781 & G & 3566 & 38733 IS \\
\hline 4.00N29.00E & 184 & 81 & $\mathrm{G}$ & 7638 & G & 7094 & 53481 IS \\
\hline $4.00 \mathrm{~N} 29.00 \mathrm{E}$ & 184 & 81 & $G$ & 7638 & G & 7094 & 53481 IS \\
\hline $4.00 \mathrm{~N} 29.00 \mathrm{E}$ & 185 & 81 & $G$ & 7638 & G & 7094 & 53481 IS \\
\hline $4.00 \mathrm{~N} 29.00 \mathrm{E}$ & 185 & 80 & G & 6055 & G & 5753 & 53479 IS \\
\hline $4.00 \mathrm{~N} 29.00 \mathrm{E}$ & 185 & 78 & G & 3781 & G & 3566 & 38733 IS \\
\hline 4.00N29.00E & 185 & 81 & G & 7638 & G & 7094 & 53481 IS \\
\hline $4.00 \mathrm{~N} 29.00 \mathrm{E}$ & 186 & 81 & G & 7638 & G & 7094 & 53481 IS \\
\hline $4.00 \mathrm{~N} 29.00 \mathrm{E}$ & 186 & 80 & $G$ & 6055 & G & 5753 & 53479 IS \\
\hline $4.00 \mathrm{~N} 29.00 \mathrm{E}$ & 186 & 81 & $G$ & 7638 & $G$ & 7094 & 53481 IS \\
\hline $4.00 \mathrm{~N} 29.00 \mathrm{E}$ & 186 & 78 & G & 3781 & G & 3566 & 38733 IS \\
\hline 4.00N29.00E & 187 & 81 & G & 7638 & G & 7094 & 53481 IS \\
\hline $4.00 \mathrm{~N} 29.00 \mathrm{E}$ & 187 & 81 & G & 7638 & G & 7094 & 53481 IS \\
\hline $4.00 \mathrm{~N} 29.00 \mathrm{E}$ & 188 & 81 & G & 7638 & G & 7094 & 53481 IS \\
\hline 4.00N29.00E & 188 & 81 & G & 7638 & G & 7094 & 53481 IS \\
\hline $4.00 \mathrm{~N} 29.00 \mathrm{E}$ & 189 & 81 & G & 7638 & G & 7094 & 53481 IS \\
\hline $4.00 \mathrm{~N} 29.00 \mathrm{E}$ & 189 & 81 & $G$ & 7638 & G & 7094 & 53481 IS \\
\hline 4.00N29.00E & 190 & 81 & G & 7638 & G & 7094 & 53481 IS \\
\hline $4.00 \mathrm{~N} 29.00 \mathrm{E}$ & 190 & 81 & G & 7638 & G & 7094 & 53481 IS \\
\hline 4.00N29.00E & 191 & 81 & G & 7638 & G & 7094 & 53481 IS \\
\hline 4.00N29.00E & 191 & 81 & $\mathrm{G}$ & 7638 & G & 7094 & 53481 IS \\
\hline $4.00 \mathrm{~N} 29.00 \mathrm{E}$ & 192 & 81 & $G$ & 7638 & G & 7094 & 53481 IS \\
\hline $4.00 \mathrm{~N} 29.00 \mathrm{E}$ & 192 & 81 & $G$ & 7638 & G & 7094 & 53481 IS \\
\hline $4.00 \mathrm{~N} 29.00 \mathrm{E}$ & 193 & 81 & G & 7638 & G & 7094 & 53481 IS \\
\hline $4.00 \mathrm{~N} 29.00 \mathrm{E}$ & 193 & 81 & G & 7638 & G & 7094 & 53481 IS \\
\hline $4.00 \mathrm{~N} 29.00 \mathrm{E}$ & 194 & 81 & G & 7638 & G & 7094 & 53481 IS \\
\hline $4.00 \mathrm{~N} 29.00 \mathrm{E}$ & 194 & 81 & G & 7638 & G & 7094 & 53481 IS \\
\hline 4.00N29.00E & 196 & 82 & $\mathrm{G}$ & 6534 & G & 6142 & 53737 IS \\
\hline $4.00 \mathrm{~N} 29.00 \mathrm{E}$ & 197 & 83 & G & 6654 & G & 8036 & 53391 IS \\
\hline $4.00 \mathrm{~N} 29.00 \mathrm{E}$ & 197 & 83 & $\mathrm{~T}$ & 5706 & G & 2291 & 55324 IR \\
\hline $4.00 \mathrm{~N} 29.00 \mathrm{E}$ & 198 & 83 & G & 6654 & $\mathrm{G}$ & 8036 & 53391 IR \\
\hline $4.00 \mathrm{~N} 29.00 \mathrm{E}$ & 199 & 84 & G & 6095 & G & 5776 & 47323 IS \\
\hline $4.00 \mathrm{~N} 29.00 \mathrm{E}$ & 200 & 89 & $S$ & 22914 & $S$ & 18122 & $52831 \mathrm{IR}$ \\
\hline $4.00 \mathrm{~N} 29.00 \mathrm{E}$ & 201 & 87 & G & 10944 & $\mathrm{G}$ & 10200 & 60744 IR \\
\hline $4.00 \mathrm{~N} 29.00 \mathrm{E}$ & 202 & 87 & G & 10944 & G & 10200 & 60744 IR \\
\hline $4.00 \mathrm{~N} 29.00 \mathrm{E}$ & 203 & 97 & $S$ & 16662 & $\mathrm{~S}$ & 12433 & 12164 IR \\
\hline $4.00 \mathrm{~N} 29.00 \mathrm{E}$ & 204 & 102 & $\mathrm{~S}$ & 59543 & $\mathrm{~S}$ & 45370 & 66247 IS \\
\hline 4.00N29.00E & 204 & 96 & S & 8198 & $\mathrm{R}$ & 5303 & 3962 IR \\
\hline
\end{tabular}




\begin{tabular}{|c|c|c|c|c|c|c|c|}
\hline PLACE OF & USE REPORT & $3 N$ & \multicolumn{2}{|c|}{$29 \mathrm{E}$} & & & \\
\hline TWP/RNG & POU-ID PO & D-ID & \multicolumn{2}{|c|}{ APP LICATION } & \multicolumn{2}{|c|}{ P ERMIT } & CERT \# USE \\
\hline 4.00N29.00E & 205 & 89 & $\mathrm{~T}$ & 5369 & $S$ & 18122 & 0 IS \\
\hline $4.00 \mathrm{~N} 29.00 \mathrm{E}$ & 205 & 90 & $\mathrm{~T}$ & 5369 & $S$ & 18122 & 0 IS \\
\hline $4.00 \mathrm{~N} 29.00 \mathrm{E}$ & 205 & 0 & $\mathrm{D}$ & 0 & $\mathrm{D}$ & 2583 & 55602 I* $^{*}$ \\
\hline $4.00 \mathrm{~N} 29.00 \mathrm{E}$ & 205 & 89 & $S$ & 22914 & $S$ & 18122 & 52831 IR \\
\hline $4.00 \mathrm{~N} 29.00 \mathrm{E}$ & 206 & 89 & $S$ & 22914 & $\mathrm{~S}$ & 18122 & 52831 IR \\
\hline $4.00 \mathrm{~N} 29.00 \mathrm{E}$ & 206 & 89 & $\mathrm{~T}$ & 5369 & $\mathrm{~S}$ & 18122 & $0 \mathrm{IR}$ \\
\hline 4.00N29.00E & 206 & 90 & $\mathrm{~T}$ & 5369 & $S$ & 18122 & 0 IR \\
\hline $4.00 \mathrm{~N} 29.00 \mathrm{E}$ & 206 & 0 & $\mathrm{D}$ & 0 & $\mathrm{D}$ & 2644 & $2644 I^{*}$ \\
\hline $4.00 \mathrm{~N} 29.00 \mathrm{E}$ & 207 & 89 & $\mathrm{~T}$ & 5369 & $S$ & 18122 & 0 IR \\
\hline $4.00 \mathrm{~N} 29.00 \mathrm{E}$ & 207 & 90 & $\mathrm{~T}$ & 5369 & $S$ & 18122 & $0 \mathrm{IR}$ \\
\hline $4.00 \mathrm{~N} 29.00 \mathrm{E}$ & 207 & 89 & $S$ & 22914 & $S$ & 18122 & 52831 IR \\
\hline 4.00N29.00E & 208 & 89 & $S$ & 22914 & $S$ & 18122 & 52831 IR \\
\hline $4.00 \mathrm{~N} 29.00 \mathrm{E}$ & 208 & 90 & $\mathrm{~T}$ & 5369 & $S$ & 18122 & $0 \mathrm{IR}$ \\
\hline 4.00N29.00E & 208 & 89 & $\mathrm{~T}$ & 5369 & $S$ & 18122 & 0 IR \\
\hline $4.00 \mathrm{~N} 29.00 \mathrm{E}$ & 209 & 91 & G & 1373 & G & 1293 & 31284 IS \\
\hline $4.00 \mathrm{~N} 29.00 \mathrm{E}$ & 210 & 92 & G & 3753 & G & 3543 & 38732 IR \\
\hline $4.00 \mathrm{~N} 29.00 \mathrm{E}$ & 211 & 93 & G & 7655 & G & 7099 & 53079 IM \\
\hline $4.00 \mathrm{~N} 29.00 \mathrm{E}$ & 212 & 94 & G & 7965 & G & 7399 & 53484 IR \\
\hline 4.00N29.00E & 213 & 94 & $\mathrm{G}$ & 7965 & G & 7399 & 53484 IR \\
\hline $4.00 \mathrm{~N} 29.00 \mathrm{E}$ & 10000 & 106 & $\mathrm{~S}$ & 14660 & $\mathrm{~S}$ & 10650 & 11010 IR \\
\hline $4.00 \mathrm{~N} 29.00 \mathrm{E}$ & 10001 & 106 & $S$ & 14660 & $S$ & 10650 & 11010 IR \\
\hline
\end{tabular}


9/21/01

PAGE 1

\begin{tabular}{|c|c|c|c|c|c|c|c|c|}
\hline POIN & T OF DIVER & SION & REP OF & RT $3 \mathrm{~N}$ & $29 \mathrm{E}$ & & & \\
\hline TWP/RNG & POD-ID AP & PLICA & \multicolumn{2}{|c|}{ TI PERMIT } & CERT \# & $\begin{array}{l}\text { USE } \\
\text { (C }\end{array}$ & $\begin{array}{l}\text { RATE } \\
\text { fs/Gpm) }\end{array}$ & $\begin{array}{l}\text { PRIORITY } \\
\text { DATE }\end{array}$ \\
\hline $2.00 \mathrm{~N} 28.00 \mathrm{E}$ & $2 \mathrm{G}$ & 66 & $45 \mathrm{G}$ & 6069 & 615 & 2 IR & & 2 C 9/5/1974 \\
\hline $2.00 \mathrm{~N} 30.00 \mathrm{E}$ & $18 \mathrm{~T}$ & 58 & $47 \mathrm{G}$ & 10 & 672 & 3 IR & 0.3 & 4 C 4/6/1955 \\
\hline $2.00 \mathrm{~N} 30.00 \mathrm{E}$ & $18 \mathrm{~S}$ & 396 & $88 \mathrm{~S}$ & 29537 & 369 & 2 IS & 0.7 & 5 C 4/ 1/1964 \\
\hline $2.00 \mathrm{~N} 30.00 \mathrm{E}$ & $18 \mathrm{~S}$ & 396 & $88 \mathrm{~S}$ & 29537 & 369 & 2 IR & 0.7 & 5 C 4/ 1/1964 \\
\hline $2.00 \mathrm{~N} 30.00 \mathrm{E}$ & $19 \mathrm{G}$ & 10 & $47 \mathrm{G}$ & 910 & 301 & 2 IR & 0.1 & 5 C 7/8/1958 \\
\hline $2.00 \mathrm{~N} 30.00 \mathrm{E}$ & $20 \mathrm{G}$ & 3 & $96 \mathrm{G}$ & 1142 & 286 & $6 \mathrm{IR}$ & 0. & 1 C 6/18/1956 \\
\hline $2.00 \mathrm{~N} 30.00 \mathrm{E}$ & $23 \mathrm{~S}$ & 251 & $29 \mathrm{~S}$ & 19771 & 237 & $7 \mathrm{IR}$ & 0.2 & 2 C 9/28/1950 \\
\hline $2.00 \mathrm{~N} 30.00 \mathrm{E}$ & $24 S$ & 291 & $97 \mathrm{~S}$ & 25222 & 318 & 9 IR & 0.1 & 3 C 5/25/1954 \\
\hline $2.00 \mathrm{~N} 30.00 \mathrm{E}$ & $25 \mathrm{~S}$ & 515 & $61 \mathrm{~S}$ & 38899 & 524 & 0 IR & 1.1 & 4 C 12/19/1973 \\
\hline $2.00 \mathrm{~N} 30.00 \mathrm{E}$ & $26 \mathrm{~S}$ & 536 & $29 \mathrm{~S}$ & 40118 & 618 & 1 IR & 0.9 & 7 C 9/12/1975 \\
\hline 2.00N30.00E & $27 S$ & 536 & $29 S$ & 40118 & 618 & 1 IR & 0.9 & 7 C 9/12/1975 \\
\hline $3.00 \mathrm{~N} 28.00 \mathrm{E}$ & $1 G$ & 33 & $34 \mathrm{G}$ & 3131 & 376 & $6 \mathrm{DO}$ & 0.0 & 7 C 1/6/1966 \\
\hline $3.00 \mathrm{~N} 28.00 \mathrm{E}$ & $2 \mathrm{G}$ & 33 & $34 \mathrm{G}$ & 3131 & 376 & $6 \mathrm{DO}$ & 0.0 & 7 C 1/6/1966 \\
\hline $3.00 \mathrm{~N} 28.00 \mathrm{E}$ & $3 S$ & 171 & $18 \mathrm{~S}$ & 12847 & 141 & 5 IS & & 3 C 9/24/1937 \\
\hline 3.00N28.00E & $4 \mathrm{~S}$ & 171 & $18 \mathrm{~S}$ & 12847 & 141 & 5 IS & & 3 C $9 / 24 / 1937$ \\
\hline $3.00 \mathrm{~N} 28.00 \mathrm{E}$ & $5 \mathrm{G}$ & 63 & $68 \mathrm{G}$ & 5964 & 516 & 4 IR & 0.9 & 5 C 12/11/1973 \\
\hline $3.00 \mathrm{~N} 28.00 \mathrm{E}$ & $6 \mathrm{G}$ & 74 & $93 \mathrm{G}$ & 6969 & 516 & 6 IS & 0.9 & 5 C 8/25/1976 \\
\hline 3.00N28.00E & $7 \mathrm{~S}$ & 539 & $61 \mathrm{~S}$ & 40707 & 548 & $6 \mathrm{IR}$ & & 4 C $2 / 27 / 1976$ \\
\hline $3.00 \mathrm{~N} 28.00 \mathrm{E}$ & $7 S$ & 613 & $29 \mathrm{~S}$ & 46560 & 537 & 3 IR & 1.1 & 1 C 3/6/1981 \\
\hline $3.00 \mathrm{~N} 28.00 \mathrm{E}$ & $44 \mathrm{~S}$ & 516 & $1 \mathrm{~S}$ & 39173 & 545 & 5 IR & 5.7 & 9 C $1 / 10 / 1974$ \\
\hline $3.00 \mathrm{~N} 28.00 \mathrm{E}$ & $44 \mathrm{~T}$ & 36 & $21 \mathrm{D}$ & 1443732 & & 0 IS & & $1 /$ \\
\hline $3.00 \mathrm{~N} 28.00 \mathrm{E}$ & $44 \mathrm{~S}$ & 516 & $45 \mathrm{~S}$ & 38943 & 537 & 2 IR & 0.7 & 5 C 2/7/1974 \\
\hline $3.00 \mathrm{~N} 28.00 \mathrm{E}$ & $44 \mathrm{~S}$ & 539 & $35 \mathrm{~s}$ & 40238 & 512 & $4 \mathrm{IR}$ & & 2 C 2/23/1976 \\
\hline 3.00N28.00E & $44 \mathrm{~S}$ & 651 & $31 \mathrm{~s}$ & 47820 & 537 & 4 IR & 0.4 & 3 C 5/19/1983 \\
\hline 3.00N28.00E & $44 \mathrm{~T}$ & 54 & $94 \mathrm{D}$ & 1443732 & & 0 IS & & / I \\
\hline $3.00 \mathrm{~N} 28.00 \mathrm{E}$ & $44 \mathrm{~T}$ & 60 & $91 \mathrm{~S}$ & 46568 & & 0 IR & & $1 /$ \\
\hline $3.00 \mathrm{~N} 28.00 \mathrm{E}$ & $45 \mathrm{G}$ & 73 & $53 \mathrm{G}$ & 6781 & 545 & 8 IS & 1.6 & 3 C 5/3/1976 \\
\hline $3.00 \mathrm{~N} 28.00 \mathrm{E}$ & $46 \mathrm{~S}$ & 685 & $87 \mathrm{~S}$ & 51126 & & 0 IS & 0.9 & 8 C 10/ 8/1985 \\
\hline $3.00 \mathrm{~N} 28.00 \mathrm{E}$ & $46 \mathrm{G}$ & 114 & $44 \mathrm{G}$ & 11148 & & $0 \mathrm{IR}$ & 0.5 & 3 C 10/ 8/1985 \\
\hline 3.00N28.00E & $46 \mathrm{~S}$ & 542 & $15 \mathrm{~S}$ & 40576 & 545 & 6 IS & 2.2 & 3 C 5/3/1976 \\
\hline 3.00N28.00E & $46 \mathrm{G}$ & 111 & $82 \mathrm{G}$ & 10292 & 644 & $1 \mathrm{IR}$ & 1.3 & 3 C 10/14/1983 \\
\hline $3.00 \mathrm{~N} 28.00 \mathrm{E}$ & $46 \mathrm{G}$ & 111 & $82 \mathrm{G}$ & 10292 & 644 & 1 IS & 1.3 & 3 C 10/14/1983 \\
\hline $3.00 \mathrm{~N} 28.00 \mathrm{E}$ & $47 \mathrm{G}$ & 111 & $82 \mathrm{G}$ & 10292 & 644 & 1 IS & 1.3 & 3 C 10/14/1983 \\
\hline 3.00N28.00E & $48 \mathrm{G}$ & 64 & $29 \mathrm{G}$ & 6038 & 537 & $6 \mathrm{IR}$ & & 9 C 2/12/1974 \\
\hline $3.00 \mathrm{~N} 28.00 \mathrm{E}$ & $48 \mathrm{G}$ & 64 & $29 \mathrm{G}$ & 6038 & 537 & 36 IS & & 9 C 2/12/1974 \\
\hline $3.00 \mathrm{~N} 28.00 \mathrm{E}$ & $49 \mathrm{G}$ & 64 & $29 G$ & 6038 & 537 & 36 IS & & 9 C 2/12/1974 \\
\hline $3.00 \mathrm{~N} 28.00 \mathrm{E}$ & $49 \mathrm{G}$ & 64 & $29 \mathrm{G}$ & 6038 & 537 & 36 IR & & 9 C 2/12/1974 \\
\hline 3.00N28.00E & $50 \mathrm{G}$ & 80 & $15 \mathrm{G}$ & 8470 & 537 & 6 IS & 0.8 & 9 C 4/11/1977 \\
\hline $3.00 \mathrm{~N} 28.00 \mathrm{E}$ & $50 \mathrm{G}$ & 80 & $15 \mathrm{G}$ & 8470 & 537 & 6 IR & 0.8 & 9 C 4/11/1977 \\
\hline $3.00 \mathrm{~N} 28.00 \mathrm{E}$ & $51 \mathrm{G}$ & 66 & $77 \mathrm{G}$ & 6229 & 545 & 57 IS & & 6 C 10/1/1974 \\
\hline $3.00 \mathrm{~N} 28.00 \mathrm{E}$ & $51 \mathrm{G}$ & 114 & $44 \mathrm{G}$ & 11148 & & 0 IR & 0.5 & 3 C 10/ 8/1985 \\
\hline $3.00 \mathrm{~N} 28.00 \mathrm{E}$ & $52 \mathrm{~S}$ & 376 & $13 \mathrm{~s}$ & 28053 & 369 & 9 IR & & 9 C 5/ 4/1962 \\
\hline $3.00 \mathrm{~N} 28.00 \mathrm{E}$ & $53 \mathrm{~S}$ & 387 & $65 \mathrm{~S}$ & 28936 & 369 & 20 IS & 0.5 & 8 C 5/20/1963 \\
\hline 3.00N28.00E & $54 \mathrm{~T}$ & 65 & $32 \mathrm{CG}$ & 6574 & & $0 \mathrm{IR}$ & 1.1 & 5 C 9/17/1975 \\
\hline $3.00 \mathrm{~N} 28.00 \mathrm{E}$ & $54 \mathrm{~T}$ & 65 & $32 \mathrm{CG}$ & 3 6574 & & 0 IS & 1.1 & 5 C 9/17/1975 \\
\hline $3.00 \mathrm{~N} 28.00 \mathrm{E}$ & $55 \mathrm{~T}$ & 65 & $32 \mathrm{CC}$ & 6574 & & 0 IR & 1.1 & 5 C 9/17/1975 \\
\hline $3.00 \mathrm{~N} 28.00 \mathrm{E}$ & $55 \mathrm{~T}$ & 65 & $32 \mathrm{CG}$ & 6574 & & 0 IS & 1.1 & 5 C 9/17/1975 \\
\hline $3.00 \mathrm{~N} 28.00 \mathrm{E}$ & $55 \mathrm{G}$ & 124 & $81 \mathrm{G}$ & 12438 & & 0 IS & 2.2 & 4 C $4 / 8 / 1991$ \\
\hline
\end{tabular}




\begin{tabular}{|c|c|c|c|c|c|c|c|c|}
\hline \multirow[b]{2}{*}{ TWP/RNG } & \multirow{2}{*}{$\begin{array}{l}\text { T OF DIVER } \\
\text { POD-ID AP }\end{array}$} & \multirow{2}{*}{$\begin{array}{l}\text { SION } \\
\text { PLICA }\end{array}$} & \multicolumn{2}{|c|}{ REP ORT $3 \mathrm{~N}$} & \multicolumn{2}{|l|}{$29 \mathrm{E}$} & \multirow[b]{2}{*}{$\begin{array}{l}\text { RATE } \\
\text { fs/Gpm) }\end{array}$} & \multirow[b]{2}{*}{$\begin{array}{l}\text { PRIORITY } \\
\text { DATE }\end{array}$} \\
\hline & & & TI PE & RMIT & CERT \# & $\begin{array}{l}\text { USE } \\
\text { (C }\end{array}$ & & \\
\hline $3.00 \mathrm{~N} 28.00 \mathrm{E}$ & $56 \mathrm{G}$ & 110 & $77 \mathrm{G}$ & 10234 & 6111 & 4 IS & 1.5 & 2 C 9/8/1983 \\
\hline $3.00 \mathrm{~N} 28.00 \mathrm{E}$ & $56 \mathrm{G}$ & 110 & $77 \mathrm{G}$ & 10234 & 6111 & 4 IR & 1.5 & 2 C 9/8/1983 \\
\hline $3.00 \mathrm{~N} 28.00 \mathrm{E}$ & $68 \mathrm{G}$ & 41 & $65 \mathrm{G}$ & 4048 & 3667 & 6 IR & 1.5 & 7 C 12/18/1967 \\
\hline $3.00 \mathrm{~N} 28.00 \mathrm{E}$ & $69 \mathrm{G}$ & 64 & $76 \mathrm{G}$ & 5275 & 6153 & 0 IR & 3.0 & 3 C 3/26/1974 \\
\hline $3.00 \mathrm{~N} 28.00 \mathrm{E}$ & $70 \mathrm{G}$ & 64 & $76 \mathrm{G}$ & 5275 & 6153 & 0 IR & 5.2 & 3 C 3/26/1974 \\
\hline $3.00 \mathrm{~N} 28.00 \mathrm{E}$ & $71 \mathrm{G}$ & 64 & $76 \mathrm{G}$ & 5275 & 6153 & 0 IR & 4.1 & 3 C 3/26/1974 \\
\hline $3.00 \mathrm{~N} 28.00 \mathrm{E}$ & $72 \mathrm{G}$ & 64 & $76 \mathrm{G}$ & 5275 & 6153 & 0 IR & 3.5 & 8 C 3/26/1974 \\
\hline $3.00 \mathrm{~N} 28.00 \mathrm{E}$ & $73 \mathrm{G}$ & 92 & $5 \mathrm{G}$ & 8570 & 5178 & 3 IS & & 2 C $4 / 19 / 1979$ \\
\hline $3.00 \mathrm{~N} 28.00 \mathrm{E}$ & $73 \mathrm{G}$ & 92 & $5 \mathrm{G}$ & 8570 & 5178 & 3 IR & & 2 C 4/19/1979 \\
\hline $3.00 \mathrm{~N} 28.00 \mathrm{E}$ & $73 \mathrm{~T}$ & 63 & $80 \mathrm{~S}$ & 6893 & & 0 IR & & $1 /$ \\
\hline $3.00 \mathrm{~N} 28.00 \mathrm{E}$ & $74 \mathrm{~T}$ & 63 & $80 \mathrm{~s}$ & 6936 & & 0 IR & & / / \\
\hline 3.00N28.00E & $74 \mathrm{G}$ & 92 & $5 \mathrm{G}$ & 8570 & 5178 & 3 IS & 2.0 & 1 C 4/19/1979 \\
\hline $3.00 \mathrm{~N} 28.00 \mathrm{E}$ & $74 \mathrm{G}$ & 92 & $5 \mathrm{G}$ & 8570 & 5178 & 3 IR & 2.0 & 1 C 4/19/1979 \\
\hline $3.00 \mathrm{~N} 28.00 \mathrm{E}$ & $75 \mathrm{~T}$ & 63 & $80 \mathrm{~S}$ & 7036 & & 0 IS & & $1 /$ \\
\hline $3.00 \mathrm{~N} 28.00 \mathrm{E}$ & $75 \mathrm{G}$ & 92 & $5 \mathrm{G}$ & 8570 & 5178 & 3 IR & & 2 C 4/19/1979 \\
\hline $3.00 \mathrm{~N} 28.00 \mathrm{E}$ & $75 \mathrm{~T}$ & 63 & $80 \mathrm{~S}$ & 7036 & & 0 IR & & $1 /$ \\
\hline $3.00 \mathrm{~N} 28.00 \mathrm{E}$ & $75 \mathrm{G}$ & 92 & $5 \mathrm{G}$ & 8570 & 5178 & 3 IS & & 2 C 4/19/1979 \\
\hline 3.00N28.00E & $80 \mathrm{G}$ & 58 & $20 \mathrm{G}$ & 5812 & 5120 & 5 IR & 4.8 & 8 C 6/12/1972 \\
\hline $3.00 \mathrm{~N} 29.00 \mathrm{E}$ & $5 \mathrm{G}$ & 87 & $72 \mathrm{G}$ & 8126 & 5628 & 2 IR & 1.9 & 2 C 4/27/1978 \\
\hline $3.00 \mathrm{~N} 29.00 \mathrm{E}$ & $6 \mathrm{G}$ & 87 & $72 \mathrm{G}$ & 8126 & 5411 & 8 IR & & $1 /$ \\
\hline $3.00 \mathrm{~N} 29.00 \mathrm{E}$ & $7 \mathrm{~T}$ & 57 & $61 \mathrm{~s}$ & 36410 & 5560 & 5 IR & 0.3 & 3 C 3/1/1972 \\
\hline $3.00 \mathrm{~N} 29.00 \mathrm{E}$ & $7 \mathrm{~T}$ & 56 & $99 \mathrm{D}$ & 2583 & 5560 & 4 IR & 0.4 & 1 C 9/11/1894 \\
\hline 3.00N29.00E & $9 \mathrm{G}$ & 14 & $9 \mathrm{G}$ & 1321 & 3761 & $5 \mathrm{MU}$ & 1.3 & 4 C 3/6/1959 \\
\hline $3.00 \mathrm{~N} 29.00 \mathrm{E}$ & $10 \mathrm{G}$ & 26 & $69 \mathrm{G}$ & 2474 & 3348 & $8 \mathrm{MU}$ & 0.2 & 2 C 7/29/1963 \\
\hline 3.00N29.00E & $11 \mathrm{G}$ & 26 & $73 \mathrm{G}$ & 2477 & 3348 & $9 \mathrm{MU}$ & 0.3 & 3 C 7/29/1963 \\
\hline $3.00 \mathrm{~N} 29.00 \mathrm{E}$ & $12 \mathrm{G}$ & 26 & $96 \mathrm{G}$ & 2501 & 3568 & 0 is & 0.2 & 7 C 8/28/1963 \\
\hline 3.00N29.00E & $13 \mathrm{G}$ & 50 & $43 \mathrm{G}$ & 4753 & 4093 & 1 IS & 0.6 & 5 C 11/25/1969 \\
\hline $3.00 \mathrm{~N} 29.00 \mathrm{E}$ & $13 \mathrm{G}$ & 50 & $43 \mathrm{G}$ & 4753 & 4093 & 1 IR & 0.6 & 5 C 11/25/1969 \\
\hline $3.00 \mathrm{~N} 29.00 \mathrm{E}$ & $14 \mathrm{G}$ & 57 & $12 \mathrm{G}$ & 5517 & 6041 & 7 IR & 0.0 & 5 C $1 / 27 / 1972$ \\
\hline 3.00N29.00E & $15 \mathrm{G}$ & 71 & $42 \mathrm{G}$ & 6592 & 4610 & 0 IS & 0.3 & 2 C 10/27/1975 \\
\hline 3.00N29.00E & $16 \mathrm{G}$ & 84 & $59 \mathrm{G}$ & 7623 & & $0 \mathrm{MU}$ & 2.2 & 2 C 9/22/1977 \\
\hline $3.00 \mathrm{~N} 29.00 \mathrm{E}$ & $17 \mathrm{G}$ & 84 & $59 \mathrm{G}$ & 7623 & & $\mathrm{OMU}$ & 2. & 2 C 3/5/1996 \\
\hline $3.00 \mathrm{~N} 29.00 \mathrm{E}$ & $18 \mathrm{G}$ & 88 & $65 \mathrm{G}$ & 8546 & & $0 \mathrm{MU}$ & 2. & 9 C 6/21/1978 \\
\hline $3.00 \mathrm{~N} 29.00 \mathrm{E}$ & $19 \mathrm{G}$ & 88 & $65 \mathrm{G}$ & 8546 & & $0 \mathrm{MU}$ & & 2 C 6/21/1978 \\
\hline $3.00 \mathrm{~N} 29.00 \mathrm{E}$ & $20 \mathrm{G}$ & 110 & $32 \mathrm{G}$ & 10196 & 6371 & 8 IR & 0.1 & 9 C 7/21/1983 \\
\hline 3.00N29.00E & $21 U$ & 4 & $71 \mathrm{U}$ & 427 & 2081 & $4 \mathrm{IR}$ & 0.07 & 5 C 3/7/1952 \\
\hline 3.00N29.00E & $22 \mathrm{~T}$ & 61 & $39 \mathrm{G}$ & 4748 & 6367 & 5 IS & 0.4 & 7 C 11/17/1969 \\
\hline 3.00N29.00E & $22 \mathrm{G}$ & & $42 \mathrm{G}$ & 44 & 2608 & 0 IS & & / I \\
\hline 3.00N29.00E & $23 \mathrm{~T}$ & 61 & $39 \mathrm{G}$ & 1854 & 6876 & 4 IS & & 11 \\
\hline $3.00 \mathrm{~N} 29.00 \mathrm{E}$ & $23 \mathrm{~T}$ & 61 & $39 \mathrm{G}$ & 4748 & 6876 & 5 IS & & I I \\
\hline $3.00 \mathrm{~N} 29.00 \mathrm{E}$ & $24 S$ & 386 & $81 \mathrm{~S}$ & 29198 & 3517 & 4 IR & 0.0 & 4 C 4/26/1963 \\
\hline $3.00 \mathrm{~N} 29.00 \mathrm{E}$ & $25 \mathrm{G}$ & 18 & $90 \mathrm{G}$ & 1729 & 3348 & 6 IS & & $1 /$ \\
\hline 3.00N29.00E & $25 \mathrm{~S}$ & 342 & $7 \mathrm{~S}$ & 26863 & 3348 & 7 IS & & 5 C 8/ 8/1960 \\
\hline 3.00N29.00E & $26 S$ & 176 & $17 S$ & 13306 & 1434 & 6 IR & & 6 C 10/1/1938 \\
\hline $3.00 \mathrm{~N} 29.00 \mathrm{E}$ & $27 \mathrm{~S}$ & 176 & $17 \mathrm{~S}$ & 13306 & 1434 & 6 IS & & 6 C 10/1/1938 \\
\hline $3.00 \mathrm{~N} 29.00 \mathrm{E}$ & $28 \mathrm{~S}$ & 176 & $17 \mathrm{~S}$ & 13306 & 1434 & 6 IS & & I I \\
\hline $3.00 \mathrm{~N} 29.00 \mathrm{E}$ & $29 \mathrm{G}$ & 21 & $41 \mathrm{G}$ & 1977 & 3680 & 1 IR & 1.7 & 9 C 10/30/1961 \\
\hline $3.00 \mathrm{~N} 29.00 \mathrm{E}$ & $30 \mathrm{G}$ & 61 & $53 \mathrm{G}$ & 6097 & 4955 & 6 IR & 0.08 & 8 C 5/31/1973 \\
\hline 3.00N29.00E & $30 \mathrm{G}$ & 61 & $53 \mathrm{G}$ & 6097 & 4955 & $6 \mathrm{IR}$ & 1.3 & 6 C 5/31/1973 \\
\hline
\end{tabular}




\begin{tabular}{|c|c|c|c|c|c|c|c|c|}
\hline \multirow[b]{2}{*}{ TWP/RNG } & \multirow{2}{*}{$\begin{array}{l}\text { T OF DIVER } \\
\text { POD-ID AP }\end{array}$} & \multirow{2}{*}{$\begin{array}{l}\text { SION } \\
\text { PLICA }\end{array}$} & \multicolumn{2}{|c|}{ REP ORT $3 \mathrm{~N}$} & \multicolumn{2}{|l|}{$29 \mathrm{E}$} & \multirow[b]{2}{*}{$\begin{array}{l}\text { RATE } \\
\text { fs/Gpm) }\end{array}$} & \multirow[b]{2}{*}{$\begin{array}{l}\text { PRIORITY } \\
\text { DATE }\end{array}$} \\
\hline & & & \multicolumn{2}{|c|}{ TI PERMIT } & CERT \# & $\begin{array}{l}\text { USE } \\
\text { (C }\end{array}$ & & \\
\hline $3.00 \mathrm{~N} 29.00 \mathrm{E}$ & $30 \mathrm{G}$ & 61 & $53 \mathrm{G}$ & 6097 & 4955 & $6 \mathrm{IS}$ & 0.08 & 8 C 5/31/1973 \\
\hline $3.00 \mathrm{~N} 29.00 \mathrm{E}$ & $30 \mathrm{G}$ & 61 & $53 \mathrm{G}$ & 6097 & 4955 & 6 IS & 1.36 & 6 C 5/31/1973 \\
\hline $3.00 \mathrm{~N} 29.00 \mathrm{E}$ & $31 \mathrm{G}$ & 124 & $16 \mathrm{G}$ & 12132 & & 0 IR & 0.5 & 5 C 2/19/1991 \\
\hline $3.00 \mathrm{~N} 29.00 \mathrm{E}$ & $32 \mathrm{D}$ & & $0 \mathrm{D}$ & 2535 & 253 & $5 \mathrm{I}^{*}$ & 0.4 & 6 C 12/31/1883 \\
\hline $3.00 \mathrm{~N} 29.00 \mathrm{E}$ & $32 \mathrm{D}$ & & $0 \mathrm{D}$ & 2577 & 257 & $71^{*}$ & 0.0 & 5 C 12/31/1903 \\
\hline $3.00 \mathrm{~N} 29.00 \mathrm{E}$ & $32 \mathrm{~s}$ & 93 & $49 \mathrm{~S}$ & 6179 & 753 & $6 \mathrm{IR}$ & 0.1 & 5 C $1 / 21 / 1924$ \\
\hline $3.00 \mathrm{~N} 29.00 \mathrm{E}$ & $32 \mathrm{D}$ & & $0 \mathrm{D}$ & 2491 & 5351 & $5 \mathrm{I}^{*}$ & 0.6 & 3 C 12/31/1896 \\
\hline $3.00 \mathrm{~N} 29.00 \mathrm{E}$ & $33 \mathrm{G}$ & 66 & $81 \mathrm{G}$ & 6233 & & 0 IR & 1.3 & 5 C 10/3/1974 \\
\hline $3.00 \mathrm{~N} 29.00 \mathrm{E}$ & $33 \mathrm{G}$ & 66 & $81 \mathrm{G}$ & 6233 & & 0 IS & 1.3 & 5 C 10/ 3/1974 \\
\hline $3.00 \mathrm{~N} 29.00 \mathrm{E}$ & $34 \mathrm{G}$ & 113 & $50 \mathrm{G}$ & 10538 & & $0 \mathrm{IM}$ & & 0 G 2/21/1985 \\
\hline $3.00 \mathrm{~N} 29.00 \mathrm{E}$ & $35 \mathrm{G}$ & & $21 \mathrm{G}$ & 64 & 3438 & $6 \mathrm{MU}$ & 0.8 & 9 C 9/24/1953 \\
\hline 3.00N29.00E & $36 \mathrm{G}$ & 71 & $25 \mathrm{G}$ & 6339 & 6001 & 9 IR & $1.4 \varepsilon$ & 8 C 10/ 1/1975 \\
\hline $3.00 \mathrm{~N} 29.00 \mathrm{E}$ & $37 \mathrm{G}$ & 71 & $25 \mathrm{G}$ & 6339 & 6001 & 9 IR & $1.4 \varepsilon$ & 8 C 10/ 1/1975 \\
\hline 3.00N29.00E & $38 \mathrm{~S}$ & 311 & $10 \mathrm{~s}$ & 24516 & 2617 & 8 IS & 0.15 & 5 C 9/11/1956 \\
\hline $3.00 \mathrm{~N} 29.00 \mathrm{E}$ & $39 \mathrm{~S}$ & 458 & $23 \mathrm{~S}$ & 34194 & 4094 & 9 IR & 0.2 & 8 C 2/28/1969 \\
\hline $3.00 \mathrm{~N} 29.00 \mathrm{E}$ & $39 \mathrm{~S}$ & 519 & $43 \mathrm{~S}$ & 37406 & 4500 & 0 IR & 0.1 & 5 C 5/15/1974 \\
\hline $3.00 \mathrm{~N} 29.00 \mathrm{E}$ & $39 \mathrm{~S}$ & 93 & $50 \mathrm{~S}$ & 6180 & 516 & 9 IR & 0.0 & 9 C 1/21/1924 \\
\hline $3.00 \mathrm{~N} 29.00 \mathrm{E}$ & $41 \mathrm{G}$ & 73 & $11 \mathrm{G}$ & 7078 & 6153 & 4 IR & 4. & 6 C 3/30/1976 \\
\hline $3.00 \mathrm{~N} 29.00 \mathrm{E}$ & $42 \mathrm{G}$ & 73 & $11 \mathrm{G}$ & 7078 & 6153 & 4 IR & 4. & 6 C 3/30/1976 \\
\hline 3.00N29.00E & $43 \mathrm{G}$ & 66 & $73 \mathrm{G}$ & 6010 & 6153 & 1 IR & 2. & 9 C 9/26/1974 \\
\hline 3.00N29.00E & $44 \mathrm{G}$ & 79 & $23 G$ & 7314 & 6153 & $5 \mathrm{IR}$ & 1.6 & 2 C $3 / 14 / 1977$ \\
\hline $3.00 \mathrm{~N} 29.00 \mathrm{E}$ & $45 U$ & 1 & $75 \mathrm{U}$ & 168 & 1961 & $3 \mathrm{MU}$ & & 1 C 8/24/1945 \\
\hline $3.00 \mathrm{~N} 29.00 \mathrm{E}$ & $46 \mathrm{U}$ & 492 & U & 444 & 2468 & 0 IR & & $1 /$ \\
\hline $3.00 \mathrm{~N} 29.00 \mathrm{E}$ & $47 \mathrm{G}$ & 114 & $57 \mathrm{G}$ & 10664 & 6111 & 5 IS & 2. & 5 C 11/29/1985 \\
\hline $3.00 \mathrm{~N} 29.00 \mathrm{E}$ & $48 \mathrm{~S}$ & 479 & $28 \mathrm{~S}$ & 35811 & 5475 & $8 \mathrm{IR}$ & & 11 \\
\hline $3.00 \mathrm{~N} 29.00 \mathrm{E}$ & $48 \mathrm{~S}$ & 617 & $36 \mathrm{~S}$ & 47673 & 6111 & 6 IR & & 11 \\
\hline $3.00 \mathrm{~N} 29.00 \mathrm{E}$ & $48 \mathrm{~S}$ & 617 & $36 \mathrm{~S}$ & 47673 & 6111 & $6 \mathrm{IR}$ & 3.6 & 2 C 7/ 1/1982 \\
\hline 3.00N29.00E & $49 \mathrm{G}$ & 70 & $31 \mathrm{G}$ & 6095 & 6153 & 3 IR & 1. & 8 C 6/30/1975 \\
\hline $3.00 \mathrm{~N} 29.00 \mathrm{E}$ & $50 \mathrm{G}$ & 70 & $31 \mathrm{G}$ & 6095 & 6153 & 3 IR & 3.0 & 6 C 6/30/1975 \\
\hline $3.00 \mathrm{~N} 29.00 \mathrm{E}$ & $51 \mathrm{G}$ & 64 & $75 \mathrm{G}$ & 6099 & 5182 & $6 \mathrm{IR}$ & 1.6 & 4 C 3/26/1974 \\
\hline 3.00N29.00E & $52 \mathrm{G}$ & 64 & $75 \mathrm{G}$ & 6099 & 5182 & $6 \mathrm{IR}$ & 1.6 & 4 C $3 / 26 / 1974$ \\
\hline $3.00 \mathrm{~N} 29.00 \mathrm{E}$ & $53 \mathrm{D}$ & & $0 \mathrm{D}$ & 2507 & 250 & $7 \mathrm{I}^{*}$ & 2.07 & 7 C 7/ 1/1884 \\
\hline $3.00 \mathrm{~N} 29.00 \mathrm{E}$ & $54 \mathrm{G}$ & 89 & $76 \mathrm{G}$ & 8369 & 5308 & 2 IR & 4. & 6 C 10/20/1978 \\
\hline 3.00N29.00E & $54 \mathrm{G}$ & 89 & $76 \mathrm{G}$ & 8369 & 5308 & 2 IR & & 6 C 10/20/1978 \\
\hline 3.00N29.00E & $55 \mathrm{G}$ & 89 & $76 \mathrm{G}$ & 8369 & 5308 & 2 IR & & $1 /$ \\
\hline $3.00 \mathrm{~N} 29.00 \mathrm{E}$ & $56 \mathrm{~S}$ & 93 & $65 \mathrm{~s}$ & 6183 & 753 & $7 \mathrm{IR}$ & $0.1 s$ & 9 C 2/ 2/1924 \\
\hline $3.00 \mathrm{~N} 29.00 \mathrm{E}$ & $57 \mathrm{~S}$ & 388 & $4 \mathrm{~S}$ & 30114 & 3667 & 9 IR & 0.3 & 2 C 2/23/1965 \\
\hline $3.00 \mathrm{~N} 29.00 \mathrm{E}$ & $58 \mathrm{~S}$ & 538 & $87 \mathrm{~S}$ & 40208 & 5307 & 2 IS & 0.6 & 3 C 2/3/1976 \\
\hline 3.00N29.00E & $59 \mathrm{~S}$ & 88 & $83 \mathrm{~S}$ & 5819 & 515 & 7 IR & 0.0 & 3 C 3/28/1923 \\
\hline $3.00 \mathrm{~N} 29.00 \mathrm{E}$ & $61 \mathrm{G}$ & 76 & $6 \mathrm{G}$ & 7041 & 5307 & 8 IR & 1.5 & 7 C 12/15/1976 \\
\hline 3.00N29.00E & $62 \mathrm{G}$ & 71 & $95 \mathrm{G}$ & 6626 & 4973 & 3 IR & 7.5 & 5 C 12/29/1975 \\
\hline $3.00 \mathrm{~N} 29.00 \mathrm{E}$ & $63 \mathrm{G}$ & 71 & $95 \mathrm{G}$ & 6626 & 4973 & 3 IR & 7.5 & 5 C 12/29/1975 \\
\hline $3.00 \mathrm{~N} 29.00 \mathrm{E}$ & $64 \mathrm{G}$ & 77 & $28 \mathrm{G}$ & 7367 & 5038 & 0 IR & & / I \\
\hline 3.00N29.00E & $65 \mathrm{~T}$ & 56 & $99 \mathrm{D}$ & 2583 & 5560 & 3 IR & 0.1 & 3 C 9/11/1894 \\
\hline $3.00 \mathrm{~N} 30.00 \mathrm{E}$ & $7 \mathrm{G}$ & 89 & $10 \mathrm{G}$ & 8367 & 5318 & 8 IR & 4.38 & 8 C 8/ 2/1978 \\
\hline $3.00 \mathrm{~N} 30.00 \mathrm{E}$ & $7 \mathrm{G}$ & 71 & $53 \mathrm{G}$ & 6600 & 5317 & $8 \mathrm{IR}$ & 2. & 2 C $11 / 12 / 1975$ \\
\hline $3.00 \mathrm{~N} 30.00 \mathrm{E}$ & $7 \mathrm{G}$ & 86 & $58 \mathrm{G}$ & 8041 & 5318 & $7 \mathrm{IR}$ & 0.68 & 8 C 2/21/1978 \\
\hline $3.00 \mathrm{~N} 30.00 \mathrm{E}$ & $7 \mathrm{G}$ & 89 & $10 \mathrm{G}$ & 8367 & 5318 & 8 IS & 4.38 & $8 \mathrm{C} 8 / 2 / 1978$ \\
\hline
\end{tabular}




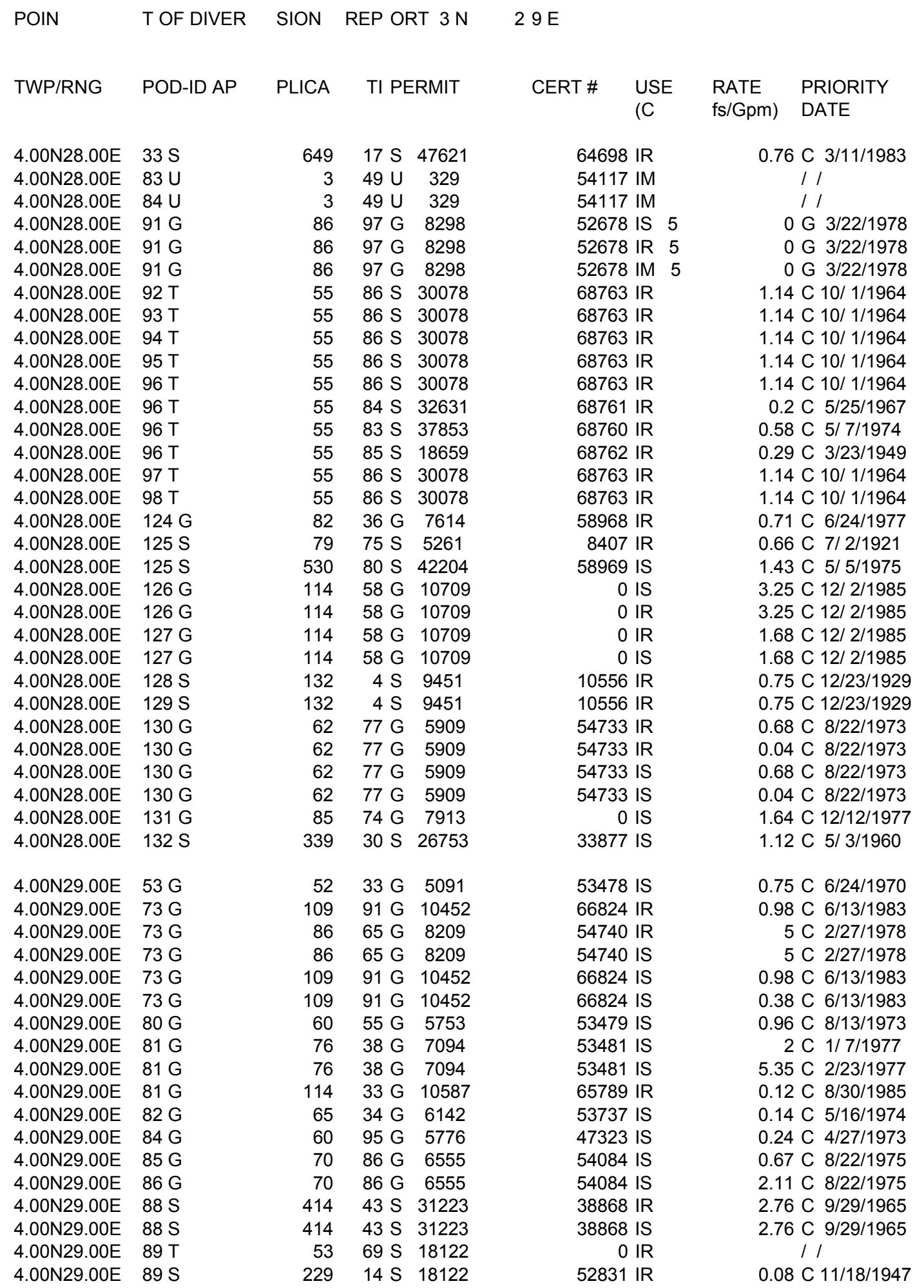




\begin{tabular}{|c|c|c|c|c|c|c|c|c|}
\hline \multirow[b]{2}{*}{ TWP/RNG } & \multirow{2}{*}{$\begin{array}{l}\text { T OF DIVER } \\
\text { POD-ID AP }\end{array}$} & \multirow{2}{*}{$\begin{array}{l}\text { SION } \\
\text { PLICA }\end{array}$} & \multicolumn{2}{|c|}{ REP ORT $3 \mathrm{~N}$} & \multicolumn{2}{|l|}{$29 \mathrm{E}$} & \multirow[b]{2}{*}{$\begin{array}{l}\text { RATE } \\
\text { fs/Gpm) }\end{array}$} & \multirow[b]{2}{*}{$\begin{array}{l}\text { PRIORITY } \\
\text { DATE }\end{array}$} \\
\hline & & & TI PEF & RMIT & CERT \# & $\begin{array}{l}\text { USE } \\
\text { (C }\end{array}$ & & \\
\hline 4.00N29.00E & $89 \mathrm{~T}$ & 53 & $69 \mathrm{~s}$ & 18122 & & 0 IS & & 11 \\
\hline 4.00N29.00E & $90 \mathrm{~T}$ & 53 & $69 \mathrm{~S}$ & 18122 & & 0 IR & & / I \\
\hline $4.00 \mathrm{~N} 29.00 \mathrm{E}$ & $90 \mathrm{~T}$ & 53 & $69 \mathrm{~S}$ & 18122 & & 0 IS & & 11 \\
\hline 4.00N29.00E & $91 \mathrm{G}$ & 13 & $73 \mathrm{G}$ & 1293 & 312 & 4 IS & 0.4 & C 2/6/1959 \\
\hline $4.00 \mathrm{~N} 29.00 \mathrm{E}$ & $92 \mathrm{G}$ & 37 & $53 \mathrm{G}$ & 3543 & 387 & $2 \mathrm{IR}$ & 0.0 & C $12 / 9 / 1966$ \\
\hline $4.00 \mathrm{~N} 29.00 \mathrm{E}$ & $93 \mathrm{G}$ & 76 & $55 \mathrm{G}$ & 7099 & 530 & $9 \mathrm{IM}$ & 0.0 & C $1 / 24 / 1977$ \\
\hline $4.00 \mathrm{~N} 29.00 \mathrm{E}$ & $94 \mathrm{G}$ & 79 & $65 \mathrm{G}$ & 7399 & 534 & 4 IR & 0.0 & + C $3 / 29 / 1977$ \\
\hline $4.00 \mathrm{~N} 29.00 \mathrm{E}$ & $95 \mathrm{~S}$ & 726 & $86 \mathrm{~S}$ & 52029 & & 0 IR 1 & & A $9 / 14 / 1992$ \\
\hline 4.00N29.00E & $95 \mathrm{R}$ & 726 & $85 \mathrm{R}$ & 11700 & & D ST & 10. & A $9 / 14 / 1992$ \\
\hline 4.00N29.00E & $96 \mathrm{~S}$ & 81 & $98 \mathrm{R}$ & 5303 & 39 & 2 IR & & 11 \\
\hline $4.00 \mathrm{~N} 29.00 \mathrm{E}$ & $97 \mathrm{~S}$ & 166 & $62 \mathrm{~s}$ & 12433 & 121 & $4 \mathrm{IR}$ & 0.4 & C 11/5/1936 \\
\hline 4.00N29.00E & $98 \mathrm{~S}$ & 573 & $47 \mathrm{~S}$ & 43323 & 530 & 3 IR & 0.0 & C $4 / 26 / 1978$ \\
\hline $4.00 \mathrm{~N} 29.00 \mathrm{E}$ & $99 \mathrm{~S}$ & 684 & $8 \mathrm{~S}$ & 49487 & & 0 IR & 0.0 & 3 C 6/24/1985 \\
\hline 4.00N29.00E & $99 \mathrm{~S}$ & 684 & $8 \mathrm{~s}$ & 49487 & & O IR & 0.06 & B C 8/5/1985 \\
\hline $4.00 \mathrm{~N} 29.00 \mathrm{E}$ & $100 \mathrm{~S}$ & 335 & $80 \mathrm{~S} 2$ & 26564 & 312 & 4 IS & 0.4 & 7 C $1 / 28 / 1960$ \\
\hline 4.00N29.00E & $101 \mathrm{~S}$ & 500 & $29 \mathrm{~S} 3$ & 37612 & 534 & $1 \mathrm{IR}$ & 0.0 & 2 C 2/6/1973 \\
\hline 4.00N29.00E & $102 S$ & 595 & $43 S$ & 45370 & 662 & 7 IS & 0.7 & 1 C 12/7/1979 \\
\hline $4.00 \mathrm{~N} 29.00 \mathrm{E}$ & $102 \mathrm{~S}$ & 595 & $43 \mathrm{~s}$ & 45370 & 662 & $7 \mathrm{IR}$ & 0.7 & 1 C 12/7/1979 \\
\hline 4.00N29.00E & $103 \mathrm{G}$ & 44 & $78 \mathrm{G}$ & 4220 & 411 & 0 IR & 0.0 & 3 C 7/ 3/1968 \\
\hline 4.00N29.00E & $104 \mathrm{G}$ & 50 & $76 \mathrm{G}$ & 4794 & 410 & $6 \mathrm{IR}$ & 0.0 & 3 C $1 / 15 / 1970$ \\
\hline $4.00 \mathrm{~N} 29.00 \mathrm{E}$ & $105 \mathrm{G}$ & 64 & $39 \mathrm{G}$ & 6042 & 534 & $3 \mathrm{IR}$ & 0.3 & 1 C $2 / 21 / 1974$ \\
\hline $4.00 \mathrm{~N} 29.00 \mathrm{E}$ & $106 \mathrm{~S}$ & 146 & $60 \mathrm{~s}$ & 10650 & 110 & 0 IR & 0.2 & 5 C 7/26/1932 \\
\hline 4.00N29.00E & $107 \mathrm{~S}$ & 480 & $70 \mathrm{~S} 3$ & 36058 & 484 & 3 IR & 0.16 & 6 C 6/16/1971 \\
\hline $4.00 \mathrm{~N} 29.00 \mathrm{E}$ & $108 \mathrm{~S}$ & 615 & $6 \mathrm{~s}$ & 45800 & 622 & 7 IS & 0.0 & 4 C 4/7/1981 \\
\hline 4.00N29.00E & $110 \mathrm{G}$ & 62 & $16 \mathrm{G}$ & 5221 & 447 & 8 IS & 0.12 & 2 C $7 / 9 / 1973$ \\
\hline $4.00 \mathrm{~N} 29.00 \mathrm{E}$ & $111 \mathrm{G}$ & 93 & $53 \mathrm{G}$ & 8629 & 534 & $6 \mathrm{IR}$ & 0.0 & 2 C 8/10/1979 \\
\hline 4.00N29.00E & $112 \mathrm{G}$ & 107 & $73 \mathrm{G}$ & 9955 & 636 & 7 IR & 0.0 & 5 C 7/9/1982 \\
\hline 4.00N29.00E & $113 \mathrm{G}$ & 116 & $81 \mathrm{G}$ & 10778 & 687 & $4 \mathrm{IR}$ & 0.3 & ( C $7 / 13 / 1987$ \\
\hline 4.00N29.00E & $114 \mathrm{~S}$ & 71 & $50 \mathrm{~S}$ & 4543 & 32 & $6 \mathrm{IR}$ & 0.0 & 3 C $3 / 16 / 1920$ \\
\hline $4.00 \mathrm{~N} 29.00 \mathrm{E}$ & 114 GR & 38 & $99 \mathrm{GR}$ & 0 & 35 & 2 IR & & $1 /$ \\
\hline This report & printed fo & $r$ req & ues $t$ rec & q_100 & 1346 & & & \\
\hline The map exte & $\mathrm{nt}$ is for & Towns & & & & & & \\
\hline
\end{tabular}

$\begin{array}{lll}\text { The followin } & \text { glayers a } & \text { re sh own on the m a p - } \\ \text { Roads } & & \\ \text { Streams and } & \text { Lakes } & \\ \text { Township/Ran } & \text { ge and Sec } & \text { tions } \\ \text { City boundar } & \text { ies and na } & \text { mes } \\ \text { Surface wate } & r \text { rights } & \\ \text { Groundwater } & \text { rights } \\ \text { Places of Us } & \text { e } & \\ \text { Points of Di } & \text { version }\end{array}$

$\begin{array}{llllcl}\text { The water ri } & \text { ghts repor } & \text { ted } \mathrm{h} & \text { ere have bee } & \mathrm{n} \text { interpret } & \text { ed by } \mathrm{D} \text { epartmen } \mathrm{t} \text { staff } \\ \text { from Departm } & \text { ent files } & \text { and } \mathrm{a} & \text { re intended } & \mathrm{t} \text { o represen } \mathrm{t} \text { that interpre tation } \\ \text { graphically. } & \text { Locations } & \text { show } & \mathrm{n} \text { o } \mathrm{n} \text { the map } & \text { are only a pproxim ate and should } \\ \text { not be used } & \text { for legal, } & \text { fina } & \mathrm{nci} \text { al or rea } & \text { I estate de cisions . For mo re } \\ \text { accurate leg } & \text { al locatio } & \mathrm{n} \text { inf } & \text { orm ation, } \mathrm{pl} & \mathrm{e} \text { ase contac } \mathrm{t} \text { the } \mathrm{D} \text { epartmen } \mathrm{t} \text {. }\end{array}$




\section{Appendix: B}

Echo Meadows Historic Diversions 
Allen Canal TOTAL MONTHLY DIVERSION (ac/ft)

\begin{tabular}{|c|c|c|c|c|c|c|c|c|c|c|c|c|c|}
\hline \multirow{3}{*}{$\begin{array}{r}\text { water year } \\
1930\end{array}$} & \multirow[b]{2}{*}{ October } & \multirow[b]{2}{*}{ November } & \multirow[b]{2}{*}{ December } & \multicolumn{2}{|l|}{ Allen Canal } & \multicolumn{3}{|c|}{ IOIAL MIONIHLY DIVERSION (ac/ft) } & \multirow[b]{2}{*}{ June } & \multirow[b]{2}{*}{ July } & & & \multirow{3}{*}{$\begin{array}{l}\text { Tot. Ann. } \\
6430.6\end{array}$} \\
\hline & & & & January & February & March & April & May & & & Aug & September & \\
\hline & 0.0 & 0.0 & 0.0 & 0.0 & 0.0 & 0.0 & 1185.3 & 986.8 & 1241.7 & 971.9 & 944.1 & 1100.8 & \\
\hline 1931 & 0.0 & 0.0 & 0.0 & 0.0 & 0.0 & 216.8 & 398.7 & 1134.1 & 857.1 & 824.3 & 677.4 & 864.4 & 4972.8 \\
\hline 1932 & 1291.2 & 384.8 & 0.0 & 0.0 & 0.0 & 0.0 & 872.3 & 936.2 & 1019.5 & 1042.5 & 1057.8 & 1111.7 & 7716.1 \\
\hline 1933 & 1241.7 & 242.0 & 0.0 & 0.0 & 0.0 & 0.0 & 1529.3 & 1243.6 & 1215.9 & 1134.5 & 1011.6 & 1015.5 & 8634.0 \\
\hline 1934 & 1628.4 & 662.5 & 0.0 & 0.0 & 0.0 & 610.9 & 1085.0 & 991.7 & 1088.9 & 920.3 & 688.3 & 297.5 & 7973.6 \\
\hline 1935 & 1207.9 & 406.6 & 698.2 & 743.8 & 31.7 & 676.4 & 1432.1 & 1223.8 & 1140.5 & 1005.6 & 846.9 & 964.0 & 10377.5 \\
\hline 1936 & 1188.1 & 793.4 & 565.3 & 404.6 & 0.0 & 366.9 & 1069.1 & 1295.2 & 1102.8 & 928.3 & 1221.8 & 1106.8 & 10042.3 \\
\hline 1937 & 1285.3 & 916.4 & 0.0 & 0.0 & 0.0 & 57.5 & 1053.2 & 1769.3 & 1162.3 & 1186.1 & 1122.6 & 1174.2 & 9726.9 \\
\hline 1938 & 1174.2 & 884.6 & 45.6 & 0.0 & 0.0 & 125.0 & 1190.1 & 1217.9 & 1136.5 & 1122.6 & 971.9 & 858.8 & 8727.3 \\
\hline 1939 & 434.4 & 0.0 & 0.0 & 0.0 & 101.2 & 454.2 & 1206.0 & 1174.2 & 932.2 & 1071.1 & 759.7 & 811.2 & 6944.1 \\
\hline 1940 & 1224.8 & 295.5 & 0.0 & 0.0 & 0.0 & 486.5 & 1194.2 & 1243.6 & 1114.7 & 864.8 & 900.5 & 1114.7 & 8439.5 \\
\hline 1941 & 1066.1 & 169.6 & 123.0 & 123.0 & 111.1 & 505.8 & 1028.4 & 1069.1 & 954.0 & 1199.0 & 816.2 & 94.2 & 7259.5 \\
\hline 1942 & 294.3 & 0.0 & 0.0 & 0.0 & 0.0 & 50.6 & 1405.3 & 957.0 & 1205.0 & 1289.3 & 1075.0 & 1088.9 & 7365.4 \\
\hline 1943 & 1360.7 & 87.9 & 0.0 & 0.0 & 0.0 & 0.0 & 308.6 & 633.1 & 920.7 & 1108.8 & 1164.3 & 991.5 & 6575.6 \\
\hline 1944 & 700.6 & 89.3 & 92.2 & 92.2 & 115.0 & 123.0 & 994.3 & 1101.0 & 1213.5 & 1386.4 & 1227.8 & 1449.3 & 8584.7 \\
\hline 1945 & 562.7 & 12.9 & 61.5 & 61.5 & 55.1 & 69.2 & 1017.5 & 522.2 & 1391.6 & 1279.3 & 1034.4 & 989.0 & 7057.0 \\
\hline 1946 & 919.5 & 19.2 & 0.0 & 0.0 & 0.0 & 0.0 & 1158.9 & 922.9 & 1283.9 & 857.9 & 912.8 & 1267.4 & 7342.6 \\
\hline 1947 & 1214.1 & 147.6 & 0.0 & 0.0 & 0.0 & 0.0 & 720.4 & 1343.8 & 1047.9 & 918.5 & 640.1 & 1109.2 & 7141.5 \\
\hline 1948 & 301.5 & 0.0 & 0.0 & 0.0 & 0.0 & 34.9 & 710.1 & 718.6 & 1123.2 & 807.1 & 783.3 & 1015.7 & 5494.4 \\
\hline 1949 & 917.8 & 985.6 & 7.3 & 0.0 & 0.0 & 0.0 & 580.4 & 1284.3 & 915.6 & 895.3 & 721.6 & 899.7 & 7207.5 \\
\hline 1950 & 771.2 & 24.6 & 0.0 & 0.0 & 0.0 & 9.3 & 489.1 & 1221.2 & 587.3 & 799.9 & 639.9 & 714.8 & 5257.4 \\
\hline 1951 & 1034.0 & 9.9 & 0.0 & 0.0 & 0.0 & 0.0 & 1285.9 & 515.3 & 843.4 & 811.8 & 637.7 & 599.0 & 5737.0 \\
\hline 1952 & 870.1 & 158.5 & 0.0 & 0.0 & 0.0 & 0.0 & 1283.3 & 304.1 & 612.7 & 550.4 & 602.6 & 480.2 & 4861.9 \\
\hline 1953 & 630.3 & 0.0 & 0.0 & 0.0 & 0.0 & 112.3 & 883.4 & 729.3 & 817.0 & 778.3 & 714.2 & 652.4 & 5317.3 \\
\hline 1954 & 561.9 & 48.0 & 0.0 & 0.0 & 0.0 & 28.8 & 1132.6 & 718.6 & 419.5 & 1011.8 & 692.8 & 560.5 & 5174.5 \\
\hline 1955 & 242.2 & 163.4 & 0.0 & 0.0 & 0.0 & 29.8 & 744.0 & 647.8 & 795.2 & 713.1 & 711.5 & 435.2 & 4482.0 \\
\hline 1956 & 122.2 & 0.0 & 0.0 & 0.0 & 0.0 & 1.4 & 885.8 & 680.9 & 725.6 & 801.5 & 705.3 & 367.9 & 4290.6 \\
\hline 1957 & 591.3 & 0.0 & 0.0 & 0.0 & 0.0 & 41.5 & 771.6 & 670.4 & 693.6 & 655.1 & 624.0 & 511.9 & 4559.4 \\
\hline 1958 & 470.7 & 103.9 & 0.0 & 0.0 & 0.0 & 65.9 & 234.4 & 617.7 & 743.6 & 906.2 & 772.0 & 604.0 & 4518.3 \\
\hline 1959 & 656.1 & 257.9 & 0.0 & 0.0 & 0.0 & 122.2 & 893.8 & 434.4 & 674.0 & 758.9 & 638.7 & 337.6 & 4773.4 \\
\hline 1960 & 404.0 & 91.2 & 0.0 & 0.0 & 0.0 & 54.9 & 918.7 & 382.8 & 781.9 & 745.2 & 758.9 & 673.4 & 4811.1 \\
\hline 1961 & 624.2 & 317.8 & 47.0 & 0.0 & 0.0 & 178.1 & 639.3 & 619.6 & 766.0 & 910.2 & 747.6 & 760.5 & 5610.2 \\
\hline 1962 & 840.6 & 4.8 & 0.0 & 0.0 & 0.0 & 27.6 & 792.4 & 709.7 & 672.4 & 850.7 & 646.6 & 807.3 & 5352.0 \\
\hline 1963 & 652.2 & 60.5 & 0.0 & 0.0 & 0.0 & 115.6 & 688.7 & 483.8 & 646.6 & 789.4 & 1060.0 & 850.7 & 5347.4 \\
\hline 1964 & 1680.4 & 491.5 & 0.0 & 0.0 & 0.0 & 172.0 & 486.5 & 778.7 & 599.6 & 602.6 & 786.6 & 844.8 & 6442.7 \\
\hline 1965 & 169.2 & 0.0 & 0.0 & 0.0 & 0.0 & 0.0 & 682.3 & 662.7 & 541.9 & 720.6 & 773.4 & 602.4 & 4152.4 \\
\hline 1966 & 785.5 & 0.0 & 0.0 & 0.0 & 0.0 & 5.6 & 858.0 & 756.7 & 404.0 & 715.8 & 793.0 & 522.4 & 4841.1 \\
\hline 1967 & 501.0 & 0.0 & 0.0 & 0.0 & 0.0 & 372.1 & 658.1 & 871.1 & 639.9 & 746.4 & 803.3 & 895.1 & 5487.1 \\
\hline 1968 & 423.7 & 0.0 & 0.0 & 0.0 & 0.0 & 453.6 & 645.2 & 620.8 & 460.2 & 718.2 & 713.1 & 909.6 & 4944.4 \\
\hline 1969 & 389.6 & 0.0 & 0.0 & 0.0 & 0.0 & 0.0 & 510.3 & 554.8 & 537.5 & 977.3 & 892.0 & 375.7 & 4237.1 \\
\hline 1970 & 317.4 & 40.1 & 0.0 & 0.0 & 0.0 & 0.0 & 513.5 & 483.4 & 632.3 & 896.5 & 951.7 & 290.0 & 4124.8 \\
\hline 1971 & 66.4 & 0.0 & 0.0 & 0.0 & 0.0 & 3.6 & 749.8 & 778.1 & 424.7 & 917.0 & 945.7 & 359.2 & 4244.4 \\
\hline
\end{tabular}




\begin{tabular}{|c|c|c|c|c|c|c|c|c|c|c|c|c|c|}
\hline 1972 & 511.7 & 24.2 & 0.0 & 0.0 & 0.0 & 0.0 & 487.7 & 822.3 & 819.2 & 1118.3 & 1087.1 & 707.3 & 5577.9 \\
\hline 1973 & 392.1 & 1.2 & 0.0 & 0.0 & 0.0 & 58.5 & 871.7 & 872.3 & 767.6 & 719.2 & 876.5 & 908.0 & 5467.2 \\
\hline 1974 & 625.2 & 0.2 & 0.0 & 0.0 & 0.0 & 0.0 & 422.5 & 663.1 & 664.1 & 711.3 & 800.0 & 900.0 & 4786.3 \\
\hline 1975 & 1021.1 & 1.4 & 0.0 & 0.0 & 0.0 & 0.0 & 400.7 & 1064.3 & 696.6 & 979.4 & 954.2 & 482.6 & 5600.3 \\
\hline 1976 & 366.9 & 0.0 & 0.0 & 0.0 & 0.0 & 0.0 & 484.2 & 1168.5 & 667.2 & 885.4 & 939.8 & 475.8 & 4987.8 \\
\hline 1977 & 632.5 & 0.0 & 0.0 & 0.0 & 0.0 & 354.8 & 1037.4 & 1029.8 & 499.2 & 1019.7 & 1156.6 & 340.4 & 6070.4 \\
\hline 1978 & 329.3 & 0.0 & 0.0 & 0.0 & 0.0 & 6.3 & 703.5 & 958.0 & 681.1 & 964.0 & 726.7 & 529.8 & 4898.8 \\
\hline 1979 & 186.4 & 232.7 & 0.0 & 0.0 & 0.0 & 0.0 & 257.1 & 738.8 & 654.7 & 507.2 & 415.3 & 116.4 & 3108.7 \\
\hline 1980 & 574.0 & 129.0 & 24.0 & 21.0 & 6.0 & 111.0 & 759.0 & 797.0 & 808.0 & 835.0 & 780.0 & 682.0 & 5526.0 \\
\hline 1981 & 413.0 & 352.0 & 0.0 & 0.0 & 0.0 & 0.0 & 734.0 & 893.0 & 461.0 & 776.0 & 673.0 & 578.0 & 4880.0 \\
\hline 1982 & 296.0 & 0.0 & 0.0 & 0.0 & 0.0 & 0.0 & 469.0 & 976.0 & 832.0 & 950.0 & 850.0 & 728.0 & 5101.0 \\
\hline 1983 & 88.0 & 0.0 & 0.0 & 0.0 & 0.0 & 0.0 & 575.0 & 927.0 & 995.0 & 914.0 & 844.0 & 936.0 & 5279.0 \\
\hline 1984 & 1.0 & 0.0 & 0.0 & 0.0 & 0.0 & 0.0 & 76.0 & 908.0 & 903.0 & 1009.0 & 973.0 & 282.0 & 4152.0 \\
\hline 1985 & 2.0 & 0.0 & 0.0 & 0.0 & 0.0 & 0.0 & 843.0 & 351.0 & 588.0 & 748.0 & 535.0 & 651.0 & 3718.0 \\
\hline 1986 & 12.0 & 0.0 & 0.0 & 0.0 & 0.0 & 0.0 & 592.0 & 601.0 & 755.0 & 572.0 & 658.0 & 544.0 & 3734.0 \\
\hline 1987 & 307.0 & 243.0 & 0.0 & 0.0 & 0.0 & 60.0 & 1323.0 & 804.0 & 732.0 & 736.0 & 807.0 & 767.0 & 5779.0 \\
\hline 1988 & 355.4 & 18.4 & 0.0 & 0.0 & 0.0 & 509.0 & 617.3 & 655.7 & 749.4 & 909.0 & 533.4 & 434.8 & 4782.4 \\
\hline 1989 & 729.9 & 0.0 & 0.0 & 0.0 & 0.0 & 0.0 & 581.2 & 206.3 & 676.4 & 821.2 & 575.2 & 559.3 & 4149.4 \\
\hline 1990 & 87.3 & 0.0 & 0.0 & 0.0 & 0.0 & 767.6 & 1124.6 & 386.8 & 537.5 & 628.8 & 458.2 & 608.9 & 4599.7 \\
\hline 1991 & 341.2 & 0.0 & 0.0 & 0.0 & 0.0 & 0.0 & 886.6 & 575.2 & 726.0 & 676.4 & 618.8 & 503.8 & 4327.9 \\
\hline 1992 & 152.7 & 0.0 & 0.0 & 0.0 & 18.4 & 202.7 & 801.3 & 717.6 & 501.6 & 441.5 & 677.8 & 427.0 & 3940.7 \\
\hline 1993 & 81.3 & 0.0 & 0.0 & 0.0 & 0.0 & 0.0 & 0.0 & 563.3 & 317.4 & 279.7 & 408.6 & 450.2 & 2100.5 \\
\hline 1994 & 226.1 & 0.0 & 0.0 & 0.0 & 0.0 & 0.0 & 444.3 & 372.9 & 553.4 & 551.4 & 630.7 & 523.6 & 3302.5 \\
\hline 1995 & 529.6 & 0.0 & 0.0 & 0.0 & 0.0 & 0.0 & 416.5 & 559.3 & 589.1 & 563.3 & 579.2 & 666.4 & 3903.5 \\
\hline 1996 & 329.3 & 0.0 & 0.0 & 0.0 & 0.0 & 0.0 & 172.6 & 827.1 & 543.5 & 610.9 & 521.7 & 591.1 & 3596.0 \\
\hline 1997 & 182.5 & 0.0 & 0.0 & 0.0 & 0.0 & 6.0 & 388.8 & 521.7 & 599.0 & 529.6 & 537.5 & 156.7 & 2921.7 \\
\hline
\end{tabular}




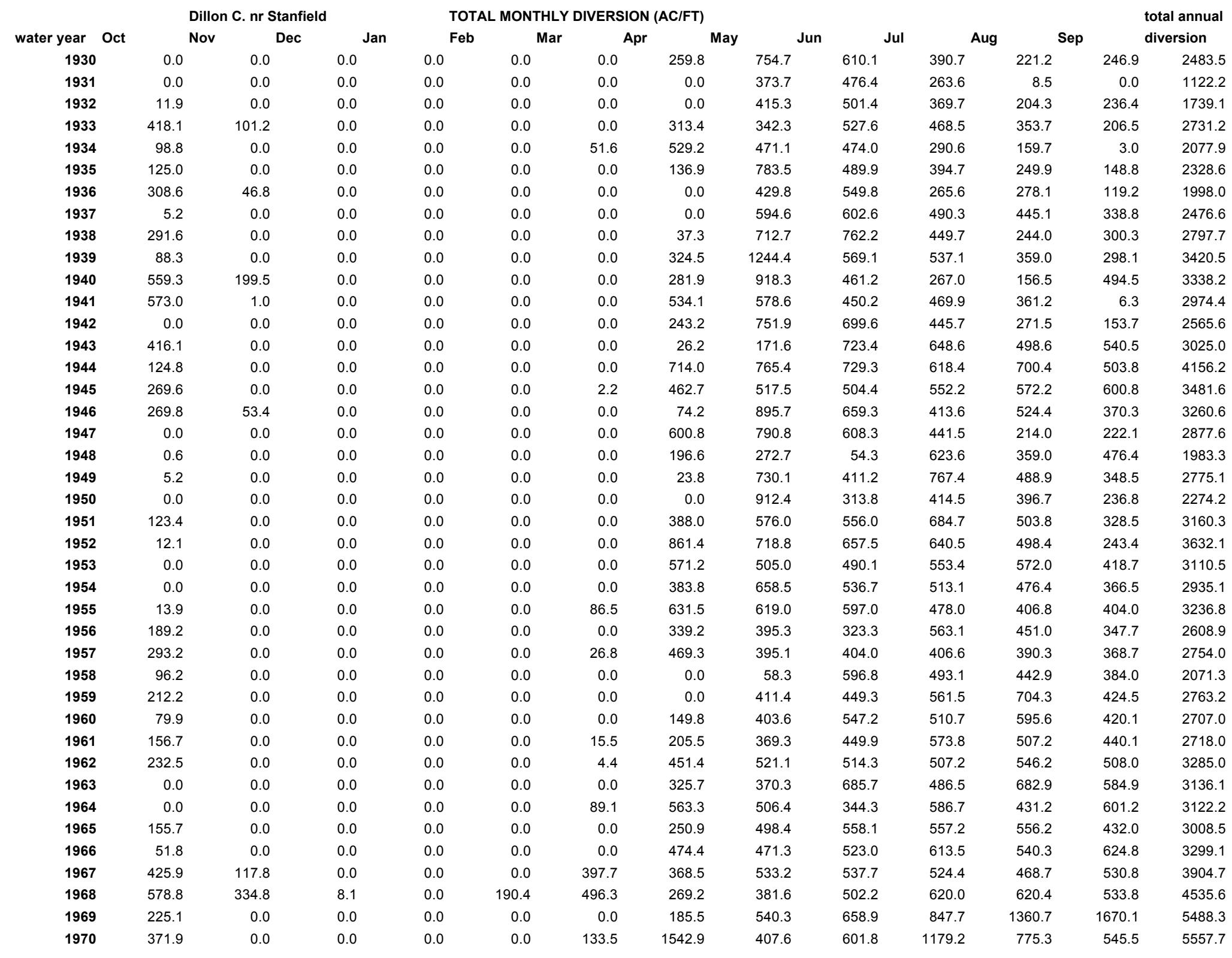




\begin{tabular}{|c|c|c|c|c|c|c|c|c|c|c|c|c|c|}
\hline 1971 & 339.0 & 0.0 & 0.0 & 0.0 & 0.0 & 457.0 & 811.2 & 645.2 & 525.2 & 998.9 & 1059.6 & 361.4 & 5197.5 \\
\hline 1972 & 261.0 & 0.0 & 0.0 & 0.0 & 0.0 & 42.0 & 652.0 & 359.0 & 750.3 & 1025.7 & 972.1 & 354.4 & 4416.6 \\
\hline 1973 & 113.3 & 0.0 & 0.0 & 0.0 & 0.0 & 69.4 & 603.6 & 371.9 & 241.2 & 664.7 & 491.5 & 364.8 & 2920.3 \\
\hline 1974 & 118.2 & 0.0 & 0.0 & 0.0 & 0.0 & 0.0 & 86.9 & 332.4 & 297.3 & 925.3 & 990.5 & 520.9 & 3271.5 \\
\hline 1975 & 37.5 & 0.0 & 0.0 & 0.0 & 0.0 & 0.0 & 461.0 & 581.2 & 651.2 & 1097.9 & 930.2 & 463.3 & 4222.2 \\
\hline 1976 & 210.4 & 0.0 & 0.0 & 0.0 & 0.0 & 0.0 & 68.6 & 728.9 & 680.7 & 1005.6 & 1011.6 & 572.4 & 4278.3 \\
\hline 1977 & 97.2 & 0.0 & 0.0 & 0.0 & 115.4 & 297.1 & 430.6 & 394.7 & 330.6 & 431.2 & 432.0 & 457.0 & 2985.9 \\
\hline 1978 & 168.4 & 11.7 & 0.0 & 0.0 & 0.0 & 0.0 & 265.2 & 429.6 & 549.2 & 651.0 & 575.0 & 319.1 & 2969.3 \\
\hline 1979 & 157.3 & 110.0 & 0.0 & 0.0 & 0.0 & 0.0 & 0.0 & 318.3 & 574.3 & 605.6 & 494.3 & 347.7 & 2607.6 \\
\hline 1980 & 108.0 & 61.0 & 0.0 & 0.0 & 0.0 & 0.0 & 336.9 & 482.2 & 475.0 & 569.7 & 449.9 & 242.8 & 2725.5 \\
\hline 1981 & 33.5 & 0.0 & 0.0 & 0.0 & 0.0 & 0.0 & 310.4 & 383.8 & 355.4 & 615.7 & 452.8 & 520.9 & 2672.5 \\
\hline 1982 & 46.0 & 0.0 & 0.0 & 0.0 & 0.0 & 0.0 & 195.6 & 639.5 & 487.7 & 662.7 & 687.5 & 0.0 & 2719.0 \\
\hline 1983 & 0.0 & 0.0 & 0.0 & 0.0 & 0.0 & 0.0 & 194.2 & 601.9 & 584.3 & 564.0 & 692.0 & 342.4 & 2978.9 \\
\hline 1984 & 19.6 & 0.0 & 0.0 & 0.0 & 0.0 & 0.0 & 35.5 & 366.9 & 450.9 & 502.9 & 506.6 & 275.4 & 2157.9 \\
\hline 1985 & 1.2 & 0.0 & 0.0 & 0.0 & 0.0 & 0.0 & 287.9 & 446.1 & 461.4 & 486.5 & 651.8 & 641.3 & 2976.1 \\
\hline 1986 & 0.0 & 0.0 & 0.0 & 0.0 & 0.0 & 0.0 & 122.6 & 368.3 & 511.3 & 523.2 & 649.8 & 331.5 & 2506.8 \\
\hline 1987 & 5.5 & 0.0 & 0.0 & 0.0 & 0.0 & 0.0 & 399.7 & 351.9 & 370.1 & 524.6 & 524.4 & 270.1 & 2446.4 \\
\hline 1988 & 381.1 & 6.7 & 0.0 & 0.0 & 0.0 & 15.8 & 334.4 & 209.1 & 193.6 & 569.9 & 444.3 & 297.3 & 2452.1 \\
\hline 1989 & 208.3 & 0.0 & 0.0 & 0.0 & 0.0 & 0.0 & 285.6 & 190.4 & 501.8 & 503.8 & 505.8 & 313.4 & 2509.1 \\
\hline 1990 & 166.6 & 0.0 & 0.0 & 0.0 & 0.0 & 0.0 & 368.9 & 468.1 & 289.6 & 454.2 & 370.9 & 452.2 & 2570.6 \\
\hline 1991 & 283.6 & 0.0 & 0.0 & 0.0 & 0.0 & 0.0 & 277.7 & 210.2 & 273.7 & 470.1 & 460.2 & 404.6 & 2380.2 \\
\hline 1992 & 318.8 & 1.7 & 0.0 & 0.0 & 0.0 & 0.0 & 558.3 & 443.5 & 534.3 & 503.2 & 361.8 & 346.9 & 3068.7 \\
\hline 1993 & 307.3 & 0.0 & 0.0 & 0.0 & 0.0 & 0.0 & 128.5 & 479.6 & 347.7 & 574.2 & 461.4 & 309.4 & 2608.2 \\
\hline 1994 & 208.3 & 0.0 & 0.0 & 0.0 & 0.0 & 69.4 & 551.4 & 382.8 & 535.5 & 414.5 & 257.9 & 363.0 & 2782.8 \\
\hline 1995 & 351.1 & 0.0 & 0.0 & 0.0 & 0.0 & 0.0 & 281.7 & 263.8 & 480.0 & 408.6 & 410.6 & 333.2 & 2528.9 \\
\hline 1996 & 188.4 & 0.0 & 0.0 & 0.0 & 0.0 & 0.0 & 162.6 & 184.5 & 390.7 & 513.7 & 370.9 & 390.7 & 2201.7 \\
\hline 1997 & 192.4 & 0.0 & 0.0 & 0.0 & 0.0 & 0.0 & 13.9 & 491.9 & 291.6 & 486.0 & 355.0 & 301.5 & 2132.2 \\
\hline
\end{tabular}


Pioneer - Courtney Canal

Total Monthly Diversion (AC/FT)

\begin{tabular}{rrrrrr} 
water year & October & November & December & January & \multicolumn{2}{l}{ February } \\
1930 & 0.0 & 0.0 & 0.0 & 0.0 & 0.0 \\
1931 & 0.0 & 0.0 & 0.0 & 0.0 & 0.0 \\
1932 & 33.3 & 0.0 & 0.0 & 0.0 & 0.0 \\
1933 & 0.0 & 0.0 & 0.0 & 0.0 & 0.0 \\
1934 & 0.0 & 0.0 & 0.0 & 0.0 & 0.0 \\
1935 & 0.0 & 0.0 & 0.0 & 0.0 & 0.0 \\
1936 & 0.0 & 0.0 & 0.0 & 0.0 & 0.0 \\
1937 & 0.0 & 0.0 & 0.0 & 0.0 & 0.0 \\
1938 & 0.0 & 0.0 & 0.0 & 0.0 & 0.0 \\
1939 & 0.0 & 0.0 & 0.0 & 0.0 & 0.0 \\
1940 & 0.0 & 0.0 & 0.0 & 0.0 & 0.0 \\
1941 & 936.4 & 40.5 & 0.0 & 0.0 & 0.0 \\
1942 & 249.5 & 0.0 & 0.0 & 0.0 & 0.0 \\
1943 & 0.0 & 0.0 & 0.0 & 0.0 & 0.0 \\
1944 & 159.5 & 0.0 & 0.0 & 0.0 & 0.0 \\
1945 & 0.0 & 0.0 & 0.0 & 0.0 & 0.0 \\
1946 & 0.0 & 0.0 & 0.0 & 0.0 & 0.0 \\
1947 & 66.4 & 0.0 & 0.0 & 0.0 & 0.0 \\
1948 & 83.7 & 0.0 & 0.0 & 0.0 & 0.0 \\
1949 & 64.7 & 0.0 & 0.0 & 0.0 & 0.0 \\
1950 & 0.0 & 0.0 & 0.0 & 0.0 & 0.0 \\
1951 & 83.7 & 0.0 & 0.0 & 0.0 & 0.0 \\
1952 & 78.1 & 0.0 & 0.0 & 0.0 & 0.0 \\
1953 & 722.4 & 0.0 & 0.0 & 0.0 & 0.0 \\
1954 & 777.1 & 173.0 & 0.0 & 0.0 & 0.0 \\
1955 & 1100.8 & 331.2 & 0.0 & 0.0 & 0.0 \\
1956 & 954.0 & 14.5 & 0.0 & 0.0 & 0.0 \\
1957 & 208.3 & 0.0 & 0.0 & 0.0 & 0.0 \\
1958 & 298.7 & 0.0 & 0.0 & 0.0 & 0.0 \\
1959 & 752.3 & 37.3 & 0.0 & 0.0 & 0.0 \\
1960 & 41.1 & 0.0 & 0.0 & 0.0 & 0.0 \\
1961 & 873.1 & 57.1 & 0.0 & 0.0 & 0.0 \\
1962 & 378.8 & 0.0 & 0.0 & 0.0 & 0.0 \\
1963 & 0.0 & 0.0 & 0.0 & 0.0 & 0.0 \\
1964 & 0.0 & 0.0 & 0.0 & 0.0 & 0.0 \\
1965 & 132.3 & 0.0 & 0.0 & 0.0 & 0.0 \\
1966 & 133.1 & 0.0 & 0.0 & 0.0 & 0.0 \\
1967 & 641.5 & 22.0 & 0.0 & 0.0 & 0.0 \\
1968 & 334.0 & 0.0 & 0.0 & 0.0 & 0.0 \\
1969 & 643.4 & 1.8 & 0.0 & 0.0 & 0.0 \\
1970 & 19.0 & 0.0 & 0.0 & 0.0 & 0.0 \\
& & & & &
\end{tabular}

March April May

$\begin{array}{lll}0.0 & 1638.3 & \text { June }\end{array}$
476.0 1638.3 1207.9 ne July $1307.9 \quad 1090.9$ $1447.9 \quad 1100.8$ 999.7 $648.6 \quad 1209.9$ 307.0

$\begin{array}{ll}0.0 & 1295.2\end{array}$

$\begin{array}{rr}0.0 & 388.8 \\ 0.0 & 1065.5\end{array}$

366.3$$
\begin{array}{r}
36.0 \\
0.0
\end{array}
$$

297.5

0.0

890.6

690.4

$\begin{array}{rr}0.0 & 726.5 \\ 0.0 & 1065.3\end{array}$

$0.0 \quad 758.7$

25.8

$\begin{array}{rr}0.0 & 1174.2 \\ 15.1 & 1527.3\end{array}$

$15.1 \quad 1527.3$

724.0

2.0
605.2

1241.7
1172.2
1163.7

1463.8
1241.7

1163.7
970.3

$\begin{array}{ll}11.5 & 970.3 \\ 12.9 & 496.5\end{array}$

169.0

27.2

0.0

1255.1

1067.1

1283.7

9.9
803.9

303.5

0.0

1065.5

671.6

$\begin{array}{ll}53.6 & 1081.0\end{array}$

$355.8 \quad 1342.8$

656.9

1102.8

1065.1

1078.8 $\begin{array}{lll}987.8 & 1081.0 & 372.9\end{array}$

$1321.0 \quad 926.3 \quad 625.2$

$1073.1 \quad 1148.4$

1001.7948 .9

1008.0

1170.2

1075.0

862.6

1025.5
833.1

710.3

1253.6

1416.2

1209.5

1275.0

801.9

1160.3

1109.2

1213.9

1041.3

1215.9

898.5

1118.7

$$
878.7
$$

995.7

$\begin{array}{lr}981.8 & 989.8\end{array}$

$930.2 \quad 940.2$

$\begin{array}{ll}930.2 & 940.2 \\ 977.9 & 918.9\end{array}$

891.2

1033.4

1086.9

1100.8

1036.8

1085.0

1055.2

933.6

1102.4

$1202.6 \quad 1261.5$
Aug

September flow

$\begin{array}{rrr}0.0 & 0.0 & 4569.1 \\ 0.0 & 54.1 & 3861.0\end{array}$

$\begin{array}{lll}285.4 & 0.0 & 4712.7 \\ 543.7 & 0.0 & 4308.1\end{array}$

$\begin{array}{lll}543.7 & 0.0 & 4308.1\end{array}$

$\begin{array}{lll}0.0 & 0.0 & 4300.2 \\ 0.0 & 0.0 & 4468.8\end{array}$

$\begin{array}{lll}402.2 & 0.0 & 4688.1\end{array}$

$\begin{array}{lll}202.9 & 505.8 & 3764.4\end{array}$

$\begin{array}{rrr}0.0 & 0.0 & 3779.7 \\ 140.4 & 0.0 & 5325.6\end{array}$

$156.5-0.0-3162.8$

$\begin{array}{lrr}353.1 & 761.7 & 6066.4\end{array}$

$\begin{array}{lll}379.6 & 0.0 & 4477.9\end{array}$

$294.5 \quad 261.0 \quad 3498.4$

$\begin{array}{lll}168.8 & 678.3 \quad 5930.0\end{array}$

$\begin{array}{lll}416.7 & 152.7 & 6740.6\end{array}$

$156.5 \quad 342.3 \quad 6103.3$

$\begin{array}{llrr}731.7 & 509.4 & 323.1 & 4891.6\end{array}$

\begin{tabular}{rrrr}
731.7 & 509.4 & 323.1 & 4891.6 \\
1178.2 & 1295.2 & 1094.9 & 6139.4 \\
\hline 1467.3 & 287.4 & 5206.6
\end{tabular}

$\begin{array}{llll}1124.6 & 558.1 & 505.8 & 5234.8\end{array}$

$\begin{array}{llll}867.2 & 446.1 & 84.1 & 5223.9\end{array}$

$\begin{array}{llll}021.9 & 369.3 & 434.8 & 5689.8\end{array}$

$\begin{array}{llll}1021.1 & 731.9 & 567.7 & 8018.0\end{array}$

$\begin{array}{llll}912.4 & 434.2 & 346.7 & 5892.3\end{array}$

$\begin{array}{llll}989.8 & 708.9 & 329.1 & 7575.7\end{array}$

$\begin{array}{lll}808.3 & 319.7 & 6054.7\end{array}$

$\begin{array}{lll}574.8 & 577.4 & 5297.9\end{array}$

$\begin{array}{lll}462.0 & 323.1 & 4590.1\end{array}$

$\begin{array}{lll}809.5 & 499.0 & 5081.7\end{array}$

$\begin{array}{lll}475.4 & 274.7 & 4897.6\end{array}$

$\begin{array}{lll}266.8 & 528.6 & 5386.7\end{array}$

$\begin{array}{llll}989.8 & 686.1 & 730.7 & 6091.8\end{array}$

$\begin{array}{llll}780.5 & 614.3 & 242.8 & 4568.3\end{array}$

$\begin{array}{llll}1190.1 & 949.7 & 687.9 & 6670.0\end{array}$

$\begin{array}{llll}1112.7 & 969.9 & 654.0 & 5721.7\end{array}$

$\begin{array}{llll}936.6 & 307.8 & 761.9 & 5501.4\end{array}$

$\begin{array}{llll}923.7 & 788.4 & 192.8 & 6891.2\end{array}$

$\begin{array}{llll}794.4 & 537.1 & 1003.6 & 6403.8\end{array}$

$\begin{array}{rrrr}1342.8 & 1192.1 & 681.9 & 6781.3\end{array}$ 


\begin{tabular}{|c|c|c|c|c|c|c|c|c|c|c|c|c|c|}
\hline 1971 & 24.6 & 0.0 & 0.0 & 0.0 & 0.0 & 153.5 & 1191.5 & 1342.8 & 1045.3 & 1196.0 & 1009.6 & 828.5 & 6791.8 \\
\hline 1972 & 679.3 & 339.0 & 0.0 & 0.0 & 0.0 & 0.0 & 928.3 & 1251.6 & 1200.0 & 1217.9 & 1148.4 & 1106.0 & 7870.4 \\
\hline 1973 & 519.7 & 134.9 & 0.0 & 0.0 & 0.0 & 352.3 & 1285.3 & 1168.3 & 1015.5 & 680.7 & 239.6 & 258.4 & 5654.7 \\
\hline 1974 & 1257.5 & 12.7 & 0.0 & 0.0 & 0.0 & 0.0 & 482.0 & 1370.6 & 1328.9 & 1283.3 & 916.4 & 704.5 & 7355.9 \\
\hline 1975 & 1069.5 & 7.5 & 0.0 & 0.0 & 0.0 & 0.0 & 774.5 & 1257.5 & 1152.4 & 969.9 & 884.6 & 956.0 & 7072.1 \\
\hline 1976 & 455.4 & 0.0 & 0.0 & 0.0 & 0.0 & 14.9 & 1114.7 & 1313.1 & 1065.1 & 1229.8 & 1243.6 & 1067.1 & 7503.7 \\
\hline 1977 & 1081.0 & 6.5 & 0.0 & 0.0 & 0.0 & 638.1 & 1124.6 & 1200.0 & 1075.0 & 1059.0 & 792.6 & 450.0 & 7426.9 \\
\hline 1978 & 634.3 & 0.0 & 0.0 & 0.0 & 0.0 & 39.9 & 729.3 & 1102.8 & 1059.2 & 1088.9 & 794.6 & 551.6 & 6000.6 \\
\hline 1979 & 316.0 & 24.0 & 0.0 & 0.0 & 0.0 & 161.0 & 1041.0 & 1133.0 & 1060.0 & 933.0 & 542.0 & 426.0 & 5636.0 \\
\hline 1980 & 316.0 & 24.0 & 0.0 & 0.0 & 0.0 & 161.0 & 1041.0 & 1133.0 & 1060.0 & 933.0 & 542.0 & 426.0 & 5636.0 \\
\hline 1981 & 316.0 & 24.0 & 0.0 & 0.0 & 0.0 & 161.0 & 1041.0 & 1133.0 & 1060.0 & 933.0 & 542.0 & 426.0 & 5636.0 \\
\hline 1982 & 316.0 & 24.0 & 0.0 & 0.0 & 0.0 & 161.0 & 1041.0 & 1133.0 & 1060.0 & 933.0 & 542.0 & 426.0 & 5636.0 \\
\hline 1983 & 316.0 & 24.0 & 0.0 & 0.0 & 0.0 & 161.0 & 1041.0 & 1133.0 & 1060.0 & 933.0 & 542.0 & 426.0 & 5636.0 \\
\hline 1984 & 316.0 & 24.0 & 0.0 & 0.0 & 0.0 & 161.0 & 1041.0 & 1133.0 & 1060.0 & 933.0 & 542.0 & 426.0 & 5636.0 \\
\hline 1985 & 316.0 & 24.0 & 0.0 & 0.0 & 0.0 & 161.0 & 1041.0 & 1133.0 & 1060.0 & 933.0 & 542.0 & 426.0 & 5636.0 \\
\hline 1986 & 316.0 & 24.0 & 0.0 & 0.0 & 0.0 & 161.0 & 1041.0 & 1133.0 & 1060.0 & 933.0 & 542.0 & 426.0 & 5636.0 \\
\hline 1987 & 316.0 & 24.0 & 0.0 & 0.0 & 0.0 & 161.0 & 1041.0 & 1133.0 & 1060.0 & 933.0 & 542.0 & 426.0 & 5636.0 \\
\hline 1988 & 316.0 & 24.0 & 0.0 & 0.0 & 0.0 & 161.0 & 1041.0 & 1133.0 & 1060.0 & 933.0 & 542.0 & 426.0 & 5636.0 \\
\hline 1989 & 316.0 & 24.0 & 0.0 & 0.0 & 0.0 & 161.0 & 1041.0 & 1133.0 & 1060.0 & 933.0 & 542.0 & 426.0 & 5636.0 \\
\hline 1990 & 316.0 & 24.0 & 0.0 & 0.0 & 0.0 & 161.0 & 1041.0 & 1133.0 & 1060.0 & 933.0 & 542.0 & 426.0 & 5636.0 \\
\hline 1991 & 316.0 & 24.0 & 0.0 & 0.0 & 0.0 & 161.0 & 1041.0 & 1133.0 & 1060.0 & 933.0 & 542.0 & 426.0 & 5636.0 \\
\hline 1992 & 316.0 & 24.0 & 0.0 & 0.0 & 0.0 & 161.0 & 1041.0 & 1133.0 & 1060.0 & 933.0 & 542.0 & 426.0 & 5636.0 \\
\hline 1993 & 316.0 & 24.0 & 0.0 & 0.0 & 0.0 & 161.0 & 1041.0 & 1133.0 & 1060.0 & 933.0 & 542.0 & 426.0 & 5636.0 \\
\hline 1994 & 316.0 & 24.0 & 0.0 & 0.0 & 0.0 & 161.0 & 1041.0 & 1133.0 & 1060.0 & 933.0 & 542.0 & 426.0 & 5636.0 \\
\hline 1995 & 316.0 & 24.0 & 0.0 & 0.0 & 0.0 & 161.0 & 1041.0 & 1133.0 & 1060.0 & 933.0 & 542.0 & 426.0 & 5636.0 \\
\hline 1996 & 316.0 & 24.0 & 0.0 & 0.0 & 0.0 & 161.0 & 1041.0 & 1133.0 & 1060.0 & 933.0 & 542.0 & 426.0 & 5636.0 \\
\hline 1997 & 316.0 & 24.0 & 0.0 & 0.0 & 0.0 & 161.0 & 1041.0 & 1133.0 & 1060.0 & 933.0 & 542.0 & 426.0 & 5636.0 \\
\hline
\end{tabular}


Echo Meadows

water year October November December Jan

$\begin{array}{llll}1930 & 0.0 & 0.0 & 0.0\end{array}$

$\begin{array}{llll}1931 & 0.0 & 0.0 & 0.0\end{array}$

$\begin{array}{llll}1932 & 1336.5 & 384.8 & 0.0 \\ 1933 & 1659.8 & 343.1 & 0.0\end{array}$

662.5

$\begin{array}{llll}1935 & 1332.9 & 406.6 & 698.2\end{array}$

$\begin{array}{lllr}1936 & 1496.7 & 840.2 & 565.3\end{array}$

$\begin{array}{llll}1937 & 1290.4 & 916.4 & 0.0\end{array}$

$\begin{array}{llrr}1938 & 1465.8 & 884.6 & 45.6\end{array}$

$\begin{array}{rrrr}1939 & 522.6 & 0.0 & 0.0 \\ 1940 & 1784.1 & 495.1 & 0.0\end{array}$

$\begin{array}{rrrr}1940 & 1784.1 & 495.1 & 0.0 \\ 1941 & 2575.5 & 211.0 & 123.0\end{array}$

$\begin{array}{rrrr}1942 & 543.9 & 0.0 & 0.0\end{array}$

$1943 \quad 1776.8 \quad 87.9$

$1944 \quad 984.8 \quad 89.3$

$1945 \quad 832.3 \quad 12.9$

$1946 \quad 1189.3 \quad 72.6$

$\begin{array}{lrr}947 & 1280.5 & 147.6\end{array}$

$\begin{array}{rrr}1948 & 385.8 & 0.0 \\ 1949 & 987.6 & 985.6\end{array}$

$1950 \quad 771.2 \quad 24.6$

$1951 \quad 1241.1 \quad 9.9$

$1952 \quad 960.4 \quad 158.5$

$\begin{array}{rrr}1953 & 1352.7 & 0.0 \\ 1954 & 1339.0 & 221.0\end{array}$

$\begin{array}{rrr}1954 & 1339.0 & 221.0 \\ 1955 & 1356.9 & 494.7\end{array}$

$\begin{array}{lrr}1956 & 1265.5 & 14.5\end{array}$

$\begin{array}{rrr}1957 & 1092.7 & 0.0 \\ 1958 & 865.6 & 103.9\end{array}$

$1959 \quad 1620.7 \quad 295.1$

$1960 \quad 525.0 \quad 91.2$

$\begin{array}{llll}1961 & 1654.0 & 374.9 & 0.0\end{array}$

$\begin{array}{rrrr}1962 & 1451.9 & 474.9 & 47.0 \\ 1963 & 652.2 & 60.5 & 0.0\end{array}$

$1963 \quad 652.2 \quad 60.5$

$1964 \quad 1680.4 \quad 491.5$

$\begin{array}{lrr}1965 & 457.2 & 0.0\end{array}$

$\begin{array}{lll}1966 & 970.3 & 0.0\end{array}$

$\begin{array}{lll}1967 & 1568.3 & 139.8\end{array}$

$1968 \quad 1336.5 \quad 334.8$

$\begin{array}{rrr}1969 & 1258.1 & 1.8 \\ 1970 & 708.3 & 40.1\end{array}$

$\begin{array}{llr}1971 & 430.0 & 40.1 \\ & & 0.0\end{array}$

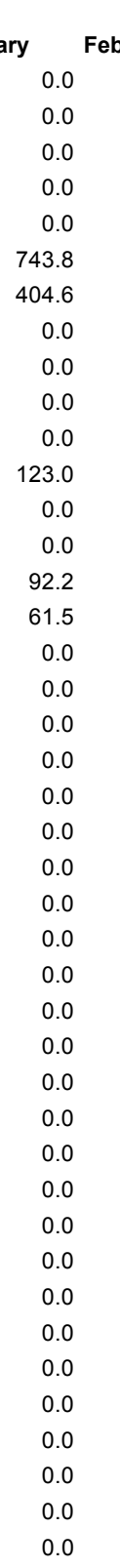

Total Monthly Diversion (AC/FT)

0.0

$0.0^{\text {April }} 3083.5$ May

2949.4

June 2938.7 July

Aug September flow Echo $\begin{array}{lrrrr}1474.5 & 685.9 & 918.5 & 12456.0 & 0.311401\end{array}$

$0.0 \quad 3166.6 \quad 2112.4$

$\begin{array}{lll}1311.1 & 2824.1 & 2450.6\end{array}$

$\begin{array}{lll}983.4 & 2858.2 & 3328.3\end{array}$

$\begin{array}{lll}366.9 & 2364.3 \quad 2798.1\end{array}$

$\begin{array}{lll}57.5 & 1442.0 \quad 3365.6\end{array}$

$125.0 \quad 2292.9$

0.0

101.2

$820.6 \quad 3275.9$

$486.5 \quad 2249.7$

$803.3 \quad 2435.3$

111.1
0.0

0.0

50.6

$\begin{array}{ll}0.0 & 1019.7\end{array}$

$123.0-3239.4$

$690.4 \quad 2611.6$

$0.0 \quad 2047.7$

$\begin{array}{rr}34.9 & 1972.0 \\ 0.0 & 1362.8\end{array}$

$35.1 \quad 1325.4$

$\begin{array}{ll}0.1 & 3672.0\end{array}$

$836.2 \quad 2918.5$

$30.7 \quad 2758.0$

$\begin{array}{ll}721.4 & 2547.8\end{array}$

$\begin{array}{ll}1.4 & 2388.7\end{array}$

$\begin{array}{ll}79.7 & 2211.2\end{array}$

$78.7 \quad 730.9$

$291.2 \quad 893.8$

$104.1 \quad 2323.6$

$220.8 \quad 1911.9$

$47.4 \quad 2527.5$

$125.6 \quad 1818.2$

$\begin{array}{ll}0.0 & 1604.8\end{array}$

$59.1 \quad 2413.5$

$1606.8 \quad 2017.2$

$0.0 \quad 1760.9$

$136.1 \quad 3135.3$

$\begin{array}{ll}614.1 & 2752.5\end{array}$

$\begin{array}{llllll}2621.8 & 2327.2 & 1547.5 & 1348.2 & 16667.9 & 0.416698\end{array}$

$\begin{array}{llllll}2743.1 & 2517.4 & 1908.9 & 1222.0 & 18173.4 & 0.454335\end{array}$

$\begin{array}{llllll}2644.0 & 1583.8 & 847.9 & 300.5 & 16851.6 & 0.42129\end{array}$

$\begin{array}{llllll}2556.7 & 2025.5 & 1096.9 & 1112.7 & 19674.9 & 0.491872\end{array}$

$\begin{array}{llllll}2801.1 & 1963.0 & 1902.1 & 1226.0 & 19228.4 & 0.48071\end{array}$

$\begin{array}{lllllll}2713.8 & 2392.9 & 1770.6 & 2018.8 & 18467.9 & 0.461698\end{array}$

$\begin{array}{llllll}2902.4 & 2274.8 & 1215.9 & 1159.1 & 17804.7 & 0.445117\end{array}$

$\begin{array}{llllll}2637.8 & 2374.8 & 1259.1 & 1109.4 & 18190.2 & 0.454756\end{array}$

$\begin{array}{llllll}2429.8 & 2480.1 & 1530.4 & 862.2 & 18800.4 & 0.470009\end{array}$

$\begin{array}{llllll}2737.6 & 2777.1 & 1726.2 & 1242.6 & 16908.9 & 0.422723\end{array}$

$\begin{array}{llllll}2354.4 & 2729.3 & 1957.5 & 1793.1 & 15599.0 & 0.389976\end{array}$

$\begin{array}{llllll}3196.4 & 2850.6 & 2096.9 & 2631.5 & 21170.8 & 0.52927\end{array}$

$\begin{array}{llllll}3312.2 & 2782.2 & 2023.3 & 1742.5 & 19779.2 & 0.49448\end{array}$

$\begin{array}{lllllll}3152.7 & 2240.7 & 1593.7 & 1980.1 & 19206.6 & 0.480164\end{array}$

$\begin{array}{llllll}2931.2 & 2091.8 & 1363.4 & 1654.4 & 17410.7 & 0.435269\end{array}$

$\begin{array}{llllll}1979.5 & 2850.8 & 2437.5 & 2587.0 & 16117.1 & 0.402928\end{array}$

$\begin{array}{llllll}2487.1 & 2840.9 & 1777.8 & 1535.6 & 17689.2 & 0.442231\end{array}$

$\begin{array}{llllll}2010.2 & 2339.1 & 1594.7 & 1457.5 & 15266.4 & 0.38166\end{array}$

$\begin{array}{llllll}2613.2 & 2363.7 & 1587.6 & 1011.6 & 16621.1 & 0.415528\end{array}$

$\begin{array}{llllll}2311.5 & 2212.8 & 1470.3 & 1158.3 & 16683.8 & 0.417095\end{array}$

$\begin{array}{llllll}2523.0 & 2404.8 & 2018.2 & 1638.7 & 18945.8 & 0.473644\end{array}$

$\begin{array}{llllll}1854.7 & 2437.3 & 1603.4 & 1273.8 & 16501.9 & 0.412548\end{array}$

$\begin{array}{llllll}2510.9 & 2180.8 & 1827.2 & 1168.3 & 17794.5 & 0.444864\end{array}$

$\begin{array}{llllll}1927.5 & 2384.9 & 1964.6 & 1035.4 & 15454.2 & 0.386356\end{array}$

$\begin{array}{llllll}2093.4 & 2107.0 & 1589.2 & 1458.0 & 15111.3 & 0.377783\end{array}$

$\begin{array}{llllll}2322.2 & 2389.1 & 1676.8 & 1311.1 & 13679.8 & 0.341996\end{array}$

$\begin{array}{llllll}2053.5 & 2260.6 & 2152.5 & 1261.1 & 15118.2 & 0.377956\end{array}$

$\begin{array}{llllll}2307.0 & 2174.9 & 1830.0 & 1368.2 & 14915.7 & 0.372893\end{array}$

$\begin{array}{llllll}2107.0 & 2253.4 & 1521.5 & 1729.2 & 16214.9 & 0.405373\end{array}$

$\begin{array}{llllll}2220.1 & 2347.6 & 1878.9 & 2046.0 & 17228.9 & 0.430721\end{array}$

$\begin{array}{llllll}2419.2 & 2056.5 & 2357.2 & 1678.4 & 15551.8 & 0.388796\end{array}$

$\begin{array}{llllll}2044.8 & 2379.4 & 2167.5 & 2133.8 & 18734.9 & 0.468373\end{array}$

$\begin{array}{llllll}2136.8 & 2390.5 & 2299.4 & 1688.3 & 15382.6 & 0.384566\end{array}$

$\begin{array}{llllll}2012.0 & 2265.9 & 1641.1 & 1909.1 & 16141.5 & 0.403538\end{array}$

$\begin{array}{llllll}2232.8 & 2194.5 & 2060.4 & 1618.7 & 18782.9 & 0.469573\end{array}$

$\begin{array}{llllll}1896.0 & 2132.6 & 1870.6 & 2447.0 & 18383.8 & 0.459596\end{array}$

$\begin{array}{lllllll}2298.8 & 3032.9 & 3244.0 & 2798.9 & 19259.9 & 0.481498\end{array}$

$\begin{array}{llllll}2495.6 & 3418.5 & 2919.1 & 1517.4 & 18963.8 & 0.474095\end{array}$

$\begin{array}{llllll}1995.2 & 3111.9 & 3014.9 & 1549.1 & 18733.7 & 0.468343\end{array}$ 


\begin{tabular}{|c|c|c|c|c|c|c|c|c|c|c|c|c|c|c|}
\hline 1972 & 1452.1 & 363.2 & 0.0 & 0.0 & 0.0 & 42.0 & 2068.0 & 2432.9 & 2769.5 & 3361.8 & 3207.7 & 2167.7 & 20364.9 & 0.509123 \\
\hline 1973 & 1025.1 & 136.1 & 0.0 & 0.0 & 0.0 & 480.2 & 2760.6 & 2412.5 & 2024.3 & 2064.6 & 1607.6 & 1531.2 & 16542.2 & 0.413555 \\
\hline 1974 & 2000.9 & 12.9 & 0.0 & 0.0 & 0.0 & 0.0 & 991.3 & 2366.1 & 2290.3 & 2919.9 & 2706.9 & 2125.4 & 17913.7 & 0.447843 \\
\hline 1975 & 2128.1 & 8.9 & 0.0 & 0.0 & 0.0 & 0.0 & 1636.2 & 2903.0 & 2500.2 & 3047.2 & 2769.1 & 1902.0 & 19394.6 & 0.484865 \\
\hline 1976 & 1032.8 & 0.0 & 0.0 & 0.0 & 0.0 & 14.9 & 1667.5 & 3210.4 & 2413.1 & 3120.8 & 3195.0 & 2115.4 & 19269.9 & 0.481746 \\
\hline 1977 & 1810.7 & 6.5 & 0.0 & 0.0 & 115.4 & 1290.0 & 2592.6 & 2624.5 & 1904.9 & 2509.9 & 2381.2 & 1247.4 & 18983.2 & 0.474581 \\
\hline 1978 & 1132.0 & 11.7 & 0.0 & 0.0 & 0.0 & 46.2 & 1698.0 & 2490.4 & 2289.5 & 2703.9 & 2096.3 & 1400.5 & 16368.6 & 0.409216 \\
\hline 1979 & 659.8 & 366.6 & 0.0 & 0.0 & 0.0 & 161.0 & 1298.1 & 2190.2 & 2289.1 & 2045.8 & 1451.6 & 890.2 & 13852.3 & 0.346307 \\
\hline 1980 & 998.0 & 214.0 & 24.0 & 21.0 & 6.0 & 272.0 & 2136.9 & 2412.2 & 2343.0 & 2337.7 & 1771.9 & 1350.8 & 16387.5 & 0.409687 \\
\hline 1981 & 762.5 & 376.0 & 0.0 & 0.0 & 0.0 & 161.0 & 2085.4 & 2409.8 & 1876.4 & 2324.7 & 1667.8 & 1524.9 & 15688.5 & 0.392213 \\
\hline 1982 & 658.0 & 24.0 & 0.0 & 0.0 & 0.0 & 161.0 & 1705.6 & 2748.5 & 2379.7 & 2545.7 & 2079.5 & 1154.0 & 15956.0 & 0.398899 \\
\hline 1983 & 404.0 & 24.0 & 0.0 & 0.0 & 0.0 & 161.0 & 1810.2 & 2661.9 & 2639.3 & 2411.0 & 2078.0 & 1704.4 & 16393.9 & 0.409846 \\
\hline 1984 & 336.6 & 24.0 & 0.0 & 0.0 & 0.0 & 161.0 & 1152.5 & 2407.9 & 2413.9 & 2444.9 & 2021.6 & 983.4 & 14445.9 & 0.361147 \\
\hline 1985 & 319.2 & 24.0 & 0.0 & 0.0 & 0.0 & 161.0 & 2171.9 & 1930.1 & 2109.4 & 2167.5 & 1728.8 & 1718.3 & 14830.1 & 0.370752 \\
\hline 1986 & 328.0 & 24.0 & 0.0 & 0.0 & 0.0 & 161.0 & 1755.6 & 2102.3 & 2326.3 & 2028.2 & 1849.8 & 1301.5 & 14376.8 & 0.359419 \\
\hline 1987 & 628.5 & 267.0 & 0.0 & 0.0 & 0.0 & 221.0 & 2763.7 & 2288.9 & 2162.1 & 2193.6 & 1873.4 & 1463.1 & 16361.4 & 0.409035 \\
\hline 1988 & 1052.5 & 49.2 & 0.0 & 0.0 & 0.0 & 685.8 & 1992.7 & 1997.8 & 2003.0 & 2411.9 & 1519.7 & 1158.1 & 15370.6 & 0.384264 \\
\hline 1989 & 1254.2 & 24.0 & 0.0 & 0.0 & 0.0 & 161.0 & 1907.8 & 1529.7 & 2238.2 & 2258.0 & 1623.0 & 1298.7 & 14794.5 & 0.369863 \\
\hline 1990 & 569.9 & 24.0 & 0.0 & 0.0 & 0.0 & 928.6 & 2534.6 & 1987.9 & 1887.1 & 2016.0 & 1371.1 & 1487.2 & 15306.2 & 0.382656 \\
\hline 1991 & 940.8 & 24.0 & 0.0 & 0.0 & 0.0 & 161.0 & 2205.3 & 1918.5 & 2059.7 & 2079.4 & 1621.0 & 1334.4 & 14844.1 & 0.371102 \\
\hline 1992 & 787.6 & 25.7 & 0.0 & 0.0 & 18.4 & 363.7 & 2400.7 & 2294.1 & 2095.9 & 1877.7 & 1581.5 & 1200.0 & 15145.4 & 0.378635 \\
\hline 1993 & 704.7 & 24.0 & 0.0 & 0.0 & 0.0 & 161.0 & 1169.5 & 2175.9 & 1725.1 & 1786.9 & 1412.0 & 1185.7 & 12844.7 & 0.321117 \\
\hline 1994 & 750.4 & 24.0 & 0.0 & 0.0 & 0.0 & 230.4 & 2036.7 & 1888.7 & 2148.9 & 1899.0 & 1430.6 & 1312.6 & 14221.3 & 0.355532 \\
\hline 1995 & 1196.7 & 24.0 & 0.0 & 0.0 & 0.0 & 161.0 & 1739.2 & 1956.1 & 2129.1 & 1904.9 & 1531.8 & 1425.7 & 14568.4 & 0.36421 \\
\hline 1996 & 833.7 & 24.0 & 0.0 & 0.0 & 0.0 & 161.0 & 1376.2 & 2144.6 & 1994.2 & 2057.6 & 1434.6 & 1407.8 & 13933.7 & 0.348342 \\
\hline 1997 & 690.9 & 24.0 & 0.0 & 0.0 & 0.0 & 167.0 & 1443.6 & 2146.6 & 1950.6 & 1948.5 & 1434.6 & 884.2 & 13189.9 & 0.329747 \\
\hline $\max$ & 2575.5 & 985.6 & 698.2 & 743.8 & 190.4 & 1606.8 & 3672.0 & 3588.9 & 3312.2 & 3418.5 & 3244.0 & 2798.9 & 21170.8 & 0.529 \\
\hline $\min$ & 0.0 & 0.0 & 0.0 & 0.0 & 0.0 & 0.0 & 730.9 & 1369.6 & 1725.1 & 1426.9 & 685.9 & 300.5 & 12456.0 & 0.311 \\
\hline avg & 1061.6 & 169.9 & 24.6 & 21.3 & 10.9 & 307.0 & 2126.3 & 2440.0 & 2343.4 & 2342.8 & 1836.1 & 1499.0 & 16683.0 & 0.417 \\
\hline Pioneer Co & & & & & & & & 500 & 500 & 500 & 500 & 500 & 2500.0 & \\
\hline
\end{tabular}


Appendix: C

Echo Meadows Monitoring Network Locations and Elevations 
Location and elevation of Echo Meadows monitoring network

as of Dec. 12, 2001

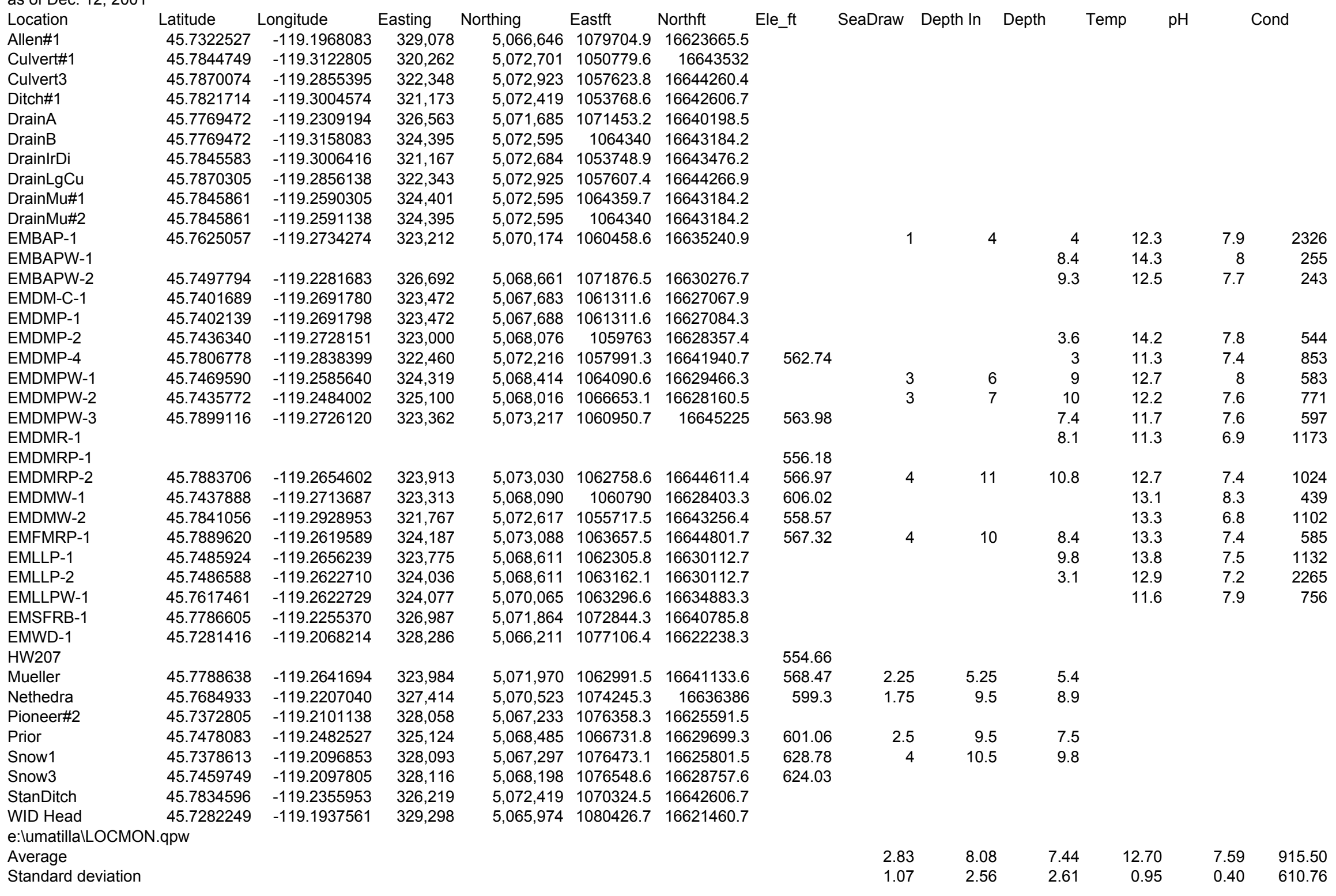


Appendix: D

Groundwater Data Base, Including Water Quality 


\begin{tabular}{|c|c|c|}
\hline ID & Date & Location \\
\hline 4 & $09 / 20 / 01$ & EMBAP-1 \\
\hline 26 & $09 / 14 / 01$ & EMBAP-1 \\
\hline 48 & 09/07/01 & EMBAP -1 \\
\hline 70 & $08 / 31 / 01$ & EMBAP-1 \\
\hline 92 & $08 / 24 / 01$ & EMBAP-1 \\
\hline 114 & $08 / 16 / 01$ & EMBAP-1 \\
\hline 136 & $08 / 10 / 01$ & EMBAP-1 \\
\hline 158 & $08 / 03 / 01$ & EMBAP-1 \\
\hline 180 & $07 / 27 / 01$ & EMBAP -1 \\
\hline \multicolumn{3}{|c|}{ Average } \\
\hline \multicolumn{3}{|c|}{ Std. Deviation } \\
\hline 11 & $09 / 20 / 01$ & EMBAPW-1 \\
\hline 33 & $09 / 14 / 01$ & EMBAPW-1 \\
\hline 55 & 09/07/01 & EMBAPW-1 \\
\hline 77 & $08 / 31 / 01$ & EMBAPW-1 \\
\hline 99 & $08 / 24 / 01$ & EMBAPW-1 \\
\hline 121 & $08 / 16 / 01$ & EMBAPW-1 \\
\hline 143 & $08 / 10 / 01$ & EMBAPW-1 \\
\hline 165 & $08 / 03 / 01$ & EMBAPW-1 \\
\hline 187 & $07 / 27 / 01$ & EMBAPW-1 \\
\hline \multicolumn{3}{|c|}{ Average } \\
\hline \multicolumn{3}{|c|}{ Std. Deviation } \\
\hline 12 & $09 / 20 / 01$ & EMBAPW-2 \\
\hline 34 & $09 / 14 / 01$ & EMBAPW-2 \\
\hline 56 & 09/07/01 & EMBAPW-2 \\
\hline 78 & $08 / 31 / 01$ & EMBAPW-2 \\
\hline 100 & $08 / 24 / 01$ & EMBAPW-2 \\
\hline 122 & $08 / 16 / 01$ & EMBAPW-2 \\
\hline 144 & $08 / 10 / 01$ & EMBAPW-2 \\
\hline 166 & $08 / 03 / 01$ & EMBAPW-2 \\
\hline 188 & $07 / 27 / 01$ & EMBAPW-2 \\
\hline \multicolumn{3}{|c|}{ Average } \\
\hline \multicolumn{3}{|c|}{ Std. Deviation } \\
\hline 21 & $09 / 20 / 01$ & EMDM-C-1 \\
\hline 43 & $09 / 14 / 01$ & EMDM-C-1 \\
\hline 65 & 09/07/01 & EMDM-C-1 \\
\hline 87 & $08 / 31 / 01$ & EMDM-C-1 \\
\hline 109 & $08 / 24 / 01$ & EMDM-C-1 \\
\hline 131 & $08 / 16 / 01$ & EMDM-C-1 \\
\hline 153 & $08 / 10 / 01$ & EMDM-C-1 \\
\hline 175 & $08 / 03 / 01$ & EMDM-C-1 \\
\hline 197 & $07 / 27 / 01$ & EMDM-C-1 \\
\hline
\end{tabular}

Average

Std. Deviation

$\begin{array}{rll}5 & 09 / 20 / 01 & \text { EMDMP-4 } \\ 27 & 09 / 14 / 01 & \text { EMDMP-4 } \\ 49 & 09 / 07 / 01 & \text { EMDMP-4 } \\ 71 & 08 / 31 / 01 & \text { EMDMP-4 } \\ 93 & 08 / 24 / 01 & \text { EMDMP-4 } \\ 115 & 08 / 16 / 01 & \text { EMDMP-4 } \\ 137 & 08 / 10 / 01 & \text { EMDMP-4 } \\ 159 & 08 / 03 / 01 & \text { EMDMP-4 } \\ 181 & 07 / 27 / 01 & \text { EMDMP-4 }\end{array}$

Average

Std. Deviation

$\begin{array}{rll}6 & 09 / 20 / 01 & \text { EMDMPW-1 } \\ 28 & 09 / 14 / 01 & \text { EMDMPW-1 } \\ 50 & 09 / 07 / 01 & \text { EMDMPW-1 } \\ 72 & 08 / 31 / 01 & \text { EMDMPW-1 } \\ 94 & 08 / 24 / 01 & \text { EMDMPW-1 } \\ 116 & 08 / 16 / 01 & \text { EMDMPW-1 } \\ 138 & 08 / 10 / 01 & \text { EMDMPW-1 } \\ 160 & 08 / 03 / 01 & \text { EMDMPW-1 } \\ 182 & 07 / 27 / 01 & \text { EMDMPW-1 }\end{array}$

Average

Std. Deviation

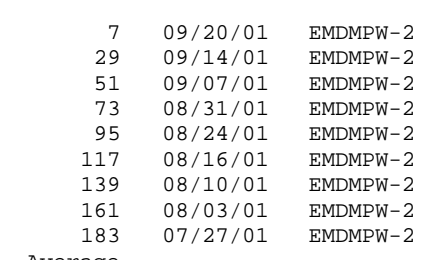

Average

07/27/01 EMDMPW-2

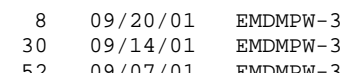

$\begin{array}{lll}30 & 09 / 14 / 01 & \text { EMDMPW-3 } \\ 52 & 09 / 07 / 01 & \text { EMDMPW-3 }\end{array}$

$\begin{array}{cc}\text { Level_ft } & \text { Level_in } \\ 5 & 9 \\ 6 & 9 \\ 8 & 7 \\ 7 & 9 \\ 8 & 0 \\ 8 & 4 \\ 7 & 11\end{array}$

$\begin{array}{cc}\text { Level_o } & \text { Leve } \\ 0 & \\ 0 & \\ 0 & \\ 0 & \\ 0 \\ 0 \\ 50\end{array}$

vel_all
5.75
6.75
8.58
7.75
8.00
8.33
7.96

Temp

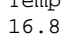

17.5

16.3

16.3

$\begin{array}{ccc}16.3 & 7.62 & 1500 \\ 16 & 8.07 & 1499 \\ 16.1 & 7.65 & 1512\end{array}$

$\begin{array}{lll}16.1 & 7.65 & 1512 \\ 16.8 & 7.72 & 1470\end{array}$

7.96

7.59

16.54

1.00

16.54

8.03

1470

$6.67 \quad 15.4$

7.52

153

25

6.00

7.67

6.67

$\begin{array}{llcl}7.92 & 15.1 & 8.36 & 162.4 \\ 4.75 & 15.2 & 8.4 & 184.8\end{array}$

15.4

$\begin{array}{lll}15.3 & 8.31 & 178.4\end{array}$

$\begin{array}{lll}15.7 & 8.66 & 161.5\end{array}$

5.50

$15 \cdot 1$

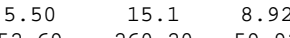

$\begin{array}{ccc}52.69 & 260.20 & 59.92 \\ 1.12 & 48.68 & 0.22\end{array}$

$8.42 \quad 15.8$

$8.85 \quad 15.9$

9.67

8.79
8.25

7.79

15.8

15.3
15.3

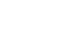

8.1

8.28

$\begin{array}{ll}8.28 & 342 \\ 8.32 & 293 \\ 8.09 & 118.6\end{array}$

$8.09 \quad 118.6$

$\begin{array}{lll}16 & 7.88 & 220.4\end{array}$

$\begin{array}{llll}8.60 & 15.68 & 8.14 & 245.49\end{array}$

$\begin{array}{llll}0.59 & 0.31 & 0.18 & 69.56\end{array}$

$17 \quad 155.9$

$\begin{array}{lll}18.3 & 6.87 & 125.7\end{array}$

$\begin{array}{lll}15.6 & 8.27 & 117.6\end{array}$

$\begin{array}{lll}19.6 & 8.36 & 118.9\end{array}$

$17.9 \quad 7.66 \quad 125.6$

$\begin{array}{lll}19.9 & 8.04 & 112.4\end{array}$

$\begin{array}{lll}19.8 & 8.4 & 113.1\end{array}$

$\begin{array}{lll}21.7 & 8.65 & 122.1\end{array}$

$\begin{array}{ll}19.6 & 115.7\end{array}$

$\begin{array}{ccc}18.82 & 8.04 & 123.00 \\ 1.82 & 0.60 & 13.26\end{array}$

$$
1.820 .602 .13 .26
$$

$$
\begin{array}{llll}
4.75 & 16.1 & 544 & 0
\end{array}
$$

$\begin{array}{cccc}4.75 & 16.1 & 544 & 0 \\ 4.33 & 16 & 555 & 0\end{array}$

$\begin{array}{lclll}4.33 & 16 & & 555 & 0 \\ 5.29 & 15.4 & 7.43 & 599 & 0\end{array}$

$\begin{array}{llcll}5.29 & 15.4 & 7.43 & 599 & 0 \\ 4.33 & 16.1 & 7.31 & 649 & 0 \\ 4.77 & 16.1 & 7.9 & 715 & 0\end{array}$

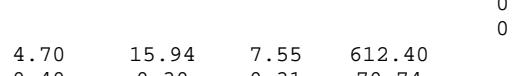

$\begin{array}{lccc}4.70 & 15.94 & 7.55 & 612.40 \\ 0.40 & 0.30 & 0.31 & 70.74\end{array}$

\section{$\begin{array}{ll}13.8 & 709\end{array}$}

$\begin{array}{lllll} & 13.8 & & 709 & 0 \\ 7.08 & 14.5 & 6.27 & 683 & 0\end{array}$

$\begin{array}{lllll}7.08 & 14.5 & 6.27 & 683 & 0 \\ 7.00 & 15.6 & 8.27 & 536 & 0\end{array}$

$\begin{array}{llll}6.67 & 18.9 & 8.6 & 347.4\end{array}$

$\begin{array}{llll}6.75 & 15.6 & 8.37 & 666\end{array}$

$\begin{array}{llll}6.88 & 15.4 & 7.72 & 724\end{array}$

$\begin{array}{rrrr} & 14.7 & 8.05 & 702 \\ 16.25 & 14.6 & 8.05 & 673\end{array}$

$16.75 \quad 14.9$

$\begin{array}{lrrr}9.63 & 15.33 & 7.90 & 639.9\end{array}$

$\begin{array}{llll}4.70 & 1.46 & 0.77 & 123.46\end{array}$

$\begin{array}{lll}14.8 & 718 & 0\end{array}$

$\begin{array}{lll}14.8 & 718 & 0 \\ 15.4 & 704 & 0\end{array}$

$\begin{array}{lll}15.4 & & 704 \\ 14.6 & 8.13 & 724\end{array}$

$\begin{array}{llll} & 14.6 & 8.13 & 724 \\ 13.67 & 14.2 & 8.43 & 772\end{array}$

$\begin{array}{lll}14.8 & 8.45 \quad 744\end{array}$

$\begin{array}{lll}14.4 & 7.9 & 726\end{array}$

$\begin{array}{lll}14.4 & 7.9 & 726 \\ 14.3 & 8.54 & 592 \\ 13.7 & 8.31 & 696\end{array}$

17.83

17.00

15.1

$\begin{array}{cccc}16.17 & 14.59 & 8.29 & 704.11 \\ 2.20 & 0.51 & 0.24 & 52.15\end{array}$

8.25
8.77

8.38
9.38

0
0
0
0
0
0
0
0
0
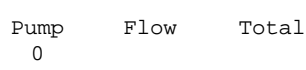

low

Total

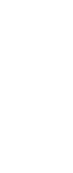

0
0
0
0
0
0
0
0
0

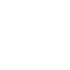




\begin{tabular}{|c|c|c|}
\hline 74 & $08 / 31 / 01$ & EMDMPW-3 \\
\hline 96 & $08 / 24 / 01$ & EMDMPW-3 \\
\hline 118 & $08 / 16 / 01$ & EMDMPW-3 \\
\hline 140 & $08 / 10 / 01$ & EMDMPW-3 \\
\hline 162 & $08 / 03 / 01$ & EMDMP W-3 \\
\hline 184 & $07 / 27 / 01$ & EMDMPW-3 \\
\hline \multicolumn{3}{|c|}{ Average } \\
\hline \multicolumn{3}{|c|}{ Std. Deviation } \\
\hline 1 & $09 / 20 / 01$ & EMDMRP - 1 \\
\hline 23 & $09 / 14 / 01$ & EMDMRP - 1 \\
\hline 45 & 09/07/01 & EMDMRP - 1 \\
\hline 67 & $08 / 31 / 01$ & EMDMRP - 1 \\
\hline 89 & $08 / 24 / 01$ & EMDMRP - 1 \\
\hline 111 & $08 / 16 / 01$ & EMDMRP - 1 \\
\hline 133 & $08 / 10 / 01$ & EMDMRP - 1 \\
\hline 155 & $08 / 03 / 01$ & EMDMRP-1 \\
\hline 177 & $07 / 27 / 01$ & EMDMRP - 1 \\
\hline \multicolumn{3}{|c|}{ Average } \\
\hline \multicolumn{3}{|c|}{ Std. Deviation } \\
\hline 18 & $09 / 20 / 01$ & EMDMRP $-1-R$ \\
\hline 40 & 09/14/01 & EMDMRP $-1-R$ \\
\hline 62 & $09 / 07 / 01$ & EMDMRP $-1-R$ \\
\hline 84 & $08 / 31 / 01$ & EMDMRP $-1-R$ \\
\hline 106 & $08 / 24 / 01$ & EMDMRP $-1-R$ \\
\hline 128 & $08 / 16 / 01$ & EMDMRP $-1-R$ \\
\hline 150 & $08 / 10 / 01$ & EMDMRP $-1-R$ \\
\hline 172 & $08 / 03 / 01$ & EMDMRP $-1-R$ \\
\hline 194 & $07 / 27 / 01$ & EMDMRP $-1-R$ \\
\hline
\end{tabular}

Average

Std. Deviation

$\begin{array}{rll}2 & 09 / 20 / 01 & \text { EMDMRP }-2 \\ 24 & 09 / 14 / 01 & \text { EMDMRP-2 } \\ 46 & 09 / 07 / 01 & \text { EMDMRP-2 } \\ 68 & 08 / 31 / 01 & \text { EMDMRP-2 } \\ 90 & 08 / 24 / 01 & \text { EMDMRP-2 } \\ 112 & 08 / 16 / 01 & \text { EMDMRP-2 } \\ 134 & 08 / 10 / 01 & \text { EMDMRP-2 } \\ 156 & 08 / 03 / 01 & \text { EMDMRP }-2 \\ 178 & 07 / 27 / 01 & \text { EMDMRP-2 }\end{array}$

Average

$$
\text { 07/27/01 EMDMRP-2 }
$$

8
8
9
8
9
8

8
8
4
9
4
10

$\begin{array}{rl} & 8.6 \\ 25 & 8.6 \\ 50 & 9.3 \\ & 8.7 \\ & 9.3 \\ & 8.8 \\ & 8.8 \\ & 0.39\end{array}$

8.6

8.75

9.33

8.83

0.39

$\begin{array}{ccccc} & 13.5 & & 1247 & 0 \\ 10.25 & 13.2 & & 1206 & 0 \\ 9.58 & 13.3 & 7.09 & 1213 & 0 \\ 10.08 & 13.2 & 6.99 & 1245 & 0 \\ 10.17 & 13.6 & 7 & 1260 & 0 \\ 10.33 & 13.8 & 6.88 & 1288 & 0 \\ 10.29 & 13.5 & 6.95 & 1318 & 0 \\ & & & & 0\end{array}$

$\begin{array}{cccc}10.12 & 13.44 & 6.98 & 1253.86 \\ 0.28 & 0.22 & 0.08 & 39.59\end{array}$

$\begin{array}{lll}15.1 & 239.1 & 0\end{array}$

$\begin{array}{llll}17.1 & 7.47 & 463.2 & 0\end{array}$

$\begin{array}{lll}15.8 & 7.73 & 467.5\end{array}$

$\begin{array}{lll}19.7 & 6.54 & 426.8\end{array}$

17.5

$\begin{array}{lll}21.1 & 6.18 & 203.7\end{array}$

$\begin{array}{lll}20.9 & 5.83 & 447.6\end{array}$

$\begin{array}{lll}21.3 & 7.79 & 429.3\end{array}$

$\begin{array}{lll}21.3 & 7.79 & 429.3\end{array}$

$\begin{array}{lll}18.87 & 7.05 & 393.47\end{array}$

$\begin{array}{lll}2.51 & 0.84 & 99.05\end{array}$

Std. Deviation

$\begin{array}{rll}9 & 09 / 20 / 01 & \text { EMDMW-1 } \\ 31 & 09 / 14 / 01 & \text { EMDMW-1 } \\ 53 & 09 / 07 / 01 & \text { EMDMW-1 } \\ 75 & 08 / 31 / 01 & \text { EMDMW-1 } \\ 97 & 08 / 24 / 01 & \text { EMDMW-1 } \\ 119 & 08 / 16 / 01 & \text { EMDMW-1 } \\ 141 & 08 / 10 / 01 & \text { EMDMW-1 } \\ 163 & 08 / 03 / 01 & \text { EMDMW-1 } \\ 185 & 07 / 27 / 01 & \text { EMDMW-1 }\end{array}$

Average

$07 / 27 / 01 \quad$ EMDMW-1

Std. Deviation

$\begin{array}{rcl}10 & 09 / 20 / 01 & \text { EMDMW-2 } \\ 32 & 09 / 14 / 01 & \text { EMDMW-2 } \\ 54 & 09 / 07 / 01 & \text { EMDMW-2 } \\ 76 & 08 / 31 / 01 & \text { EMDMW-2 } \\ 98 & 08 / 24 / 01 & \text { EMDMW-2 } \\ 120 & 08 / 16 / 01 & \text { EMDMW-2 } \\ 142 & 08 / 10 / 01 & \text { EMDMW-2 } \\ 164 & 08 / 03 / 01 & \text { EMDMW-2 } \\ 186 & 07 / 27 / 01 & \text { EMDMW-2 } \\ \text { Average } & & \\ \text { Std. Deviation } & \\ & & \\ 3 & 09 / 20 / 01 & \text { EMFMRP-1 } \\ 25 & 09 / 14 / 01 & \text { EMFMRP-1 } \\ 47 & 09 / 07 / 01 & \text { EMFMRP-1 } \\ 69 & 08 / 31 / 01 & \text { EMFMRP-1 } \\ 91 & 08 / 24 / 01 & \text { EMFMRP-1 } \\ 113 & 08 / 16 / 01 & \text { EMFMRP-1 } \\ 135 & 08 / 10 / 01 & \text { EMFMRP-1 } \\ 157 & 08 / 03 / 01 & \text { EMFMRP-1 } \\ 179 & 07 / 27 / 01 & \text { EMFMRP-1 } \\ \text { Average } & & \\ \text { Std. Deviation } & \\ & & \\ 19 & 09 / 20 / 01 & \text { EMSFRB-1 } \\ 41 & 09 / 14 / 01 & \text { EMSFRB-1 } \\ 63 & 09 / 07 / 01 & \text { EMSFRB-1 } \\ 85 & 08 / 31 / 01 & \text { EMSFRB-1 } \\ 107 & 08 / 24 / 01 & \text { EMSFRB-1 } \\ 129 & 08 / 16 / 01 & \text { EMSFRB-1 } \\ 151 & 08 / 10 / 01 & \text { EMSFRB-1 }\end{array}$




\begin{tabular}{|c|c|c|}
\hline 173 & $08 / 03 / 01$ & EMSFRB \\
\hline 195 & $07 / 27 / 01$ & EMSFR \\
\hline Average & & \\
\hline Std. De & ation & \\
\hline 20 & $09 / 20 / 01$ & EMWD-1 \\
\hline 42 & $09 / 14 / 01$ & EMWD -1 \\
\hline 64 & 09/07/01 & EMWD-1 \\
\hline 86 & $08 / 31 / 01$ & EMWD-1 \\
\hline 108 & $08 / 24 / 01$ & EMWD - 1 \\
\hline 130 & $08 / 16 / 01$ & EMWD-1 \\
\hline 152 & $08 / 10 / 01$ & EMWD -1 \\
\hline 174 & $08 / 03 / 01$ & EMWD-1 \\
\hline 196 & $07 / 27 / 01$ & EMWD-1 \\
\hline
\end{tabular}

Average

Std. Deviation

$\begin{array}{rll}13 & 09 / 20 / 01 & \text { Mueller } \\ 35 & 09 / 14 / 01 & \text { Mueller } \\ 57 & 09 / 07 / 01 & \text { Mueller } \\ 79 & 08 / 31 / 01 & \text { Mueller } \\ 101 & 08 / 24 / 01 & \text { Mueller } \\ 123 & 08 / 16 / 01 & \text { Mueller } \\ 145 & 08 / 10 / 01 & \text { Mueller } \\ 167 & 08 / 03 / 01 & \text { Mueller } \\ 189 & 07 / 27 / 01 & \text { Mueller }\end{array}$

Average

Std. Deviation

$\begin{array}{rll}17 & 09 / 20 / 01 & \text { Netherda } \\ 39 & 09 / 14 / 01 & \text { Netherda } \\ 61 & 09 / 07 / 01 & \text { Netherda } \\ 83 & 08 / 31 / 01 & \text { Netherda } \\ 105 & 08 / 24 / 01 & \text { Netherda } \\ 127 & 08 / 16 / 01 & \text { Netherda } \\ 149 & 08 / 10 / 01 & \text { Netherda } \\ 171 & 08 / 03 / 01 & \text { Netherda } \\ 193 & 07 / 27 / 01 & \text { Netherda }\end{array}$

std. Deviation

\begin{tabular}{|c|c|c|}
\hline 14 & $09 / 20 / 01$ & Prior \\
\hline 36 & $09 / 14 / 01$ & Prior \\
\hline 58 & 09/07/01 & Prior \\
\hline 80 & $08 / 31 / 01$ & Prior \\
\hline 102 & $08 / 24 / 01$ & Prior \\
\hline 124 & $08 / 16 / 01$ & Prior \\
\hline 146 & $08 / 10 / 01$ & Prior \\
\hline 168 & $08 / 03 / 01$ & Prior \\
\hline 190 & $07 / 27 / 01$ & Prior \\
\hline \multirow{2}{*}{\multicolumn{3}{|c|}{$\begin{array}{l}\text { Average } \\
\text { Std. Deviation }\end{array}$}} \\
\hline & & \\
\hline 15 & $09 / 20 / 01$ & PriorPump \\
\hline 37 & 09/14/01 & PriorPump \\
\hline 59 & 09/07/01 & PriorPump \\
\hline 81 & $08 / 31 / 01$ & PriorPump \\
\hline 103 & $08 / 24 / 01$ & PriorPump \\
\hline 125 & $08 / 16 / 01$ & PriorPump \\
\hline 147 & $08 / 10 / 01$ & PriorPump \\
\hline 169 & $08 / 03 / 01$ & PriorPump \\
\hline 191 & $07 / 27 / 01$ & PriorPump \\
\hline \multirow{2}{*}{\multicolumn{3}{|c|}{$\begin{array}{l}\text { Average } \\
\text { Std. Deviation }\end{array}$}} \\
\hline & & \\
\hline 16 & $09 / 20 / 01$ & Snow \\
\hline 38 & 09/14/01 & Snow \\
\hline 60 & 09/07/01 & Snow \\
\hline 82 & $08 / 31 / 01$ & Snow \\
\hline 104 & $08 / 24 / 01$ & Snow \\
\hline 126 & $08 / 16 / 01$ & Snow \\
\hline 148 & $08 / 10 / 01$ & Snow \\
\hline 170 & $08 / 03 / 01$ & Snow \\
\hline 192 & $07 / 27 / 01$ & Snow \\
\hline \multicolumn{3}{|c|}{ Average } \\
\hline \multicolumn{3}{|c|}{ Std. Deviation } \\
\hline 22 & $09 / 20 / 01$ & Stanfield \\
\hline 44 & 09/14/01 & Stanfield \\
\hline 66 & 09/07/01 & Stanfield \\
\hline 88 & $08 / 31 / 01$ & Stanfield \\
\hline 110 & $08 / 24 / 01$ & Stanfield \\
\hline 132 & $08 / 16 / 01$ & Stanfield \\
\hline 154 & $08 / 10 / 01$ & Stanfield \\
\hline 176 & $08 / 03 / 01$ & Stanfield \\
\hline 198 & $07 / 27 / 01$ & Stanfield \\
\hline
\end{tabular}

Std. Deviation

$\begin{array}{ccccc} & 18.3 & 7.57 & 193.3 & 0 \\ 15.75 & 17.3 & & 201 & 0 \\ & 18.00 & 7.71 & 192.34 & \\ 15.75 & 0.85 & 0.29 & 6.92 & \\ & & & & \\ & 17.2 & & 123.4 & 0 \\ 19.8 & & 121.8 & 0 \\ 18.8 & 7.15 & 123.6 & 0 \\ 22.1 & 8.77 & 116.9 & 0 \\ 20.2 & 8.94 & 121.1 & 0 \\ 24.4 & 9.24 & 113.5 & 0 \\ 23.5 & 9.29 & 105 & 0 \\ 23 & 8.55 & 122.1 & 0 \\ 19.5 & 8.13 & 116.6 & 0 \\ 20.94 & 8.58 & 117.57 & \\ 2.41 & 0.75 & 6.13 & \end{array}$

5.67

6.25
6.33

6.29

6.67

6.35

6.25

6.38

6.30

0.27

75

9.83
9.73

9.73

10.25

10.50

10.25

10.17

10.13

10.50

10.17

0.28

0.42

0.1

$\begin{array}{rr}19 & 288.62 \\ & 8.20\end{array}$

$\begin{array}{llll}14.3 & & 271.5 & 0 \\ 14.3 & & 282.9 & 0 \\ 14.2 & 8.24 & 278.8 & 0 \\ 13.6 & 8.33 & 290.1 & 0 \\ 14.1 & & 283.7 & 0 \\ 14.6 & 7.89 & 298.7 & 0 \\ 13.4 & 8.1 & 297.5 & 0 \\ & & & 0 \\ 14.07 & 8.14 & 288.62 & \end{array}$

6.25
5.90

8.92

8.92

8.25

50

8.92

50

8.54

8.75

8.00

7.88

1.14

$\begin{array}{cccc} & & & 0 \\ & & & 0 \\ 16.2 & 8.27 & 467.1 & 0 \\ 15.3 & 8.35 & 459.4 & 0 \\ 16.5 & 7.83 & 414 & 0 \\ 16.2 & 8.06 & 467.9 & 0 \\ & & & 0 \\ 16.05 & 8.13 & 452.10 & \end{array}$

$\begin{array}{lll}16.05 & 8.13 \quad 452.10\end{array}$

$\begin{array}{lll}0.52 & 0.23 \quad 25.69\end{array}$

$18 \quad 184.8$

$18.2 \quad 175 \quad 1$

$\begin{array}{llll}16.8 & 8.7 & 169.8\end{array}$

$\begin{array}{lll}18.8 & 8.56 & 162.9\end{array}$

$18.4 \quad 8.45 \quad 184.2$

$\begin{array}{lll}20.3 & 7.39 & 179.7\end{array}$

10.33

10.33
10.17

10.17
10.25

17.5

$8.11 \quad 163.2$

$\begin{array}{lll}18.29 & 8.24 & 174.23\end{array}$

$\begin{array}{lll}1.10 & 0.52 & 9.23\end{array}$

$13.7 \quad 625$

$\begin{array}{ll}625 & 0 \\ 540-0 & 0\end{array}$

$\begin{array}{llll}12.13 & 14.3 & 540 & 0\end{array}$

$\begin{array}{lllll}12.33 & 14.4 & 8.01 & 662 & 0\end{array}$

$\begin{array}{lllll}12.75 & 15.9 & 7.98 & 689 & 0 \\ 12.79 & 14.7 & & 658 & 0\end{array}$

$\begin{array}{ccccc}12.83 & 16.3 & 7.43 & 474.7 & 0 \\ 13.00 & 14.8 & 7.9 & 545 & 0\end{array}$

12.83

12.92

12.70
0.30

$\begin{array}{lll}14.87 & 7.83 & 599.10\end{array}$

$\begin{array}{ccc}0.92 & 0.27 & 79.66\end{array}$ 


\begin{tabular}{|c|c|c|c|c|c|c|c|c|c|c|c|}
\hline Date & Location & Level_ & ft Level_in & Level_o & Temp & $\mathrm{pH}$ & Conductivity & Well & Pressure & Flow & Total \\
\hline $07 / 20 / 01$ & EMDMP W-1 & 7 & 8 & & 14.60 & 7.83 & 679 & 0 & 0 & 0 & 837850 \\
\hline $07 / 20 / 01$ & EMDMPW-2 & 16 & 8 & 0 & 13.40 & 8.02 & 762 & 1 & 60 & 250 & 862994 \\
\hline $07 / 20 / 01$ & EMDMP W-3 & 8 & 11 & 0 & 13.20 & 7.02 & 655 & 0 & 0 & 0 & 0 \\
\hline $07 / 20 / 01$ & EMLLPW-1 & 5 & 6 & 0 & 15.20 & 7.15 & 871 & 0 & 0 & 0 & 0 \\
\hline $07 / 20 / 01$ & EMBAPW-1 & 5 & 5 & 50 & 15.10 & 8.27 & 166 & 0 & 0 & 0 & 0 \\
\hline $07 / 20 / 01$ & EMBAPW-2 & 0 & 0 & 0 & 0.00 & 0.00 & 0 & 0 & 0 & 0 & 0 \\
\hline $07 / 20 / 01$ & EMDMW-1 & 3 & 0 & 50 & 16.40 & 8.20 & 481 & 0 & 0 & 0 & 0 \\
\hline $07 / 20 / 01$ & EMDMW-2 & 5 & 7 & & 13.70 & 6.60 & 1343 & 0 & 0 & 0 & 0 \\
\hline $07 / 13 / 01$ & EMDMP W-2 & 10 & 3 & 0 & 14.30 & 7.98 & 808 & 0 & 0 & 0 & 855640 \\
\hline $07 / 13 / 01$ & EMDMPW-3 & 8 & 9 & 0 & 13.30 & 7.83 & 682 & 0 & 0 & 0 & 0 \\
\hline $07 / 13 / 01$ & EMLLPW-1 & 5 & 5 & 0 & 14.20 & 7.48 & 852 & 0 & 0 & 0 & 0 \\
\hline $07 / 13 / 01$ & EMBAP W-1 & 5 & 11 & 0 & 15.40 & 8.10 & 168 & 0 & 0 & 0 & 0 \\
\hline $07 / 13 / 01$ & EMBAPW-2 & 0 & 0 & 0 & 0.00 & 0.00 & 0 & 0 & 0 & 0 & 0 \\
\hline $07 / 13 / 01$ & EMDMW-1 & 4 & 2 & 0 & 14.80 & 8.10 & 480 & 0 & 0 & 0 & 0 \\
\hline $07 / 13 / 01$ & EMDMW-2 & 5 & 10 & 0 & 12.40 & 6.70 & 1322 & 0 & 0 & 0 & 0 \\
\hline $07 / 06 / 01$ & EMDMPW-1 & 15 & 9 & 50 & 14.50 & 8.00 & 624 & 1 & 62 & 300 & 822788 \\
\hline $07 / 06 / 01$ & EMDMP W-2 & 16 & 10 & 0 & 14.30 & 7.90 & 745 & 1 & 60 & 250 & 847767 \\
\hline $07 / 06 / 01$ & EMLLPW-1 & 4 & 6 & 0 & 22.40 & 7.45 & 689 & 0 & 0 & 0 & 0 \\
\hline $07 / 06 / 01$ & EMBAPW-1 & 6 & 8 & 0 & 14.10 & 8.43 & 162 & 0 & 0 & 0 & 0 \\
\hline $07 / 06 / 01$ & EMBAPW-2 & 0 & 0 & 0 & 0.00 & 0.00 & 0 & 0 & 0 & 0 & 0 \\
\hline $07 / 06 / 01$ & EMDMW-1 & 3 & 6 & 50 & 15.30 & 8.10 & 481 & 0 & 0 & 0 & 0 \\
\hline $07 / 06 / 01$ & EMDMW-2 & 5 & 5 & 0 & 12.60 & 6.70 & 1318 & 0 & 0 & 0 & 0 \\
\hline $06 / 22 / 01$ & EMDMP W-1 & 15 & 2 & 0 & 15.30 & 7.90 & 636 & 1 & 62 & 300 & 810871 \\
\hline $06 / 22 / 01$ & EMDMP W-2 & 16 & 3 & 0 & 15.00 & 8.49 & 804 & 1 & 60 & 250 & 832406 \\
\hline $06 / 22 / 01$ & EMDMP W-3 & 8 & 0 & 0 & 12.70 & 7.68 & 661 & 0 & 0 & 0 & 0 \\
\hline $06 / 22 / 01$ & EMLLPW-1 & 4 & 4 & 50 & 21.10 & 7.55 & 699 & 0 & 0 & 0 & 0 \\
\hline $06 / 22 / 01$ & EMBAPW-1 & 6 & 4 & 50 & 15.20 & 8.47 & 155 & 0 & 0 & 0 & 0 \\
\hline $06 / 22 / 01$ & EMBAPW-2 & 0 & 0 & 0 & 0.00 & 0.00 & 0 & 0 & 0 & 0 & 0 \\
\hline $06 / 22 / 01$ & EMDMW-1 & 4 & 2 & 50 & 15.00 & 7.95 & 468 & 0 & 0 & 0 & 0 \\
\hline $06 / 22 / 01$ & EMDMW-2 & 5 & 4 & 0 & 12.40 & 6.46 & 1259 & 0 & 0 & 0 & 0 \\
\hline $06 / 15 / 01$ & EMDMP W-1 & 15 & 4 & 0 & 14.80 & 8.10 & 437 & 1 & 62 & 300 & 803560 \\
\hline $06 / 15 / 01$ & EMDMP W-2 & 15 & 10 & 0 & 13.40 & 7.91 & 828 & 1 & 60 & 250 & 824230 \\
\hline $06 / 15 / 01$ & EMDMP W-3 & 8 & 0 & 0 & 12.20 & 7.60 & 653 & 0 & 0 & 0 & 0 \\
\hline $06 / 15 / 01$ & EMLLPW-1 & 4 & 2 & 0 & 16.90 & 7.60 & 756 & 0 & 0 & 0 & 0 \\
\hline $06 / 15 / 01$ & EMDMW-1 & 3 & 7 & 0 & 14.20 & 7.94 & 468 & 0 & 0 & 0 & 0 \\
\hline $06 / 15 / 01$ & EMDMW-2 & 3 & 11 & 0 & 12.80 & 6.40 & 1256 & 0 & 0 & 0 & 0 \\
\hline $06 / 08 / 01$ & EMDMP W-1 & 7 & 11 & 50 & 14.70 & 7.80 & 622 & 0 & 0 & 0 & 797844 \\
\hline $06 / 08 / 01$ & EMDMPW-2 & 15 & 2 & 50 & 13.50 & 7.81 & 784 & 1 & 60 & 250 & 815845 \\
\hline $06 / 08 / 01$ & EMDMP W-3 & 7 & 11 & 0 & 11.90 & 7.70 & 648 & 0 & 0 & 0 & 0 \\
\hline $06 / 08 / 01$ & EMLLPW-1 & 3 & 11 & 0 & 17.60 & 7.90 & 689 & 0 & 0 & 0 & 0 \\
\hline $06 / 08 / 01$ & EMBAP W-1 & 5 & 3 & 0 & 14.50 & 8.30 & 160 & 0 & 0 & 0 & 0 \\
\hline $06 / 08 / 01$ & EMBAPW-2 & 0 & 0 & 0 & 0.00 & 0.00 & 0 & 0 & 0 & 0 & 0 \\
\hline $06 / 08 / 01$ & EMDMW-1 & 3 & 11 & 0 & 13.40 & 7.70 & 474 & 0 & 0 & 0 & 0 \\
\hline $06 / 08 / 01$ & EMDMW-2 & 5 & 3 & 0 & 12.70 & 5.98 & 1111 & 0 & 0 & 0 & 0 \\
\hline $06 / 01 / 01$ & EMDMP W-1 & 15 & 4 & 0 & 15.10 & 7.40 & 586 & 1 & 60 & 300 & 790309 \\
\hline $06 / 01 / 01$ & EMDMP W-2 & 15 & 2 & 0 & 13.60 & 7.40 & 869 & 1 & 62 & 250 & 807528 \\
\hline $06 / 01 / 01$ & EMDMP W-3 & 7 & 11 & 0 & 11.90 & 9.37 & 636 & 0 & 0 & 0 & 0 \\
\hline $06 / 01 / 01$ & EMLLPW-1 & 4 & 7 & 0 & 15.30 & 11.80 & 788 & 0 & 0 & 0 & 0 \\
\hline $06 / 01 / 01$ & EMBAPW-1 & 4 & 5 & 0 & 13.60 & 7.20 & 160 & 0 & 0 & 0 & 0 \\
\hline $06 / 01 / 01$ & EMBAPW-2 & & & & & & & 0 & 0 & 0 & 0 \\
\hline $06 / 01 / 01$ & EMDMW-1 & 4 & 0 & 50 & 12.40 & 10.90 & 4755 & 0 & 0 & 0 & 0 \\
\hline $06 / 01 / 01$ & EMDMW-2 & 4 & 9 & 0 & 12.50 & 6.30 & 1313 & 0 & 0 & 0 & 0 \\
\hline $05 / 24 / 01$ & EMDMP W-1 & 14 & 7 & 0 & 14.30 & 8.30 & 608 & 1 & 62 & 300 & 781290 \\
\hline $05 / 24 / 01$ & EMDMP W-2 & 14 & 7 & 0 & 14.00 & 8.20 & 870 & 1 & 60 & 250 & 799337 \\
\hline $05 / 24 / 01$ & EMDMP W-3 & 7 & 11 & 0 & 11.80 & 8.00 & 623 & 0 & 0 & 0 & 0 \\
\hline $05 / 24 / 01$ & EMLLPW-1 & 3 & $\begin{array}{c}1+ \\
8\end{array}$ & 50 & 15.00 & 7.90 & 715 & 0 & 0 & 0 & 0 \\
\hline $05 / 24 / 01$ & EMBAPW-1 & 4 & 3 & 50 & 17.50 & 8.60 & 122 & 0 & 0 & 0 & 0 \\
\hline $05 / 24 / 01$ & EMBAPW-2 & 0 & 0 & 0 & 0.00 & 0.00 & 0 & 0 & 0 & 0 & 0 \\
\hline $05 / 24 / 01$ & EMDMW-1 & 4 & 9 & 75 & 12.50 & 8.42 & 472 & 0 & 0 & 0 & 0 \\
\hline $05 / 24 / 01$ & EMDMW-2 & 3 & 11 & 75 & 14.10 & 6.55 & 1286 & 0 & 0 & 0 & 0 \\
\hline $05 / 18 / 01$ & EMDMP W-1 & 14 & 4 & 0 & 14.10 & 8.00 & 628 & 1 & 62 & 300 & 777233 \\
\hline $05 / 18 / 01$ & EMDMP W-2 & 14 & 1 & 0 & 13.60 & 8.10 & 862 & 1 & 60 & 250 & 791738 \\
\hline $05 / 18 / 01$ & EMDMP W-3 & 7 & 7 & 75 & 11.00 & 7.60 & 524 & 0 & 0 & 0 & 0 \\
\hline $05 / 18 / 01$ & EMLLPW-1 & 2 & 9 & 0 & 15.00 & 7.80 & 637 & 0 & 0 & 0 & 0 \\
\hline $05 / 18 / 01$ & EMBAP W-1 & 3 & 7 & 0 & 13.90 & 8.40 & 126 & 0 & 0 & 0 & 0 \\
\hline $05 / 18 / 01$ & EMBAPW-2 & & & & 0.00 & 0.00 & 0 & 0 & 0 & 0 & 0 \\
\hline $05 / 18 / 01$ & EMDMW-1 & 4 & 3 & 75 & 11.90 & & 470 & 0 & 0 & 0 & 0 \\
\hline $05 / 18 / 01$ & EMDMW-2 & 4 & 1 & 0 & 11.70 & 6.00 & 1178 & 0 & 0 & 0 & 0 \\
\hline $05 / 11 / 01$ & EMDMP W-1 & 14 & 2 & 0 & 15.30 & 7.94 & 579 & 1 & 62 & 325 & 771700 \\
\hline
\end{tabular}




\begin{tabular}{|c|c|c|c|c|c|c|c|c|c|c|c|}
\hline $05 / 11 / 01$ & EMDMPW-3 & 7 & 0 & 50 & 10.60 & 7.60 & 594 & 0 & 0 & 0 & 0 \\
\hline $05 / 11 / 01$ & EMLLPW-1 & 2 & 10 & 50 & 10.10 & 7.60 & 654 & 0 & 0 & 0 & 0 \\
\hline $05 / 11 / 01$ & EMBAPW-1 & 6 & 0 & 0 & 14.10 & 8.40 & 205 & 0 & 0 & 0 & 0 \\
\hline $05 / 11 / 01$ & EMBAP W-2 & & & & & & & 0 & 0 & 0 & 0 \\
\hline $05 / 11 / 01$ & EMDMW-1 & 5 & 6 & 0 & 12.40 & 8.40 & 467 & 0 & 0 & 0 & 0 \\
\hline $05 / 11 / 01$ & EMDMW-2 & 3 & 9 & 0 & 12.30 & 5.99 & 1299 & 0 & 0 & 0 & 0 \\
\hline $02 / 20 / 01$ & EMDMPW-1 & 4 & 5 & 75 & 10.80 & 8.42 & 595 & 1 & 0 & 0 & \\
\hline $05 / 04 / 01$ & EMDMPW-1 & 5 & 4 & & 14.40 & 7.83 & 601 & 0 & 0 & 0 & \\
\hline $05 / 04 / 01$ & EMDMP W-2 & 7 & 10 & 50 & 13.00 & 7.90 & 844 & 0 & 0 & & \\
\hline $05 / 04 / 01$ & EMLLPW-1 & 2 & 9 & 0 & 14.00 & 7.70 & 597 & 0 & 0 & 0 & 0 \\
\hline $05 / 04 / 01$ & EMBAPW-1 & 5 & 3 & & 15.00 & 8.10 & 202 & 0 & 0 & 0 & 0 \\
\hline $05 / 04 / 01$ & EMBAPW-2 & 0 & 0 & 0 & 0.00 & 0.00 & 0 & 0 & 0 & 0 & 0 \\
\hline $05 / 04 / 01$ & EMDMW-1 & 5 & 5 & 25 & 11.80 & 8.20 & 460 & 0 & 0 & 0 & 0 \\
\hline $05 / 04 / 01$ & EMDMW-2 & 4 & 2 & 50 & 12.00 & 6.20 & 1269 & 0 & 0 & 0 & 0 \\
\hline $04 / 27 / 01$ & EMDMPW-1 & 13 & 9 & & 14.60 & 7.90 & 588 & 1 & 62 & 300 & 764820 \\
\hline $04 / 27 / 01$ & EMDMP W-2 & 8 & 10 & 0 & 14.20 & 7.90 & 887 & 0 & 0 & 0 & 855640 \\
\hline $04 / 27 / 01$ & EMDMP W-3 & 6 & 2 & 0 & 10.60 & 7.22 & 581 & 0 & 0 & 0 & 0 \\
\hline $04 / 27 / 01$ & EMBAPW-2 & & & & & & & 0 & & & \\
\hline $04 / 27 / 01$ & EMDMW-1 & 5 & 3 & 0 & 12.20 & 8.30 & 449 & 0 & 0 & 0 & 0 \\
\hline $04 / 27 / 01$ & EMDMW-2 & 3 & 7 & 75 & 12.30 & 8.30 & 449 & 0 & 0 & 0 & 0 \\
\hline $04 / 20 / 01$ & EMDMP W-1 & 4 & 10 & 50 & 12.90 & 8.60 & 473 & 0 & & & \\
\hline $04 / 20 / 01$ & EMDMPW-2 & 12 & 1 & 0 & 13.20 & 8.20 & 845 & 1 & 62 & 150 & 775846 \\
\hline $04 / 20 / 01$ & EMDMPW-3 & 5 & 11 & & 11.50 & 7.00 & 292 & 0 & 0 & 0 & 0 \\
\hline $04 / 20 / 01$ & EMLLPW-1 & 2 & 8 & 25 & 10.70 & 7.70 & 650 & 0 & 0 & 0 & 0 \\
\hline $04 / 20 / 01$ & EMBAPW-1 & 7 & 7 & & 13.80 & 8.20 & 197 & 0 & 0 & 0 & 0 \\
\hline $04 / 20 / 01$ & EMBAPW-2 & & & & & & & 0 & 0 & 0 & 0 \\
\hline $04 / 20 / 01$ & EMDMW-1 & 5 & 4 & 50 & 12.80 & 7.90 & 10 & 0 & 0 & 0 & 0 \\
\hline $04 / 20 / 01$ & EMDMW-2 & 4 & 3 & 50 & 11.90 & 5.90 & 1313 & 0 & 0 & 0 & 0 \\
\hline $04 / 13 / 01$ & EMDMP W-1 & 4 & 9 & 75 & 10.30 & 8.00 & 519 & 0 & & & \\
\hline $04 / 13 / 01$ & EMDMPW-2 & 7 & 8 & 75 & 11.70 & 7.70 & 786 & 0 & & & \\
\hline $04 / 13 / 01$ & EMDMPW-3 & 6 & 0 & 50 & 10.70 & 7.10 & 506 & 0 & 0 & 0 & 0 \\
\hline $04 / 13 / 01$ & EMLLPW-1 & 2 & 7 & & 8.40 & 7.48 & 669 & 0 & 0 & 0 & 0 \\
\hline $04 / 13 / 01$ & EMBAPW-1 & 8 & 6 & 25 & 13.30 & 7.50 & 182 & 0 & 0 & 0 & 0 \\
\hline $04 / 13 / 01$ & EMBAPW-2 & 0 & 0 & 0 & 0.00 & 0.00 & 0 & 0 & 0 & 0 & 0 \\
\hline $04 / 06 / 01$ & EMDMP W-1 & 4 & 9 & 0 & 11.20 & 8.00 & 564 & 0 & & & \\
\hline $04 / 06 / 01$ & EMDMPW-2 & 7 & 8 & 25 & 11.50 & 7.80 & 748 & 0 & & & \\
\hline $04 / 06 / 01$ & EMDMP W-3 & 6 & 3 & 0 & 10.90 & 7.60 & 539 & 0 & 0 & 0 & 0 \\
\hline $04 / 06 / 01$ & EMLLPW-1 & 2 & 8 & 50 & 9.10 & 6.50 & 674 & 0 & 0 & 0 & 0 \\
\hline $04 / 06 / 01$ & EMBAPW-1 & 9 & 8 & 75 & 13.20 & 7.70 & 195 & 0 & 0 & 0 & 0 \\
\hline $04 / 06 / 01$ & EMBAPW-2 & & & & & & & 0 & 0 & 0 & 0 \\
\hline $04 / 06 / 01$ & EMDMW-1 & 5 & 3 & 50 & 10.60 & 7.60 & 433 & 0 & 0 & 0 & 0 \\
\hline $04 / 06 / 01$ & EMDMW-2 & 6 & 7 & 75 & 12.20 & 7.80 & 1258 & 0 & 0 & 0 & 0 \\
\hline $03 / 30 / 01$ & EMDMPW-1 & 4 & 9 & 50 & 12.20 & 7.90 & 587 & 0 & 0 & 0 & \\
\hline $03 / 30 / 01$ & EMDMPW-2 & 7 & 9 & 25 & 12.20 & 7.80 & 786 & 0 & & & \\
\hline $03 / 30 / 01$ & EMDMPW-3 & 6 & 1 & 50 & 10.50 & 7.33 & 528 & 0 & 0 & 0 & 0 \\
\hline $03 / 30 / 01$ & EMLLPW-1 & 2 & 8 & 0 & 8.20 & 7.70 & 704 & 0 & 0 & 0 & 0 \\
\hline $03 / 30 / 01$ & EMBAPW-1 & 11 & 5 & 0 & 13.60 & 7.64 & 197 & 0 & 0 & 0 & 0 \\
\hline $03 / 30 / 01$ & EMBAPW-2 & & & & & & & 0 & 0 & 0 & 0 \\
\hline $03 / 30 / 01$ & EMDMW-1 & 6 & 5 & 50 & 11.30 & 8.00 & 429 & 0 & 0 & 0 & 0 \\
\hline $03 / 30 / 01$ & EMDMW-2 & 9 & 5 & 25 & 12.80 & 6.00 & 1216 & 0 & 0 & 0 & 0 \\
\hline $03 / 23 / 01$ & EMDMPW-1 & 4 & 7 & 75 & 12.90 & 7.91 & 587 & 1 & & & \\
\hline $03 / 23 / 01$ & EMDMPW-2 & 7 & 9 & 0 & 12.40 & 7.90 & 781 & 0 & & & \\
\hline $03 / 23 / 01$ & EMDMPW-3 & 6 & 5 & 50 & 10.30 & 7.43 & 528 & 0 & 0 & 0 & 0 \\
\hline $03 / 23 / 01$ & EMLLPW-1 & 2 & 8 & 0 & 7.30 & 7.48 & 780 & 0 & 0 & 0 & 0 \\
\hline $03 / 23 / 01$ & EMBAPW-1 & 12 & 4 & 0 & 14.40 & 7.74 & 194 & 0 & 0 & 0 & 0 \\
\hline $03 / 23 / 01$ & EMBAPW-2 & & & & & & & 0 & 0 & 0 & 0 \\
\hline $03 / 23 / 01$ & EMDMW-1 & 6 & 9 & 50 & 11.50 & 8.00 & 424 & 0 & 0 & 0 & 0 \\
\hline $03 / 23 / 01$ & EMDMW-2 & 7 & 10 & 0 & 13.00 & 5.95 & 1148 & 0 & 0 & 0 & 0 \\
\hline $03 / 16 / 01$ & EMDMPW-1 & 4 & 8 & 50 & 12.00 & 8.03 & 592 & 1 & & & \\
\hline $03 / 16 / 01$ & EMDMPW-2 & 7 & 9 & 50 & 12.00 & 7.91 & 785 & 0 & & & \\
\hline $03 / 16 / 01$ & EMDMP W-3 & 6 & 10 & 50 & 10.40 & 7.55 & 588 & 0 & 0 & 0 & 0 \\
\hline $03 / 16 / 01$ & EMLLPW-1 & 2 & 7 & 50 & 6.50 & 7.98 & 825 & 0 & 0 & 0 & 0 \\
\hline $03 / 16 / 01$ & EMBAPW-1 & 11 & 11 & & 13.20 & 7.82 & 190 & 0 & 0 & 0 & 0 \\
\hline $03 / 16 / 01$ & EMBAPW-2 & & & & & & & 0 & 0 & 0 & 0 \\
\hline $03 / 16 / 01$ & EMDMW-1 & 7 & & 50 & 11.30 & 8.26 & 419 & 0 & 0 & 0 & 0 \\
\hline $03 / 16 / 01$ & EMDMW-2 & 6 & 2 & & 12.70 & 5.82 & 1128 & 0 & 0 & 0 & 0 \\
\hline $03 / 08 / 01$ & EMDMP W-1 & 4 & 7 & 50 & 12.20 & 8.08 & 591 & 1 & & & \\
\hline $03 / 08 / 01$ & EMDMP W-2 & 7 & 8 & & 12.10 & 8.10 & 784 & 0 & & & \\
\hline $03 / 08 / 01$ & EMDMPW-3 & 7 & 3 & 25 & 10.20 & 7.47 & 585 & 0 & 0 & 0 & 0 \\
\hline
\end{tabular}




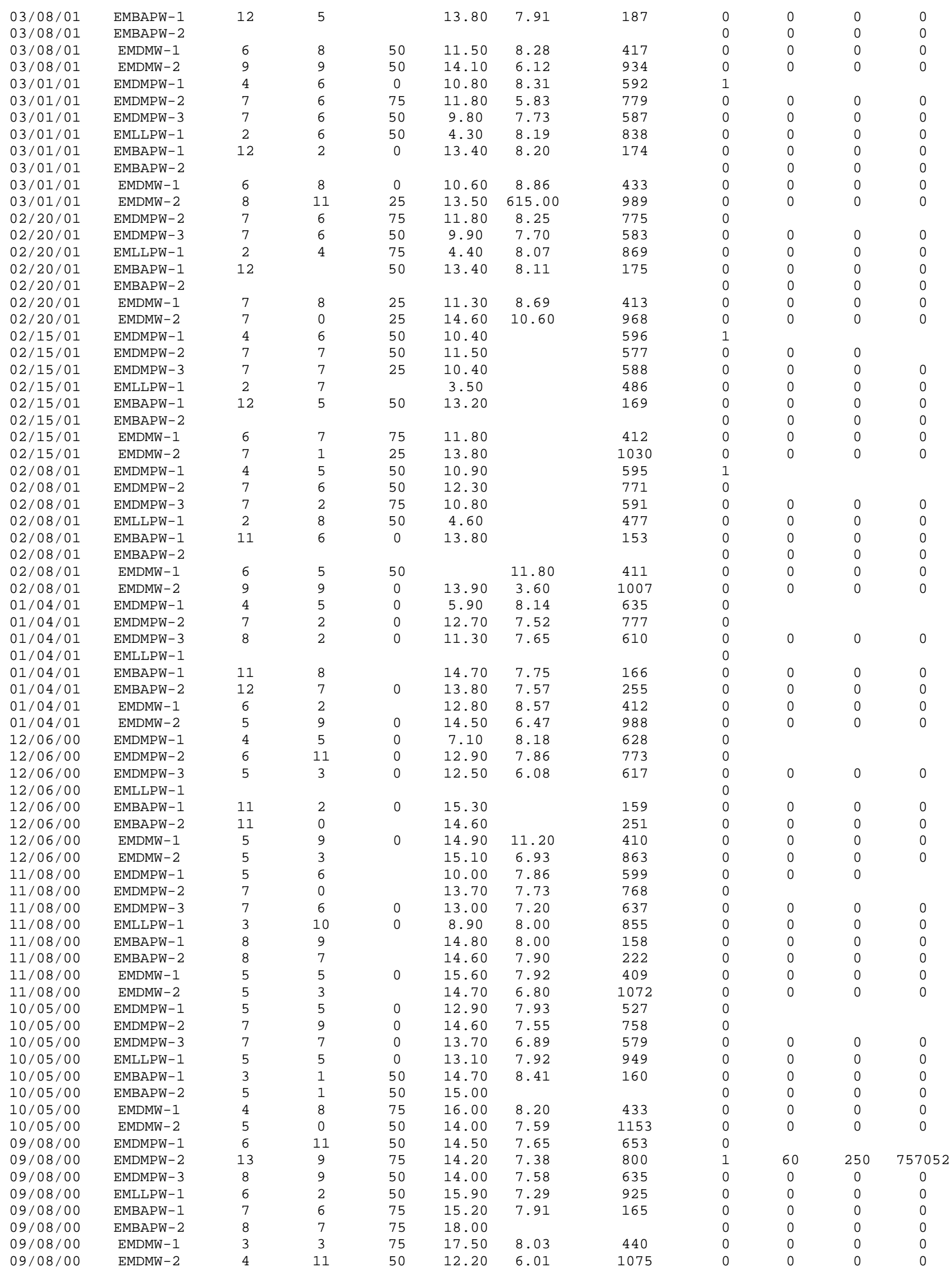




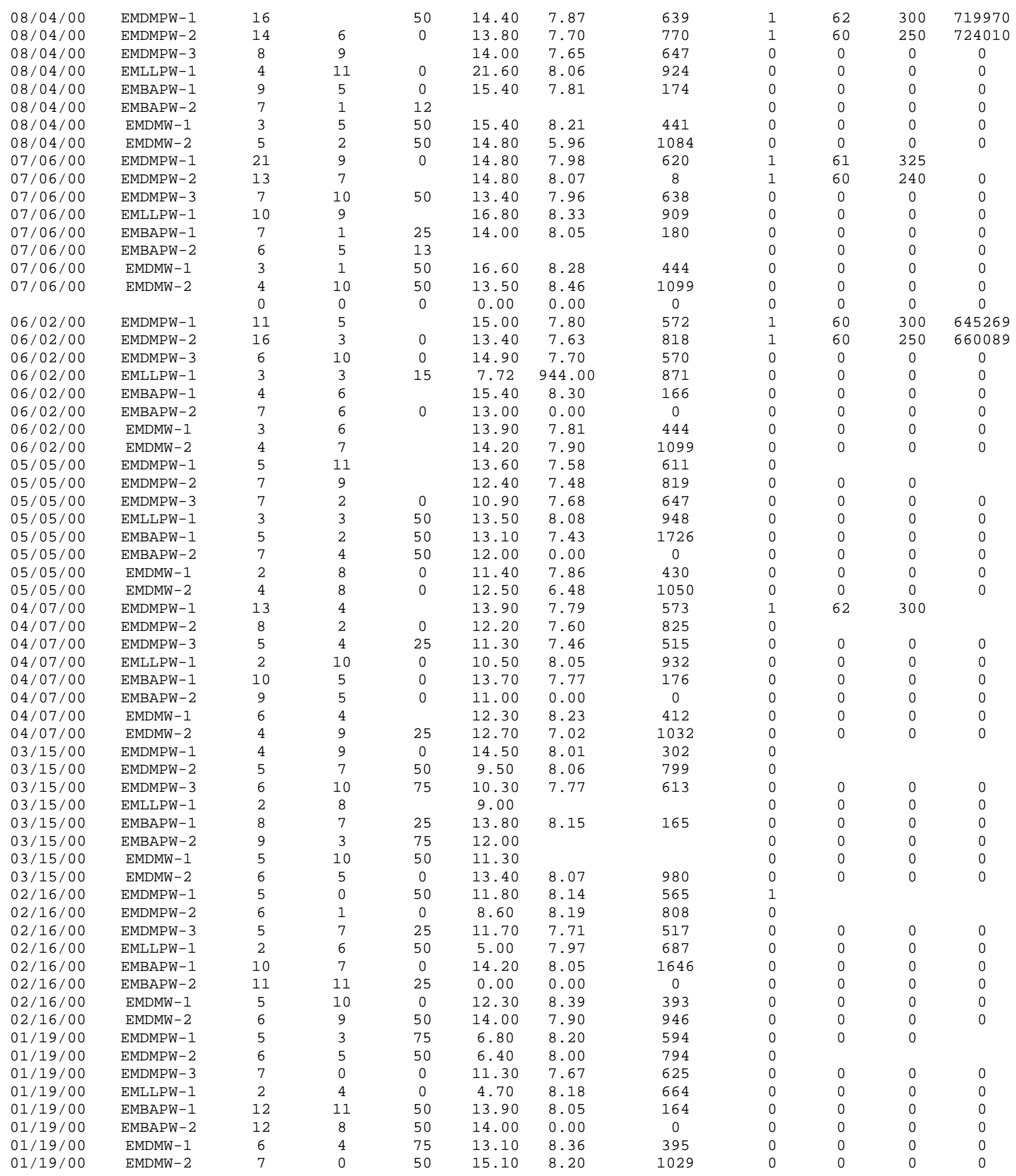




\begin{tabular}{|c|c|c|c|c|c|c|c|c|}
\hline Date & Location & Level_ & ftLevel_in & Level__o & Level_all & Temperature & $\mathrm{pH}$ & Conductivity \\
\hline $01 / 12 / 00$ & EMBAP-1 & 3 & 2 & 25 & 3.19 & 8.90 & 8.20 & 1552 \\
\hline $02 / 16 / 00$ & EMBAP-1 & 2 & 8 & 75 & 2.73 & 7.60 & 8.13 & 1849 \\
\hline $03 / 15 / 00$ & EMBAP-1 & 4 & 4 & & 4.33 & 8.00 & & \\
\hline $03 / 30 / 00$ & EMBAP - 1 & 4 & 0 & & 4.00 & 10.00 & 7.86 & 1783 \\
\hline $04 / 07 / 00$ & EMBAP-1 & 3 & 6 & 50 & 3.54 & 10.60 & 7.78 & 1736 \\
\hline $05 / 05 / 00$ & EMBAP-1 & 3 & 6 & & 3.50 & 13.20 & 7.85 & 1883 \\
\hline $06 / 02 / 00$ & EMBAP - 1 & 3 & 8 & 75 & 3.73 & 16.40 & 7.44 & 2232 \\
\hline $07 / 06 / 00$ & EMBAP-1 & & & & & & & \\
\hline $08 / 04 / 00$ & EMBAP-1 & 4 & 9 & 50 & 4.79 & 20.50 & 8.16 & 2005 \\
\hline $09 / 08 / 00$ & EMBAP-1 & 3 & 9 & 75 & 3.81 & 22.40 & 7.60 & \\
\hline $10 / 05 / 00$ & EMBAP-1 & 3 & 11 & 50 & 3.96 & 17.40 & 7.63 & 1920 \\
\hline $11 / 08 / 00$ & EMBAP-1 & 3 & 8 & 73 & 3.73 & 13.10 & 7.60 & 1931 \\
\hline $12 / 06 / 00$ & EMBAP-1 & 3 & 9 & & 3.75 & 10.30 & 8.38 & 2092 \\
\hline $01 / 04 / 01$ & EMBAP-1 & 3 & 9 & 50 & 3.79 & 8.40 & 8.24 & 2169 \\
\hline $02 / 08 / 01$ & EMBAP-1 & 3 & 5 & & 3.42 & 7.40 & & 2383 \\
\hline $02 / 15 / 01$ & EMBAP-1 & 3 & 5 & & 3.42 & 6.50 & & 2515 \\
\hline $02 / 22 / 01$ & EMBAP-1 & 3 & 3 & 50 & 3.29 & 6.70 & 8.39 & 2585 \\
\hline 03/01/01 & EMBAP - 1 & 3 & 6 & & 3.50 & 6.80 & 8.32 & 2657 \\
\hline $03 / 08 / 01$ & EMBAP-1 & 3 & 5 & & 3.42 & 7.50 & 8.04 & 2712 \\
\hline 03/16/01 & EMBAP-1 & 3 & 6 & 75 & 3.56 & 8.10 & 7.96 & 2739 \\
\hline $03 / 23 / 01$ & EMBAP-1 & 3 & 9 & & 3.75 & 9.40 & 7.76 & 2751 \\
\hline $03 / 30 / 01$ & EMBAP-1 & & & & & & & \\
\hline $04 / 06 / 01$ & EMBAP - 1 & 3 & 8 & & 3.67 & 9.60 & & 2896 \\
\hline $04 / 13 / 01$ & EMBAP-1 & 3 & 2 & 50 & 3.21 & 10.20 & 7.67 & \\
\hline $04 / 17 / 01$ & EMBAP - 1 & 3 & 7 & 50 & 3.63 & 12.60 & 7.86 & 2670 \\
\hline $04 / 20 / 01$ & EMBAP-1 & 3 & 2 & & 3.17 & 10.50 & 7.80 & 2665 \\
\hline $05 / 04 / 01$ & EMBAP - 1 & 3 & 5 & 50 & 3.46 & 12.50 & 7.76 & 2775 \\
\hline $05 / 11 / 01$ & EMBAP - 1 & 3 & 4 & 75 & 3.40 & 13.20 & 7.82 & 2669 \\
\hline $05 / 18 / 01$ & EMBAP-1 & 3 & 10 & 50 & 3.88 & 14.50 & 7.73 & \\
\hline $05 / 24 / 01$ & EMBAP-1 & 4 & 6 & & 4.50 & 16.70 & 7.59 & 2753 \\
\hline $06 / 01 / 01$ & EMBAP-1 & 5 & 1 & 50 & 5.13 & 15.70 & & 2211 \\
\hline $06 / 08 / 01$ & EMBAP-1 & 5 & 4 & & 5.33 & & & \\
\hline $06 / 15 / 01$ & EMBAP-1 & 5 & 4 & & 5.33 & & & \\
\hline $06 / 22 / 01$ & EMBAP-1 & 4 & 0 & 50 & 4.04 & 17.00 & 7.94 & 1795 \\
\hline $06 / 29 / 01$ & EMBAP-1 & 5 & 3 & & 5.25 & 17.40 & 7.86 & \\
\hline $07 / 06 / 01$ & EMBAP-1 & 4 & 10 & & 4.83 & 18.10 & 7.98 & \\
\hline $07 / 13 / 01$ & EMBAP-1 & & & & & & & \\
\hline $07 / 20 / 01$ & EMBAP-1 & 7 & 7 & 50 & 7.63 & 15.70 & 7.60 & 2091 \\
\hline $01 / 12 / 00$ & EMDMP - 2 & & & & & & & \\
\hline $02 / 16 / 00$ & EMDMP - 2 & 2 & 7 & 50 & 2.63 & 15.70 & 7.87 & 765 \\
\hline $03 / 15 / 00$ & EMDMP - 2 & & & & & & & \\
\hline $03 / 30 / 00$ & EMDMP - 2 & 2 & 2 & 50 & 2.21 & 15.40 & 7.80 & 462 \\
\hline $04 / 07 / 00$ & EMDMP - 2 & 2 & 5 & & 2.42 & 16.70 & 7.92 & 281 \\
\hline $05 / 05 / 00$ & EMDMP - 2 & 4 & 10 & & 4.83 & 15.80 & 7.65 & 449 \\
\hline $06 / 02 / 00$ & EMDMP - 2 & 2 & 3 & & 2.25 & 15.00 & 7.95 & 616 \\
\hline $07 / 06 / 00$ & EMDMP - 2 & & & & & & & \\
\hline $08 / 04 / 00$ & EMDMP - 2 & 2 & 0 & & 2.00 & 11.20 & 7.91 & 234 \\
\hline $09 / 08 / 00$ & EMDMP - 2 & & & & & & & \\
\hline $10 / 05 / 00$ & EMDMP - 2 & 3 & 9 & 25 & 3.77 & 15.10 & 7.81 & 872 \\
\hline $11 / 08 / 00$ & EMDMP - 2 & 4 & 5 & 25 & 4.44 & 12.10 & 8.16 & 413 \\
\hline $12 / 06 / 00$ & EMDMP - 2 & 2 & 3 & & 2.25 & 13.70 & 7.61 & 582 \\
\hline $01 / 04 / 01$ & EMDMP - 2 & 2 & 11 & 25 & 2.94 & 12.00 & 8.33 & 487 \\
\hline $02 / 08 / 01$ & EMDMP - 2 & & & & & & & \\
\hline $02 / 15 / 01$ & EMDMP - 2 & & & & & & & \\
\hline $02 / 22 / 01$ & EMDMP - 2 & & & & & & & \\
\hline $03 / 01 / 01$ & EMDMP - 2 & 2 & 8 & 50 & 2.71 & 18.30 & 7.40 & 714 \\
\hline $03 / 08 / 01$ & EMDMP - 2 & 6 & 4 & 50 & 6.38 & 8.20 & 7.80 & 3 \\
\hline $03 / 16 / 01$ & EMDMP - 2 & & & & & & & \\
\hline $03 / 23 / 01$ & EMDMP - 2 & & & & & & & \\
\hline $03 / 30 / 01$ & EMDMP - 2 & & & & & & & \\
\hline $04 / 06 / 01$ & EMDMP - 2 & 2 & 7 & 50 & 2.63 & 17.10 & 7.82 & 469 \\
\hline $04 / 13 / 01$ & EMDMP - 2 & 4 & 6 & 50 & 4.54 & 24.00 & 8.16 & \\
\hline $04 / 20 / 01$ & EMDMP - 2 & 6 & 9 & & 6.75 & 11.40 & 8.08 & \\
\hline $04 / 27 / 01$ & EMDMP - 2 & 4 & 3 & & 4.25 & 8.30 & 7.37 & 978 \\
\hline $05 / 04 / 01$ & EMDMP - 2 & & & & & & & \\
\hline 05/11/01 & EMDMP - 2 & & & & & & & \\
\hline $05 / 18 / 01$ & EMDMP - 2 & 3 & 11 & 25 & 3.94 & 16.60 & 8.15 & 496 \\
\hline $05 / 24 / 01$ & EMDMP - 2 & 4 & 10 & 50 & 4.88 & 12.20 & 8.36 & 232 \\
\hline $06 / 01 / 01$ & EMDMP - 2 & & & & & & & \\
\hline $06 / 08 / 01$ & EMDMP - 2 & & & & & & & \\
\hline
\end{tabular}


Piez00_01

\begin{tabular}{|c|c|c|c|c|c|c|c|c|}
\hline $06 / 15 / 01$ & EMDMP - 2 & 4 & 6 & 50 & 4.54 & 9.90 & 7.67 & 936 \\
\hline $06 / 22 / 01$ & EMDMP -2 & 2 & 10 & & 2.83 & 14.50 & 7.51 & 411 \\
\hline $06 / 29 / 01$ & EMDMP - 2 & & & & & & & \\
\hline $07 / 06 / 01$ & EMDMP - 2 & 3 & 9 & 50 & 3.79 & 8.60 & 7.55 & 956 \\
\hline 07/13/01 & EMDMP - 2 & 3 & 0 & 50 & 3.04 & 20.50 & 7.53 & 530 \\
\hline $07 / 20 / 01$ & EMDMP - 2 & & & & & & & \\
\hline $01 / 12 / 00$ & EMDMP - 4 & 2 & 5 & 50 & 2.46 & 8.20 & 7.88 & 680 \\
\hline $02 / 16 / 00$ & EMDMP - 4 & 1 & 9 & & 1.75 & 6.60 & 7.87 & 740 \\
\hline $03 / 15 / 00$ & EMDMP - 4 & 1 & 10 & & 1.83 & 7.60 & 7.82 & 783 \\
\hline $03 / 30 / 00$ & EMDMP - 4 & 2 & 11 & & 2.92 & 9.40 & 7.54 & 932 \\
\hline $04 / 07 / 00$ & EMDMP - 4 & 1 & 1 & 50 & 1.13 & 8.90 & 7.51 & 897 \\
\hline $05 / 05 / 00$ & EMDMP - 4 & 2 & 9 & 50 & 2.79 & 11.30 & 7.49 & 784 \\
\hline $06 / 02 / 00$ & EMDMP - 4 & 3 & 9 & 50 & 3.79 & 13.70 & 7.43 & 810 \\
\hline $07 / 06 / 00$ & EMDMP - 4 & 3 & 11 & & 3.92 & 15.50 & 7.07 & 1652 \\
\hline $08 / 04 / 00$ & EMDMP - 4 & 10 & 4 & & 10.33 & 13.60 & 7.57 & 772 \\
\hline $09 / 08 / 00$ & EMDMP - 4 & 5 & 1 & 75 & 5.15 & 16.80 & 7.22 & 1131 \\
\hline $10 / 05 / 00$ & EMDMP - 4 & 4 & 10 & 50 & 4.88 & 15.60 & 7.41 & 1268 \\
\hline $11 / 08 / 00$ & EMDMP - 4 & 3 & 5 & & 3.42 & 12.10 & 7.20 & 1153 \\
\hline $12 / 06 / 00$ & EMDMP - 4 & 3 & & & 3.00 & 8.70 & 6.58 & 1091 \\
\hline 01/04/01 & EMDMP - 4 & 2 & 9 & & 2.75 & 7.10 & 8.01 & 1034 \\
\hline $02 / 08 / 01$ & EMDMP - 4 & 2 & 6 & 50 & 2.54 & 7.60 & & 506 \\
\hline $02 / 15 / 01$ & EMDMP - 4 & 2 & 8 & & 2.67 & 6.30 & & 1137 \\
\hline $02 / 22 / 01$ & EMDMP - 4 & 2 & 7 & & 2.58 & 6.50 & 8.02 & 504 \\
\hline 03/01/01 & EMDMP - 4 & 2 & 5 & 50 & 2.46 & 6.00 & 5.63 & 883 \\
\hline $03 / 08 / 01$ & EMDMP - 4 & 2 & 6 & & 2.50 & 7.40 & 7.65 & 869 \\
\hline $03 / 16 / 01$ & EMDMP - 4 & 2 & 2 & 50 & 2.21 & 7.60 & 7.48 & 834 \\
\hline $03 / 23 / 01$ & EMDMP - 4 & 2 & 1 & 50 & 2.13 & 7.80 & 7.20 & 835 \\
\hline $03 / 30 / 01$ & EMDMP - 4 & 2 & 2 & 25 & 2.19 & 9.40 & 7.36 & 821 \\
\hline $04 / 06 / 01$ & EMDMP - 4 & 2 & 5 & 25 & 2.44 & 9.50 & 7.69 & 818 \\
\hline $04 / 13 / 01$ & EMDMP - 4 & & & & & & & \\
\hline $04 / 20 / 01$ & EMDMP - 4 & 1 & 5 & & 1.42 & 11.10 & 6.86 & \\
\hline $04 / 27 / 01$ & EMDMP - 4 & 1 & 5 & 50 & 1.46 & 11.40 & 7.11 & 732 \\
\hline $05 / 04 / 01$ & EMDMP - 4 & 2 & 10 & 50 & 2.88 & 11.90 & 7.30 & 737 \\
\hline $05 / 11 / 01$ & EMDMP - 4 & 2 & 1 & & 2.08 & 11.70 & 7.51 & 741 \\
\hline $05 / 18 / 01$ & EMDMP -4 & 2 & 11 & 25 & 2.94 & 12.30 & 6.87 & 752 \\
\hline $05 / 24 / 01$ & EMDMP - 4 & 3 & 8 & 75 & 3.73 & 14.00 & 7.89 & 765 \\
\hline $06 / 01 / 01$ & EMDMP - 4 & 3 & 9 & 50 & 3.79 & 17.50 & 6.67 & 713 \\
\hline $06 / 08 / 01$ & EMDMP - 4 & 3 & 9 & 50 & 3.79 & 14.10 & 7.71 & 770 \\
\hline $06 / 15 / 01$ & EMDMP - 4 & 3 & 4 & & 3.33 & 13.60 & 7.57 & 772 \\
\hline $06 / 22 / 01$ & EMDMP - 4 & 4 & 1 & 50 & 4.13 & 14.30 & 7.70 & 768 \\
\hline $06 / 29 / 01$ & EMDMP - 4 & 4 & & 50 & 4.04 & 14.50 & 7.58 & 776 \\
\hline 07/06/01 & EMDMP - 4 & 3 & 11 & 50 & 3.96 & 14.80 & 7.53 & 765 \\
\hline 07/13/01 & EMDMP - 4 & 3 & 11 & 25 & 3.94 & 16.90 & 7.89 & 783 \\
\hline $07 / 20 / 01$ & EMDMP - 4 & 3 & 9 & 50 & 3.79 & 17.50 & 6.67 & 713 \\
\hline $01 / 12 / 00$ & EMDMP R-1 & 8 & 10 & 25 & 8.85 & 7.90 & 7.44 & \\
\hline $02 / 16 / 00$ & EMDMPR-1 & 6 & 5 & 25 & 6.44 & 10.30 & 7.31 & 1374 \\
\hline $03 / 15 / 00$ & EMDMP R-1 & 6 & 9 & 75 & 6.81 & 10.40 & 7.40 & 1453 \\
\hline $03 / 30 / 00$ & EMDMP R-1 & 7 & 8 & & 7.67 & 11.60 & 7.60 & 1528 \\
\hline $05 / 05 / 00$ & EMDMP R-1 & 8 & 6 & & 8.50 & 11.20 & 6.90 & 1457 \\
\hline $06 / 02 / 00$ & EMDMP R-1 & 9 & 1 & 50 & 9.13 & 14.50 & 7.50 & 1730 \\
\hline $07 / 06 / 00$ & EMDMP R-1 & 8 & 10 & 50 & 8.88 & 17.00 & 7.85 & \\
\hline $08 / 04 / 00$ & EMDMP R-1 & 10 & 3 & 50 & 10.29 & & & \\
\hline $09 / 08 / 00$ & EMDMP R-1 & & & & & & & \\
\hline $10 / 05 / 00$ & EMDMP R-1 & 8 & 11 & & 8.92 & 11.30 & 7.24 & \\
\hline $11 / 08 / 00$ & EMDMPR-1 & 10 & 0 & & 1.00 & 12.90 & 7.10 & 1128 \\
\hline $12 / 06 / 00$ & EMDMP R-1 & & & & & & & \\
\hline $01 / 04 / 01$ & EMDMPR-1 & 9 & 9 & & 9.75 & 12.10 & 7.07 & 774 \\
\hline $02 / 08 / 01$ & EMDMP R-1 & 8 & 8 & 25 & 8.69 & 10.30 & 1.89 & 1462 \\
\hline $02 / 15 / 01$ & EMDMP R-1 & 8 & 11 & & 8.92 & 10.10 & & 1450 \\
\hline $02 / 22 / 01$ & EMDMPR-1 & 9 & 1 & 50 & 9.13 & 8.50 & 7.48 & \\
\hline $03 / 01 / 01$ & EMDMP R-1 & 8 & 9 & 50 & 8.79 & 5.80 & 6.81 & \\
\hline $03 / 08 / 01$ & EMDMP R-1 & 8 & 8 & & 8.67 & 10.60 & 6.59 & 1369 \\
\hline $03 / 16 / 01$ & EMDMP R-1 & 8 & 3 & 50 & 8.29 & 10.20 & 6.38 & 1360 \\
\hline $03 / 23 / 01$ & EMDMP R-1 & 7 & 9 & 50 & 7.79 & 10.40 & 6.54 & 1411 \\
\hline $03 / 30 / 01$ & EMDMP R-1 & 8 & 4 & 50 & 8.38 & 10.20 & 6.72 & 1382 \\
\hline $04 / 06 / 01$ & EMDMP R-1 & 7 & 7 & 25 & 7.60 & 10.40 & 7.59 & 1322 \\
\hline $04 / 13 / 01$ & EMDMPR-1 & 7 & 1 & & 7.08 & 10.40 & 6.64 & 1316 \\
\hline $04 / 20 / 01$ & EMDMPR-1 & 8 & 4 & & 8.33 & 10.50 & 7.01 & 619 \\
\hline $04 / 27 / 01$ & EMDMP R-1 & 5 & 7 & 75 & 5.65 & 12.00 & 7.18 & 1190 \\
\hline $05 / 04 / 01$ & EMDMP R-1 & 7 & 6 & 75 & 7.56 & 10.80 & 6.77 & 1167 \\
\hline $05 / 11 / 01$ & EMDMP R-1 & 8 & 6 & & 8.50 & 11.30 & 6.74 & 1187 \\
\hline
\end{tabular}




\begin{tabular}{|c|c|c|c|c|c|c|c|c|}
\hline $05 / 18 / 01$ & EMDMPR-1 & 9 & 2 & & 9.17 & 10.90 & 5.90 & 851 \\
\hline $05 / 24 / 01$ & EMDMPR-1 & 8 & 10 & & 8.83 & 7.54 & & \\
\hline $06 / 01 / 01$ & EMDMP R-1 & & & & & & & \\
\hline $06 / 08 / 01$ & EMDMPR-1 & 9 & 0 & & 9.00 & 14.20 & 7.23 & 18 \\
\hline $06 / 15 / 01$ & EMDMPR-1 & 8 & 8 & 75 & 8.73 & 14.60 & 7.33 & \\
\hline $06 / 22 / 01$ & EMDMPR-1 & 8 & 10 & 75 & 8.90 & 15.80 & 7.54 & 14 \\
\hline $06 / 29 / 01$ & EMDMPR -1 & 9 & 0 & 50 & 9.04 & 16.70 & 6.94 & \\
\hline $07 / 06 / 01$ & EMDMP R-1 & & & & & & & \\
\hline $07 / 13 / 01$ & EMDMP R-1 & & & & & & & \\
\hline $07 / 20 / 01$ & EMDMPR-1 & & & & & & & \\
\hline $04 / 07 / 00$ & EMDMRP -1 & 6 & 4 & 50 & 6.38 & 9.70 & 7.12 & 1424 \\
\hline $01 / 12 / 00$ & EMDMRP - 2 & 11 & 1 & 50 & 11.13 & 12.70 & 7.38 & 1017 \\
\hline $02 / 16 / 00$ & EMDMRP -2 & 9 & 5 & & 9.42 & 12.20 & 7.31 & 1000 \\
\hline $03 / 15 / 00$ & EMDMRP - 2 & 8 & 11 & & 8.92 & 11.70 & 7.28 & 1021 \\
\hline $03 / 30 / 00$ & EMDMRP - 2 & 8 & 11 & & 8.92 & 12.30 & 7.30 & 1017 \\
\hline $04 / 07 / 00$ & EMDMRP -2 & 8 & 3 & 25 & 8.27 & 11.60 & 7.12 & 1023 \\
\hline $05 / 05 / 00$ & EMDMRP -2 & 10 & 6 & & 10.50 & 11.80 & 7.21 & 1075 \\
\hline $06 / 02 / 00$ & EMDMRP -2 & 10 & 9 & & 10.75 & 13.30 & 7.30 & 1185 \\
\hline $07 / 06 / 00$ & EMDMRP -2 & 10 & 3 & 50 & 10.29 & 18.30 & 7.74 & 4 \\
\hline $08 / 04 / 00$ & EMDMRP - 2 & 12 & 8 & & 12.67 & 14.60 & 7.48 & 1185 \\
\hline $09 / 08 / 00$ & EMDMRP - 2 & & & & & & & \\
\hline $10 / 05 / 00$ & EMDMRP - 2 & 11 & 7 & & 11.58 & 13.60 & 7.21 & 1106 \\
\hline $11 / 08 / 00$ & EMDMRP -2 & 11 & 5 & & 11.42 & 14.10 & 7.10 & 1138 \\
\hline $12 / 06 / 00$ & EMDMRP - 2 & 11 & 6 & & 11.50 & 13.60 & & 1047 \\
\hline $01 / 04 / 01$ & EMDMRP -2 & 11 & 6 & & 11.50 & 13.00 & 7.88 & 1001 \\
\hline $02 / 08 / 01$ & EMDMRP - 2 & 10 & 6 & 25 & 10.52 & 12.40 & & 946 \\
\hline $02 / 15 / 01$ & EMDMRP - 2 & 10 & 11 & 75 & 10.98 & 11.50 & & 926 \\
\hline $02 / 22 / 01$ & EMDMRP - 2 & 10 & 11 & 50 & 10.96 & 9.80 & 7.84 & \\
\hline $03 / 01 / 01$ & EMDMRP - 2 & 10 & 9 & 25 & 10.77 & 11.00 & 7.82 & 875 \\
\hline $03 / 08 / 01$ & EMDMRP - 2 & 10 & 9 & & 10.75 & 12.10 & 7.48 & 858 \\
\hline $03 / 16 / 01$ & EMDMRP - 2 & 10 & 2 & 25 & 10.19 & 12.10 & 7.23 & 938 \\
\hline $03 / 23 / 01$ & EMDMRP - 2 & 9 & 5 & 50 & 9.46 & 12.00 & 7.08 & 998 \\
\hline $03 / 30 / 01$ & EMDMRP - 2 & 8 & 6 & 50 & 8.54 & 12.20 & 7.19 & 1097 \\
\hline $04 / 06 / 01$ & EMDMRP -2 & 9 & 2 & 25 & 9.19 & 12.20 & 7.28 & 1092 \\
\hline $04 / 13 / 01$ & EMDMRP - 2 & 9 & 2 & 50 & 9.21 & 11.60 & 7.32 & 660 \\
\hline $04 / 20 / 01$ & EMDMRP -2 & 9 & 1 & 50 & 9.13 & 11.80 & 7.17 & 984 \\
\hline $04 / 27 / 01$ & EMDMRP -2 & 9 & 4 & 75 & 9.40 & 12.60 & 7.63 & 938 \\
\hline $05 / 04 / 01$ & EMDMRP - 2 & 9 & 1 & 50 & 9.13 & 11.90 & 7.41 & 945 \\
\hline $05 / 11 / 01$ & EMDMRP -2 & 10 & 2 & & 10.17 & 12.10 & 7.61 & 903 \\
\hline $05 / 18 / 01$ & EMDMRP - 2 & 10 & 6 & & 10.50 & 12.20 & 7.55 & \\
\hline $05 / 24 / 01$ & EMDMRP - 2 & 11 & & & 11.00 & 14.10 & 7.53 & 1164 \\
\hline $06 / 01 / 01$ & EMDMRP - 2 & 14 & 9 & & 14.75 & 13.40 & 6.85 & 1431 \\
\hline $06 / 08 / 01$ & EMDMRP -2 & 11 & 4 & & 11.33 & 12.60 & 7.15 & 1129 \\
\hline $06 / 15 / 01$ & EMDMRP - 2 & 13 & 0 & & 13.00 & 12.80 & 7.25 & 1151 \\
\hline $06 / 22 / 01$ & EMDMRP -2 & 11 & 3 & 50 & 11.29 & 12.90 & 7.34 & 1124 \\
\hline $06 / 29 / 01$ & EMDMRP -2 & 11 & 5 & & 11.42 & 12.60 & 7.20 & 1151 \\
\hline $07 / 06 / 01$ & EMDMRP - 2 & 11 & 4 & 25 & 11.35 & 13.10 & 7.21 & 1162 \\
\hline $07 / 13 / 01$ & EMDMRP - 2 & 11 & 9 & & 11.75 & 12.90 & 7.43 & 1121 \\
\hline $07 / 20 / 01$ & EMDMRP - 2 & 14 & 9 & & 14.75 & 13.40 & 6.85 & 1431 \\
\hline $01 / 12 / 00$ & EMFMRP - 1 & 9 & 10 & 25 & 9.85 & 14.80 & 7.63 & 530 \\
\hline $02 / 16 / 00$ & EMFMRP-1 & 6 & 7 & 75 & 6.65 & 13.40 & 7.77 & 527 \\
\hline $03 / 15 / 00$ & EMFMRP-1 & 6 & 8 & 75 & 6.73 & 12.50 & 7.57 & 527 \\
\hline $03 / 30 / 00$ & EMFMRP - 1 & 7 & 5 & & 7.42 & 12.70 & 7.68 & 533 \\
\hline $04 / 07 / 00$ & EMFMRP-1 & 6 & 1 & 25 & 6.10 & 12.00 & 7.49 & 537 \\
\hline $05 / 05 / 00$ & EMFMRP -1 & 8 & 10 & & 8.83 & 12.60 & 7.42 & 526 \\
\hline $06 / 02 / 00$ & EMFMRP-1 & 9 & 5 & & 9.42 & 14.20 & 7.43 & 520 \\
\hline $07 / 06 / 00$ & EMFMRP - 1 & 8 & 3 & & 8.25 & 14.80 & 7.90 & 591 \\
\hline $08 / 04 / 00$ & EMFMRP -1 & 10 & & & 1.00 & 15.20 & 7.39 & 652 \\
\hline $09 / 08 / 00$ & EMFMRP -1 & 9 & 0 & 75 & 9.06 & 16.10 & 7.12 & 612 \\
\hline $10 / 05 / 00$ & EMFMRP -1 & 8 & 1 & 25 & 8.10 & 16.00 & 6.32 & 721 \\
\hline $11 / 08 / 00$ & EMFMRP-1 & 10 & 2 & & 10.17 & 15.30 & 7.60 & 334 \\
\hline $12 / 06 / 00$ & EMFMRP -1 & 10 & 4 & & 10.33 & 16.60 & 7.94 & 912 \\
\hline $01 / 04 / 01$ & EMFMRP - 1 & 10 & 3 & & 10.25 & 14.30 & 7.86 & 599 \\
\hline $02 / 08 / 01$ & EMFMRP - 1 & 8 & 9 & 25 & 8.77 & 12.80 & & 670 \\
\hline $02 / 15 / 01$ & EMFMRP -1 & 9 & 2 & 50 & 9.21 & 12.30 & & 674 \\
\hline $02 / 22 / 01$ & EMFMRP-1 & 9 & 0 & 75 & 9.06 & 11.60 & 7.97 & 664 \\
\hline $03 / 01 / 01$ & EMFMRP -1 & 9 & 10 & 50 & 9.88 & 11.80 & 7.88 & 648 \\
\hline $03 / 08 / 01$ & EMFMRP-1 & 8 & 8 & 50 & 8.71 & 12.40 & 7.65 & 634 \\
\hline $03 / 16 / 01$ & EMFMRP -1 & 9 & 1 & 75 & 9.15 & 11.90 & 7.49 & 626 \\
\hline $03 / 23 / 01$ & EMFMRP - 1 & 7 & 8 & 25 & 7.69 & 12.00 & 7.14 & 468 \\
\hline $03 / 30 / 01$ & EMFMRP - 1 & & & & & & & \\
\hline
\end{tabular}


Piez00_01

\begin{tabular}{|c|c|c|c|c|c|c|c|c|}
\hline $04 / 06 / 01$ & EMFMRP-1 & 7 & 5 & & 7.42 & 11.80 & 7.14 & 591 \\
\hline $04 / 13 / 01$ & EMFMRP-1 & 7 & 9 & & 7.75 & 11.60 & 7.08 & 609 \\
\hline $04 / 20 / 01$ & EMFMRP-1 & 5 & 6 & 50 & 5.54 & 11.70 & 7.27 & 664 \\
\hline $04 / 27 / 01$ & EMFMRP - 1 & 7 & 5 & & 7.42 & 12.30 & 7.48 & 602 \\
\hline $05 / 04 / 01$ & EMFMRP-1 & 7 & 5 & 25 & 7.44 & 11.90 & 7.71 & 604 \\
\hline $05 / 11 / 01$ & EMFMRP-1 & 8 & 8 & 50 & 8.71 & 12.00 & 7.79 & 596 \\
\hline $05 / 18 / 01$ & EMFMRP-1 & 8 & 9 & 75 & 8.81 & 12.90 & 7.74 & 583 \\
\hline $05 / 24 / 01$ & EMFMRP-1 & 9 & 4 & & 9.33 & 13.10 & 7.71 & 560 \\
\hline 06/01/01 & EMFMRP-1 & 9 & 6 & & 9.50 & 12.70 & 2.58 & 550 \\
\hline $06 / 08 / 01$ & EMFMRP-1 & 8 & 5 & & 8.42 & 13.10 & 7.66 & 549 \\
\hline $06 / 15 / 01$ & EMFMRP - 1 & 8 & 11 & 50 & 8.96 & 12.90 & 7.82 & 543 \\
\hline $06 / 22 / 01$ & EMFMRP-1 & 9 & 0 & & 9.00 & 13.40 & 7.47 & 648 \\
\hline $06 / 29 / 01$ & EMFMRP-1 & 8 & 6 & & 8.50 & 13.40 & 7.81 & 518 \\
\hline $07 / 06 / 01$ & EMFMRP-1 & 9 & 2 & & 9.17 & 14.10 & 7.50 & 515 \\
\hline $07 / 13 / 01$ & EMFMRP-1 & 9 & 9 & & 9.75 & 13.90 & 7.53 & 552 \\
\hline $07 / 20 / 01$ & EMFMRP - 1 & 9 & 11 & & 9.92 & 14.40 & 7.40 & 440 \\
\hline $01 / 12 / 00$ & EMLLP-1 & 10 & 4 & 25 & 10.35 & 12.90 & & 779 \\
\hline $02 / 16 / 00$ & EMLLP-1 & 9 & 10 & 50 & 9.88 & 11.70 & 8.14 & \\
\hline $03 / 15 / 00$ & EMLLP-1 & 9 & 8 & 25 & 9.69 & 12.10 & 7.93 & 1011 \\
\hline $03 / 30 / 00$ & EMLLP-1 & 11 & 6 & & 11.50 & 11.70 & 7.60 & 1038 \\
\hline $04 / 07 / 00$ & EMLLP-1 & 10 & 6 & & 10.50 & 13.10 & 7.65 & 1049 \\
\hline $05 / 05 / 00$ & EMLLP-1 & 10 & 7 & & 10.58 & 11.80 & 7.45 & 1093 \\
\hline $06 / 02 / 00$ & EMLLP-1 & 11 & 7 & & 11.58 & 14.80 & 7.53 & 1059 \\
\hline $07 / 06 / 00$ & EMLLP-1 & 10 & 9 & & 10.75 & 21.00 & 7.59 & \\
\hline $08 / 04 / 00$ & EMLLP-1 & 11 & 4 & 25 & 11.35 & 19.40 & 7.39 & \\
\hline $09 / 08 / 00$ & EMLLP-1 & 8 & 10 & & 8.83 & 17.40 & 7.50 & \\
\hline $10 / 05 / 00$ & EMLLP-1 & 11 & 1 & & 11.08 & 14.50 & 7.46 & 1038 \\
\hline $11 / 08 / 00$ & EMLLP-1 & 11 & 5 & & 11.42 & 14.80 & 7.47 & 1027 \\
\hline $12 / 06 / 00$ & EMLLP-1 & 11 & 1 & & 11.08 & 14.70 & 8.09 & 1166 \\
\hline 01/04/01 & EMLLP-1 & 11 & 0 & & 11.00 & 12.40 & 7.78 & 1203 \\
\hline $02 / 08 / 01$ & EMLLP-1 & 10 & 0 & 75 & 10.06 & 11.60 & & 1217 \\
\hline $02 / 15 / 01$ & EMLLP-1 & 10 & 0 & 25 & 10.02 & 11.40 & & 1231 \\
\hline $02 / 22 / 01$ & EMLLP-1 & 9 & 8 & 50 & 9.71 & 12.00 & 8.38 & 1231 \\
\hline $03 / 01 / 01$ & EMLLP-1 & 10 & 3 & 50 & 10.29 & 10.90 & 8.17 & 1247 \\
\hline $03 / 08 / 01$ & EMLLP-1 & 9 & 10 & 50 & 9.88 & 12.10 & 8.06 & 1256 \\
\hline $03 / 16 / 01$ & EMLLP-1 & 10 & 3 & 25 & 10.27 & 11.60 & 7.89 & 1270 \\
\hline $03 / 23 / 01$ & EMLLP-1 & 10 & 2 & & 10.17 & 12.40 & 7.66 & 1299 \\
\hline $03 / 30 / 01$ & EMLLP-1 & & & & & & & \\
\hline $04 / 06 / 01$ & EMLLP-1 & 10 & & 50 & 10.04 & 11.50 & 7.52 & 1294 \\
\hline $04 / 13 / 01$ & EMLLP-1 & 8 & 4 & 75 & 8.40 & 11.50 & 7.59 & 1266 \\
\hline $04 / 20 / 01$ & EMLLP-1 & 9 & 7 & 50 & 9.63 & 16.60 & 7.96 & \\
\hline $04 / 27 / 01$ & EMLLP-1 & 9 & 9 & 50 & 9.79 & 13.70 & 7.80 & 1283 \\
\hline $05 / 04 / 01$ & EMLLP-1 & 10 & 5 & & 10.42 & 13.90 & 7.69 & 1316 \\
\hline $05 / 11 / 01$ & EMLLP-1 & 10 & 2 & 25 & 10.19 & 14.50 & 7.87 & 1259 \\
\hline $05 / 18 / 01$ & EMLLP-1 & 10 & 0 & & 1.00 & 13.10 & 7.71 & 1306 \\
\hline $05 / 24 / 01$ & EMLLP-1 & 9 & 11 & 50 & 9.96 & 14.50 & 8.03 & 1191 \\
\hline $06 / 01 / 01$ & EMLLP-1 & 10 & 7 & & 10.58 & 19.20 & 5.86 & \\
\hline $06 / 08 / 01$ & EMLLP-1 & 10 & 3 & & 10.25 & 14.80 & 7.47 & 1179 \\
\hline $06 / 15 / 01$ & EMLLP-1 & 10 & 6 & & 10.50 & 19.00 & 7.53 & \\
\hline $06 / 22 / 01$ & EMLLP-1 & 10 & 6 & & 10.50 & 21.30 & 7.51 & \\
\hline $06 / 29 / 01$ & EMLLP-1 & & & & & & & \\
\hline $07 / 06 / 01$ & EMLLP-1 & 10 & 7 & & 10.58 & 15.00 & 7.53 & 1167 \\
\hline $07 / 13 / 01$ & EMLLP-1 & & & & & & & \\
\hline $07 / 20 / 01$ & EMLLP-1 & & & & & & & \\
\hline $01 / 12 / 00$ & EMLLP-2 & 2 & 0 & 50 & 2.04 & 7.50 & 7.51 & 3272 \\
\hline $02 / 16 / 00$ & EMLLP-2 & 1 & 5 & 75 & 1.48 & 7.00 & 7.62 & 3767 \\
\hline $03 / 15 / 00$ & EMLLP-2 & 1 & 10 & 75 & 1.90 & & & \\
\hline $03 / 30 / 00$ & EMLLP-2 & 3 & 1 & & 3.08 & 9.60 & 7.56 & 3080 \\
\hline $04 / 07 / 00$ & EMLLP-2 & 2 & 6 & 50 & 2.54 & 9.10 & 7.51 & 2746 \\
\hline $05 / 05 / 00$ & EMLLP-2 & 1 & 1 & 50 & 1.13 & 11.30 & 7.70 & 2041 \\
\hline $06 / 02 / 00$ & EMLLP-2 & 3 & 3 & 75 & 3.31 & 15.00 & 7.60 & 646 \\
\hline $07 / 06 / 00$ & EMLLP -2 & 4 & & & 4.00 & 16.80 & 7.16 & 2410 \\
\hline $08 / 04 / 00$ & EMLLP-2 & 4 & 10 & 50 & 4.88 & 16.60 & 7.57 & 2172 \\
\hline $09 / 08 / 00$ & EMLLP-2 & 4 & 8 & 50 & 4.71 & 17.90 & 7.59 & 1215 \\
\hline $10 / 05 / 00$ & EMLLP-2 & & & & & & & \\
\hline $11 / 08 / 00$ & EMLLP-2 & 5 & 3 & & 5.25 & 12.00 & 7.09 & 2570 \\
\hline $12 / 06 / 00$ & EMLLP-2 & 4 & 4 & & 4.33 & 12.30 & 7.45 & 2476 \\
\hline 01/04/01 & EMLLP - 2 & 3 & 8 & & 3.67 & 8.50 & 7.43 & 2292 \\
\hline $02 / 08 / 01$ & EMLLP-2 & 2 & 5 & & 2.42 & 65.00 & & 2274 \\
\hline $02 / 15 / 01$ & EMLLP-2 & 3 & 4 & & 3.33 & 5.40 & & 2668 \\
\hline $02 / 22 / 01$ & EMLLP-2 & 1 & 11 & & 1.92 & 6.10 & 7.80 & 2342 \\
\hline
\end{tabular}


Piez00_01

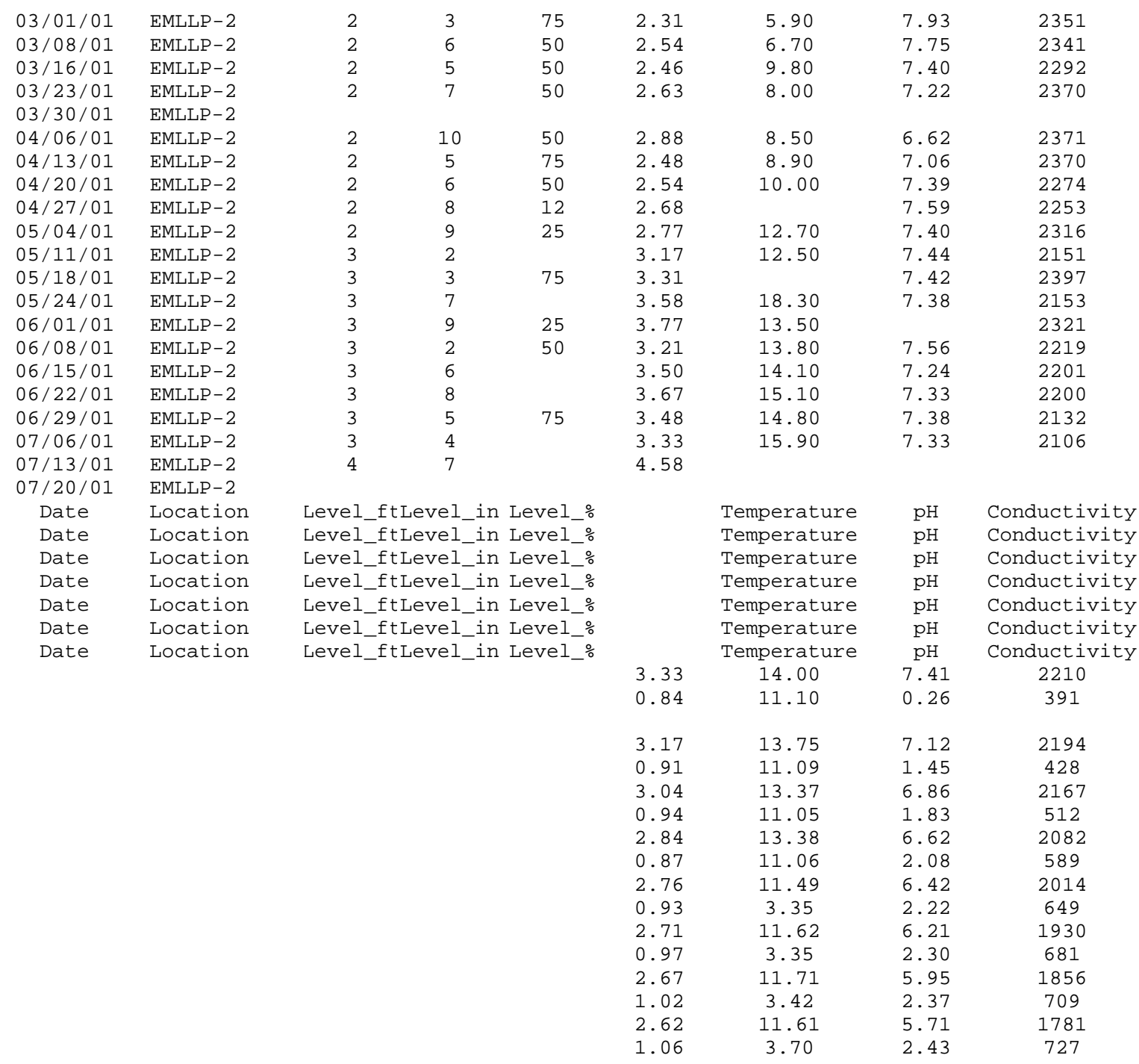


Appendix: E

Contour Plots from Appendix D 


\section{Average water temperature of groundwater}

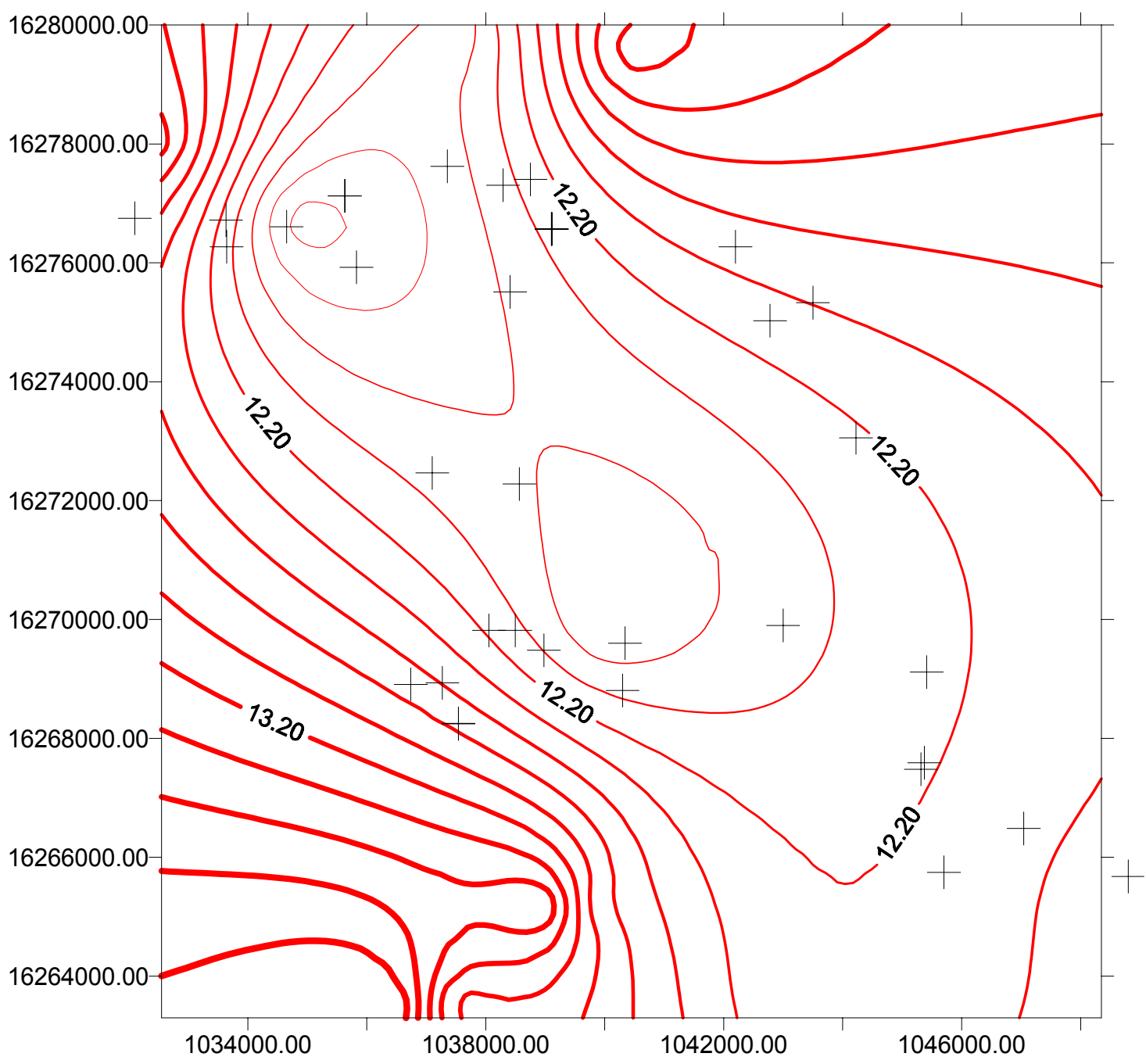




\section{Conductivity of groundwater in us}

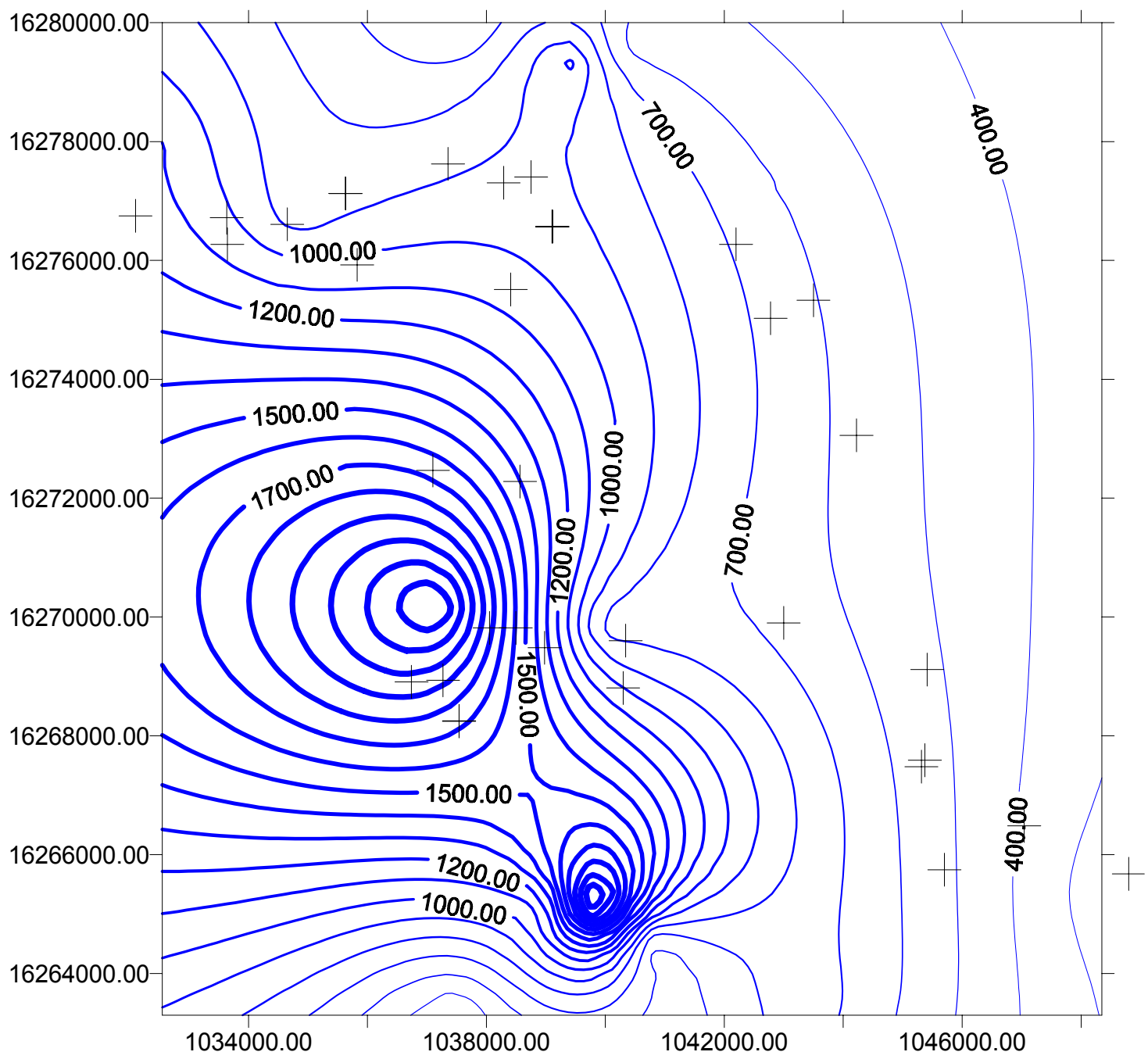




\section{PH of Groundwater}

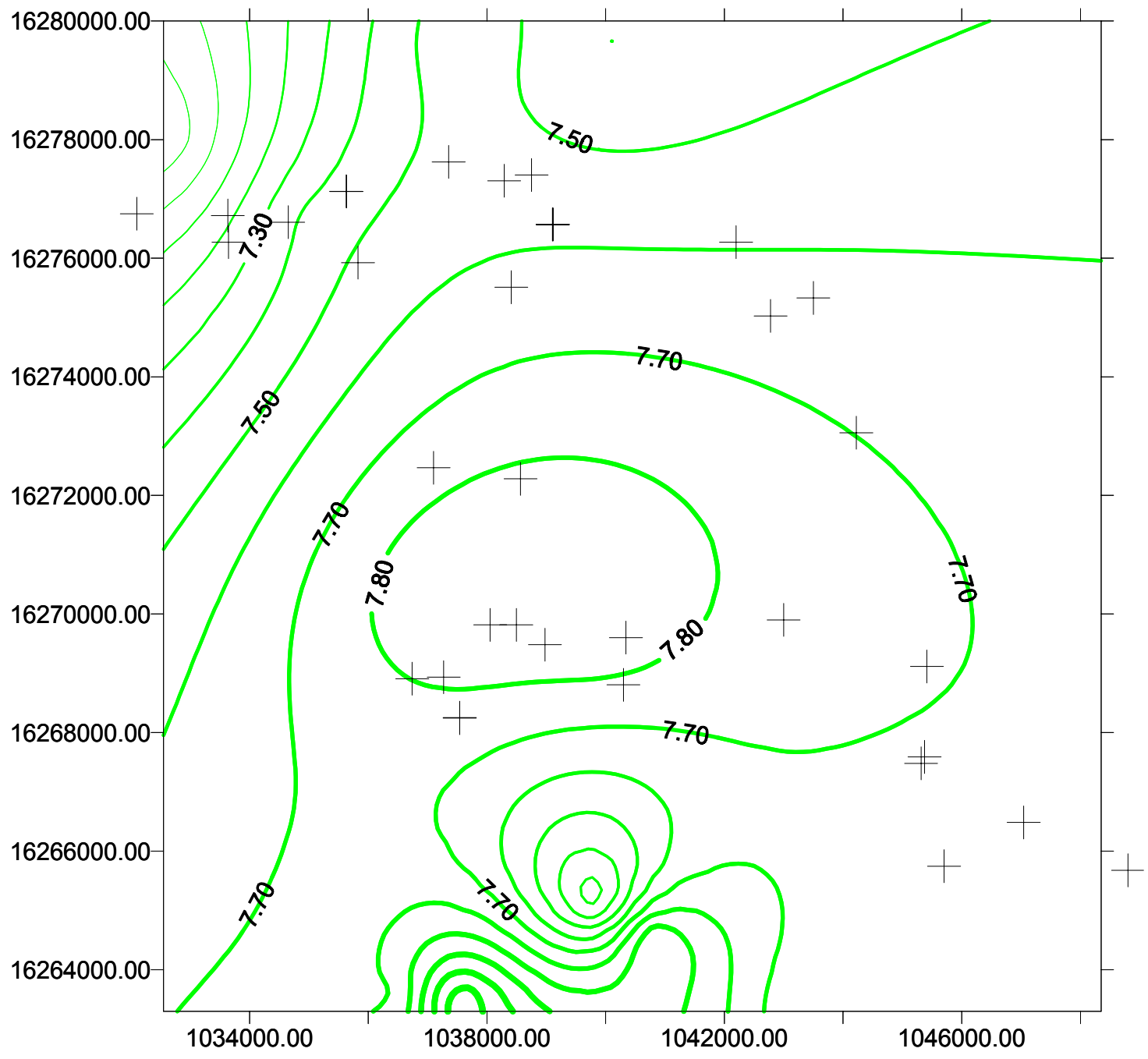


Appendix: F

Groundwater and Surface Water Quality Laboratory Analysis 
September 4,2001

Fred Ziari, CEO

IRZ Consulting

505 E. Main Street

Hermiston, OR. 97838

RE: Water quality analysis- Echo Meadows recharge project. IRZ Verbal Authorization. Principals Group Project No. 01-09-04.IRZ.

Dear Mr. Ziari:

Enclosed are the laboratory results from the Echo Meadows recharge project. During this quarterly sampling, I sampled 5 wells and piezometers in the area, 2 locations on the Umatilla River, and 1 location on Hunt Ditch.

As can be seen in the laboratory results, the groundwater quality was good. Nutrient levels were low. Nitrate levels were well below applicable standards phosphorous concentrations were low-suggesting that fertilizer migration to the underlying aquifer is not a problem.

All of the wells had less 6 colonies of fecal coliform per 100 milliliters or less. These concentrations are above drinking water standards, but are significantly lower than that in the Umatilla or the Hunt Canal. This shows the typical decrease in bacteria as water is filtered through the soil column.

I would expect that surface water that would be used for the recharge project would have a far lower level of fecal coliform when it is applied in the winter/early spring. I do not see water quality as a major concern, based on these results.

Sincerely,

Principals Group

James D. Graham, RPG

Enclosures: 1 laboratory report

CC: Central files, I01-09-04.IRZ 
COFFEY LABORATORIES, INC.

CHAIN OF CUSTODY AGREEMENT

CENTRAL OREGON BRANCH

$827 \mathrm{SW} 7 \mathrm{th}$

Rmond, OR

HONE/FAX (541) 548-0972

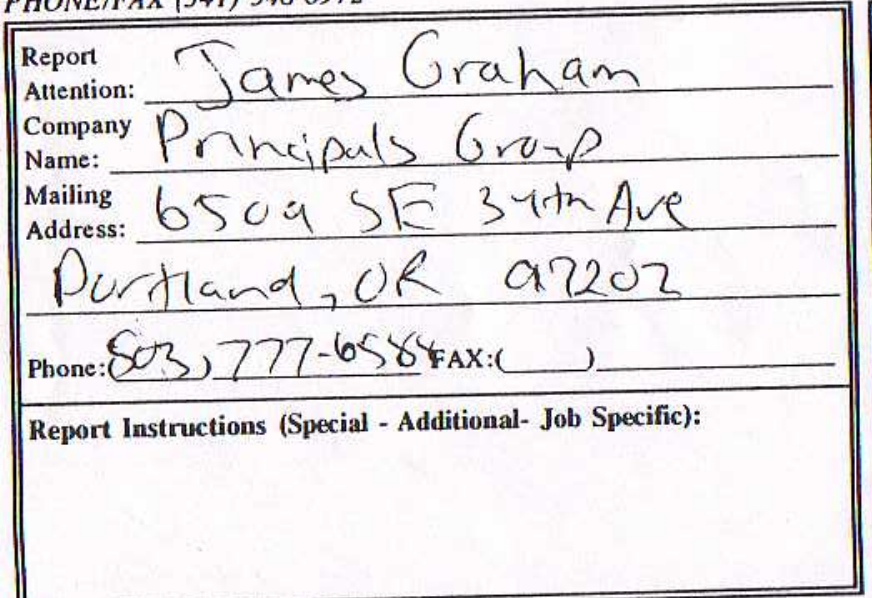

\begin{tabular}{|l|}
\hline Sample ID \\
\hline Show Well \\
\hline River 4 S \\
\hline EN F M RP-1 \\
\hline RiverDS \\
\hline EMDMRP-1 \\
\hline EMDNRP-1 \\
\hline EM BA P-1 \\
\hline
\end{tabular}

CORPORATE HEADQUARTERS

I2423 NE Whitaker Way

Portland, OR 97230
(503) 254-1794 FAX: (503) 254-1452

PO Number:

Project Number:

Project Name:

EPA Protocol Containers: Y/N Other:

Sample Turnaround
Standard

$\square$ Priority (Additonal Fee)

$\square$ Rush (Additional Fee)

$\square$ Emergency (Additional Fee)

Initials:

$\quad$ Reporting Request
$\square$ State Compliance Format
$\square \quad$ FAX Results - Preliminary
$\square \quad$ FAX Results-Final
$\square \quad$ Verbals Results
$\square \quad$ Extra Report Copy
(Fees Associated)

EASTERN OREGON BRANCH

$419 \mathrm{SW}$ 5th

Pendleton, OR 9780

PHONE/FAX (54I) 276-0385

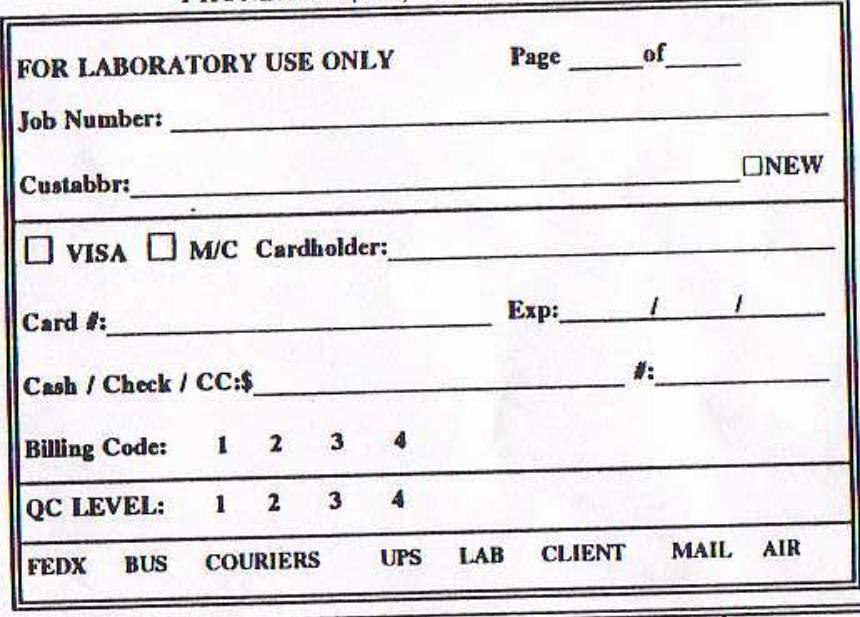

\begin{tabular}{|c|c|c|c|c|c|c|c|}
\hline \multirow[t]{2}{*}{ Loc. } & \multirow[t]{2}{*}{ ID } & \multirow[t]{2}{*}{ \# } & \multicolumn{2}{|c|}{$\begin{array}{c}\text { Collection } \\
\text { Date } / \text { Time }\end{array}$} & \multirow{2}{*}{$\begin{array}{l}\text { Media } \\
\text { Dw }\end{array}$} & Analysis Requested & \multirow[t]{2}{*}{$\begin{array}{l}\text { Test! } \\
\text { Profile }\end{array}$} \\
\hline & & & 7127 & 0735 & & TKN, Nu3, P, Fecal Colifurn & \\
\hline & & & 11 & 0710 & , & TKN Nus, Pecal culifurn & \\
\hline & & & 2126 & 1930 & $\checkmark$ & TKN NUB,P & \\
\hline & & & $71264 v 1$ & hoo & P. & $\left.T K N_{1}, N\right)_{3}, P$ & \\
\hline & & & $2126) 101$ & 1830 & & Fecal colifern & \\
\hline & & & 7126101 & 1810 & & NC3, P,TKN & \\
\hline & & & & & & $+K_{n} \mathrm{NU}_{3}, P, \mathrm{Fecal}$ & \\
\hline & & & & & & & \\
\hline & & & & & & & \\
\hline & & & AUTHORIZE & D CUSTOME & SIGNATURE & DATE: & \\
\hline
\end{tabular}

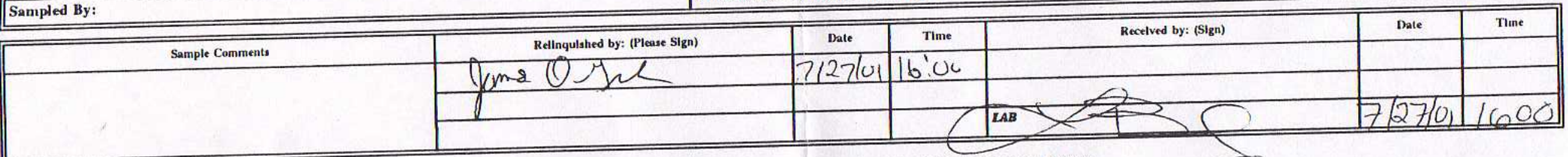

White Copy-Laboratory Yellow Copy - Customer

COMPLETE THIS FORM PER INSTRUCTIONS ON REVERSE SIDE

SUBMISSION OF SAMPLES WITH TESTING REOUIREMENTS TO CLI WILL BE UNDERSTOOD TO BE AN AGREEMENT FOR SER VICES IN ACCORDANCE WITH THE CONDITIONS LISTED ON THE BACK OF THE CLIENT COPY. 
Report Date: August 4, 2001

Job Number: A10727AH

PO Number: None Provided

Project No: None Provided

Jim Graham

Project Name: None Provided

Principals Group

6509 SE 34th Ave.

Portland, OR 97202

\section{Analytical Narrative}

The sample was received on 07/27/01 by Coffey Laboratories, Inc. (CLI) Sample Reception personnel under strict chain of custody protocol. The following information was provided at the time of sample reception:

\begin{tabular}{||lllll||}
\hline Laboratory & Fample ID & Matrix Identification & Collection & $\begin{array}{l}\text { Collection } \\
\text { Time }\end{array}$ \\
\hline A10727AH-1 & Snow Well & Water & $07 / 27 / 01$ & 0735 \\
A10727AH-2 & River US & Water & $07 / 27 / 01$ & 0710 \\
A10727AH-3 & EMFMRP-1 & Water & $07 / 26 / 01$ & 1930 \\
A10727AH-4 & River DS & Water & $07 / 26 / 01$ & 1700 \\
A10727AH-5 & EMDMRP-1 & Water & $07 / 26 / 01$ & 1830 \\
A10727AH-6 & EMBAP-1 & Water & $07 / 26 / 01$ & 1810 \\
\hline \hline
\end{tabular}




\section{Analytical Narrative (continued)}

The recommended holding time for each batch of analyses was in accordance with the data quality objectives as specified in the CLI Quality Assurance Plan unless otherwise noted.

Acceptable precision and accuracy were achieved for all analyses associated with this work order as demonstrated by the recoveries of the quality control samples analyzed concurrently with each batch.

The data submitted in this report is for the sole and exciusive use of the above-named client. All samples associated with the work order will be retained a maximum of 15 days from the report date or until the maximum holding time expires. All results pertain only to samples submitted.

Thank you for allowing Coffey Laboratories to be of service to you. If you have questions or need further assistance, please do not hesitate to call our Customer Services Department.

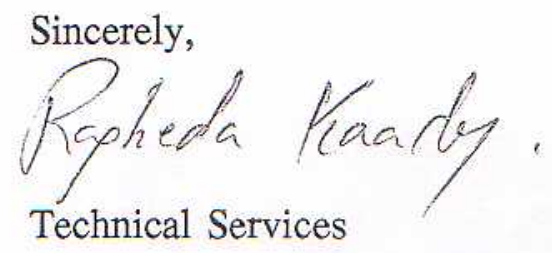

TS /atc 


\section{Analytical Data}

Principals Group

Job Number: A10727AH

Page Number: 3 of 8

Lab Sample ID: A10727AH-1

Field ID: Snow Well

Date/Time: 07/27/01 0735

Matrix: Water

EPA Category: Microbiological

\begin{tabular}{lllll} 
Parameter & Method & $\begin{array}{l}\text { Detection } \\
\text { Limit }\end{array}$ & $\begin{array}{l}\text { Analytical } \\
\text { Result }\end{array}$ & Units \\
\hline Fecal Coliform & SM 9222-D & -- & 6 & $/ 100 \mathrm{ml}$
\end{tabular}

EPA Category: Conventional Parameters

\begin{tabular}{lllll} 
Parameter & Method & $\begin{array}{l}\text { Detection } \\
\text { Limit }\end{array}$ & $\begin{array}{l}\text { Analytical } \\
\text { Result }\end{array}$ & Units \\
\hline Nitrate & EPA 300.0 & 0.1 & 0.2 & $\mathrm{mg} / \mathrm{L}$ \\
Total Kjeldahl Nitrogen & SM 4500-Norg-B & 0.2 & 0.5 & $\mathrm{mg} / \mathrm{L}$ \\
Total Phosphorus & SM 4500-P-B5D & 0.05 & 0.07 & $\mathrm{mg} / \mathrm{L}$
\end{tabular}




\section{Analytical Data}

Principals Group

Job Number: A10727AH

Page Number: 4 of 8

Lab Sample ID: A10727AH-2

Field ID: River US

Date/Time: 07/27/01 0710

Matrix: Water

EPA Category: Microbiological

\begin{tabular}{lllll} 
Parameter & Method & $\begin{array}{l}\text { Detection } \\
\text { Limit }\end{array}$ & $\begin{array}{l}\text { Analytical } \\
\text { Result }\end{array}$ & Units \\
\hline Fecal Coliform & SM 9222-D & --- & 42 & $/ 100 \mathrm{ml}$
\end{tabular}

EPA Category: Conventional Parameters

\begin{tabular}{lllll} 
Parameter & Method & $\begin{array}{l}\text { Detection } \\
\text { Limit }\end{array}$ & $\begin{array}{l}\text { Analytical } \\
\text { Result }\end{array}$ & Units \\
\hline Nitrate & EPA 300.0 & 0.1 & ND & $\mathrm{mg} / \mathrm{L}$ \\
Total Kjeldahl Nitrogen & SM 4500-Norg-B & 0.2 & 0.7 & $\mathrm{mg} / \mathrm{L}$ \\
Total Phosphorus & SM 4500-P-B5D & 0.1 & ND & $\mathrm{mg} / \mathrm{L}$
\end{tabular}

ND means none detected at or above the detection limit listed. 


\section{Analytical Data}

Principals Group

Job Number: A10727AH

Page Number: 5 of 8

Lab Sample ID: A10727AH-3

Field ID: EMFMRP-1

Date/Time: 07/26/01 1930

Matrix: Water

EPA Category: Conventional Parameters

\begin{tabular}{lllll} 
Parameter & Method & $\begin{array}{l}\text { Detection } \\
\text { Limit }\end{array}$ & $\begin{array}{l}\text { Analytical } \\
\text { Result }\end{array}$ & Units \\
\hline Nitrate & EPA 300.0 & 0.1 & 3.1 & $\mathrm{mg} / \mathrm{L}$ \\
Total Kjeldahl Nitrogen & SM 4500-Norg-B & 0.2 & 3.6 & $\mathrm{mg} / \mathrm{L}$ \\
Total Phosphorus & SM 4500-P-B5D & 0.1 & 0.6 & $\mathrm{mg} / \mathrm{L}$
\end{tabular}




\section{Analytical Data}

Principals Group

Job Number: A10727AH

Page Number: 6 of 8

Lab Sample ID: A10727AH-4

Field ID: River DS

Date/Time: 07/26/01 1700

Matrix: Water

EPA Category: Conventional Parameters

\begin{tabular}{lllll} 
Parameter & Method & $\begin{array}{l}\text { Detection } \\
\text { Limit }\end{array}$ & $\begin{array}{l}\text { Analytical } \\
\text { Result }\end{array}$ & Units \\
\hline Nitrate & EPA 300.0 & 0.1 & 3. & $\mathrm{mg} / \mathrm{L}$ \\
Total Kjeldahl Nitrogen & SM 4500-Nor g-B & 0.2 & 0.7 & $\mathrm{mg} / \mathrm{L}$ \\
Total Phosphor us & SM 4500-P-B5D & 0.05 & ND & $\mathrm{mg} / \mathrm{L}$
\end{tabular}

ND means none detected at or above the detection limit listed. 


\section{Analytical Data}

Principals Group

Job Number: A10727AH

Page Number: 7 of 8

Lab Sample ID: A10727AH-5

Field ID: EMDMRP-1

Date/Time: 07/26/01 1830

Matrix: Water

EPA Category: Microbiological

\begin{tabular}{lllll} 
Parameter & Method & $\begin{array}{l}\text { Detection } \\
\text { Limit }\end{array}$ & $\begin{array}{l}\text { Analytical } \\
\text { Result }\end{array}$ & Units \\
\hline Fecal Coliform & SM 9222-D & --- & $<2$ & $/ 100 \mathrm{ml}$
\end{tabular}

EPA Category: Conventional Parameters

\begin{tabular}{lllll} 
Parameter & Method & $\begin{array}{l}\text { Detection } \\
\text { Limit }\end{array}$ & $\begin{array}{l}\text { Analytical } \\
\text { Result }\end{array}$ & Units \\
\hline Nitrate & EPA 300.0 & 0.1 & 3.1 & $\mathrm{mg} / \mathrm{L}$ \\
Total Kjeldahl Nitrogen & SM 4500-Norg-B & 0.2 & 1.3 & $\mathrm{mg} / \mathrm{L}$ \\
Total Phosphor us & SM 4500-P-B5D & 0.05 & 0.18 & $\mathrm{mg} / \mathrm{L}$
\end{tabular}




\section{Analytical Data}

Principals Group

Job Number: A10727AH

Page Number: 8 of 8

Lab Sample ID: A10727AH-6

Field ID: EMBAP-1

Date/Time: 07/26/01 1810

Matrix: Water

EPA Category: Microbiological

\begin{tabular}{lllll} 
Parameter & Method & $\begin{array}{l}\text { Detection } \\
\text { Limit }\end{array}$ & $\begin{array}{l}\text { Analytical } \\
\text { Result }\end{array}$ & Units \\
\hline Fecal Coliform & SM 9222-D & $-\ldots$ & 2 & $/ 100 \mathrm{ml}$
\end{tabular}

\section{EPA Category: Conventional Parameters}

\begin{tabular}{lllll} 
Parameter & Method & $\begin{array}{l}\text { Detection } \\
\text { Limit }\end{array}$ & $\begin{array}{l}\text { Analytical } \\
\text { Result }\end{array}$ & Units \\
\hline Nitrate & EPA 300.0 & 0.1 & ND & $\mathrm{mg} / \mathrm{L}$ \\
Total Kjeldahl Nitrogen & SM 4500-Norg-B & 0.2 & 1.6 & $\mathrm{mg} / \mathrm{L}$ \\
Total Phosphorus & SM 4500-P-B5D & 0.2 & 0.4 & $\mathrm{mg} / \mathrm{L}$
\end{tabular}

ND means none detected at or above the detection limit listed. 


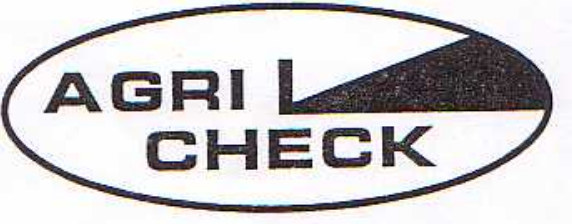

\section{AERI - CHECK, INC. \\ AGRICULT TURAL TESTING LABGRATORY CREP SEIENCE CONSUL TANTS}

323 SIXTH STREET • P.O.BOX 1350 - UMATILLA, OREGON 97882

\section{CHAIN OF CUSTODY}

Date Sampled $7 / 10 / 01$

CustomerJanes Graham

SAMPLE TYPE 6509 SE 34k tue Soil Portiand, OR 97202

XX Water (503) 2226588 Fertilizer, feed, manure, compost, misc.

SAMPLE ID

TIME SAMPLED/ANALYSES NEEDED 1 Prior well Nitrate, TKM, Phoshoras (total, ortho)
2 W. (anal "

5

6

7

8

9

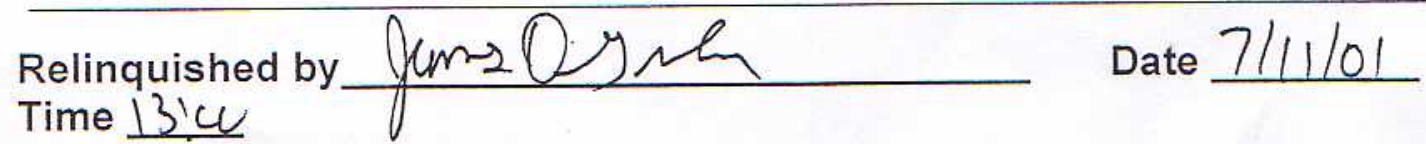

Relinquished by

Date

Time

Received by

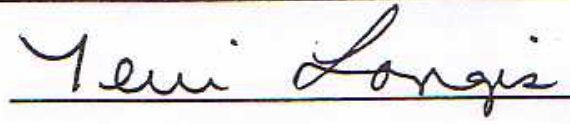

Received by

Comments:
Date $7-11-01$ Time $1.00 \mathrm{pm}$

Date Time 
COFFEY LABORATORIES, INC.

CHAIN OF CUSTODY AGREEMENT

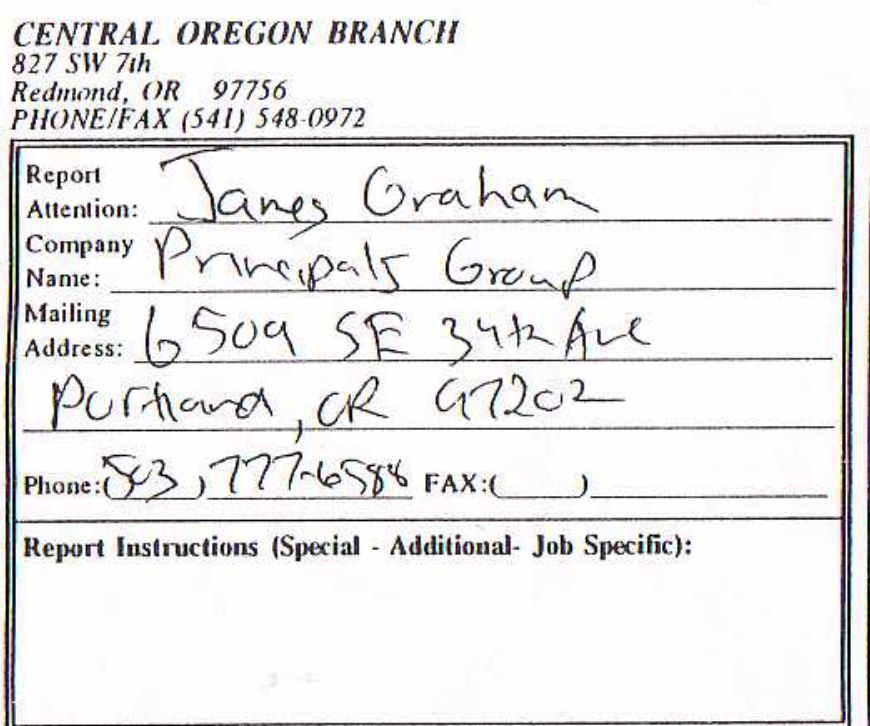

CORPORATE HEADQUARTERS

12423 NE Whilaker Way

(503) 254-1794 FAX: (503) 254-1452

\begin{tabular}{||l|l|}
\hline PO Number: \\
Project Number: \\
Project Name: \\
EPA Protocol Containers: Y/N Other: & \\
\hline $\begin{array}{l}\text { Sample Turnaround } \\
\text { Standard }\end{array}$ & $\square$ State Compliance Format \\
$\square$ Priority (Additonal Fee) & $\square$ FAX Results - Preliminary \\
$\square$ Rush (Additional Fee) & $\square$ FAX Results-Final \\
$\square$ Emergency (Additional Fee) & $\square$ Eerbals Results \\
Initials: & (Fees Associated) \\
\hline
\end{tabular}

EASTERN OREGON BRANCH 419 SW 5 ih

Pendleton OR 9780

PHONE/FAX (54I) $276-0385$

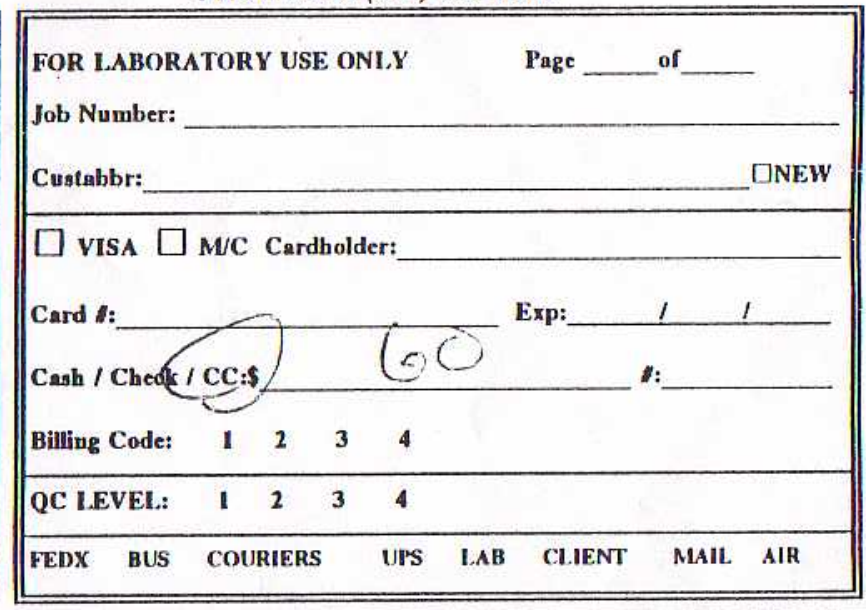

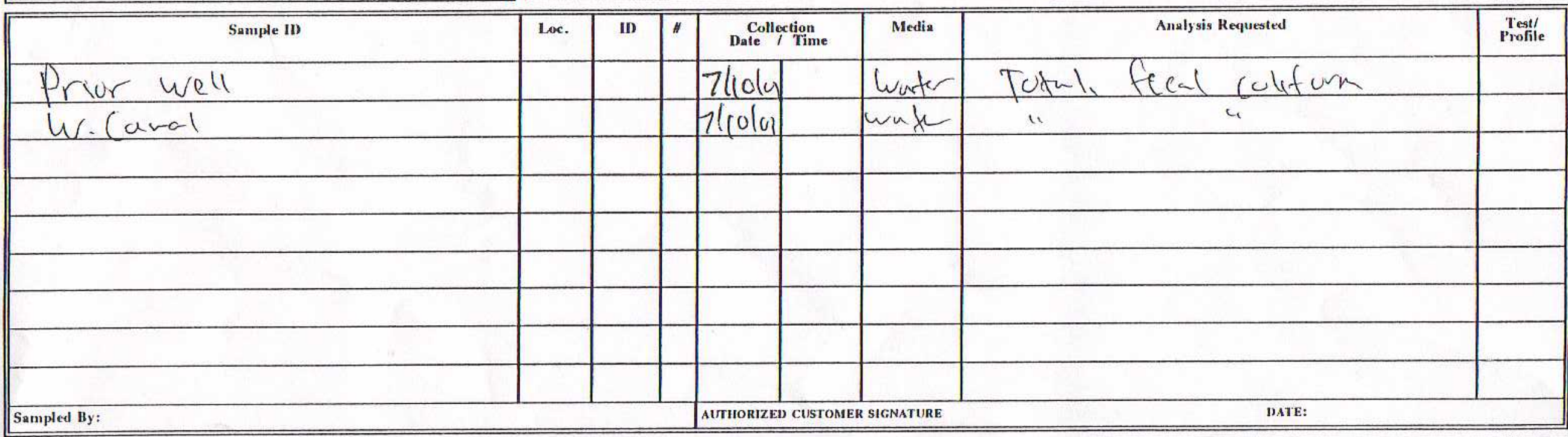

\begin{tabular}{|c|c|c|c|c|c|c|}
\hline Sumple Comments & Hellnquilshed by: (I'leuse SIgn) & Date & Thine & Recelived by: (SIgn) & Date & Tlme \\
\hline & $\left.\left(\ln _{m-2} \cup\right)^{3}\right)_{h}$ & 111101 & 16,00 & & & \\
\hline & & & & $L A B$ & & \\
\hline
\end{tabular}

White Copy-Laboratory Yellow Copy-C'ustomer

COMPLEIE TIIS FORM PER INSTRUCTIONS ON REVERSE SIDE

SUIBMISSION OF SAMPLES WITII TESTING REQUIREMENTS TO CLI WILL BE UNIDERSTOOI) TO BE AN AGREEMENT HOR SLRVICES IN ACCORDANCE WITII THE CONDITIONS LISTEID ON TUE BACK OF TIIE CLIENT COPY. 
Report Date: July 13, 2001

Job Number: A10711BX

PO Number: None Provided

Project No: None Provided

Jim Graham

Project Name: None Provided

Principals Group

6509 SE 34th Ave.

Portland, OR 97202

\section{Analytical Narrative}

The sample was received on 07/11/01 by Coffey Laboratories, Inc. (CLI) Sample Reception personnel under strict chain of custody protocol. The following information was provided at the time of sample reception:

\begin{tabular}{|lllll||}
\hline Laboratory & & Matrix & Collection & Collection \\
Sample ID & Field Identification & Wate & Time \\
\hline A10711BX-1 & Prior Well & Water & $07 / 10 / 01$ & NP \\
A10711BX-2 & W Canal & Water & $07 / 10 / 01$ & NP \\
\hline
\end{tabular}

The recommended holding time for each batch of analyses was in accordance with the data quality objectives as specified in the CLI Quality Assurance Plan unless otherwise noted.

Acceptable precision and accuracy were achieved for all analyses associated with this work order as demonstrated by the recoveries of the quality control samples analyzed concurrently with each batch.

The data submitted in this report is for the sole and exclusive use of the above-named client. All samples associated with the work order will be retained a maximum of 15 days from the report date or until the maximum holding time expires. All results pertain only to samples submitted.

Thank you for allowing Coffey Laboratories to be of service to you. If you have questions or need further assistance, please do not hesitate to call our Customer Services Department.

Sincerely,

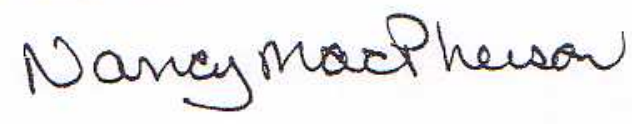

Technical Services

TS /atc 


\section{Analytical Data}

Principals Group

Job Number: A10711BX

Page Number: 2 of 3

Lab Sample ID: A10711BX-1

Field ID: Prior Well

Date/Time: 07/10/01

Matrix: Water

EPA Category: Microbiological

\begin{tabular}{lllll} 
Parameter & Method & $\begin{array}{l}\text { Detection } \\
\text { Limit }\end{array}$ & $\begin{array}{l}\text { Analytical } \\
\text { Result }\end{array}$ & Units \\
\hline Fecal Coliform & SM 9222-D & --- & 6 & $/ 100 \mathrm{ml}$
\end{tabular}




\section{Analytical Data}

Principals Group

Lab Sample ID: A10711BX-2

Field ID: W Canal

Date/Time: $07 / 10 / 01$

Matrix: Water

EPA Category: Microbiological
Job Number: A10711BX

Page Number: 3 of 3

\begin{tabular}{lllll} 
Parameter & Method & $\begin{array}{l}\text { Detection } \\
\text { Limit }\end{array}$ & $\begin{array}{l}\text { Analytical } \\
\text { Result }\end{array}$ & Units \\
\hline Fecal Coliform & SM 9222-D & $-\cdots$ & 103 & $/ 100 \mathrm{ml}$
\end{tabular}


Appendix: G

Pump Test Analysis Report 
November 30,2001

Fred Ziari, CEO

IRZ Consulting

505 E. Main Street

Hermiston, OR. 97838

\section{RE: Pump Test Analysis- Echo Meadows recharge project.}

Dear Mr. Ziari:

On October 3 and 4, 2001, I completed two pump tests in Echo Meadows. They were at:

- $\quad$ EMDMPW-3 and

- $\quad$ EMDMRP-2.

These pump tests are described below.

\section{EMDMPW-3 pump test}

This was a twenty four hour pump test of this well. The well is 8 feet in diameter and is 18 feet deep from the top of the casing. I used a submersible pump that pumped 5 gallons per minute. In hindsight, this pumping rate was too low and complicated the analysis. However, I believe that the test was reasonably good and that the data gathered was useful.

Drawdown during the pump test was measured manually and with a pressure transducer and data logger. Figure 1 shows the data logger data (Series 1) and the manual data collection (Series 2). A factor of 2.393 feet was added to the data logger data (an arbitrary datum) so it would be consistent with the manual data collection. As can be seen in Figure 1, there is fair agreement with the two methods of data collection and the differences are probably due to the low amount of drawdown observed at the well at this pumping rate.

In Figure 2, the data is transformed to a semi-log plot for pump test analysis. The scales have been changed to reflect drawdown at the well and the elapsed time in minutes. Figure 2 contains a "best fit line" through the manual data and the data logger data and the changes in drawdown are calculated through 1 log cycle of data (at 10 and 100 minutes). The transmissivity for both sets of data are calculated on the figure as well.

The calculated transmissivity for the data logger data is $1,842 \mathrm{ft}^{\wedge} 2 /$ day and the manual data is $4,375 \mathrm{ft}^{\wedge} 2 /$ day. Assuming the aquifer is 50 feet thick (from nearby well logs), this equates to a hydraulic conductivity of $37-88 \mathrm{ft} /$ day (approximately $1^{\wedge} \mathrm{E}-2 \mathrm{~cm} / \mathrm{sec}$ ). The 
hydraulic conductivity is probably a better term for this pump test as this aquifer is largely unconfined. The hydraulic conductivity in this range indicates that the formation is in the range of well sorted sands to gravels (fee fine sediments). The calculated hydraulic conductivity is greater than that expected from our shallow soil borings at the nearby piezometers, indicating that the well may tap areas of greater hydraulic conductivity.

The calculated storativity from this pump test is 0.11 , which further suggests that the aquifer is unconfined. In most single well pump tests, the storativity cannot be calculated, because the drawdown in the well cannot be assumed to be equal to that immediately outside of the well. In this test, however, the discharge of the pump test is low compared to the capacity of the well and the water level in the well should be identical to that outside of the well, so the assumption is reasonable.

This pump test showed some irregularities. Normally when drawdown is plotted on a semi-log plot, the plot is closer to linear unless some hydrogeological boundary is encountered. There appears to br some flattening of the curve from about 100 minutes to 500 minutes (less drawdown than might be expected). This flattening of the data may be due to flood irrigation that was occurring in the field immediately to the south, or just because the measurements are close to the sensitivity of the instrument. In addition, the data logger data that was collected after the pump test was through showed additional lowering of the water table (the water table would be expected to rise after the test was through). However, the rate of the rise after the pump test was much less than during the pump test, suggesting that the long term trend in the water table level was an increasing depth to groundwater.

\section{EMDMRP-2 Pump Test}

The EMDMRP-2 pump test was a short term test at the two piezometers (3 feet apart) northeast of EMDMPW-3. The test was originally planned as a long term pump test (several hours to one day). However, the capacity of the two inch submersible pump exceeded the capacity to supply water by the formation, so the pumping well went dry. As a result, the pump test was quickly changed to a piezometer slug test where water level recovery was measured after the well went dry. This is known as the Hvorslev method.

Like the pump test at EMDMPW-3, both manual and pressure transducer data was recorded. The manual record was recorded in the pumped well (Series 2 in Figure 3) and the pressure transducer data was recorded in the nearby observation piezometer (Series 1 in Figure 3).

It appears that there is a time difference in the two series in Figure 3. The small rise and fall in water level at about 13:15 could correspond to the slug test in Series 2 at about 12:00. If the time sequence can be worked out, it may be possible to analyze the data from Series 2, but the remainder of this pump test is devoted to the recovery observed in Series 1.

As can be seen in Series 1, the pumping well was pumped dry between 12:00 and 12:07 on October 4, 2001. The rest of the observations show the recovery of this well. 
In Figure 4, the time series from Series 2, Figure 3 is transformed as elapsed time from when the well was pumped dry along the $x$ axis and the head ratio along the $y$ axis. The head ratio is 1 at time $\mathrm{h} 0$ and is 0 when the head has fully recovered. The $y$ axis is a log of the recovery to make the recovery linear. The time is calculated when the head recovery is $37 \%$. During this pump test the time is 1100 seconds when the head recovery is $37 \%$.

Based on Hvorslev equation and the geometry of the piezometer (screen length 5 feet, diameter 2 inches, diameter of filter pack 4 inches), the calculated hydraulic conductivity of this material is $0.44 \mathrm{ft} /$ day or $2^{\wedge} \mathrm{E}-4 \mathrm{~cm} / \mathrm{sec}$. This rate equates to materials like silty sands or fine sands which is like the material that we encountered when installing the piezometers.

Based on these two pump tests, I will change the model to reflect these pump tests. This material is significantly different than what we encountered in the southern portion of the Meadows and should mean that the recharge project will work better than I anticipated.

Please call if you should have any questions regarding these pump tests.

Sincerely,

Principals Group

James D. Graham, RPG

Enclosures: 4 pump test figures

CC: Central files, c:IIRZI01-11-29.IRZ 


\section{EMDMPW-3 Pump Test}

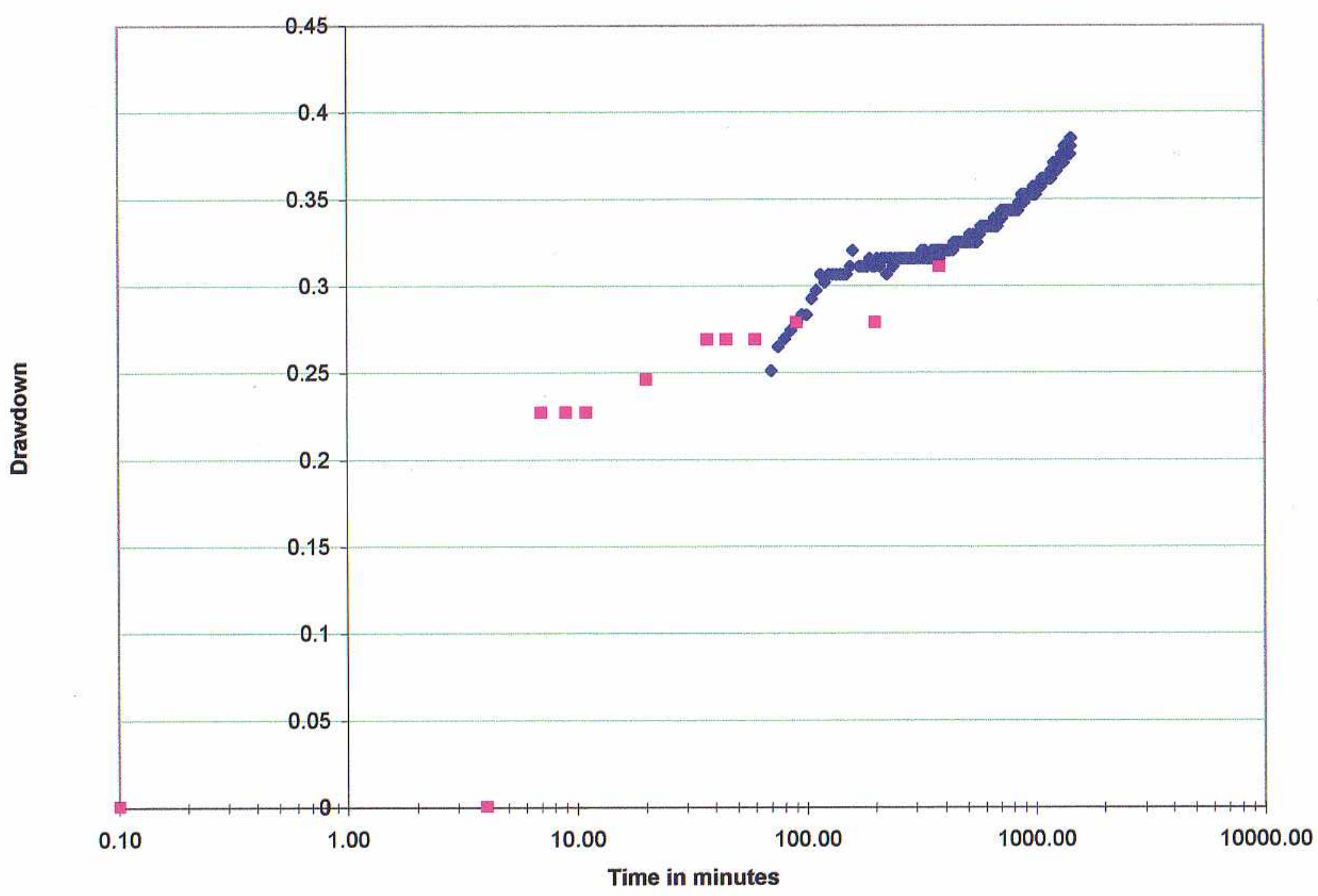




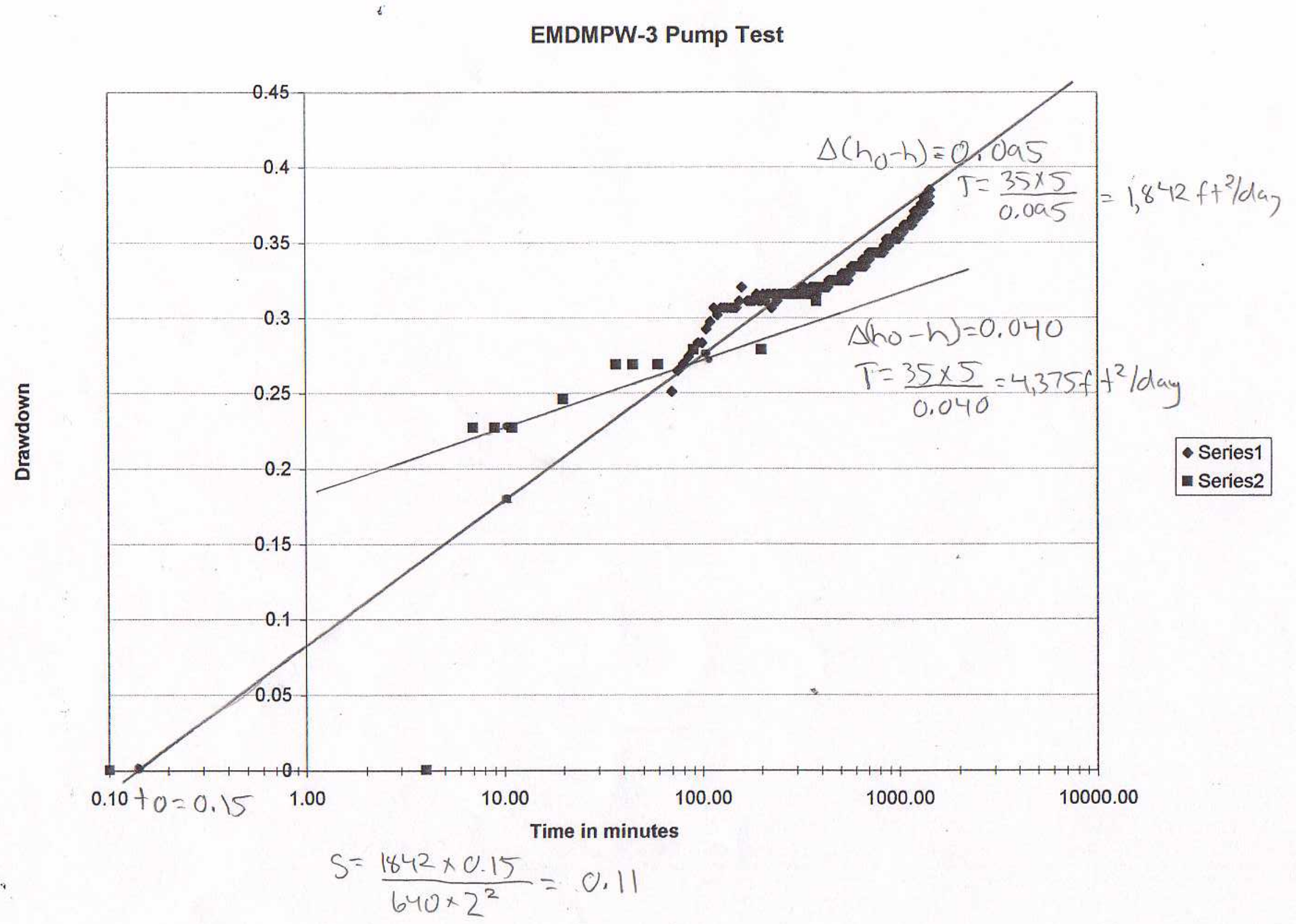

+1
5
6
$\vdots$
$N$ 


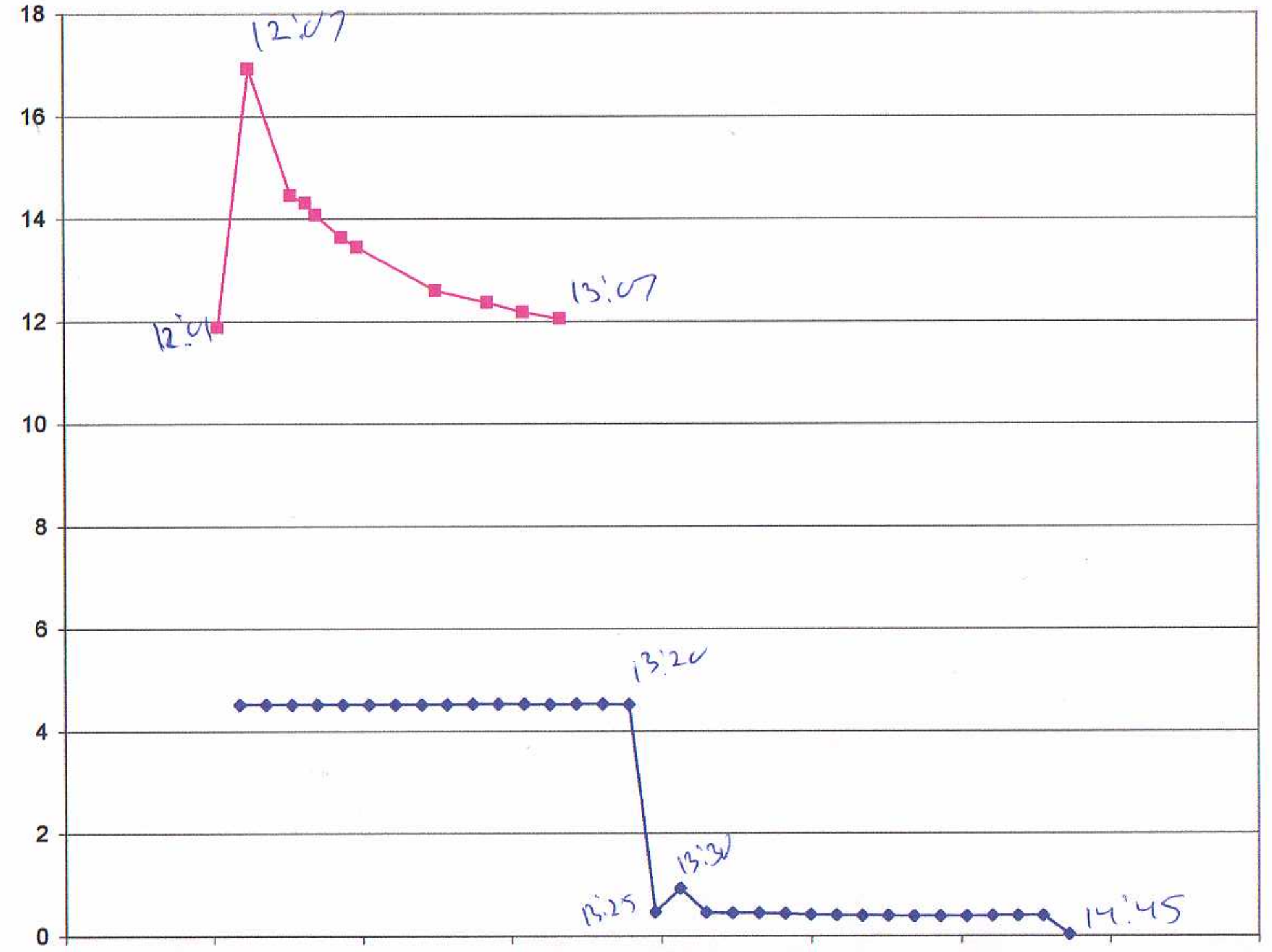

10/4/01 11:31 10/4/01 12:00 10/4/01 12:28 10/4/01 12:57 10/4/01 13:26 10/4/01 13:55 10/4/01 14:24 10/4/01 14:52 10/4/01 15:21 
Figue 4

DMRP-2 Pump Test

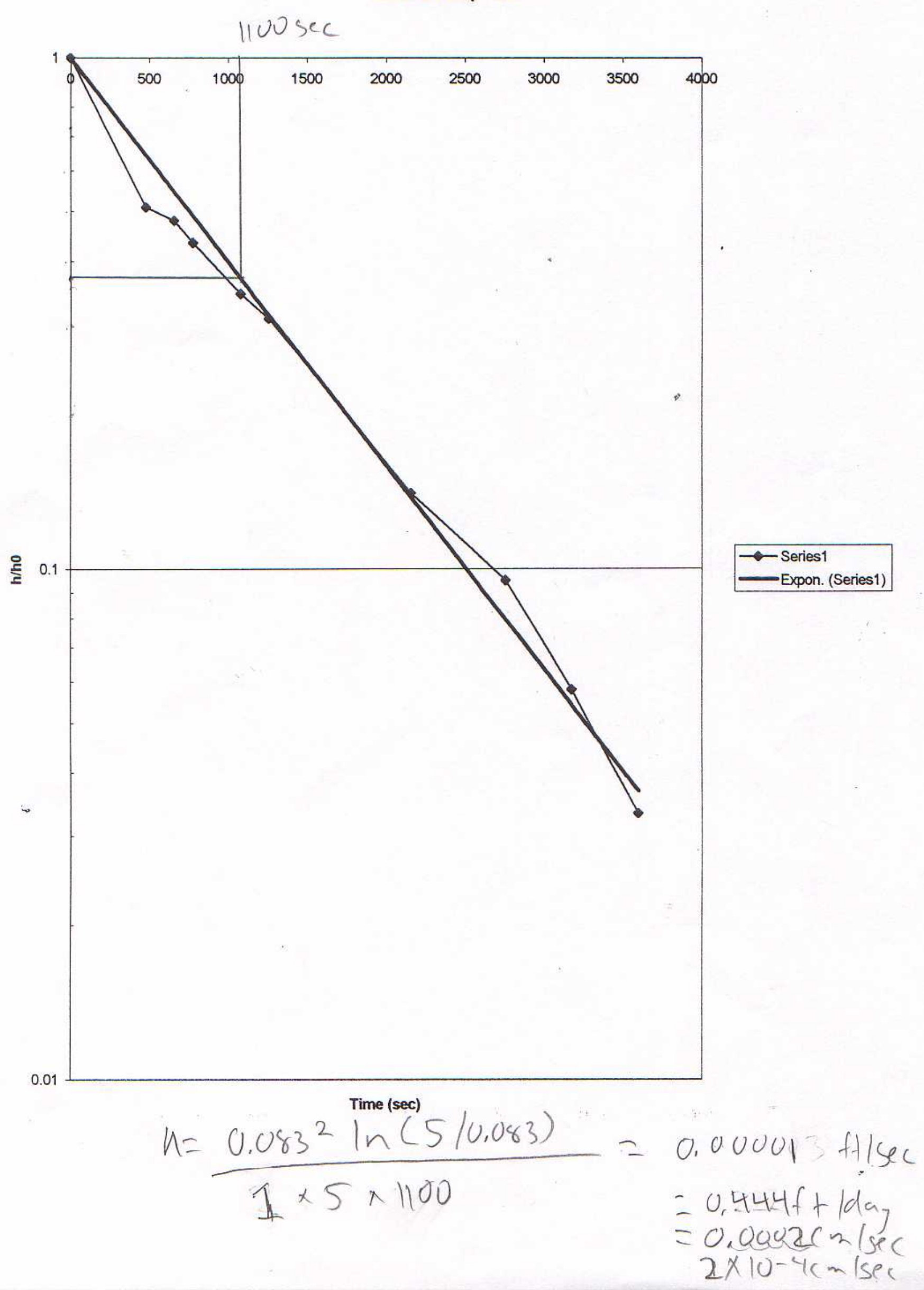




\section{EMDMPW-3 Pump Test}

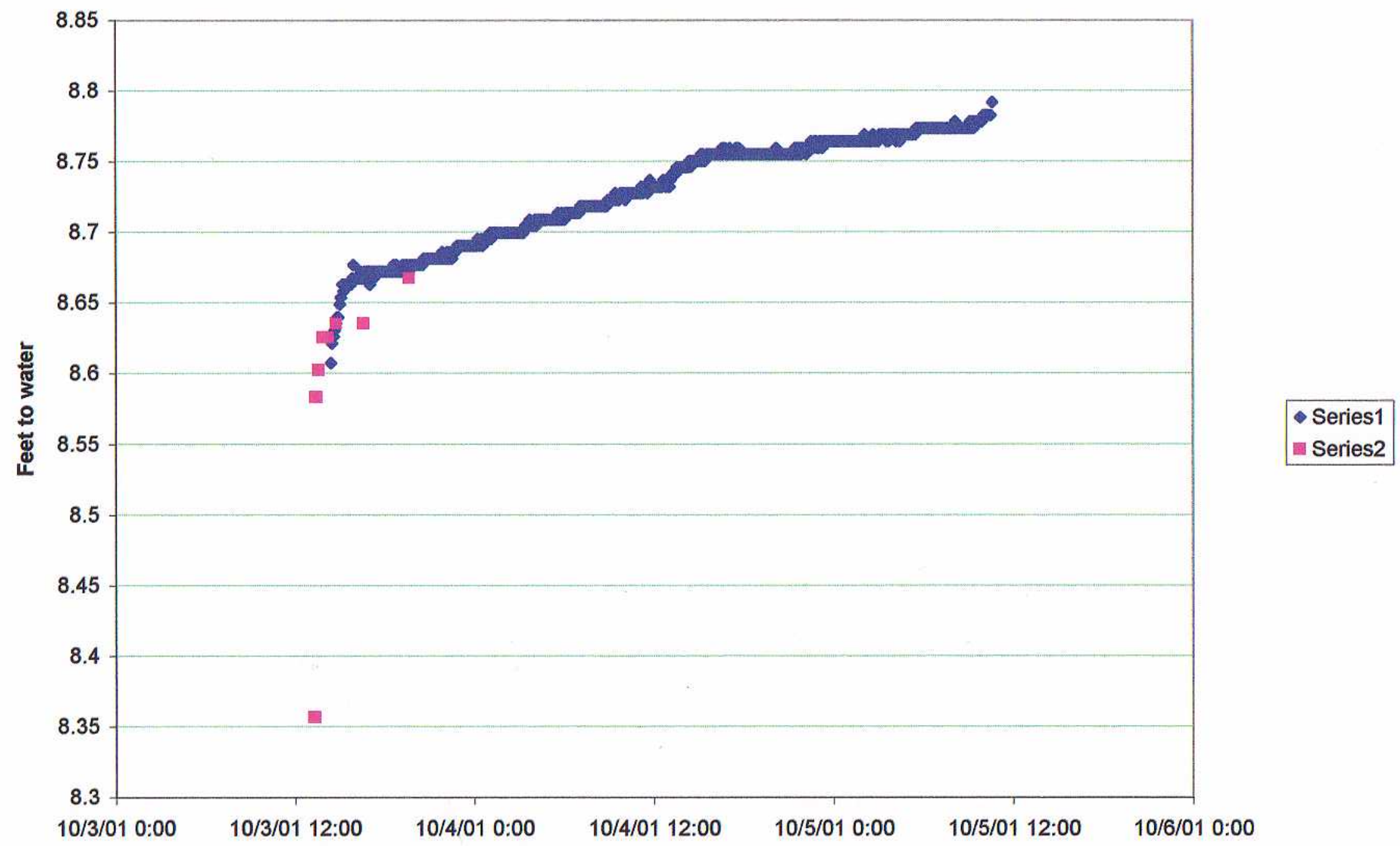


Appendix: H

Groundwater Model Report 
May 19, 2001

Fred Ziari, CEO

IRZ Consulting, LLC

505 E. Main St.

Hermiston, OR. 97838

RE: Echo Meadows Modeling.

Dear Mr. Ziari:

This report is written to keep you informed regarding my progress on the Echo Meadows Recharge Project. 'During this past month, we completed an Echo Meadows groundwater model that shows great promise. It still has some finish work, but it provides some answers that I felt could not wait.

Figure 1 shows the area of the model. The green line is the model predicted heads and the blue line was developed by the WRD. This shows a pretty good match, considering 亚haven't used our surveyed well elevations (yet).

Figure 2 shows an observation well's water level during the two year modeling period. The first year uses average recharge conditions, so it is good that the water levels don't vary a lot. The second year uses the monthly recharge condition. The water levels go up with recharge in the spring then begin to drop through the summer and rising again in the fall. This plot can be used against observed water levels when I get them into the model.

Figure 3 shows return flows to the Umatilla River. The first condition (Series 2) is the base condition, the second condition (Series 3 ) is applying a total of 3 feet of water on one square mile on the south side of the meadow during February-April. The base condition shows about the right amount of discharge to the river (maybe 5-10 cfs too high). As can be seen from comparing these simulations, recharge is about 2 cfs higher during the summer and fall months due to the project recharge. During the first year, about 940 of the 1920 acre feet of applied water is seen at the river. The rest is still in the aquifer.

This is pretty great. This shows that the project should influence return flow during the summer months and a couple of years after recharge.

Please let me know if you have any questions regarding this report. Thank you for allowing me to assist you.

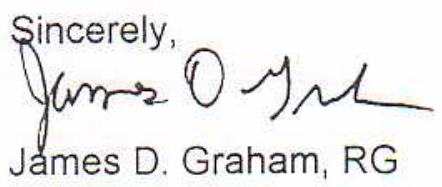

Enclosures: 3 figures

CC: Central Files C:URZI01-10-25.IRZ 
figure 1
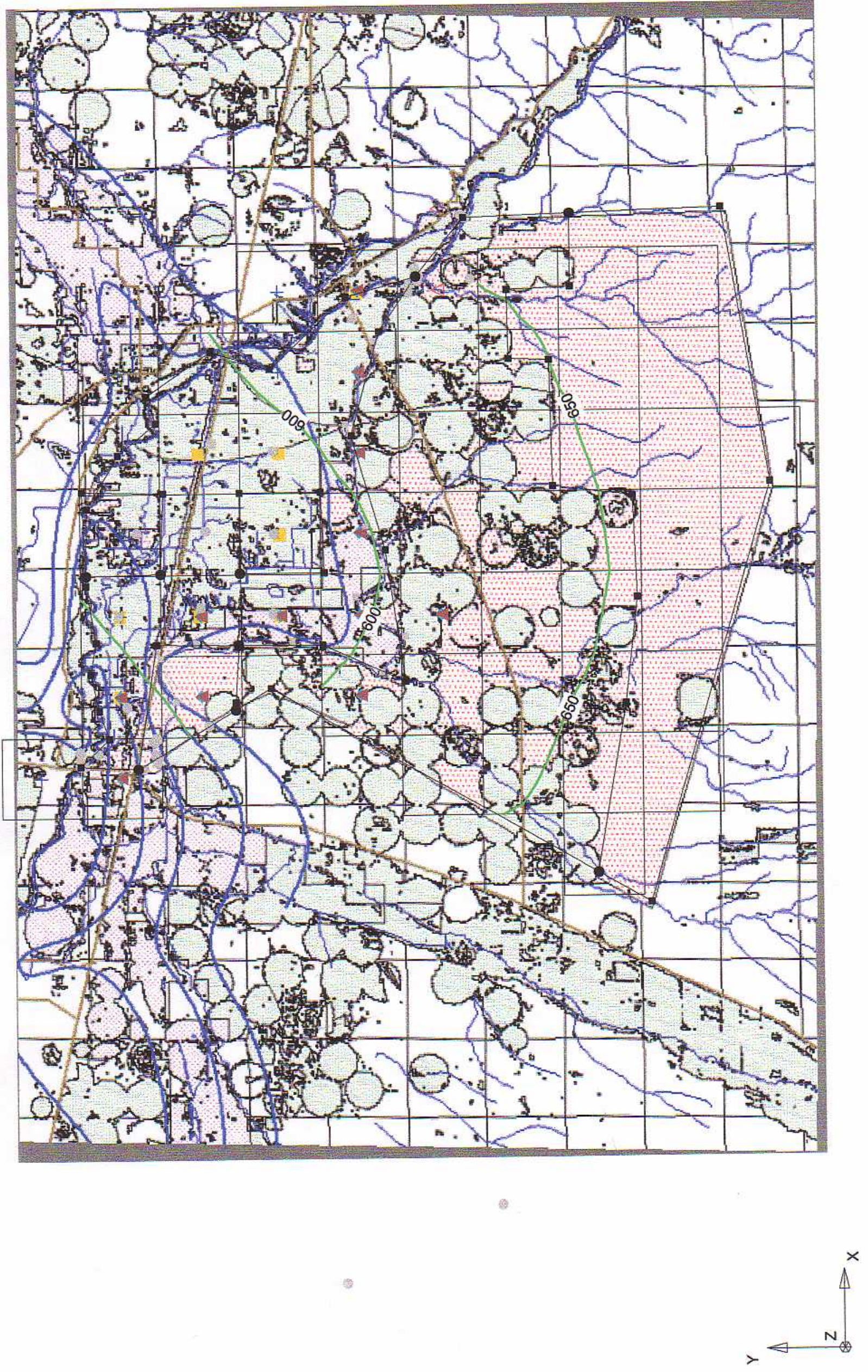


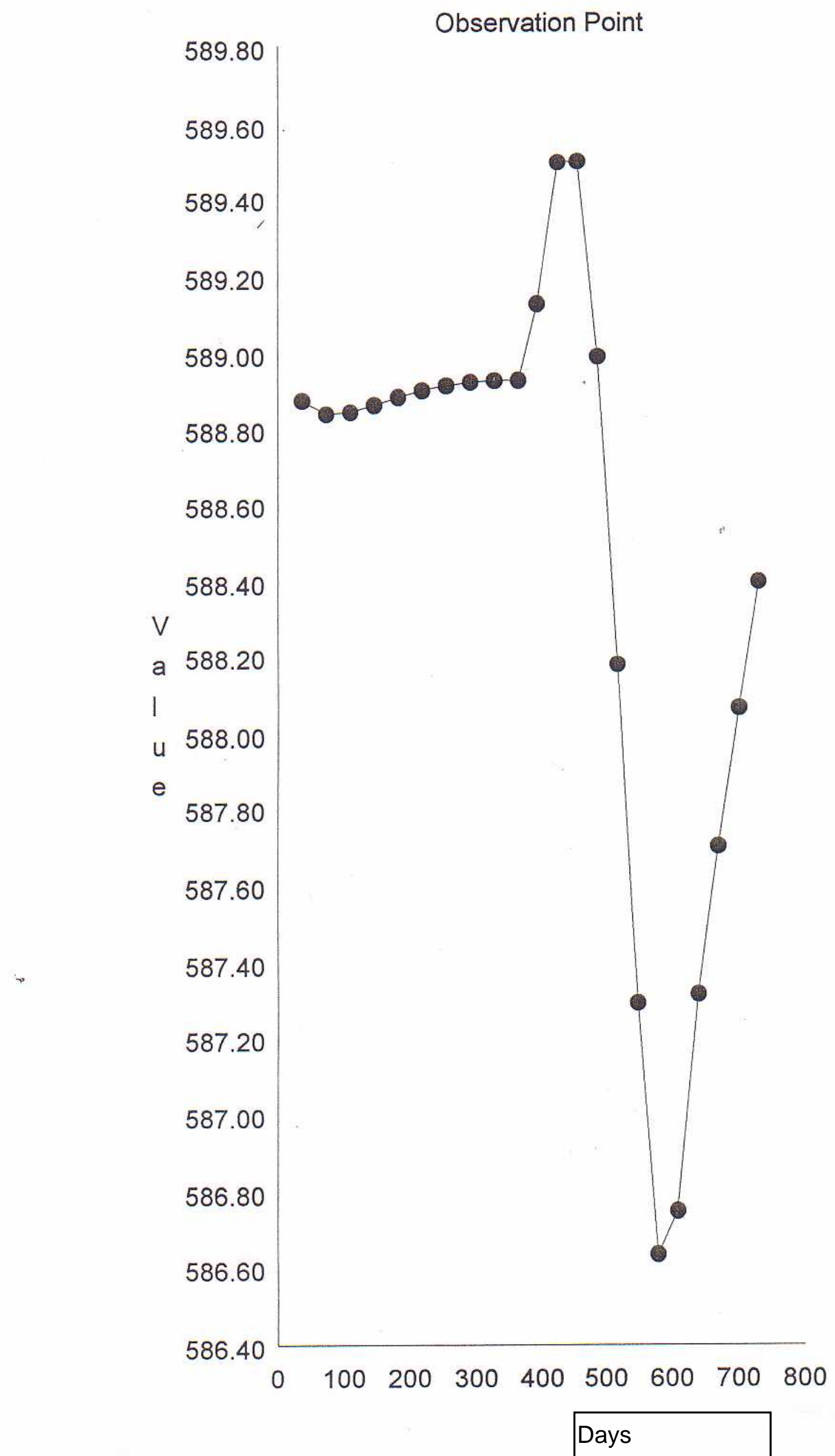


Umatilla Recharge

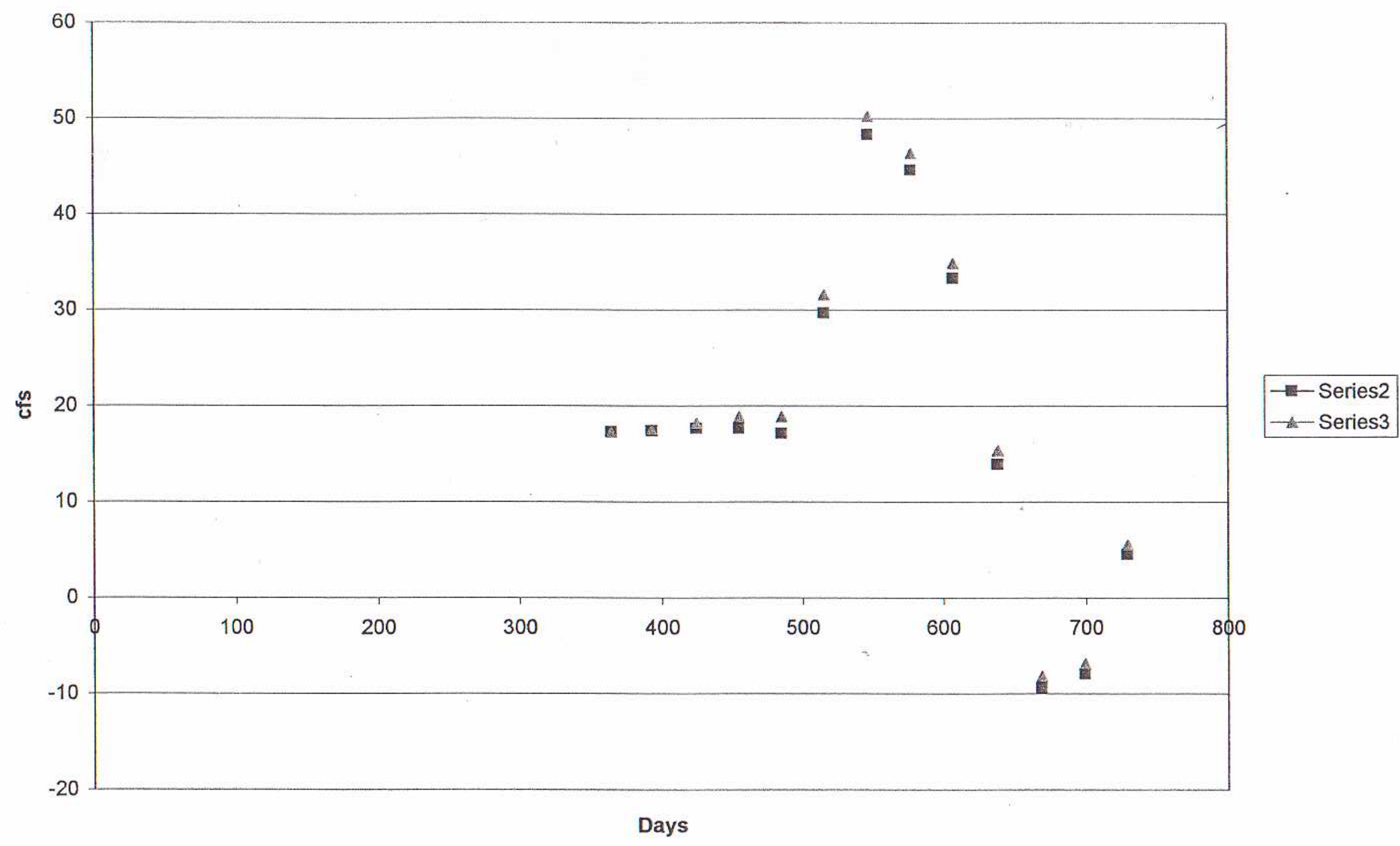

$T$
$\vdots$
$\zeta$
$\zeta$ 
Base Line- w/o additional recharge

HEADS AND FLOW TERMS SAVED ON UNIT 29 FOR USE BY MISD TRANSPORT MODEI

1 HEAD IN LAYER 1 AT END OF TIME STEP 1 IN STRESS PERIOD 8

\begin{tabular}{|c|c|c|c|c|c|c|c|c|c|c|}
\hline & 1 & 2 & 3 & 4 & 5 & 6 & 7 & 8 & 9 & 10 \\
\hline 01 & -999.0 & -999.0 & 533.9 & -999.0 & -999.0 & -999.0 & -999.0 & -999.0 & -999.0 & -999.0 \\
\hline 0 & -999.0 & -999.0 & 532.8 & 540.1 & 551.2 & 562.5 & 574.1 & 583.4 & -999.0 & -999.0 \\
\hline 3 & -999.0 & -999.0 & -999.0 & 557.7 & 567.8 & 576.1 & 583.8 & 591.1 & -999.0 & -999.0 \\
\hline 0 & -999.0 & -999.0 & -999.0 & -999.0 & 583.0 & 586.1 & 592.0 & 603.1 & 611.1 & -999.0 \\
\hline 0 & -999.0 & -999.0 & -999.0 & 611.2 & 596.8 & 597.2 & 606.9 & 612.8 & 616.2 & -999.0 \\
\hline 0 & -999.0 & -999.0 & 641.6 & 630.1 & 618.2 & 617.3 & 624.8 & 627.1 & -888.0 & -888.0 \\
\hline 0 & -999.0 & -999.0 & 648.9 & 644.0 & 639.1 & 638.4 & 641.6 & 646.1 & 654,8 & -999.0 \\
\hline 0 & -999.0 & 661.2 & 656.8 & 653.4 & 650.8 & 650.5 & 652.4 & 655.1 & 658.3 & -999.0 \\
\hline 0 & -999.0 & -999.0 & 659.5 & 657.8 & 656.4 & -656.5 & 658.9 & 659.6 & 660.8 & -999.0 \\
\hline 010 & -999.0 & -999.0 & -999.0 & -999.0 & -999.0 & -999.0 & 662.9 & -999.0 & -999.0 & -999.0 \\
\hline
\end{tabular}

OHEAD WILL BE SAVED ON UNIT 30 AT END OF TIME STEP 1, STRESS PERIOD 8

1 DRAWDOWN IN LAYER 1 AT END OF TIME STEP 1 IN STRESS PERIOD 8

\begin{tabular}{|c|c|c|c|c|c|c|c|c|c|c|}
\hline & 1 & 2 & 3 & 4 & 5 & 6 & 7 & 8 & 9 & 10 \\
\hline 0 & -999.0 & -999.0 & -0.6243 & -999.0 & -999.0 & -999.0 & -999.0 & -999.0 & -999.0 & -999.0 \\
\hline 0 & -999.0 & -999.0 & 1.852 & 3.070 & 3.251 & 2.922 & 3.036 & 2.147 & -999.0 & -999.0 \\
\hline 0 & -999.0 & -999.0 & -999.0 & 0.2855 & 2.105 & 1.140 & 1.609 & 2.923 & -999.0 & -999.0 \\
\hline 0 & -999.0 & -999.0 & -999.0 & -999.0 & 3.281 & 2.943 & 2.410 & 2.918 & 2.006 & -999.0 \\
\hline 0 & -999.0 & -999.0 & -999.0 & 1.319 & 1.376 & 1.314 & 1.196 & 2.597 & 4.839 & -999.0 \\
\hline 0 & -999.0 & -999.0 & 3.148 & 2.468 & 1.884 & 2.008 & 3.572 & 9.831 & -888.0 & -888.0 \\
\hline 0 & -999.0 & -999.0 & 3.498 & 3.179 & 2.826 & 2.715 & 3.165 & 4.609 & 5.163 & -999.0 \\
\hline 0 & -999.0 & 4.161 & 3.862 & 3.626 & 3.363 & 3.160 & 3.177 & 3.338 & 3.414 & -999.0 \\
\hline 0 & -999.0 & -999.0 & 4.048 & 3.905 & 3.700 & 3.495 & 3.366 & 3.164 & 3.066 & -999.0 \\
\hline 010 & -999.0 & -999.0 & -999.0 & -999.0 & -999.0 & -999.0 & 3.580 & -999.0 & -999.0 & -999.0 \\
\hline
\end{tabular}

ODRAWDOWN WILL BE SAVED ON UNIT 35 AT END OE TIME STEP 1, STRESS PERIOD 8

VOLUMETRIC BUDGET FOR ENTIRE MODEL AT END OF TIME STEP 1 IN STRESS PERIOD 8

CUMULATIVE VOLUMES L L*3 RATES EOR THIS TIME STER


IN:

STORAGE $=0.91403 \mathrm{E}+09$ CONSTANT HEAD $=0.0000$

WELLS $=$

RTVER LEAKAGE $=$

RIV DEP BOUNDS =

$\begin{aligned} \text { HEAD DEP BOUNDS } & =0.38719 \mathrm{E}+0 \\ \text { STREAM LEAKAGE } & =0.0000\end{aligned}$

TOTAL IN $=0.21406 \mathrm{E}+10$ OUT:

STORAGE $=0.53125 \mathrm{E}+08$

CONSTANT HEAD $=0.0000$

WELLS $=0.44388 \mathrm{E}+09$

RECHARGE $=0.0000$

RIVER LEAKAGE $=0.16436 \mathrm{E}+10$

HEAD DEP BOUNDS $=32749$.

$\begin{aligned} \text { STREAM LEAKAGE } & =0.0000 \\ \text { TOTAL OUT } & =0.21406 \mathrm{E}+10\end{aligned}$

TOTAL OUT $=0.21406 \mathrm{E}$

PERCENT DISCREPANCY $=$
IN:

STORAGE = HEAD = WELLS $=$
CHARGE $=$

RECHARGE $=$

TVER LEAKAGE $=$

HEAD DEP BOUNDS =

STREAM LEAKAGE $=$

$$
\text { TOTAL IN }=0.58677 \mathrm{E}+
$$

OUT:

STORAGE $=0.0000$

CONSTANT HEAD $=0.0000$

WTIT $=0.165980+07$

RECHARGE $=0.0000$

RIVER LEAKAGE $=0.42077 \mathrm{E}+07$

EAD DEP BOUNDS $=264.01$

STREAM LEAKAGE $=0.0000$

$\begin{aligned} \text { TOTAL OUT } & =0.58678 \mathrm{E}+07 \\ \text { IN }- \text { OUT } & =-66.000\end{aligned}$

PERCENT DISCREPANCY $=$ wlo recharge

$44.6 \mathrm{cts}$ 
Add Recharge to South Meadows

ARANSPORT MODEI

1 HEAD IN LAYER 1 AT END OE TIME STEP 1 IN STRESS PERIOD 8

\begin{tabular}{|c|c|c|c|c|c|c|c|c|c|c|c|c|c|}
\hline & & 1 & 2 & 3 & 4 & 5 & 6 & 7 & 8 & 9 & 10 & & \\
\hline 0 & $i$ & -999.0 & -999.0 & 533.9 & -999.0 & -999.0 & -999.0 & -999.0 & -999.0 & -999.0 & -999.0 & & \\
\hline 0 & 2 & -999.0 & -999.0 & 532.8 & 540.1 & 551.3 & 562.6 & 574.1 & 583.5 & -999.0 & -999.0 & & \\
\hline 0 & 3 & -999.0 & -999.0 & -999.0 & 557.9 & 568.5 & 576.9 & 584.3 & 591.2 & -999.0 & -999.0 & & \\
\hline 0 & 4 & -999.0 & -999.0 & -999.0 & -999.0 & 584.2 & $587.5)$ & 592.8 & 603.2 & 611.2 & -999.0 & 592.6 ad & peak \\
\hline 0 & 5 & -999.0 & -999.0 & -999.0 & 611.5 & 597.8 & 598.4 & 607.3 & 612.9 & 616.2 & -999.0 & & \\
\hline 0 & 6 & -999.0 & -999.0 & 641.6 & 630.1 & 618.5 & 617.6 & 624.9 & 627.1 & -888.0 & -888.0 & & \\
\hline 0 & 7 & -999.0 & -999.0 & 648.9 & 644.0 & 639.2 & 638.5 & 641.6 & 646.1 & 654.8 & -999.0 & & \\
\hline 0 & 8 & -999.0 & 661.2 & 656.8 & 653.4 & 650.9 & 650.5 & 652.4 & 655.1 & 658.3 & -999.0 & & \\
\hline 0 & 9 & -999.0 & -999.0 & 659.5 & 657.8 & 656.4 & 656.5 & 658.9 & 659.6 & 660.8 & -999.0 & & \\
\hline 01 & 0 & -999.0 & -999.0 & -999.0 & -999.0 & -999.0 & -999.0 & 662.9 & -999.0 & -999.0 & -999.0 & & \\
\hline
\end{tabular}

OHEAD WILL BE SAVED ON UNIT 30 ATT END OE TIME STEP 1, STRESS PERIOD 8

1 DRAWDOWN IN LAYER 1 AT END OF TIME STEP 1 IN STRESS PERIOD 8

\begin{tabular}{|c|c|c|c|c|c|c|c|c|c|c|}
\hline & 1 & 2 & 3 & 4 & 5 & 6 & 7 & 8 & 9 & 10 \\
\hline $0 \quad 1$ & -999.0 & -999.0 & -0.6263 & -999.0 & -999.0 & -999.0 & -999.0 & -999.0 & -999.0 & -999.0 \\
\hline 02 & -999.0 & -999.0 & 1.847 & 3.041 & 3.173 & 2.821 & 2.984 & 2.124 & -999.0 & -999.0 \\
\hline 03 & -999.0 & -999.0 & -999.0 & $1.5869 \mathrm{E}-02$ & 1.462 & 0.3178 & 1.122 & 2.866 & -999.0 & -999.0 \\
\hline 04 & -999.0 & -999.0 & -999.0 & -999.0 & 2.093 & 1.490 & 1.580 & 2.823 & 1.970 & -999.0 \\
\hline 0 & -999.0 & -999.0 & -999.0 & 1.092 & 0.4164 & 0.1124 & 0.7297 & 2.518 & 4.826 & -999.0 \\
\hline 0 & -999.0 & -999.0 & 3.143 & 2.426 & 1.653 & 1.671 & 3.484 & 9.807 & -888.0 & -888.0 \\
\hline 0 & -999.0 & -999.0 & 3.497 & 3.173 & 2.801 & 2.677 & 3.153 & 4.606 & 5.163 & -999.0 \\
\hline 0 & -999.0 & 4.161 & 3.862 & 3.625 & 3.361 & 3.156 & 3.176 & 3.337 & 3.414 & -999.0 \\
\hline 9 & -999.0 & -999.0 & 4.048 & 3.905 & 3.699 & 3.494 & 3.365 & 3.164 & 3.066 & -999.0 \\
\hline 010 & -999.0 & -999.0 & -999.0 & -999.0 & -999.0 & -999.0 & 3.580 & -999.0 & -999.0 & -999.0 \\
\hline
\end{tabular}

ODRAWDOWN WILI BE SAVED ON UNIT 35 AT END OE TIME STEP 1, S'TRESS PERIOD 8

VOLUMETRIC BUDGET FOR ENTIRE MODEL AT END OF TIME STEP 1 IN STRESS PERIOD 8

CUMULATIVE VOLUMES L**3 RATES FOR THIS TIME STEP


IN :

STORAGE $=0.92302 \mathrm{E}+09$

CONSTANT HEAD $=0.0000$

WELLS $=0.0000$

RIVER LEAKAGE $=0.59092 \mathrm{E}+09$

HEAD DEP BOUNDS $=0.38480 \mathrm{E}+09$

STREAM LEAKAGE $=0.0000$

TOTAL IN $=0.22228 \mathrm{E}+10$ OUT:

STORAGE $=0.11753 \mathrm{E}+09$

WELLS $=0.44388 \mathrm{E}+0$

RECHARGE $=0.0000$

RIVER LEAKAGE $=0.16613 \mathrm{E}+10$

HEAD DEP BOUNDS $=38051$

$\begin{array}{rc}\text { STREAM LEAKAGE } & =0.0000 \\ \text { TOTAI OUT } & =0.22228 \mathrm{E}+10\end{array}$

IN - OUT $=13824$.

PERCENT DISCREPANCY $=$
IN :

STORAGE $=0.44565 \mathrm{E}+07$

CONSTANT HEAD $=0.0000$

WELLS $=0.0000$

$\begin{aligned} \text { RECHARGE } & =0.55779 \mathrm{E}+06 \\ & 0.33701 \mathrm{E}+06\end{aligned}$

$\begin{aligned} \text { RIVER LEAKAGE }= & 0.33701 \mathrm{E}+06 \\ \text { EAD DEP BOUNDS } & =0.65093 \mathrm{E}+06\end{aligned}$

STREAM LEAKAGE $=$

TOTAL IN $=0.60023 \mathrm{E}+07$

OUT:

STORAGE $=0.0000$

CONSTANT HEAD $=0.0000$

WELLS $=0.16598 \mathrm{E}+07$

RECHARGE $=0.0000$

RIVER LEAKAGE $=0.43422 \mathrm{E}+07$

HEAD DEP BOUNDS $=357.44$

$35 A D$ DEP BOUNDS $=$
STREAM LEAKAGE $=0.0000$

TOTAL OUT $=0.60024 \mathrm{E}+0^{\circ}$

IN - OUT $=-113.00$

PERCENT DISCREPANCY =
46.4 (f) 